\title{
Cosmopolitanisms and the Jews
}

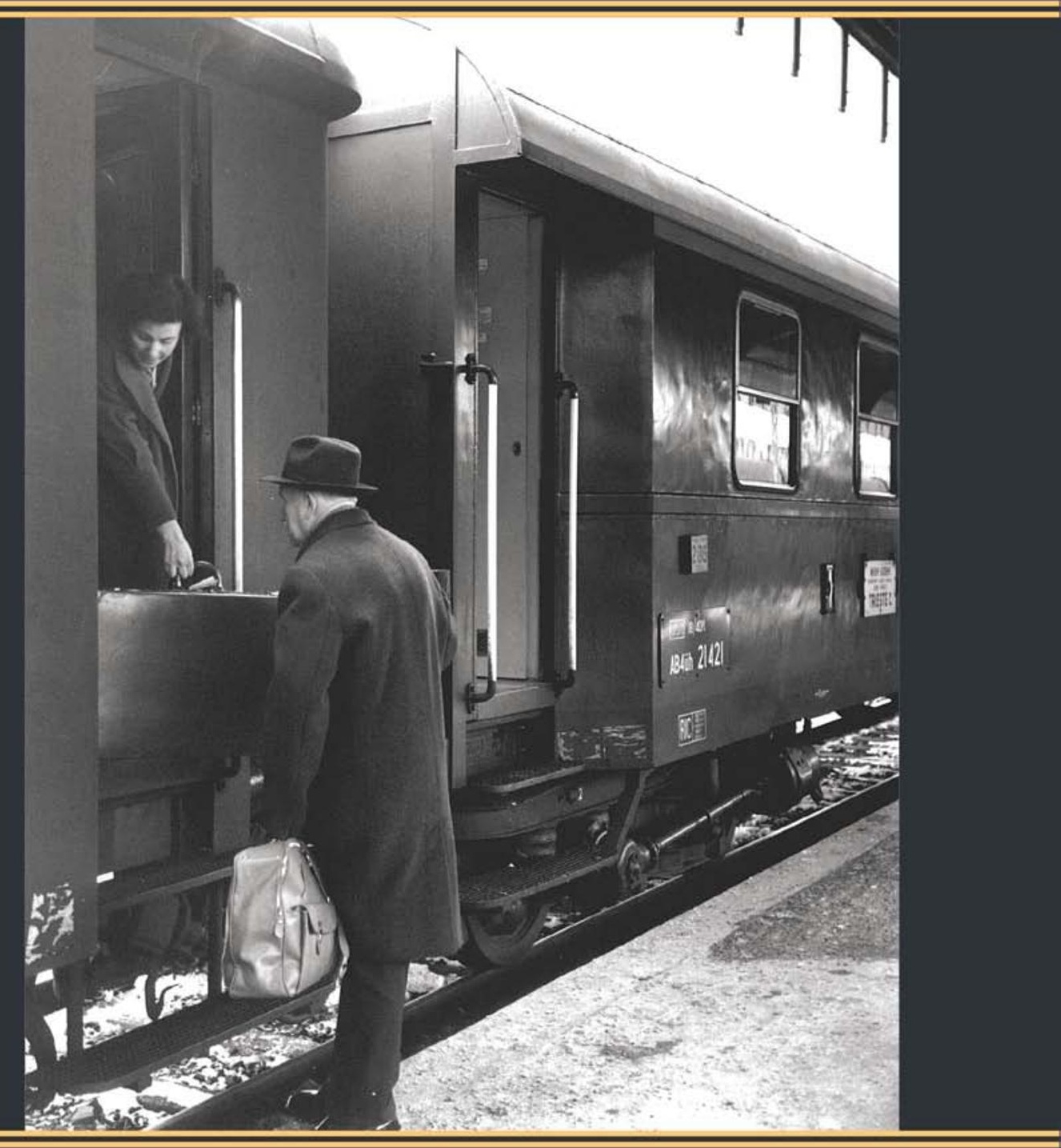

Cathy S. Gelbin \& Sander L. Gilman 
Cosmopolitanisms and the Jews 


\section{Social History, Popular Culture, and Politics in Germany}

Kathleen Canning, Editor

Geoff Eley, Founding Editor

\section{Recent Titles}

Cathy S. Gelbin and Sander L. Gilman, Cosmopolitanisms and the Jews

Jay Howard Geller and Leslie Morris, Editors, Three-Way Street: Jews, Germans, and the Transnational

Deborah Ascher Barnstone, Beyond the Bauhaus: Cultural Modernity in Breslau, 1918-33

Pepper Stetler, Stop Reading! Look!: Modern Vision and the Weimar Photographic Book

Greg Eghigian. The Corrigible and the Incorrigible: Science, Medicine, and the Convict in Twentieth-Century Germany

Anna M. Parkinson, An Emotional State: The Politics of Emotion in Postwar West German Culture

Alexander Sedlmaier, Consumption and Violence: Radical Protest in Cold-War West Germany

Sandrine Kott, Communism Day-to-Day: State Enterprises in East German Society

Heather L. Gumbert, Envisioning Socialism: Television and the Cold War in the German Democratic Republic

Nina Berman, Klaus Mühlhahn, and Patrice Nganang, Editors, German Colonialism Revisited: African, Asian, and Oceanic Experiences

Scott Moranda, The People's Own Landscape: Nature, Tourism, and Dictatorship in East Germany

David Imhoof, Becoming a Nazi Town: Culture and Politics in Göttingen between the World Wars

A complete list of titles in the series can be found at www.press.umich.edu 


\section{Cosmopolitanisms and the Jews}

CATHY S. GELBIN AND SANDER L. GILMAN

UNIVERSITY OF MICHIGAN PRESS

Ann Arbor 
Copyright $(9) 2017$ by Cathy S. Gelbin and Sander L. Gilman All rights reserved

This book may not be reproduced, in whole or in part, including illustrations, in any form (beyond that copying permitted by Sections 107 and I08 of the U.S. Copyright Law and except by reviewers for the public press), without written permission from the publisher.

Published in the United States of America by the University of Michigan Press

Manufactured in the United States of America

@ Printed on acid-free paper

$\begin{array}{llllllll}2020 & 2019 & 20 I 8 & 20 I 7 & 4 & 3 & 2 & \text { I }\end{array}$

A CIP catalog record for this book is available from the British Library.

Library of Congress Cataloging-in-Publication data has been applied for.

ISBN: 978-0-472-I304I-2 (hardcover : alk. paper)

ISBN: 978-0-472-I 2296-7 (ebook) 


\section{Contents}

Preface vii

I How Did We Get Here from There? I

Introducing the Problem I

The Cosmopolitanist Debates 9

The Jew in Contemporary Theories of Cosmopolitanism I 2

Nomads, Gypsies, Jews $\quad$ I7

Jews and the Nation-State 28

2 Moving About: Cosmopolitanism from Jews

in Coaches to Jews on Trains 3 I

The Enlightenment Imagines Cosmopolitan Jews 3 I

Writers in Coaches 42

Jews Writing Their Own Cosmopolitanism 6I

3 "Everyone Is Welcome": The Contradictions of Cosmopolitanism in the Imperial Worlds of Austro-Hungarian and Wilhelmine Jewry 69

From Vienna to Berlin and Beyond 69

Vienna, Zionism, and Cosmopolitanism 73

Prague: On the Fringes of Empire 9I

Berlin: Another Empire Ioo

4 Jewish Cosmopolitanism and the European Idea, I9I8-I933

After the Deluge I I 3

Stefan Zweig: The Model European I20

Joseph Roth's Hotel Patriotism I 27

Lion Feuchtwanger: The Empire Strikes Back I37

Cosmopolitanism Tottering on the Brink of Catastrophe I42 
5 "The World Will Be Your Home": Cosmopolitanism under National Socialism and in Exile

The Revolution of I933 I44

Thomas Mann and Egypt I45

Joseph in Sigmund Freud's Egypt I59

Heidegger's Rootless Jew I62

Zweig's Erasmus in Exile: The Cosmopolitan par Excellence I65

Roth and Zweig: Idealizing the Austro-Hungarian Empire $\quad$ I 70

Zweig's Brazil: The Farthest Exile $\quad$ I74

Lion Feuchtwanger's History in Exile, the Josephus Trilogy $\quad$ I 82

6 Rootless Cosmopolitans: German Jewish Writers

and the Stalinist Purges

The Left in World War II and Thereafter $\quad$ I87

Communism, National Socialism, and the Jews I88

Writing the Stalinist Purges: Alice Rühle-Gerstel, Arthur Koestler, and Manès Sperber I97

The Left and the Stalinist Purges after I945: Rudolf Leonhard, Peter Weiss, and Stefan Heym 2 I 3

7 Russian Jews as the Newest Cosmopolitans

Rooted German Cosmopolitans? 223

In Germany, Gogol Is Not Sholem Aleichem 226

In America, Nabokov Really Is Not Sholem Aleichem 243

8 Walls and Borders: Toward a Conclusion

Notes 


\section{Preface}

This book represents a collaboration between two scholars whose interests overlap for both personal and academic reasons. Cathy S. Gelbin was born in the German Democratic Republic, the daughter of a Jewish-American father and a German mother. Educated in Wall-time West Berlin and the United States, where she received her doctorate, she has taught in Germany and the United Kingdom and is now at Manchester University. Sander L. Gilman, of Russian Jewish descent, was her doctoral supervisor at Cornell and now teaches at Emory University in Atlanta. He has taught at numerous universities in North America, Europe, Africa, and Asia. Both are Jewish, both are self-labeled cosmopolitans, and both are actively engaged in trying to understand what such a status means for their work in light of their biographical trajectories. This project has brought them together to examine the history into which they, in complex and fragmentary ways, fit.

The title of this volume evokes the multiple meanings of both cosmopolitan and Jew in the discourse about cosmopolitanism. Indeed, the term cosmopolitan is oftentimes contested as to exactly what type of cosmopolitanism can be denoted by that term. We can only speak of cosmopolitanisms as it is impossible easily to bring the distinctions between a "moral" cosmopolitism, such as that advocated by Martha Nussbaum, and the "utilitarian" cosmopolitanism of Peter Singer into the same conceptual category. The multiple, contradictory meanings of Jews constitute a well-known problem in postmodern theory since at least I988 when Jean-François Lyotard published Heidegger et "les juifs," evoking the jew (lowercased in the English translation) as the mark of ineffable alterity rather than lived experience. Thus we write of "cosmopolitanisms and the Jews."

We do not seek to provide an exhaustive exploration of the oftcontradictory meanings of these two categories but rather to provide both a historical framework for their multiple meanings through detailed analyses of 
cultural products—novels, plays, poetry, philosophical essays-that illustrate the radical conceptual shifts associated with the notion of global mobility. Both authors are not only mundivagant but also define themselves as rooted in a specific national culture (or see themselves as suspended between these two experiential poles) and explored the complexity of cosmopolitanism in their works. Thus, we have taken the position that one of the functions of literature is to serve as a thought experiment for authors dealing, in our cases, with the questions of globalization, acculturation, migration, exile, national identity, and the like. We are quite aware that literature can have many other functions and can also be read in ways radically different than we have undertaken. Our project is a literary as well as a historical one. We hope that we have shown how relatively close readings of literary texts can be used to help frame the simultaneous contradictions and ambiguities of conceptual history, such as the history of the cosmopolitan that we have undertaken.

This volume was produced with the support of the Arts and Humanities Research Council in Great Britain and with the engagement of the Leo Baeck Institute for the Study of German-Jewish History and Culture (London). We thank Susannah Herzog for help with the preparation of the manuscript and Stephanie Schüler-Springorum of the Center for Antisemitism Research, Berlin, for her support. LeAnn Fields, our editor at the University of Michigan Press, has been especially helpful in formulating the project. 


\section{CHAPTER I}

\section{How Did We Get Here from There?}

\section{Introducing the Problem}

In the twenty-first century, the debate surrounding cosmopolitanism has become a surrogate for thinking about the positive or negative aspects of the new globalization. ${ }^{1}$ Yet cosmopolitanism is the concretion of a range of concepts firmly embedded in historical memory, and like other such concepts, it has been constantly refashioned for use in different periods and with specific shades of meaning. Hidden within today's cosmopolitanism is a whole range of meanings and concepts that, like an intellectual Venn diagram, come to be included within or indeed self-consciously excluded from our understanding of this concept. We can recall how George Bernard Shaw in 1907 ironically lampooned Broadbent, the ultimate Englishman, who decried everything and everyone who was not English enough: "You are thinking of the modern hybrids that now monopolize England. Hypocrites, humbugs, Germans, Jews, Yankees, foreigners, Park Laners, cosmopolitan riffraff. Don't call them English. They don't belong to the dear old island, but to their confounded new empire; and by George! They're worthy of it; and I wish them joy of it."2 Things change; things remain the same. From rootless riffraff at the turn of the twentieth century, the cosmopolitan has turned into a global elite at the turn of the twenty-first century.

Yet over and over again cosmopolitanism and its sister concept, nomadism, have taken on quite different meanings when their referent is the Jews. ${ }^{3}$ Once this litmus test is applied, both cosmopolitanism and nomadism are clearly revealed as symbolic manifestations of the antisemitic stereotype that associates Jews with capital. Over time, as we shall see, the related concept of the nomad gives way to that of the exile, the refugee, the D[isplaced] P[erson]. The association with capital also wanes but never quite vanishes. This is also part of the tale. Such a history of the cosmopolitan points toward the ambivalence of these concepts when applied in the present day to specific categories of social and geographic mobility, whether they refer to the Jew, the asylum 
seeker, the migrant, the undocumented immigrant. The riffraff of Edwardian London and of Wilhelminian Germany may have transmuted into the global citizen of the twenty-first century in some instances, but the aura of the corrupt and corrupting, of the rootless and the transitory, of the foreign and the unhoused always remains beneath the surface and shapes the sense of what it means to be cosmopolitan and global. And as such it impacts on the self-image of those so defined as mundivagant.

With the turn of the millennium, cosmopolitanism-that intellectual tradition culturally extolled but politically reviled in the European context between the I80os and the I950s-had come back into vogue. Cosmopolitanism is the new diaspora-indeed, the new multiculturalism. The latter, celebrated (or at any rate paid lip service) by many in the I990s, has now largely been disavowed by the new conservatives, such as Theresa May, now dominating Europe in the early twenty-first century. Indeed the British Prime Minister was quite clear about this at the 2016 Conservative Party Conference, where she stated that "if you believe you are a citizen of the world, you are a citizen of nowhere. You don't understand what citizenship means." Shaw would not have been surprised at the parochialism of a post-Brexit politics. The new nationalism has many faces, but not that of the cosmopolitan.

Indeed, the cosmopolitan has come to be threatened by its old foe, the lo$\mathrm{cal}$, the national, the autochthonous, the indigenous. As Peter Geschiere notes, citing Tania Murray Li, "With the present-day 'global conjuncture of belonging,' all over the world more cosmopolitan forms of citizenship are being discarded in a return to highly exclusive definitions of the nation." ${ }^{5}$ The struggle of the various notions of the cosmopolitan against the local and the historic and contemporary function of the image of the Jew as a proof text for such struggles lies at the core of our project. Given that Geschiere sees "religion play[ing] a front-stage role in this quest for belonging," this question continues to engage us in the twenty-first century. ${ }^{6}$ While it is evident that today as well as historically, being Jewish is not conterminous with being a practicing religious Jew (in any or all of its manifestations), it is clear that Jewish ethnicity, Jewish religious practice, and (at least in religious Zionism) Jewish political identity often overlap or are confused. ${ }^{7}$ We know that "being Irish," especially in the diaspora, is a vague and often confusing identity. On St. Patrick's Day, a minor religious holiday in the Republic of Ireland, the Chicago River is dyed green: on that day, "everyone is Irish." Yet such an Irish identity seems not to demand any religious subtext. Other religious identities have played and continue to play a role in both Irish identity and Irish politics (in the republic as well as in Northern Ireland). Indeed, Anne Kane notes that "the construction of Catholic 
Irishness was strengthened by the disaster of famine from I845 to I849. . . Religious affiliation became increasingly a surrogate for national identity as the effective agent for communal solidarity." Such contradictions and transformations are no different with "being Jewish."

To what extent, however, does the current idealizing or demonizing discussion of cosmopolitanism need to be challenged, especially given the divisive history and implications of this concept? Modern cosmopolitanist discourse has been markedly ambivalent, and its often anti-Jewish and Eurocentric uses have reproduced rather than dispelled discursive margins and centers. The twenty-first-century rise of a new radical nationalism in Greece and Hungary has seen the reproduction of older attacks on minorities such as the Jews and the Sinti and Roma (Gypsies) as well as on "asylum seekers" and economic refugees as cosmopolitans undermining the nation-state. Other forms of modern nationalism, such as in Russia, use the presence of a resuscitated Jewish community with strong links to the country's authoritarian regime to prove the liberalism of core governmental attitudes even as that regime aggressively pursues strongly national positions vis-à-vis other minorities and nations.

Given the rise in radical nationalism, why has the concept of the cosmopolitan reemerged in academic discourse? Is it merely a knee-jerk liberal response to what has been perceived as a conservative realignment of national politics, specifically in regard to the legal or illegal movement of peoples across national borders? In philosophy as well as in cultural, political and social theory, diaspora and multiculturalism have similarly come to be questioned, albeit for entirely different reasons. Today's debates about cosmopolitanism are shaped not solely by the prospect of large-scale legal immigration and its challenges to traditional cultural hierarchies, as signified by the evolution in contemporary Germany of the concept of Leitkultur, but also by the invisible history of that concept and the function of the Other in such theories. ${ }^{9}$

All three concepts - diaspora, multiculturalism, and cosmopolitanismare concerned with diversity. In contemporary theory, however, cosmopolitanism reflects more clearly the imagined crossing and mixing of cultures and ethnicities in the savvy environments of contemporary globalized cities, whereas the concepts of diaspora and multiculturalism more readily invoke notions of difference and separation. As Saskia Sassen has notably commented, such nodal points are the point of the conflict, concentrating on both "the leading sectors of global capital" and "a growing share of disadvantaged populations (immigrants, many of the disadvantaged women, people of color generally, and, in the megacities of developing countries, masses of shanty dwellers)." ${ }^{10}$ But they are also rooted in nation-states, as Singapore has shown, 
where the global city becomes the nation-state, with all its anxieties about the control of the masses moving through and remaining in its sphere. Those moving into the new global cities are diasporic by definition, whether wealthy British businessmen or marginal Indonesian contract laborers. The former are rarely seen as disadvantageous, because they are the agents of global capital; the latter are seen as potentially dangerous because they represent the diasporic in its most marginal form. Diaspora literally means to exist in two spheres, suggesting that the diasporic subject has its roots "elsewhere," whereas multiculturalism suggests the coexistence of different cultures and ethnicities.

In contrast, Ulrich Beck, a late German sociologist and contemporary theoretician of cosmopolitanism, argues that it "has become the defining feature of a new era, the era of reflexive modernity, in which national borders and differences are dissolving and must be renegotiated." ${ }^{11}$ Whereas globalization is frequently understood as the now global flow of commodities, people, and communications as well as of cultural artifacts, Beck casts cosmopolitanism as a type of internal globalization, an outlook producing a "global sense, a sense of being without boundaries. An everyday, historically alert, reflexive awareness of ambivalences" that "reveals not just the 'anguish' but also the possibility of shaping one's life and social relations under conditions of cultural mixture. It is simultaneously a skeptical, disillusioned, self-critical outlook."12 Such a view of cosmopolitanism, which saw a common bond among the European nations, appeared as a liberal defense against the nationalist excesses that had led to World War I and had paved the way for the rise of National Socialism. For Beck, this complex system of cosmopolitanisms reaches from merely empathetic to the political:

What, then, does the cosmopolitan outlook signify? It does not herald the first rays of universal brotherly love among peoples, or the dawn of the world republic, or a free-floating global outlook, or compulsory xenophilia. Nor is cosmopolitanism a kind of supplement that is supposed to replace nationalism and provincialism, for the very good reason that the ideas of human rights and democracy need a national base. Rather, the cosmopolitan outlook means that, in a world of global crisis and dangers produced by civilisational and international, us and them, lose their validity and a new cosmopolitan realism becomes essential to survival. ${ }^{13}$

Such a view is embedded in history. It is not merely a form of contemporary existence in the global marketplace but one that has carefully crafted who and 
what defines the borders of such a fluid identity. Who is dangerous in their ability to cross boundaries, and who is benign? And how are they perceived as such over time? In this book, we will look at how the Jews, however defined, come to shape the various contemporary models of the cosmopolitan and how such models, in turn, come to redefine what is understood as Jewish.

Modern Jewish historians, such as Jacob Neusner in Self-Fulfilling Prophecy: Exile and Return in the History of Judaism, have argued for a material understanding of diaspora. ${ }^{14}$ For Neusner, that understanding is the model of wilderness and land, the dialectic between tent and house, nomadism and agriculture, wilderness and Canaan, wandering and settlement, diaspora and state. Welsh Congregationalist W. D. Davies has argued in The Territorial Dimension in Judaism that this dichotomy is well balanced in the Bible, that for every quote praising wilderness as the decisive factor in Judaism, there could be found a counterpart in praise of the land of Zion. ${ }^{15}$ Analogous problems are present the scholarship dealing with Jews beyond of the sphere of Ashkenazi Jewry. As Ammiel Alcalay notes, such a dichotomy "must be grounded in a context that is both broader and more specific that the standard binary approach, which would see 'rabbis' on one side and thought that 'dislikes residence and offers itself as a philosophy for nomads' on the other." ${ }^{16}$ Diaspora presents a complex problem of being self-aware of inherent binaries as structuring principles for self-definition.

The involuntary dispersion of the Jews (galut or golah), conversely, is often understood as the experienced reality of being in exile, albeit structured by the internalization of the textual notion of the diaspora and tempered by the daily experience (good or bad) of life in the world. The Jew experiences the daily life of exile through the mirror of the biblical model of expulsion, whether the expulsion from the Garden of Eden or freedom from slavery in Egypt. Galut has formed the Jewish self-understanding of exile. Yet for some thinkers today galut is articulated as being inherently different from the voluntary exile of the Jews (diaspora or tfutsot). ${ }^{17}$ These two models exist simultaneously in Jewish history in the image of uprooted and powerless Jews on the one hand and rooted and empowered Jews on the other. It is possible to have a firm, meaningful cultural experience as a Jew in the galut or to feel alone and abandoned in the diaspora (as well as vice versa) - two people can live in the same space and time and can experience that space and time in antithetical ways. Indeed, the same person can find his or her existence bounded conceptually by such models at different times and in different contexts. Moreover, there are galuts within galuts, diasporas within diasporas. ${ }^{18}$ The children of Israeli Jews 
in Berlin become German Jews in New York; Soviet Jews in New York come to see themselves as American refugees in Russia. What at one moment are antitheses come to be felt as complementary situations.

If the debates about the Leitkultur define acceptable political identity in contemporary Germany (and variants of this concept exist today in every European and North American country), the impact of such views can also be found within discussions of what being Jewish means in the contemporary world. The strongly nationalistic tone of modern Zionism, which has dismissed and continues to dismiss the cosmopolitan as an aberration of Jewish identity, has paralleled much of the recent general movement against a positive cosmopolitan identity, at least for Jews. The idea of shilat ha'golah (the negation of the diaspora), has deep roots in Zionism, though, as we shall see, not necessarily in the thought of its modern founder, Theodor Herzl. Recently, there has been a Jewish reaction to such dismissal of the cosmopolitan. Alan Wolfe wrote in 20I4 that "for universalists who viewed particularism as a step down from cosmopolitanism, selectivism was a step down from particularism: The circle of concern was narrowed from all humanity, to all Jews, and finally only to those Jews deemed worthy of the name." ${ }^{19}$ Indeed, Wolfe sees such a movement as contrary to the general adaptation of Jews in the diasporic world, in "such cosmopolitan centers as Berlin, London, and Chicago" (W, 42), where their deeply Eastern European Jewish identity enabled them to draw "universal lessons that could be applied to any people wrestling with questions of identity and meaning" (W, 42-43). For Wolfe, the diaspora provided and provides all Jews with "the opportunity that living in a land not their own has offered: a deep understanding of unfairness and a commitment to the absolute necessity of fighting against it" (W, 2). Thus, diasporic cosmopolitanism offers "a blessing in disguise" (W, 2). Here, Wolfe quotes British liberal Rabbi David J. Goldberg, who sees this cosmopolitanism as bridging the "tension between particularism and universalism" (W, 2) that haunts modern Jewish identity. Virtually all commentators on Jews and cosmopolitanism stress this tension, and it forms a paradigm for the evaluation of the radical poles of identity, not for the complex construction of identity itself. The question of an authentic life grounded not in geography but in belief, as Neusner and other scholars advocate, provides an alternative meaning for cosmopolitan Jewish culture in the diasporic situation, at least in the United States (W, 6). Even here, the contradictions and conflicts out of which a fluid and evolving identity is formed become defined by a single quality of experience. The cosmopolitan remains contested beyond and within debates about Jews' identity but rarely without references to the Jews as evidence for the benign or corrosive presence of the cosmopolitan. 
Unlike Natan Sznaider's excellent study, Jewish Memory and the Cosmopolitan Order, we do not use "'Jewishness' as a metaphor for people on the margins, people who are minorities, whether against their will or by choice."20 We examine the representation of Jews in writing by Jews (however defined) and others as cosmopolitans not as a means of either judging "their victimhood" or of "exploring the possibilities of autonomous cosmopolitan social and political action" (Sz, 6I) but as an index to the ever-shifting internal sense of a Jewish cultural identity rooted both in experience and in its representation in the world. On one level, we see the literary text as the author's ability to undertake a thought experiment, to think him- or herself into a world analogous to or radically different from his or her own and to make such images accessible to the public sphere. Thus, we do not agree with Sznaider that "Jews were cosmopolitan before Europe became cosmopolitan" (Sz, I97); instead, we see the notion of cosmopolitanism as arising at a historical moment and being shaped by its image of the Jew. Here, we agree with the late Benedict Anderson's now classic formulation that the concept of the nation "was born in an age in which Enlightenment and Revolution were destroying the legitimacy of the divinely-ordained, hierarchical dynastic realm. Coming to maturity at a stage of human history when even the most devout adherents of any universal religion were inescapably confronted with the living pluralism of such religions, and the allomorphism between each faith's ontological claims and territorial stretch, nations dream of being free, and, if under God, directly so. The gage and emblem of this freedom is the sovereign state." ${ }^{21}$ Religious identity recedes in importance, defining the nation-state as the plurality of religions becomes more and more evident following the wars of religion or at least by the early Enlightenment. Ironically, cosmopolitanism and the idea of the Jews become inexorably linked at this moment as national identity separate from religion comes to define rootedness and the Jews come to define its antithesis, the cosmopolitan.

In this new nation-state, the Jews were tagged as representing the limits of autonomy and thus of the national, and they began to understand themselves in these terms. Concepts such as rooted cosmopolitanism evolved to explain such shifts. The Jews became cosmopolitan in all of its varieties as the world came to codify what the cosmopolitan could and could not be. In Imperial Encounters: Religion, Nation, and Empire, Peter van der Veer notes that these terms are perhaps deemed to demand that "the enlightened assumption is that a cosmopolitan person has to transcend religious tradition and thus be secular."22 Thus the tensions that arose also denied the core of a Jewish religious identity in the early modern period, stressing its secular nature. Indeed, if Talal Asad is 
correct in his assumption that the break with the idea of religion in the Enlightenment is the construction of a radical discourse of secularization, then the "problem" of the Jews was that they were seen to continue to link both spheres in a world where the separation had come to be a pillar of the new nationstate. ${ }^{23}$ They were a religion (if merely of the abdomen, if Ludwig Feuerbach is to be believed) as well as a nation (or at least a nation within a nation, according to Johann Gottlieb Fichte's view). The irony is that by the late twentieth century, as Bruce Robbins points out in Perpetual War: Cosmopolitanism from the Viewpoint of Violence, religion is "certainly considered worth dying for by many" and is "at least as cosmopolitan as it is national." 24 This is the inherent difficulty in Geschiere's notion of the function of religion in the public sphere as solely the prerogative of the local, the national, the autochthonous, the indigenous. This volume is underpinned by the tension between the universal and the particular, between the secular and the religious, between identity and action. Our argument reflects a basic debate about whether the postEnlightenment is an age of increased or decreasing secularization by postulating that the debate about cosmopolitanism also reflects the question of the space of alterity in the modern world. ${ }^{25}$ And for all of these fragile and partial dichotomies, the Jews, defined as religion, ethnicity, culture or "race," serve as a litmus test.

This chapter traces the evolution of the modern concept of the cosmopolitan in relation to the Jews, who became its central signifier in the twentieth century. We show how Enlightenment cosmopolitanism excluded the Jews, seen as rootless nomads, from its idea of a rooted universality. We offer an alternative historical reading to that of Yuri Slezkine, who has defended a "cosmopolitan, nomadic Jewish identity" rooted in a transhistorical notion of "service nomads," people who serve in agrarian society as the purveyors of resources beyond those easily accessible to that society. He observes, "In complex agrarian societies (no other preindustrial kind has much interest in cosmopolitanism), and certainly in modern ones, service nomads tend to possess a greater degree of kin solidarity and internal cohesion than their settled neighbors. This is true of most nomads, but especially the mercurial kind, who have few other resources and no other enforcement mechanisms." ${ }^{26}$ For him, this social role defines the cosmopolitan and provides nomads with a marginalized and often ostracized social role that guarantees their ultimate financial and social success. While such an approach certainly has value in providing a matrix into which most of such "service nomads" fit, we are interested in the historical context of such social roles and how they are read as part of a retrospective history of the nomad and the cosmopolitan. Slezkine acknowledges 
that the Sinti and Roma constitute exceptions to his model, and these exceptions are important in the construction of the idea of Jewish particularism for specific reasons at a specific historical moment. How Jews become Gypsies and how Gypsies become Jews is part of our tale.

We also show how Enlightenment discourses on both the cosmopolitan and the nomad remained ambivalent in their treatment of the Jews, who nonetheless functioned as the archetype of these notions within Immanuel Kant's cosmopolitanist dialectic of particularist universality. The period between I880 and I933 nevertheless saw the generalized eclipse of a cosmopolitan self-image with positive connotations, particularly among German-speaking Jewish intellectuals. Twentieth-century discourse on cosmopolitanism and the Jews found its nadir in the National Socialists' annihilation of the Jews as "rootless parasites" and the Stalinist persecutions of Jews as "rootless cosmopolitans." The memory of these images, which prevailed until a few decades ago, is largely absent from the new academic discourses on the nomad and the cosmopolitan.

\section{The Cosmopolitanist Debates}

The history of the term cosmopolitanism reflects its historical constitution. Whereas the concepts of diaspora and multiculturalism refer to (often essentialized) ideas about Otherness, cosmopolitanism appears on the surface to be a more readily inclusive concept, addressing the condition of a universalized human subject regardless of its positionality - that is, its discursive fixation in discourses about culture, race, and ethnicity in particular. Yet cosmopolitanism's universalism betrays its origins in Enlightenment thought, which, like the concept of the diaspora, took its cues from ancient Greek thought. The term cosmopolitanism is derived from the Greek words cosmos (the universe) and polites (citizen, referring to an inhabitant of a city-state). When asked about his origins, Diogenes of Sinope, also known as the Cynic (ca. 4I2 BCE), founder of stoicism, reportedly responded that he was a cosmopolites (citizen of the world). ${ }^{27}$ (This was the same rather odd Diogenes who also lived in a large, empty jar and sought out an honest man with his lantern in the daylight.) This term connoted the allegiance to the polis (city-state) as well as a sense of belonging to a wider, universal context beyond local ties. During the Enlightenment, when cosmopolitanism came to define a certain set of relationships to the modern nation-state, the archaic baggage that the Greeks (understood as proto-Germans in togas) provided for this concept allowed it to become part of a modern vocabulary of identity. 
The tension between the universal and local meanings of cosmopolitanism originally arose in the Enlightenment, as did the common use of the term itself. Standard etymologies in various European languages note that while the term is Greek, its modern usage in English was borrowed from the French as early as the sixteenth century by necromancer John Dee to denote a person who is "A Citizen ... of the ... one Mysticall City Vniuersall." ${ }^{28}$ However, the word only became common in English in the early nineteenth century. In German, the term Weltbürger (world citizen) was likewise generated in the early sixteenth century to provide an alternative to the French cosmopolitisme and cosmopolite. The French Academy documents cosmopolitisme in its I762 dictionary, but that is the first official recognition of a much older, if rare, usage. As in English, the earlier German usages are sporadic. Erasmus seems to have been the first to use it: in the early sixteenth century, he wrote to Zwingli that when Socrates had been asked of what city he was a citizen, he replied that he was a "cosmopolites sive mundanum." 29 The term came into wider use earlier than it did in English but nevertheless not until the German Enlightenment. Jakob Friedrich Lamprecht seems to have popularized the term in German with his periodical, Der Weltbürger ( $174 \mathrm{I}-42$ ). G. E. Lessing used the term cosmopolitan (rather than Weltbürger) in I747, with a wide range of Enlightenment figures quickly following suit. In all of these European languages, the widespread use of cosmopolitan is linked to social and conceptual shifts in the course of the eighteenth century. Indeed, what seems on its surface to be a coherent concept revealed itself already in the eighteenth century, as we shall show, to be a range of cosmopolitianisms with multiple, contradictory adaptions and transmutations. Functioning as the litmus test for the cosmopolitanisms in the German Enlightenment in all of its myriad cases is the status of the Jews.

In modern Western discourse, both diasporic subjectivities and the cosmopolitan became inextricably linked with the figure of the Jew in Enlightenment thought. Jewish intellectuals themselves played an important role in this discourse, through which they inscribed themselves as cultural and political agents within European and German-speaking culture in particular but at the same time maintained their Jewish specificity. But after the Holocaust, the notions both of the diaspora and of the cosmopolitan lost currency in the Jewish context. The diaspora was seen as having rendered the Jews culturally defenseless, establishing the preconditions for their situation. The Holocaust and the persecution of Jews as rootless cosmopolitans by both Hitler and Stalin led to a turning inward among Jews, an assertion of particularity over universality. Especially during the first decades after its founding, Israel disavowed the di- 
aspora Jew as a shameful, passive figure. Indeed, the recent diaspora of Israelis, especially in Germany, has resuscitated the charge of rootlessness, now against those whose Israeli roots seemed to have provided them with a firm national identity.

Jews have been largely excluded from the rehabilitation of the concepts of diaspora and the cosmopolitan since the I99os. In his essay on "Cultural Identity and Diaspora" (1990), Stuart Hall goes so far as to construct Jews as the imperialist antithesis to postcolonial diasporas. They are not among the people who "originally 'belonged' there." ${ }^{\text {30 }}$ Because of its seemingly heightened inclusivity, the concept of cosmopolitanism has, in contrast, recently assumed a key position in academic debates on diversity. Cosmopolitanism is frequently seen as a solution to discourses and social practices of exclusion based on cultural and ethnic (or racial) Otherness, an Otherness that the discourses of diaspora and multiculturalism seek to maintain (though the latter has retained an important place in political practices seeking to address the existing social inequalities between ethnic groups in the United Kingdom and elsewhere). Yet in the current discourse on cosmopolitanism, the Jewish story has likewise been nearly forgotten or is at best marginalized.

In this way, modern cosmopolitanist discourse inadvertently repeats its own history of exclusion. When the first theories of cosmopolitanism arose in the critical discourse of the Enlightenment, the Jews came to exemplify the virtues and ills of this concept because of the weight given to Jewish emancipation and mobility during the eighteenth century. A closer glance at the status accorded to the Jews, that quintessential example of a people beyond borders, within cosmopolitanist thought can thus help us ascertain the possibilities and limitations of this discourse. After all, early modern cosmopolitanist theory saw Jews as the antithesis of its lofty universalism. The ancient Greek concept of cosmopolitess saw a revival in Germany just as the French Revolution was ushering in the end of feudal absolutism in Europe and heralding the beginnings of the modern state. Modern cosmopolitanism combined patriotism, presumed to be progressive, with universalism. It became a powerful tool in nascent German nationalism, which opposed the particularist division of the German-speaking lands into a myriad of duchies and kingdoms.

Immanuel Kant became a key figure in the rise of modern cosmopolitanist discourse when his Third Article of his Perpetual Peace (1795) demanded a Weltbürgerrecht (law of world citizenship) to which all humans would be entitled. ${ }^{30}$ Kant's idea of cosmopolitan rights formed the basis not only of a unified legal order following the Peace of Westphalia but ultimately of global norms of justice today, including concepts such as crimes against humanity 
and, to quote Hannah Arendt in the preface to The Origins of Totalitarianism, "the right to have rights." 32 A century and a half would pass before Kant's dream of a universal law, a "Foedus Amphictyonum," as he calls it in his I784 Idea of a Universal History with Cosmopolitan Intent, with all of its caveats, took root in the legal realm, and this process arguably remains under way, littered with loopholes and exceptions. ${ }^{33}$ These footnotes, exceptions, and caveats interest us and are explored in terms of Kant's views in greater detail in chapter 2.

\section{The Jew in Contemporary Theories of Cosmopolitanism}

In one of the most striking attempts recently to understand the new use of this old concept, New York University philosopher and public intellectual Kwame Anthony Appiah has attempted to bridge the idea of the local/community and the global/transnational by demanding that both be respected as aspects of human identity in our globalized world. Appiah notes that "the idea behind the Golden Rule is that we should take other people's interests seriously, take them into account. It suggests that we learn about other people's situations, and then use our imaginations to walk a while in their moccasins. These are aims we cosmopolitans endorse. It's just that we can't claim that the way is easy." ${ }^{34}$ Local meanings modify claims about cosmopolitan universals; the cosmopolitan as a surrogate for the global is effective only insofar as it reflects the specific experiences of individuals and communities.

The universal claim of globalization and its surrogate, cosmopolitanism, is that all human beings share certain innate human rights, including the free movement of peoples across what are seen as the superficial boundaries of nation, class, race, caste, and perhaps even gender and sexuality. ${ }^{35}$ This notion, projected onto the New World by Anglo-Jewish dramatist Israel Zangwill (I864-I926), is sometimes referred to as the melting pot, the title of his I908 play, and finds its classic expression in the model of the hybrid, the "Golden" or "New Man," of the merging of differences to form a world that incorporates the best qualities of the cultures that contribute to it and is constantly being revised, altered, and changed precisely by the movement of all peoples across all boundaries. ${ }^{36}$ This is what Shaw satirizes at the same moment on the London stage. The local form, sometimes referred to as "cultural pluralism," to use the phrase coined in I9I 5 by early American Zionist thinker Horace Kallen ( $882-$ I974), recognizes that local claims always modify such human rights regarding change and that the flexibility demanded by the melting pot is super- 
imposed rather than self-generated.

Appiah's views today echo one of the major Enlightenment thinkers, the Abbé Grégoire, who attacked the facile use of a universal claim of cosmopolitanism before the National Assembly during the French Revolution:

A writer of the last century (Fénélon) said: I love my family better than myself: I love my country better than my family but I love mankind better than my country. Reason has criticized both those extravagant people who talked about a universal republic and those false people who made a profession out of loving people who lived at a distance of two thousand years or two thousand leagues to avoid being just and good towards their neighbors: systematic, de facto cosmopolitanism is nothing but moral or physical vagabondage. ${ }^{37}$

For the Abbé, the local case was the question of the universal emancipation of French Jewry as French citizens, trumping their specifically Jewish identity, an idea he powerfully advocated. ${ }^{38}$ For the Enlightenment-and this tale begins with the Enlightenment-Jews in Paris, not in the distant past or in faraway Palestine, are the test for true French cosmopolitanism. The attention to the immediate and the proximate defined true cosmopolitanism, a topic much debated at the time.

Another significant problem with Appiah's otherwise praiseworthy book involves his discussion of the Jews - or, rather, what is missing from his discussion even of the French and German Enlightenment. His tale begins with Voltaire, but Appiah also enthusiastically quotes perhaps the first major German literary advocate of cosmopolitanism, Christoph Martin Wieland, who in the I780s devoted several essays, most famously "The Secret of Cosmopolitan Order" (I788), to cosmopolitanism: "Cosmopolitans . . . regard all the peoples of the earth as so many branches of a single family, and the universe as a state, of which they, with innumerable other rational beings, are citizens, promoting together under the general laws of nature the perfection of the whole, while each in his own fashion is busy with his own well-being" (A, xiv-v). But Appiah does not note that Wieland, like the philosophes, sees this as a transcendental category, trumping the local. Wieland is himself paraphrasing Friedrich II's oft-cited June I740 note concerning Huguenot and Catholic toleration but not emancipation: "Each should be blessed in their own manner." In I750, this toleration was grudgingly extended to Prussian Jewry. ${ }^{39}$ Wieland's own Enlightenment views on the Jews are clear: his Private History of Pereginus Proteus ( 7 78I) mocks the pagan whose grandfather "had a boundless aversion for Jews and Judaism; his preju- 
dices against them, were, perhaps, partly unjust, but they were incurable"; however, Wieland equally detested Christians, who "passed for a Jewish sect." ${ }^{40}$ Enlightenment thought more generally promoted a rooted cosmopolitanism, a universalist sensibility based in the nation. Religious affiliation, particularly that of the Jews, was rejected for its particularity. Wieland's cosmopolitanism thus contests the religious exclusivity of both Christians and Jews over the universal. In contrast, Appiah draws on Wieland but invokes an ideal type of universal cosmopolitanism when referring to the Jews:

For many long years, in medieval Spain under the Moors and later in the Ottoman Near East, Jews and Christians of various denominations lived under Muslim rule. This modus vivendi was possible only because the various communities did not have to agree on a set of universal values. In seventeenth-century Holland, starting roughly at the time of Rembrandt, the Sephardic Jewish community began to be increasingly well integrated into Dutch society, and there was a great deal of intellectual as well as social exchange between Christian and Jewish communities. Christian toleration of Jews did not depend on fundamental values. (A, 70)

Appiah's view of the Jews is predicated on the notion that toleration is a sign of the positive cosmopolitanism in the Ottoman Empire and early modern Holland. For him cosmopolitanism neither incorporates the contentious multiculturalism of contemporary Israel nor indeed any of the many contemporary cases in which global toleration bumps up against resurgent local prejudice concerning the Jews (for example, contemporary Hungary). Rather he draws on the distant and mythic world of historical Jewry for his proof. Thus these Jews come to be the sign of a world in cosmopolitan harmony in Appiah's account. Yet given the complex history of the so-called Golden Age of Spain, harmony may not be a particularly apt term. This account of the Iberian Golden Age is a fantasy created by Central European Jews in the mid-nineteenth century striving to find a model of utopian integration into the evolving European nation-states. Rembrandt's Amsterdam is no less fraught with its complex internecine conflicts among Jews (such as Spinoza's earlier excommunication) and between Jews and their Protestant neighbors, given that the drive to open England to Jewish migration from Holland was begun by these Jews. Appiah's model is, if anything, utopian, at least when it comes to the idealized history of the Jews in his concept of cosmopolitanism.

Yet Appiah's view of Jewish cosmopolitanism and the Jews as embodying a successful cosmopolitan moment constitutes a clear counterpoint to the idea 
that the Jews defined the corrosive cosmopolitan element and thus were inimical to the nation-state. The latter view climaxed under National Socialism and later Stalinism. As National Socialist ideologue Alfred Rosenberg claimed in a I935 talk,

Marx recognized that the age of technology had descended upon the world and that this required an attendant maturation of the social framework. He, along with his followers, an international swarm of Jewish orators and literati from the cosmopolitan centers of increasingly racially degenerate cities, got together to formulate a set of social tenets for the despairing victims of an age who are so estranged from land and landscape as to have been stripped of the standards for judging this disastrous doctrine of doom. ${ }^{41}$

Rosenberg's idea of Jewish cosmopolitanism is the antithesis of Appiah's, and the fulcrum that makes them so radically different is striking. Rosenberg assumes that cosmopolitanism in his moment is rooted in the economic function attributed to stereotypical Jews in his fantasy of mid-twentieth-century Europe. Marxist-Leninist ideology uses the term in much the same manner. Appiah avoids any possible discussion of the stereotyped role of the Jews as an economic factor in the Ottoman Empire or in Holland and does not evoke the role of the Jews in the twenty-first century in this or indeed any other manner. For Appiah, the past is a safe haven for images of the cosmopolitan.

Jewish cosmopolitanism is contested when it is defined in terms of capital; when it is uncontested, any discussion of capital is avoided. Indeed, any discussion of the fantasies about some type of unitary definition of Jewish cosmopolitanism necessarily hangs on the meaning associated with capital and its function within the new nation-state. The fantasy of the Jews is that of a people or nation or race driven solely by their own economic motivation. It is Shylock's curse that historian Derek Penslar so elegantly presents as a core reference for Jewish identity in modernity. ${ }^{42}$ But this modernity is indeed what Zygmunt Bauman has called "liquid modernity," a modernity ever up for renegotiation and rethinking, especially by those caught up in it and formed by its conflicts. ${ }^{43}$

Richard Wolin has argued that modernity itself, in its contemporary form, benefits from a new (if utopian) cosmopolitanism. His claim that today the notion of a "Western sovereignty has been permanently decentered. The rhetoric and the commonplaces of European hegemony-moral, historical, and technological—can no longer be parroted naively." He sees undermining "the relationship between Self and Other, subject and subaltern" as central, "even in 
instances where such discursive transformations have become merely perfunctory or obligatory (as is often the case with contemporary global elites)." "In this sense," he continues, "the West, too, has become the beneficiary of a new cosmopolitanism that has constructively challenged the insularities of ethnocentrism in Europe, North America, and elsewhere. In this sense, the Other has helped liberate the Western Self from the constraints of its own complacency, from the constrictions of its own self-referentiality." 44

The notion that this "new cosmopolitanism" is a tool to confront the problems of historical particularism is inherent in the history of the claims of the cosmopolitan. By confronting and thus transcending the local through claims on the universal, the cosmopolitan, according to Wolin, comes to define modernity. Central to the argument of this book is this claim that transcendence in the present and in the past is to a great degree a poisoned chalice.

Benedict Anderson argues in Imagined Communities: Reflections on the Origin and Spread of Nationalism (1983) that the image of the modern nationstate is "fully, flatly, and evenly operative over each square centimetre of a legally demarcated territory. But in the older imagining, where states were defined by centres, borders were porous and indistinct, and sovereignties faded imperceptibly into one another." Beginning in the seventeenth century, the automatic legitimacy of the sacred monarchy in Western Europe began to decline. As late as I9I4, dynastic states remained a majority, but they were already using the idea of the nation, rather than the sacred principle, as a source of legitimacy. ${ }^{45}$ Such nation-states had to deal with those who did not fit the new model but could have been accommodated in the older one.

Thus Anderson, like Appiah, turns to the Iberian experience of the Jews, whose integration into the collective nation-state Anderson sees in terms of the older imperial model as imagined in "Portugal, earliest of Europe's planetary conquerors, [which] provides an apt illustration of this point. In the last decade of the fifteenth century Dom Manuel I could still solve his 'Jewish question' by mass, forcible conversion - perhaps the last European ruler to find this solution both satisfactory and "natural." ${ }^{45}$ There is no idea of a Golden Age here: forced conversion is a model for integration, even though we know that such converts were then targeted by the Inquisition as false Christians, whatever their actual beliefs. The doubts about the efficacy of such conversions for Dom Manuel I (and the other Iberian monarchs of the early modern period) was the role that the Jews played in the newly evolving world of capital and exchange. As long as they were imagined to fulfill this role, no matter what their religious practices or social realities, they remained Jews in the eyes of the authorities. This is lost on Anderson. ${ }^{47}$ 
As with other modern concepts such as multiculturalism, the Jews as an abstract and as a social reality come to be the proof through which these notions' potential and difficulties can be analyzed. ${ }^{48}$ When cosmopolitanism is examined under this lens, we have a double focus: first, the role that the abstraction the Jews played in formulating theories of the acceptability of or dangers in the movement of peoples beyond and across national boundaries; and, second, the response of actual individuals who define themselves as Jews to such attitudes and meanings. This idea is a forerunner of what British scholar of geography Ulrike Vieten calls the "novel form of regional cosmopolitanism [that] is underway in Europe." 49 But it has deeper historical roots. As the meanings of all of these concepts (cosmopolitanism, boundary, Jews, as well as capital) shift and evolve, so too do the responses of those generating them and seeing them as applicable or inapplicable to their particular circumstances.

\section{Nomads, Gypsies, Jews}

The Enlightenment had an alternative manner of speaking about the Jews as a people that offers a different history of the concept of cosmopolitanism. For Christian Enlightenment thinkers, cosmopolitanism was the hallmark of the Enlightened subject rooted in a particularist universality. Jews, confined to their backward particularity, could not, by definition, achieve this status. They were simply nomads out of time and space. Contemporary theories of nomadism, like those of cosmopolitanism, attempt to recuperate the term from its negative associations in National Socialist ideology. In I933 publicist Eberhard Freidank stressed that the cosmopolitanism of the "November criminals" (that is, the Weimar state) was innately foreign to the Aryan. "For many years, Michel [the prototypical German] was happy to be seen as cosmopolitan; the spiritual fruits borne of such breeding ground were hardly recognizable as expressions of a pure German nature, much in the same way the myriad foreign influences to which the German has been subjected since time immemorial, among other things the alien religious circle once foist upon us, made it difficult to discern between what was foreign and what was ours." As a result "a swelling antisemitic movement, the expression of a healthy German drive for self-preservation, sought to rein in the raging Jewish incursion." 50 This incursion by intellectual nomads is now understood as the antithesis of the pure German spirit.

In contrast to these defamations, a romanticized vision of the nomad prevails in today's academic discourse on globalization and cultural difference. This new vision takes its central cues from Gilles Deleuze and Félix Guattari's 
rehabilitation of the nomad in their Mille Plateaux (1980; A Thousand Plateaus, 1987). As with Appiah's cosmopolitanism, this work resuscitates a corrupted concept to answer its misuse in European nationalistic discourse. Deleuze and Guattari's nomad, never actually defined, is the liminal and the anxiety-provoking, the unsettled in a world of supposed settlement. But it is a state of ethical being rather than a being unless that being is the oft-cited Prague Jewish writer Franz Kafka. In such a world in flux,

Jews, Gypsies, etc., may constitute minorities under certain conditions, but that in itself does not make them becomings. ... [E]ven the Jews must become-Jewish (it certainly takes more than a state). If this is the case then becoming Jewish affects the non-Jew as much as the Jew. . . A becoming-minoritanian exists only by virtue of a deterritorialized medium and subject that are like its elements. ${ }^{51}$

This is a version of Jean-Paul Sartre's idea of the Jew as a label based on outside perception rather than an ethnic or religious category. ${ }^{52}$ The nomad is the new subject for the late twentieth century that resists centralization and is the key to a modern deterritorialized state that moves and flows, becoming reterritorialized as it changes over time. The nomad is the new world citizen, not quite Jewish enough when only a Jew with a new nation. But to create this new nomad, Deleuze and Guattari must distance the idea from any thought of the National Socialist notion of the Jew as moneylender and capitalist, even in a work saturated with Marxist assumptions.

After A Thousand Plateaus, nomadism suddenly became the new cosmopolitanism..$^{53}$ Australian philosopher Paul Patton's nomadism is an answer to the claims of a state philosophy that

pretends to universality, even when its concerns are the most particular, providing the theoretical foundations for existing orders of temporal power. ... The real alternative is not the position of the mystical Other of state philosophy, the relativist for whom all distinction is impossible and nothing is any better than anything else, but that of the nomad-not so much the member of a tribe as an activist in a movement, a militant on behalf of an avowedly partial perspective. Above all, it is the relation to theoretical space that is not the same. ${ }^{54}$

Here, unlike in his French source, the Jews are completely missing. We are all nomads, according to this view, in the sense that when we leave or are 
forced to leave the symbolic space of the nation-state we become cosmopolitan. Similarly, Rosi Braidotti's Nomadic Subjects invokes the concept of the nomadic to theorize the "nonunitary subject" in the current context of "global hybridity." 55 This state, Braidotti argues, arises from the fragmenting power of advanced capitalism, which requires a search for new analytical tools that cut across the formerly fixed lines of scholarly subjects. The feminist academic becomes the privileged site of this "nomadic subjectivity" and its quest for "a creative alternative space of becoming that would fall not between the mobile/ immobile, the resident/foreigner distinction, but within all these categories" $(\mathrm{B}, 7)$. Through this embodied and situated subject in becoming, Braidotti wishes to disrupt the traditional binaries of margins and centers, home and belonging, and instead to pose "an act of resistance against methodological nationalism and a critique of Eurocentrism from within" $(\mathrm{B}, 7)$.

Despite owing a debt to Deleuze and Guattari, neither Patton nor Braidotti discusses the Jewish predicament at any length. While Patton elides the Jews altogether, Braidotti references "the woman, the Jew, or the black" as "certainly 'different' from the figuration of human subjectivity based on masculinity, whiteness, and Christian values that dominates our scientific thinking" (B, 242). Also missing here, however, is a critical awareness of the historical concept of the nomad and of the image of the Jews within it. Taking this concept into account, of course, would inevitably have made Braidotti's resignification of the concept more complex and problematic.

Patton's and to a large extent Braidotti's elisions of the Jews are all the more remarkable given that during the latter half of the twentieth century, the nomadic state has generally been associated with the diaspora of European Jewry fleeing National Socialism. As early as I95I, Theodor Adorno, having returned to Frankfurt from exile in California, claimed in Minima Moralia that "dwelling, in the proper sense, is now impossible. The traditional residences we grew up in have grown intolerable . . the house is past . . it is part of morality not to be home in one's home." 56 With great irony, such a sense of the modern nomad turns all cosmopolitans into Jews, in the same way that after World War II and the Holocaust, German-language writers such as Alfred Andersch in his novel Zanzibar; or, The Last Reason (1957) and Max Frisch in his drama Andorra (I96I) turned the actual experience of Jews during the Holocaust into the symbolic representation of the cosmopolitan sacrificial victim. By the I990s, Edward Said, citing Adorno's Minima Moralia, concludes "Reflections on Exile" with the universal claim that "exile is life led outside habitual order. It is nomadic, decentred, contrapuntal; but no sooner does one get accustomed to it than its unsettling force erupts anew." 57 Well it may, but the link between the 
nomadic and the exilic have deeper and much more unsettling roots in the debates about Jewish cosmopolitanism, which are effaced in Said's text.

These postwar writers demonstrate little awareness of historic uses of the nomad prior to Goebbels's account and its mid-twentieth-century recuperation. This is found in the overlapping history of the Sinti and Roma and the Jews. Some early German commentators, such as W. E. Tentzel at the close of the seventeenth century, correctly argued that the "Gypsies" had come from South Asia even if those commentators were uncertain of the exact origins (Tenzel guessed Ceylon, today's Sri Lanka). ${ }^{58}$ However, those theologians who focused on converting the Jews looked closer to home. Christian Hebraist Johann Christoph Wagenseil claimed in his Benachrichtigungen Wegen Einiger die Gemeine Jüdischheit Betreffenden Sachen (I705) that the first Gypsies ("Zigeuner") were indeed Jews who fled into the forests in the fourteenth century after having been accused of poisoning wells. Claiming that they had come from Egypt, these Gypsies cheated the peasants there by alleging that they had the power to effect wondrous cures, tell the future, and prevent fires. The Gypsies eventually returned to the cities, again became sedentary, and declared themselves Jews. But thieves and beggars had joined the group and continued their nomadic ways. As proof, Wagenseil declared that the Gypsies were unknown before the fourteenth century, that the Gypsy language was full of Hebrew words, and that their amulets used Kabbalistic formulas. ${ }^{59}$ Johann Jakob Schudt's infamous Jüdische Merckwürdigkeiten (I7I4) includes a long chapter that argues that Wagenseil was simply wrong and that the Jews were condemned to their wanderings in Egypt for having rejected Jesus and Mary on the flight to Egypt. ${ }^{60} \mathrm{He}$ follows this with a long digression on the Eternal Jew, the shoemaker Ahasverus (Cartaphilus), whose rejection of Christ led the savior to condemn Ahasverus to wander the world, learning the language of each country he visits (Sc, 502), until the Second Coming. According to Schudt, the Jews, like the Turks, are "sanctimonious cheats" because of their usury (Sc, 504). The economic role of the Jews as pseudo-nomads is integral to these contradictory images. Whether authentic or not, the Jews are nomadic in the same way as the Sinti and Roma, even if they are not "Gypsies" per se.

The Enlightenment saw nomads as failing to productively use their given space. As early as the mid-eighteenth century, Goethe's Wilhelm Meister presented the nomad through the lens of the colonist, explaining why Germans seek adventures abroad. The novel's protagonist, Lenardo, speaks of the enticement of "immeasurable spaces [that] lie open to action" and have "great stretches of country roamed by nomads." ${ }^{\prime 61}$ In the present, nomads have no value and must be replaced by those who do, but this is a false promise that 
may lead to the corrosion of the Europeans' national identity. Here, Goethe loosely follows Immanuel Kant's Conjectural Beginning of Human History (I786), which sees the nomad as an idealized stage of human development that is possible as long as there is little competition for resources. ${ }^{62}$ It is a leisurely life that, unlike agriculture, is not toilsome. The nomads deplore the ownership of land that comes with the rise of agricultural society, since it limits their ability to graze their flocks. Yet these flocks damage the hard-won crops and force farmers to protect their fields and thus move into settlements. With the movement to settlements that is the result of agriculture, Kant claims, the centrality of the deity gives way to the authority of the ruler. His example is the Bedouins, who even today willingly abandon the leadership of their putative tribe and join another since no property is at stake in such an action. ${ }^{63}$ Pastoral life, for Kant, is a necessary but transient stage of societal development ill suited for the modern, rational society that follows. The Jews do not figure in Kant's argument, since he sees them merely as a political and legal community rather than a religion and thus brackets Judaism as having no essential connection to the one universal religion, Christianity.

In this Enlightenment view, nomads add no value to the land today and thus seem to need to be replaced by members of a national community. But these nomads were the starting point for the nation-state and for its most egregious exploitative feature, capital. Karl Marx wrote in Capital that "nomad races are the first to develop the money form, because all their worldly goods consist of moveable objects and are therefore directly alienable; and because their mode of life, by continually bringing them into contact with foreign communities, solicits the exchange of products." ${ }^{64}$ The nomad is implicitly cast as the ur-capitalist, the Jew, whose drive in the modern world is shaped by his inheritance from the desert. (This is also analogous to the explanation for the rise of monotheism among the Jews: the need for a portable God after the destruction of the Temple. $)^{65}$

In contrast to Marx, Georg Simmel explains in the Philosophy of Money (I900) that "as a rule, nomadic peoples hold land as common property of the tribe and assign it only for the use of individual families; but livestock is always the private property of these families. As far as we know, the nomadic tribe has never been communistic with regard to cattle as property. In many other societies too movables were already private property while land remained common property for a long period thereafter." 66 Not so much ur-capitalists as ur-communists, perhaps?

Two decades earlier, Russian Zionist Leon Pinsker argued in his German-language pamphlet, Auto-Emancipation (I882), that the Jew's state- 
lessness in the age of nationalism condemned him to be a nomad. For the Jewish people produce

in accordance with [their] nature, vagrant nomads; so long as [they] cannot give a satisfactory account of whence [they come] and whither [they go]; so long as the Jews themselves prefer not to speak in Aryan society of their Semitic descent and prefer not to be reminded of it; so long as they are persecuted, tolerated, protected or emancipated, the stigma attached to this people, which forces [them] into an undesirable isolation from all nations, cannot be removed by any sort of legal emancipation. ${ }^{67}$

For Pinsker, these are nomads living as "Jew peddlers" because they refuse to acknowledge their rootedness in the desert as true nomads. At the same time, the diaspora has conditioned the absence of a Jewish national state and made the Jews into cosmopolitans:

The Jews are not a nation because they lack a certain distinctive national character, inherent in all other nations, which is formed by common residence in a single state. It was clearly impossible for this national character to be developed in the Diaspora; the Jews seem rather to have lost all remembrance of their former home. Thanks to their ready adaptability, they have all the more easily acquired characteristics, not inborn, of the people among whom fate has thrown them. Often to please their protectors, they recommend their traditional individuality entirely. They acquired or persuaded themselves into certain cosmopolitan tendencies, which could no more appeal to others than bring satisfaction to themselves. ${ }^{68}$

Unlike Enlightenment German theologians such as J. G. Herder (discussed in chapter 2) who see the Jews as less adaptable because of the coherence of their religious practice, Pinsker sees them as highly adaptable and thus lacking that "natural" coherence that Herder saw as essential to the nationstate. For Pinsker, as for most pre-Holocaust writers, this is an imperfect state. To become Jews again, Pinsker maintains, the Jews must regain their former national identity. The counter to this idea in the age of integration, Bavarian reform rabbi Kaufmann Kohler argued in defense of the Jews in I88I, is to see the Jew as "a true cosmopolitan, but only disgusting and uncomfortable to those authorities who wish to rule and dominate with blood and iron, who destroy freedom, support bigoted hypocrisy and wish to corrupt eternal human rights"- that is, to the new German nationalism of Bismarck and his anti- 
Catholic politics. ${ }^{69}$ Pinsker argues in favor of Jewish nationalism, which rescues the Jews from their nomadism, whereas Kohler privileges Jewish cosmopolitanism as a sign of Jewish universalism. By and large, however, Jewish writers evoked the concept of race, that science of the time, to propose a Jewish nationalism that was both particularist and universal. As an anonymous author wrote in the influential Jüdische Monatsschrift,

The Jewish race alone has the capacity to dwell in every portion of the earth, to reproduce and to develop without abandoning its racial specificity, but also in healthier circumstances than the indigenous population. . . . One can see in this the promise of God that Israel will spread to the limits of the world. ${ }^{70}$

Here and elsewhere, Jewish racial identity thus provides the key to an understanding of the Jews' cosmopolitanism. Ironically, at the same moment, Friedrich Nietzsche, who in Beyond Good and Evil ( I 886) saw the Jews as the strongest people in Europe because of their constant persecution, condemns in The Antichrist ( I 888) the Christian appropriation of the Jewish God by Paul as creating as weak, global, boring God who "will become modest and full of fear, he will cringe in corners and recommend 'peace of soul.' Forbearance, an end to hatred, and 'love of friends and enemies.' He will constantly moralize, he will creep into the crevices of private virtue, he will be a god for one and all, a private and cosmopolitan god." Prior to this, God had been the God of the Jews, "the strength of a people, all aggression and thirst for power in the soul of a people."71 For Nietzsche, the corruption of Pauline Christianity leads to such ubiquitous, shallow cosmopolitanism. The Jews may have many faults, but this is not one of them.

If the nation-state has its roots in a nomadic world before capital, and if the cosmopolitan symbolically represents the dangers (and advantages) of capital, we can turn to a major Jewish thinker of the late nineteenth century for a sense of the linkage between the two concepts. Ignaz Goldziher (I850-I92 I), a great Jewish Hungarian scholar of Islam, published a detailed I876 study of the constitution of Jewish mythology that adds further nuance to our sense of the ambivalent image of the cosmopolitan hovering between advantage and danger. ${ }^{72}$ For Goldziher, "The national level [of Jewish mythopoeia] can be sorted out of the mix. It was Abraham, not yet rethinking these tales in national terms, who was not yet a cosmopolitan figure but an individual," who formed these tales $(\mathrm{G}, 59)$. In this portrayal of the biblical Abraham, individuality (the particular) and cosmopolitanism (the universal) are portrayed as dichotomous. 
Abraham is an individual, not a cosmopolitan, for he is part of "the nomadic level that found its element in a continual wandering from grazing pasture to grazing pasture, in the continual changing of their abode, before it was historically grounded in the completion of its movement to agriculture" (G, 64). Like the Arabs, whom Goldziher idealizes, the Jews (here he cites Philo) "glorify their nomadic life" (G, I03). The Jews detest artisan labor, no matter how intense "their desire for money," as beneath their status as nomads (G, I05). They are thus inherently different in their storytelling from the ancient Greeks and the Aryan inhabitants of South Asia:

The Hellenes and the Indians have their primary figures of myth being of a cosmopolitan character, for Zeus and Indira have no specific national character, even though now and then they are specifically local. The figures of Hebrew myth in this period become the national ancestors of the Hebrew people, where myth is raised to become the national prehistory of the Hebrew people before its settlement in the land of Canaan. $(\mathrm{G}, 306)$

Here, the national and the cosmopolitan appear diametrically opposed. Jewish tales are restrictedly national and local rather than cosmopolitan and global. They are the product of the world of the nomad, at least as imagined from the point of view of the biblical national Jewish state, which remained local, unlike the transcendental worlds of Greece and India.

Nomadism is also pressed into service to explain the origin of the Jews' "natural" relationship to cosmopolitanism and to capital. One of the most quoted academic antisemites of the late nineteenth century, blind socialist economist and philosopher Eugen Dühring, echoed in I88 I the notion that the Jews were both nomads and gypsies as the core of their economic role in the West: "The Jews' skull is certainly not that of a thinker. The Lord God and business have since ancient times taken up much to much room there in, as much as it is not empty. . . . With such an armament these nomads, and, as Voltaire called them, these Gypsies from Palestine have forced their way to our tables in the North to mock and tease us."73 More centrally, another Berlin economist, Werner Sombart, in his classic response to Max Weber's The Protestant Ethic and the Spirit of Capitalism (I905), wrote in The Jews and Modern Capitalism (I9I I) of the "restless wandering Bedouins [who] were the Hebrews," who established in "this promised land" an "economic organization" where "the powerful and mighty among them after having conquered large tracts of land instituted a sort of feudal society. Part of the produce of the land they took for themselves, either by way of rent in kind, by farming it out 
to tax-collectors, or by means of the credit nexus."74 In other words, the Jews were protocapitalists of a particularly nasty kind - the origin of the stereotyped Jewish banker in the world of the nomad. For Sombart, contemporary Jews represent an extension of the earlier nomad as far as their character and relationship to capital are concerned. ${ }^{75}$

Weber argues against such a view in Ancient Judaism (I920-2 I). ${ }^{76} \mathrm{He}$ accepts the existence of a narrative (but not historical) succession of "the stages of the three Patriarchs from the 'nomad' Abraham to the 'peasant' Jacob" (W, 438). However, he refutes the idea that the nature of Jewish usury stems from any biblical claims to divine approbation in Deuteronomy 28:43-44: "The medieval and modern money and pawn usury of the Jews, the caricature in which this promise was fulfilled, was certainly not intended by the holy promise."77 Rather, Weber reads Jewish usury as symbolizing the triumph of city over countryside, "which prevailed in every typical polis throughout early Antiquity from Sumerian-Accadian times" (W, 69). While a quality of the urbanized Jews, usury as practiced by them is no different from the manner by which it was undertaken elsewhere in the cosmopolitan world of the ancient city. Such cities created their own myth of a pure origin in an agrarian settlement that existed without incipient capitalism.

Weber is not alone, of course. R. H. Tawney in 1926 rejected the notion that the Jews, as cosmopolitans, are the origin of capitalism. ${ }^{78}$ Yet he was not exactly friendly to the idea of the Jews in history. He dismissed Calvin as "legalistic, mechanical, without imagination or passion. . . Calvin's system was more Roman than Catholic, more Jewish than either" (T, I3I). The rise of capitalism stemmed from Catholic Florence, where usury was forbidden and lenders punished. The city imported Jews in the early fifteenth century "to conduct a business forbidden to Christians" (T, 37). For Tawney, this movement of the Jews is cosmopolitan but not nomadic, and he sees cosmopolitanism as a productive quality of rising nationalism and capitalism: "Of that cosmopolitan country, destined to be the refuge of the international idea when outlawed by every other power in Europe, Antwerp, 'a home common to all nations,' was the most cosmopolitan city" ( $\mathrm{T}, 73)$. The fine line between the nature of the Jews and the nature of capital is drawn, and the Jews, as Weber also maintained, are freed of the onus of capital but not of their innate nature.

The Jews are nomads according to the theology of the German Enlightenment (as chapter 2 shows), and the essence of the Jew is captured by his nomadism in the present-day world of the nineteenth-century pan-European antisemite. In Foundations of the Nineteenth Century (I9I2), the seminal antisemitic work by Richard Wagner's son-in-law, Houston Stewart Chamber- 
lain, the history of the Jew in the distant past is again the history of the Jew today: "Of all the histories of the ancient world there is none that is more convincing, none more easily to be realized, than that of the wanderings of the patriarch Abraham. It is a story of four thousand years ago, it is a story of yesterday, it is a story of today." But it is the history of a degenerate people, Chamberlain argues, for

any change in the manner of living is said to have a very bad effect on the high qualities of the genuine and purely Semitic nomads. The learned [A. H.] Sayce, one of the greatest advocates of the Jews at the present day, writes: "If the Bedouin of the desert chooses a settled life, he, as a rule, unites in himself all the vices of the nomad and of the peasant. Lazy, deceitful, cruel, greedy, cowardly, he is rightly regarded by all nations as the scum of mankind."79

And it is the history of an impure race as well: "As a matter of fact the current opinion is that the Semite and even that purest Bedouin type are the most absolute mongrels imaginable, the product of a cross between negro and white man!"80 Mixed races, Chamberlain suggests, have no spaces left for them, so they simply wander. As early as I887, Austrian-German Orientalist Adolf Wahrmund had cast the Jew as nomad as the essential capitalist:

Thus we have the typical image of the private enterprise of the nomad that continues to today, in the form of the wandering merchants and dealers who cross the land selling junk, stocks, and . . . thus rob our peasants and return on the Sabbath with their plunder home to wife and children. ${ }^{81}$

The nature of capitalism is that of the "parasitic" nomad and is the essential nature of the Jew. However, the Jews are not very good nomads insofar as they violate one version of the Enlightenment's underlying assumptions concerning the claims of cosmopolitanism: the Greek concept of xenia, guest friendship. As German journalist Otto Gildemeister noted in I92 I, "Even the highest law regarding the safety of the stranger is not recognized by these nomads. Thus the Jewess Jael murders Sisera after having been tempted into a tent and served milk. Trusting her he goes to sleep. Then Jael drives a stake into his temple and mocks his mother when she comes to seek her son." ${ }^{\text {"1 }}$ Beginning in the Enlightenment, "true nomads" are ideals against which the Jews are often set. ${ }^{83}$ Indeed, the ancient Jews violate the rules of many of the nomads described in Lebensraum theorist Friedrich Ratzel's History of Mankind (I896), where the Jews are seen as originally 
nomads like their kinsmen in Arabia and Syria. . . . Their oldest books know nothing of fixed altars and their sacrifices are always of cattle. They took to a settled life on conquering and dividing the land of Canaan. But the promised land was only an oasis. . . The misfortunes of the national ruin, however, brought about a purification, which in a race aesthetically deficient, but spiritually proud and austere, tended to strengthen the conception of a deity all powerful and all-knowing, and at the same time jealous and severe. ${ }^{84}$

It is only through "contact with the Greeks, fundamentally Aryan, yet touched by a Semitic spirit, who, independently of the Jews, had gone through a process of spiritual refinement in the direction of truth, knowledge, and beauty, [that] Christianity developed into a power capable of transforming races" ( $\mathrm{R}, 547)$. The Jews' only value derives from qualities that were filtered through Greek sensibility and contributed to the creation of a modern consciousness. For Ratzel, the Jews' initial contribution to Western culture may have been a sort of primitive monotheism (as opposed to Christianity), but their long-term impact is on "above all the economic life of other nations" $(R, 548)$.

The impact of such late-nineteenth-century discussions of Jewish nomadism as a permanent reflex of Jewish character becomes part of the romantic restatement of Jewish character among early Zionists. "You say," they paraphrase, "that we are of the desert. We agree, but we are not and never have been nomads. We are the descendants of the makers of empires and the builders of cities." It is no wonder that Max Brod, writing in Buber's periodical, The Jew, in I9I6, complained, "One should not inject us with being a centrifugal force in society and then marvel at the findings of 'nomadism' and 'critical destruction' in our corpse." 85 This internalization of the cosmopolitan and the nomad has come to define the Jew in the post-Enlightenment world, even into the twenty-first century. But the Zionists and their allies see themselves as defined not by the Jewish nomad, the Jewish cosmopolitan, but by the Jewish nationalist. Others at the time, however, believed that the Jews were terrible at being nomads because, well, they were Jews. As Adolf Hitler stated baldly in Mein Kampf, echoing his reading of Chamberlain,

Since the Jew never possessed a state with definite territorial limits and therefore never called a culture his own, the conception arose that this was a people that should be reckoned among the ranks of the nomads. This is a fallacy as great as it is dangerous. The nomad does possess a definitely limited living space; only he does not cultivate it like a sedentary peasant, but lives from the yield of his herds with which he wanders about in his 
territory. The outward reason for this is to be found in the small fertility of a soil that simply does not permit of settlement. The deeper cause, however, lies in the disparity between the technical culture of an age or people and the natural poverty of a living space. ${ }^{86}$

The Jews are only symbolic nomads in the modern world. That the Jews are nomads in this pejorative sense means that they are parasites on settled, non-nomadic national peoples. Echoing Wagner's claim that the Jews lack the ability to create original art, psychologist C. G. Jung stated in a I934 lecture in Hitler's Berlin,

The Jew who is something of a nomad, has never yet created a cultural form of his own, and as far as we can see never will, since all his instincts and talents require a more or less civilized nation to act as a host for their development. Aside from certain creative individuals, the average Jew is already much too conscious and differentiated to be pregnant with the tensions of the unborn future. The Aryan unconscious has a higher potential than the Jewish; that is the advantage and the disadvantage of a youthfulness not yet fully estranged from barbarism. ${ }^{87}$

It is not what one does but who one is that defines the nomad, defines the cosmopolitan, symbolizing the role that identity is seen as playing in the world one inhabits.

\section{Jews and the Nation-State}

In the Enlightenment game of cosmopolitanism, the Jews as a category take on symbolic value in the new game of national definition, as William Bloom states concerning the function of related images. This symbolic function comes to define "national identity . . that paradigm condition in which a mass of people have made the same identification with the national symbols-have internalized the symbols of the nation - so that they may act as one psychological group when there is a threat to, or the possibility of the enhancement of, these symbols of national identity." 88 This national symbolic language is not necessarily one of affirmation but of definition. Precisely because of this quality, the Jews serve both as a negative symbol defined by their perceived cosmopolitanism and as, in fewer cases, a positive symbol of a national cosmopolitanism. 
According to Bloom, "The nation-state into which the infant is born as citizen is in a state of permanent competition with its international environment. Other countries are competitors in the great international game." 89 How the Jews are figured in this game of opposites is central to any consideration of the shifting meanings of cosmopolitanism.

As Appiah and virtually all other contemporary theorists who write on cosmopolitanism acknowledge, the term has ancient classical roots in Greek thought and practice. However, both our and their understanding of the world of Greece and Rome is also a product of the Enlightenment. The reality is that cosmopolitanism as a concept is truly the product of the European Enlightenment and its constantly debated category of l'homme, the human being. Central to that definition is the relationship of the individual to the state and to the definition of state economy. The Encyclopédie (I75I-72) acknowledges in "Cosmopolitain, ou Cosmopolite," that the cosmopolitan was often used to signify a "man of no fixed abode, or a man who is nowhere a stranger." 90 The Encyclopédie's essay on the Jews, provides an account that uses an economic factor to explain the Jews' cosmopolitanism. Louis, Chevalier de Jaucourt, states that the persecution of the Jews by Christian states forced them into usury:

These ordinances, and other similar ones, tie them most tightly together, fortify them in their belief, separate them from other human beings, and leave them for their subsistence only commerce, a profession long disdained by the majority of the peoples of Europe. It is for this reason that this profession was left to them during the centuries of barbarism; and as they necessarily enriched themselves through it, they were called infamous usurers. Kings who could not go through the pockets of their subjects tortured the Jews, whom they did not regard as citizens. ${ }^{91}$

But, according to Jaucourt, in the Enlightened world of Europe, the

princes have opened their eyes to their own interests and treated the Jews with greater moderation. They have sensed, in some parts of the north and south, that they could not do without their help. But (without speaking of the Grand Duke of Tuscany) Holland and England, which are animated by the noblest principles, have accorded them every possible mild treatment under the invariable protection of their governments. Thus dispersed in our day with the greatest security they have ever had in every country in Europe where commerce reigns, they have become instruments by means 
of which the most distant nations can converse and correspond together. They have become like the pegs and nails that one uses in a great building, and which are necessary to join all of its parts. ${ }^{92}$

Jews, now defined by their relationship to capital, are seen as the models for the new cosmopolitanism advocated by the Abbé Grégoire. The Jews as an abstraction come to function as the limit case of what is possible to understand and debate within the concept of the cosmopolitan. As Benedict Anderson argued, not only did the Enlightenment see the creation of the idea of the nationstate, but such nations are, in his oft-cited formulation, "an imagined political community — and imagined as both inherently limited and sovereign . . . because the members of even the smallest nation will never know most of their fellow-members, meet them, or even hear of them, yet in the minds of each lives the image of their communion." ${ }^{93}$ The function of the image of the Jews in this symbolic realm, prefigured by their similar function in the world of medieval Europe (following Johan Huizinga's understanding of the symbolic meaning of medieval hierarchies), means that the Jews continue to define the boundaries of who is included within that sense of community that defines cosmopolitanism as a positive or a negative factor.

The concepts of cosmopolitanism and nomadism take on quite different meanings when the index is the Jews-in particular, when they are symbolically defined by capital. Such a history points toward the ambivalence of these concepts when applied in our day to specific categories-the Jew, the asylum seeker, the migrant, the illegal, the undocumented. This study examines how these labels come to be both internalized and developed by cultural producers who understand themselves as Jewish from the Enlightenment states that subsequently became Germany and those of the imperial state and republic that has its capital in Vienna. Our view extends then to the diasporic situation, another means of understanding cosmopolitanism and nomadism, under and following National Socialist domination of these nation-states. We conclude with an examination of the implications of this phenomenon in a contemporary Israeli context informed by the ideological debates surrounding Zionism and diaspora, as cultural producers deal with Jews from lands other than Europe and migrants, legal and illegal, whose identity comes to be Israeli or indeed cosmopolitan but not just Jewish. 


\section{Moving About: Cosmopolitanism from Jews in Coaches to Jews on Trains}

\section{The Enlightenment Imagines Cosmopolitan Jews}

In I749, Gotthold Ephraim Lessing, a German Protestant gadfly and author, wrote a one-act comedy, The Jews. ${ }^{1}$ Short, pithy, enlightened, it tells the story of robbers masquerading as Jews and a Jew incognito as a Traveler who rescues the Baron and his daughter from the robbers. Lessing's Traveler is the paradigm of Enlightened cosmopolitan gentility and courtesy, a model of the new bourgeois gentleman later sketched by the Mr. Manners of his day, Adolf Freiherr von Knigge (I752-96), whose handbook of correct behavior, Practical Philosophy of Social Life (Über den Umgang mit Menschen, I788), became and remains the German best seller on social etiquette. ${ }^{2}$ It provides a measure of what economic success looks like when the bourgeoisie have access to resources hitherto limited to the upper classes. Thus, traveling in a carriage with livery has become so middle class by the I780s that Knigge observes that it is "an uncommon phenomenon to see a gentleman travelling on foot; as it excites the curiosity of the multitude, and innkeepers know not how to treat him" (K, 23I). For "travelling renders us sociable; we get acquainted, and in a certain degree intimate with people whom otherwise we probably should not have chosen for companions, which can produce not bad consequences if we carefully avoid putting too much confidence in those strangers we meet on the road, lest we should be taken in by adventurers and knaves" (K, 224). Or even Jewish adventurers and knaves. ${ }^{3}$

The Enlightened man is gracious, generous, and brave, as Lessing's Traveler remarks:

It's no small pleasure for me that I've earned the thanks of so many decent people with such a slight service. Your gratitude is more reward than I need for what I did. I did it because I had to, because I care for people. I 
felt it was my duty, and I would be content if it weren't taken as anything else. You are too kind, dear people, to thank me for what you yourselves would undoubtedly have done with just as much zeal if I had been in a similar danger. ${ }^{4}$

Here we have a far cry from Knigge's warning about the new bourgeoisie and their anxiety about dealing with strangers, especially Jews. For though "at Berlin, many Jewish families cannot be distinguished in the least from those that belong to other religious sects" (K, 3I5): "It is necessary we should look very sharp in all our dealings with Hebrews of the common class. It is natural that a Christian should not rely upon their conscientiousness and solemn protestations." 5 Jews are entering the bourgeoisie, Knigge warns, and they are just like you and me (at least superficially); just watch out for the "common class" of Jews, who remain dangerous because they economically exploit the (Christian) middle class. ${ }^{6}$

Indeed, the Baron's invective against the Jews, which resulted from his robbery by individuals dressed as Jews, very much echoes Knigge's warning, not Lessing's sentiment. But Lessing seeks to show that this is simply a longheld belief, not a truth:

BARON. And isn't it true that they have something in their face that prejudices us against them? You can practically read it in their eyestreachery, unscrupulousness, selfishness, trickery, lying. . . . But why are you turning away from me?

TRAVELER. As I hear, sir, you are a great expert in physiognomy, and I'm afraid that mine. ...

BARON. Oh! You offend me. How could you come to such a suspicion? Without being any expert in physiognomy, I have to tell you that I've never found such a sincere, generous and pleasant face as yours. ${ }^{7}$

Prejudices, as the one philosopher that Enlighteners read on the topic, Georg Friedrich Meier, noted in I766, were always formally wrong because they were based on insufficiently grounded judgment but could be-and here the Germans are quite different from the French Enlighteners such as the Baron d'Holbach—quite accurate in their content. ${ }^{8}$ Lessing clearly would have disagreed with Meier, Thomas Abbt, and others on this point. All prejudices against the Jews vanish when we see them as human beings and define them as well-dressed people who can afford a coach ride within the carriage, not on its roof. According to Knigge, truly cosmopolitan travelers "are the citizens of the 
world at large, and feel as comfortable and as much at ease at the top of a stage coach as in a splendid chariot" (K, 3I9).

The flirtation between the Baron's daughter and the Traveler seems to seal the claim that Jewish invisibility is the key to understanding the cosmopolitan Jew as an economically acceptable human being. ${ }^{9}$ All human beings are equal, at least when correctly attired, accompanied by servants, and traveling across the landscape in a bourgeois means of transport:

TRAVELER. Excuse me, miss. I just wanted to tell my servant to get everything ready for our departure.

YOUNG LADY. What are you talking about? Your departure? When was your arrival? Granted, if you had been here for a year and a day, then a moment of melancholy might have given you such an idea. But now? Not even to stay a whole day? That's awful. I tell you I will be angry if you ever think of it again.

TRAVELER. You couldn't threaten me with anything that would hurt me more.

YOUNG LADY. No! Seriously? You mean you would be hurt if I were angry with you?

TRAVELER. Who could be indifferent to the anger of a kind woman?

Indeed, the flirtation proceeds to the point where the Baron imagines the Traveler as a son-in-law. This moves the Traveler to reveal himself as a Jew, which ends all talk of the possibility of marriage:

TRAVELER. Even this offer is of no use to me, since the God of my Fathers has given me more than I need. All I ask as my compensation is that from now on you judge my people more kindly and with less generality. If I kept myself hidden from you it isn't because I'm ashamed of my religion. No! But I saw that you had sympathy for me and antipathy for my nation. And a person's friendship, whoever he may be, has always been priceless to me.

BARON. I'm ashamed of how I acted.

Yet the social impossibility of a liaison in a world still very much defined by religion underlines the key metaphor of this story, which is the physical mobility of all, with the coach transporting the Traveler and the others being the great leveler in society. This is the Enlightenment ideal writ large. Buy a ticket, pay a fee, and you can go where you want and be whomever you care to 
be-with, of course, built-in and unspoken limitations. Here we have a set of core underpinnings of the Enlightenment, what modern historian James Joll has called in another context "unspoken assumptions": you can become what you wish to be and go where you wish to go, unless there is a supervening qualification..$^{10}$ But equality exists only among equals. Indeed, after the play was published in I754, Göttingen theologian Johann David Michaelis complained in print that the problem with Lessing's image of the Traveler was that such a version of the Jew as a German gentleman could never exist. Michaelis believed firmly that the Jews were a people of the desert, frozen in their nature as a "southern people." ${ }^{11}$ No first-class coach ticket to London, Paris, or Berlin could change that.

In 1940, the National Socialists redid this scene of the cosmopolitan or at least nomadic Jew in their most successful antisemitic film, Veit Harlan's Jud Süss. ${ }^{12}$ There, too, a Jew disguised as an eighteenth-century gentleman enters a coach with a young German woman and beguiles her with tales of travel across the world and through society. He is Joseph Süss Oppenheimer (played by Ferdinand Marian), who has tricked Karl Alexander, the Duke of Wurttemberg (played by Heinrich George), into giving him a pass so that he can enter the city of Stuttgart, forbidden to the Jews for more than a century. When we first see Oppenheimer, he appears as a ghetto Jew, with beard and side locks and the clothing associated with the ghetto. He is promising the duke economic support for frivolities such as a ballet that his economic councillors have denied. In the next scene, Oppenheimer is transformed into a traveler, clad like a gentleman, and is rescued from the side of the road after a coach accident by Dorothea Sturm (played by Kristina Söderbaum in all her blond glory). They enter the gates of the city after the guard checks that "Herr Oppenheimer, from Frankfurt" is on the list of those permitted to enter the city. As they enter the town in her coach, the naive young woman asks where he has traveled. He answers that he has been to Paris, Versailles, London, Rome, Madrid, Lisbon. When she asks where he feels most at home, he replies "Everywhere." And when she asks, "Have you no home?" he says that "the world" is his home. Everyone except the young woman, whom he will eventually rape, recognizes him as a Jew despite his attire and his entry into Stuttgart. She is amazed to learn that he is a Jew, pointing out that he was admitted through the city gates without question. After he is confronted and revealed as a Jew, it is strongly suggested that he take the next coach out of the city, since Jews were not allowed, even if they arrived by coach. Indeed, when Süss's machinations permit the nomadic Jews to enter the city, they stream in on foot, clearly dressed as Jews. Mobility - the ultimate sign of cosmopolitanism for the National Social- 
ists - is a curse, allowing Jews, with their essential gift of mimicry, to infiltrate and economically exploit German society.

The Enlightenment anxiety about mobility or its lack and the inability or ability of Jews to become cosmopolitan haunts the eighteenth century because it is the public means of demonstrating the social mobility associated with becoming cosmopolitan. The various courts from the seventeenth century on had proto-cosmopolitan Jews - the so-called Court Jews (Hoffaktoren) such as the real Joseph Süss Oppenheimer in Stuttgart, Meyer Amschel Rothschild at the Court of Wilhelm I of Hesse, and Daniel Itzig at the court of Frederick the Great. In the time they were seen as simultaneously inhabiting the world of these pocket principalities as well as the more global world of "Jewish" finance. The I906 Jewish Encyclopedia labeled these men "cosmopolitan" when ruminating on the declining world of the Jewish bankers: "Of more recent years, non-Jewish financiers have learned the same cosmopolitan method, and, on the whole, the control is now rather less than more in Jewish hands than formerly." Court Jews such as the Rothschilds are seen as typical of a "mobile, cosmopolitan minority people [that] had a genuine advantage in that early stage of banking."13 The major difference is the acknowledgment of economic as well as social mobility and the ability to move anonymously across borders and boundaries. But the Enlightenment enabled not only Jews but also members of a new, burgeoning economic class, the bourgeoisie, including (Jewish and non-Jewish) women, to be more mobile and therefore at least superficially cosmopolitan.

After Lessing wrote his play about travel and cosmopolitanism, he met the young factor of a Berlin silk weaving firm, Moses Mendelssohn, who came to fulfill Lessing's idealization of a cosmopolitan Jew. Critics today speak, for example, of "Moses Mendelssohn's religious cosmopolitanism"14 or quote Mendelssohn's rejection of any improvement of the "human race" in light of the fact that only individual humans can move toward Enlightenment. ${ }^{15}$ Yet Mendelssohn's account of his life in Berlin is hardly that of someone who has a cloak of invisibility because of the cosmopolitan nature of the society into which he has entered. Mendelssohn becomes Lessing's embodied Jew: Mendelssohn is, as he himself would have said, an individual struggling with his own Enlightenment, but he becomes a living metaphor for Jewish adaptability and the new and contradictory cosmopolitanism advocated by the avant-garde.

Mendelssohn left Dessau for Berlin in I743. ${ }^{16}$ When asked at Berlin's Rosenthaler Gate why he wanted to enter the city, he supposedly answered, stammering in pidgin German, "Learn." The sentry's log for that day in October I743 notes, "Today passed through the Rosenthaler Gate six oxen, seven pigs, 
one Jew"- not a cosmopolitan view but one that in this provincial capital was typical of the attitude toward mobility in the early eighteenth century. Mendelssohn's life in Berlin was always tenuous. He avoided getting involved, for example, in a I77I public debate between Lessing and Swiss preacher Johann Kaspar Lavater about Mendelssohn's own potential for conversion. (If Mendelssohn is really so smart, Lavater claimed, Mendelssohn should recognize the truth of Jesus as preached by Charles Bonnet and convert or refute Bonnet.) ${ }^{17}$ Even in I763, when the king of Prussia, Friedrich II (Frederick the Great), conferred on Mendelssohn the status of "a Jew under special protection," he was still not guaranteed the right to unrestricted residence. He remained unrooted in a national identity but not, as he observed, in a religious one.

Mendelssohn wrote a I784 essay on what it meant to "enlighten." ${ }^{18} \mathrm{He}$ seems to look for universals here, but they are always universals in the context of what came to be called Realpolitik. Thus, he notes that human enlightenment can often come into conflict with the demands of citizenship. Here, the question of public political cosmopolitanism - that is, the rational plurality of systems of law - and the private sphere of belief overlap. Mendelssohn's discussion of political identity implies economic identity: in a state dominated not by economic classes but by inherited status, the role of the bourgeoisie remained invisible. Indeed, the idea of "enlightenment" is fragmented: Frederick the Great's political enlightenment does not completely mesh with the claims of Lessing and others as to what Enlightenment demands. ${ }^{19}$ In Concerning the Amelioration of the Civil Status of the Jews (178I), the classic statement of Jewish emancipation, Christian Wilhelm von Dohm argued that one of the ways that the Jews could become emancipated was to give up all of their traditional associations with commerce and capital. Even though Mendelssohn disagreed with Dohm, many other Jews and non-Jews agreed that Jews needed to abandon commerce. ${ }^{20}$

If we are to examine these debates about the Jews as the touchstone of cosmopolitanism in the Enlightenment in general and specifically within the German-language Enlightenment, then the two conflicting definitions of the Jews must first be separated. First, the Jews are a people who ascribe to a particular religious belief and practice and who at least potentially can freely follow their beliefs in the new, Enlightened world of the European nation-state. Second, the Jews are seen as the concrete manifestation of the exploitative force of capital, and their rise parallels the establishment of such states.

Theologian and essayist Johann Gottfried Herder (I 744-I803) is torn between these two poles. In his Ideas for a Philosophy of the History of Mankind ( I784-9I), he defines the nation as "a group of people having a common origin 
and common institutions, including language"; the nation-state represents the union of the individual with the national community; each people is unique; polyglot entities are "absurd monsters contrary to nature." 21 The Jews must join the body politic by integrating their linguistic practice into that of the naturally occurring nation-state. But can they? According to Herder, "The Jews of Moses are properly of Palestine, outside of Palestine there can be no Jew" $(\mathrm{H}, 35 \mathrm{I})$. Yet "a time will come when no person in Europe will inquire whether a man be a Jew or a Christian. Jews will live according to European laws and contribute to the state" $(\mathrm{H}, 486)$. Nevertheless, "each nation has its center of happiness in itself, like every sphere its center of gravity" $(\mathrm{H}, 486)$, he writes in Also a History of Mankind ( I774). In his Theological Letters ( I780-8I), he approvingly quotes a remark by François de Salignac de la Mothe Fénelon, Archbishop of Cambrai, that was later evoked by the Abbé Gregoire (and virtually every other Enlightened commentator on cosmopolitanism), "I love my family more than myself; more than my family my fatherland; more than my fatherland humankind."22

Yet for Herder, the status of the nation, of the fatherland, lies at the core of any and all questions of individual identity and thus individual happiness. The nation in question is not a racial entity but rather a linguistic and cultural one. (Indeed, in the Ideas and elsewhere, Herder rejects the concept of a biologically defined race.) For Herder, Jewish emancipation was anathema as it precluded any form of total cultural assimilation. His opposition was the exception to the rule that, according to Isaiah Berlin, stressed the primacy of communal belonging and the diversity of the other ethnolinguistic communities and their rootedness in historical and geographical environments. ${ }^{23}$ Herder's views reflect those of the time as expressed by Johann Georg Schlosser in the critical poem "Der Kosmopolit" (I777): "It is better to be proud of one's nation than to have none." Are the Jews a nation or merely wandering cosmopolitans $?^{24}$ If a nation, can or should they become part of another nation? Or are they a threat, as Johann Gottlieb Fichte notoriously stated in his I793 pamphlet, A Contribution to Correcting Judgments about the French Revolution: "In nearly all the nations of Europe, a powerful, hostile government is growing, and is at war with all the others, and sometimes oppresses the people in dreadful ways: It is Jewry!" The Jews are a "state within the state," incapable of any integration and thus damned to wander the world. ${ }^{25}$

According to Herder, writing in the Ideas for a Philosophy of the History of Mankind, even if the Jews had stayed "in the land of their fathers, and in the midst of other nations, ... they would have remained as they were; for and even when mixed with other people they may be distinguished for some generations 
downward" $(\mathrm{H}, 36)$. The "more secluded they live, nay frequently the more they were oppressed, the more their character was confirmed" $(\mathrm{H}, 36)$. In fact, he suggests that ideally, "if every one of these nations had remained in its place, the Earth might have been considered as a garden, where in one spot one human national plant, in another, another, bloomed in its proper figure and nature" $(\mathrm{H}, 36)$. The movement of peoples interferes with the natural function of language in defining people. But the reality of history is that almost every people on earth, as Herder points out, "has migrated at least once, sooner or later, to a greater distance, or less" $(\mathrm{H}, 36)$. The impact of this migration is shaped by the "time when the migration took place, the circumstances by which it was occasioned, the length of the way, the previous state of civilization of the people, the reception they met with in their new country, and the like" (H, 36).

And yet Herder sees the origin of "the coining of money" as one of the contributions of the "many little wandering hordes" in the Middle East, "according to the Hebrews" (H, 3I7). As the Jews spread across Europe "in the manner that they spread abroad as a people," they held its nations in thrall thanks to their command of money. They did not invent usury, Herder states, but "brought it to perfection" $(\mathrm{H}, 335)$. The Jews move among and across the nations like everyone else, yet Herder is happy to quote from Kant's lectures on practical philosophy: "Every coward is a liar; Jews, for example, not only in business, but also in common life." 26 On this point, Herder and Kant agree.

Contemporary "moral" philosophers such as Martha Nussbaum most often cite Kant as the central thinker on cosmopolitanism in the German Enlightenment and beyond, citing his essay, Idea for a Universal History with a Cosmopolitan Purpose ( I784), with its answer to Herder's romantic speculation on the nature of man, and later his Perpetual Peace (I795). ${ }^{27}$ Kant's I784 argument is teleological-only among the European states, rooted in a universal cosmopolitanism, is there even the potential for a true civil society; theocratic non-European states entirely lack that potential. ${ }^{28}$ The end goal of history is a perpetual peace defined by a cosmopolitan order. In Perpetual Peace, Kant contends that the "use of the right to the earth's surface which belongs to the human race in common" will "finally bring the human race ever closer to a cosmopolitan constitution." ${ }^{29}$ This belief is rooted in the idea that an innate rule of hospitality to the stranger, the Greek idea of xenia (guest-friendship), defines the cosmopolitan, for "cosmopolitan right shall be limited to conditions of universal hospitality" (PP, 357). Hospitality is defined here as "the right of a foreigner not to be treated with hostility because he has arrived on the land of another" (PP, 357-58). This is the central theme ascribed to the physical as 
well as social mobility of the Enlightenment Jew, which is quite different in the practice of the time. This is not yet Jürgen Habermas's understanding of civic cosmopolitan in the transnational sense of a global community. Habermas's view answers Kant's assumption that the state not only exists but guarantees xenia. It is not, as many commentators have claimed, a version of Kant's rewriting of the Golden Rule as his categorical imperative; rather, it invests in the state the ability to monitor the central cosmopolitan rule of hospitality. ${ }^{30}$ This may mean monitoring claims on the ability to cross (state or social) boundaries with impunity.

Kant refers to this right in a I 784 footnote concerning the Jews. He notes that we are bound by our sources in any argument concerning the historical record for the nature of the state, for "outside it, everything else is terra incognita; and the history of peoples outside it can only be begun when they come into contact with it. This happened with the Jews in the time of the Ptolemies through the translation of the Bible into Greek, without which we would give little credence to their isolated narratives" (UH i I 8). The Jews are included in Kant's view, but only as a peripheral people, and even then only as mediated through the Greeks.

For Kant, the question of the Jews is only partly a question of the meaning of Judaism as a historical religion, for "Judaism is properly speaking not a religion at all." 31 Kant sees religion as available to the rational mind, with specific religions drawing on revelation for their internal coherence. Kant is not anti-Jewish in terms of his attitude toward Judaism as a religious practice per se; he sees Jews, like Christians and Muslims, as potentially having a rational religion. But their self-imposed isolation, combined with their universal presence, disqualifies them as true cosmopolitan citizens. In his view, as Pauline Kleingeld argues, "cosmopolitan egalitarianism trumps cultural pluralism," at least as far as religious practice is concerned. ${ }^{32}$

When Kant, like Herder, looks at the Jews not as a religious practice but as a force of capital, his view is radically different. In his Anthropology ( I798), Kant footnotes his view of the Jews and money:

The Palestinians living among us have, for the most part, earned a not unfounded reputation for being cheaters, because of their spirit of usury since their exile. Certainly, it seems strange to conceive of a nation of cheaters; but it is just as odd to think of a nation of merchants, the great majority of whom, bound by an ancient superstition that is recognized by the State they live in, seek no civil dignity and try to make up for this loss by the advantage of duping the people among whom they find refuge, and 
even one another. The situation could not be otherwise, given a whole nation of merchants, as non-productive members of society (for example, the Jews in Poland). So their constitution, which is sanctioned by ancient precepts and even by the people among whom they live (since we have certain sacred writings in common with them), cannot consistently be abolished-even though the supreme principle of their morality in trading with us is "Let the buyer beware." I shall not engage in the futile undertaking of lecturing to these people, in terms of morality, about cheating and honesty. Instead, I shall present my conjectures about the origin of this peculiar constitution (the constitution, namely, of a nation of merchants). ${ }^{33}$

Kant's image of the Jew is the Jew in Poland, the Jew as the cosmopolitan nation of usurers spread throughout Europe. We could claim, as the Encyclopédie does, that this is a mere prejudicial continuation of medieval attitudes toward the Jews and money, but the dichotomy between Kant's understanding of cosmopolitanism and his more complex discussion of Judaism as a religious system is belied by his representation of the Jew as merchant. Capital is central to his differentiation.

Nonetheless, Kant's notion of a rational religion held a strong appeal for the proponents of the Jewish Enlightenment, the Haskalah, who would argue from the I 790 os onward for the universal core of Jewish religion. ${ }^{34}$ In so doing, these maskilim (followers of the Jewish Enlightenment) laid the foundation for the later perception of ancient Judaism itself as a forerunner of the cosmopolitan, a perception that twentieth-century Jewish cosmopolitanist writers would promote. Mendelssohn, the father of the Haskalah, had argued that rational and therefore transcendental truths, which may be a force for individual good, may come in conflict with the demands of citizenship. ${ }^{35}$ This is echoed in Jerusalem (I783), where he clearly distinguishes between the absolute obligations of the individual to the state and the persuasive power of religion on the individual: the state can order and punish, while religion should only educate and persuade. ${ }^{36}$ How this works out within the world of the mobile Jew in the real Prussian state is reflected in Mendelssohn's short essay on "what is the best constitution for the state." As in Jerusalem, he echoes John Locke and the central notion of that a tolerant modern state can mandate some actions and punish those who violate these mandates, but the state cannot command individual conscience. The boundary between religion and the state is manifest, but the idea of religion is limited by the state's obligations to respect the dictates of individual conscience that do not violate the mandates of the state. The cosmopolitan thus is bound by the dictates of the local, not the universal, in terms of 
the state; religion, however, allows the cosmopolitan to have access to religious belief that transcends the local.

In this context of the ideal state, Mendelssohn not only reflects Montesquieu's notion that each state can be good for its own citizens as each reflects the needs and desires of the citizenry but simultaneously dismisses the idea of nomadism as compatible with an understanding of Enlightened culture. ${ }^{37}$ Mendelssohn dismisses the role of European Jews as "service nomads," to use Yuri Slezkine's transhistorical concept - that is, a group, like the Chinese in Southeast Asia, whose role was mainly the delivery of goods and services. Yet haunting Mendelssohn's views is also the Enlightenment image of the stigmatized Gypsies, defined by their perceived impermanence in society and their perpetual mobility, adding nothing of value to civilization. Mendelssohn saw the Jews as rooted in the Enlightened, Greco-Roman (read: German) world of eighteenth-century intellectual culture, a location that assured individual happiness. "Should the Greeks and the Romans have not lived like the Bedouins?" he asks, answering, "NO! The progress to a higher bourgeois perfection was the intent of Divine providence that determined these human beings; that it was more appropriate for their happiness than that simple nomadic life, that for a few millennia had assured the happiness of the Bedouins." 38 Irrespective of the fall of the ancient world, it was inappropriate for them, for all kingdoms must eventually fall. Kant later observed the natural tension between a human desire for what comes to be called privacy and the fact that human beings "have an inclination to associate with one another because in such a condition they feel themselves more human, more in a position to develop their natural predispositions" (PP, 2 I). Mendelssohn sees the form of that association as reflected in the nature of the state. Not nomadic wanderings for the new European but rather the fixity of empire and city-state. Borders, not pastures; high urban culture, not the tents of wandering shepherds.

In what may be the first volley fired by modern racial antisemitism in Germany, Carl Wilhelm Friedrich Grattenauer, hiding behind a pseudonym, "the Voice of a Cosmopolitan," published Against the Jews ( I803), bringing together all of the earlier charges against these nomads from the Orient, "The Jew in general, the Jew everywhere and nowhere." ${ }^{39}$ Grattenauer's book is a riposte to Dohm's I78I On the Civil Improvement of the Jews, which demanded true reform within the Jewish community before emancipation but saw emancipation as the goal. ${ }^{40}$ Dohm implicitly accepted the local notion of a cosmopolitanism defined by the standards of European (read: Protestant) society, which became the benchmark for the integration of Jews into the Prussian body politic. He was opposed by the universal cosmopolitanism espoused by 
diplomat and thinker Wilhelm von Humboldt, who argued for a universal model of the citizenry in which the Jews should be accepted as individuals, not as the idealized form of the Jew theorized by Protestant writers such as Lessing in his Nathan the Wise (I775). ${ }^{41}$ For Humboldt, Jews constituted a community of believers, analogous to the one of the Christians, not a national entity analogous to the Germans. Prussian minister Leopold Freiherr von Schrötter had made the same argument in his I808 draft for a new constitution for the Jews in Prussia, which sought to transform Jews into "useful citizens" and to which Humboldt had been asked to respond. ${ }^{42}$ Enlightenment "tolerance" might suffer the Jews as a collective, but admitting Jews as individuals into a new idea of the nation-state demanded an acknowledgment and acceptance of individual differences. ${ }^{43}$ This is the voice, according to Grattenauer, of the true cosmopolitan, not that of Jewish mendicants and merchants such as Moses Mendelssohn, Lessing's model Jew, "who extort their claims of their rights of citizens to inflict damaging interest on innocent Christians" $(\mathrm{G}, 2)$. They are not truly cosmopolitan; they are, according to Grattenauer - who defines himself as the true cosmopolitan - in the end merely Jews using this claim for their own pernicious ends.

\section{Writers in Coaches}

The assumptions about cosmopolitanism's roots in the nation were reiterated in the late-eighteenth-century emergence of Romantic cosmopolitanism, which argued that Germans represented the cosmopolitan nation per se. As August Wilhelm Schlegel wrote in his I804 Vorlesungen über schöne Litteratur und Kunst (Lectures on Belles Lettres and Art), "Universality, cosmopolitanism is of truly German nature"; consequently, the German language would soon become "the common means of communication among the educated nations." 44 In a religious variant of this argument, Friedrich Novalis claimed in his I799 Christianity in Europe that Germans would lead the restoration of European unity to the Christian commonwealth that had existed during the Middle Ages. ${ }^{45}$ Over the nineteenth century, these ideas of a specifically German national and religious cosmopolitanist mission were transferred to the Jews in writings by both Jewish and non-Jewish authors. Acculturated Germanspeaking Jews in particular saw this special mission as yet another imagined point of convergence between German and Jewish culture.

But the idea of mobility as a means of representing the flexibility of Enlightenment attitudes toward the Jews as both cosmopolitans and newly 
integrated citizens of the nation-state can be seen most clearly in the work of a minor yet engaging Jewish writer, Ephraim Moses Kuh (I73 I-90). A frequent guest in Mendelssohn's home, Kuh was one of the first Jewish poets to write in German. ${ }^{46} \mathrm{He}$ was one of the maskilim who also understood (as did their bourgeois non-Jewish contemporaries) that mobility implied a universal cosmopolitanism.

Mendelssohn equated Judaism with "natural religion" (that is, rational religion) and argued that Jewish ritual practice was merely another logical means of following the same rational path as Christianity and other religions. His disciple, David Friedländer, saw conversion to a rational form of Christianity (one that did not embrace the divinity of Christ) as a pathway for charging his readers to abandon the generalities about the Jews and their lack of decorum and the threats that such a lack implied to the society in which they lived. ${ }^{47}$ The "stronger," he noted, had a duty "to extend an arm to the weaker" and "say 'let us be friends." "48 Indeed, stressing the corrupt nature of the manner by which Jews worshipped and acted only exacerbated hatred of the Jews.

Moses Ephraim Kuh was born in Breslau in I73 I to traditional Orthodox parents. ${ }^{49}$ His education followed a pattern common among the maskilim. Coming from a merchant family of some means, he was introduced to Western letters only after an intense Jewish education that, according to biographer Moses Hirschel, comprised "scholastic dogmatics, sophistic hypothesis, artificial subtleties, and other such nothings." Such a traditional rabbinic education provided Kuh with an extremely good command of Hebrew and the Talmud. His teacher was, however, a disciple of the German Enlightenment who also introduced Kuh to German rationalist philosophy. Trained as a bookkeeper, Kuh was interested in foreign literature, especially British and French belles lettres. After much effort, he learned German, even though he felt that German lacked the elegance and grace of either French or English, a view shared by many others of his time, including Frederick the Great. Kuh went to Berlin in I 763, after the death of his father, ostensibly to assume the position of bookkeeper in his uncle's gold and silver business. However, his primary reason for going to Berlin was to seek out the company of the new generation of German Enlightenment thinkers, among them Mendelssohn and Lessing. Under their tutelage, Kuh for the first time turned seriously to the pursuit of German letters. He mastered the highly artificial style of the mid-eighteenth century, with its elaborate rules for prosody patterned after an impression of classical poetry. His German quickly became polished under the direction of Karl Wilhelm Rainier, a friend of Lessing's and Mendelssohn's and editor of The German Museum, a periodical that printed Kuh's early poetry. All the while Kuh was 
spending his inheritance on "good works"- supporting Christian as well as Jewish students, giving money to almost anyone who asked for it—with a sense of generosity that sprang from his newly found position in the German Enlightened community.

In I 768 Kuh left Berlin and undertook the classic European voyage to Italy. He toured the Netherlands, France, Italy, Switzerland, and the German states in the manner of any Enlightened traveler of the late eighteenth century. Accompanying him on this long and arduous trip were three huge trunks full of books, the treasures of British, French, German, and Latin letters. On his return to Berlin in I77I, an incident completely altered his life. Jewish merchants were forced to pay a duty when they crossed any of the innumerable borders between the petty German states. But when Kuh crossed the border into Saxony, he refused to acknowledge his identity. As one of Kuh's contemporaries described a decade later, he "dared to travel ... as a simple human being and merchant without admitting to the customs officials his faith. He was discovered and had to pay duty, not on goods, but on the oldest faith in the world, a duty amounting to several thousand dollars." ${ }^{.50}$

When Kuh reached the border at Sachsen-Gotha, his coach was again stopped by customs authorities. They asked whether anyone had anything to declare, and Kuh did not answer. They then asked whether any passengers were Jews. Again Kuh did not answer. After asking some more questions, the guards identified Kuh as a Jew, although he was dressed as a gentleman, much as Lessing's Traveler must have been dressed. How could the guards have known that Kuh was a Jew? It must have been through his accent. As a native Yiddish speaker who learned German fairly late in life, he probably spoke with a Yiddish accent. Language was the key to Kuh's unmasking as a counterfeit, as a Jew in intellectual's dress. Stripped of his money and his clothes, Kuh was forced to fall back on his non-Enlightened Orthodox family in Breslau. In one of the very few biographical poems written during the resulting madness, Kuh recapitulates his experience at the border:

\section{The Customs Official in E. and the Traveling Jew}

OFFICIAL: Hey you, Jew, you have to pay three dollars. JEW: Three dollars? So much money? Why, sir? OFFICIAL: You ask me? Because you're a Jew. If you were a Turk, a heathen, an atheist, We wouldn't want anything from you. 
But as a Jew we must collect from you.

JEW: Here is the money! Does your Christ teach you this? (Kuh, I:I87)

The customs official's tone-he addresses the Jew in the familiar-is that of the state addressing the Jew. But the official's harsh tone clearly represents a response to the Jew having identified himself as a Jew. Kuh's refusal to identify himself resulted in the confiscation of all his money and goods. The poem replays the situation, but rather than undergoing the humiliation of being revealed to be a Jew and being forced to turn to his family for aid, the Jew in Kuh's poem wins the confrontation. Unlike Martial's open-ended epigrams, this one concludes with the lesson the writer needs to have his readers draw from his text. True Christians do not—cannot—act like the customs official, like the state. But, of course, they do, and their brutality exceeds that of the situation portrayed by Kuh.

After returning, impoverished, to his family in Breslau, Kuh began to write compulsively, poem after poem. His depression concerning his state, a depression that his contemporaries described with the fashionable eighteenthcentury term melancholia, turned to mania. Kuh's madness, which his contemporaries saw as the result of "his thankless treatment by mankind," turned into a sense of being persecuted by the traditional Orthodox community in Breslau. He saw in his poetry, in his ironic comments, the reason for their hatred of him. Calling on his rights as a citizen of Prussia, he began to attack the Breslau Jewish community for persecuting him.

The attacks on the Breslau Jewish community caused Christian missionaries to take a strong interest in Kuh, who appeared to be a perfect subject for conversion, and they launched an intense attempt to bring him into the Protestant fold. However, Kuh's belief that the Breslau Jews were persecuting him did not induce him to desire conversion, and he rejected the Protestant advances. His shattering experience at the Saxon border had revealed to him the limitations of the Christian world. He wrote another epigram aimed at the conversion of Elector August II of Saxony to Catholicism to obtain the Kingdom of Poland-Lithuania in I697. This poem mirrors Henri IV's I593 statement that "Paris was worth a mass" when he converted to Catholicism:

\section{The Polish Jew, Who Became a Christian}

A great noble, who is not threatened by anything

Denies his religion 
To aspire to a new title, a new throne:

And I-lacking roof and bread-

You mock with bitter laughter. (Kuh, I:I57)

He withdrew as much as possible from any contact with human beings, becoming phobic when approached by anyone. The form of his phobia was not unexpected. He saw all strangers as religious fanatics out to rob him of his freedom of conscience or, indeed, to murder him. Under close supervision by hired nurses, he saw them as members of this same conspiracy. He began to fixate on the danger that he felt from members of the Prussian garrison in Breslau, seeing in this uniformed authority a force that intended him bodily harm. This force was personified in the Prussian monarch, Frederick the Great, who stated in I 740 concerning Huguenot and Catholic toleration, that "in my kingdom everyone can be blest, according to their fashion." The state was Frederick II, and Frederick II was toleration epitomized-except, of course, when Johann Georg Sulzer wanted to have Mendelssohn join the philosophical department at the Prussian Academy of Sciences in I77I. That effort took equality too far.

The notion of physical movement as an index for social movement is revolutionary within the German Enlightenment. Friedrich Schiller's 1782 drama, The Robbers, certainly presents the conflict between the Moor brothers, the good economic revolutionary and the conservative advocate of the status quo, around Karl Moor's new occupation as a robber. He, unlike Lessing's highwaymen, is a noble thief, as one of his confederates recounts:

RAZMANN: The other day we were told at a tavern that a rich count from Ratisbon was about to pass through, who had gained the day in a suit worth a million of money by the craftiness of his lawyer. The captain was just sitting down to a game of backgammon. "How many of us are there?" said he to me, rising in haste. I saw him bite his nether lip, which he never does except when he is very determined. "Not more than five," I replied. "That's enough," he said; threw his score on the table, left the wine he had ordered untouched, and off we went. The whole time he did not utter a syllable, but walked aloof and alone, only asking us from time to time whether we heard anything, and now and then desiring us to lay our ears to the ground. At last the count came in sight, his carriage heavily laden, the lawyer, seated by his side, an outrider in advance, and two horsemen riding behind. Then you should have seen the man. With a pistol in each hand he ran before us to the 
carriage,- - and the voice with which he thundered, "Halt!" The coachman, who would not halt, was soon toppled from his box; the count fired out of the carriage and missed - the horseman fled. "Your money, rascal!" cried Moor, with his stentorian voice. The count lay like a bullock under the axe: "And are you the rogue who turns justice into a venal prostitute?" The lawyer shook till his teeth chattered again; and a dagger soon stuck in his body, like a stake in a vineyard. "I have done my part," cried the captain, turning proudly away; "the plunder is your affair." And with this he vanished into the forest. ${ }^{51}$

But for Schiller, the role of the robber is not unblemished. Lessing's robbers were simply peasants turned villains; Schiller's seem to be revolutionaries manqué. Yet the social mobility of the newly cosmopolitan Jews makes the calling of the revolutionary suspect. Moritz Spiegelberg, the hidden Jew as bandit, seduces and corrupts. That he is a Jew is clear. Schiller shows Spiegelberg's duplicity by having Spiegelberg deny his Jewish identity-exactly what the nomadic Jew does. The character refers to himself as having been "miraculously born circumcised" yet advocates circumcision for all others. ${ }^{52}$ His denial of the religious origin of his circumcision is a comment on the nature of the Jew, seen, at least by Schiller, as mendacious. ${ }^{53} \mathrm{He}$ claims that all of the robbers should become Jews and therefore become truly cosmopolitan:

SPIEGELBERG. (jumping up). Bravo! Bravissimo! you are coming to the right key now. I have something for your ear, Moor, which has long been on my mind, and you are the very man for it-drink, brother, drink! What if we turned Jews and brought the kingdom of Jerusalem again on the tapis? But tell me is it not a clever scheme? We send forth a manifesto to the four quarters of the world, and summon to Palestine all that do not eat Swineflesh. Then I prove by incontestable documents that Herod the Tetrarch was my direct ancestor, and so forth. There will be a victory, my fine fellow, when they return and are restored to their lands, and are able to rebuild Jerusalem. Then make a clean sweep of the Turks out of Asia while the iron is hot, hew cedars in Lebanon, build ships, and then the whole nation shall chaffer with old clothes and old lace throughout the world. Meanwhile_ ${ }^{54}$

Schiller may have been a revolutionary in terms of the rising bourgeoisie, but his engagement with Jewish emancipation was limited, except perhaps on a literary level, as he admired Lessing's Nathan the Wise as a drama. ${ }^{55}$ Here the 
robber as nomad dominates the portrait of the Jew as mock revolutionary. Lessing's Jerusalem in Nathan the Wise-the space where the Abrahamic religions can resolve conflicts-becomes Spiegelberg's cosmopolitan Jerusalem.

Later in the nineteenth century, emancipated Jews became obsessed with Schiller's life and work as the embodiment of revolutionary change; however, his view of the Jews here, at least in Spiegelberg, falls very much within the paradigm of the dangers of Jewish mobility. Karl Moor may be a noble Robin Hood, but Spiegelberg is clearly nomadic only in the most negative sense that he is a man of the world. This prefigures Humboldt's claim in his comments on the I808 draft for the inclusion of the Jews in a new state constitution that among the primary qualities that defined Jews were their "nomadic life often subordinate to foreign power," their "religious practice, which often does not even rest of true belief," and their "pattern of self-isolation." ${ }^{56}$ These problems were to be ameliorated by their inclusion in the Prussian state not as a religious community but as individuals. Even Spiegelberg had a chance to become a valuable member of the Prussian state if he shed those qualities that had isolated him from the true body politic.

Spiegelberg is not the ideal of that most cosmopolitan of eighteenthcentury poems, Schiller's "On Joy" ("An die Freude") written in 1785 and published in Schiller's periodical Thalia the next year (and revised again in 1803 in the version best known to readers and listeners). Following Beethoven's highly abridged setting emphasizing the early stress on universal brotherhood, this text becomes in the twentieth century the anthem for global cosmopolitanism. ${ }^{57}$

Joy, beautiful sparkle of the gods,

Daughter of Elysium,

We enter, fire-drunk,

Heavenly one, your shrine.

Your magics bind again

What custom has strictly parted.

[ I 785 version: What custom's sword has parted.]

All men become brothers

[I 785 version: Beggars become princes' brothers.]

Where your tender wing lingers. ${ }^{58}$

Spiegelberg may have been one of the nomadic beggars who become princes' brothers in The Robbers, but by $\mathrm{I} 803$ he is replaced by the claim that "all men become brothers." Schiller's poetic cosmopolitanism was focused on the national and when it spoke of a universal meant only the idea of primus 
inter pares. He may have espoused a pantheistic cosmopolitanism, but it had a religious veneer that defined who is among the equals, who gets to travel inside the carriage, who can cross borders.

Schiller's anxiety about the meaning of cosmopolitanism and the Jews was not limited to his early drama and his rather crudely cosmopolitan Spiegelberg. In I790, Schiller wrote an essay on the origins and nature of the Jews, "The Legation of Moses." Martha Helfer has provided a close and detailed reading of this essay, which is important because Schiller placed it as the lead essay in Thalia. ${ }^{59}$ Schiller picks up two strands from the Enlightened discourses about Judaism: that it is a rational religion (and thus the basis of a rational Christian and Islam) and that it is thus the underlying causal structure for the Enlightenment itself. In spite of such claims, the Jews and the Enlightenment pose major problems for Schiller. The Jews are inherently corrupt as a consequence of their persecution (in Egyptian exile and then, by extension, in Christian Europe), and in contrast to the mid-eighteenth-century arguments of Enlightened thinkers such as Dohm, that corruption is irrevocable. They are "the coarsest, most malicious, most depraved people on earth, made savage by three hundred years of neglect, made despondent and embittered by slavish oppression, debased in their own eyes by an inherited infamy that clung to them, enervated and lamed to all heroic decisions, through such a long-standing dumbness finally case down almost to the level of the animal." 60 In addition, they are infected by leprosy, which mars their bodies as well as their souls and poses a danger to the people around them.

In Egyptian slavery, these Jews also maintained their essential nature, however. They "lived segregated from the Egyptians, segregated both in their choice of living quarters and in their nomadic status, which made them the abhorrence of the native inhabitants of the country and excluded them from all participation in the civil rights of the Egyptians" ( $\mathrm{S} / \mathrm{H}, 40)$. They become a nation within a nation (Schiller anticipates Fichte's I808 "Addresses to the German Nation"), for "such a segregated mass of people at the heart of the realm, made idle by its nomadic lifestyle, who kept themselves very precisely and had no common interest whatsoever with the state, could be dangerous in an enemy attack, and could easily be tempted to avail themselves of the state's weakness" (S/H, 4I). Moses, filled with a "bloody hatred" against the oppressors in Egypt, marks the Jewish soul, which he "carried with him into the Arabian desert. His mind was full of ideas and plans, his heart was full of bitterness, and nothing distracted him in this unpopulated desert" $(\mathrm{S} / \mathrm{H}, 50)$. In the desert, then, the nomadic spirit of the Jews, their self-segregation, and Moses's anger and bitterness coalesce into the character of modern Jewry. 
This theme of the nomadic mobility of the Jews quickly became part of the Enlightenment representation of the Jew. Poet and Merchant (Dichter und Kaufmann) (I839), the second novel by Bertold Auerbach (I8I 2-82), Germany's first popular Jewish novelist, retells Kuh's life story. (Auerbach had previously published essays on Kuh's life and writing in I836.) Set in the time of Mendelssohn (as indicated in the subtitle to the 1855 revision) among the Jews of Breslau, the novel opens with Jews gathered at an inn, having "wandered there begging from city to city, from village to village," on foot. ${ }^{61}$ It was rare, Auerbach notes, that such Jews "were able to raise themselves out of this life of a gypsy [Zigeunerleben]" (A, 2). Persecution in the midst of civilized Europe has reduced them to the nomadic state of their ancestors in the "Arabian desert" (A, 3). Yet on the Sabbath, they entered into the community of Jews wherever they were. In a bow to Kantian cosmopolitanism, Auerbach writes that these wanderers "were called by the name 'Guests' which quickly took on a pejorative meaning" (A, 2). For Auerbach $(\mathrm{A}, 38)$ the Jews are the barometers of humanity-their treatment enables one to judge the nature of the statefriendship, toleration, and emancipation. Into this world comes Kuh, whose life as an artist is part of his family's claim on bourgeois rather than nomadic identity, but his experiences in Enlightened Europe force him to return to Breslau in tatters. The notion of the wandering Jew discomfits Auerbach, for Jewish cosmopolitanism represents the absence of a grounded Judaism, a Judaism as a confession rather than as a ethnic or tribal identity. Wandering, not traveling by coach as a full member of society, remains anathema to Auerbach. As late as 1872 , he despaired at the thought that large numbers of Romanian Jews would emigrate to America: "This very thought of a mass emigration evokes something gypsy-like among the Jews. . . We are rooted where our parents and ancestors lie in their graves." ${ }^{62}$ In this view, Jews were neither nomads nor cosmopolitans but members of a national cultural community.

Auerbach quotes from Kuh's poetry throughout the novel, well before the character meets Lessing, who sees in Kuh the new Jewish poet. Kuh has exemplary adventures with Enlighteners of all strands-Lavater and Mendelssohn as well as the Jewish physician-playwright Elcan Isaac Wolf and the Jewish Kantian Salomon Maimon - as Auerbach places his character in the context of this new, rooted, German Jewry. Another wanderer, Venetian adventurer Giacomo Casanova, introduces Kuh to the Prussian Court disguised as an Italian count, but the mask is ripped from him and he is revealed as merely Rabbi Ephraim. Stripped of all his possessions, he returns to Breslau, and Auerbach labels him a new Werther, Goethe's mad lover. Ritchie Robertson has noted that Kuh's descent into madness may be Auerbach's attempt to judge the im- 
possibility of such integration in terms of the Enlightenment. ${ }^{63}$ From the standpoint of the early nineteenth century, however, the novel argues that the new cosmopolitan Jew is seen always as the nomadic Jew. Poet and Merchant may be a novel of modernization and therefore not of integration, as Jonathan Skolnik argues, but the litmus test for modernization is whether the nomadic can be transformed into the cosmopolitan. ${ }^{64}$ Auerbach's character returns in much the same state as the begging Jews who open the novel, and his decline into madness is the price paid for his cosmopolitanism as poet and traveler. Michael A. Meyer's claim that the Enlightenment caused Jewish identity to become "segmental and therefore problematic" is at least supported by Auerbach's reflections in the I830s. ${ }^{65}$

Some newly emancipated (and culturally active) Jews may have interpreted the new nationalism as incorporating this viewpoint because the older idea of the nation espoused by Herder and others seems to be strangely mired in an agrarian - indeed, prelapsarian - utopia. This older conception is distinct from the rootless nomadic existence represented by the Jews but is also the antithesis of the modern city, which the Jews equally come to signify. The Enlightenment viewed the new eighteenth-century mega-metropolis-London, Paris, Vienna, Frankfurt, Milan-with particular horror. The modern metropolis is the haunt of the Jews in the form of the Rothschilds, the avatars of capitalism, and contemporaries came to see the Rothschilds as both nomads and city dwellers. ${ }^{66}$ Thus, the limits of cosmopolitanist benevolence are quickly reached, as when Friedrich von Müller recounted his September 23, I 823, exchange with Johann Wolfgang von Goethe concerning the recent law that permitted marriage between Jews and Germans: Goethe became "violently enraged," prophesying the "worst and most frightful consequences," particularly the "undermining of all moral feelings of families that rest in religious feelings." He sought to prevent such marriages from enabling a Jewess to become Oberhofmeisterin in his court. Goethe stated that "those abroad must believe in bribery to understand the passage of this law; who knows whether the allpowerful Rothschild is responsible for it." ${ }^{\prime \prime 7}$ In the end, all corruption flows from the cities and has its roots in capital. The implicit cosmopolitan who crosses borders here is the Jew who violates the taboo of sexual contact and social boundaries.

In imagining his ideal society, Goethe reifies the modern city-state in complicated ways, removing from it such things as intermarriage. While Goethe would come to represent the cosmopolitan for nineteenth-century Europe, he is much more focused on the particularist local than on the global. Today, of course, we remember primarily Goethe's universalism and his claims about 
world literature (Weltliteratur). Although Jewish writers later claimed Goethe as their hero, Goethe's idea of a cosmopolitan art and indeed a world literature made no specific reference to the Jews. In I8o I, for example, he wrote,

It is to be hoped that people will soon be convinced that there is no such thing as patriotic art or patriotic science. Both belong, like all good things, to the whole world, and can be fostered only by untrammeled intercourse among all contemporaries, continually bearing in mind what we have inherited from the past. ${ }^{68}$

In other words, society is defined not by adventurous expansionism but rather by the space of the garden. "Hier oder nirgend ist Amerika!," Goethe had written in Wilhelm Meister's Apprenticeship (I795-96): "I will return, and in my own house, my own orchard, in the midst of my own people, I will say: "Here or nowhere is America." ${ }^{69}$ The orchard metaphor also appears in Goethe's reading of the "Decalogue in His Two Important yet Unasked Biblical Questions" (I773), where he calls the Jews a "a wild, unfruitful stock that stood in a circle of wild, unfruitful trees"70 Likewise, in his paean to the emigrants driven from revolutionary France, Hermann und Dorothea (I796-97), he uses similar imagery in his description of the cosmopolitan, Der Weltbürger:

Ne'er would I censure the man whom a restless activity urges,

Bold and industrious, over all pathways of land and of ocean, Ever untiring to roam; who takes delight in the riches, Heaping in generous abundance about himself and his children. Yet not unprized by me is the quiet citizen also,

Making the noiseless round of his own inherited acres. ${ }^{71}$

Such views of the ideal state, with the German rooted, as always, in an agrarian, precapitalist society, dominate the conservative view of the nation. Indeed in Wilhelm Meister's Apprenticeship, the mysterious Society of the Tower that silently but powerfully shapes Wilhelm's education comes to replace the romantic world of the blind and mad harper, Augustin, and his daughter, Mignon. The harper, a nomad whom people might even think to be Jewish, is marginalized; the members of the Tower Society give expression to some explicitly antisemitic sentiments and are the new wanderers, investing in America and Russia, never staying in one place. ${ }^{72}$ Rootedness is the antithesis of those "untiring to roam," but in Goethe's sense, the modern Jew, whom he time and again defines as the transgressive wandering merchant, is also not a 
real cosmopolitan. He is merely a usurer, unlike the wandering members of the Society of the Tower, who are not motivated economic concerns.

Traveling in a coach certainly seems a natural place for the converted though still very Jewish poet Heinrich Heine, at least when he wrote Germany: A Winter's Tale (I844) in Paris about returning home to Hamburg in I843. ${ }^{73}$ Heine had positioned himself carefully against the German nationalism of Friedrich “Turnvater" (Father of Gymnastics) Jahn. In I 8 Io, Jahn had declared that "a nation without a state is a dead, floating chimera like the nomadic Gypsies and Jews. A state and Volk together create a Reich, but the power of the Volksthum preserves it." Nomads cannot have any sense of national identity; they are zombies because "they have died and yet are not dead, they continue in this corpse life like a madman's horrific double," damned to eternal wandering. ${ }^{74}$ In The Romantic School (I833), Heine bemoans such abandonment of what he considers the German contribution to the Enlightenment, "that universal brotherhood of man, that cosmopolitanism which our greatest thinkersLessing, Herder, Schiller, Goethe, Jean Paul—and all German scholars have always revered," simultaneously evoking the antisemitism of such German nationalists as Jahn and Fichte. ${ }^{75}$

In exile in France since I839, when his works were banned in the Germanspeaking states, Heine's ironic voice in Germany: A Winter's Tale is that of the German poet returning to the land of his birth to be healed:

The German heart within my breast

Is suddenly ailing;

There's but one doctor, in the North,

Who'll cure it without failing.

His cures are famous, his cures are fast,

They are world-wide renowned;

Yet, I confess, I already dread

The mixtures he will compound. ${ }^{76}$

Heine's disease is the classic illness cured by travel home in the nineteenth century, the disease of Swiss soldiers abroad first described in the late seventeenth century by Johannes Hofer-homesickness. By the time of Heine and the German Romantics, especially Jean Paul in Selina (I8I9), homesickness has become a metaphor for creativity. Travel away from home causes it; travel home cures it — even travel back to Germany.

If Heine's identity, to again evoke Meyer, is segmental and therefore prob- 
lematic, his voice is neither. He writes in this and other texts of the I840s as a German-language poet resident in France, a model for the European cosmopolitan since the days of Rousseau's friend, Friedrich Melchior, Baron von Grimm. Yet the disease from which he suffers is not purely a German one. Heine's ironic tone speaks elsewhere of a disease carried not by Germans distant from their homes but by cosmopolitan Jews, even in Germany, when they travel. In his I 842 poem on the founding of the Hamburg Jewish hospital, "Das neue israelitische Hospital zu Hamburg," Heine channeled Schiller's view of nomadic Jews and disease:

A hospital for the poor and weary Jew,

For sons of man that suffer three-fold ills;

Burdened and band with three infirmities;

With poverty, disease, and Judaism!

The worst of all has ever been the last,

The Jewish sickness of the centuries,

The plague caught in the Nile stream's slimy vale,

The old unwholesome faith that Egypt knew. ${ }^{77}$

The anticosmopolitan disease of the German is nostalgia for a specific rooted space; for the Jew, the nomadic wanderer, travel is marked by the disease, religion, brought from the Middle East.

But in I844, as Heine parodies the nostalgic German longing for his Heimat, he quickly reaches a border, like Kuh, but for Heine it is the Rhine boundary of the new German Customs Union. As early as I828, Heine had written about the border between France and the German states in Jewish terms: "Paris is the new Jerusalem and the Rhine is the Jordan, that separates the promised land of freedom, from the lands of the Philistines." ${ }^{78} \mathrm{He}$ is stopped and searched at that border between civilization and the Philistines (in the sense that Matthew Arnold later adapts the usage), not as a Jew but as a potential revolutionary:

The Prussian customs searched my trunk, Looking for hidden treasures.

They sniffed everything, rummaged through

Shirts, pants and hand

kerchiefs, for hidden

Needle-point lace or for gems, And for books that were forbidden. 
You fools that search inside my trunk!

There's nothing for you to find:

The contraband that travels with me,

Is hidden in my mind.

Here the travelling cosmopolitan is not humiliated by being revealed as Jew, for his contraband is his poetic and therefore most dangerous gift. He concludes the poem with a restatement of the dangerousness not of the Jewish cosmopolitan but of the cosmopolitan poet's calling:

Have you ever heard of Dante's hell,

With its frightful verses and rhyme?

Whoever the poet imprisons there,

No God can ever free on time.

No God, no Saviour can deliver him

From those flames that burn.

Beware! O king and better behave,

For soon may well be your turn!

Heine sarcastically comments that the Customs Union also demands a unity of German spirit and thought, quite different from his own self-conscious sense of a fragmentary German and Jewish and cosmopolitan sensibility. Such is Theodor Adorno's reading of "Heine's Wound," where Heine represents the damaged sensibility of those "today, after the destiny that Heine felt has actually been fulfilled, everyone has at the same time become homeless; everyone is, in their being and language, just as damaged as the outcast was. His word is representative of theirs: there is no other homeland than a world in which nobody else would be cast off, that of a truly liberated humanity."79 Yet Heine's response to his world is hardly the sort of reaction that we see in Kuh or indeed in Auerbach's retelling of Kuh's life. Rather, Heine's response constitutes an acknowledgment that the neutral claims of cosmopolitanism were always rooted in the parallel claims of national identity.

The metaphor of the cosmopolitan poet has him traveling outside on a coach beyond the border through the German states. Despite the dirty, uncomfortable, and unpleasant journey, the traveler is buoyed by the fresh air of the "fatherland":

The fare from Cologne to Hagen costs

Five Prussian thalers six groschen. 
As the coach was full, I had to use

The trailer that was open.

The coach-wheels ploughed in mud,

In a late autumn morning dark and grey;

A sense of well-being pulsed through me,

Despite the bad weather and the way.

It is the air of home again,

That my glowing cheek could feel!

Even the filth on the country-roads

Carried my fatherland's appeal!

The fatherland is reached through the coach, and the further the poet travels, the less he suffers from homesickness. Riding on the outside of the coach, he appears merely to be a traveler, like all of the others. His Germanness reflects his sense that his national identity is but one more form of camouflage that enables the cosmopolitan to move invisibly across borders. But his goal is Hamburg and his very Jewish mother:

And when I reached my mother's place,

She trembled with an immense joy;

She clapped her hands and cried:

"My sweet and darling boy!

Thirteen years must have elapsed,

Since I last saw you, my sweet!

Surely, you must be starving,

Just say, what would you like to eat?

I've got some fish and some goose,

And lovely oranges after that."

Then give me some fish and some goose,

And lovely oranges after that.

For Heine, the movement across borders is a question of taste-in every sense of the word, from that of food to that of politics. ${ }^{80}$

"My dear child! What are your views now?

Is your addiction still strong 
For political matters?

To which party do you belong?"

The oranges, dear little mother,

Are good; I swallowed their sweet juice

With true delight. On the other hand,

For their peel, I have no use.

The cure for homesickness is ironic distance from the role of the dutiful son. Heine's Jewishness, unstated but omnipresent in the poem, makes the metaphor of travel even more ironic. ${ }^{81}$ In retrospect, the fact that Heine is confined to his "mattress grave" in his Paris apartment after I 849 makes the link between disease, travel, and identity even more telling.

Heine's ironic cosmopolitanism rooted in the very fragmented nature of a Jewish identity in the diasporic Enlightenment is very much paralleled by that of Karl Marx in the early I 840s. ${ }^{82}$ Heine's long if not epic poem was published in installments first in Vorwärts!, a radical periodical funded by Franco-Jewish composer Giacomo Meyerbeer to which Marx and many other German radicals in Paris, among them Friedrich Engels and Georg Weerth, contributed. According to Eleanor Courtemanche, Marx was in a dialogue with Heine in I 843-44 regarding the nature of true cosmopolitanism, which she calls "economic cosmopolitanism." Courtemanche notes that "Marx's 'Critique of Hegel's Philosophy of Law' argues that Germany must accomplish a difficult backward somersault ("salto mortale") over the dialectical boundary of the Rhine to transcend the impasses of French politics and British industrialism" (Co 58). For her, "both Heine and Marx transformed their critique of Prussian autocracy into a more generalized cosmopolitan radicalism, though Heine's aestheticism is sometimes confounding to Marxist critics" (Co 58). In the end, "Marx's engagement with the German tradition of Nationalökonomie is complex: while he critiques the Prussian nationalist use of free trade theories, the internationalism of his economic vision brings him closer to the British classical tradition of Smith and Ricardo than to German romantic protectionists like Friedrich List" (Co 58).

Courtemanche mentions but does not highlight the fact that for Marx, baptized as a child in Trier, did not see such an economic cosmopolitanism in a neutral manner any more than Heine did. If the word Jew does not appear in Heine's nostalgic trip back home (even though its echoes are present throughout the text), Marx's works of the time focus clearly "On the Jewish Question," written in I843 and published in I844 in the forerunner to Vorwärts!, the German-French Yearbooks (Deutsch-Französische Jahrbücher). In October 
I843 Marx had moved to Paris, thus associating himself with Heine and the other Jewish liberals who lived there and wrote in German. Contemporariesboth allies such as the coeditor of the German-French Yearbook, Arnold Ruge, and ideological opponents such as Eduard Müller-Tellering — saw Marx's writings as the product of a Jew. ${ }^{83}$ Marx was linked in the popular mind with other "Jewish" radical writers such as Moses Hess, who advocated an eclectic anarchosocialism that interested the young Marx. Indeed, Marx evidently used an unpublished essay by Hess in formulating his answer to theologian and historian Bruno Bauer's I843 book, On the Jewish Question. Bauer had argued that the Jews had to abandon their sectarianism to become truly emancipated in the modern secular state. The strength of the association between Bauer and Hess, between the idea of the Jew and the radical, is evident not only in Hess's unpublished paper but also in Marx's essay "On the Jewish Question," which constitutes his first attempt to deal with materialist categories of history and to counter the idea of the cosmopolitan Jew as a model for the new world citizen.

Hess later explicitly rejected the idea of a Jewish cosmopolitanism in his Rome and Jerusalem: The Last National Question (I862). There, he advocates for a Jewish national state using his early engagement with Marx's concept of the Jew as a psychological category and rejecting an economic cosmopolitanism that is not tied to a Jewish national identity, even to the exclusion of emancipation: "Even the rationalistic Mendelssohn did not know of a cosmopolitan Judaism. It is only in modern times that, for the purposes of obtaining equal rights, some German Jews denied the existence of Jewish nationality. Moreover, they have convinced themselves, contrary to the fact that the further existence of Judaism will not be at all threatened by the elimination of its innermost essence." 84 While in the I840s Hess's views were much less articulated in regard to a Jewish national identity, he and Marx had already clearly rejected the idea of the cosmopolitan Jew.

Marx's "On the Jewish Question" can be read in this complex matrix of striving to provide an understanding of the Jews and their world within the highly esoteric world of his sojourn in Paris. ${ }^{85}$ "On the Jewish Question" rejects the abstractions in which Bauer clothed his argument but accepts much of the basic structure of that argument. Marx agrees with Bauer's characterization of the nature of the Jew and of the Jews' lack of a place in the historical process and with his rejection of Jewish particularism. But most important, Marx accepts Bauer's view of Judaism as a cult of egoism. Marx reflects Ludwig Feuerbach's heightening of Kant's refusal to see Judaism as a religion. In I84I, Feuerbach labeled Judaism a gastronomic cult, since Jews perceive the world through their stomachs. ${ }^{86}$ Indeed, when Heine evokes 
his mother's kitchen, he is turning such claims into a claim for a nostalgic Jewish past (and repast). Marx offers his own reading of the nature of the Jew based on Bauer and Feuerbach.

As Jonathan Sperber has noted in his superb biography of Marx, "During the mid-nineteenth-century debate on Jewish emancipation, their theological position was politicized. It was used to condemn Jewish economic practices as self-interested, immoral, and exploitative, and to assert that individuals tied to a self-centered and particularist faith could not act as citizens of a wider polity, along with people not sharing their religion." Indeed, that had been the theme of Bauer's essay, which depicted Judaism as "particularist and self-centered."

For Marx, modernity reflects the "secular cult of the Jew" that articulates their egoism. True emancipation for "our age" would be the "emancipation from haggling and money." ${ }^{86}$ Western society has already become Judaized in that it has accepted the role of money as the basis for social order. Thus, the Jews have emancipated themselves in turning society into a cult of money. "The god of the Jews has been secularized and has become the god of the world. Exchange is the actual god of the Jew. His god is only the illusion of exchange" (M, 68). This illusion is the Jew's answer to the creativity of the non-Jewish, Western world:

What lies abstract in the Jewish religion, a contempt for theory, art, history, man as an end in himself, is the actual, conscious standpoint, the virtue of the money man. The species relationship, the relationship of man to woman, etc. becomes an object of commerce! Woman is bartered. $(\mathrm{M}, 68)$

Marx bases his argument on the difference between economic and civil emancipation within the modern (German Christian) state. He concludes by seeing that state not as German Christian but as Jewish. And the Jewishness of that state is manifested in the language ("haggling"), the aesthetics ("contempt for theory, art, history"), and the sexualized nature of the Jew ("Woman is bartered"). Marx sees his own life-his recent marriage to his noble Protestant wife; his writing, especially this essay; and his poetic creations - as the antithesis of this image of the Jew. He sees himself not as a bookkeeper but as a creator of books. And he sees himself as the antithesis of the money Jew: in the "practical Jewish spirit, Judaism or commerce," the this-worldliness of the Jew is manifest. Marx's economic determinism begins, then, with the pun inherent in the German use of the concept Jew, a term that by analogy had come to mean commerce in the vilest and basest sense. 
For Marx, this is the transformation of the settled world of the European Protestant into the wandering world of the cosmopolitan Jew. If Goethe admonishes his reader that "America must be HERE (In Europe) or nowhere," Marx sees the New World as a model for mobility and transformation. He quotes Thomas Hamilton's Men and Manners in America (I 833) regarding the nature of economics in the new United States:

The devout and politically free inhabitant of New England is a sort of Laocoön who makes not the least effort to escape from the snakes that enlace him. Mammon is his idol, they adore him not with their lips alone but with all of the strength of their body and soul. In their eyes the world is nothing but a Stock Exchange and they are convinced that here on earth their only vocation is to become richer than other men. The market has conquered all their other thoughts, and their one relaxation consists of bartering objects. When they travel they carry, so to speak, their wares or their display counter about with them on their backs and talk of nothing but interest and profit. If they lost sight for a moment of their own business, this is merely so that they can pry into someone else's. (M, 66)

The new American has become the wandering Jew, at least as a metaphor. According to Marx,

This is no isolated fact. The Jew has emancipated himself in a Jewish manner, not only because he has acquired financial power, but also because, through him and also apart from him, money has become a world power and the practical Jewish spirit has become the practical spirit of the Christian nations. The Jews have emancipated themselves insofar as the Christians have become Jews. (M, 66)

This is the cosmopolitanism of capitalism. It is the world of the Hoffaktor now read as the model for all modern states and actors. And on this point, Marx quotes Bruno Bauer, whom he otherwise rebuts:

The Jew, who in Vienna, for example, is only tolerated, determines the fate of the whole Empire by his financial power. The Jew, who may have no rights in the smallest German state, decides the fate of Europe. While corporations and guilds refuse to admit Jews, or have not yet adopted a favorable attitude towards them, the audacity of industry mocks at the obstinacy of the material institutions. (M, 66) 
Jewish cosmopolitanism is destructive because it is the spirit of capital. Marx adds a further implication to the idea of Jewishness. "On the Jewish Question" responds to an essay that posits the rhetoric of the Jew as immutable until converted into Christianity; Marx, however, sees all of Christianity as already converted into the basest nature of the Jews. But he also sees Bauer's argument as reflecting the type of attack lodged against the writings of Jews or those labeled as Jews. The Enlightenment rejection of religion as a litmus test for citizenship or, indeed, for national identity has been reversed:

Man emancipates himself politically from religion by banishing it from the sphere of public law to that of private law. Religion is no longer the spirit of the state, in which man behaves-although in a limited way, in a particular form, and in a particular sphere-as a species-being, in community with other men. Religion has become the spirit of civil society, of the sphere of egoism, of bellum omnium contra omnes. It is no longer the essence of community, but the essence of difference. (M, 54)

Marx adapts Bauer's rhetoric to criticize that world with which, by implication, Bauer has associated Marx - the world of Jewish cosmopolitanism. For Marx, the Jew is that internal cosmopolitan who turns all into the search for profit.

Over the first half of the nineteenth century, the nomadic state of the Jews, past and present, set them apart from the universalist Enlightenment idea of the cosmopolitan. The rootless state of the nomadic Jews, which is seen as originating in their biblical wanderings through the desert, renders them essentially different from the rooted cosmopolitanism of Christian Enlightenment thought. Thus, like Goethe, Bismarck opposed intermarriage with Jews in the I847 Landtag debate on civic emancipation although in I869 he advocated for virtually full emancipation. ${ }^{89}$ His reason was clear at both moments. Jews had "no real home, ... they are generally European, cosmopolitan, nomads. [But] there are good honest people among them." ${ }^{90}$ Most writers see the Jews' rootless nomadism as the source of their mental and spiritual corruption in modernity or at least as marking their character is ways different that others in the Enlightened world of the nineteenth century.

\section{Jews Writing Their Own Cosmopolitanism}

J. G. Herder's Ideas for a Philosophy of the History of Mankind (I784-9I) had provided a rather standard Enlightened Protestant theological reading of the 
Hebrew Bible (Tanakh) that presented the Jews as a nomadic people. Whether or not this account was ever historically true, the texts assembled into what Christians called the Old Testament are clearly the product of city-states. Whether or not the Jews were just one of "many little wandering hordes" $(\mathrm{H}$, 5I), as Herder describes them, the Old Testament, at least in Genesis, represents a nostalgia for a simpler time and space that came to be defined in the Enlightenment as "nomadic." Herder lists all of the innovations of these nomads, including the invention of "trade by weight and measure"-capitalism $\left(H, 5_{2}\right)$. Herder sees the Jews as one of the "cultures" of the ancient world, but the Jewish Volksgeist that defined the rise of protocapitalism. ${ }^{91}$ Given that Herder probably coined the term nationalism (Nationalismus), Jewish cosmopolitanism came to define its antithesis. ${ }^{92}$

In Herder's The Spirit of Hebrew Poetry (1782-83), the Jews' cultural corruption began with their diasporic dispersion. ${ }^{93}$ Whereas ancient Hebrew had matched the sublimity of Arabic, rabbinical Hebrew began to distort "the genius of [Hebrew's] original structure" as "this unfortunate people was dispersed throughout the world" (SHP, I63). In contrast, Herder argues, biblical Jews had in their previous nomadic state in the Holy Land produced an authentic and sublime culture tied to their own land, which they roamed. The pure spirit of biblical poetry reflects the close relationship with nature resulting from this genuine nomadism and even prefigures the modern Enlightenment: "The poetry of the Hebrews belongs under the open sky and, if possible, in the light of the early dawn. . . . Because this poetry was itself the dawn of the enlightenment of the world" (SHP, I72).

In Letters Concerning the Study of Theology (I8I9), Herder went even further, arguing that the incomplete history of the Jews was the stuff of universal poetry and that it anticipated the future history of humanity at large. The analogy here between Jews and Germans-both of them peoples without a nation-state in the age of nationalism-is implicit. The history of the Jewish teachings, which then found their universal mouthpiece in Christianity, represents "the most encompassing plan for all humanity and certainly that which develops our whole, earthly labyrinth."94

Although the Jews no longer figured in Goethe's concept of world literature, Jewish writers from the mid-nineteenth century onward increasingly invoke the notion of world literature to argue for the universal nature of Jewish literature. In this viewpoint, a truly cosmopolitan Jewish culture emerged in the diaspora, particularly Islamic Spain, when the Jews encountered European culture. ${ }^{95}$ Once estranged from its "original soil" of Asia, Michael Sachs argues, Judaism was forced to adapt to a new course that brought it into contact with 
new cultures and forms of knowledge. This tendency had been present even during antiquity, for "Judaism as a divine institution . . . has been an open eye to the world at all times." Yet this cosmopolitan spirit came to full fruition only in the medieval Spanish diaspora, with its "rich cultural life," which finally "severed European Jews' connection with Asia."96

Leopold Zunz's Zur Geschichte und Literatur (On History and Literature), also published in I845, develops a full-fledged argument for Jewish literature as world literature. Rooted in antiquity and at the same time closely aligned with Christianity and the medieval sciences, Jewish literature is both universal and particular: indeed,

it is supplementary to general literature. Its peculiar features, themselves falling under universal laws, are in turn helpful in the interpretation of general characteristics. . . . If the aggregate results of mankind's intellectual activity can be likened unto a sea, Jewish literature is one of the tributaries that feed it. ${ }^{97}$

The Christian diaspora, however, had caused Jewish culture to remain stagnant and even regress. Unlike Islamic Spain, which was culturally and linguistically connected to the scientifically advanced Islamic world, Christian countries lacked a common lingua franca, and so did the Jews in these countries. Furthermore, Christian cultures of the time were far inferior to the Jews', for "the literature of each nation hardly yet deserved to be called such, and their lesser developed cultures were no match for their congenital Jewish counterpart." 98 Medieval Spain, in contrast, enhanced both the particular and the universal nature of Jewish culture. Here, Jews became once again a national entity and had a common language, Arabic, that again mediated between them and the world.

In Judaism and Its History ( I 865), Abraham Geiger similarly stresses the universal potential of ancient Judaism's ability to "behold the innermost nature of Human Morality," which he assumed to be universal. ${ }^{99}$ Ancient Greece had proved itself "the most talented nation of Antiquity, which was distinguished by noble culture and exercised the most profound influence upon the development of the whole human race" (JH, 23). The Jews, in their encounter with Greek culture and language, had adopted many of its traits without abandoning their religion. By being open to new influences while maintaining their particular practices, the Jews once again emerge as mediators between cultures. In the third volume of this work, Geiger even claims that the cosmopolitan spirit represented the essence of ancient Judaism. In contrast to other ancient peo- 
ples, which had seen themselves as "the perfect embodiment of humanity" (JG, 2), Judaism, despite maintaining its ethnic particularity, had continually "striven beyond the nation" (JG, 3) and "toward entire humanity" (JG, 4). ${ }^{100}$

Taking this idea even further, Moritz Steinschneider claims that the cosmopolitan core of Jewish tradition persisted from biblical times through modernity in his 1872 Ueber die Volkslitteratur der Juden (On Jewish Popular Literature). Like Geiger, Steinschneider argues that the consistent trait of Jewish culture lies in the Jews' role as mediators and translators of the other cultures with which they come into contact:

The Jews, however, had long since become polyglots even before their Bible was published as a polyglot, that is, in many languages ..., and since that time Jews never stopped being their own translators and that of other nations. ${ }^{101}$

Once in exile, Steinschneider argues, the Jews

compensated for their exclusion and seclusion from and in life through lively literary exchanges, which nourished in them the seed of the cosmopolitanism that the prophet's universal promise had planted in the Jewish awareness. ${ }^{102}$

This cosmopolitan potential, literary scholar Gustav Karpeles argues in his I 886 Geschichte der jüdischen Literatur (History of Jewish Literature), reached fruition in Islamic Spain. Jewish literature had already evinced its universal nature in the ancient homeland, for "the cradle of human culture is also the cradle of Jewish literature." ${ }^{103}$ Through medieval Jewish writers such as Yehuda ibn Gabirol, Yehuda Halevi, and Moses Maimonides, Islamic Spain had produced "all greatness and beauty ... in world poetry" (GJL, 447). This account reflects the special status attributed in the circles of Wissenschaft des Judentums (Studies of Jewry) to medieval Spanish Jewish culture as the locus of Jewish cultural authenticity in the diaspora. Like others writing in this vein, Karpeles sees the great cultural and scientific achievements of the medieval Spanish Jews coming to fruition in the Wissenschaft des Judentums. After centuries of Jewish cultural destitution in the German-speaking lands, he claims, the rise of Wissenschaft has led to the cosmopolitan renewal of German-Jewish literature as one stream leading "into the vast sea of world literature" (GJL, 429).

For most nineteenth-century Christian writers, however, ancient Judaism's nomadism had impeded any significant cultural developments and set 
Jews aside from the civilized nations. Literary historian and Orientalist Richard Gosche argued for the essentially antithetical nature of nomadism and genuine literature in his I870 Idyll and Village Tales in Antiquity and the Middle Ages: "Culture and Nomadism must be contrasted against one another. This rupture is most evident in various verses of the Song of Songs." 104 Solomon's songs, however, remained but a brief interlude in the stunted development of a genuine Jewish culture, which failed altogether when ancient Jewry lost the struggle for its homeland.

At the close of the nineteenth century, French philosopher Ernest Renan (I823-92) saw in the Jews the survival of "nomadic instincts" and the "nomadic nomos" in modern times, while René Guenon wrote of the "perverse nomadism of the Jews." 105 In a widely translated I 883 lecture, Renan stressed both the mixed racial nature of the Jews and their important contributions to the progress of humanity at large. Although Renan saw only Hinduism and its progeny, Buddhism, as well as Christianity and Islam as "universal religions" because they could be found across different races, the Jews emerge as a both particularist and universalist force in Renan's claim that the prophets "made this cult of Yahweh into the universal religion of the civilized world." 106 Subsequently, "the whole world entered in" (JRL, 92). Conceded Renan,

The Israelite race has rendered the world the greatest services. Assimilated to different nations, in harmony with diverse national units, it will continue to do in future what it has done in the past. By its collaboration with the liberal forces of Europe, it will make an eminent contribution to the social progress of humanity. (JRL, IOO)

As Renan expanded in his I 887 History of the People of Israel, the Jews' catalytic nature had emerged only in their encounter with other cultures. During antiquity, "the Semitic shepherd" and "nomad Semite" had been among "the first to conceive sentiments of order and the pride which is born of selfrespect, . . . contribut[ing] in a certain measure to morality." 107 But they had mostly kept to themselves to maintain their "purity of blood" (HPI, I: I4). This limited racial predicament had been reflected in their stunted language and cultural imagination. At the same time, the limited imagination of these "Semitic hordes" (HPI, I: I I) had led them to create the purest religion because they were least inclined toward superstition. This, Renan contended, had been a blessing for humanity at large: "And yet these ancient patriarchs of the Syrian desert were in reality corner-stones for humanity. . . . Judaism, Christianity, and Islamism all proceed from them" (HPI, I: 5I). For Renan, however, ancient 
Judaism delivered only the raw ingredients for a universal narrative of humanity, most likely as a consequence of Judaism's limitations. The great homogenizing force was Rome, an idea that was developed in the cosmopolitanist works of such twentieth-century Jewish writers as Stefan Zweig and Lion Feuchtwanger. Argued Renan,

The world, before it was ready to accept Hellenism and Christianity, had to be prepared and made smooth, so to speak. A great humanizing force had to be created - a force powerful enough to beat down the obstacles which local patriotism offered to the idealistic propaganda of Greece and Judea. Rome fulfilled this extraordinary function. Rome, by prodigies of civic fortune, created the force of the world, and this force in reality served to propagate the work of Greece and the work of Judea, that is to say, civilisation. Force is not a pleasant thing to contemplate, and the recollections of Rome will never have the powerful attraction of the affairs of Greece and of Israel; but Roman history is none the less part and parcel of these histories. (HPI, I: $\mathrm{x}$ )

In his two lectures on Babel and Bibel (1902-3), German Orientalist Friedrich Delitzsch further underlined Renan's argument about ancient Jewry's lack of cultural imagination. According to Delitzsch, biblical lore itself was devoid of any authenticity. Ancient Israelites had merely borrowed and in so doing corrupted and destroyed the creative imagination originally present in these stories. Merely the YAHVE faith itself was genuinely Israelite in origin, and it displayed the limitations of the Semite's nomadic mind. Jews and Jewish culture thus emerged as the particularist paradigm and thus implicitly as the antithesis of the cosmopolitan universal:

Even the Yahwè-faith, by which, as under a banner, Moses bound together in unity the twelve nomad tribes of Israel was, and continues to be, with kinds of human limitations: . . . above all, with Israelite exclusiveness. ${ }^{108}$

Theology and ideology merge here in the debates in the public sphere (if they were ever separate), and civil society becomes the contested ground for the Jew as imagined nomad. As Jewish writers in the German-speaking world reflected on their rootedness as cosmopolitans, the world of fiction became a thought experiment for conservative German writers, who imagined how this process would play out in their fictive Germany. ${ }^{109}$ In Wilhelm Raabe's antisemitic novel, The Hunger Pastor (I864), the arch-Jew Moses Freudenstein 
points out that being German is a garment easily discarded, and he transforms himself into an immoral and corrupt Frenchman, Théophile Stein. As Freudenstein becomes a European, in his Jewish identity is equally easily discarded:

I have the right to be a German when I so desire it and the right to give up this honor at any given moment. We Jews are indeed the true cosmopolitans, Weltbürger by the grace of God, or if you will, by God's ungraciousness. From the creation to the Ioth of $\mathrm{Ab}$ in $70 \mathrm{AD}$ we have lived in extraordinary circumstances and after the destruction of the Temple this remained for us, if in a somewhat different manner. . . . Since they stopped murdering us as well-poisoners and the murderers of Christian children, we are much better off, than all of you, however you want to call yourselves, you Aryans: Germans, French, English. . . . My friend Harry Heine in Paris remains, in spite of his white catechist's robe, a true Jew, for whom all the baptismal water, all the French champagne and German Rhine wine could not wash the Semitic blood out of his veins. ${ }^{110}$

These dismissals of cosmopolitanism mirror the ranting about Jewish exceptionalism in Gustav Freytag's best-selling Debit and Credit (Soll und Haben) ( I 855), one of Raabe's evident models. Freytag's novel presents the conflict between the rootless and dishonest Jewish father and his son, whose rejection of his parentage and desire for total assimilation leads inevitably to his suicide. As George Mosse has noted, such novels were immensely popular (Freytag's had more than fifteen different editions within a few years after publication) and populated the libraries of Jewish households throughout Germany. ${ }^{111}$ Such views were further developed in a series of best-selling antisemitic novels from Adolf Barthels's The Dithmarchers ( I 898) to Josefa BerensTotenohl's Der Femhof ( I934).

For such writers, the nation-state is predicated on citizens who are rooted in place and do not wander the world, and it must defend itself against outsiders who seek to enter. A state that manages this can accomplish great things, as Renan proclaimed in an I882 lecture, "What Is a Nation?" He defined the nation by the desire of a people to live together, which he summarized with what has become an oft-cited phrase: "having done great things together and wishing to do more." 112 But this idea became a commonplace by the I920s, echoed by thinkers such as Carl Schmitt in his dichotomy of "friend and foe" in The Concept of the Political (1927). Schmitt argues that the potential for conflict between nation-states defines them. In "Group Psychology and the Analysis of the Ego" (I92 I), another early twentieth-century Jewish thinker stated succinctly, 
Every time two families become connected by a marriage, each of them thinks itself superior to or of better birth than the other. Of two neighbouring towns each is the other's most jealous rival; every little canton looks down upon the others with contempt. Closely related races keep one another at arm's length; the South German cannot endure the North German, the Englishman casts every kind of aspersion upon the Scot, the Spaniard despises the Portuguese. We are no longer astonished that greater differences should lead to an almost insuperable repugnance, such as the Gallic people feel for the German, the Aryan for the Semite, and the white races for the coloured. ${ }^{113}$

But the symbolic meaning of such contrasts between the rooted and the cosmopolitan defines the identities of the members of each collective. Aryan and Semite (however each is defined) define the other. The rooted versus the cosmopolitan is part of this symbolic language of nomadism and the agrarian world.

Over the second half of the nineteenth century, the idea of exclusivity closely bound to the nomadic came to shape the Jewish interest in cosmopolitanism. The idea declined after I 848 , when assimilation became the dominant paradigm, rejecting both the nomadic and the cosmopolitan in favor of the national. In response to this new nationalism at the close of the nineteenth century, Jewish nationalism was recuperated in the form of Zionism and in the extraordinary expansion of antisemites' charges of permanent Jewish nomadism. Jewish cosmopolitanism became a third force, torn between essential definitions of the Jew as a national citizen (German or Zionist) or a modern nomad. The antisemite defined the Jew as an impossible candidate for true citizenship because of his nomadic nature, proven by his desire to return to the desert in the Zionist project. This is hammered out most clearly not in Imperial Germany but in the complex world of the Austro-Hungarian Empire, where modern Zionism is formulated. 


\section{CHAPTER 3}

\section{"Everyone Is Welcome": The Contradictions of Cosmopolitanism in the Imperial Worlds of Austro-Hungarian and Wilhelmine Jewry}

\section{From Vienna to Berlin and Beyond}

Modernity can be defined by the potential for movement across geographic spaces as well as through tiers of society. ${ }^{1}$ The introduction of the train meant that over the nineteenth century, what had been a world of German-speaking Jews moving across space and class in horse-drawn coaches became a more complex metaphor of mobility. As a means of turning the Jews into "race" with unchanging physical and moral characteristics, the nomad appears (or, indeed, reappears) to challenge such mobility, which the rising non-Jewish bourgeoisie shared.

Mobility generates anxiety, especially among those whose stability is questioned by the expansion of other cohorts (the bourgeoisie, the Jews, or most frightening of all, the Jewish bourgeoisie) as well as by those made suddenly mobile in ways abstractly promised by the Enlightenment but now seemingly realizable. For Jews, mobility differs because of the claim that they are eternal and essential nomads and that their cosmopolitanism merely masks this unchangeable quality. They are not like all of the others being driven across the landscape of geography and class by the steam engines that drive locomotives as well as economic change. Especially for those who define themselves at the periphery of empire or society, the train comes to redefine such movement.

Vienna, Berlin, and to a lesser degree Prague and Budapest form the cultural centers of the German-speaking world and its Jews during this period, and the overlapping and divergent debates about Jews, the nation, and cosmopolitanism receive new currency in these cities. In this era of intensifying nationalism, Jews, who overwhelming embraced the ideal of assimilation into German culture, increasingly became seen as outsiders to the German nation. This pro- 
cess facilitated the fin de siècle Jewish Renaissance, which promoted the idea of the Jewish people and their specific national culture. Theodor Herzl's Zionism is but one emanation of this idea. Both his political Zionism and early twentieth-century Central European cultural Zionism cannot simply be subsumed under the European nationalisms of their time; rather, they emerged at the crossroads of the nationalistic and cosmopolitanist discourses of the era. In so doing, both political and cultural Zionism straddled the dichotomy between universalism and particularism that had formed the dialectical points of tension in Enlightenment cosmopolitanism. This is not to say, of course, that Zionists of either persuasion wholeheartedly embraced cosmopolitanism. In particular, political Zionists, who unlike cultural Zionists emphasized the need for a Jewish homeland, tended to reject the cosmopolitanist vision as unviable, given the Jews' historic persecutions in Europe and the rise of political antisemitism at the end of the century. However, the recent vilification of Zionism as the antithesis of a cosmopolitanist theory and practice is far too simple as well as historically inaccurate. ${ }^{2}$ On the contrary, cosmopolitanism formed one of the intellectual sources of early Zionism and still echoes, albeit increasingly distantly, in today's Israel with the promotion of Tel Aviv as a modern city.

A dichotomy between the two imperial mind-sets of the late nineteenth century can be seen in this age of rapid change: Vienna represents in the European Jewish imaginary a centrifugal force, defining its cosmopolitan ideal as ever expanding beyond "national" borders of the component states of the ancient empire (even though Vienna remains the permanent center of such centrifugal motion). Indeed, the supranational structure of the dual monarchy and its protection of the equal rights of its national constituents as enshrined in the Austrian constitution seemed conducive to fostering a cosmopolitan sensibility among its subjects. According to Article XIX of the Austrian constitution, "All ethnic tribes of the [Austrian] people are equal. Each ethnic tribe has an indisputable right to preserve and practice its national customs and its language in particular."3 Berlin, conversely, seems to represent in these imagined worlds a centripetal cosmopolitanism, reinforcing a stable national identity for Jews as members of the new state with all of the older identities (for example, Prussians, Bavarians) subsumed into a new German identity. Writers in Prague and Budapest, with their German-speaking minorities divided by "religion" (read as "race") (Jews and Christians), struggle on a self-conscious periphery to debate and engage the other centers. Their variants on the themes of rootedness and cosmopolitanism reflect such engagement from a self-conscious periphery in an imagined "East." Living in these two imagined worlds shaped the idea of Jewish cosmopolitanism, including the idea of what a Jewish identity could be. 
And both provide models that engage the center-periphery dichotomy with variant forms of cosmopolitanism and rootedness for the cosmopolitan that were at base surprisingly similar.

This phenomenon can be sensed in the imperial world of the AustroHungarian Empire (after I 867 officially the Kingdoms and Lands Represented in the Imperial Council and the Lands of the Holy Hungarian Crown of Saint Stephen). Imperial Austro-Hungarian Jewry came to define this physical and social movement as discomfiting - indeed, as dangerous to one's health. They saw only one real center in this centripetal world: the imagined core and the permanence of the empire, symbolized by the emperor. And there really was only one emperor for Jews in the Austro-Hungarian Empire in the late nineteenth and early twentieth centuries-Franz Joseph I. Indeed, in an odd way, the emperor represented a train running from the center to the periphery and back. The train line created between Vienna and Prague in I 866 was named the Kaiser-Franz-Josephs-Bahn. From the perspective of Vienna, the train moved people from the periphery in the East to the unmistakable center, Vienna. This construct was, of course, merely a fantasy of German-speaking Austrians, who imagined themselves at the cultural, political and geographical midpoint of the empire and its Slavic subjects as peripheral easterners. Geographically, Prague, which was predominantly German-speaking until the turn of the century, was located northeast of Vienna and thus represented the old Central Europe even more than Vienna itself did. In any case, the first train station inside the old wall of Vienna was the Franz Joseph Station on this line, opened in I872, and huge numbers of Jews moved West through its portals, if only in cultural terms.

According to legend, the Habsburg emperors loved their Jews. They told the tale that, like Harun al-Rashid in the IOOI Nights, Franz Joseph had anonymously stopped one evening at a Jewish inn to find out the reality of Jewish life. There, as a stranger, he was treated well, given whiskey and herring, and thus loved his Jews thereafter. The reality was quite different. After the failure of the Revolution of I848, the new emperor, who became emperor of Austria and apostolic king of Hungary that year and did not die until I9I6, abrogated many of the rights of the Jews guaranteed in the so-called Pillersdorf Constitution of I 848 but did allow his Jews to own taverns. His sense of the pace of Jewish emancipation was very much driven by the precarious balancing of the claims of ethnicities, nationalisms, and religions in his complicated imperial realm. His I 869 visit to Jerusalem (after the liberals were again in the ascendancy in Vienna) was heralded by the Jews of the empire as a sign of his magnanimity and his toleration for their difference and as a sign of his positive attitude toward them, and he played them off against other ethnicities. 
The prayers for the emperor that appeared in the synagogues through the empire were a sign of Jewish allegiance to the Habsburgs and to their multicultural realm. These Jews claimed that they were not nomads, that they were settled, that they were the best citizens of the dual monarchy. Many wandered from the eastern reaches of the empire-from Galicia, from Poland, even from the now modernizing Hungary-into Austria proper, and not rural Austria but the imperial capital, Vienna. The age of intensifying nationalism led some Jews to resolve their conflicting German, Yiddish, Hungarian, and Slavic allegiances to reject any previous German affinities, ${ }^{4}$ yet others saw themselves as even better citizens than the emperor. They were not merely imperial citizens; they had become Germans. ${ }^{5}$ They were now rooted in a pan-German identity, even if their parents had spoken Yiddish or Hungarian. And their emperor was really just the symbol of a world of cosmopolitan difference that incorporated the Jews but never gave them status as Austrians. Furthermore, the empire was large (indeed, too large), and the emperor was too far away.

Max Nordau (from peripheral Budapest but writing in cosmopolitan Paris) and Sigmund Freud (from the fringes of empire-Freiburg in Moraviabut writing in pluralistic Vienna) most clearly felt such a displacement. The anxiety generated for Jewish intellectuals by the implications of their own social and geographic mobility comes to be imbricated in the late-nineteenthcentury explosion of scientific and technological advances in the Germanspeaking lands. The decline of the imperial era in Austria and the rise of the new Germany framed new discourses of universalism, which in turn prepared the ground for the explosion of cosmopolitanist engagement after the outbreak of World War I. Owing to its seeming "supranational" structure, the AustroHungarian Empire became a hotbed of both conflicting and overlapping discourses about the nation, race, and science. ${ }^{6}$ Yet imperial national identity rooted in a German (read: Austrian) cultural hegemony was a powerful reality for Jews. While it seemed to be supranationalist, it was in fact simply a means of avoiding the poisoned chalice of regional nationalisms, including the other head of the two-headed imperial eagle, Hungary. ${ }^{7}$ The empire provided geographic mobility (and in some cases economic mobility) for Jews willing to move from what were perceived as provincial languages and cultures (such as Czech) into the German cultural sphere. Franz Kafka's family, for example, moved from Yiddish to Czech to German in three generations while moving from the Bohemian provinces into Prague, and they were not unique. ${ }^{8}$ The language wars that dominated much of the imperial focus during this period were surrogates for new nationalisms, and Jews often were able or were forced by anti-Jewish feelings to make choices that underlined their cosmopolitanism. 
For some, but not all, such movement heightened their sense of being Jewish, whatever they understood that to be. The supranational state and its dominant German cultural sphere had its own fantasies about Jews and cosmopolitanism. From Zionism through the Jewish Renaissance and psychoanalysis, to mention just a few of the key movements that took their course from the Habsburg Empire, Jewish intellectuals attempted to position the Jew at the core of a universal narrative of humankind, whether the nation as the supposedly natural organization of humanity or the universal human mind. Only during World War I did this new universalism assume the widespread overtones of a European identity beyond national borders, even though its buddings can be seen during the imperial era.

\section{Vienna, Zionism, and Cosmopolitanism}

Vienna formed the undeniable center of the imperial Austro-Hungarian German-speaking avant-garde at the fin de siècle, and Jews played a disproportionate role in shaping all areas of modern Viennese culture. As with most such claims, this one requires qualification: "Jewish overrepresentation" in specific fields such as the arts, medicine, and journalism has more to do with access to such endeavors than any specific Jewish predisposition for such fields. The center of a multiethnic and multilingual empire, Vienna presented Jews with more complex questions of identity and cultural location than did the Wilhelmine empire. ${ }^{9}$

At the fringes of empire, Theodor Herzl - a secular Jew, a Hungarian (born in Pest before it was merged with Buda), a Viennese (where he lived, studied, and worked after he turned eighteen), a citizen of the dual monarchy (with German-speaking parents born in Serbia), certainly a cosmopolitanhad been watching in Paris on 5 January I 895 when French staff officer Alfred Dreyfus was stripped of his rank and sent to Devil's Island for treason (and for being a Jew). Herzl saw parallel developments at home, too. Karl Lueger was elected the Christian Socialist mayor of Vienna that year on an antisemitic platform. The emperor refused to seat him until I897 after a request from the beleaguered Pope Leo XIII—not solely because Lueger was an antisemite but because the emperor feared that nomadic Jewish capital would flee Vienna for the new economic center in Budapest.

After I 895, Herzl, by that time a middle-aged journalist and popular dramatist, struggled with the conflict between a new Jewish national identity that was local and the global idea of a Jewish cosmopolitanism. For Herzl, the 
cosmopolitan must give way to the national. Herzl acknowledges the ability of cosmopolitan Jews to undertake such a transformation and sees it as a force for state building. Herzl's Jews adapt to their environment: "Darwin's theory of imitation will be validated. The Jews will adapt. They are like seals that have been thrown back into the water by an accident of nature. . . . if they return to dry land and manage to stay there for a few generations, their fins will change back into legs." 10 Cosmopolitanism can be changed into a new nationalism through natural selection.

The Darwinian notion that underpins Herzl's view of Jewish adaptability is colored by his acceptance of Herbert Spencer's idea (which Darwin, too, accepts) of antagonism as central to evolution. In Herzl's Judenstaat (The Jewish State) (I896), the Jews are both universalist subjects and essentially Jewish particularists, since being Jewish as a national identity meant de facto claiming universal values. ${ }^{11}$ According to Herzl,

It might further be said that we ought not to create new distinctions between people; we ought not to raise fresh barriers, we should rather make the old disappear. But men who think in this way are amiable visionaries; and the idea of a native land will still flourish when the dust of their bones will have vanished tracelessly in the winds. Universal brotherhood is not even a beautiful dream. Antagonism is essential to man's greatest efforts. ${ }^{12}$

But the idea of the universal is held within the essence of the Jew. Herzl and other Jewish writers thus wrote the Jew back into eighteenth-century Enlightenment cosmopolitanism, which had promoted a universality rooted in the nation by excluding the Jews. With regard to this particularist universality, Johann Gottlieb Fichte had stated that "every cosmopolitan [Kosmopolit] is necessarily, given his limitations by the nation, a patriot, and each who in his nation is the strongest and most active patriot is therefore the most active cosmopolitan [Weltbürger]." 13 The distinction between Kosmopolit and Weltbürger reflects the universalism of Kosmopolit as opposed to the German term Weltbürger, which here marks the particularist element. In Fichte's world, the terms came to be understood as compatible, but not if claimed by the Jews. For Herzl, however, they are necessarily compatible for the Jews.

Herzl's I 896 fantasy of Zion in fact constituted a reworking of the idea of movement and progress (in August Comte's sense of the word) inherent in the cosmopolitan: 
It will be carried out in the midst of civilization. We shall not revert to a lower stage, we shall rise to a higher one. We shall not dwell in mud huts; we shall build new more beautiful and more modern houses, and possess them in safety. We shall not lose our acquired possessions; we shall realize them. We shall surrender our well earned rights only for better ones. We shall not sacrifice our beloved customs; we shall find them again. We shall not leave our old home before the new one is prepared for us. Those only will depart who are sure thereby to improve their position; those who are now desperate will go first, after them the poor; next the prosperous, and, last of all, the wealthy. Those who go in advance will raise themselves to a higher grade, equal to those whose representatives will shortly follow. Thus the exodus will be at the same time an ascent of the class. (JS, 82)

And indeed, Herzl's idea of progress was connected to high culture. In January I 898, he wrote that "during the last two months of my residence in Paris [in I 895] I wrote the book The Jewish State. . . . I do not recollect ever having written anything in such an elevated frame of mind as that book. . . I worked at it every day until I was completely exhausted; my only relaxation in the evening consisted of listening to Wagner's music, especially to Tannhäuser, an opera I went to every time it was performed. Only on the evenings when there was no performance at the Opera did I feel doubts about the correctness of my ideas." 14 Herzl imagined a Jewish state, first in Argentina, and then in Palestine, with a side trip to Uganda, where European culture would dominate- a world imagined to look like Switzerland or the Austro-Hungarian Empire without the nationalist conflicts and bound together by Jewish identity and Western high culture.

Whoever has seen anything of the world knows that just these little daily customs can easily be transplanted everywhere. The technical contrivances of our day, which this scheme intends to employ in the service of humanity, have heretofore been principally used for our little habits. There are English hotels in Egypt and on the mountain-crest in Switzerland, Vienna cafes in South Africa, French theatres in Russia, German operas in America, and best Bavarian beer in Paris. When we journey out of Egypt again we shall not leave the fleshpots behind. . . . We cannot journey out of Egypt today in the primitive fashion of ancient times. We shall previously obtain an accurate account of our number and strength. 
The undertaking of that great and ancient gestor of the Jews in primitive days bears much the same relation to ours that some wonderful melody bears to a modern opera. We are playing the same melody with many more violins, flutes, harps, violoncellos, and bass viols; with electric light, decorations, choirs, beautiful costumes, and with the first singers of their day. (JS, I35)

Herzl's new cosmopolitanism of the Jews would certainly not be a democracy. He mistrusted the idea of parliaments ruled by individuals other than the elites:

Hence I incline to an aristocratic republic. This would satisfy the ambitious spirit in our people, which has now degenerated into petty vanity. Many of the institutions of Venice pass through my mind; but all that which caused the ruin of Venice must be carefully avoided. We shall learn from the historic mistakes of others, in the same way as we learn from our own; for we are a modern nation, and wish to be the most modern in the world. Our people, who are receiving the new country from the Society, will also thankfully accept the new constitution it offers them. Should any opposition manifest itself, the Society will suppress it. The Society cannot permit the exercise of its functions to be interpreted by short-sighted or ill-disposed individuals. (JS, I45)

Herzl sees the New Jerusalem as Venice, the home of the first ghetto. For cosmopolitanism run by a hoi polloi is anarchy. Zionists after Herzl were similarly obliged to negotiate this apparent dichotomy. In I903, Franz Oppenheimer wrote that

Zionists are accused of being reactionary because we wish not to proceed to an ideal that lies before us but rather to recede to an ideal in the past. ... The future lies not in an emphasis on nationalism, not in that which divides peoples rather than in that which connects them. ... Is the high ideal of a Weltbürgerthum un-Zionist or indeed anti-Zionist? . . . Today there spreads across the land a new culture that wishes to eradicate the differences between peoples. Today we are the new Maccabees struggling against this. ${ }^{15}$

A manly Zionism must resist the temptation of a soft, weak, and rootless cosmopolitanism, the sort that Friedrich Nietzsche came to detest. ${ }^{16}$ All of these debates almost completely exclude any idea of Jews and capital except as 
a flagrant antisemitic calumny. Only when the cosmopolitan boogeyman is evoked does the economic occur as a reflex of Jewish rootlessness. Thus, labor Zionist Aaron David Gordon ( I 856-I922) wrote, "We have no roots in the soil; there is no ground beneath our feet. And we are parasites not only in an economic sense but in spirit, in thought, in poetry, in literature, and in our virtues, our ideals, our higher human aspirations. Every alien movement sweeps us along, every wind in the world carries us." 17 The fantasy nation-state of Zion is somehow created without any reference to Jewish economic activity, which remained a sign of the rootless cosmopolitan. Herzl's Zionist project develops out of the supranational fantasies of the mobility of the Austro-Hungarian Empire. Yet Herzl, unlike his contemporary, Francophone journalist Bernard Lazare (I856-I903), did not comprehend, as Hannah Arendt claimed in I942, that "antisemitism was neither an isolated nor a universal phenomenon and that the shameful complicity of the powers in the East European pogroms had been symptomatic of something far deeper, namely, the threatened collapse of all moral values under the pressure of imperialist politics." 18 Yet this image of imperial mobility is shaped by the experienced reality of a railroad system that can whisk any of the Jewish citizens of the empire from the eastern periphery to Vienna or even further afield, to the social and intellectual center of Europe, Paris. But such mobility in space had its dangers.

For physician Max Nordau, a Jew from imperial Budapest living in republican Paris in the I89os, the railroad becomes the sign of the overloading of the nervous system through the pressures of modern life. ${ }^{19}$ "Even the little shocks of railway travelling, not perceived by consciousness, the perpetual noises, and the various sights in the streets of a large town . . . cost our brains wear and tear." ${ }^{20}$ For Nordau, the "constant vibrations undergone in railway travel" and the "effects of railway accidents" lie at the center of "modern nervousness" and "degeneration." But missing and unstated in Nordau's comments is the subtext that the nervousness attributed to modernity, with its increased speed of life, is most often and most evidently seen as a Jewish problem, a problem of the Jewish cosmopolitan. Herzl approached Nordau, an established literary figure and a prominent intellectual, after the Dreyfus Affair, and he quickly became the first major adherent of Herzl's idea of a Zionism that would recuperate the cosmopolitanism of diaspora Jewry.

For Nordau, following Herzl, cosmopolitanism has made the Jews the sick people of Europe:

Zionist societies use every effort that the members and the Jewish masses in general may know the history of their nation, and become acquainted with the sacred and profane literature in the Hebrew tongue. They teach 
the Jews to hold their heads high, to be proud of their descent, and to despise the antisemitic lies... . [T]hey care, in the measure of their strength, for the amelioration of the hygiene of the Jewish proletariat, for its economic improvement by means of association and solidarity, for well directed education of children, and for the instruction of women. . . . [T]hey preach the duty of leading a faultless, spiritual life, the rejection of crude materialism, into which the assimilation Jews, on account of the want of a worthy ideal, are only too apt to sink, and strict self-control in word and deed. They found athletic societies in order to promote the long neglected physical development of the rising generation. ${ }^{21}$

Nordau seems quite comfortable with the contradictions of his universal assumptions of what Ilan Zvi Baron calls "naturalistic political thought" rooted in claims that modernity and its corollary, cosmopolitanism, reek of social degeneration. ${ }^{22}$ Nordau's had already stated these widely held views in his I 892 book, Degeneration, which was a worldwide best seller and made his reputation. As Baron argues, Nordau sets this idea against his claims regarding a "Jewish identity that was capable of taking on the ultimate political task of fighting for the Jewish people." 23 After the Treaty of Versailles, Nordau, speaking to an audience in London in I920, stressed the need for a Jewish homeland in Palestine as an answer not to cosmopolitanism but to the endemic antisemitism of the postwar moment. Yet his talk stressed the loyalty of the Jewish soldiers to their homeland during the war, a loyalty repaid after the war by those "countries which discriminated heinously against them, for those countries, humiliated and enslaved them like criminals, hunted them like beasts of the wilderness." ${ }^{24}$ National loyalty during the war was no shield against antisemitism. This talk followed a more common approach to cosmopolitanism followed by British Zionists such as Arthur D. Lewis in which such loyalty was deemed a form of self-deception for "as long as we think as cosmopolitans, in the name of whatever theory our cosmopolitan ideals suggest to us, we shall have adherence in words, not in deeds. The national tradition, the love of brother for brother, the religious sentiment, sleeping, waiting to be awakenedthese alone can arouse the inert to action, give faith to the fearful, the scourge of self-sacrifice to the calculating, enthusiasm to those who reject with distrust all merely intellectual ideas." Lewis goes on to argue that "cosmopolitanism is a mere abstraction; no real man is cosmopolitan." The Jew would be "a madman or an imbecile if cut off from the life of his contemporaries." 25 Juxtaposing Nordau's I920 condemnation of the postwar rise in antisemitism as a result of growing nationalism with Lewis's I9I9 call for a rejection of cosmopolitan 
intellectualizing presents one of the central problems confronting early twentieth-century political Zionism: how to think about a nationalism that was rooted in emotions, not coolly rational, yet inclusive, perhaps even cosmopolitan, at least concerning the wide range of nationally oriented Jews who represented all sides in World War I. Cosmopolitanism and Zionism are read along parallel but quite different tracks. Antisemitism remains for Nordau a disease of the modern nation-state; for Lewis, the disease is cosmopolitanism. The cure is Zion, an inclusive national homeland.

The nervousness of modern life as symbolized by the railroad is Jewish cosmopolitan nervousness. It is the nervousness of the modern economic world in which the "nomadic Jew" must function. Train travel and the meaning of trauma had a secondary context for Jews in the nineteenth century. Like the coaches of the Enlightenment, the train remained one of the public spaces, defined by class and economic power, in which the Jew could still purchase status. It was part of the image of the world of modern life that helped deform the psyche of the Jew. A ticket assured one of traveling among one's economic equals - but not as racial equals. The association of trains and the trauma of confronting one's Jewish identity is a powerful topos of the time and a trope in the emerging sociological literature that comes to define the cosmopolitan nature of capitalism.

In turn-of-the-century Vienna, the capital of imperial Austria-Hungary, neurologist turned psychoanalyst Sigmund Freud had already linked his "phobia of travelling by train" to the move from the "East" when he was three years old and he saw gas flames in the Breslau railroad station burning like "souls in hell."26 But the older Freud also linked the anxiety associated with the train with the sense of social displacement that he felt after leaving the economically déclassé world of the Eastern Jew (to which he feared he always belonged) — the world of his father as a wandering merchant - to come to Vienna to become a professional. As Yuri Slezkine has observed, "Secularized Jewish fathers—-stern or indulgent, bankers (like [György] Lukács's father) or haberdashers (like Kafka's) — did their best to bring up free, cosmopolitan men: men without fathers. They were remarkably successful: indeed, few generations of patriarchs were as good at raising patricides and gravediggers as first-generation Jewish liberals. And no one understood this better than Sigmund Freud and Karl Marx." ${ }^{27}$ Such tensions both liberated and encumbered Jewish cosmopolitans. On the one hand, they were freed from the social constraints and limits they perceived in their fathers' religious identity as Jews; on the other hand, this freedom demanded some type of rethinking of their place in both the nation-state and transnational definitions of social roles such as those ascribed to the Jews. 
Freud's interest in the structure of the human psyche and social structures was to no little degree shaped by a powerful rejection of racial (read: Jewish) particularism that saw the Jewish psyche as damaged and damaging. ${ }^{28}$ The result was psychoanalytic theory, which brought with it broader cosmopolitanist implications as a consequence of its postulate of a universal human psychology rather than clearly demarcated racialized psychotypologies. His struggle with a national understanding of the Jews was always pitted against the scientific claims of an inherent Jewish inferiority.

Indeed, though Freud shared with many of his Viennese contemporaries an ambiguous relationship toward any expressions of Jewish nationalism, he was also clear about his sense of Jewish identity. Many middle-class Austrian Jews, Freud included, distanced themselves from revisionist Zionism after World War I. ${ }^{29}$ For Freud, being Jewish meant sharing "many obscure emotional forces, which were the more powerful the less they could be expressed in words, as well as a clear consciousness of inner identity, the safe privacy of a common mental construction." ${ }^{30}$ His Viennese contemporaries such as Theodor Reik (who joined Freud and Eduard Hintschmann as the only psychoanalysts who were members of the B'nai B'rith) "were especially struck" by these words as the appropriate central definition of the Jew. ${ }^{31}$ Jews were cosmopoli$\tan$ (in the late-nineteenth-century reading of Immanuel Kant), according to Freud, because they were human beings able to function in any and all aspects of the public sphere, but they were also emotionally tied to their Jewish cultural (not religious) context in the privacy of their inner being. ${ }^{32}$ To paraphrase Moses Mendelssohn's late-eighteenth-century understanding, they were Viennese on the street but Jews on the couch. This ambiguity caused anxiety, since the cosmopolitan Jew was claimed to be quite visible on the streets of Vienna by Lueger, the city's mayor.

In I900, Freud had evoked such an episode of Jewish cosmopolitan mobility and its consequences in The Interpretation of Dreams. He observed that such dreams are constituted out of half-remembered and half-processed day residue and recounted one of his own dreams:

An impecunious Jew had stowed himself away without a ticket in the fast train to Karlsbad. He was caught, and each time tickets were inspected he was taken out of the train and treated more and more severely. At one of the stations on his via dolorosa he met an acquaintance, who asked him where he was travelling to. "To Karlsbad," was his reply, "if my constitution can stand it." My memory then passed on to another story: of a Jew who could not speak French and had been recommended when he was in 
Paris to ask the way to the rue Richelieu. Paris itself had for many long years been another goal of my longings; and the blissful feelings with which I first set foot on its pavement seemed to me a guarantee that others of my wishes would be fulfilled as well. "Asking the way," moreover, was a direct allusion to Rome, since it is well known that all roads lead there. Again, the name Zucker [sugar] was once more an allusion to Karlsbad; for we are in the habit of prescribing treatment there for anyone suffering from the constitutional complaint of diabetes. The instigation to this dream had been a proposal made by my friend in Berlin that we should meet in Prague at Easter. What we were going to discuss there would have included something with a further connection with "sugar" and "diabetes." (SE, 4:I93-94)

Freud's dream is the dream of the Viennese cosmopolitan Jew still very much aware of and anxious about the stability of his identity. Yet this positive view of a Jewish cosmopolitanism rooted in ethnic identity rather than political nationalism had a negative side. As with Friedrich Schiller and Heinrich Heine, the idea of the movement of the Jew on trains in Paris comes to be linked with a "Jewish disease" - in the case of the late nineteenth century, diabetes. The Eastern Jew, now traveling illegally on the train, is set upon and beaten at each stop. He nevertheless continues traveling, Freud implies, if his body will tolerate the beatings. His trip to take the waters in Karlsbad via Paris and Rome, toward which all roads lead, marks the ill and wandering Jew as the new European economic cosmopolitan. But in the end, he remains a Jew, suffering from diabetes, which, as British eugenicist George Pitt-Rivers notes, was by the I920s commonly called a "Jewish disease." ${ }^{33}$ As a physician, Freud knew that this charge was understood as a comment on Jews' inability to function in cosmopolitan society without succumbing to diseases defined by the Jews' innate nature as the embodiment of capitalism. The standard medical literature of the time stated baldly, "All observers are agreed that Jews are specially liable to become diabetic. . . . A person belonging to the richer classes in towns usually eats too much, spends a great part of his life indoors; takes too little bodily exercise, and overtaxes his nervous system in the pursuit of knowledge, business, or pleasure. . . Such a description is a perfectly accurate account of the well-to-do Jew, who raises himself easily by his superior mental ability to a comfortable social position, and notoriously avoids all kinds of bodily exercise." ${ }^{34}$ Freud's dreams are full of ill traveling Jews whose claim on a truly cosmopolitan identity is denied by the world in which they dwell.

Yet Freud is quite aware that the hidden Eastern Jew traveling through the 
empire that haunts his dreams is also the stuff of the comic. In I905 he noted an old joke:

A Galician Jew was travelling in a train. He had made himself really comfortable, had unbuttoned his coat and put his feet up on the seat. Just then a gentleman in modern dress entered the compartment. The Jew promptly pulled himself together and took up a proper pose. The stranger fingered through the pages of a notebook, made some calculations, reflected for a moment and then suddenly asked the Jew: "Excuse me, when is Yom Kippur (the Day of Atonement)?"

"Oho!," said the Jew, and put his feet up on the seat again before answering. (SE, 8:79-80)

Freud's account of the Jew, disguised as a traveler returns us to Gotthold Ephraim Lessing and the cosmopolitan Jew who can never be truly acculturated no matter how well dressed simply because he is Jewish. Freud's comment is that "it cannot be denied that this representation by something small is related to the 'tendency to economy,' which we were left with as the last common element after our investigation of verbal technique." Freud's double pun on economy is clearest in the German: "die Tendenz zur Ersparnis anknüpft," where he employs the term for financial savings as well as the means of a joke compressing multiple levels of meanings into the tiniest of packages. "Oho!" ["Aesoi" in the original] says the Jew in Yiddish, recognizing in the cosmopolitan traveler merely another nomadic Jew.

Freud's lifelong anxiety involved missing a train rather than being on a train. If he had missed the train west, he would not have come to Vienna and become cosmopolitan, and he would have permanently remained an Eastern Jew. Both Jews on the train are Freud, and Freud is the instantiation of the dichotomy felt by imperial Jewry: to be both cosmopolitan and provincial, to be seen and to be invisible. This anxiety can be related to this early sense of change and loss associated with the world of the Eastern European Jew. Here, the Enlightenment ideal of the cosmopolitan Jew, invisible, crossing borders, beyond the world of commerce, remains the ghost in the machine of Enlightenment in Central Europe throughout the early twentieth century. Indeed, one of Freud's most remarkable responses to Herzl and early Zionism was to read it in terms of cosmopolitanism. After seeing Herzl's I 894 play, The New Ghetto, Freud noted in I 898 that "the Jewish problem" was a "concern about the future of one's children, to whom one cannot give a country of their own, concern 
about educating them in such a way that they can move freely across frontiers" (SE, 5:442) Freud's phrase is both metaphor and fact-one must be trained to respond to the trauma that can occur when crossing frontiers.

Such traumas came to be the focus of perhaps the most widely read Austrian novelist whose creative life spanned the world between imperial Vienna and Hitler's Third Reich. For Stefan Zweig ( I88 I-I942), the contradictions of Jewish cosmopolitanism were layered by even greater complexity. Unlike Freud, whom Zweig admired, or Herzl, who partially inspired Zweig's early work, Zweig was a "real" Austrian Jew, born in Vienna of upper-middle-class, German-speaking parents who saw themselves as ethnically if not religiously Jews. Indeed, he would have been one of the "invisible" Jews Hitler evoked in Mein Kampf (1925) when he recounted recognizing Jewish difference only in Vienna: "There were few Jews in Linz. In the course of the centuries their outward appearance had become Europeanized and had taken on a human look; in fact, I even took them for Germans. The absurdity of this idea did not dawn on me because I saw no distinguishing feature but the strange religion." But when he first arrived in Vienna in I908, he suddenly saw Jews for the first time in their "true" form:

Once, as I was strolling through the Inner City, I suddenly encountered an apparition in a black caftan and black hair locks. Is this a Jew? was my first thought. For, to be sure, they had not looked like that in Linz. I observed the man furtively and cautiously, but the longer I stared at this foreign face, scrutinizing feature for feature, the more my first question assumed a new form: Is this a German $?^{35}$

The sight of Eastern European or ultraorthodox Jews causes Hitler to realize that he had never seen Jews in small-town Austria (Braunau, Linz) because they looked (and acted) like "real" Austrians. Yet even such upper-middle-class Austrian Jews as the Zweigs felt superior to the Eastern Jews, assimilated or not, who haunted Hitler's nightmares.

In the German and Austrian literary canon, Zweig remains among the writers revered for their staunch cosmopolitanism, but he has been all but forgotten among Anglophone audiences. He was one of the most widely translated prewar German-language authors and lived in British exile from I935 to I939. His work recently has gained renewed popular appreciation as a result of Wes Anderson's 2014 film, The Grand Budapest Hotel, which credits Zweig's writings as its inspiration. ${ }^{36}$ According to Anderson, his film borrowed heavily from Zweig's exile novels, Beware of Pity (1939) and The Post Office Girl 
(first published posthumously in I982), ${ }^{37}$ and his main protagonist, Monsieur Gustave, was modeled on the real-life Zweig. ${ }^{38}$ Furthermore, many of the film's images of lift boys and mountain hotels seem to be drawn from Zweig's I9I3 novella Burning Secret, which itself invoked the racialized and sexualized portrayals of Thomas Mann's hotel-set Der Tod in Venedig (Death in Venice, I9I2). ${ }^{39}$

Indeed, what makes Zweig such a salient and rewarding read today is his humanistic engagement of modern society's racialized, gendered, and sexualized outsiders even though his portrayals remain tinged by the biologism they seek to undo. Zweig's novellas in particular feature numerous sensitive portrayals of women that celebrate female self-determination and sexual license as "a wonderful liberation of woman with regard to her body, her blood, her freedom, her independence." ${ }^{40}$ In addition, another novella, Confusion, offers a sympathetic depiction of male homosexual desire. ${ }^{41}$ Burning Secret's androgynous Jewish boy, Edgar, illustrates Zweig's close intertwining of these outsider predicaments and his consequent maintenance of an essentialized and hence problematic discourse of difference over assimilation. ${ }^{42}$

To what extent, then, does today's German admiration of Zweig as a model European and cosmopolitan adequately capture his writings before World War I? Until recently, Zweig's reception has tended to obscure the Jewish aspects of his writing not merely because they frequently remained subdued but perhaps also because they would have strained against the dominant perception of Zweig's cosmopolitanism. ${ }^{43}$ But Zweig's concerted cosmopolitanist engagement emerged only in the course of World War I, which he had initially greeted with patriotic fervor. Zweig attempted to volunteer for service but was deemed unfit for the military and rejected. Nonetheless, the precursors to Zweig's cosmopolitanism are already present in his early writing, which imbues the Jews and Judaism with the dialectical tension between universalism and particularity.

Zweig's prewar writings display a particularly strong tendency to essentialize and sometimes explicitly racialize ethnic affiliation. This tendency was later partially mitigated by his cosmopolitanism, although even then his references to race and cosmopolitanism continued to supplement each other. This approach only seemed paradoxical. In any case, Zweig's prewar laments regarding the absence of Austrian patriotism are a far cry from his later celebration in The World of Yesterday of the cosmopolitan spirit that had governed prewar Austria, especially its capital, Vienna. ${ }^{44}$ In his I909 essay, "Das Land ohne Patriotismus" (The Land without Patriotism), Zweig argued that the miss- 
ing bond of Austrian nationalism had created a pervasive mood of depression among the empire's inhabitants:

What is absent, and one soon recognizes it as absent from all the sublime things that genuinely turn an empire into a nation, a human mass into a people, is a unifying belief-or, if you will, the madness — of patriotism, of fervent love for one's home country. Here in Austria there exists no Austrian patriotism, no nationalism similar to its German, French, Italian, and English counterparts, that glorious unity fashioned from language, race, pride, and exuberance. ${ }^{45}$

Zweig sees this problem as resulting from the dual monarchy, which created conflicting alliances to Austria, Hungary, and Austria-Hungary. In addition, the Austrian must also feel German as a consequence of the common language while rejecting the foreign-language Czech or Croat with whom the Austrian shares a national bond. There exist, Zweig concedes, only individual ethnic allegiances but no Austrians at heart, and Austrian writers are similarly committed to their regional affiliations rather than a greater Austrian spirit. Their love for Emperor Franz Joseph remains the sole unifying bond. Although Zweig still proposes the importance of one's love for a homeland, a belief he would all but abandon over the course of the war, his affirmation of Austrian supranationalism is nonetheless discernable here. For him the problem is not the empire's multiethnic makeup but rather the split allegiances arising from its political and ethnic hierarchies, which have failed to create a broader sense of commonwealth beyond the monarchy.

Yet two essays written in August I9I4, at the outbreak of World War I, indicate Zweig's strong German patriotism, which fueled his initial welcome of the war. Returning to Austria from a trip to Belgium, Zweig describes his travel through Germany in "Heimfahrt nach Österreich" (Homewards to Austria) in terms of a homecoming now that the beloved sounds of French seem hostile and Russia has declared war: "One has come to resent reading that Austria wants to rape the Slavic world and brutal Germany is hungry for war." Having crossed the German border, Zweig finally "feels Germany and with it a deep relief." 46 A few days later, he declares that

Germany must now attack left and right, with both fists, to wrest itself from the double clutch of its enemies. . . . In this moment of crisis, Germany's destiny is linked to ours. . . . The German method, which has 
drawn the admiration of the entire world ... is doubly effective because it was fashioned from within, by the determination of race, through the discipline of character, because that overarching determination is in constant rhythmic unity with the individual's within. ${ }^{47}$

Just a few months later, Zweig reiterated his German rather than Austrian allegiances in "Vom 'österreichischen' Dichter" (On the 'Austrian' Writer, I9I4), in which he argued that the notion of a specific German-Austrian writing was misleading given its vastly diverse literary manifestations. Arguing that the dual monarchy had not created sufficient differences between German and Austrian culture, Zweig rejected the label Austrian author because, he concluded, "we see Germany as our homeland and would like to be seen as belonging there." 48 The racial imagery invoked in Zweig's references to Germany is by no means incidental to his understanding of ethnicity. Despite his later ostensible embrace of cosmopolitanism and his rejection of racial ideology, which found its strongest expression in his 1942 book, Brazil, Zweig's understanding of ethnic difference retained a strong racial element throughout. ${ }^{49}$ Essentialisms and racialisms by no means are particular to Zweig's oeuvre but rather formed the widely accepted models of understanding difference across all strata of German-speaking culture at the time. And the Jews, of course, formed the racially overdetermined element par excellence in that context.

Zweig's early Jewish novellas evince the writer's ambivalent gauging of the Jew's potential to signify the particularist universality that Zweig would later reframe in his cosmopolitanist writings. In part, these novellas show Zweig's partial affinities with cultural Zionism, while others again convey his budding vision of a universal European culture shaped by Christianity with Judaism remaining in its palimpsest. In stressing the inherently relational and diasporic nature of Jewish existence, these novellas seem to point primarily to the weave of social and racial relations of which the Jew in European society forms a paradigmatic part. This construct can be seen as one possible stance within Central European cultural Zionism, which Herzl's opponents had formed to counteract Herzl's political Zionism and its general disregard of the question of culture. At the same time, German-speaking cultural Zionism also departed from Ahad Ha'am, the father of the Jewish Renaissance, who had proposed Hebrew as the language of Jewish cultural renewal in the diaspora.

Instead, Central European cultural Zionism, which emanated from Vienna with the work of Martin Buber and Berthold Feiwel, stressed the possibility of a distinct Jewish culture in the European context and in European languages rather than Hebrew..$^{50}$ This construct itself had cosmopolitanist implications in 
that it stressed culture as an overarching concept for the nation. Buber hesitantly embraced Palestine as the authentic location of Jewish culture only in the wake of concerted criticism of this vision, whereas others sympathetic to cultural $\mathrm{Zi}$ onism, including Zweig and Kafka, remained primarily invested in the diaspora as the site of Jewish cultural creativity. ${ }^{51}$ But while still espousing the notion of the Eastern Jew and Yiddish as signifiers of a supposedly authentic Jewish diaspora culture, German-speaking cultural Zionism increasingly asserted the possibility of a Jewish national culture in any linguistic and national context. ${ }^{52}$

Zweig's identification of German culture more broadly, which he conceives as universal, and his partial affinities with cultural Zionism can be seen in his novella Im Schnee (In the Snow, I90I), which he had initially offered to Karl Emil Franzos, himself a Jew and editor of the journal Deutsche Dichtung (German Literature). ${ }^{53}$ Zweig submitted the piece to Deutsche Dichtung because most other German literary venues tended to avoid explicitly Jewish writing, while Jewish publications were equally unsuitable because the piece "contains absolutely none of the national leanings that dominate most Jewish novellas." In writing the piece, he had therefore aimed to abstain from ennobling his Jewish characters while portraying them without "hatred and derision but rather with the great empathy we each do or at least should have for our ancestors." 54 For reasons unknown, Franzos did not accept the piece, and it was ultimately published in the Zionist weekly Die Welt, most likely because of the novella's construction of a distinctly Jewish culture in the diaspora, which resonated with aspects of cultural Zionism. ${ }^{55}$

A closer reading of In the Snow, however, also suggests Zweig's critical stance toward Zionism, even in its cultural configuration. The novella's German-speaking Jews are trapped in a deadly medieval predicament, but their turn toward the East has equally dire consequences. In the story, set in the fourteenth century, residents of a rural Jewish community in a German town near the Polish border decide to flee to Poland in the face of impending Christian attacks. Along the way, they are caught in deep snow, and they freeze to death in long, drawn-out scenes that highlight their suffering.

Zweig's descriptions of the Jews' misshapen houses, which are crowded together in the narrow streets of the ghetto, symbolize the Jews' bedraggled social state in the diaspora, which has deformed them in body and mind. In the wake of Christian attacks on the eve of Hanukkah, they decide to flee because they perceive escape-“the weaker man's worn-out, shameful, and yet irreplaceable mode of fighting the stronger" (IS, IO4) — as their only option. Resistance seems out of question: "A Jew should fight or defend himself? That was ludicrous and unthinkable in their eyes, for they no longer lived in the time of 
the Maccabees. These were once again the days of bondage, the days of the Egyptians" (IS, I04). This course of action contrasts starkly with that of the Maccabees in the the biblical Hanukkah story, of which the novella's Jews are aware. In Zweig's time, the Maccabees, who had liberated ancient Judea from foreign Hasmonean rule, became the new heroes of political Zionism and its espousal of a new Jewish type, the muscle or warrior Jew. Nordau had coined the term muscle Jew in I 898 at the Second Zionist Congress in Basel, where he demanded that this new type of Jew replace the shameful and disempowered ghetto mentality of diaspora Jewry. This idea became one of the central tenets of the Zionist movement, but even the muscle or warrior Jew, who makes a fleeting appearance in the figure of Josua in the novel, is doomed to a futile self-sacrifice under the disempowering condition of diaspora Jewry.

Josua, "a tall, black-bearded man" (IS, IOI) from a nearby community, had fought off the mob when it first arrived and then mounted an attacker's horse and ridden to warn the town's Jews of the impending attacks. Josua powerfully embraces his fiancée, Lea, wrapping his "strong arm tightly around her maidenly, slim body" (IS, I07), conveying the Zionist gendering of the muscle Jew, whose masculine properties contrast with the feminized diaspora Jew. The latter is here configured through the fin de siècle cliché of la belle juif (the beautiful Jewess), whose loveliness and innocence redeem her partially from the flaws of her race but who is nonetheless punished through a tragic ending. ${ }^{56}$ But Josua remains a singular figure, and his failure to shed his effeminate ghetto nature, which is signified by his attachment to Lea, leads to his ultimate death in the snow along with the other Jews.

Zweig's depiction of the muscle Jew's failure indicates the author's reservations regarding the stifled predicament of the diaspora Jew as well as the promises of Zionism. And indeed, Zweig's doubts about Zionism are evident in his personal writings. Although The World of Yesterday must be read with some caution because it was written from the idealizing perspective of hindsight, some credence can be given to its ironic but nonetheless warm portrayal of Zweig's brief I90 I encounter with Herzl, then editor of the Viennese newspaper Neue Freie Presse (New Free Press). The nineteen-year-old Zweig notices both Herzl's "actually regal" (WY, 88) countenance, with his high forehead and blue-black beard, and his theatrical demeanor, which seemed to be copied from the Viennese Burgtheater style. Herzl's acceptance of the young Zweig's submission to the paper occurs in the same theatrical style, conveying Herzl's future leadership qualities: "It was as if Napoleon had pinned the Knight's Cross of the Legion of Honour upon a young sergeant on the battlefield" (WY, 89). Zweig further claims that Vienna's German-speaking Jews, 
among whom he counted himself, were baffled at Herzl's ideas, which found an enthusiastic reception mainly among disenfranchised Eastern European Jews. Zweig made his reservations regarding Zionism evident when he wrote in I9I7 to Buber, "My only point of departure from you and your comrades is that I did not want Judaism to once again become a nation . . . , that I love and affirm the diaspora as the essence of [Judaism's] idealism, its cosmopolitan, universal human mission." ${ }^{57}$ But this explicit embrace of the presumed cosmopolitan essence of Judaism came only through Zweig's experience of the war. ${ }^{58}$

Zweig found more generically Austrian publication outlets for his later Jewish novellas, which also featured Christian protagonists and conveyed his search for a more universalizing stance. Die Wanderung (The Journey), first published in 1904 in Neue Freie Presse, narrates the voyage of a young Judean embroiled in the messianic fervor of his day. ${ }^{59}$ Having heard pilgrims' reports about the appearance of the messiah, he sets off to Jerusalem see the man. On the way, the young man is seduced by the young Syrian wife of a Roman centurion whom Pilates has ordered to Jerusalem to assist in the execution of three criminals. With her highly sexualized, animalistic, and materialistic features, the wife displays the stereotypical features of the Oriental femme fatale. This female figure, which was no doubt inspired by Viennese philosopher Otto Weininger's seminal work, Sex and Character (I903), again symbolizes the perceived negative aspects of Jewishness, here pointing to the Jews' alleged Oriental nature, which the story's male Jew fails to overcome. ${ }^{60}$ Weininger had claimed that the Jew must overcome his base nature by embracing the Christianity to which Judaism had given birth. And indeed, the story's young man finally recognizes that he has abandoned his higher spiritual mission for the lowly desires of sex and wrests himself from the woman's embraces, but it is too late. Once in Jerusalem, he carelessly passes three crosses without noticing the man crucified in the middle, whom the reader knows to be the Christian messiah.

Far from promoting the Zionist ideal of the Jewish warrior type in his ancient Jewish homeland, the novella signifies Zweig's increasing distance from Zionism and his exploration of a triangular relationship involving Judaism, Christianity, and Rome, which in his later writings formed the core of the European idea. As the story implies, Judaism in its original setting was too particularistic to become a universalizing force, even though it bore the universalist impetus in its core. This universalism reached fruition in Judaism's progeny, Christianity, which embraced all peoples but was politically ineffective. The Roman Empire finally created the unified political structure for the blueprint of the European idea, but it was bare of a civilized humanity. Given the obvious influence of Weininger's ideas, this is, of course, a version of the 
relationships between Judaism, Christianity, and Europe that is far less sympathetic toward the Jews than the one Ernest Renan had painted in "Judaism as Race and Religion," which claimed that Judaism was the only truly universal religion. ${ }^{61}$

Zweig's novella, Die Wunder des Lebens (The Miracles of Life, I904), then, makes explicit the cultural and moral superiority of Christianity and its universal love. The story again suggests the close intertwining of Jewish and Christian cultural narratives while at the same time imbuing both Jews and Christians with ambivalence. Set in sixteenth-century Antwerp at the outbreak of Protestant violence against Catholics, an elderly painter vows to find the perfect model for his planned copy of a picture of the Holy Mother pierced by a sword. He finds this model in Esther, a beautiful young Jewish girl he sees sitting in a window. Esther was orphaned during an unspecified "Christian" attack, but she nonetheless agrees to sit for the painter, oblivious to his ulterior motive of converting her. When the finished painting is displayed in a church, Esther frequently visits to see the image of the baby with whom she had posed. One day, Protestants attack the church and kill the young Jewess, who has leapt to protect the painting from their sword strokes. "A strange miracle" occurs: the dying Esther, "who embodied his image of the Madonna in life," (93) now reflects the original painting of the pierced Madonna that she never had beheld. ${ }^{62}$

Zweig again seeks to draw empathy for the martyred Jews in the heart of Europe by infusing them with imagery of suffering - here by employing Christian iconography. Like The Journey, The Miracles points to the shared origins of Judaism and Christianity and ambivalently gauges the Jews' potential to overcome their particularity and signify a universal predicament in a hostile Christian world. Only the painter, who prefigures Zweig's later essayistic claims that European art represented a humanizing and cosmopolitan force, stands apart from the Christian violence routinely enacted against the Jews. In his kindly attitude toward the young Jewess, the painter approximates the Christian impetus of universal love, which ultimately overrides even his desire to convert her. Against this stands Esther's essentially lacking relationship to Christianity, which is predicated on her physical urge for the child rather than a true appreciation of Christianity and its art. These depictions again bear the influence of Weininger's claim of the Jews' base nature and deficient spiritual facilities, which he saw epitomized in the Jewess.

Zweig's early quest for a narrative of Jewish presence in Europe that would pay tribute both to Jewish particularity and to the Jews' role as progenitors of Europe as a universal idea was thus marred by essentialisms that bordered on antisemitic stereotype. But such essentialisms formed part and parcel 
of the cultural language of the day, including cultural Zionism's idea of a distinct Jewish culture in the diaspora.

\section{Prague: On the Fringes of Empire}

Though Prague was part of the same empire, the Jewish predicament there differed strongly from the situation in Vienna. ${ }^{63}$ While the city's German population was in the minority, it nonetheless exerted a dominant cultural influence into the early twentieth century. German-speaking Jews had become the pillars of local German culture, and Christian Germans therefore largely abstained from the rabid antisemitism of their fin de siècle Viennese counterparts. As a result, political Zionism had much less currency among Prague's Jews. However, as the German influence in Prague waned in favor of the Czech, Jewish cultural affinities became increasingly fluid. In negotiating a complex web of German, Czech, and Jewish affiliations, cultural Zionism, with its idea of a Jewish ethnic identity, whether tied to the Jewish homeland or in the diaspora, held increasing attraction for Prague Jewish intellectuals such as Franz Kafka, Felix Weltsch, and Max Brod. This construct had its roots in Austrian supranationalism, where Jews could see themselves as representing one nation among the others, though the Jews lacked territorial aspirations. But the embrace of Austrian supranationalism was itself largely catalyzed by the First World War. One of the early proponents of this idea, Austrian-Polish rabbi and parliamentary deputy Joseph Samuel Bloch, thus declared in August I9I4, just a few days after the outbreak of war, "Today, from all the nationalities of the state, a holy, great and irresistible Austro-Hungarian nation has come into being." 64

But on the fringes of the empire, in a Bohemia torn by riots about what language and what culture defined the supposed periphery, the emperor in $\mathrm{Vi}$ enna was as distant as the emperor of China. In the waning years of the nineteenth century, that other distant and dying world, the Middle Kingdom, became a point of fascination for the expanding imperial designs not of Franz Joseph but of his rival and ally, Wilhelm II, the new emperor of Germany. The scramble for China matched the scramble for Africa. And the Jews of Europe were part and parcel of that expansion as well as part of the cultural world that saw the emperor in the Forbidden City as much a fantasy figure as the one who inhabited Schönbrunn Palace. Kafka, a civil servant in Prague, published in I9I9, after the death of the emperor (and his empire), that he "it is said — sent to you, the one apart, the wretched subject, the tiny shadow that fled far, far from the imperial sun, precisely to you he sent a message from his deathbed. He bade the messenger kneel 
by his bed, and whispered the message in his ear. So greatly did he cherish it that he had him repeat it into his ear. With a nod of his head he confirmed the accuracy of the messenger's words." ${ }^{\circ 5}$ Kafka's words were directed at the very Jewish audience of Die Selbstwehr (Self-Defense), a Prague Zionist journal. Is the empire as much a fantasy as the never yet always dead emperor? The emperor may have been dead, but Franz Joseph's rail line from Prague to Vienna, ending in his own train station, continued, not recording his passing.

Kafka was born in Prague, in what was then part of the Austro-Hungarian empire, on July 3, I883, in his family's home at the corner of the Maislgasse and Karpfengasse. ${ }^{66}$ The family moved frequently-at least seven times between Kafka's birth and I907. Each move signaled social and economic improvement, but the family always remained within the confines of the Prague's Old City. Prague was a complicated city, much like Kafka himself. Kafka's grandfathers spoke Yiddish, the language of Central European Jewry; his father, Hermann (I852-I93I), spoke Czech, but when he moved to Prague in I 88 I from the village of Osek (Wossek) in southern Bohemia, he opted to identify with the German-speaking community and raised his son speaking that language. But two antithetical German-speaking worlds existed: that of the poet Rainer Maria Rilke (I875-I926), Christian and antisemitic to the core, and that of the Kafkas, seen as Jews no matter what their beliefs. Czechs, too-Catholic, Reformed, or New Church,- - for the most part looked down on the Jews no matter their language-and even if they bore a Czech name such as Kafka (jackdaw) that evoked the countryside. Were such people nomadic Jews or cosmopolitan Austrians? At the time, they were considered "merely" international Jews. ${ }^{67}$ An antisemitic comment on Jews in Kafka's world observed that

according to the newspapers, the Jews in the new state of "CzechBohemia" are now taking Czech names. This has been the case in Hungary for a long time. The Jew is essentially international. Where there is a deal to be made, he sacrifices his "Rosenzweig" or "Knoblauch." It is an inherent error therefore to imagine the Jews as a harmless faith, which only wants to live in peace and merely worships God in a particular manner. . . Chaim Fingernagel, the former nomad now "residing" in Vienna, can change his name to "Guschelbauer" or something similar. 68

The authority for the writer is Adolf Wahrmund's I 887 screed about the Jews as nomads. ${ }^{69}$ Becoming "Kafka" did not make his family any less nomadicindeed, it only masked their cosmopolitan Jewishness.

By arguing that Kafka was essentially "a symbol of European Jewish iden- 
tity unbridled by ethnic exclusiveness," an image pointing to both the particularist Jewish and the assumed universalist aspects of his writing, Jewish contemporaries such as Walter Benjamin and later Hannah Arendt suggested the cosmopolitan nature of Kafka's writing. ${ }^{70}$ Kafka becomes a prime example of Arendt's sense of the Jew as pariah rather than nomad. She thus manipulates Max Weber's and Bernard Lazare's ambiguous sense of caste exclusion to give Kafka greater autonomy in becoming a pariah. ${ }^{71}$ Marginality becomes a positive quality that defines the creative energy of the Jew, not a limitation of the Jew's ability to function in the public sphere. Kafka thus answers, from the margins of European culture, the problem of the Jew as nomad. His sense of alienation lies at the heart of his creativity. But Arendt also stresses that he is a cosmopolitan answer to the Jewish rootedness, which she labels the "parvenu"- - the conformist, assimilationist response to social exclusion - and finds in Kafka's role as a pariah his means of having a Jewish identity beyond conformity. ${ }^{72}$

In I9I7 Kafka had written about the building of the Great Wall to protect the empire from those people to the north, from the barbarians, from the Germans: "Against whom was the Great Wall to serve as a protection? Against the people of the north. Now, I come from south-east of China. No northern people can menace us there. We read of them in the books of the ancients...." (TCS, 24I). But defending the empire also causes a great movement of the peoples of China:

Why, then, since that is so did we leave our homes, the stream with its bridges, our mothers and fathers, our weeping wives, our children who needed care, and depart for the distant city to be trained there, while our thoughts journeyed still further away to the wall in the north? Why? A question for the high command. Our leaders know us, know our petty pursuits, see us sitting together in our humble huts, and approve or disapprove the evening prayer which the father of the house recites in the midst of his family." (TCS, 24I)

The result is a life freed of inhibitions against movement, a cosmopolitan life:

Now the result of holding opinions is a life on the whole free and unconstrained. By no means immoral; however; hardly ever have I found in my travels such pure morals as in my native village. But yet a life that is subject to no contemporary law, and attends only to the exhortations and warnings that come to us from olden times. (TCS, 247)

Displaced in the empire but with only a vague and unsatisfying purpose, to protect against "the people from the North," they are restless and unmoored 
(TCS, 24I). The message from the dead emperor will never arrive in this diaspora-indeed, it will never even leave the palace:

The messenger immediately sets out on his journey; a powerful, an indefatigable man; now pushing with his right arm, how with his left, he cleaves a way for himself through the throng; if he encounters resistance he points to his breast, where the symbol of the sun glitters; the way is made easier for him than it would be for nay other man. But the multitudes are so vast; their numbers have no end. If he could reach the open fields how fast he would fly, and soon doubtless you would hear the welcome hammering of his fists on your door. But instead how vainly does he wear out his strength; still he is only making his way through the chambers of the innermost palace; never will he get to the end of them; and if he succeed in that nothing would be gained; the courts would still have to be crossed; and after the courts the second outer palace; and once more stairs and courts; and once more another palace; and so on for thousands of years; and if at last he should burst through the outer most gates-but never, never can that happen-the imperial capital would lie before him, the center of the world, crammed to bursting with tis own sediment. Nobody could fight his way through here even with a message from a dean man. (TCS, 244)

As this passage suggests, at the end of empire lies the end of cosmopolitanism and the unspoken demand that the Jews, too, become a nation, with their own boundaries and their own emperor. The Jews as nomads are also threatening to those who imagine themselves rooted in and settled on the land. In "An Old Manuscript" (I9I9), published in Kafka's collection, The Country Doctor, the narrator, an aged shoemaker, looks out on the square and sees it suddenly occupied by northern nomads - true nomads by the anthropological discussions of the day: "As is their nature, they camp under the open sky, for they abominate dwelling houses. They busy themselves sharpening swords, whittling arrows and practicing horsemanship. This peaceful square, which was always kept scrupulously clean, they have made literally into a stable" (TCS, 4I6). They also speak a strange and incomprehensible tongue; they are barbarians in the Greek meaning of the word:

Speech with the nomads is impossible. They do not know our language; indeed they hardly have a language of their own. They communicate with each other much as jackdaws do. A screeching of jackdaws is always in 
our ears. Our way of living and our institutions they neither understand nor care to understand. And so they are unwilling to make sense even out of our sign language. You can gesture at them till you dislocate your jaws and your wrists and still they will not have understood you and will never understand. They often make grimaces; then the whites of their eyes turn up and foam gathers on their lips, but they do not mean anything by that, not even a threat; they do it because it is their nature to do it. (TCS, 4I6)

Even the emperor and his guards can do nothing about the nomads. Kafka's nomads, his cosmopolitan Jews, are heavily camouflaged, as was his wont. They are the Chinese; they are the nomads from the North. But in this tale Kafka outs the nomads as Jews, for they speak like "jackdaws"—kavky in Czech. In his diaries Kafka bemoans the fate of the nomads living in an inhospitable land. After reading German ethnologist Oskar Iden-Zeller's I9I3 account of the nomads in Siberia, Kafka wondered why they did resettle where their lives would be better: "But they can't: everything that is possible happens, but the only thing that can happen is what is possible." ${ }^{73}$ This fatalism haunts Kafka's image of the cosmopolitan Jew.

In I9I I-I 2 Kafka wrote a fragmentary novel about Karl Rossmann's travels to Amerika-not America but its German-language funhouse mirror doppelgänger, a fabulous, cosmopolitan land for the Jews, a guldene medina. Shipped off to America for having gotten a maid pregnant, seventeen-year-old Karl enters New York Harbor with Lady Liberty brandishing the sword of justice, not the lamp of welcome, from atop the London's Old Bailey courthouse. Rossmann's journey in the land of upward mobility will be a tumble down the rabbit hole of poverty and disaster. Harsh experience after harsh experience teaches Karl little about the pitfalls of this new cosmopolitan land. Expelled by his uncle from his mansion, Karl inhabits ever less opulent surroundings. He eventually winds up in Oklahama, a closed frontier with limited possibility:

He could report for a job that was not shameful, but to which, instead, a public invitation was issued! And the promise was given just as publicly that he too would be accepted. He asked for nothing better, he wanted to find the beginning of a respectable career at last, and here perhaps it showed itself. Even if all the bombast in the poster was a lie, even if the great theatre of Oklahama were a small travelling circus, it was seeking to employ people, that was sufficient. Karl did not read the poster a second time, but he did once again seek out the sentence: "Everyone is welcome." 74 
That was the promise; the reality was radically different at every moment in America. Kafka knew about such promises of cosmopolitanism from imperial Prague and its situation in the old monarchy before the emperor dies and his message is sent out, never to leave the palace, to those building the Great Wall.

As much Charles Dickens as Horatio Alger, Kafka's Amerikan dystopia is an answer-unknown - to the other Zionist utopia of America, an extraordinarily popular play, The Melting Pot (1909), by Israel Zangwill (I 864-I926). ${ }^{75}$ Zangwill was one of "those energetic Jews to whom" Herzl had first addressed his idea of a Jewish state while in London on November 24, I895. Zangwill had presided at that meeting of the Maccabean Club, and his play became the hit of New York's 1908 theatrical season. ${ }^{76}$ The melting pot came to be the overriding image of the excision of national difference and the creation of a true cosmopolitan-here called the New American. ${ }^{77}$ It embodied what Theodore Roosevelt, who loved the play, saw as the opposition "against all hyphenated Americanism and all hyphenated Americans," as he wrote to German Jewish psychologist Hugo Münsterberg. ${ }^{78}$

Zangwill's play tells the tale of turn-of-the century America as the ultimate cosmopolitan space. Like Karl Rossmann, young violinist David Quixano arrives in New York, but he is the sole member of his immediate family to have survived the Easter 1903 Kishinev Pogrom. His America is

God's Crucible, the great Melting-Pot where all the races of Europe are melting and re-forming! Here you stand, good folk, think I, when I see them at Ellis Island, here you stand [Graphically illustrating it on the table] in your fifty groups, with your fifty languages and histories, and your fifty blood hatreds and rivalries. But you won't be long like that, brothers, for these are the fires of God you've come to-these are the fires of God. A fig for your feuds and vendettas! Germans and Frenchmen, Irishmen and Englishmen, Jews and Russians-into the Crucible with you all! God is making the American. ( $\mathrm{Z} / \mathrm{W}, 33)$

As he notes in a Nietzschean mode, "The real American has not yet arrived. He is only in the Crucible, I tell you - he will be the fusion of all races, perhaps the coming superman. Ah, what a glorious Finale for my symphony - if I can only write it" $(\mathrm{Z} / \mathrm{W}, 34)$. As with Herzl's Zion, America is a great symphonic orchestra melding into a new cosmopolitan nationalism.

Zangwill and his contemporaries saw high culture as a defining space for such cosmopolitanism. ${ }^{79}$ It is the limited cosmopolitanism of the Enlightenment, not universal but national in its contours. Zangwill saw Zionism's claim 
on a Jewish homeland beyond Europe as analogous to his vision of America, not Kafka's. Indeed, Zangwill spoke of young working-class Jews (unlike Karl Rossman) who "would pay their own passage to the new territory as they paid it to the United States." ${ }^{80}$ His voice was heard in the German-speaking world as loudly as in Great Britain in that first generation of Zionists. Although Zionism became anticosmopolitan over the years, it initially laid claim to much the same ideology as did the Enlighteners, at least those such as Herder. The debate between what came be called the territorialists and the nationalists involved caste in the language of cosmopolitanism. At the same moment as Zangwill was lecturing the Americans on Zionism, Julius J. Frank, a secondgeneration German Jewish immigrant who was a New York attorney and a member of "Our Crowd" (the Jewish elite), spoke of the Jews "as Commercial Factors" in the history of the United States who had knitted mankind as "the great instrument of civilization which today is bringing men together, bringing them to learn each other's beliefs, bringing them into that close cosmopolitanism which is fast taking the place of the narrower patriotism. ... [T] he Jew was conserving community, or nation, or country and doing that . . which from time immomorial has been the aspiration of the Jew-the brotherhood of man." 81 This dichotomy haunted the world of Austrian Jewry: Is the cosmopolitan the enemy of a modern Jewish identity or a natural state? Is it what Zionism promises or contradicts?

While Zangwill's political Zionism rallied Jews in London's East End and provided Jews on New York's Lower East Side with a model for a new diasporic cosmopolitanism in the world of the melting pot, Prague's Jewish intellectuals wrestled with a new form of mystical Jewish identity that defined itself as antithetical to both Zionism and acculturation. In I9I3 the editors of Vom Judentum (On Jewry), a collection issued by the cultural Zionists of the Verein jüdischer Hochschüler Bar-Kochba in Prague, presented opinions from a wide range of Jewish public figures writing in German about the status of contemporary Jewry. ${ }^{82}$ In displaying the full breadth of often dissenting voices from political Zionism to a deterritorialized form of cultural Zionism that espoused the diaspora rather than a national Jewish homeland as the fertile ground of modern Jewish culture, the volume constitutes a unique expression of Prague's young Jewish generation. As a consequence of the city's particular geographic and cultural location, the quest for a middle ground between modernity and tradition, Vienna and Berlin, and Jewish, German, and Slavic cultural affiliations had become particular salient in Prague, resulting in a particular freshness of voices in the search for a viable Jewish modern identity. These voices tended to emphasize ethnicity and culture over the national Jewish homeland. 
Many of the authors, such as Jakob Wassermann, art historian Erich Kahler, essayist and political commentator Gustav Landauer, and poet (and disciple of Stefan George) Karl Wohlskehl were quite removed from the project of political Zionism. The volume's genus loci, its "spiritual guide," was Martin Buber, already famous for having resuscitated a German version of Eastern European mystic writing in his 1906 and I908 adaptations of Hasidic texts. ${ }^{83}$ Buber's vision of a Jewish renewal drew on a claim of an authentic, mystical "Oriental" Jew located in the East (rather than the historical fantasy of many German-speaking Jews, including Herzl, who located the authentic Jew in medieval Spain). ${ }^{84}$ Such Jews were the antithesis of the cosmopolitan. Margarete Susman's essay in the volume constitutes a brilliant tour-de-force on Spinoza, damning what she sees as the pathetic "reaching of the hands of the nations in the name of cosmopolitanism that exacerbates the abyss that exists between human beings. . . . No people can sense this unique immovability more deeply and more pressingly than the Jews." 85

Moritz Goldstein agreed, noting that the proponents of a Jewish cosmopolitanism were representatives of the passé order of "humanism and cosmopolitanism" that had given way to "individualism and nationalism." 86 For Goldstein, this abandonment of cosmopolitanism is the necessary result of the recentering of Jewry in the world of a new mystical Jewry. Cosmopolitanism is the Enlightenment writ large; it is Kant's reading of the potential for a world without borders, either geographic or human, that is rooted in rational understanding. This stands against the mystical essence of a people, of the Jews. In giving Zionism a European dimension, however, Goldstein invokes the vocabulary of cosmopolitanism when he argues that Herzl's ideas had been "by no means a Jewish, but rather an entirely European event. . . . He did nothing but apply an all-European idea to the Jews." 87 Similarly, Goldstein's argument of an intellectual and spiritual European tradition drew on Romantic cosmopolitanism in the vein of Schlegel and Novalis, albeit with a Jewish twist. Even in his rejection of cosmopolitanism, Goldstein invoked the image of Jews and Judaism as a universalizing force, and this image became the cornerstone of Jewish cosmopolitanist thought. Jews, Goldstein argued, had not only inspired and shaped that European tradition but led the way to universal salvation in superseding Europe by asserting their own particularist nationalism:

After providing perhaps the strongest inspiration to the creation of a spiritual and intellectual Europe, ... we are now asserting our place outside of this Europe. This is the ultimate consequence of European provenance. 
We are turning hyper-European, and in the course of world history, salvation thus once again emanates from Judea. ${ }^{88}$

Herzl's Zionism in its most political form, especially after the First Zionist Congress ( 1897 ), was quite at odds with such a mystical reading of a cultural Jewish nationalism rooted in a spiritual regeneration, even when political Zionism agreed with the intended "anticosmopolitan" tone. There Ahad Ha'am, whose perspective was shaped in response to Leon Pinsker's move to create the first aliyah, broke with Herzl over the distinction between a "Jewish state" (with strong emphasis on the communality of a uniform inner Jewish experience) and a state of the Jews, with its cosmopolitan overlay borrowed from Herzl's Viennese experience. In Germany after World War I, Gershom Scholem noted that he had responded to the request that he contribute to a I920 reissue of Buber's collection with "a vehement invective against the pseudoreligious and pseudorevolutionary element of Prague Zionism."89 Scholem's idealistic Zionism of the I920s was clearly much more political in its understanding of the goals of Zionism. (Scholem seemed to enjoy making ideological points in turning down invitations to contribute to collected volumes, as in his 1962 denunciation of the "German-Jewish dialogue" in a letter to the editor of a Festschrift for Susman, who had figured so prominently in the I9I6 Buber anthology. $)^{90}$

Walter Benjamin agreed with Scholem, as did Kafka, whom Scholem reported as supporting his antimystical stance. ${ }^{91}$ Kafka took this view even though Robert Weltsch, the Prague-born cousin of one of Kafka's closest Prague friends, Felix Weltsch, and a close friend of Max Brod, contributed the essay on Herzl to this collection. Weltsch condemns all cosmopolitan writers as literary philistines, as the antithesis of the "New Jew," not in Zangwill's cosmopolitanist sense of the melting pot but in the sense of Prague's new Jewish mystical Zionism. The Jew, according to Weltsch, "is a community of blood and fate." 92 Weltsch also evidenced a sense of cultural Zionism (and paraphrased Ahad Ha'am) when he noted that "experience has shown us even Palestine can be the diaspora [Galut]" if one is not of pure heart, "striving for a unity and harmony and a radical alteration of one's life." 93 This is the answer to the present-day cosmopolitanism of the diaspora Jewry (ZerstreuungsJudentum). But it is, of course, one of the rereadings of Kantian cosmopolitanism as an Enlightenment experience: all human beings have the obligation of seize control of their lives and reform themselves as human beings. While all of the variants of Zionism represented a questioning of the terms of the En- 
lightenment concept of assimilation and acculturation as the model Jewish cosmopolitanism, each adapted some form of cosmopolitanism in particular model of Zionism. In this world of a cosmopolitan supranational state, from the political periphery of Prague, Zionism itself becomes a supranational ideal.

\section{Berlin: Another Empire}

If imperial Austria and its periphery seemed to offer Jews, especially those involved in the public sphere, models for mobility and expansion, it was also clear to most observers that the empire was aging as rapidly as its emperor. After the suicides at Mayerling in I889, a further centrifugal anxiety about the decay of the supranational state could be sensed: the tenuous, cosmopolitan world of the monarchy was entering into its senescence along with the emperor. ${ }^{94}$ Adolf Hitler, who was born in 1889 , later regaled his cronies with mythic tales of the "fragility of former Habsburg Empire. . . Emperor Franz Josef's simple, wistful character. The tragedy of Mayerling. Beautiful Empress Elizabeth." 95 After I870, in the new imperial capital of Berlin, conversely, a clear excitement existed about what Heinrich August Winkler calls the centripetal movement from a national idea to a national state, from an "emancipatory to an integral nationalism" that suspended any sense of a pan-German cosmopolitanism rooted in German culture as advocated by G. E. Lessing in the eighteenth century. ${ }^{91}$

Berlin, the capital of a new nation that was created in the Prussian model and that excluded imperial Austria, was more engaged in a process of integration, bringing very diverse but primarily German-speaking states into the imperial fold. The struggle between Protestant and Catholic states that had ameliorated following the wars of religion in the seventeenth-century flared again with Bismarck's Kulturkampf in the I870s and reached a sort of odd truce with the coterminous rise of political antisemitism. The Catholic-Protestant struggle was replaced by a common enemy of Christianity (and the new imperial state): the Jews.

Although Jewish intellectuals flocked to the Wilhelmine capital, the Jewish Renaissance did not flourish there until after World War I, when Berlin briefly established itself as the new center of German Jewish culture. ${ }^{97}$ As Mark Gelber has argued, the newness of the cultural structures in Berlin, from the avant-garde publishing houses to the various formal and informal teaching centers such Franz Rosenzweig's Lehrhaus, invigorated a modern Jewish cultural experience. ${ }^{98}$ The cosmopolitanism of World War I, when Jews such as 
Rosenzweig experienced Eastern European Jewry firsthand, merged with the sense of a new authentic Jewry in answer to the diasporic cosmopolitanism that dominated Berlin. Cosmopolitan thinking thus came to appear as the passé provenance of the Jews. A Berlin historian and member of Parliament, Heinrich von Treitschke, fired the first salvo in what became known at the Berlin antisemitic debate of I878, condemning international Jews as having infiltrated the European states by donning the mask of members of the nation. "The Jews are our misfortune," noted Treitschke. Bernard Förster, Friedrich Nietzsche's unloved brother-in-law, quickly began to circulate a petition to deprive the Jews' of their civil rights. ${ }^{99}$

But Treitschke also lumped the Jews with the "well-known muddle of feelings of German cosmopolitanism, which even when it seemed to have been abandoned always seemed to reappear" (T, I:I4). Treitschke associates such feelings with the sort of nation-state that was typified by "the old German imperium, which attempted to conquer nations that could not be integrated as living limbs into the state. Through such passive cosmopolitanism, we are still being punished after a thousand years" (T, I:IO4). He was referring to the Prussian expansion into Poland and Denmark, which incorporated non-German speakers, among them Jews, into the state. This reference reflected the problems that he believed to be inherent in the Austro-Hungarian model as well as Treitschke's sense that the cosmopolitan Jews from the East had infiltrated the German state. "A cleft has always existed between Occidental and Semitic essences. . . . [T]here will always be Jews who are nothing more than Germanspeaking Orientals. A specific Jewish civilization will also always flourish, as befits a historically cosmopolitan power." ${ }^{100}$ Here can be heard the odd echo of Herzl's political Zionism as received by Scholem and other Berlin Jews of the next generation. After Bismarck's dismissal in I890, Treitschke's Jewsdisguised-as-Germans had begun yet another adventure that frightened him, the German colonial project.

Treitschke as well a large number of pan-German intellectuals such as Wilhelm Raabe felt that this "scramble for Africa" violated the newly acquired centripetal force of German nationalism. Raabe's I 890 novel, Stopfkuchen: A Sea and Murder Mystery, reads colonialism in Africa in both German national and racial terms. The closing scene focuses on the return of the narrator, Eduard, to the Orange Free State- “"among palms and sycamores and blackamoors in this tropical heat" - and to his mixed-race family, which can never be truly German. ${ }^{101}$ For Raabe, colonialism is merely another form of cosmopolitanism that leads to the destruction of the true German (an odd parallel to Joseph Conrad's I 899 Heart of Darkness and the moral and emotional decline of Belgians 
in the Congo.) Only Raabe's title character, the obese Heinrich Schaumann, remains true to his farm, and its crop of sugar beets (answering the presumed colonial need for sugar plantations) remains essentially German. Raabe simply translated into an anticolonial context the central theme of his I864 novel, The Hunger Pastor - the pitfalls of weakening national (and racial) identity by admitting Jewish cosmopolitans, who could transform themselves at will. Treitschke's antisemitism was at heart also an anticosmopolitanism that elaborated the underlying claims of Berlin's new nationalism.

Treitschke's views on the national state were reinforced by his student and successor as editor of the Historische Zeitschrift, Friedrich Meinecke. In Cosmopolitanism and the National State ( 1907), an account of the rise of German nationalism, Meinecke provides a history of the transition from Enlightenment cosmopolitanism to the modern German state. In that context Meinecke evoked Wilhelm von Humboldt as one of the major thinkers who stressed the role of the nation-state in enabling the capacities of the citizen but who also saw the notion of the cosmopolitan as necessary for the citizen. Meinecke stressed Humboldt's belief that "a more subtle view, which the custodians of German culture have always esteemed, is that the true, the best German national feeling also includes the cosmopolitan ideal of a humanity beyond nationality." Moreover, it is "un-German to be merely German." Only "so-called public opinion" saw a distinction between a German culture with and without a cosmopolitan component. ${ }^{102}$ Yet his definition of these categories is open to interpretation. In a rather straightforward manner, Meinecke tracks the progress from Humboldt's cosmopolitanism (with all of its limitations) to the modern German national state. As his student Felix Gilbert noted, "The process which [Meinecke] describes and on which he comments with approval is that of the gradual renunciation of all commitments to cosmopolitan values until at the end the sovereign national state is recognized as the supreme value and final goal of history" (M, ix). Thus, Meinecke commented on the contrast between the Prussian patriot and the cosmopolitan that Humboldt saw: "the old absolutistic power state was alien to his wishes, but so, too, was the modern national state, which comes into existence through the will and participation of the people and is based on a strong constitutional life that binds together the ruling and the ruled. Wherever he looks, he sees potential chains for the spontaneous individual whose productivity stems purely from inner resources, and his sensitive eye sees every small cloud that could darken the freedom of the inner life" (M, 37). This analysis did not include the Jews, whom Meinecke did not see as "bearers of German culture" (M, 22). They were a too successful foreign economic entity because of their inherent Jewish character. Indeed, he condemned 
the pernicious impact of Jewish emancipation on German liberalism, feeling that Jewish inclusion sullied Humboldt's liberal ideals. ${ }^{103}$ Feeling marginalized by such views, many Jewish intellectuals in imperial Berlin begin to think of themselves more and more in national or at least anticosmopolitan terms.

Another one of Treitschke's young students in Berlin saw this debate firsthand and from a most remarkable position. For at least one young American scholarship holder, arriving by train in the new imperial capital offered an opportunity to experience a sense of the cosmopolitan that had been lacking at Harvard. With his impeccable clothes, silk ties, and walking stick, African American W. E. B. Du Bois was an elegant cosmopolitan in Wilhelm II's Germany. But during his I 892-94 studies in Berlin, he seemed more like a nouveau riche Jew than a solid, middle-class German student. Nevertheless, he described himself simply as "an American student." 104 On only one occasion did Du Bois feel that he suffered from racism in Germany: "Once he discovered that he had been cheated by a cab driver on a trip to the university, which led him to ponder whether this happened because of his color or because he was dressed as an affluent university student. He decided it was the latter." 105 Class makes one very visible in a highly stratified society but makes one's race invisible.

It is possible that this moment represented the beginning of the evolution of Du Bois's sense of black double consciousness. He fully developed that theory in his groundbreaking I903 book, The Souls of Black Folk, with its caricatures of southern Jews. ${ }^{106}$ But as Kwame Anthony Appiah has argued, the roots of Du Bois's idea lie in his time in Berlin. ${ }^{107}$ In I 893 Du Bois wrote,

It may surprise one at first to see a recrudescence of anti-Jewish feeling in a civilized state at this late day. One must learn however that the basis of the neo-antisemitism is economic and its end socialism. Only its present motive force is racial hatred. It must be ever remembered that the great capitalists of Germany, the great leaders of industry are Jews; moreover, banded together by oppression in the past, they work for each other, and aided by the vast power of their wealth, and their great natural abilities, they have forced citadel after citadel, until now they practically control the stock-market, own the press, fill the bar and bench, are crowding the professions - indeed there seems to be no limit to the increase of their power. This of course is a menace to the newly nationalized country. ${ }^{108}$

As a student of Treitschke, Du Bois sees the new state as at risk from Jewish cosmopolitan economic power, a foreign presence now seemingly German. 
Du Bois sees that the historical pattern of German integration places the indigenous German at the mercy of the Jews, at home everywhere and nowhere, spreading their cosmopolitan ideology of socialism. Du Bois was quite aware of the double problem of a German nationalism that both enabled Jews to function in the society and charged them with being unable to be real Germans. This problem arose from the German psychology: "The whole nation in spite of excellent qualities seems largely to lack that robust faith in itself which builds men and peoples. It is thus that the American comes to realize that this new federation of the old world is starting its history from premises dramatically opposite to those from which the old federation of the new world, started. Instead of a boundlessly optimistic state founded on individual freedom, we have a restlessly pessimistic state founded on obedience." ${ }^{109}$ Du Bois also sees the Jews' economic presence as a menace to the untested nationalism of the new Germany. While there, he wrote that Germans "piled on the shoulders of the Jew, all the evils ever attributed to capitalism. All that Marx, Blanc, or Bellamy ever laid at the door of capitalism, is by the German anti-Semitic party, charged upon the Jew because the Jew happens to be the great capitalist of Germany." 110 But the Jew is also the antithesis of the "slow-going good-natured German burger," who does not succeed in such a cosmopolitan modernity because of his "lack of capital and business sense, together with the irresistible competition of sharp, and sometimes unscrupulous, Jews." ${ }^{111} \mathrm{He}$ also thought that such racism was limited and could well be ameliorated over time.

For another wildly popular lecturer at the Berlin university—one with whom Du Bois evidently did not study—-the "subordination of social behavior to compressive systems" such as social mobility and the mobility of capital are linked, a problem that Du Bois evokes in The Philadelphia Negro (I898). ${ }^{12}$ Georg Simmel noted in the Philosophy of Money (1907), "Only if the profit of an enterprise takes a form that can be easily transferred to any other place does it guarantee to property and the owner, through their spatial separation, a high degree of independence or, in other words, self-mobility. It enables the property to be managed exclusively according to objective demands while it gives its owner a chance of leading his life independently of the specific demands of his possessions." 113 Simmel may be the classic case of mobility and cosmopolitanism in imperial Berlin. ${ }^{114}$ Born in Berlin in I874, when it was still only the capital of Prussia, he was the child of a wealthy chocolate manufacturer who had been born Jewish and converted to Catholicism. When Simmel was a child, both he and his mother were baptized as Protestants. In I 885, after completing his doctorate, he became a Privatdozent at the Berlin university, but in I 905 he was made merely a professor without a chair because he was consid- 
ered Jewish. As a Jew he was considered to be a stranger, while his intimate sense of self was bound to a Germany into which he fit poorly.

In Simmel's often quoted if rarely read appendix on the stranger (I908), he wrote, "If wandering in the liberation from every given point in space, and thus the conceptional opposite to fixation at such a point, the sociological form of the 'stranger' presents the unity, as it were, of these two characteristics. . . The stranger every where appears as the trader, or the trader as stranger." 115 And the Jew exemplifies Simmel's stranger. Despite his Jewish origin, Simmel was suspicious of Jewish cosmopolitans such as those in fin de siècle fantasies of seventeenth-century Amsterdam. He refers to "racially inferior Jews" in his I9I6 study of Rembrandt, an artist who after I900 served as a touchstone for antisemitic critiques of contemporary diaspora Jewry. ${ }^{116}$ In this world of trains, social mobility is tied to capital over and over again. But for Jews, the association was often terrifying. Picking up on Du Bois's problematic understanding of the outsider's psychological means of coping with an alienating and hostile society in a double sense of identity, Paul Gilroy has claimed that "striving to be European and Black requires a special kind of consciousness" and that the same held true for European Jews before the Holocaust. ${ }^{117}$ Till van Rahden has labeled this special (not double) consciousness "situational ethnicity." 118 It lies at the root of the conflicted questions of the Jew as cosmopolitan in imperial Germany. ${ }^{119}$

No Jew in imperial Germany better represented the conflicts mirrored by Du Bois than did a young Walter Rathenau, the scion of one of the wealthiest Jewish families in Berlin and by I897, shortly after Du Bois left Berlin with a failed dissertation, one of the most extraordinary commentators on the problems of Jewish cosmopolitanism. In an anonymous essay, "Hear O Israel," published in Maximilian Harden's radical periodical, The Future, Rathenau addressed his Jewish and Christian contemporaries in what has come to be one of the most problematic accounts of Jewish rootedness. ${ }^{120}$

For Rathenau, the Jew is a nomad, out of place in imperial Germany: "In the midst of German life [there is] an isolated, strange human tribe, resplendently and conspicuously adorned, hot-blooded and animated in its behavior. An Asian horde on the soil of the March" of Brandenburg (R, I73). Like Du Bois, Rathenau writes as a member of the Talented Tenth, the economic and cultural elite, in this case of German Jewry. Wealthy, well-educated, and fashionable, he remained a Jew in his inner life if not in his public one, a status echoed in how he defined the Jew. For him, the Jew is not defined by capital: "For a long time yet, I fear, the lower classes of Jewry will be dependent on the profession of commerce and trade. It is natural and justified that, like any lop- 
sided endeavor, commerce, too, and especially its typical participants, should arouse a counterforce and opposition. The meaning of this process is more mercantile than cultural" (R, I74). The nomadic Jews have thus changed from their biblical role as warrior-kings to that of commerce and trade:

Do you think the old tribal God will send his messiah king to help you? Alas, you have not noticed that he has not had anything to do with you for several thousand years! The Lord of Wrath took delight in a nation of warriors; he is not interested in a nation of grocers and brokers. He who is enthroned on Horeb and Zion does not relocate to Rosenthalerstraße or Heidereutergasse. You said that you are clever and skilled in worldly affairs: "He who has the wealth, has the power." Now you have the wealthand the rich among you are less esteemed than your poor. (R, I75)

For Rathenau, becoming rooted constitutes an impossibility:

Assimilation not in the sense of Darwin's "mimicry," adopting the color of their surroundings, but assimilation in the sense that tribal qualitiesregardless of whether they are good or bad-that are demonstrably hateful to fellow Germans are cast off and replaced by more suitable ones. If it were possible for this metamorphosis to simultaneously improve the overall balance sheet of moral values, then that would be a happy accomplishment. The goal of the processes should not be imitation Germans, but Jews who are German by nature and education. At first, it is necessary for an intermediate condition to develop, which, recognized by both sides, represents a line of separation and connection between Germandom and typical Jewry, a Jewish patriciate, not of property, but of intellectual and physical culture. Through its roots, this estate will continuously draw up new nourishment from below, and in time it will absorb all the material that is digestible and capable of transformation. (R, I76)

Writing in I897, Rathenau uses the same Darwinian model for Jewish cosmopolitanism as does Herzl - that of adaptability and malleability through antagonistic experience. Adolf Wahrmund and the other antisemites of the time stress that no matter how elegant, how educated, how fine the Jews become, they remain essentially nasty nomads. Indeed, Wahrmund defined a generation later became Rathenau's underlying claims about modernity as merely the impact of a modified Jewish nomadism on European life. As Wahrmund argued, Jews had a natural advantage in the mobility that defines the modern age be- 
cause of their nomadism. ${ }^{121}$ As one of the Jewish reviewers of Wahrmund's book, Isaac Hirsch, commented, Wahrmund had "hung onto the fact that the Jews were always nomads and are so unto this very day. But because the Aryans, especially the Germans, were agricultural, so there remained an unbridgeable chasm between the Jewish and the Aryan beings. . . . What the author cannot grasp is that even if the ancestors of the Jews were nomadic, which was never the case, the ancestors of the Germans were in point of fact, actually nomadic herders and hunters." 222 According to Hirsch, then, not Jews but Germans were truly nasty nomads.

Do Jewish cosmopolitans' claims to a German identity merely reflect the innate rootlessness of the Jew? Rathenau later seems to see equivalent problems and advantages with a German as well as a Jewish identity. As Shulamith Volkov notes concerning Rathenau's economic views in his I9I 2 work Critique of the Times, such rooted nationalism was ill prepared to "respond to the challenges of the capitalist age. Capitalism knew no political boundaries, just as it accepted no custom barriers. It was cosmopolitan by definition. The tension between nationalism and cosmopolitanism, then was another unhealthy outcome of the age of mechanization, forcing us to find a proper middle way between the two, a way that would permit continuous economic growth without giving up established, age-old collective identities." ${ }^{123}$ Mere mimicry of the authentic German world is not possible for Rathenau because it devalues that which is copied as well as those it copies. (This idea is a rather ironic prefiguration of Walter Benjamin's I936 theory of the reproducibility of art and the lack of "essence" in the photographic copy.) Rathenau rejects a dichotomy of "Jews" versus "Germans" as his model, seeing a "natural" melding of both traditions and mind-sets to produce the modern German. ${ }^{124}$ This concept is analogous to the idea of a performance of identity as the source of a modern Jewish identity in the German-speaking world. ${ }^{125}$

The collapse of the German Empire altered many Berlin intellectuals' sense of the role that the Jews could have in a liberal Germany. By the time he wrote his I920 essay, "De Profundis," Rathenau had altered his view of his own identity as a Jew in what had clearly become for him a sectarian world: "They say: admit your guilt and believe. Certainly, I admit my guilt. But how am I guilty for my guilt? I was trapped even before I as aware of it. And if I wanted to extricate myself, that had no value." On the drive for assimilation, he continues, "Your desire is as good as it is bad. It desires itself, but it is desired for your sake."126 Jews are inextricably bound by the needs of their German (Christian) neighbors. The more Jews desire to change, the less they are seen as able to do so. As Rathenau wrote to Lilli Deutsch in I922, "In our lives, 
everything was set in the law: things simply existed on their own. Nothing was pointless, nothing could be thought away, nothing could be sacrificed."127

Rathenau became foreign minister of the Weimar Republic in 1922 and was murdered later that year, condemned by his assassins as a one of the hidden Elders of Zion, the ultimate cosmopolitan Jew, whose aim was to rule the world. Thomas Mann heard one professor in Munich pleased that there was now "one less Jew!"128 A year later, Zweig wrote of Rathenau, who had become a symbol of the inherent double bind in which the new cosmopolitan Jew was trapped, "Nothing surprised me more about him as the brilliant organization of his public life, this being free and having time for everything and all in the midst of his extreme activity." 129 Rathenau's external life was that of the German, yet it masked a complex and difficult world in which he symbolized both Weimar Jewish cosmopolitanism and the innate transformability of the settled Jewish nomad. The Jew had been martyred to the cause of cosmopolitanism.

Rathenau's world was that of the German national; the rise of German Zionism, as Michael Berkowitz has well illustrated, was thus inherently different than its Austro-Hungarian counterpart. ${ }^{130}$ In the Weimar state, Jews played highly visible roles, not only from Rathenau's role as foreign minister but also at all levels of the civil service and in the wider cultural life. German Zionism thus had to deal with both an integrative state that at least tolerated Jewish public presence and a claim of Jewish cosmopolitanism that contested the claims of a Jewish national project. ${ }^{131}$ Yet Weimar also revealed the crumbling structure of the claims of the Enlightenment, demonstrating contradictions about Jewish emancipation, identity, and rootedness, that were labeled as corrupt by Treitschke, who bemoaned, "such blasphemies [as] are offered to our people [by Jewish intellectuals such as Heine] as the newest acquisitions of 'German' Enlightenment."'132

Such trends had already begun to appear in the immediate prewar period in the works of wildly popular German Jewish novelist Jacob Wassermann. Born in Fürth in I873 and thus a citizen of the new German state at the age of six, Wassermann worked unsuccessfully as a businessman in Vienna; at a Munich satirical magazine, Simplicissimus; and as a critic before hitting his stride as a wellrespected and very widely read novelist living in Vienna and Altensee, Austria. He was considered the Jewish parallel to Thomas Mann as a commentator on times and mores. ${ }^{133}$ A member of the Prussian Academy of the Arts, Wassermann was a Jew within the German-speaking world and in no way a Zionist, but he nevertheless deeply doubted cosmopolitanism as a modern project.

In I909 Wassermann came to define being Jewish in the diaspora not in 
terms of a religion or of a Zionist project; rather, he distinguished between himself as a creative Jewish writer and the cosmopolitan Jew, who incorporated all negative antitheses:

There is a reason that there are so many literati among the Jews. They are the most atheistic or the most religious; the most socially aware, though in old, dead antiquated form or in the new utopian mode that wishes to destroy the old, or he seeks anarchic solitude within himself. . . . All of this has damned the Jews as a people to the role of the literati. . . . The Jew as a European, as a cosmopolitan, is merely a member of the literati; the Jew as an Oriental, not in the ethnographic but in the mythic sense through which the contemporary creative drive is present, makes him into a creator. ${ }^{134}$

Wassermann repeated these views verbatim in a long I9I3 letter to Martin Buber that was reprinted in Vom Judentum. ${ }^{135}$ The cosmopolitan is the assimilated and therefore culturally inauthentic Jew, whereas the Oriental is authentic and therefore the only true creator of art. The sole possibility is either sublimation (and some level of literary production) or repression (and the resultant self-loathing). Thus did Wassermann view the role of Jews in early twentiethcentury literary life.

By 1900 the Zionist ideal promulgated by Herzl in light of his understanding of an Austro-Hungarian cosmopolitanism, with national languages and cultures subservient to a supranational ideal, had taken on a taint of the mysticism associated with German nationalism from the German romantics (and their strongly antisemitic rhetoric) at the beginning of the nineteenth century. These views were clearly anti-Enlightenment in every sense of the word. Wassermann saw the irreconcilable struggle between the cosmopolitan and the Oriental as defining the German Jew.

Wassermann's image of the Oriental is not that of the nomad. Rather, it evokes anthropologist Friedrich Ratzel's ecological view of appropriate races in appropriate spaces. For Ratzel, the evolution of race was determined by the geographic location of peoples. Their distinctive differences, including character, resulted from this geographical specificity. When people moved out of their appropriate spaces, they were inherently rootless. He distinguished between that rootlessness and what he called a "spiritual cosmopolitanism, such as Christianity has approved. . . . The Semite is an individualist, holding faster to religion and the family than to the state." 136 Jews can rarely become true citizens of the nation-state because of their nature, wherever they live. Their cos- 
mopolitanism is merely a mask for their rootlessness. They are bound not to the universal or the cosmopolitan but to the local and the autochthonous. When confronted with such universals as the truly cosmopolitan, according to Wassermann, Jews are in a permanent double bind.

For Wassermann the cosmopolitan literati are never truly creative but are merely adaptive, as only the essential national can be truly original. In his I92 I autobiography, My Life as a German and a Jew, Wassermann stresses that the cosmopolitan is the essentially inauthentic:

I have known many Jews who have languished with longing for the fairhaired and blue-eyed individual. They knelt before him, burned incense before him, believed his every word; every blink of his eye was heroic; and when he spoke of his native soil, when he beat his Aryan breast, they broke into a hysterical shriek of triumph. . . . I was once greatly diverted by a young Viennese Jew, elegant, full of suppressed ambition, rather melancholy, something of an artist, and something of a charlatan. Providence itself had given him fair hair and blue eyes; but lo, he had no confidence in his fair hair and blue eyes: in his heart of hearts he felt that they were spurious. $^{137}$

For Wassermann, the "self-shame" of the cosmopolitan marks the relationship of the Jew to his own sense of self as a human being:

I was often overcome by discouragement, by a sense of shame at all those tumbling, stumbling selves among whom I too now was numbered, but who from far away had seemed to me superhuman creatures dwelling in an enchanted garden. At times I was moved to wonder whether the narrow spitefulness, the pecuniary squabbling combined with the striving toward universal goals, the provincial dullness and brutal ambition, the mistrust and stubborn misunderstanding where achievement and perfection, ideas and an exchange of impulses were at stake, where thoughts and images were concerned-whether all this was a peculiarly German disease or a by-product of the métier as such, its somber lining, the same with us as in other lands. ${ }^{138}$

Wassermann notes the inauthenticity of such forms of identification and the concomitant rejection, evident to the outside observer, that destabilizes Jewish identity. The poisonous seed was planted in the works of Jewish cosmopolitan authors: 
The fact that those who hate blindly and those who agitate invidiously are in the wrong does not prove that wrong is really being done. Suppressing or coloring matters does not strengthen a weak cause. Possibly the underlying cause of my irritation was Heine's blood. A time-conditioned figure, he was Jewish in a time-conditioned sense; the most striking thing about him is the rude contiguity of ghetto spirit and cosmopolitanism, of Jewish bourgeoisie and Europeanism, of poetic imagination and a Talmudic Jewish fondness for plays on words, ornamental words, fanciful words. The latter combination, erroneously called romantic irony, actually is a result of the miraculous Jewish adaptability and of a deep-lying inner uncertainty of life and the world. ${ }^{139}$

Siegmund Kaznelson's review of Wassermann's autobiography, which appeared in 1922 in Buber's periodical, Der Jude (The Jew), dismisses Jewish cosmopolitanism as the "long abandoned liberal missionary ideal to further humanity." 140 That Wassermann also channels Treitschke shows how powerfully the claim of a cosmopolitan identity confronted German notions of a mystical, antirational national identity, whether espoused by antisemites or by Jews. The cosmopolitan neither enables the Jew to become part of antisemitic culture nor provides Wassermann with a positive Jewish identity; rather, it transforms him into a psychopathological case. Such Jewish cosmopolitan characters haunt the literature of the day in works by non-Jews such as Thomas Mann ("Blood of the Walsung" [1905]) as well as Jews such as Arthur Schnitzler (The Road into the Open [1908]) and indeed Wassermann himself (his covert portrait of Rathenau, the "cosmopolitan traveler who "suffered under Germany," in Etzel Andergast [193 I]). ${ }^{141}$ Here, the Enlightenment cosmopolitan ideal shows itself to be merely the acquiescence to the mimicry decried by Jewish nationalists, who model their sense of a new Jewish identity on an anticosmopolitan German nationalism. The results are always catastrophic.

Post-World War I Berlin established itself as the center of the new German cosmopolitan cultural space that for good or ill seemed to define the Weimar Republic, replacing the radical anticosmopolitanist nationalism of the short-lived world of imperial Germany. Vienna became the hydrocephalic capital of the rump state of Austria, with a new rump nationalism replacing the Austro-Hungarian Empire and its multiethnic citizenry, which had vanished. The Austro-Hungarian hotbed of cosmopolitan ideas had dissipated into the worlds of the various successor nations, with their German-language, Jewish writers now existing in an imagined community in the world after the dual monarchy, which was not unlike that of the German cultural sphere before 
I 879. The first shots of World War I had been fired in this multiethnic empire, heralding a new era in the increasingly violent nationalism of the new century. What had been a mystical national fantasy turned out to fuel the killing fields of the Western and the Eastern Fronts, where Jewish soldiers, imbued with their own national feelings, whether German, Austrian, British, or Palestinian, died alongside all others for this soon abandoned mystic ideal of a national state. The period following World War I saw the most concerted assertion of cosmopolitanism during the twentieth century in remnants of the Hohenzollerns' empire as well as that of the Habsburgs. 


\section{Chapter 4}

\section{Jewish Cosmopolitanism and the European Idea, I9I8-I933}

\section{After the Deluge}

The brief period between the two world wars saw concerted efforts by liberal and leftist-leaning German and Austrian Jewish writers to promote the cosmopolitan ideal. For a little over a century, the cosmopolitan dream of a united Europe had been nascent among Christian and Jewish intellectuals in the German-speaking realm. Following the nationalist disaster of World War I and the rise of antisemitism throughout the I920s, the cosmopolitanist project assumed particular urgency for Jewish intellectuals. ${ }^{1}$ Examining cosmopolitanist tropes in the writings by Stefan Zweig, Joseph Roth, and Lion Feuchtwanger, this chapter argues that Jewish sensitivities were by no means incidental to their cosmopolitanism but rather drove it in essential ways. ${ }^{2}$ These authors rewrote the older notion of the rootless Jewish nomad into the central paradigm of the modern cosmopolitan. ${ }^{3}$

In asserting a cosmopolitanist sensibility, a concept that came to be synonymous with the European idea, these writers opposed not only the rabid nationalism that had led to the disaster of World War I and posed the threat of renewed world war but also the rise of political antisemitism throughout the interwar era. The I922 assassination of German Jewish foreign minister Walter Rathenau demonstrated to these writers the urgent need for an effective defense against the growing nationalism and antisemitism. Cosmopolitanism placed the Jew at the heart of a new particularist universality from which a unified Europe beyond borders, national strife, and antisemitism would emerge. German-speaking Jewish writers, whose cosmopolitanist engagement came to the fore during the interwar period, felt compelled to straddle these conflicting images of cosmopolitanism, nomadism, and the Jews. ${ }^{4}$ Their construction of a nomadic cosmopolitanism, which fused the stereotypical image of the rootless 
Jew with the seemingly more universal notion of the cosmopolitan, attempted to position the Jew at the core of a universal narrative of humankind. Given the anti-Jewish implications of both cosmopolitanism's universalism as well as the discourse of the nomad, this strategy remained necessarily ambivalent.

Of course, cosmopolitanism was but one of a wide variety of interwar intellectual trends that were broadly catalyzed by the war experience..$^{5}$ Jews could be found on all sides of the overlapping and conflicting debates regarding cosmopolitanism, the nation, and the socialist revolution. Some, among them Rosa Luxemburg and Kurt Eisner, had joined or even led Germany's failed I9I 8-I9 socialist revolutions. At the other end of the political spectrum stood ultranationalists such as Max Naumann, an army officer and holder of the Iron Cross as well as chair of the League of Nationalist German Jews. Naumann violently opposed Eastern Jews, whom he considered legitimate targets of antisemitism, and saw cosmopolitanism as the bane of Germans of Jewish descent. However, both radical socialists and nationalists remained a minority among Weimar Jews, who in overwhelming numbers supported the republic and its promise of full integration.

Likewise, German-speaking Jewish writers were not alone in promoting the cosmopolitan ideal but were just one voice in a literary chorus that included non-Jewish writers, primarily from France and Germany, such as René Schickele, Romain Rolland, and Thomas Mann. The breadth of cosmopolitanist thinking of the period ranged from a reiteration of Immanuel Kant's rooted cosmopolitanism to a nomadic or solely intellectual cosmopolitanism and even included calls for a confederation of European states. ${ }^{6}$ Mann, for example, who went on to win the Nobel Prize, advocated a national cosmopolitanism in his I9I 8 Betrachtungen eines Unpolitischen (Reflections of a Nonpolitical Man) although he was aware of the "in-built ambivalences" of such a position. ${ }^{7}$ As Mann elaborated in his I925 essay, "Kosmopolitismus" (Cosmopolitanism), he "experienced cosmopolitanism or Europeanism essentially in German."

Mann's national cosmopolitanism was hotly contested by Austrian Jewish writer Stefan Zweig, who like Mann initially proposed cosmopolitanism as an intellectual affinity rather than a political project. Zweig, however, saw in Mann but a late convert to the European idea. Zweig's i9i8 essay, "Opportunismus, der Weltfeind" (Opportunism, the World's Enemy), thus distinguished between the genuine German-speaking cosmopolitan, "the German European, who saw his ideal in democracy" and his nemesis, the German national democrat by necessity, "the sudden German democrats of tomorrow." For Zweig, the latter, who like Mann had initially welcomed the war, had been swayed by its disastrous outcome rather than by a deeper identification with the European 
idea. In his I926 essay "Internationalismus oder Kosmopolitismus" (Internationalism or Cosmopolitanism), Zweig takes an implicit swipe at Mann in mentioning those writers who are last to embrace the European idea, after even politicians and bankers have already done so. Their credo, however, is but a lower form of cosmopolitanism, "a merely social, conventional and mutual hospitality" in the vein of Kant's universal hospitality, whereas Zweig imbued internationalism with an altogether more radical gist: "Internationalism is an assertion of the indestructible unity of nation, independent of the chaos and bigotry of politics," and would survive even the challenges of war. ${ }^{10}$

And indeed, Mann's cosmopolitanism questioned the radical internationalism of pacifists such as Schickele, whom Zweig admired and who was then seen as the German cosmopolitan par excellence..$^{11}$ Likewise, the German writer Annette Kolb and her French colleague, Rolland, can be seen as proponents of a rooted European (not national) cosmopolitanism, which reflected Woodrow Wilson's Fourteen Points and the resultant notion of international self-determination. ${ }^{12}$ At the same time, these writers offered a radical rereading of the promise of Wilson's platform rather than reiterating Wilson's suspicion of rootless cosmopolitans. Wilson thus claimed in his Second Inaugural Address on 5 March I9I7 that Americans "are a composite and cosmopolitan people. We are of the blood of all the nations that are at war." But Wilson's was not that vague cosmopolitanism, "where sympathy was neither here nor there." ${ }^{13}$ Americans, too, are a newly rooted people composed of those who have fled oppression and injustice, and they included Jews, who "are good citizens" of the national state as opposed to the "Jews of Poland" and their Zionist demand at Versailles for a Jewish state. ${ }^{14}$ Rooted cosmopolitanism, in their case, is a poor second to assimilation. Many flavors of cosmopolitanism existed simultaneously in the postwar world.

For most writers of the period, the ideal of European unity was based on the assumption of shared intellectual traditions across national borders and languages, although some, including Heinrich Mann, already promoted Europe as a political idea-for example, in the shape of a confederation of European states. For all of these authors, however, the cosmopolitan idea of a united Europe represented a powerful bulwark against the ravages of nationalistic war. Although the interwar writings of Zweig, Roth, and Feuchtwanger are regularly considered to have spearheaded the German cosmopolitanist engagement, their close intertwining of Jewish sensitivities and cosmopolitanist thought has previously remained underexamined..$^{15}$

The previously unknown movement of people across Europe and the globe the nineteenth and early twentieth centuries had increasingly undone 
the relationship between national identity and geographic affiliation, which nationalism had claimed was fixed, and the diasporic condition was thus becoming ever more common. Conversely, the mass atrocities of World War I increasingly discredited the nationalistic excesses from which they had risen and catalyzed new interest in the cosmopolitan idea. As a result, cosmopolitanism became increasingly detached from patriotism, and the notion of a nomadic cosmopolitanism, often linked to the city, increasingly took hold. The Jewish condition of the diaspora with its deterritorialized particularist affiliation thus seemed to be turning into a universal condition, and cosmopolitanist ideas particularly appealed to German-speaking Jews, who sought to claim both their Jewish and German affiliations. Franz Rosenzweig's I926 anthology, Zweistromland (Land of Two Rivers), which cast the Germanspeaking diaspora between the Danube and Rhine as the new Babylon, thus spoke for many who believed that their Jewish and German affiliations could flow together seamlessly. ${ }^{16}$

Zweig, Roth, and Feuchtwanger stood at the forefront of Jewish cosmopolitanist engagement during the interwar period, but the cosmopolitanist aspect of their writing has not yet received in-depth attention. As this chapter shows, all three writers proposed the deterritorialized state of the diaspora Jew as the paradigm of the future European citizen beyond national boundaries. With its idea of one God above the nations, they claimed, Judaism promoted universalism at its core. The diaspora, then, formed the necessary condition for Judaism's wider dissemination of its humanistic mission. These authors' cosmopolitanist position thus remained distinct from the diametrically opposed camps of the acculturists in the Centralverein deutscher Staatsbürger jüdischen Glaubens (the Central Association of German Citizens of Jewish Faith, founded in I 893) and the Zionists, with their nationalistic claims.

The nomadic cosmopolitanism proposed by Zweig, Roth, and to a lesser degree Feuchtwanger intervenes in Kant's rooted cosmopolitanism with its patriotic implications on the one hand and the stereotype of rootless Jewishness on the other. Whereas Zweig's cosmopolitanism showed close affinities with the assimilationist position, Roth's construction of the Jews as a diasporic ethnicity was borrowed from the cultural Zionism of Ahad Ha'am and Martin Buber. In contrast, Feuchtwanger increasingly conceded the importance of a Jewish polity in Palestine, thus balancing Zionist sympathies with his cosmopolitanist engagement. Despite these important differences, all three writers propose a cosmopolitan prototype in the Jew's mobile and liminal subjectivity, which effects a transient belonging through contingent and shifting regional affiliations. 
Sigrid Thielking has already observed the Weimar era's emergent linkages between nomadism and cosmopolitanism, which became associated with a rising, highly mobile urban elite. ${ }^{17}$ In contrast, Roth, Zweig, and Feuchtwanger link the deterritorialized figure of the Jew, whom they position in the palimpsest of the cosmopolitan, to peripheral and liminal subjectivities from the premodern fringes of the Austro-Hungarian Empire rather than its centers.

Whereas mobility represented in terms of the movement through space and time (by carriage or by train) dominated the metaphors of cosmopolitanism in the eighteenth and nineteenth centuries, a more sedentary but perhaps also more subversive image arises in post-World War I writings. The hotel and the coffeehouse, both reflecting the transience of the modern individual and the Jew as its emblem, become the salient signifiers of this body of writing. These reference the cosmopolitan nodal points for travelers through space and time, perhaps best exemplified by Vicki Baum's best-selling I929 novel (and I932 Academy Award-winning film) Menschen im Hotel (Grand Hotel). Zweig and Roth in particular frequented these institutions of Austro-Hungarian public life.

In turn, critics of modernity during the I920s, such as Oswald Spengler in his Decline of the West (1922), saw in these spaces the sign of the weakened racial instincts of the urban intellectual and viewed cosmopolitanism as the downfall of the Western world. ${ }^{18}$ Spengler's global best seller famously referred to cosmopolitanism as a pure fiction advocated by writers of such fiction. Charges Spengler, "The world cities are pure intellect, rootless"; they harbor "born world-citizens, world-pacifists, and world reconcilers" who are but a

minority of timeless a-historic, literary men, men not of destiny, but of reasons and causes, men who are inwardly detached from the pulse of blood and being. . . . Cosmopolitanism is a mere waking-conscious association of intelligentsias. (DW, 2:184-85)

These are, of course, only thinly disguised references to the stereotype of the rootless Jews and the city as their site. Here Spengler implicitly draws on the work of Otto Weininger, a Viennese Jew whose 1903 Sex and Character had claimed the Jew's purely materialistic nature and lacking historical awareness. Furthermore, Spengler pointed to the largely literary medium of cosmopolitanist thought, by which he simultaneously declared its illusory nature: "Cosmopolitanism is literature and remains literature, very strong in reasons, very weak in defending them otherwise than with more reasons, in defending them with the blood" (DW, 2:I85). Spengler even dismissed altogether the cosmopolitanist idea of Europe, which he believed had erroneously integrated Russia 
into the West, and instead called for the creation of "an ideal frontier corresponding to the physical frontier between "Europe" and "Asia" instead" (DW, I: 6 n. I). This notion of the cosmopolitan is underlined when Spengler sees in the cosmopolitan intellectual the evolution of a new urban nomad:

In place of a type-true people, born of and grown on the soil, there is a new sort of nomad, cohering unstably in fluid masses, the parasitical city dweller, traditionless, utterly matter-of-fact, religionless, clever, unfruitful, deeply contemptuous of the countryman and especially that highest form of countryman, the country gentleman. (DW, I:32)

The "country gentleman" is rooted in the soil, and the difference between the Germans and the Jews rests in this dichotomy. Accordingly, the medieval German was still a "Gothic" peasant bound to the land when the Jews were "megalopolitan" with their "superior, almost cynical, intelligence and [their] finished expertise in "money-thinking", (DW, I:368). Modernity is merely the continuation of this

new nomadism of the Cosmopolis, for which slaves and barbarians in the Classical world, Sudras in the Indian, and in general anything and everything that is merely human, provide an undifferentiated floating something that falls apart the moment it is born, that recognizes no past and no future. (DW, I:368)

Indeed, Spengler's vision in the midst of World War I that Germany was in the grasp of the inorganic, cosmopolitan masses, which had to give way to a new "agricultural-intuitive" awakening, ruled by an "organic structure of political existence" (DW, I:73-75) is simply nineteenth-century views on the rootedness of the Germans turned into historical theory. ${ }^{19}$ For Spengler, this reawakening is only true of the German Volk and such races that "never wander" (DW, 2:254). They are fixed in space and time, whereas the Jews represent money and can only be overcome by "blood" (DW, 2: 287), which defined the inherent rootedness of the Volk, as Alex Bein has argued. ${ }^{20}$

At least one writer born in imperial Austria was sure he had the answer to the question of Jewish cosmopolitanism. Adolf Hitler, born in I889 to a petit bourgeois family in Braunau, an Austrian border town close to Bavaria, reflected while in Landsberg Prison in I923-24 about how he understood Jewish cosmopolitanism in imperial Austria. During his incarceration, Hitler authored Mein Kampf, which in a not-too-subtle manner recounts his coming to terms 
with his own cosmopolitanism when he is forced to recognize the Jew as the true cosmopolitan. ${ }^{21}$ In Linz, where he was raised, Jews seemed to him to have been invisible. Even Hitler's father, a civil servant, abjured crude antisemitism: "I think the old gentleman would just have considered those who used [the word Jew] in this way as being uneducated reactionaries. In the course of his career he had come to be more or less a cosmopolitan, with strong views on nationalism" (MK, 5I). Rejecting his father's and his own Austrian cosmopolitanism meant stressing Jewish difference, but not in terms of ideas of the Jew as nomad. For the Jews were sui generis: they were so without roots that they actually defined corrosive cosmopolitanism.

Mein Kampf thus thoroughly debunked the notion of the Jewish nomad as a reading of Jewish cosmopolitanism because, as Hitler claimed, the Jew had "never possessed a state with definite territorial limits and therefore never called a culture his own" (MK, 300-3 I I). In contrast, "the nomad does possess a definitely limited living space; only he does not cultivate it like a sedentary peasant, but lives from the yield of his herds with which he wanders about in his territory" (MK, 324-27). For Hitler, Bolshevik internationalism was at its core a reflex of perceived rootlessness of the Jew and his inherent detachment from the land.

In multiethnic, cosmopolitan Vienna, Hitler "understood the language of the Jew. I realized that the Jew uses language for the purpose of dissimulating his thought or at least veiling it, so that his real aim cannot be discovered by what he says but rather by reading between the lines. This knowledge was the occasion of the greatest inner revolution that I had yet experienced. From being a soft-hearted cosmopolitan I became an out-and-out antisemite" (MK, 63). Moreover, he argues, cosmopolitanism is inherently non-German: "Our national stock has been so much adulterated by the mixture of alien elements that, in its fight for power, Jewry can make use of the more or less 'cosmopolitan' circles which exist among us, inspired by pacifist and international ideologies" (MK, 524). In other words, the Jews have polluted German self-identity with their false cosmopolitanism. This is merely a mask by which they undermine national values.

In the unpublished sequel to Mein Kampf, Hitler writes of the decay of modern Europe under the influence of the Jews. He quotes the German historian Theodor Mommsen on the destruction of the Roman Empire, evoking the association of imperial Germany with Rome: "In the old world as well, Jewry was an effective ferment of cosmopolitanism and national decomposition and in this respect a preferentially entitled member of that Caesarean state whose polity was actually nothing but cosmopolitanism, whose national character 
was basically nothing but humanity." 22 Remembering the odd identification of imperial Austria with Rome (in contrast to the German Empire's image of itself as a new Greece), Hitler sees that the roots of Jewish cosmopolitanism have entangled themselves with the destruction of empire from the beginnings of imperial history.

\section{Stefan Zweig: The Model European}

The discourse of cosmopolitanism, in turn, enabled leftist-liberal Jewish writers such as Zweig, Roth, and Feuchtwanger to undermine the imagined physical, ideological, and racial frontiers and to rewrite the antisemitic image of the Asiatic Jew into the productive prototype of a cosmopolitan humanity.

The hotel and the coffeehouse were the most recognizable public institutions of the Austro-Hungarian Empire, which in Zweig's and Roth's interwar writings now signifies the lost Europe before World War I. This was, as Zweig nostalgically claimed in his World of Yesterday, a world beyond fortified national borders in which passports were unknown and everyone could travel freely. ${ }^{23}$ Mark H. Gelber and Anna-Dorothea Ludewig, as well as Karl Müller have thus pointed out the limitations of Zweig's cosmopolitanism, arguing that it is essentially centered on the "old Austria" and Western Europe more broadly and is based on the idea of shared European intellectual and spiritual traditions rather than political thought. ${ }^{24}$ Similarly, Robert Wistrich has argued that The World of Yesterday idealizes the Austro-Hungarian Empire for its presumed political and social stability while largely eliding its internal contradictions. ${ }^{25}$

Yet the political implications of Zweig's writings must not be underestimated. During a time when aggressive nationalism and antisemitism were once again on the rise, Zweig and other cosmopolitanist writers' emphasis on common humanistic values across the boundaries of nation and race held political implications in and of themselves. After all, Zweig's idealized vision of the pre-I9I4 cosmopolitan Europe have largely materialized in post-I989 Western societies with their multi- and transcultural populations and open borders within the European Union, although these are currently under siege by nationalist movements across the European Union as well as Britain's planned exit from the EU. ${ }^{26}$ Zweig and others of his generation saw literature as the ideal medium to promote this dream. They did so by drawing on Goethe, who represented the humanistic values on which German-speaking Jews in particular had pinned their hopes for integration, despite his occasional, less flattering comments on the Jews. ${ }^{27}$ Goethe's deterritorialized concept of world literature 
was the beacon of these writers and the Jew its emblem. ${ }^{28}$ These interwar cosmopolitanist writers thus provided the intellectual and cultural justification for the project of European unity, which has now become political reality.

Zweig's cosmopolitanism was essentially based on the premise of shared European intellectual traditions, and his writing can be considered largely assimilationist in gist. After all, Zweig grew up in a highly assimilated middleclass family in Vienna and saw himself as partaking in the dominant Germanspeaking culture of the Austro-Hungarian Empire. In contrast to Zweig's fin de siècle cycle of Jewish novellas, few of his post-World War I works feature explicitly Jewish characters. Zweig's universalism obviously overrode his Jewish affinities, which nonetheless formed the implicit core of his sympathies for the disenfranchised in society. Mark Gelber has thus argued for an evident "Jewish sensitivity" in Zweig's writing ${ }^{29}$ that seems to have been based on racialized presuppositions. In his I93 I interview with David Ewen, Zweig stated that he had been aware of his Jewish "blood" for as long as he could remember..$^{30}$ Blood, of course, has a long symbolic history in German literature as a means of representing racial identity. ${ }^{31}$ Such invocations of race by an avowed cosmopolitan may sound paradoxical, but they demonstrate the extent to which racialized concepts of identity had become widely accepted even among Jews of the period.

Zweig's alignment of the cosmopolitan with the European idea is evident throughout his interwar writings, where Jewish paradigms remain in the palimpsest that is fundamental to his understanding of the modern cosmopolitan. These premises are evident in Zweig's essay, "Der Turm zu Babel" (The Tower of Babel, I9I6), in which Zweig draws on the Hebrew Bible to configure the modern cosmopolitan vision. The tower in the story is the product of human unity, which God seeks to destroy by creating different languages and thus sowing misunderstanding and strife. For thousands of years, humans lived in disunity, each clinging to his own land, until a few wise men began to sow the seeds of shared knowledge and science. And so the tower is resurrected, taller than ever before, and will have to be completed "in our Europe, where it was begun, and not incidentally in foreign parts of the world, in America, in Asia." ${ }^{2}$

Zweig's 1932 essay "Der europäische Gedanke in seiner Entwicklung" (The Development of the European Idea) also placed the Jewish paradigm at the core of the cosmopolitanist sensibility. Once again, Zweig returns to the Hebrew Bible's story of the Babylonian tower to symbolize the human drive for unity. This story, however, is not merely a story told by the Jews and for the Jews: it is an archetypal story, which belongs to all humanity. "What else are myths but the wishful dreams of entire peoples?," Zweig asks rhetorically, 
thereby suggesting that none other than the Jews originated the universal dream of humanity. ${ }^{33}$

Zweig's I927 collection of stories, Sternstunden der Menschheit (Sidereal Hours of Humanity), translated as The Tide of Fortune, must be read as a literary monument to this dream of universality. ${ }^{34}$ Each of the five stories in the initial collection draws its subject from the history and culture of Western countriesFrance, Germany, the United States, Russia, and Britain. As in Zweig's earlier Jewish-themed novellas, a hitherto insignificant man catalyzes in each of these stories an event of supposedly global significance, "world history." 35 In their totality, the stories thus imply a vision of Europe based on shared historical, political, economic, cultural, and scientific traditions and structures. The first story, "Die Weltminute von Waterloo" (The World Minute of Waterloo, translated as "The Decisive Hour at Waterloo"), treats Napoleon's final defeat at Waterloo in I 8 I 5 as the moment of birth of a new, unified Europe. The parallels to Zweig's hopes that the World War I disaster would spawn European unity are evident. The twenty years of Napoleonic Wars end and a new war is averted when the English, Prussian, Austrian, and Russian ministers cease to bicker and unite their armies in battle. But the driving force behind this new Europe is Jewish banker Nathan Mayer Rothschild, who rushes to London to exploit the yethidden news of Napoleon's defeat at the stock market. Through this streak of genius, Rothschild "founded another empire, established a new dynasty" (ToF, I62) in linking the financial fates of the European nations.

Another story, "Marienbader Elegie" (The Marienbad Elegy), shows the emergence of universal humanism in nineteenth-century European literature through the towering figure of Goethe. Inspired by his last love, the German Prince of Poetry not only writes his greatest poem, an expression of the universal sentiment of love in the equally universal medium of poetry, but also goes on to complete his Wilhelm Meister and Faust, which have themselves become considered world literature. The volume's cosmopolitanist vision culminates in its final story, "Der Kampf in den Südpol" (Quest of the South Pole), which charts the final voyage of British explorer Robert Falcon Scott in I9I2. In a period of heightened nationalistic fervor, Norwegian Roald Amundsen and Scott vied to plant their national banners on the South Pole, which remains the last spot on earth to have resisted scientific and nationalistic conquest. Yet Scott, who loses this battle and dies on the ice, who in dying realizes his kinship with the both English nation and all of humanity. Scott's tragedy, in turn, lends his story a universal significance. While Scott's last letters, written in his dying hours, thus "speak to the whole of mankind" (ToF, 236), they also turn his journey into "a strenuous appeal to humanity" (ToF, 240). 
Sternstunden der Menschheit evinces the largely subdued treatment of Jewish themes and protagonists in Zweig's interwar writings, which may relate to his intensified sense of urgency regarding the cosmopolitan mission. As the figure of Rothschild indicates, a "Jewish sensitivity" nonetheless remained at the core of Zweig's cosmopolitan thinking.

Zweig's Jewish figures often carry stereotypical connotations that seem to jar with his cosmopolitanism. The seeming chasm between racialized imagery and cosmopolitanist thought emerges perhaps most clearly in "Buchmendel" (The Old-Book Peddler, I929), which represents Zweig's most explicit treatment of Jewish themes during the interwar period. ${ }^{36}$ In the story, Zweig proposes the Jew, with his particularist nature and universalist strivings, as the prototype of the deterritorialized cosmopolitan on the one hand and as the litmus test for universal human rights on the other. "The Old-Book Peddler" recounts the story of Mendel, a Galician Jew whom the narrator first met at the smoky Café Gluck in pre-World War I Vienna. A book peddler, Mendel had spends days at the café, sourcing for his customers rare titles from booksellers across the European continent.

Dressed in shabby clothes and shortsighted to the point of near-blindness, Mendel typifies the antisemitic perception of the deformed Jewish body and soul, which became epitomized in the Eastern Jew. ${ }^{37}$ Yet this unassuming man displays almost total recall of every book he has ever seen. His mental efforts represent Zweig's clearest borrowing from the repertoire of modern antisemitism, for Mendel's "brilliant book-brain" (OBP, 32) emerges as a dubious celebration of Jewish intellect. First made by the German composer Richard Wagner in his infamous I 850 essay, Judaism in Music, this claim became a common trope in the repertoire of antisemitism. ${ }^{38}$ Mendel reads these books not for their intellectual and aesthetic content but merely for information:

Only their authors and titles, their prices, their outward forms, their titlepages drew his attention. In the final analysis, though unproductive and uncreative, and only a register of a hundred thousand titles and names stamped into the soft cortex of a mammalian brain, instead of being written in a book catalogue. (OBP, 35)

Zweig twins these tainted images of the unoriginal and demonic Jewish intellect with the stereotype of the hypersexual yet castrated Jew who diverts spiritual and sexual energy into a warped type of promiscuity. Thirty-three years earlier (a number invoking the age of the Christian messiah, who according to the Gospel died at the age of thirty-three), Mendel had studied for the 
rabbinate; however, he soon abandoned the monotheistic God and succumbed to the "sparkling and thousand-fold polytheism of books" (OBP, 4I). Polytheism, which was linked to Temple prostitution during antiquity, here serves as a reference to the Jew's distorted mental and sexual preoccupations, which Austrian Jewish writer Otto Weininger had claimed in his best-selling I903 work, Sex and Character. ${ }^{41}$ Touching books gives Mendel the same pleasure that other men would experience while holding a woman: "These moments were his Platonic love nights" (OBP, 40).

These essentializing portrayals only seemingly conflict with the universalizing premises of cosmopolitanism, where the particular and the universal remain in dialectic tension. For assimilated Jews such as Zweig, who had little knowledge of or even interest in Jewish culture and tradition, the body forms a last resort as the assumed locus of innate difference.

Zweig's essentialisms problematically indicate the Jew's difference in the diaspora even under the conditions of assimilation. His book Brazil, completed shortly before his 1942 suicide, similarly relied on racialized essentialisms to propose its vision of Brazil as the cosmopolitan model of the future. Although it is problematic, this strategy resists the clear-cut assimilation of the Jew into the universal, as earlier critics have claimed, ${ }^{40}$ and instead draws on the Jew to stress the particularist universality of the cosmopolitan ideal. Characteristically, however, Zweig's Mendel represents merely a prototype of the cosmopolitan that ultimately remains unactualized in both human awareness and society. The suspension of the cosmopolitan ideal in all but Zweig's final work, The World of Yesterday, which idealized the Austro-Hungarian Empire as the social manifestation of cosmopolitanism, conveys the fragile liberal consensus of the interwar period as well as Zweig's sense of his politically impotent humanism. ${ }^{41}$

Mendel's essentialized portrayal simultaneously embodies the Eastern Jew's stereotypical qualities and the inherent universalism of Judaism, which Zweig had claimed in his fin de siècle Jewish novellas. A "unique memory"indeed, "a veritable encyclopedia, a universal catalogue on two legs" (OBP, 3I) - Mendel reflects Zweig's prewar suggestion that Judaism had anticipated the cosmopolitan spirit from antiquity on. Furthermore, Mendel's pursuits are solely for the sake of his books, and he thus refuses to profit from his customers or even accept offers of paid work from globally renowned libraries such as Princeton. Mendel thus conveys Zweig's assertion elsewhere of the Jew's “secret longing to resolve the merely Jewish - through flight into the intellectualinto humanity at large" (WY, 2I). As Zweig further argues in The World of Yesterday, the assumption that Jews sought solely to become rich was simply wrong; rather, riches were a means for the Jew, rather than his goal: 
The real determination of the Jew is to rise to a higher cultural plane in the intellectual world. Even in the case of the Eastern Orthodox Jewry, where the weaknesses as well as the merits of the whole race are more intensely manifested, this supremacy of the will to the spiritual over the mere material finds plastic expression. (WY, 20)

The Viennese café, then, represents for Zweig the ideal site for the universalist strivings of the Jew, who represents the transience of modern subjectivities and their emergent cosmopolitan awareness. Like Mendel, Viennese intellectuals and writers of the period practically lived in the coffeehouse, where they worked, ate and drank, and conducted private affairs. The coffeehouse, which represented the essence of urban Viennese lifestyle, was a specifically Austrian institution. It was practically unrivaled elsewhere in Europe, with the notable exception of one Viennese-style café in Berlin and another in Zurich. ${ }^{42}$ The idea's somewhat clichéd implications today result precisely from the numerous literary references to the coffeehouse in writings by Zweig, Roth, and Franz Werfel, to mention but a few, who made it the salient signifier of AustroHungarian society.

The World of Yesterday describes the Viennese coffeehouse as the site of education in all current cultural and political affairs, where every Austrian regardless of class or ethnic affiliation could access an unlimited range of newspapers and journals and discuss all daily matters with his friends. A "sort of democratic club to which admission costs the small price of a cup of coffee," it was "the best place to keep up with everything new" (WY, 4I). In Zweig's description, the coffeehouse practically spawned Austrian cosmopolitanism, for "perhaps nothing contributed to the intellectual mobility and the international orientation of the Austrian that he could keep abreast of all world events in the café, and at the same time discuss them in the circle of his friends" (WY, 4I). The Viennese coffeehouse becomes the democratic institution per se and the Jews progenitors of the city's cosmopolitan spirit.

Through the figure of Mendel, Zweig portrays the Jew's particularist identity and universalist strivings as the prototype of the cosmopolitan. The Jew epitomizes the nascent cosmopolitan condition of the interwar period, though contemporary political developments prevent that condition from materializing in the political realm. A cosmopolitan Europe is but an unrealized dream whose violent destruction the story anticipates in Mendel's inadvertent demise. As the narrator learns, Mendel was arrested just after the outbreak of World War I for having sent a postcard inquiry to a bookseller in Paris. Mendel, who lives solely in the deterritorialized world of books, had been unaware of 
the new political situation, which placed Paris in enemy land. Zweig's construction of the full absurdity of nationalistic excesses is apparent in the Austrian censor's dismayed and puzzled response to the postcard:

To think that anyone should carelessly send a letter from Austria to France, should so light-heartedly and so simply mail a postal card to an enemy country, as if these boundaries had not been bristling with barbed wire since I9I4, and as if on every single day France, Germany, Austria, and Russia were not lessening one another's male population by a few thousand. (OBP, 52)

Unsure whether the postcard constitutes a strange joke or an act of political subversion, the censor has the case reported, and Mendel is arrested. Now, in the new world of institutionalized national borders and affiliations, the rootless Jew's lack of national sentiment becomes his fatal flaw. Mendel's birthplace in the Russian Empire, now also behind enemy lines, and his failure either to obtain Austrian citizenship or to register as an enemy alien after the outbreak of war, both born of sheer ignorance, now render him a dangerous suspect. The guileless Mendel is interned in a concentration camp, where lack of books and literate companions lead to his spiritual and physical demise. Mendel's tragic ending symbolizes the deep war trauma and its irrevocable destruction of the dual monarchy's humanistic legacy, which Zweig openly idealized in his final work, The World of Yesterday.

Mendel thus emerges as the litmus test of the universal human rights first formulated in Kant's notion of universal hospitality even among the most atavistic peoples. The European nations of France, Germany and England had committed "a crime against civilization" (OBP, 58-59) by interning civilians behind barbed wire, thereby denying those enemy aliens "the sacredness of the right of asylum, respected even among the Tungusians and the Araucanian" (OBP, 58). ${ }^{43}$ Indeed, Zweig's recognition of this humanitarian crisis and its spawning of a European cause dates back to his I9I7 essay, "Das Herz Europas" (The Heart of Europe), which considered the Geneva Red Cross the last safeguard of Europe's "crucified body" and now its "heart." 4

The deep trauma of the war and the irrevocable wounds it has inflicted on the fabric of the old Austria's humanistic society emerge in Mendel's tragic death, which occurs not during the war but after its end. Having been liberated from the camp, a broken Mendel returns to Café Gluck, but his customers have forgotten him, and the café owner thinks him a useless parasite. After accusations of theft, Mendel is evicted. Confused and emaciated, he arrives one more 
time on its doorstep and collapses dead. The story thus anticipates the core themes of Zweig's final work, The World of Yesterday, with its idealized portrayals of the cosmopolitan Austro-Hungarian Empire as a model Europe and Zweig's profound sense of homelessness after its ending.

\section{Joseph Roth's Hotel Patriotism}

Zweig's story shares many similarities with the portrayals of Eastern Jews in the works of his close friend, Joseph Roth. Born in I894 in Brody, a town in Eastern Galicia (now Ukraine), on the outer edges of the Austro-Hungarian Empire, Roth spent most of his highly successful career in Vienna and later Berlin. Beginning in I923, his work as a reporter for the Frankfurter Zeitung led him to travel widely across Europe, visiting Albania, France, Italy, Poland, and the Soviet Union, that new multiethnic state in which Jews had not only been recognized as a nationality in their own right but had also been given their own republic, Birobidzhan. ${ }^{45}$

Much like Zweig, Roth promoted a diasporic sensitivity, although he was more clearly a cultural Zionist, in the sense that he attributed to diaspora Jewry a distinct culture and ethnic identity. Roth's origins in the Austro-Hungarian Empire's Slavic provinces rather than the German-speaking capital of Vienna fueled his increasingly prominent construction of the Jews as a distinct ethnic group - understood in Austro-Hungarian terms as a nationality-with strong ties to the Slavic peoples in the empire. Ilse Lazaroms has highlighted Roth's depiction of the exilic condition of the Jews, which stands at the center of many of his novels. ${ }^{46}$ Roth uses these portrayals of Jewish exile to construct the Jew as the prototype of the cosmopolitan condition, which once again remains suspended in his novels.

Perhaps even more than Zweig, Roth felt himself irrevocably uprooted and homeless after the end of the Austro-Hungarian Empire in I9I8. Like Zweig, Roth thus increasingly turned toward a nostalgic vision of the empire in which he saw the cosmopolitan ideal approximated if not fully realized. As Lazaroms suggests, throughout the I920s, Roth sought to create an intellectual community across European borders, a community founded on the conditions of exile and faith in European humanism. ${ }^{47}$ Furthermore, in arguing for Roth's and Zweig's sense of a Jewish identity in crisis, Armin A. Wallas contends that both writers "replaced their Jewish identity through supranational constructs such as cosmopolitanism or European and universal culture respectively." 48

The close linkages between the cosmopolitanist and supranationalist proj- 
ects are evident, and indeed, both discourses have historically advocated the ethnic plurality of the Habsburg Empire. ${ }^{49}$ Although intricately related, these concepts, however, must not be understood interchangeably. Recent theorization has defined supranationalism as a political structure promoting a type of overarching nationalism, a political project "existing above and beyond the nation," with prime examples found in the dual monarchy and the Soviet Union. ${ }^{50}$ Even Zweig's and Roth's occasional references to the Jews as an "Übernation" (supranation) indicate the meanings of overarching territorial and political structures that have dominated this concept from its beginnings in the Austro-Hungarian context. ${ }^{51}$ Broadly speaking, supranationalism can thus be imbued with the potential to produce the cosmopolitan sensibility, although in the case of the Stalinist Soviet Union such was arguably not the case. In turn, some strands of cosmopolitanism have historically seen supranationalism as the political and territorial manifestation of their aims, whereas national cosmopolitanists such as Thomas Mann did not. In the case of the dual monarchy, Malachi Haim Hacohen thus aptly distinguishes between the "supranational empire" and the "cosmopolitan attitude" of its "Westernized" Jews. ${ }^{52}$ Overall, supranationalism does not carry the rich historic connotations of cosmopolitanism, with its arguably romanticized vision of a cultural, ethnic, and national diversity steeped in humanistic values. For better or worse, these connotations have revived cosmopolitanism as a salient concept across academic disciplines and wider public debates since the I990s.

Contrary to Wallas's assertion, Zweig's and Roth's cosmopolitanist or supranationalist engagement did not simply replace or override their Jewish affinities, which remained in the palimpsest of their cosmopolitanist writings. Indeed, Zweig's and Roth's cosmopolitanism emerged precisely in their attempts to integrate the particularist sensibility of the Jew with their universalizing constructs of the dual monarchy as a utopian "miniature Europe." 53 This reading thus not only furthers an understanding of the diasporic and cosmopolitanist sensibilities of both writers but also illuminates their literary portrayals of the dual monarchy and the Jews, which indicate their vision of a deterritorialized cosmopolitanism beyond the nation.

Throughout his major novels, Roth configures the seminomadic inhabitants of the borderlands as the prototype of the cosmopolitan. The borderlands, by implication, represent the cosmopolitan model because their heterogeneous populations disrupt the assumed clear-cut affiliations between the nation-state, ethnicity, and soil. In Roth's later novels, this vision is underlined by suggestions that the dual monarchy provided the unifying umbrella and humanistic safeguard for these heterogeneous populations. Roth's Jewish protagonists in 
particular represent the burgeoning cosmopolitanism that we have already seen in Zweig's interwar references to the Jews. Like Zweig, Roth's ultimate suspension of the cosmopolitan awareness acknowledges its utopian status as a consequence of the competing forces of violent nationalism on the one hand and social revolution on the other.

The hotel and the café are the central images in Roth's cosmopolitan vision of a Europe beyond national borders, and Roth has been deemed "a hotel patriot," in contrast to the nationalistic patriotism of his time. ${ }^{54}$ The novel Hotel Savoy (I924), which remains Roth best-known work, consolidated both this image and Roth's literary fame. ${ }^{55}$ Set in an industrial town at the eastern "gates of Europe" (HS, 9), the Savoy's location invokes the textile-manufacturing city of Lodz, which has often been referred to as the Polish Manchester. The historically Polish settlement of Lodz lay on the border with the German-speaking lands and saw the arrival of a substantial German-speaking middle class during the nineteenth century.

Scholars often note Roth's cosmopolitanist engagement but have not fully explored the subject. As Lazaroms has shown, Roth's "itinerant existence," which was expressed through his constant moves between countries and hotels, has led to the perception of his cosmopolitan flair. ${ }^{56}$ Roth was, of course, not alone in his ambiguous experience of hotel life. During the interwar years, the Paris hotel epitomized to many Eastern European Jews the comforts of a bourgeois lifestyle; in later years, however, those exiled from National Socialist Germany saw the hotel as symbolizing the ambiguities of refugee life, and some exiles therefore preferred to stay in hotels rather than find flats. ${ }^{57}$ The hotel also became the site of desperation. In May I939 Roth's friend, anarchist playwright and political revolutionary Ernst Toller, learned that his sister and brother had been sent to concentration camps and hanged himself in a room at the Mayflower Hotel in New York City. In Hotel Savoy in particular, Roth resists the obscene glorification of the nomadic existence enforced by war and exile for which Lazaroms chastises much of Roth's reception. ${ }^{58}$ At the same time, Roth's evident references to the cosmopolitan call for examination, especially in light of his awareness of the class privilege associated with the nomadic lifestyle. Indeed, the Hotel Savoy emerges as the ambiguous sign of the transience of all national, geographic, ethnic, and class-based ties, which give rise to a cosmopolitan awareness in the novel's Jewish narrator, Dan. In leaving the cosmopolitan condition unactualized, Roth points to the nationalistic, racialized, and class-based strife that hinders the emergent cosmopolitan under the current political conditions.

Born in this industrial town to Russian Jewish parents, Dan represents the 
liminal subjectivity of the borderland inhabitants that Roth privileges throughout his novels. After three years of wartime detainment in a Siberian POW camp, Dan spent a year wandering westward toward his hometown, where he now permanently resides at the Savoy. Dan's budding cosmopolitan awareness is displayed in his sense of his essence in heterogeneity, which at the same time reflects Roth's deterritorialized vision of particularist universality:

One can absorb such a lot and yet remain unchanged in body, in walk, in behaviour. One can drink from a million glasses and never quench one's thirst. A rainbow may quiver with all its colours but can never change the spectrum. (HS, IO)

However, this quasi-natural state of the individual cannot flourish as a consequence of the profound disruptions caused by the war. Dan had previously dreamed of becoming a writer, but his war experience has left him isolated and deprived of the belief that he possessed the universal voice that writing requires: "I went to the war and now I feel there is no point in writing. I am a solitary person and cannot write for the public" (HS, 24).

The Hotel Savoy is the salient signifier of the nomadic and atavistic state of post-World War I society, in which the individual has become totally objectified and social injustice reigns supreme. The hotel, "where one would live and another die, ... and girls had to strip naked before factory owners and house agents" (HS, 52), exemplifies the extreme inhumanity of postwar capitalism, which exploits some while offering a dazzling new social mobility for others: "One might arrive at the Hotel Savoy with a single shirt and leave it as the owner of twenty trunks" (HS, 56). The view of the hotel as the sign of a rootless and ruthless international capitalism can be traced back at least to the sentiments expressed in Theodor Fontane's essay on "Der deutsche Gasthof, das kosmopolitische Hotel, und die Engländer" (The German Inn, the Cosmopolitan Hotel, and the English, I867). There, Fontane's German contemporaries share an anger about the social shifts that saw "the vast majority of hotels, which are increasingly ... replacing the good and honest German inns wherever the cosmopolitan stream of tourists arrives." 59 With their "pure national arrogance, which is based on the coarsest pride in money" $(\mathrm{G}, 374)$, the masses of English travelers had indeed become "a genuine nuisance" (G, 373), particularly in their regular success in securing the better rooms. In contrast, German tourists felt frequently slighted by their substandard accommodation in English hotels "in a kind of cave room, ... . which receives its light from a similarly dim corridor" $(\mathrm{G}, 376)$. Fontane concludes that the situation is not a 
matter of anti-German hostility but rather "as nearly everything nowadays, a question of money and ownership, rather than of nationality" (G, 376).

Roth's construction of the hotel touches on "The Hotel Lobby," an essay written by eminent Weimar cultural critic Siegfried Kracauer between I922 and I925 as part of a larger piece on the detective novel. ${ }^{60}$ Kracauer sees the hotel lobby as the modern inversion of the house of prayer, where adherence to a universal code had assured the subject of its rooted status in a community. The hotel lobby, in contrast, represents a negative universality that reflects the total reification and lacking essence of the modern individual, for "in the hotel lobby what emerges is the inessential foundation at the basis of rational socialization" (HL, I79). The humans populating the lobby display the rootless and vacuous condition of modern society: "Lacking any and all relation, they drip down into the vacuum" (HL, I76). In different ways, Zweig's I9I8 essay "Bei den Sorglosen" (Visiting the Carefree) had portrayed the hotel as the site of a modern human vacuity and social indifference, which becomes supremely obscene in the context of the war. ${ }^{61}$ The rich take flight to luxury hotels to escape from the war-ravaged cities with their disturbing poverty and the desolate proletariat. They dance at costume balls, "nowhere a human face among them," while "Europe falls in ruin. The gypsy band fiddles. Ten thousand people die every day" (S, I I I, I IO). The absence of social ties and the concerns of the rich echo in the jarring shapes of the gigantic hotels they inhabit, which stand

impudent . . . their hard foreheads facing the scenery, unconcerned, whether their insolent presence destroys that wonderfully harmonious line, equally indifferent toward that other world and the humans which they house. (S, I06)

Hotel Savoy, then, closely ties the vacuous condition of the modern human to the war-ravaged society of Roth's day. In later years, this ambiguous portrayal of the hotel yielded to Roth's wholehearted and ironic celebration of the hotel as the site of the cosmopolitan. His I929 essay, "Arrival in the Hotel," regards the hotel as a sort of "fatherland" where "people seem to come together ... and at least appear to be what they should always be: children of the world." ${ }^{2} 2$ Echoes of Kracauer's "Hotel Lobby" are discernable when the narrator of Roth's essay exclaims his love for "the 'impersonal' quality of that room, as a monk may love his cell" (HY, I56). The lobby "is home and the world, foreign and familiar, my ancestorless gallery!" (HY, I59). In this nationally uninscribed space, Roth's narrator decides "to write about my friends, the hotel personnel. Such characters they are! Cosmopolites! Students of humanity! Ex- 
pert readers of languages and souls! No Internationale like theirs! They are the true internationals! (Patriotism only begins with the owners of the hotel.)" (HY, I 59). The hotel comes to be the global home of the mundivagant cosmopolitan, unfettered by the claims of national rootedness.

In Roth's portrayal of the Hotel Savoy, too, class rather than national homeland emerges as the central dividing line. Dan is among the novel's legions of defeated Czech, German, Polish, and Serb soldiers who have become modern nomads. The war has destroyed not only their sense of home but also all their possessions and personal ties. After years of having wandered westward to return to their homes, these men now flood the small border town. "They had gone to war proud, strong men" (HS, 77), but their boots have grown dusty and worn from their long wanderings. In their rootlessness and deindividualized state, these defeated soldiers resemble the Wandering Jew, which was seen to embody the nomadic essence of the Jews: "They have all travelled the same road in their grey clothes, the dust of their wandering years on their feet, on their faces. It is as if they belonged to the rain. They are as grey and as enduring" (HS, I I4).

Living in barracks without latrines, these broken men defecate in the street and no longer seek regular work, preferring instead to steal food from peasants and beg. Although he, too, has suffered through the war experience, Dan occupies a privileged position vis-à-vis these defeated soldiers. His difference implicitly derives from his predicament as an assimilated Jew and bourgeois intellectual. Dan's role as the first-person narrator, a function imbuing him with access to subjectivity, and his residence at the hotel are the external signs of this privilege. As Roth suggests throughout his writings, the Jews, a people beyond borders who have survived centuries of ostracism, persecution, and expulsion, have created a historical and temporal rootedness beyond fixed geographical or national affiliations. Through their mobile and heterogeneous identity, the Jews thus appear better equipped than others to cope with modern rootlessness and prefigure the particularist universality that forms the precondition of the cosmopolitan.

The nomadic condition marks all Jewish protagonists in the novel regardless of whether they are religious or assimilated. In his I927 essay, The Wandering Jews, Roth suggests that the Jews' centuries of wandering, initially out of sheer necessity to flee from persecution, have produced in the Eastern Jew in particular an inadvertent drive to roam that now marks their modern condition. ${ }^{63}$ Centuries of persecution and ostracism have rendered all Jews rootless and unproductive nomads. The religious Jews, who comprise the vast majority of Jews, epitomize the unproductive nomad, who roams the land that feeds him 
without developing any ties to it: "For the most part, Eastern Jews experience the countryside only as beggars or vagrants. The majority don't understand the soil that feeds them" (WJ, 7). At the same time, these religious Jews represent the cosmopolitan prototype that writers such as Zweig, Roth, and Feuchtwanger see as emergent in Jewish tradition from its beginning: "This Jew is not a "nationalist' in the Western sense. He is God's Jew" (WJ, 30).

This type is reflected in the impoverished religious Jews who populate the other side of town in Hotel Savoy. These absurd and diminished creatures, who stand begging by the Jewish cemetery fence and in the alleys "like human cypresses" (HS, 48), evoke the figure of the Eternal or Wandering Jew, who represents the timeless and thus fixed nomadic condition of the Jews:

We come into a little alley. Jews are standing about, strolling in the middle of the street, carrying umbrellas ludicrously rolled and with crooked shafts. They either stand still looking thoughtful or else walk ceaselessly to and fro. Here, one will disappear. There, one will emerge from a house door, look enquiringly to left and to right and begin to stroll about. Silent as shadows, people pass each other. It is an assembly of ghosts and the long dead gather here. For thousands of years this race has been wandering in narrow alleys. (HS, 37)

According to The Wandering Jews, the Jew's drive to wander is born of centuries of persecution and war. It is epitomized in a group that Roth broadly defines as "the emigrants." These individuals have fled to the United States, which Roth time and again describes in negative terms, as well as Vienna, Berlin, and Paris, which Roth presents as Western Europe's very different Jewish nodal points. Tired of poverty and nationalistic strife, the emigrants display the budding cosmopolitan awareness that also marks Hotel Savoy's narrator, Dan. Originating "from the Russian borderlands, not from Russia itself," the emigrant believes that today's "national squabbles" in the West "are just a hollow echo of yesterday's; that the West has a vision of Europe, which, maybe one day, not before time and not without suffering, will ripen into a vision of the world" (WJ, Io).

Dan's birth to Russian Jewish emigrants thus emerges as an important element in his own incipient cosmopolitan awareness, which Roth implicitly associates with the Russian Revolution and its promotion of a new universalist society beyond class and ethnic divides. At the same time, The Wandering Jews declares this society impeded by "the unnatural social structure of the Jews" (WJ, I09). The Jews' predominantly middle-class characteristics invariably set 
them apart from their non-Jewish counterparts. This problem materializes in Dan, who sympathizes with the town's striking workers but ultimately fails to offer practical support.

Hotel Savoy shows how the social, political, and discursive chasms of the post-World War I period impede even the notional existence of the cosmopolitan, at which it nonetheless gestures. The novel's Jewish protagonists remain limited by their class-based and religious affiliations to catalyze a genuine cosmopolitan awareness, whereas the non-Jews cannot bring about effective social change because they refuse to address the problem of antisemitism. The hotel stands as the only symbol of universal potential, and it is negatively charged. In the end, the striking workers destroy the hotel in their attempts to target the Jewish industrialist Bloomfield, whom they wrongly blame for their inhumane working conditions.

Even more clearly than Hotel Savoy, Roth's later major novels, Radetzky March (I932) and The Emperor's Tomb (I938), foreground a recurring cast of Jewish and southern Slavic protagonists to construct the liminal subjectivities engendered by the southern borderlands as cosmopolitan prototypes. ${ }^{64}$ In doing so, Roth attempts to distance the Jewish type from the antisemitic discourse about Jews, disease, and the city. ${ }^{65}$ Of course, his new construction, which instead links the Jew to the healthy Slavic countryside, is no less problematic since it merely reverses the racialized discourse about the healthy racial type springing from the healthy soil. Consequently, Roth now depicts the political malaise of the empire as wrought by its dominant German population in Vienna, whose rabid nationalism has driven the empire to the brink of destruction.

Radetzky March centers around three male generations of the Trotta family, whose trajectory mirrors the rise and decline of the Austro-Hungarian Empire. The empire and its Jews, which are closely tied together through the last Trottas' apparent Jewish affinities, represent the particularist and universalist aspects of the cosmopolitan condition, which cannot emerge fully into reality under the current historical conditions. Similarly to Dan in Hotel Savoy, Carl Joseph in Radetzky March represents a nascent rather than actualized cosmopolitan awareness. This emerges, for example, in Carl Joseph's realization that other countries have their own history and society, which causes him to begin to relativize his political and social circumstances. Roth emphasizes deterritorialized ethnic affiliations by privileging the liminal subjectivities of the borderlands through his intertwined images of the Trottas, who are descended from ennobled Slovenian peasants, and the Jews of the Slavic provinces. In so doing, Roth undermines the poisoned nationalistic agendas that he and other 
Jewish writers still perceived in a rooted cosmopolitanism. Instead, Roth suggests the contingent regional allegiances that he sees prefigured in the dual monarchy's Jews. They form the model for the deterritorialized "Oriental" nationality that he had outlined in The Wandering Jews:

Only in the East do people live who are unconcerned with their "nationality," in the Western European sense. They speak several languages, are themselves the product of several generations of mixed marriages, and fatherland for them is whichever country happens to conscript them. $(\mathrm{WJ}, \mathrm{I} 5)^{66}$

Even the assimilated Eastern Jews consider themselves a nation, Roth contends, and modern Zionism could thus only have arisen in Austria, where representatives of all the country's nations fought in the Viennese parliament for their national rights and privileges. Jews, the only nation in the empire without a designated territory, were the notable exception. The setting nonetheless became "the cradle of modern Zionism," which was "founded by an Austrian journalist. No one else could have founded it" (WJ, I 5). As a consequence of its Western European origins, Zionism's territorial aspirations implicitly break with the Orient's inherent cosmopolitanism and must invariably lead to conflict and war with Palestine's Arab population. Therefore, "the immigration of young Jews into Palestine increasingly suggests a kind of Jewish Crusade, because, unfortunately, they also shoot" (WJ, I9).

The treatment of Zionism is notably absent from Radetzky March, which presents the empire's seminomadic, deterritorialized country Jews and Slavs as the cosmopolitan prototype. Roth's close interweaving of the Trottas, the empire, and its Jews suggests this as a specifically Austrian predicament. Carl Joseph is implicitly linked to the stereotype of the Jew's flawed masculinity by his lack of riding skills and his inability to integrate himself with the other men in his regiment. Furthermore, the Jewish doctor, Max Demant, remains Carl Joseph's only close friend in his mostly Ukrainian and Rumanian regiment in the Moravian borderlands.

Both Carl Joseph and Demant represent the liminal subjectivities that Roth sees as spawning the cosmopolitan prototype. Whereas Carl Joseph, "a descendant of a Slovenian veteran and the extraordinary hero of Solferino" (RM, 43), originates from Slovenian peasants in the monarchy's southern borderlands, Demant is the grandson of a Galician innkeeper in one of the Eastern border towns. ${ }^{67}$ Franz Joseph's politics of tolerance toward all his subjects have allowed both Carl Joseph and Demant to rise from their lowly social and mar- 
ginal ethnic origins and become equal citizens of the monarchy. As Carl Joseph's father writes to his son, "Fate has brought us from being simple border peasants to Austrian subjects. Let us remain so" (RM, I38). Whereas the father thus feels the Habsburgs' city of Vienna to be his home, Carl Joseph rejects this world when he asks to be stationed on the Ukrainian-Russian border. This narrative construction mirrors the processes of nineteenth-century Jewish assimilation and its early twentieth-century countermovement, which Shulamith Volkov has termed dissimilation. ${ }^{68}$

While these linkages indeed suggest the parallel crises of the Jewish condition and the dual monarchy, ${ }^{69}$ they are also salient for Roth's construction of the cosmopolitan, which emerges precisely from the complex and often uneasy relationship between the empire's center and its margins, Vienna and the borderlands, which signify the universal and the particular. Roth's close intertwining of the monarchy, the Trottas, and the Jews conveys the close interdependence between the monarchy's institutionalized humanism and its particularist subjects in producing the cosmopolitan condition.

The hotel and the café in the Ukrainian-Russian border town, Burdlaki, where Carl Joseph von Trotta is stationed, once again represent the ubiquitous institutions of the empire's universalizing mission whose encounter with its liminal Jewish and Slavic subjects engenders the cosmopolitan prototype. In turn, the region's numerous peddlers, among them many Jews, display the seminomadic, transient rootedness that lies at the heart of Roth's suspended cosmopolitanism:

Always in transit, always on the move, with quick speech and a clear understanding, they would have been equipped to conquer half the world, if they had understood the world at all. But they did not. Because they lived far away from it, between east and west, jammed in between night and day, a kind of living ghost that was sprung from the night and went about in the daytime. Did I say they lived as though "jammed in"? The nature of their homeland never gave them that sensation. Nature had set an endless and impressive horizon around these frontier people, and put them in the midst of green forests and blue hills. And even when they walked in the shade of dark pine forests, they could reckon themselves favoured by God. (RM, I39-40)

Both peaceful and dynamic as these images may be, they belong to the agrarian world of the past, which though it does not yet know it, is being swept away by the war. Only the Jews, lacking territory and thus a firm location 
within the ensuing battles of the nations and classes, represent a moment of passive resistance to the violent fervor gripping the world. The Jews "were saluting an extraordinary Sabbath, a Sabbath of blood," making each of their houses "already like a tomb. Death itself had lit the candles" (RM, 344). The Jews' loud mourning of every one of their sons who has been drafted into war further suggests them as the prime victims of the rising age of mass atrocity, in which the humanistic legacy of the empire will be violently destroyed.

\section{Lion Feuchtwanger: The Empire Strikes Back}

Feuchtwanger's Josephus trilogy (1932-42), based on a historical figure, ancient Judean historiographer Flavius Josephus, represents the transition of German Jewish cosmopolitanist writing into the exile period. The first novel in the trilogy, Der jüdische Krieg (The Jewish War) (1932), marks Feuchtwanger's most concerted attempt to defend the cosmopolitan against the rising National Socialist peril..$^{70}$ Like Zweig, Feuchtwanger and his German Jewish cosmopolitanism railed against the arbitrary administrative boundary of birth and national affiliation that determines one's friends and enemies. Natan Sznaider views Feuchtwanger as "trying desperately to protect a European cosmopolitanism composed of Jewish, Greek, Christian, and Muslim identities against the rise of National Socialism." 71

Such composite cosmopolitanisms were not rare at the time. Oskar Maria Graf's liberal Catholic cosmopolitanism originated in Leo Tolstoy's primitive Christianity as well as his national patriotism. Tolstoy wrote: "If men would only finally grasp that they are not children of some fatherland but of God the father!" 72 Oskar Maria Graf, in turn, argued, "The world must become provincial. Only then will it become human." This socialist "provincialism" colored his well-known I933 response to the National Socialists' attempt to invite him "to join the ranks of exponents of the 'new' German spirit!" Graf's rejoinder underwrote his own understanding of the cosmopolitan: "The proponents of this barbaric nationalism, which has nothing, absolutely nothing at all, to do with what it means to be German, have the nerve to claim me as one of their own in 'spirit,' to place me on their white list, a list that can only be a blacklist in the eyes of the world's conscience!"73 Being cosmopolitan could mean being German, but being German encompassed a European cosmopolitanism of inclusion.

Feuchtwanger had already pronounced the death of the cosmopolitan in his world-famous novel, Jud Süss (1924), which treated the real-life fig- 
ure of the eighteenth-century court Jew Josef Süss Oppenheimer. Together with Lothar Mendes's I 934 British film Jew Süss, itself made in defense of the Jews, Feuchtwanger's novel inspired the National Socialist propaganda film, Jud Süss (1940), ${ }^{74}$ which distorted the pro-Jewish constructs of both previous versions into twisted portrayals of Jews. Feuchtwanger modeled his Süss on the assassinated German Jewish industrialist, economic theorist, and foreign minister Walther Rathenau. In portraying Süss as an early prototype of the Jewish cosmopolitan, Feuchtwanger invokes Rathenau's public perception as a cosmopolitan, which was closely linked to his role as German foreign minister in I922 and formed the antisemitic justification for his murder.

Both Feuchtwanger's Süss and Josephus ultimately remain singular figures, "free-floating intelligentsia" in the sense of Karl Mannheim, as Wulf Köpke has asserted with regard to Josephus in particular. ${ }^{75}$ Their cosmopolitanism is doomed to fail under the conditions of violent antisemitism. At the same time, the Josephus trilogy's first volume, published in the same year as Roth's Radetzky March, still asserts the viability of the diaspora as the cradle of the cosmopolitan sensibility. Like Zweig and Roth, Feuchtwanger sees traditional Jewish religion as the core of a universalism that will spawn the cosmopolitan awareness under the conditions of diaspora. For Feuchtwanger, this awareness does not simply remain unactualized under the imperfect political conditions of the present. Instead, he asserts, the diasporic Jewish writer constitutes the actualization of the cosmopolitan ideal.

Like Zweig's and Roth's works, Der jüdische Krieg rejects Zionism, which charts the path of the ancient Hebrew warriors from the Hanukkah revolt to Masada, and instead traces Flavius Josephus's path from nationalistic Judean to diasporic cosmopolitan. The novel depicts the life of Josephus, who was born into the Judean upper caste of Jewish priests, in Alexandria and Rome before his return to Judea to participate in the anti-Roman Jewish uprising between 66 and 67 B.C.E. He is taken into Roman captivity and released two years later, only to return to Judea with the Roman forces that besiege Jerusalem in 70 B.C.E. The novel closes with Josephus's decision to write a chronicle of the war, an undertaking that will render him the greatest Jewish writer of the period. Through this trajectory, Feuchtwanger implicitly criticizes those Weimar Jews who failed to embrace cosmopolitanism and instead clung to their particularist Jewish affiliations. As Feuchtwanger had declared in his essay "Was ist Wahrheit?" (What Is Truth?), the Roman Empire's cosmopolitan politics had made "the United States of Europe a reality," but one group had anachronistically insisted on its particularity. The Roman Jews had sought to 
be "national . . amid a cosmopolitan world."76 Josephus's Judean War chronicle will be his lasting literary achievement.

The stages of Josephus's political development in the novel invoke the conflicting and overlapping discourses of Zionism, Jewish assimilation, and cosmopolitanism during the Weimar era, closing with a clear affirmation of cosmopolitanism. The novel's portrayals of the Roman Empire and its Jews thus mirror the Weimar era at the crossroads of war and peace and of nationalism and cosmopolitanism. At the beginning of the novel, Rome, like Weimar, arises like a phoenix from the ashes of Nero's fire. The city is being rebuilt by the new emperor in a wave of widespread optimism and revitalized life. Like Weimar, the Rome of the novel is a Janus-faced beast of humanistic progress through science and technology on the one hand and inhumane barbarity on the other.

Positioned at the center of the ancient world, Rome's multiethnic population, which is held together by the unified philosophy and legislature of GrecoRoman culture, reflects the modern cosmopolitan predicament. Likewise, Zweig's I932 essay, "The Development of the European Idea," had described Rome as the dawn of the cosmopolitan idea, since Rome "first lent Europe a unified shape."77 And indeed, Feuchtwanger's construction of Rome's transcontinental reach-its heterogeneous mix of populations and its enshrined politics of tolerance toward other religions, including Judaism, as long as they do not proselytize - implicitly reflects the particularist universality of Kantian cosmopolitanism. At the same time, Feuchtwanger, like Zweig and Roth, promotes through Josephus a deterritorialized vision of the cosmopolitan that inherently opposes the exclusive particularism of Jews and non-Jews. Furthermore, Feuchtwanger, too, stresses the importance of the borderlands in creating the cosmopolitan sensibility. Josephus's transformation from Judean nationalist to cosmopolitan subject is thus catalyzed in Alexandria, which is,

after Rome ... the greatest city of the known world and certainly the most modern. . . . Standing at the intersecting point of three continents, at the meeting place of the Orient and the Occident, and on the main route to India, Alexandria has raised itself to the position of the greatest trading centre of the world. (J, 297)

By ancient standards a Moloch, this metropolis invokes the fast-paced interwar Berlin with its greed for life and amusement. Alexandria is the crucible of East and West, with inhabitants from all corners of the world, just as Berlin in the early twentieth century was the scene of wide-scale immigration 
of Eastern European Jews. Abandoning their origins, Alexandria's newcomers quickly embrace the city's vibrant art scene, its loudmouthed humor, and above all its constant quest for new thrills. Likewise, the city's Jews mirror the predicament of Berlin's largely acculturated Jews, who formed the largest constituent of German Jewry during the Weimar period. Josephus's encounter with the highly confident, wealthy, and educated Alexandrian Jews, who have reconciled their Bible with the Greek world and have "skilfully and harmoniously adapted their Jewish qualities to the forms of life and the general ideas of the Grecian Orient" (J, 30I), is the catalyst for his budding cosmopolitan awareness. While in Alexandria, Josephus writes a famous poem that is later titled "Psalm of the Citizen of the World" in which he lets the Jewish God speak to the nations of the world. Having poured out his spirit over the nations, God demands that they traverse beyond their borders and roam the earth rather than grow roots into the soil, for "a tree has only one food. / But man nourishes himself on all things / That I have created beneath the heavens" (J, 3I 2).

Feuchtwanger constructs Josephus as the first modern Jew and Jewish writer per se. A Romanized Jew on the empire's margins, Josephus embodies the synthesis of deterritorialized particularist and universalist sentiments. He is the product of Judaism, with its universal teachings, and the European civilization that arose from Rome, a multiethnic entity that has not yet transcended nationalism despite its politics of tolerance. The Jewish cosmopolitan thus remains a singular figure in his time:

He was the first man to live deliberately in accordance with this conception. He was a new kind of man, no longer a Jew, nor a Greek, nor a Roman, but a citizen of the whole civilized world. ( $\mathrm{J}, 303)$

Like Zweig and Roth, Feuchtwanger positions traditional Judaism as the universalist prototype that emerges into the cosmopolitan in its encounter with European culture. For alone among the peoples, Jews worship a god who has no image and whose invisibility signifies his universality. The Jewish prohibition against making an image predicates the existence of the Jewish writer, for "the word and the image mutually excluded each other" (J, 60), and the Jew must thus turn to words. By implication, then, the Jew represents the cosmopolitanist sensibility and its dissemination through literature as the universal art. Of course, Josephus as the first Jewish historian and writer of world literature reflects Feuchtwanger's self-positioning as a Jewish cosmopolitan and historical novelist within German and world literature.

Representing the Jewish writer in European culture, Josephus functions as 
a mediator between Judea and Rome, East and West. Feuchtwanger implicitly wrote against Oswald Spengler's creation of essential frontiers between these political, cultural, and territorial entities. Spengler had opposed the idea of history and culture as a linear progress "from Homer or Adam . . . through Jerusalem, Rome, Florence and Paris," 78 which he sees as having exhausted itself not least because Paris implicitly stands for the commune and the revolution as well as the twentieth-century decadence of the cafés, artists, and sexual licentiousness of the Left Bank. Feuchtwanger, in turn, constructs the Jew as an essential link in the chain of cultural and social progress reaching from ancient Greece and Judea through to Rome as the beginning of the Western world. In the Jewish War, all three entities essentially predicate each other in the creation of the cosmopolitan. Its materialism has led the West to merely plunder the East's physical riches, "bring[ing] back pearls and spices and curious animals" while "leav[ing] its best treasures, its books, lying where they are" (J, 53). Having lived as both a Judean and Roman, Josephus is uniquely positioned to introduce the Romans to these cultural riches in shape of the Jews' great history and literature. Until the modern era, Josephus receives only praise from first his Greek and Roman contemporaries and later his Christian audiences. His Jewish readers, however, reject his writing because it lacks the expected nationalistic fervor, written, as it was seen, by a renegade from the Maccabean cause.

Feuchtwanger stresses the unique position of the cosmopolitan Jew in his contrasting portrayals of Roman and Judean nationalistic excess. As the novel makes clear, the Roman Empire's benign face is essentially predicated on colonial conquest and domination, which have created the empire's political, economic, and cultural foundations. Although this portrayal invokes Spengler's claim that Rome had conquered the world only because its subjects failed to resist (DW, I:36 n. 23), Feuchtwanger poses the Jews as the noteworthy exception to the ancient world's passivity vis-à-vis its Roman conquerors. Feuchtwanger draws on the Zionist image of the ancient warrior Jew, which sought to remasculate the Jew in the diaspora. In the novel, Judeans become the butt of Roman hatred because they alone have resisted and hindered its further expansion:

The world was Roman, the world was pacified through the harmonious Roman-Greek system. Only the Jews held out and refused to recognise the blessings of this all-powerful organisation which bound the peoples together. The great trade routes to India, destined to carry Greek culture to the distant Orient, could not be rendered secure until this rebellious, stiffnecked people were humbled to the dust. $(\mathrm{J}, 66)$ 
Rome's inhumane face emerges in its treatment of three incarcerated Judean rebels, whose brutal slave labor in a Roman brickworks points back to the World War I atrocities as well as anticipates the Holocaust:

The three men were squatting side by side. They were half-naked, their clothes hung upon them in tatters, their faces were leaden. Round their ankles they wore rings to which chains were attached; on their foreheads they were branded with the letter E. Their hair was shorn bare to their very skulls. (J, 3I)

Again later in the novel, Feuchtwanger eerily foreshadows inmate experiments in National Socialist concentration camps, such as the SS drowning experiments at Dachau, when Roman military doctors select Judean captives to study the statistical relationship between physical strength and the dying process during crucifixion. The dehumanizing treatment of these prisoners is at least partially driven by the Romans' growing hatred of the Jews, which reflects the rising antisemitism of the Weimar era.

Although the novel gives the Jewish nationalistic cause some credibility, given the Romans' aggressive politics of expansion, it similarly rejects the latter for its practices of violence and exclusion. The Judean war thus results in the reckless sacrifice of Jewish lives despite the evident futility of this struggle. At the same time, Josephus faces ostracism from within the Jewish community. Extremist Alexandrian Jews violently oppose his cosmopolitan verses, while the established Jewish community declares them a heresy. Such radical Jewish positions are clearly criticized when the first volume charges Judeans with always insisting "on executing their private whims" and having a "mania for being in the right" $(\mathrm{J}, 23)$. Only in the later volumes of the trilogy, which Feuchtwanger completed while in hiding in exile, did he reverse this stance.

\section{Cosmopolitanism Tottering on the Brink of Catastrophe}

In I932-33, however, all did not seem lost. Whereas Walter Benjamin and Willi Haas lamented the decline of the cosmopolitan in "Vom Weltbürger zum Großbürger” (From World Citizen to Upper-Class Citizen), Prague-born literary scholar Erich von Kahler propounded the now familiar idea of a Jewish mission of universality ("jüdischer Weltauftrag") in Israel unter den Völkern (Israel among the Peoples). The volume would fall victim to the National Socialists' book destruction immediately after its initial appearance. ${ }^{79}$ Likewise, 
Zweig's "The Development of the European Idea" once again positioned the Jews at the center of the modern European idea. Zweig suggested, as Feuchtwanger did in Josephus, that this universal dream first achieved political, linguistic, and legal reality in the Roman Empire, which created the foundation of the contemporary European idea. Ruling over the "still unformed and intellectually stifled European nations," Rome had created the peoples and cultures of Europe today (SW, I 89). As Zweig contends, Rome "was the first and, one feels tempted to say, last to give Europe a completely unified shape, for never again was the world more unified in structure than it was then" (SW, I89). Zweig's description of the "dreadful intellectual and moral devastation" (SW, I90) that the empire's fall brought to Europe reflects the European predicament at the crossroads of two world wars.

The arts—in particular, music and literature-have always upheld the old idea of unity. In presenting the arts and sciences as the deterritorialized bearers of the cosmopolitan, heralded by his twentieth-century (and very Jewish) reading of Goethe's concept of world literature, Zweig once more asserts his essential right to consider himself "a European, a citizen of this as yet nonexistent State of Europe" (SW, 209). It is a lost call to humanity, made on the brink of the total destruction of the old Europe and its Jews in smoke and ash. 


\section{CHAPTER 5}

\section{"The World Will Be Your Home": Cosmopolitanism under National Socialism and in Exile}

\section{The Revolution of $\mathbf{1 9 3 3}$}

January 30, I933, brought the National Socialists into power in a not-so-silent coup. It was a "revolution," as Joseph Goebbels noted in his account of the moment, even though the transition, like the previous twenty-two separate coalition governments during the Weimar Republic, was the result of a normal shift of power. ${ }^{1}$ At the beginning of 1933, aging President Paul von Hindenburg appointed a minority cabinet headed by—but not, he hoped, controlled byAdolf Hitler.

The meaning of Hitler's ascendance for the idea of a Jewish or a German or a German Jewish cosmopolitanism was clear, however. Jewish cosmopolitans-and indeed, non-Jewish German cosmopolitans who did not support the regime after July I933-were quickly transformed into "exiles" and "refugees." ${ }^{2}$ This nomenclature represented more than a mere shift in terms; it constituted an epistemological shift in identity. While fleeing from National Socialist antisemitism, some assimilated Jews suddenly understood themselves as Jewish for the first time. ${ }^{3}$ Indeed, Jewish exile reified the condemnation of Jews as cosmopolitans and nomads by the new political order and its advocates such as Martin Heidegger. German cosmopolitans of the Left, such as Heinrich Mann, president of the Literature Section of the Prussian Academy of Arts, became exiles, no longer voluntary cosmopolitans, even though they returned to places such as Paris where they had been part of the new cosmopolitan Europe. ${ }^{4}$

In some cases, however, such as that of the poet Stefan George, who was offered Mann's former post, exile was indeed voluntary, at least in 1933. For Jews, especially with the passage of the first round of antisemitic laws that 
year, leaving Germany was rarely voluntary in the same sense. They had become "wanderers," in an older understanding of Jewish cosmopolitanism, even when they thought their sojourn would be very short-lived. Cosmopolitanism, however, was never banished as a theme in the writing of Jewish thinkers. Often struggling with their status as exiles and refugees and simultaneously trying to earn a living in settings where doing so was difficult for multiple reasons, they turned to writing great historical novels that documented, in an imagined past or a fabled landscape, the complications and travails of their altered status. ${ }^{5}$ They were no longer flaneurs but rather, as Thomas Mann's son, Klaus, contended from his exile in the United States, cosmopolitans by force. In I942, on the ninth anniversary of his exile from Germany, Klaus Mann, who was of German, Brazilian, and Jewish ancestry, wrote in his diary,

You can't go home again, nor can you find a new home. The world will be your home, or you will be homeless, disconnected, doomed. The world will be your home: if there is a world. The issue, therefore, is not exile or return. The issue is whether there will be a world for people like us to live in, to work for. And this world, if it comes into being, will accept and need our services. . . . The drama of our deracination may turn out to be the most effective training for the vast and delicate service ahead. ${ }^{6}$

These writers in exile became focused on what cosmopolitanism may have meant and perhaps could mean again, and the Jew became the salient symbol of their enforced rootless state, which they nonetheless chose to embrace. Kurt Tucholsky's I935 death from an overdose at Hindås, Sweden; Joseph Roth's miserable I939 death in Paris after hearing that Ernst Toller had hanged himself in New York; and Stefan Zweig's I942 suicide in Pétropolis, Brazil, only begin to illustrate the protracted human cost of this exile.

\section{Thomas Mann and Egypt}

In I926, three years before he would win the Nobel Prize for Literature for his "family" novel, Buddenbrooks (I90I), Thomas Mann sat down to begin a new historical novel. The Buddenbrooks were Großbürger in the sense of the early twentieth century. They dominated the social and economic life of Lübeck, where they came to represent a new form of bourgeoisie whose collapse Mann tracks. A fascination with what Walter Benjamin and Willi Haas described in I932 as the transformation of the cosmopolitan bourgeoisie into the "grand 
bourgeoisie" dominated Mann's account of their physical and moral decay, from Gabriele Kloterjahn in Tristan (I903) to Gustav Aschenbach in Death in Venice (I9I2) and beyond. ${ }^{7}$ Such texts chronicle the peripatetic if not nomadic life of the grand bourgeoisie in search of some type of succor for the lost center of their lives. For Mann, this was not merely the topic of grand historical novels, it became a way of representing the dynamics of social change in the new German state.

The new social order, however, remained fascinated with its own history, at least in fictionalized form. The craze for long historical novels in Germany and beyond (for example, Emil Ludwig) was evident from every best-seller list, and Mann, having completed his philosophical coming to terms with World War I (as well as with nomadism, Jews, and illness) with the publication of The Magic Mountain in I924, turned to his account of the biblical tale of Joseph and his brothers. ${ }^{8}$

The novel was published sixteen years later in a different world, one in which Thomas Mann found himself in California exile, the de facto intellectual leader of the non-Jewish antifascist exiles, invited to have cocktails at the White House, and publishing a novel about Jews in a quite different exilic tradition. The novel represents the subtle shifts in the meaning of cosmopolitanism from Weimar Germany to the world of the non-Jewish exile. It is a novel with an odd history of its own: Mann was abroad lecturing on Wagner when the National Socialists came to power in January I 933 and did not return to Germany until after I945. At the end of April I933, Mann's chauffeur in Munich, who was also a government spy, gave the suitcase with the draft manuscript and other materials to state authorities. The National Socialists seized some of Mann's contracts but sent the suitcase on to him in Switzerland, as the text held no interest for them. Mann had become an exiled cosmopolitan.

Mann had always seen himself as cosmopolitan, but as one commentator observed, his cosmopolitanism had an odd, German turn: "Mann had a generally cosmopolitan attitude, considered German culture quintessentially European and opposed democracy that he [initially] confused with ideology. His anti-National Socialism is not a reversal, but a continuation of Mann's Observations of a Non-Political Man."9 The essay, which was published between I9I5 and I9I8, advocated a German "civilization" (O, I8). It was his most important political statement about the meaning of the Great War, and he distinguished between the healthy "cosmopolitan" and the corrupt "international," which he detested:

The difference between intellect and politics, as a further example, is the difference between cosmopolitan and international. The former concept 
comes from the cultural sphere and is German; the latter comes from the sphere of civilization and democracy and is-something quite different. The democratic bourgeois is international, even though he may drape himself everywhere ever so nationally; the burgher . . . is cosmopolitan because he is German, more German than princes and "nation": this man of the geographical, social, and spiritual "middle" has always been and remains the bearer of German intellectuality, humanity, and antipolitics. $(\mathrm{O}, \mathrm{I} 8)$

For Mann and his protofascist contemporaries such as Gottfried Feder, such a sense of the international reflects that which is not-German. ${ }^{10}$ It very much echoes the discussion that began in eighteenth-century Germany with Kant's cosmopolitanism about the compatibility between cosmopolitanism and nationalism. ${ }^{11}$ Indeed, in I909, Swiss theologian Karl Barth simply equates cosmopolitanism with "being without character," since "in a republic all are answerable." 12 This view closely resembles Friedrich Meinecke's argument in his 1907 Cosmopolitanism and the National State. One very articulate voice that was clearly in opposition to this rereading of the cosmopolitan was that of Mann's left-leaning brother, Heinrich, who in 1923 condemned such revanchist nationalism, disguised as the cosmopolitan, as the "newly aggressive form of the preservation of the state." 13 Jewish thinkers of the Left took a very different turn. During World War I, the founding father of socialist revisionism, Eduard Bernstein distinguished among Jewish patriotism for the national state (Landespatriotismus), patriotism for the Jewish community (Stammespatriotismus), and a cosmopolitan orientation (weltbürgerlicher Patriotismus).${ }^{14} \mathrm{He}$ stressed that for the Jews and their descendants, these ideas were complementary rather than contradictory.

At least in his 1907 essay, "Die Lösung der Judenfrage" (Solving the Jewish Question), Thomas had seen the parallel "Jewish Question" as "purely psychological" because the Jew is "always recognized as a stranger, feeling the pathos of being excluded, he is an extraordinary form of life." ${ }^{15}$ Mann's views also parallel the discussion of the "international Jew" as a central trope of the debates of the time, including those among the other contributors to the special I4 September 1907 issue of the Münchner Neuesten Nachrichten, where Mann's essay appeared. The progress of cosmopolitan German culture, not Zionism or assimilation, Mann argued, permitted—indeed, demanded—-the spiritual integration of the Jews into Europe. Mann's fantasy of the Jews imagines them primarily as provincial inhabitants of the ghettos of Eastern Europe (L, 243). Their movement into European culture is not mere social acculturation but, in the terms of his comments a decade later, the movement from inter- 
nationalism to cosmopolitanism. ${ }^{16}$ Mann sees this movement as parallel to the replacement of the ghetto Jew, with his "hump back, crooked legs, and red, gesticulating hands" (L, 244), by "young people who have grown up with English sports and all of the advantages without denying their type and with a degree of physical improvement." (L, 245). For Mann, this transformation is part and parcel of the "general cultural development" of Europe-of the new cosmopolitanism (L, 246).

Mann's rethinking of cultural cosmopolitanism as a German national project had odd implications for Jewish thinkers in the I930s. After Hitler's ascent to power, Robert Weltsch, editor of the Berlin-based Jüdische Rundschau (Jewish Review, founded in I896, the journal of the Zionist Federation in Germany); a Zionist; and a vocal opponent of the National Socialist government, argued that Jews should be proud of their Jewishness: "Tragt ihn mit Stolz, den gelben Fleck" (Wear it with Pride, the Yellow Badge) ${ }^{17}$ But Weltsch also defends his brand of Jewish identity in this context against those who "preached to us nationally-oriented Jews often enough the ideals of an abstract cosmopolitanism in an effort to destroy all deeper values of Judaism" (W/JR, I47). He wrote, "there is a new type of Jew: the new, free Jew, a kind as yet unknown to the non-Jewish world" (W/JR, I47). Such Jews work against the stereotypes perpetrated by "the National Socialist and German patriotic newspapers" (W/JR, I48) of the self-hating cosmopolitan Jews who "applauded their own degradation, and many attempted to create an alibi for themselves by joining in the mockery" (W/JR, I49). Such Jews, he argued, "have tried to derive a financial profit from the Jews" (W/JR, I50) and are the source of the Nationalist Socialist view that Jews and capital were inherently linked.

Weltsch thus places the National Socialists' stress on the Jewish economic function in Germany on the same plane as the function of the cosmopolitan Jews. They are equally destructive, at least from the perspective of I933. This was not a new argument for Weltsch. In I9I3 he contributed an essay on Theodor Herzl to the collection of materials put together by members of the Prague Jewish circle on the state of Jewish identity. Weltsch's piece quoting Jacob Wassermann's I909 views (W/JR, I 58) as the antithesis of modern education and the true literary type. ${ }^{18}$ The nationalism of Weltsch's Zionism rejects Jewish cosmopolitanism as strongly as Mann's recycles the cosmopolitan during World War I to his own ends. But from the position of the non-Jewish writer, Mann makes the question of Jewish cosmopolitanism and its function one of the litmus tests for modernity's focus on geographic and economic mobility.

Inspired by his I925 trip to Egypt, Mann wrote a four-part novel, Joseph 
and His Brothers, that used the account of Joseph's life before, during, and after his time in Egypt to frame what is clearly the most complex account of Jews on the move written by a non-Jewish writer during the National Socialist era. ${ }^{19}$ For Mann, Egypt was the antithesis of the Greco-Roman classical world, a world of the exotic cosmopolitan. ${ }^{20}$ Joseph was not to be understood as a novel about Jews - it was not a "Jew book," Mann wrote to Eduard Jedidjah Chavkin in August I934; rather, it was a "picture book and historical account of human beings," a point he repeated in August I944, calling the novel "not a Jewish Novel but a happy-serious song of humanity."21 Yet Mann's novel is shaped by the antisemitic rhetoric of his time and is in complex ways, like his model Friedrich Nietzsche, a work of anti-antisemitism, as he wrote to Ludwig Lewisohn on April I9, I948. ${ }^{22}$ Speaking on "The Theme of the Joseph Novels" at the Library of Congress in November I942, Mann declared that he saw the novel as a reaction to anti-Semitism: "Most certainly there were hidden, defiantly polemic connections between it and certain tendencies of our time which I always found repulsive from the bottom of my soul; the growing vulgar antiSemitism."23

He was addressing an audience with at least potentially a number of American Jews, for whom public antisemitism, which arose with the Joseph Seligmann Affair in I877, had taken on a more sinister coloration by the I930s. In 1877 the Jewish owner of a private investment bank, J. \& W. Seligman, a major figure of Gilded Age New York and a crony of Jay Gould, was turned away from a spa hotel in Saratoga Springs, New York, because he was a Jew, even though he and his family had stayed there before. By World War I the Jewish grand bourgeoisie no longer faced social ostracism. The lynching of Jewish factory manager Leo Frank in Marietta, Georgia, in I9I 5 had set a tone of confrontational antisemitism echoed in the I920s by Henry Ford as well as Father Charles Coughlin. This strain of thought stressed that Jews could not become "real Americans" because of their cosmopolitanism. During the I930s, the isolationists ("America-firsters"), led by Charles Lindbergh, picked up this thread of Jewish cosmopolitanism as one of the components of their antiSemitic rhetoric. In this period of heightened antisemitism, any German exile text that featured Jews, especially evocative of the common ground between Jews and Christians, was read as philosemitic. ${ }^{24}$ In the mid-I950s, Lewisohn saw the Joseph cycle as a "super-midrash," a metacommentary seen from a Jewish perspective. ${ }^{25}$ Lewisohn picked up on Mann's comment in his Washington talk that the novel "often reads like an exegesis and an amplification of the Tora, like a rabbinical Midrasch." ${ }^{26}$ Here Mann provides his American as well as his Jewish readers with a point of identification between his reading of Jew- 
ish cosmopolitanism and that of the acculturated and integrated American Jewish reader, such as Lewisohn.

Mann's novel is a complex account of cosmopolitanism in the most difficult reading of the "Old Testament" as a Jewish forerunner of Christianity's sense of the cosmopolitan. As Gabriel Josipovici notes, Mann surrenders to the traditional Christian preference for fulfillment narratives - in other words, tidy endings rather than the open-ended account in Genesis that keeps open the question of rootedness. ${ }^{27}$ Mann's account is part of a long tradition of non-Jewish German constructions of Jewish cosmopolitanism that is at heart problematic and perhaps even tragic in its expectations, much as the Jews' flawed claim to chosenness clouds the question of transmutability inherent in this notion.

The key lies in the moment when Joseph enters into the Kingdom of Egypt as a slave of the Midianite caravan that has purchased him from his brothers. In a scene redolent of Nietzsche's crippled dwarf riding on Zarathustra's shoulders in Thus Spoke Zarathustra, the caravan is greeted by a dwarf, Gottliebchen, whose nickname is that of the comic god Bes-em-heb and who speaks in "an asthmatic, cricket-like voice" (JB, 642). Gottliebchen sees himself "left here among the overstretched, all a dwarf can do is yawn. I don't wish to buy your monstrous wares and I'd not accept your thumping wit even as a gift. I simply want to see if anything new in your giant epoch has come to our courtyard - strange men, men of misery and sand, wild nomads, in clothes no man wears . . phooey!"' (JB, 642). These are not cosmopolitans but nasty nomads, dirty, dangerous, and threatening, except that the dwarf sees that they are nothing of the sort. They are just pathetic strangers. Thus, he becomes Joseph's friend and confidant.

The caravan with Joseph is quickly confronted by the malicious dwarf, Dudu, another servant of the Potiphar, one of the "Greats of the Great" in Amenhotep III's kingdom (GW, 4:7 I 8). Dudu comes to be Joseph's true adversary in the court and attempts to discourage Potiphar from purchasing Joseph. Dudu is aware that Joseph's presence will disrupt the rules of the Old Kingdom, which the dwarf upholds and which give him his status. Gottliebchen had recognized Joseph as a merely wild man, as a nomad, as the object of merchants now hawking him among their other exotic wares. Joseph presents a real danger, leading Dudu to first stoke Mut-em-enet's attraction to Joseph and then to betray her to her husband, Potiphar. Through Potiphar's agency, the Jew from the desert, the nomad, becomes an acculturated Egyptian while remaining a Jew. According to one of Mann's sources (Arthur Weigall's study of the monotheistic Pharaoh Akhnaton), Egypt was a cosmopolitan society. ${ }^{28}$ Wei- 
gall's image of the Egyptian court bears striking parallels to its depiction in Mann's work:

He had not walked in the shadow of the cedars of Lebanon, nor had he ascended the Syrian hills; but nevertheless the hymns of Adonis and the chants of Baal were probably as familiar to him as were the solemn chants of Amon-Ra. At the cosmopolitan court of Thebes men of all nations were assembled. The hills of Crete, the gardens of Persia, the incense-groves of Araby, added their philosophies to his dreams, and the haunting lips of Babylon whispered to him mysteries of far-off days. From Sardinia, Sicily, and Cyprus there must have come to him the doctrines of those who had business in great waters; and Libya and Ethiopia disclosed their creeds to his eager ears. ${ }^{29}$

It is not lost on Mann that this "cosmopolitanism" prefigures, as Weigall observes, the creation of the core of Jewish beliefs. "This Aton worship . . . developed into an exalted monotheism, and it originated in Heliopolis. Now Heliopolis is the ancient On, where Moses learnt all 'the wisdom of the Egyptians'; and thus there may be some connection between the Jewish faith and that of the Aton." 30 The open and syncretic cosmopolitan court is linked to the narrowness of monotheism and the dictates of the one God. It is thus not German cosmopolitanism in the sense of Mann's I9I 8 discussion but a form of internationalism.

In The Magic Mountain, Mann had already used the figure of the dwarf servant to comment on the nature of the social structure, as Diego Velázquez did in Les Meninas. States the aged and dying Mynherr Pieter Peeperkorn, one of the few characters whose sympathetic qualities define him,

"You are small — what is that to me? On the contrary. I find it a positive good, I thank God, that you are as you are; I thank God you are so small and full of character. What I want of you is also small and full of character. But in the first place, what is your name?" She said, smiling and stammering, that her name was Emerentia. ${ }^{31}$

Emerentia is the supposed name of one of Christ's grandmothers, and she sets the stage for our understanding of the idea of empathy in the social structure of the novel. But as in our introduction of Joseph as a nomad, this is a false and even rather cheap means of using a disability to provide insight into the nature of the world into which our protagonists are thrust. 
Hans Castorp's move to The Magic Mountain brings him not only into a world of contradictory psychological and philosophical motivations but also into the international world of the tuberculosis sanitarium, in which Jews have a special role as placeholders for the corrupt and the corrupting. At Davos, Castorp meets Leo Naphta, who is immediately revealed as a Jew by his appearance, which is "caustically, one could almost say corrosively, ugly":

Somehow everything about him was caustic: the aquiline nose dominating the face; the small, pursed mouth; the pale gray eyes behind thick lenses in the light frames of his glasses; even his studied silence, from which it was clear that his words would be caustic and logical. (MM, 366) ${ }^{32}$

Leo (or as he was then called, Leib) Naphta comes from the eastern reaches of the Austrian empire, from the Galician-Volhynian border, a far distant world from Switzerland. And he is defined not only by his appearance but also by his rhetoric, his language, which is demonic because it is coldly rational and legalistic - in other words, Jewish. And Mann is more than explicit about this.

Leo Naphta is at Davos being treated for tuberculosis because his mother was tubercular. According to Mann, Leo has inherited his lung disease from his mother and his extraordinary intelligence from his father (MM, 432). Both traits define his Jewish cosmopolitanism. In Mann's representation of the sanatorium as microcosm of the cosmopolitan world, Naphta is the regressive pedagogical force (opposed to Settembrini and Peeperkorn) in the fictive world of Mann's "magic mountain." But the only truly modern figure in the novel is Castorp, who learns from experience, under the motto placet experiri, rather than from books or tradition-and who is not actually tubercular. The vicarious experience of death and dying in the sanatorium serves as his true introduction to life. Much like the Tower Society in Goethe's Wilhelm Meister's Apprenticeship, the sanatorium is Castorp's means of learning about the world beyond. He is in this cosmopolitan world but not of it. Indeed, the sanatorium represents a rejection of the international cosmopolitan for the healthy and the rooted.

Naphta's physical appearance reveals him as a wandering Jew, just as the Joseph novels represents the nomadic Jews through their inalterable physiognomy. But Joseph, like Naphta in the chapter in which Joseph "becomes visibly an Egyptian," is to always remain a Jew (GW, 5:959-77). The Semites' language is shaped by their biology. They are "thick lipped"-a stereotyped quality of "Semitic" features and their language (GW, 4:586, 588, 667, 779). Joseph's acculturation moves him from the language of the Jews, which is analogous to the "asthmatic, cricket-like voice" of the dwarves, to "be" an Egyptian: 
He was nourished by the airs and juices of Egypt, he ate Keme's foods; the cells of his body swelled with the thirst-quenching water of the Two Lands, whose sun's rays filled them with warmth. . . . [E]ach day his eyes actively took in realities and hallmarks that human hands had shaped out of these same silently determinative and all-embracing impulses; and he spoke the language of the land, which reformed his tongue, lips, and jaw from what they once were, so that Jacob, his father, would very soon have said to him: "Damu, my twig, what is wrong with your mouth? I no longer recognize it.” (JB, 780-8I; GW, 5:963)

Yet this is a misapprehension. In his I907 essay on the Jewish Question, Mann gave an odd account of physical transformation in which the "gesticulating Jews" of Eastern Europe become Europeans, if not Germans, through English sports but never shed their essential type. ${ }^{33}$ Even international Jews-and Joseph here is the most international of all the Jews through his exposure to Egyptian society in the novel—ultimately remain Jews. This is the slipperiness of the cosmopolitan, as expressed in one bon mot of the time recorded in a Viennese paper: "A real cosmopolitan is someone who thinks in one language, speaks another, and acts in a third." 34 Here again we have Kafka's nomads, their jackdaw language incomprehensible, learning a new language but ultimately remaining only settled nomads. For the secret of Jewish cosmopolitanism is that it remains Jewish at its core.

Heinz Schlaffer points to this double standard of competency in his definition of what is "German" in "German literature" when he notes, "German culture, which had appeared from a sacral language, was resecularized by Jews at the close of the nineteenth century." Language became the true proof for "integration into German society in general." "By the early twentieth century," Schlaffer quite correctly opines, "if one does not understand the word "German' to have a purely ethnic dimension, one can consider the Jews to be the more serious Germans," since they claimed a complete identification with German culture because of their commitment to the written word. ${ }^{35}$ This view became part of the mantra of exiled Jewish writers between I 933 and I945 when they claimed that they were the "real German culture," preserving the German language from National Socialist thugs. Mann takes a slightly different view, noting the transformation of Jews into speakers of Egyptian with the disconcerting quality that their Jewishness remained legible.

Such a transformation evokes over and over again the question of Jews and their relationship to models of economic exchange as central to the definition of the cosmopolitan Jew. ${ }^{36}$ Joseph is not only successful as a new Egyp- 
tian: he introduces a new form of economic exchange as the "Pharaoh's great marketer" (JB, I440). He is first and foremost a factor, an economic wheelerdealer, the "rascal servant" (JB, I438). But because he is also a hidden Jew, he is an economic trickster:

He acquires a mythical popularity ... based above all on the shimmering mixed character and ambiguity — mirrored by the laughter in his eyes—of his measures, which functioned, as it were, in two directions at once, combining in a thoroughly personal way his various purposes and goals with a kind of magical wit. (JB, I438)

$\mathrm{He}$ is, according to the omniscient narrator, the consummate economic manipulator: "Joseph's conduct was aimed entirely at casting a magic spell over the idea of property, at leaving it hovering between ownership and nonownership, in a state of conditional or feudal tenure" (JB, I44I-42).

Joseph's model is joint private-state ownership, a sort of quasi-communal structure where the individual retains four-fifths of the rights to the land and property but the collective, the state, still has a determining voice. "The people of the land would likewise regard themselves as not more than custodians of the soil and pay one-fifth tax - but not to some Horus in his palace, but to Yahweh, for He alone was King and Lord" (JB, I444). "Property still remained property" (JB, I444), but the state (read: Joseph as the agent of the Pharaoh) determined value and exchange, and the Jewish God was now its recipient. Nomadic Jews were still benefiting a Jewish God—as well as themselves; cosmopolitans were now benefiting their host but doing so for their own parochial gain (JB, I444). Mann hammers home this point by paraphrasing David's Psalm 23: "To the mythically trained ear this salient and formulaic word ascribes to Jacob's son the role and character of a good shepherd who tends his people, who grazes them in green pastures and leads them to fresh waters" (JB, I440-4I). Why does Mann evoke David at this juncture? He is not merely a prefiguration of the rule of the Kingdom of Israel and Judea, a pharaoh in his own right, but also the prophetic ancestor of Christ. In the novel, Joseph moves from Jewish nomad to a harbinger of Christian civilization.

This view of a form of economy that benefits the settled nomad is Mann's version of Georg Simmel's view in the Philosophy of Money (I900) that "if the whole property of a primitive group consisted of landed property, then development would take place in two main directions. First, by producing food from property it gains a more mobile character; as soon as this happens, private property emerges." For Simmel, "nomadic peoples hold land as common prop- 
erty of the tribe and assign it only for the use of individual families; but livestock is always the private property of these families. As far as we know, the nomadic tribe has never been communistic with regard to cattle as property." Real, unsettled nomads, unlike those who have transitioned into landowning, as Simmel notes, are very different, since the "Arab nomadic tribes were prohibited by law from sowing grain, from building a house, or similar things in order to avoid disloyalty to the tribal traditions by becoming settled." ${ }^{37}$ Indeed, the economic model of the settled nomad is Joseph's model for agricultural Egypt - at its core that of the nomad in transition to the model of agriculture, with the common property now that of the state yet with individuals retaining the rights to much of their own labor.

Simmel's views on the cosmopolitanism of the settled nomad were diametrically opposed to those present in Mann's Joseph novels. Simmel used the term nomadism in the Philosophy of Money to speak about a historical moment in the development of capitalism where groups move from an avoidance of settlement to contingent rootedness, with all of its potential conflicts. Simmel's work encouraged Max Weber to turn to the question of the meaning attached to the origins of capitalism in I905 and helped Simmel come to terms with nomads and pariahs, including the Jews, well before Thomas Mann but in texts well known to him. Mann was familiar with Weber's view that being settled means becoming part of a community within the paradigm of mobility. ${ }^{38} \mathrm{Sim}$ mel's essays, such as "Bridge and Door" (I909) and "The Metropolis and Mental Life" (I903), stressed an absolute imperative of urban modernity: to connect with others in ways that define what we now call human mobility. He uses the term nomadism in the general context of other forms of mobility, such as wandering, a royal tour, diasporic travel, migration, and even adventure. What is unique is the "form of sociation in the case of a wandering group in contrast to a spacially fixed one." 39

Yet Simmel's sojourner-his stranger described in the oft-quoted appendix to his I908 Sociology, "who comes today and goes tomorrow," with no specific structural position in society_reflects both Weber's coinage of pariah capitalism, with its association with the negative status of the Jews as a result of their self-isolation, and Mann's contingent image of the economics of the Jews in Joseph's Egypt. ${ }^{40}$ Simmel's Sociology also provides an extensive map of the qualities ascribed to the nomad. ${ }^{41}$ But the stranger differs from the wanderer:

The stranger will thus not be considered here in the usual sense of he term, as the wanderer who comes today and stays tomorrow-the potential wanderer, so to speak who, although he has gone no further, has not 
quite got over the freedom of coming and going. He is fixed within a certain spatial circle — or within a group whose boundaries are analogous to spatial boundaries - but his position within it is fundamentally affected by the fact that he does not belong in it initially and that he brings qualities into it that are not, and cannot be indigenous to it. ${ }^{42}$

His position is determined by the fact that he may leave again. ${ }^{43}$ Joseph fulfills the image held by Simmel, a baptized Jew, of the "strangerness" of the ghetto Jew-what Simmel labeled "racially inferior Jews." ${ }^{44}$ Mann evokes that Jew in his I907 essay, and that Jew runs like a red thread through the Joseph novels.

By the I930s, the view that Mann espouses in the Joseph novels has a parallel in the theory of cosmopolitanism and the role of the stranger in defining it in the writing of jurist and philosopher Carl Schmitt. ${ }^{45}$ Schmitt had coopted the basic framing of the antagonism of the crowd (and the role of the leader) from the World War I discussion of the mob in thinkers such as Simmel as well as from Freud's I92 I essay, "Group Psychology and the Analysis of the Ego.” In The Concept of the Political (I927), Schmitt had examined the enmity between groups and "the other, the stranger" as "in a specially intense way, existentially something different and alien, so that in the extreme case conflicts with him are possible." But this enmity could be breached, since "it may be advantageous to engage with him in business transactions." ${ }^{46}$ Schmitt makes concrete this economic abstraction of the Other after the National Socialists' rise to power.

By the I930s, Schmitt has defined the enemy in terms of Jewish nomadism. For Schmitt, commenting on the new concept of National Socialist law, the existence of such an enemy explains the domination of normative law in post-Enlightenment Europe. Such law was essentially a product of the Jews as a nomadic people, now in the status of the metic, a resident alien who required rational statutes and abstract Cartesian principles- "the artificial superstructure of the idées generals"-for protection, whereas indigenous people could rely on the communality of blood. Schmitt opposes the normalization of the nomad as part of the nation because

this abstract normativism has been driven into healthy German brains. The normativistic way of thinking that thus arose among us was further encouraged in the nineteenth century by the fact that the influx of the Jewish guest Volk drove this development [even] further in the direction of a normativistic way of thinking about the law. 
The Jews see this process from a radically different angle as

it goes without saying that a foreigner, a guest, a metic, sees the law of a Volk under whom he is guest normativistically and only from the point of view of legal certainty, from the point of view of the predictability of legal decisions. This foreigner certainly does not belong to the reality of the Volk, the reality in which he lives. The foreigner perceives this reality's law as a calculably effective norm, as a standard of the state's functioning to which he conforms, upon whose basis he can calculate outcomes and upon "whose basis he can protect himself from the state." The foreigner wants to have the timetable in order to know when and where he can get on and get off. As a result, he puts in place of justice the law in the sense of a previously determined, calculable norm. ${ }^{47}$

This is the definition of Joseph's economic reforms in Egypt. They are intended to solidify the status of "a foreigner, a guest, a metic," exposed to the enmity of the Egyptians as a pariah people, now controlled by a new rule of law, a law defined by the practices and beliefs of the monotheistic God.

The image of the settled nomad as a productive (if still alienated) member of society is part of a discourse of the I920s in which both Simmel's images and Schmitt's theory participated. Lenin's nationality policies had demanded in the I920s that nomads, such as the Kazakhs in Central Asia, become settled or sedentary so that they could become productive parts of the new state. A continuation of imperial policy, Lenin's edict was articulated in a social Darwinian model of the survival of the fittest understood in terms of the modern industrial state, as the model saw nomads as less productive and settlement as transforming them into modern citizens. This was a radical break with the romanticized view of writers such as high Victorian George Barrow and of the British Gypsy Lore Society, in which Romani culture was depicted as a healthy alternative to the urbanization of nineteenth-century industrial life. Proponents of this view were inspired by the German Romantic notions of writers such as Goethe, but Western European nations echoed policies of forced settlement (or expulsion) with regard to the Sinti and Roma, whom the National Socialists considered a pure race but whose nomadic life was unacceptable in a völkisch state. Heinrich Himmler, obsessed by the Sinti and Roma, saw their criminality as a result of race mixing but also saw that they could never become part of the nation-state:

Previous cumulative experiences in combating the Gypsy plague and the knowledge gained through racial biological research appear to indicate 
that control over the Gypsy question can be achieved through racial principles. Experience shows that those of mixed race are involved in most of the Gypsy criminality. On the other hand, it has been shown that the attempt to make Gypsies sedentary, especially among the racially pure Gypsies, has failed as a consequence of their strong nomadic drive. ${ }^{48}$

As a result, in 1939, Sinti and Roma were confined to concentration camps to begin their elimination from the new state. For Mann, the settled Jews of Egypt were just as inassimilable as the Sinti and Roma and were not romanticized as they had been in the nineteenth century.

Mann's hesitation about Jewish nomadic internationalism dates from his views during World War I, which positioned the Jews as neither culturally valid nor rooted, unlike true German cosmopolitans. His I907 essay on the "Final Solution of the Jewish Problem" sees this risky and nomadic internationalism developing among the young Jewish Weltbürger and posits it as lying at the core of his portrayal of Joseph. Mann had evoked this idea well before the I907 essay, which had demanded a true Jewish cultural integration into European society even to the point of mixed marriages and baptism (GW, I3:459). Mann does not see this happening in I907. Yet Mann's not-very-veiled antisemitic tale, "Blood of the Walsung" (I905), with its antisemitic Yiddish ending altered in publication to avoid offending his Jewish in-laws, suggested that such integration was inherently impossible in that the Aryan-looking Aarenhold twins remain at their incestuous core Jewish.

This was mere formal acculturation, not the psychological transformation of the Jewish essence that Mann demanded. Thus despite his ironic "becoming an Egyptian" (JB, I44I-42), Joseph remains Jewish in the blood, as he and his people assume an Egyptian identity but reinterpret it through their essentially Jewish perspective. Thus the Egyptian custom of male circumcision becomes a "mystical" religious obligation of the blood for Mann's Jews. (GW, 4:79-80) Ruth Klüger sees Joseph as a rare example of the German-Jewish symbiosis from a philosemitic point-of-view. ${ }^{49}$ Yet Mann's Jews truly differ little from the National Socialist image of the Jews as superficial cosmopolitans, whose socalled acculturation was merely a form of cultural camouflage. In Mann's Egypt they borrowed local customs such as circumcision. In the Germanspeaking world, according to National Socialist propaganda such as Veit Harlan's film Jüd Süss (I940) (as discussed in chapter 2), they assume the mantle of German high culture. Yet this only provides a disguise for those who cannot see their true nature beneath their cosmopolitian veneer. They can acquire but 
also shed their cosmopolitan identities as needed by circumstance. In the end they remain Jews.

\section{Joseph in Sigmund Freud's Egypt}

The figure of Joseph captured at least one other writer during the period of exile. In I934, Sigmund Freud, still sitting his apartment in Vienna, wrote to Arnold Zweig, a historical novelist and disciple now in British mandated Palestine. Zweig had begun to write an account of Napoleon's campaign in Egypt, and Freud commented,

Incorrigible dreamer that [Napoleon] was, he had to play the rôle of Joseph in Egypt, and later on provided for his brothers in Europe, just as though he had been successful in his conquest of Egypt. And by the way, we owe the deciphering of the hieroglyphics to this piece of folly on $\mathrm{Na}$ poleon's part. ${ }^{50}$

Freud's free association provides a moment of insight into his relationship with his much older brothers, distant yet always competitive. Indeed, given Mann's lectures on Freud during the I920s, such a claim about decoding an unknown script also reflects Mann's sense of reading the relationship between settled Germans and nomadic Jews as revealed in the figure of Joseph. ${ }^{51}$ Freud had earlier noted that psychoanalysis was indeed much like the Rosetta Stone in deciphering the unconscious a view that Mann echoes. ${ }^{52}$ Thus Joseph is a case study in sibling rivalry, not an inappropriate model for the German-Jewish symbiosis, at least according to its Zionist critics.

Later, in his exile, Freud again turned to Joseph in Moses and Monotheism. ${ }^{53}$ Given that Moses was in Egypt because of Joseph's movement of his people into the land of plenty, it is not surprising that this ancestry would appear in Freud's account of the Jews. Freud's fascination with Moses was a leitmotif of his work even before his I9I3 visit to Rome, where he first saw Michelangelo's sculpture, and Freud's I9I4 essay on the work. His fascination with Joseph takes a very different turn. Freud begins with the idea of a Jewish character based on the idea of the chosen people, since the Jews

have a particularly high opinion of themselves, that they regard themselves as more distinguished, of higher standing, as superior to other 
peoples - from whom they are also distinguished by many of their customs. At the same time they are inspired by a peculiar confidence in life, such as is derived from the secret ownership of some precious possession, a kind of optimism: pious people would call it trust in God. (SE, 23:IO4)

And this is certainly not a modern development: as Freud observes, the Jews "behaved in Hellenistic times just as they do to-day, so that the complete Jew was already there; and the Greeks, among whom and alongside of whom they lived, reacted to the Jewish characteristics in the same way as their 'hosts' do to-day" (SE, 23:I05). But as with the model of Jacob choosing Joseph as his favorite son, being chosen leads to antisemitism and persecution:

If one is the declared favourite of the dreaded father, one need not be surprised at the jealousy of one's brothers and sisters, and the Jewish legend of Joseph and his brethren shows very well where this jealousy can lead. The course of world-history seemed to justify the presumption of the Jews, since, when later on it pleased God to send mankind a Messiah and redeemer, he once again chose him from the Jewish people. The other peoples might have had occasion then to say to themselves: "Indeed, they were right, they are God's chosen people." But instead of this, what happened was that redemption by Jesus Christ only intensified their hatred of the Jews, while the Jews themselves gained no advantage from this second act of favouritism, since they did not recognize the redeemer. (SE, 23:I04-5)

The "stiff-neckedness" of the Jews has its roots in the father's preference for one of his sons. Sibling rivalry, the key to G. E. Lessing's "Parable of the Three Rings," which defined the complex Enlightenment relationships among Judaism, Christianity, and Islam, comes to explain Jewish particularism through Freud's reading of Jewish chosenness. This is an odd claim, as Freud evokes Lessing's Nathan as "a curious Jew" as early as I 882. ${ }^{54}$ Jewish character and practice (Freud, like Mann, is evoking, circumcision, which they and many other European intellectuals saw as retrograde and primitive) inevitably lead to exile and to the jealousy and hatred of others- that is, to antisemitism. Indeed, according to Freud, the rejection and murder of the first Moses, who demanded that the Jews serve only one, invisible God, leads to the murder of the initial Moses, and this patricide eventually causes the Jews eventually to accept the second Moses. Jewish monotheism is rooted in the first act of disavowal, which has its roots in Joseph's exile. Freud, as he reveals in an unpub- 
lished letter of 23 February I938 to a Czech correspondent, Frank Selinek, knows well Friedrich Schiller's negative account of Moses and the corruption of the Jews in Egypt after Joseph, which we discussed in chapter 2, as well as an essay by the young Goethe gesturing toward the murder of Moses by the Jews. Thus the nomad Joseph sets the stage not simply for any rebellion against the father but for a specific rebellion that shapes and structures Jewish belief and Jewish character. Freud's Joseph is the product of exile-specifically, the exile of the Jews in a diaspora that very much mirrored Germany and Austria, a phenomenon that shaped Freud's relationship to the Austrian state and Jewish identity in the diaspora.

When Freud comes to imagine the origin of antisemitism in exile, he sees the present status of the Jews as the result of the Germans' false universalism in their semiconversion to Christianity. Just as Mann sees Jewish immutability underlying the definition of the causes of antisemitism, Freud sees in London exile the incomplete transition of the Germans to a new, cosmopolitan worldview, that of Christianity. He observes that the Germans were "mis-baptized" as they were coerced into conversion to the new universal faith (SE, 23:9I): "They have been left, under a thin veneer of Christianity, what their ancestors were, who worshipped a barbarous polytheism. They have not got over a grudge against the new religion, which was imposed on them; but they have displaced the grudge on to the source from which Christianity reached them" (SE, 23:9I). Antisemitism is only the crude displacement of anti-Christian feelings onto the Jews, who are the featured players in the Gospels, because

hatred of Jews is at bottom a hatred of Christians, and we need not be surprised that in the German National-Socialist revolution this intimate relation between the two monotheist religions finds such a clear expression in the hostile treatment of both of them. (SE, 23:9I)

As Freud suggests, German antisemitism is really a hatred of Christian cosmopolitanism in contrast to the rootedness ascribed to the Germans.

For Freud as for many commentators on National Socialism, the sense of an opponent common to both Christians and Jews creates a bond in exile. The reality of the Catholic Church's I933 concordat with the National Socialists and the rise of German Protestant groups, with their overt antisemitic rhetoric even before 1933, are lost in this fantasy alliance of Jews and Christians in exile. The tale of Joseph captures moments of cosmopolitan identity both as a German/European and as a Jew, while the Germans remain parochial and 
mired in their pagan rootedness and inability to be transformed into what for Thomas Mann was true cosmopolitanism.

\section{Heidegger's Rootless Jew}

The relationship between the non-Jewish exiles from and the supporters of the Third Reich was usually clear-cut. In I933, the National Socialist press dismissed Mann as having "had the misfortune to forfeit his erstwhile national sentiments at the time of the establishment of the Republic, exchanging them for cosmopolitan-democratic views." 55 Yet the views of some exiles (such as Mann) and those of fascist thinkers such as Martin Heidegger overlapped substantially with regard to the rootlessness of the Jewish cosmopolitan. In Sein und Zeit (Being and Time) (I927), Heidegger defined the philosophic notion of being in the world as existing in the truest sense, since "taking up relationships towards the world is possible only because Dasein, as Being-in-the-world, is as it is." 56 What it is becomes defined in terms of being bodenständigautochthonous, or, more simply, rooted. George Steiner calls this idea Heidegger's "stress on rootedness, on the intimacies of blood and remembrance, which an authentic human being cultivates with his native ground. Heidegger's rhetoric of 'at-homeness,' of the organic continuum which knits the living to the ancestral dead buried close by, fits effortlessly into the official cult of 'blood and soil."' As a result, Heidegger's "critique of 'theyness,' of technological modernity, of the busy restlessness of the inauthentic," mirrors the "Hitlerite denunciation of 'rootless cosmopolitans,' the urban riff-raff, and unhoused intelligentsia that live parasitically on the modish surface of society"- that is, Jews. ${ }^{57}$

After his term as rector at Freiburg and his unqualified support for the new National Socialist government as well as his subsequent dissatisfaction with the new regime, Heidegger restated more or less the same idea in a I937 lecture: "A Slavic people would experience the essence of our German space certainly differently than we do. Semitic NOMADS would most probably not experience it at all." ${ }^{58}$ Heidegger again echoed this viewpoint in his I94I Black Notebooks, when he defined the Jews not as a people but as a state of mind: "The question of the role of world Jewry is not a racial but rather a metaphysical one about the type of human specificity that in all cases can be extrapolated as a world-historical 'goal' from the ROOTLESSNESS of the becoming from being." 59 Jews, now a state of mind, cannot grasp the notion of a national or particularist space. This is the key to post-Friedrich Ratzel views of the scien- 
tific relationship between a people and their geographic space. Ratzel had argued that space defined character, and while this older claim had its roots in German idealism (contrary to Herder), Ratzel rested it on scientific claims of physiology, space, and mind. According to Heidegger's interpretation of this view, the Slavs had an ideology of pan-Slavism that was rooted in their national identity and geographic space. The Jews - and Heidegger clearly rejects a Zionist model for Jewish identity rooted in the land-had no such possibility of identification. His image of the Jew is that of the perpetual wanderer and the eternal capitalist.

If there is a trope that ties Heidegger to the straightforward rhetoric of classical nineteenth-century antisemitism, which he shared with Karl Marx, it is the notion that the such a metaphysical notion of the Jews is made concrete by their economic exploitation: "One of the most secret forms of the gigantic, and perhaps the oldest [qualities of the Jew], is his tenacious skillfulness in calculating, hustling, and intermingling through which the worldlessness of Jewry is grounded." 60 That such views are not unique to Heidegger after I933 is evident when he turns to a critique of Jews and capital:

Even though the spirit of egotism, self-aggrandizement, and ruthless greed had already become the driving force behind economic activities by the time of the 1789 revolution as a result of the prevailing doctrine of Freemasonry and had dismissed the Christian doctrine of the individual's inherent obligation to the common good as antiquated and backward, there were still certain internal reservations non-Jews had to overcome before they could adopt without any qualms the Jewish economic methods that fed into capitalism. So non-Jewish devotees of capitalism always came in a few lengths behind their unscrupulous Jewish forerunners in the capitalist race. ${ }^{61}$

A consistency exists within racial antisemitism as a continuation of the religious charges of usury against the Jews. Thus, the Jews corrupted Western society with a model of capitalism that is Jewish to its metaphysical core. Hitler repeated the substance of what he had learned about Jews in the boardinghouses of Vienna before the war in a I9I9 letter and echoed those ideas again in Mein Kampf (1925-26):

His power is the power of money, which multiplies in his hands effortlessly and endlessly by way of accrued interest, and which forces the Volk under the most dangerous of yokes whose ultimately tragic consequences 
are concealed by the initial attraction of gold and glitter. Everything men strive after as a higher goal-be it religion, socialism, or democracy-is to the Jew but a means to an end, a way for him to satisfy his lust for money and domination. ${ }^{62}$

For Hitler, the Jew is defined by the rootlessness of capital, the ability to move seamlessly across all boundaries, both geographic and moral. Jewish rootlessness is a permanent stain on Jewish character and contrasts with the stability of the German or even the Slav. Unlike the nomad, who has a territory, albeit a huge one, the Jew is truly rootless. This is a standard trope of National Socialist rhetoric. In a I3 September I935 talk, "Communism with the Mask Off," Goebbels observed that Jewish cosmopolitanism constituted the core of contemporary "Judeo-Bolshevism," since "Bolshevism is not merely antibourgeois; it is against human civilization itself. In its final consequences it signifies the destruction of all the commercial, social, political and cultural achievements of Western Europe, in favor of a deracinated and nomadic international cabal that has found its representation in Judaism." ${ }^{63}$ That the Jews are simultaneously a race and not a race, nomadic as well as cosmopolitan, is reflected in National Socialism's eclectic arguments about the Jews: they represent all forms of evil.

By the I940s, this rationalization provided the rhetoric not only for exclusion but also, given Hitler's January 30, I939, statement about the Jewish Bolshevik responsibility for any further war and its implications for the survival of the Jews, for genocide. The press specialist in the anti-Comintern section of the German Foreign Office, Karl Baumböck, wrote in I942 that

with ice-cold, diabolical calculation, [the Jews] unleashed a new world war that they hoped would defeat the national-authoritarian nations. After destroying these nations, the way would once again be open to establish Jewish domination of the remaining nations. The immutable and lunatic goal of world Jewry is and remains the domination of every nation on its own territory, by firmly lodging itself in nations' organs and exercising complete control of their soil, their money, and all their goods. ${ }^{64}$

Heidegger's September I94 I version of this claim states that

at the start of the third year of the planetary war.-Common sense would like to calculate history, and longs for a balance sheet. . . . World Jewry, spurred on by the emigrants who have been let out of Germany, is intan- 
gible everywhere and, as much as it develops its power, never has to take part in warlike activities, whereas the only thing left for us is to sacrifice the best blood of the best of our own people. ${ }^{65}$

German Jews specifically are at the forefront of the destruction of Germany through their planned world conflagration. When Heidegger (and Gottfried Benn and an entire cohort of Weimar intellectuals in thrall to National Socialism) turn on the "intellectuals"- a trope of antisemitism reaching back to the Dreyfus Affair-he, too, echoes the rhetoric of the party's attack on rootless intellectuals, now literally driven from pillar to post:

This island of whining, fault-finding, bloodless intelligentsia floating in a sea of swirling renewal and change is admittedly growing smaller by the month and far more seldom seen. Nevertheless, even if there are scarcely a hundred thousand of them left in Germany today, they are all the more numerous in foreign countries, which, for the New Germany, is perhaps as pertinent. There they are in league with German outcasts and emigrants, those who have been dismissed from their positions and thus remain vicious enemies. ${ }^{66}$

The reality of the war is the rationale for seeking its causes. If World War I was caused by a Jewish stab in the back on the home front (as argued by General Erich Ludendorff, who joined Hitler during the I923 Beer Hall Putsch) rather than by the ineptitude of the country's leaders, then World War II must also have its roots in the betrayal of Germany by pseudo-Germans-in this case, German Jewish exiles such as Stefan Zweig. Such a metaphysical definition of the Jews demands the existence solely of a nomadic mind-set that may mask itself as national identity but that is permanently opposed to the true grounded spirit of the rooted Aryan.

\section{Zweig's Erasmus in Exile: The Cosmopolitan par Excellence}

By 1934, Zweig had left his beloved Austrian home in Salzburg into exile in London, where he turned to his literary biography of Renaissance Dutch scholar Erasmus of Rotterdam, through whom Zweig made his increasingly urgent call for a cosmopolitan society. Erasmus (1934) represents Zweig's final attempt to rescue European culture from the vandalism of extreme nationalism. ${ }^{67}$ 
The conditions of exile lead Zweig to use the figures of the cosmopolitan and the wanderer to convey the unalterable yet constantly unstable nature of society and culture, an image that was also being foreshadowed in Mann's Joseph. Given Zweig's refuge in London, it is not coincidental that the book contains a number of favorable passages about Britain, which Zweig depicts as an early harbinger of a positively conceived cosmopolitanism, in contrast to the antiquarian and contradictory cosmopolitanism of Mann's biblical Egypt. ${ }^{68}$ Erasmus also represents Zweig's perhaps most concerted effort to assert the quintessentially European roots of cosmopolitanism and culture at large as a world of texts shared by intellectuals across European languages and borders. Zweig presents the Renaissance scholar as "the first conscious European and cosmopolitan" (E, 4), recognizing "no superiority of one nation over another" (E, 4) and transcending both national and scholarly boundaries in his life and work. Erasmus's mastery of Renaissance Latin, Zweig argues, gave the ancient language a new lease on life as a means of global communication in the age of exploration. The irony, of course, is that Erasmus had attempted to resuscitate the classical Greek term cosmopolitan in the early sixteenth century and transformed it into a label for the positive and constructive sojourner.

In Erasmus, Zweig implicitly constructs parallels to his own life and cosmopolitanist beliefs as Hitler persecuted his political opponents and Jews and Stalin conducted his Great Purges. Like Zweig and his cosmopolitan peers in interwar Europe, Erasmus believes before the Thirty Years' War that political neutrality and general education would lead the way to a better world. And like Zweig and his contemporaries, Erasmus lives in an era of great scientific and intellectual promise. For the first time since the end of the Roman era, Zweig argues, scientific and artistic innovation during the Renaissance have created a collective confidence among Europeans and with it a cosmopolitan sensibility fostering a common culture and ideal of human welfare.

Through Erasmus, Zweig reprises his vision of a cultural rather than political cosmopolitanism. Renaissance humanism is presented as a strong point of attraction for intellectuals from all countries, "so that in every land the finest idealists flocked to the standard of humanism. Each desired to acquire citizenship in the new world of culture" (E, 6). But humanism's investment in knowledge also causes its ultimate downfall, creating an educated elite that arrogantly disregards the lower classes. This construction invokes the emerging twentieth-century chasm between bourgeois cosmopolitanism and revolutionary socialism, which Zweig's friend, Joseph Roth, had begun to treat in his I 924 novel Hotel Savoy. ${ }^{69}$ Because humanism catered only to the "happy few, not for the broad multitude" (E, 85), its cosmopolitan message could not suc- 
ceed during the Renaissance and, the text implies, is equally doomed to fail in the present.

Nonetheless, Zweig represents politically neutral cosmopolitanism, which he embraced, as the only viable stance in the age of dictatorship. Erasmus's cold intellect, which grows from his fierce desire for intellectual and moral independence, regularly leads him to withdraw into impartiality when partisanship is demanded. Erasmus's tragedy, according to Zweig, is that

the most unfanatical, the most anti-fanatical of men, living at a moment when the supranational ideal was taking a solid hold upon European thinkers, had to witness one of the wildest outbreaks of national and religious mass-passion that history has ever had to relate. $(\mathrm{E}, 8)$

The battle in question is that between Pope Leo X and Luther, between Catholicism and Protestantism, between the political establishment and the Reformation. It is the greatest controversy of Erasmus's time and will set off the Thirty Years' War, destroying large parts of the European population.

Because, as Zweig contends, "humanism can never be revolutionary" (E, 6I), Erasmus choses to remain neutral in this epic battle, which implicitly reflects the monumental clash between communism and fascism, Stalinism and National Socialism, in Zweig's time. Zweig paints in Luther the unmistakable image of Hitler. This is not incidental, given that in spite of its ostensibly antireligious stance, National Socialism from early on co-opted both Luther's figure and his virulent antisemitism. ${ }^{70}$ Like his modern counterpart Hitler, Zweig's Luther, "the fanatical man of action, baked by the irresistible force of a mass movement" (E, 88) —Zweig adds the word national here in the German original-brutally shatters the "supranational dream" (E, 88) of Europe. The text parallels this onslaught with the ancient Germans' destruction of Rome. It brings the advent of the Thirty Years' War as a new world war, whose blaze "was to destroy with incendiary force the ideal world so confidently expected by the humanists" (E, 88). The emphasis on the direct line between the destructive aspect of early modern culture and the mid-twentieth century comes to be one of the themes of the so-called inner emigration in Germany. German Catholic Werner Bergengruen penned a novel, Der Großtyrann und das Gericht (The Great Tyrant and the Court, I935), that presents exactly such a moral dilemma, with a Machiavellian ruler who brutally reshapes the state in specific historical terms. For Bergengruen, like Zweig, the appropriate world is that of a fantasy European Renaissance. Such historical distance paradoxically made Bergengruen's novel acceptable even to the SS, and it ultimately became a best 
seller in Hitler's Germany, praised as the "Führer novel of the Renaissance."71

Erasmus's implicit Jewish attributes in Zweig's portrayal further highlight the text's apparent analogy between Luther and Hitler. Zweig's invocation of the concept of race in this context is therefore not incidental. Like German and Jew in National Socialist ideology, Luther and Erasmus are described in terms of essential differences in body and mind: "From the outward bodily manifestation to the finest of nerve-fibres they hailed from different and hostile races, so far as habit of body and mind were concerned. The conciliatory temperament as opposed to the fanatical, cosmopolitanism against nationalism, evolution versus revolution" (E, 90).

Luther, the son of miners and farmers who are attached to the land, reflects the vitality and physical strength that National Socialist ideology ascribed to the Aryan. Like leading National Socialists Goebbels and Alfred Rosenberg, Luther is the holder of an academic degree who also revels in battle: "In the arena, the erudite doctor theologiæ was instantly transformed into a soldier" (E, 96). In contrast, Zweig lends Erasmus implicit Jewish attributes to suggest the affinities between the cosmopolitan project and the Jews. Erasmus has "no mother country, no home. In a certain sense, he was born in void space" (E, 2 I). This description reflects the condition of the Jewish luftmensch, the rootless Jew, who had come to represent the cosmopolitan prototype in Zweig's, Roth's, and Feuchtwanger's great novels of the interwar period. This predicament is only reinforced when Erasmus, like Zweig in exile, becomes a "lifelong nomad" (E, 28) wandering the countries of Europe, "always (like Beethoven) living 'in the air"' (E, 28). Of course, the historical Erasmus, while an excellent Hebraist, had little time for his Jewish contemporaries, and like most of the figures of the Northern Renaissance, dismissed the worldliness and materialism that they saw both in Judaism as a religious system and in their stereotype of the Jews of their world. As he wrote in an oft-quoted 30 January I 523 letter, "I have a temperament such that I could love even a Jew, if only he were well-mannered and friendly, and did not mouth blasphemy on Christ in my presence."72

The tensions between humanist tolerance and anti-Jewish sentiment are maintained in Zweig's portrayal of Erasmus, which is itself tinged with antiJewish imagery. Both physically and mentally, Erasmus, with his "delicate, almost feminine hand" (E, 43), displays the stereotypical features of the sickly, emasculated, cold intellectual Jew. Indeed, Zweig's portrayal of Erasmus recollects the figure of Buchmendel, the Jewish book peddler in Zweig's I929 novella. ${ }^{73}$ Like Buchmendel, the feeble and neurotic Erasmus lives solely in his abstract intellectualism rather than also in his body: "He saw with his mind's 
eye, not with his living and absorbing organ of sight" (E, 48). This portrayal parallels that of the sickly, cosmopolitan Jewish intellectual whom Thomas Mann had presented in the figure of Leo Naphta. Naphta's stereotypical Jewish features are displayed through not only his intellectualism but also his corrosive critique of all religion. Written at a time when these attributes became conflated in the images of the scholar and the Jew, Zweig's portrayal of Erasmus thus both cites and reiterates the common humanist ambivalence on the subject.

Through Erasmus's Jewish features, Zweig imbues cosmopolitanism with a quasi-innate stance of resistance against the forces of extremism that, in the guise of the Pope and Luther in Erasmus, demand that the intellectual take sides. This, Zweig argues in reference to his political position, is a false choice because the intellectual can never succeed in direct battle and thus must maintain neutrality: "An intellectual cannot afford to take sides, his realm is the realm of equable justice; he must stand above the heat and fury of the contest" (E, 98). As philosopher Peter Sloterdijk has noted, such a view of humanism sees itself as a force based primarily in words rather than action. ${ }^{74}$ This is true for both Zweig and his Erasmus, whose lacking intervention gives free rein to the forces of violence. Yet consent to extremism appears as the far more problematic stance, since violence, even in its revolutionary guise, only breeds further destruction. Now in clear reference to the Russian Revolution and its aftermath, Luther thus suffers the "fate of every revolutionary" (E, I42) when he is overrun by even more radical zealots in the guise of Thomas Münzer and the "communistic theologians" (E, I44). The Thirty Years' War, with its destruction of vast populations in Western Europe, a thinly disguised reference to the new world war on the horizon, is the consequence of these ideological battles.

But the cosmopolitanist rejection of the impossible choice between two evils leaves the individual with a crushing historical guilt. Erasmus's insistence on neutrality not only destroys the personal lives of his friends but discredits the cosmopolitan idea at large. Having refused to take sides between Luther and his adversaries, Erasmus rejects offering shelter to German humanist U1rich von Hutten, who dies, homeless and miserable, in Zurich. With him goes the cosmopolitan dream "of a spiritually-united, humanistic Europe" (E, I 55). Yet Zweig again defends Erasmus's legacy by asserting the inherently intellectual rather than political nature of the humanistic ideal as an "ideal grounded upon breadth of vision and clarity of mind, ... . destined to remain a spiritual and aristocratic dream which few morals are capable of dreaming" (E, I68).

Throughout his writings, Zweig thus maintained the separation between the aspects of the intellectual, moral, and aesthetic, on the one hand, and politics, on the other. ${ }^{75}$ For Zweig, Erasmus heralds the inevitable defeat of the 
intellectual in the face of brute violence, a phenomenon that camp survivors Jean Améry and Primo Levi later described so eloquently. ${ }^{76}$ In contrast, Thomas Mann, whose Joseph had remained suspended between observation and the call for action, ultimately recognized, at least after I 945 with the publication of Dr. Faustus (I947), that the artist and intellectual could not remain apolitical in times of crisis.

\section{Roth and Zweig: Idealizing the Austro-Hungarian Empire}

Following the publication of Erasmus, Zweig's vision of a future cosmopolitanist Europe increasingly receded. His pessimism found its perhaps clearest literary expression in a short story, "The Buried Candelabrum" (I937), that revisited his Jewish legends of the fin de siècle, in particular the ancient Roman-Jewish encounter in "Die Wanderung" (The Journey, I904). ${ }^{77}$ The image of the buried candelabrum anticipates the theme of lost hope, which is reprised in the closing metaphor of an old man's dead body lying in the open road in the shape of a crucifix, its lips "firmly closed, as if guarding a secret that was to endure after death." 78 Zweig subsequently located the cosmopolitanist project in the distant worlds of the Austro-Hungarian Empire before World War I and on the shores of modern Brazil. Zweig's idealization of the Austro-Hungarian Empire in his memoir The World of Yesterday (I94I), which he completed in Brazil just one day before his suicide, was no doubt influenced by Joseph Roth's similarly nostalgic portrayals beginning with his best-selling Radetzky March ( I932). ${ }^{79}$ Although Roth had been living in Paris exile since I933, much of The Emperor's Tomb (1938), in which he reprised the leading themes of Radetzky March, was penned during his stay with Stefan and Friderike Zweig near Salzburg in I937. ${ }^{80}$ When Austria was united with National Socialist Germany in March I938, Roth had finished all but the last chapter of the novel, which he completed under the immediate impression of the seemingly joyful Austrian incorporation into the National Socialist state. Within a year of the novel's publication, Roth had drunk himself to death in Paris.

The Emperor's Tomb has often been considered a prime example of Roth's nostalgia for the monarchy as a guarantor of humanism and integrity. These portrayals must be read as an immediate response to the end of Austria's humanistic legacy brought on by the Anschluss. This event reverberated across the spectrum of exiles from National Socialism, as when Klaus Mann contended that "the end of Austria, although long predicted and anticipated, still 
came as a stunning shock." 81 But Roth also injects his narrative of nostalgia with doubt. ${ }^{82}$ Again, the hotel and now also the coffeehouse and the train station function as ubiquitous signifiers of the monarchy and its equalizing institutions, which form the humanistic precursors of the cosmopolitan condition. As the first-person narrator, Franz Ferdinand von Trotta, the second cousin of Carl Joseph von Trotta, Roth's hero in Radetzky March, concedes, only after World War I, called by this name not so much because it affected the entire world but rather because it had destroyed the world of the past, that he had realized how the dual monarchy's "natural law of a strong spirit" (ET, 40-4I) had united its distinct "landscapes, fields, nations, races, huts and cafés of all sorts" (ET, 40), be they in Zlatograd, Sipolje, or Vienna. (On Io September I9I 8 the British Lieut. Col. Charles Repington met with an American officer in France and discussed the fact that this would not be the last Great War in the twentieth century. Repington published his diary entitled The First World War in I920 reenforcing this sad prophecy.)

Roth's close alignment of the monarchy with the spirit of universal humanism again emerges in his portrayals of the empire's liminal subjects and their rooted nomadism. The earthy Slavs and bucolic Jews from Radetzky March reappear forcefully in The Emperor's Tomb in the wandering Slovenian Maroni seller Branco and the Galician Jewish coachman Manes Reisiger, who become the young von Trotta's closest friends. In The Wandering Jews, Roth had already glorified the Eastern European country Jew, whose ties to the land resemble those of the native Slavic farmer and who therefore displays a special vigor. Roth's essay evokes the essentializing links between the land and ethnic type that figured so strongly in National Socialist ideology:

The rustic Jew of Eastern Europe is a type completely unknown in the West. No wonder: He has never gotten there. No less a "son of the soil" than the peasant, he is half peasant himself. He is a sharecropper or a miller or a village innkeeper. He has never learned a trade. . . . He is big and strong and of an improbably sound constitution. He is physically brave, doesn't mind a fistfight, and is afraid of nothing. ${ }^{83}$

In The Emperor's Tomb, the rooted nomadism of these Jewish and Slavic subjects feeds and is in turn nourished by the monarchy as an overarching and unifying principle. Franz Ferdinand's father, for example, represents the monarchy's assimilated Slavic constituent in his dreams of a Slavic kingdom, a monarchy of Austrians, Hungarians, and Slavs that would be ruled by the Habsburgs. Roth's positive configuration of the monarchy's cosmopolitan 
spirit is further reflected in the figure of Count Chojnicki, a protagonist who had also featured in Radetzky March. There, Chojnicki's southward travels had catalyzed Carl Joseph von Trotta's emergent cosmopolitan awareness. In both $R a$ detzky March and The Emperor's Tomb, the last von Trottas represent the weakened bourgeois consensus, which fails to effectively resist the impending National Socialist catastrophe. In contrast, Chojnicki in The Emperor's Tomb becomes a point of resistance to the forces of extremism. As Chojnicki contends, Austria's apparent anomaly - that is, its lack of ethnic and national coherencerepresents the natural state of polities: "So far as Austria-Hungary is concerned, the ostensibly peculiar is perfectly natural. It's only in this crazy Europe of nation-states and nationalists that the natural looks peculiar" (ET, I5).

Through Chojnicki, Roth once again stresses the importance of liminal and deterritorialized subjectivities for the creation of a cosmopolitan sensibility. Chojnicki thus asserts that the monarchy had truly been sustained and affirmed by the "tragic love" (ET, 68) of empire's peripheral subjects, among them "the gypsies from the Puszta, the sub-Carpathian Hutsuls, the Jewish cabbies from Galicia, my own relatives, the Slovene chestnut roasters from the Bačka, the horse-breeders from the Steppe, the Ottoman Sibersna from Bosnia" (ET, 68) - in short, the poor and deprived of all of the dual monarchy's provinces. In contrast, the German-speaking middle class, "those Nibelung cretins" (ET, I35), had betrayed this love through their nationalism. Therefore, the true Austrian spirit was found in the Slavic crown lands rather than the country's German-speaking center: "The heart of Austria is not the centre, but the periphery. ... The substance of Austria is drawn and replenished from the Crown Lands" (ET, I 5). The German derision for the empire's other nationalities, Roth contends through Chojnicki, had caused the Slavs to hate the dual monarchy and resulted in the fatal shots at Sarajevo.

The benevolence and altruistic love of these marginal subjects for the monarchy, whose ruling German class has only exploited them, is again epitomized in the Jews. After hearing that the new pro-National Socialist rulers have disbanded Austria's democratic government, Trotta's friends leave the Viennese café in which they had been sitting, failing to pay the Jewish owner. But Trotta insists on paying for his last schnapps, but the Jew refuses to accept the money because there is no time left. Instead, he makes a fast exit to safety and leaves Trotta to shut down the café in an image signifying the impending apocalypse: "All the lights in the café went out, and pale, with a black top hat on his head, looking more like an undertaker than the jovial, silver-bearded Jew Adolf Feldmann, he handed me a massy lead swastika" (ET, I8I). The closure of the café symbolizes the end of the Habsburg era. As the final chapter of the 
novel thus suggests, the decisive trauma for the self-professed cosmopolitan Roth occurred when Austria was joined to Germany-the ultimate end of the dual monarchy's humanistic legacy, which had received its first fatal blows with the outbreak of World War I. But even after the loss of empire, Roth's cosmopolitan dream still found nourishment in the democratic setting of the new Austrian Republic, if only in the shape of nostalgia. The Emperor's Tomb literally represents Austria's union with Germany as the final nail in the coffin of this vision, and the narrative shifts into the stark events of March I938.

By virtue of his elegiac fictions of the dual monarchy in Radetzky March and The Emperor's Tomb, Roth can be credited with having both shaped and popularized the nostalgic image of the Austro-Hungarian Empire that pervades both scholarship on the period and Austrian culture today. In The World of Yesterday, Zweig implicitly pays homage to his dead friend's idealized vision. The memoir represents the multiethnic Austro-Hungarian Empire as a hotbed of both cosmopolitan and radical nationalist ideas, from antisemitism and $\mathrm{Zi}$ onism to the Serb nationalism that sparked World War I. Vienna, with its mix of European peoples and cultures-Germans, Slavs, Hungarians, Spaniards, French, Italians, and Flandrians-exemplifies this cosmopolitan drive: "Nowhere was it easier to be a European" (WY, 28). Culture and above all music fuses this mix into a new, Austrian, Viennese, and ultimately cosmopolitan spirit that transcends even class boundaries, "and subconsciously every citizen became supernational, cosmopolitan, a citizen of the world" (WY, 22).

The Jews' passionate participation in this culture, Zweig argues, had perhaps been nowhere more productive and successful as in Austria. Yet he also suggests that the cultural productivity of Viennese Jews had not been specifically Jewish but intensely Austrian and Viennese, giving "through a miracle of understanding ... . to what was Austrian, and Viennese, its most intensive expression" (WY, 28). This cultural symbiosis, which had grown from millennia of Jewish intellectual activity, then invigorated and renewed the exhausted Austrian tradition. Its catalysts were a quartet of mostly Jewish fin de siècle writers-Arthur Schnitzler, Hermann Bahr, Richard Beer-Hofmann, and Peter Altenberg - “in whom the specific Austrian culture, through a refinement of all artistic means, had for the first time found European expression" (WY, 45).

Zweig paints the era before World War I, with its consolidation of national borders, legislatures, and cultures, as a truly cosmopolitan period with unlimited freedom for bourgeois individuals:

We could live a more cosmopolitan life and the whole world stood open to us. We could travel without a passport and without a permit wherever 
we pleased. No one questioned us as to our beliefs, as to our origin, race, or religion. I do not deny that we had immeasurably more individual freedom and we not only cherished it but made use of it as well. (WY, 77)

Zweig even claims that he that never experienced any antisemitism until Karl Lueger became mayor of Vienna in I897. This statement arises from both Zweig's privileged experience as a sheltered, upper-middle-class schoolboy and his retrospective desire to idealize the lost world of his past life from the farthest point of his exile, when the cosmopolitan dream has been radically destroyed:

I was aware that our past was done for, work achieved was in ruins, Europe, our home, to which we had dedicated ourselves had suffered a destruction that would extend far beyond our life. Something new, a new world began, but how many hells, how many purgatories had to be crossed before it could be reached! (WY, 327) ${ }^{84}$

As Zweig's vision of a cosmopolitan Europe vanished together with his world of the past, he turned toward the distant shores of other worlds, where he now located the cosmopolitanist future.

\section{Zweig's Brazil: The Farthest Exile}

Erasmus glorifies Columbus's landing on American shores and Magellan's circumvention of the world as the burgeoning of a European awareness of universalizing dimensions, when the "heroic intelligence of its race made Europe the ruler of the whole earth" (E, I6). Zweig is undoubtedly correct in pointing out the historical linkages between European colonialism and the cosmopolitan vision growing from its global reach. Despite occasionally chastising the colonialist practices of genocide and slavery, however, Zweig largely portrays European colonialism as a productive force, as when he claims that "thanks to the heroism" of its peoples - though the German original uses the word Rasse (race) instead of Völker (peoples)_ "Europe had become the focus and ruler of the whole world" (E, I6). ${ }^{85}$ The reflection of this global reach in humanism, then, briefly gave rise a unifying European idea that sought to renew the world through intellect: "In its unity, in itself as a whole, Europe felt itself paramount. .. . Now or never was spirit to renew the world" (E, 20).

Zweig's literary biography of the Portuguese explorer Magellan, who led 
the first successful circumvention of the world - although he did not live to see its end, having died in battle in the Philippines in I52 I-marks the transition between Zweig's writings on the lost world of Europe and his vanishing hopes for the future. ${ }^{86} \mathrm{Zweig}$ finds the latter in his idealized image of a racially harmonious Brazil arising from the presumed ideas of tolerance that the colonizers brought — alongside genocide and slavery. Zweig first expressed his interest in writing "a kind of handbook for foreigners" on Brazil in I936, when he visited the country as a guest of the PEN club. ${ }^{87}$ Zweig began writing the first sections this project on his return journey to Britain. In January I94 I, now living in New York, Zweig paid a second brief visit to Brazil. He completed the manuscript in March I94I and decided to move to Brazil at the end of that year.

Zweig's positive images of race mixing in Brazil contrast starkly with the destructive nature attributed to the racial hybrid in nineteenth-century racial theory. ${ }^{88}$ Wilhelm Raabe had given these images literary provenance in his I890 Stopfkuchen: A Sea and Murder Mystery, which proposed the dangers of German colonialism in its presumed dissolution of the true German spirit through intermarriage with the mixed-race peoples of South Africa. Thomas Mann had reprised these images, albeit more ambivalently, in his construction of a hybrid colonial South America in a number of his characters, from Gerda and Toni in Buddenbrooks to Consuelo in “Tonio Kröger.” As a German Brazilian, Mann's mother, Júlia da Silva Bruhns, was the product of "whitening" in nineteenthcentury imperial Brazil. In Lübeck, however, where she was educated and later married, she was perceived as black, and her memoir, Aus Dodos Kindheit (From Dodo's Childhood) (I903), suggests that she felt more at home in a fantasy world of Brazilian colonialism and slavery than she did in Germany. This conflict was played out in Mann's frequent metaphor of two souls divided against themselves, which he also saw at the core of his own life. ${ }^{89}$

Fueled by Eugen Fischer's studies on mixed-race children in the German colony of South West Africa (now Namibia), the debates regarding race mixing entered the German parliament after World War I in the shape of proposals to forcibly sterilize the offspring of French North African troops and German women in the Rhineland. This plan was carried out during the early years of National Socialist rule. The I935 Nuremberg Laws forbade intermarriage between those of "German blood" and "Jews," positioning the perceived problem of racial hybridity at the core of National Socialist ideology. At precisely this political and discursive juncture, Zweig becomes interested in Brazil. Zweig's early drafts of his book followed the writings of Alfred Döblin, who had fled to France in I933. Two years later, Döblin began writing his Amazonas trilogy (I937-39), in which he, like Zweig, projected the cosmopolitan ideal onto Brazil. 
Döblin began his work in the Bibliothèque Nationale in Paris, ruminating over maps of South America to fill his time during his exile. In the second volume, The Blue Tiger (I938), Döblin moves his cosmopolitan Christian characters between Central Europe and northern Brazil in the age of the great Jesuit missions in the sixteenth and seventeenth centuries. For Döblin, this presumed civilizing mission is destructive, with no possible moral good. Indeed, the words placed in the mouths of the Jesuits and their allies repeatedly echo the demeaning rhetoric of German racial science. Unlike Döblin's image of Brazil, which seems partially to mirror National Socialist Germany and its racial politics, Zweig presents Brazil as a utopian if ambiguous refuge. ${ }^{90}$ The cosmopolitan nature of the Jesuits in an odd way reiterates the fantasy of the cosmopolitan Jew. Brazil was the first large Jewish settlement in the Americas, with more than fifteen hundred Jews living in northeastern Brazil in the seventeenth century, when it was a Dutch colony. When the Portuguese reconquered Brazil in I654, these Jews fled to other parts of the New World. ${ }^{91}$ When they tried to reestablish themselves in New Amsterdam, Peter Stuyvesant quickly pointed out that they were refugees, not good Dutch Protestant settlers, and turned them away.

In Brazil, Zweig feels himself "immediately transported into colonial days, where everything was close and handy; . . . when walking was still a peaceful pastime"-like the prewar Vienna he went on to depict in The World of Yesterday. ${ }^{92}$ Zweig's seemingly paradoxical portrayal of Brazil of the site of colonialist benevolence unwittingly exposes both the conditioning of modern cosmopolitanism by European colonial expansion and cosmopolitanism's fundamentally Eurocentric predisposition. Although Zweig partially reflects on the problems of European racism and colonialist domination, he overall suggests colonialism's productive impact on Brazil. Zweig acknowledges that his previous "ideas of Brazil" involved a "semi-civilized" rather than cultural nation and "coincided with those of the average European and North American" (ZB, I ). Now, however, he sees Brazil as offering a foretaste of "the future of our world" (ZB, 4), since, according to James Bryce, "No large country in the world belonging to a European race possesses such wealth of soil for the development of human existence and creative industry" (ZB, 80). This phrasing stresses the dominant European properties in Zweig's perception of Brazil.

Zweig contends that Brazil has solved a problem of utmost urgency for humanity - that is, how "to make it possible for human beings to live peacefully together, despite all the differences of race, class, colour, religion, and creed" (ZB, 7). Zweig argues that the history of European nationalism and racism could be expected to predict major strife in this heterogeneous nation. 
Instead, however, Brazil's disparate populations_-descended from Portuguese colonizers, Native Americans, African slaves, and more recently Italian, German, and Japanese immigrants - have no greater ambition than to abandon their former particularities and transform themselves into "Brazilians as quickly as possible, and thus form a new and united nation" (ZB, 7-8). In contrast to the United States, his previous country of exile, Brazil is a successful melting pot that has achieved genuine social harmony: "One lives here a more peaceful, more humane existence," Zweig claims, "not so mechanical or standardized as in the United States; not so irritated and poisoned by politics as in Europe" (ZB, I8I).

Zweig arrives at this image by largely obliterating the legacies of slavery and social injustice that continue to blight the lives of Brazil's black inhabitants. Despite Zweig's explicit abhorrence of racial ideologies, his depiction of Africans is riddled with racist stereotypes such as that of atavistic creatures bare of intellectual capacity. Adopting the dominant view of European slaveholding societies that also informs his written sources, among them documents from Brazil's slaveholding era, which persisted until i 888, Zweig largely objectifies black Brazilians and even euphemizes and justifies the slave labor that made Brazil's wealth in the sugar plantations:

Two slaves (an ox would be too expensive) hold onto the vertical handle and move around in a kind of treadmill. Their tireless rounds cause the rolling pins to press upon each other until the last ounce of treacle is extracted from the cane. $(\mathrm{ZB}, 86)$

Zweig briefly considers some of slavery's atrocities, such when he describes the "nightmare" slave ships, where "half of the Negroes, chained and herded together, die on the voyage" (ZB, 9I). Although these ambivalent passages denounce the murderous consequences of slavery, Zweig's objectified and aestheticized portrayals of the slaves and their labor ultimately vindicate those horrors, as in the case of Zweig's description of "a plundered and depopulated Africa" (ZB, 9I), which has supplied Brazil with millions of slaves, albeit at uncertain economic gain. Although the slaves themselves may generate profit, costs are also incurred in importing "a strong-boned Negro from Guinea or Senegal" (ZB, 9I) as a consequence of the freight price and "loss of merchandise damaged and thrown into the sea during the voyage" (ZB, 9I92). The objectifying term merchandise refers to human beings. Fetishistic portrayals of Africans as a faceless and only partially embodied mass in colonialist production - that "machine kept going by these millions of black arms" 
(ZB, 92) - further reiterate the objectified state of Africans in the discourse of slavery. Zweig's colorful depiction of colonial sugar production, then, aestheticizes slavery and consequently minimizes its horrors: "With amazing rapidity white sugar, extracted from brown canes with green leaves by black slaves, is being converted into heavy yellow gold" (ZB, 87).

Zweig's sentimental portrayals of colonialism and slavery climax in his suggestion that they have become objects of melancholia even for the former slaves themselves. In the evenings, he claims, black plantation workers would sit and sing "their melancholy songs. Perhaps one or two of the white-haired Negroes walking calmly and contently around here still remember the old days" (ZB, 228). Zweig's descriptions of present-day Brazil are similarly problematic. Black people add color and exoticism to his perception, for example when he argues that black settlements render Rio "so colorful and picturesque" (ZB, I95). Such passages airbrush the brutal postslavery social conditions and suggest that these descendants of former slaves voluntarily live in the most primitive conditions because that is the unchanging nature of their origins. Their huts, although built from discarded rubbish, are exactly the same as those "which their ancestors built hundreds of years ago in their African kraals" (ZB, I96). Climbing up remote cliffs to these favelas, Zweig observes guileless and gold-toothed people in "the lowest form of living conditions" (ZB, I 42 - - indeed, in their "primitive original state" 93 in their clay and bamboo huts: "The Negro carrying water smiles at one with gleaming teeth, even helps one up the slippery muddy steps. Women nursing their children look up kindly and without embarrassment" (ZB, I42).

These images oscillate between Zweig's racist perception of black Brazilians as particularly threatening and his equally problematic images of their excessive naïveté. Both meanings are signified by the mention of the men's shiny teeth, which suggest both the claims of Africans' cannibalism and their primitive lust for adornments. And indeed, Zweig goes to some lengths to discuss cannibalism in his treatment of native Brazilians, whose depiction remains similarly problematic. Zweig identifies culture wholly with the European element, who are driven to biologically fuse the country's diverse ethnic constituents into one nation, Native Brazilians, too, appear to have no genuine culture of their own. According to Zweig, "So far not even the most diligent research has succeeded in finding a contribution of any importance made by the naked and cannibalistic aboriginals toward the culture of Brazil" (ZB, I36). In this representation, prior to the arrival of the Jesuits, the natives were cultureless nomads-noble savages in the vein of Jean-Jacques Rousseau, unclothed and without religion, technology, or any concept of labor. But they also 
lacked any philosophy of menace against their enemies: "These savages live so far removed from any cultural or moral understanding that to them the eating of prisoners means no more or less than such festive pleasures as drinking, dancing, and sleeping with women" (ZB, 32).

Unlike Africans, the natives' weak stamina und unwilling attitude render them unfit for slavery, which Zweig's portrayal minimizes. The natives thus waste away, innately unfit to survive: "They wore themselves out in a few weeks under the whip, then lay down and died" (ZB, 84). Whereas Africans still appear inherently primitive, native Brazilians can be redeemed for the Jesuits' civilizing mission in that they become willingly Christianized. While "the Jesuits, being the scholarly and ever-watchful realists that they are, realize this indolent thoughtless consent, the bowing and genuflexion of cannibals, is still far removed from real Christendom" (ZB, 33), the natives' conversion is the first step in the Christians' concerted efforts to produce a mixed-race population that will align itself with the colonizers. Zweig's positive wording of the Jesuits' efforts indicates that he sees this as a productive process, leading toward the ethnically heterogeneous Brazil of his own time. It is therefore not surprising that he barely refers to its flip side, the gruesome extinction of Brazil's native population. Zweig's uncritical celebration of Brazil's history of ethnic fusion must be read against the backdrop of the National Socialists' murderous project to create a racially pure German people, which had caused Zweig's flight into exile. For him, Brazil's ethnic heterogeneity, regardless of its inscriptions of colonial violence and genocide, therefore now points the way to humanity's cosmopolitan future:

Whereas our old world is more than ever ruled by the insane attempt to breed people racially pure, like race-horses and dogs, the Brazilian nation for centuries has built upon the principle of free and unsuppressed miscegenation, the complete equalization of black and white, brown and yellow. What in other countries is only theoretically stated on paper and parchment - an absolute civil equality in public as well as in private lifeshows itself here in reality in the schools, offices, churches, in business, in the army and the universities. . . The allegedly destructive principle of race mixture, this horror, this "sin against the blood" of our obsessed race theoreticians, is here consciously used as a process of cementing national culture. $(\mathrm{ZB}, 8-9)^{94}$

Seeking to counter the National Socialists' obsession with racial purity, Zweig privileges racial hybridity. ${ }^{95}$ In doing so, however, he unwittingly per- 
petuates the racial logic, which itself centered on narratives of hybridity. ${ }^{96}$ For race mixing is, as Zweig himself acknowledges, a concept steeped in racial ideology, and Zweig's attempts to positively resignify the late-nineteenthcentury American term miscegenation (miscigenação, or mestizaje in Brazilian Portuguese) itself thus cannot escape the racial logic. ${ }^{97}$

The context of Brazilian history was even more complicated. The question of mixed race as a category is complicated in light of both the status of whitening as a measure of the relationship to Europe and the ever-shifting status of slavery. Thus mixed-race individuals in Brazil often self-identify as white even when their mixed-race status is apparent to others. The case of the most popular Brazilian writer of the period, Machado de Assis, is exemplary. ${ }^{98}$ Shortly after Machado's death in I908, journalist José Veríssimo wrote an article in which he referred to Machado as a "mulatto." Machado's close friend, abolitionist and politician Joaquim Nabuco, penned a note to Veríssimo in an attempt to prevent the use of that highly offensive word to describe the author:

Your article is very beautiful, but there is one sentence that gave me chills: "A mulatto, he was indeed a Greek of the best epoch." I would have never called Machado mulatto, and I think that nothing would have hurt him more than your having concluded this. I implore you to omit this remark when you convert your article into permanent form: The word is not literary, it is pejorative. To me, Machado was white, and I believe he considered himself to be as well: whatever foreign blood he may have had in no way affected his perfect Caucasoid makeup. I, at least, saw only the Greek in him. ${ }^{99}$

Zita Nunes has more recently argued that the making of the Brazilian nation was a "project by and for white men" and that the "father of the nation is thus the white man, the only appropriate sexual partner for both white women and women of color." 100 And this ideology had not vanished from Zweig's Brazil. For Jews, this meant dealing with the problem of identifying oneself as marginally "nonwhite" in the Brazilian context. The situation for non-Jewish Europeans, such as Thomas Mann's mother in Brazil, was radically different. She became "exotic" only when her family returned to Germany.

Zweig leaves the reader in no doubt that the Brazilian hybrid type, which he deems supreme in body and soul, does not result from just any racial fusion but precisely from the white admixture, which lends this mélange of "chocolate, milk and coffee" (ZB, 8) its cosmopolitanist face. This wording conveys the full extent of Zweig's disturbing fetishism of race and colonial slavery, for 
it translates the biblical notion of the "land of milk and honey" into the context of Brazil's colonial predicament. Brazil's major economic assets—chocolate and coffee-are mapped onto its production of a corresponding palette of skin tones, in which milk - the signifier of whiteness and spiritual purity - acts as an ennobling ingredient. Throughout the text, Zweig leaves no doubt of his view that the white European immigrants, in contrast to their atavistic African and native Brazilian counterparts, have improved this racial mix through their superior intellect, culture, and technology. As a result,

one seldom sees anywhere in the world more beautiful women and children-delicate in build, gentle in manner - than among these hybrids. It is a joy to look at the half-dark face of a student and to find there an intelligence coupled with a quiet modesty and politeness. $(\mathrm{ZB}, 9)$

Although this contention must once again be read as a defense against the National Socialist obsession with racial purity, Zweig's reading of racial hybridity as an ennobling of races was itself part and parcel of racial theory. ${ }^{101}$ Indeed, most racial theorists agreed that mixing among related European groups was of beneficial effect, and even the National Socialists promoted the Aufnordung (Nordification) - that is, the improvement of European groups perceived to be partially related yet inferior, such as Poles of "Aryan" appearance, through restricted interbreeding with Germans. Zweig's intended dissent from racial theory is clear in his celebration of the productive rather than degenerate effects of mixing among Europeans, Africans, and Native Americans, which racial theorists would have seen as the downfall of civilization. Furthermore, Zweig positions extensive mixing of different "blood-groups" (ZB, I35) at the center of his European narrative itself in claiming that "the first European arrival in Brazil, the Portuguese of the sixteenth century, is anything but of pure race. He represents, in fact, a mixture of his Iberian, Roman, Gothic, Phœnecian, Jewish, and Moorish ancestors" (ZB, I35).

This description of the Portuguese as an inherently mixed-race group implicitly parallels the conception of the Jews, whom racial theorists since Houston Stewart Chamberlain had constructed as the quintessential mongrel race. Through this construct, which affords the Jews a special status within the Portuguese mix and the European arrivals in Brazil more generally, Zweig implicitly positions the Jews at the center of his cosmopolitanist narrative. The majority of early colonists, he claims, were rabble, brutal slaveholders who pillaged native villages and raped native women. Arriving in the mid-sixteenth century, the Jesuits added a humanist element to this mix. Not yet the religious, politi- 
cal, and economic power they would become in later centuries, the Jesuits represent a purified power striving for spiritual rather than physical or material superiority. Zweig depicts the Jesuits as a humanizing force that opposes the enslavement and destruction of native Brazilians, seeking instead to civilize them through religious conversion and racial hybridization:

Just because the native standard of living is low, they shall not sink still further into [the conditions of animalism] and slavery. They shall, in fact, be raised up, made into conscious members of the human race, and through Christianity they shall be drawn toward western civilization; and through miscegenation and education a new nation shall develop here. $(\mathrm{ZB}, 29)^{102}$

In Erasmus, Zweig had similarly portrayed the humanist project as an effort to lift the lower strata of society into the higher echelons of culture. Just as the humanists envisioned a common European project, the Jesuits in Brazil strive to transcend the divide between "a master nation of whites and a slave nation of coloured folk" and to create "a unified free people on free soil" (ZB, 37).

Contrasting with "the inferiority of the cultural material sent to Brazil by the Portuguese" (ZB, 53), Jesuits and Jews (as well as the Dutch) represent the noble exceptions. The freshly baptized Jews are, in fact, "the only colonists who arrive of their own accord" (ZB, 23) rather than fleeing persecution. Having accepted baptism while still in Portugal, the Jews are motivated by caution and fear during the looming Inquisition. Entire communities of baptized and unbaptized Jews settled in the Brazilian harbor towns, becoming the country's "first real civilian colonizers" (ZB, 23) and thus its oldest families. However, Jews were not simply the first actual Brazilians, given that they chose this land more or less voluntarily; "with their knowledge of the world market" (ZB, 24), they began to create the later wealth of the Brazilian export economy. Through this construct, Zweig once again positions Jews at the core of the humanizing mission of the cosmopolitan.

\section{Lion Feuchtwanger's History in Exile, the Josephus Trilogy}

Whereas Roth and Zweig maintained their diasporic cosmopolitanism until the end of their lives, Lion Feuchtwanger's turned from an affirmation of cosmopolitanism to Zionism in the second and third volumes of his Josephus trilogy, which were written in exile. In terms of the circumstances of its writing from 
its beginnings in Weimar Germany to completion in exile, Josephus parallels Thomas Mann's Joseph. Yet Feuchtwanger drew different conclusions from the new Jewish reality of exile and annihilation. Unlike the other writers, Feuchtwanger's realization of the failure of the cosmopolitanist project changed the perception of the Jews' particularist universality that the first volume of his trilogy had claimed. This shift is obvious in the trajectory of his trilogy, which moves from the initial critique of Jewish nationalism in the first volume to its reconsideration in the third volume. The National Socialists' rise to power thus dramatically changed Feuchtwanger's thinking about the relationship between nationalism and cosmopolitanism, a development that his essays also echoed.

This shift over the second volume was no doubt conditioned by the dramatic change in Feuchtwanger's life circumstances during the decade during which he worked on the trilogy. ${ }^{103}$ In I932, when the first volume was published, Feuchtwanger had already conceptualized and completed much of its successor, but the National Socialists looted Feuchtwanger's house in March I933, while he was traveling abroad, and destroyed his drafts. Feuchtwanger and his wife settled in southern France, where he completed the reconceptualized volume in I935. After several other projects, Feuchtwanger returned to the trilogy in I939, but its completion was delayed by his two-month internment at the French Les Milles and Saint Nicolas camps in I94I. After escaping from Saint Nicolas, Feuchtwanger went into hiding in Marseille, where he resumed working on the third volume. Feuchtwanger and his wife ultimately escaped to the United States, where the first complete edition of the trilogy appeared in I942. Only in I945 did Berman-Fischer publish the German original.

Whereas Feuchtwanger's first volume, through the figure of Josephus, criticized Jews who continued to cling to their Jewish particularity, the second and third volumes returned to a proto-Zionist affirmation of Jewish nationalism on Judean soil. In light of the violent Roman onslaught, the second volume sees the Jews beginning to abandon their "universal mission which had been faithfully carried out for centuries." 104 The novel suggests the destruction of the cosmopolitan Jewish mission in the Romans' murder of Josephus's son, Matthias, the last in his Jewish line, who Josephus had hoped "would attain what he himself had not been able to attain: to be a Jew and at the same time a Greek, a citizen of the world." 105 In the second volume, Josephus's dream of the Jew's particularist universality had already begun to clash with the violent antiJewish hatred that is spreading among the Romans and their allies. In an allusion to the National Socialist ideology, the German troops stationed in Rome are particularly hostile to the Jews: 
There was one species of human beings that got on their nerves: the Jews. In the swamps and forests of Germany wild legends were current about the peoples of the East, and about the Jews in particular, how they hated all fair-haired faces and loved the sacrifice of blond heads to their donkeyheaded God. These bogey tales still reverberated in the minds of the German troops who were stationed at Rome, and they were liable to panic whenever they encountered people from the East. (JR, 239)

Under the new emperor, Domitian, a figure with a strong resemblance to Hitler, Rome's war campaigns reflect ever more clearly the National Socialist war of total annihilation: "This was the ruthless countenance of Rome which doomed to destruction everything in which it sensed the slightest hint of menace to its power" (JR, 320). ${ }^{106}$ Through the Roman war against the Dacians to the east on the Danube, Feuchtwanger thus invokes the National Socialist campaign in Eastern Europe, with its special implications for the destruction of European Jewry: "The new war that now came rolling onward, this war in the East, could have unforeseen consequences for him and for Judæa" (DWC, Io).

The Jews, having been "the first on earth to proclaim that their God belonged not to them alone but to the whole earth, turned into the most fanatical particularists" (JR, 363). Nationalist violence breeds armed resistance, which the novel increasingly condones through Josephus's renewed gravitation toward the Judean cause. However, the novel does not leave this without debate. In an apparent allusion to World War I, Feuchtwanger thus has Joseph's rival and friend, Judean writer Justus, blame the lost Judean War for driving the younger generation toward the impotent Christian messiah. "The present generation," he surmises, "have little reason to imitate their fathers. Their fathers waged that dreadfully foolish war, and were dreadfully defeated, as was only right" (JR, 533). In response, "the sons have fashioned another crutch for their weakness, they pretend to themselves that a Messiah can help them, a Messiah who died for them on the cross. Belief in the nation, belief in the Messiah: both of them a foolishness, an expression of weakness" (JR, 534).

Feuchtwanger here implicitly links Christianity to the pacifist response to World War I, which had also informed Zweig's notion of an intellectual cosmopolitanism that must abstain from political action. In the face of total destruction, Feuchtwanger suggests, such a purely intellectual stance is no longer viable. The novel's early Christians, who have rejected the radical nationalism of their Jewish counterparts, now present another avenue toward the universalism that the Jews have largely abandoned. No longer promoting the Jewish God as 
Israel's inheritance but rather the God of the entire world, they seek to unite their teachings with those of the Jews and Greeks. In doing so, however, their cosmopolitanism has become diluted because it lacks the deterritorialized particularity of the Jews. Cosmopolitanism and nationalism, Feuchtwanger has Justus contend, ultimately condition each other, and the Christians are adept at neither:

The universalism of these people . . . is a mass commodity like all that they teach. They purchase their universalism at the expense of all that Judaism has achieved in the way of a great and strong tradition, of a history that has become spirit. One must have experienced nationalism in order to know what universalism is. $(\mathrm{JR}, 459)^{107}$

The Christians' meek pacifism and diluted universalism thus fail to respond to the crisis of the Jews' annihilation. Josephus's renewed turn toward the Jewish national cause, which Feuchtwanger penned under the immediate impression of his own internment and impending death, suggests that violent destruction necessitates armed resistance, even if this resistance leads to death and tragedy. The cosmopolitanist project is temporarily suspended, yet the German title of the trilogy's last volume, Der Tag wird kommen (The Day Shall Come), suggests the utopian hope that its moment will return. It is not incidental that the novel represents this path through two Jewish writers, Josephus and Justus, for Feuchtwanger attributes to the politicized Jewish writer a special role in preserving the cosmopolitanist project for future generations. While the writer's role may indeed seem politically inconsequential- "It was easy enough to be bold at one's desk and to feel a cosmopolitan" (JR, 35 I) - the writer's position is by no means neutral, for his power lies in his ability to shape history through writing:

The statesman passes away and his work passes away. The general dies and his triumphs fade. Are their achievements real and palpable? ... And then comes the writer and takes these events in his grasp and presents them concretely, giving them a clear and delicate outline, so that they are visible for all time. . . . He has the mysterious power of staying the toppling wave so that it does not break but remains imperishably fixed for ever. This fact was early recognised by the Jews. For generations their history has been preserved in a tradition revealed to them by their God. They write history in the grand style. (JR, I33) 
Josephus's unattainable dream to become a cosmopolitan in a world of sectarian violence is ultimately crushed in the murder of his son, which the emperor, Domitian, had plotted to deal Josephus a vital blow. Josephus now renounces his cosmopolitanism and joins the militant particularists in Judea on their suicidal mission.

Josephus's path from Jewish nationalist to cosmopolitan and his ultimate return to the Jewish national cause exemplify Feuchtwanger's view of the failed cosmopolitan project. In contrast, a distinct Jewish particularity played a far less important role in Zweig's oeuvre, which, with the exception of his Jeremias, largely abstained from treating Jewish themes in epic format. Zweig's suicide in Brazil, the country that he cherished and praised as a cosmopolitan model for the future of humanity, may convey his sense of personal failure to make a fresh start in this new world. This, however, does not signal an enforced embrace of a Jewish particularist stance through his persecution as a Jew. On the contrary, Zweig emphasized the vital necessity of the cosmopolitan project for humanity into his final works. However, this path is no longer viable for the individual under the circumstances of extreme political adversity. Zweig's Erasmus had claimed the liberal cosmopolitan's essential pacifism, a position that ultimately renders the individual politically ineffective and defenseless. Erasmus, on whom Zweig had modeled himself, thus dies an isolated and shameful death. Feuchtwanger's Josephus rises to meet his enemies in battle, only to die at their hands. The cosmopolitan project remains ambivalent in texts about Jews and "exile" from the critical Thomas Mann and antagonistic Martin Heidegger to the engaged historical works of Stefan Zweig, Joseph Roth, and Leon Feuchtwanger. Thus the transformation of the cosmopolitan into the exile, the nomad into the refugee, remains suspended as the Holocaust unfolds. 


\section{Chapter 6}

\section{Rootless Cosmopolitans: German Jewish Writers and the Stalinist Purges}

\section{The Left in World War II and Thereafter}

Between the I920s and the I940s, Jews were drawn in disproportionate number to the idea as well as to the practice of communism. Yet the paradox from the I920s that inquired why there were so many Bolshevik Jews in the young USSR and yet why so very few Jews there became Bolsheviks held true for the numbers of Jews on the far left in Weimar Germany and beyond. Although a number of Jews from the young convert to Christianity Karl Marx onward became highly visible within the Communist Party leadership, the communist movement was but one arena of Jewish political engagement in the twentieth century. While Jerry Muller has claimed that "new, more modern forms of anti-Jewish animus, rooted less in religious difference than in the resentment of Jewish economic success . . . led in turn a small but salient minority of Jews to embrace Communism, the most radical form of anticaptialism," Michael Berkowitz has shown that equivalent numbers of Jews before 1933 were attracted to Zionism, some for the same economic rationale. ${ }^{1}$ Indeed, legendary German Jewish scholar Gershom Sholem and his siblings exemplify the scale of Jewish political engagement during the early twentieth century. Whereas Gershom (born Gerhard) became a noted German Zionist and later world-renowned expert on Jewish mysticism who made aliyah to Palestine in I923, his brother, Werner, was a Communist Party deputy to the Reichstag from I924 until I928. In I926 he had been ousted from the Communist Party of Germany for opposing the purge of the Trotskyites in the USSR. Another brother, Erich, represented the views of the mainstream organization of German Jews, the Centralverein deutscher Staatsbürger jüdischen Glaubens (Central Association of German Citizens of Jewish Faith). Finally, the oldest brother, Reinhold, was a German nationalist who, according to 
Gershom, would have joined the right-wing Deutschnationalen (German nationalists) had they welcomed Jewish members. ${ }^{2}$

Nonetheless, some Jews saw communism as an ideal theory through which to liberate the world from social injustice as well as antisemitism, particularly during the political rise of National Socialism in the I920s and the establishment of state antisemitism of the Third Reich. Various strands of Marxist ideology tied antisemitism to variant forms of capitalism, including the corporatism of National Socialism. Conversely, the National Socialists (and many of the nationalists across Eastern Europe) saw the interchangeability of Jews and communists as a given. Party propagandist Engelbert Huber argued in I933 that the National Socialists' political success resulted from "the time of the Jewish-Bolshevik Soviet rule in Bavaria, the time of tyranny at the hands of those Jewish 'Lenin's Boys' in Hungary, the time when Jewish criminals in Russia slaughtered all of the bourgeois intellectuals-nearly two million people."' "Jewish Bolshevism" was a given for the National Socialists, and the presence of racially defined Jews in all of these revolts from the left was seen as proof of their interconnectedness.

At the same time, Jewishness remained a contested question in Marxist theory and practice beginning with Marx's I 844 response to Bruno Bauer, "On the Jewish Question." ${ }^{\prime 4}$ In the mid-twentieth century, then, the labels of internationalism, cosmopolitanism, and Jewishness assumed deadly meanings within the Soviet Union and its later Eastern Bloc satellite countries. Finding themselves as outsiders and ultimately presumed enemies within the communist project, a number of Jewish communists and sympathizers became the earliest outspoken critics of the Stalinist crimes, which they began to address in their writings as early as the late I930s. Their works enable us to trace the Jewish leftist predicament that sustained the socialist-communist project on the one hand and ultimately called for its critical interrogation on the other. Nowhere has the examination of the Stalinist crimes occurred in a more passionate and soul-searching manner than in writings by German-speaking Jewish authors caught in the crossfire of the National Socialist and Stalinist regimes and their aftermath between the I930s and the I970s.

\section{Communism, National Socialism, and the Jews}

Between the world wars, the affinities between cosmopolitanism and communism seemed obvious, for the proponents of both ideas strove to transcend the rabid nationalism that had thrown Europe into the World War I disaster and 
fueled the rising antisemitism and the National Socialists' ascent to power. For many Jews, both cosmopolitanist and leftist ideas thus held considerable attraction, and communist internationalism in particular seemed to resonate with the cosmopolitanist sensibility. Both cosmopolitanist thought and the communist fight for social justice offered left-leaning Jewish intellectuals a route to transcend the presumed stigma of Jewish particularity through affiliation with a universalist project. This was, of course, so because communist internationalism was itself putatively heir to the cosmopolitanist strand of philosophy in the German-speaking Enlightenment. ${ }^{5}$ Under Stalin's rule, however, Soviet Party communism took an increasingly hostile stance toward cosmopolitanism and the Jews, and communist internationalism was sidelined in favor of a new Soviet nationalism.

Until the second half of the I920s, however, Jewish cosmopolitanist affinities with the communist project were not merely imagined. Following the early revolutionary condemnation of antisemitism, Soviet propaganda of the I920s officially forbade antisemitism as a "reactionary relic of Tsarism." At the same time, Jewish particularism was seen as standing in opposition to the revolutionary idea of nationalism, according to which ethnic particularities were to be completely assimilated and integrated into the Soviet national project. ${ }^{7}$ In I9I9, the Communist International (the Comintern or the Third International) was founded in Moscow to safeguard proletarian internationalism - the idea of international workers' solidarity - and to promote the global communist revolution. Together with its predecessor, the Second International, the Comintern-with participating organizations from across Europe and several Asian countries-formed one of the few global political structures promoting what Philip Spencer has termed "a radical cosmopolitan politics" to organize workers across the boundaries of the nation state. ${ }^{8}$ But from the late I920s onward, communist internationalism was explicitly pressed into the service of unfailing support for the Soviet Union, and any aberration from this line was deemed treason to the cause of communism. As Stalin declared in a I927 speech, "The International Situation and the Defense of the USSR," "An internationalist is one who, unreservedly, without hesitation, without conditions, is ready to defend the Soviet Union because it is the basis of the revolutionary movement." 9 This assertion was reiterated in the Comintern's final statutes in I928.

Communist internationalism was placed in explicit opposition to bourgeois nationalism, which was aligned with cosmopolitanism as the credo of the liberal bourgeois intellectual. Cosmopolitanism thus became seen as a product of precisely that class and its individualist strivings, which the communist movement sought to overcome. During the I930s, this campaign assumed in- 
creasingly antisemitic undertones as Leon Trotsky emerged as the figurehead of anti-Stalinist opposition. While even Stalin could not risk being openly antisemitic during this period of consolidation, his Great Purges all but destroyed the country's budding independent Jewish culture. ${ }^{10}$ Furthermore, Jews died in disproportionate numbers at the height of Stalin's terror between I937 and I938, when he purged the Bolshevist first guard, with its inordinately high numbers of Jews. But although antisemitism no doubt played an implicit role in conceiving and justifying these events, Jews were but one group among the millions of Stalin's Soviet victims between I93 I and I939. An estimated six to nine million people died of starvation, mostly in the countryside, during the forced collectivization of agriculture, and approximately three quarters of a million Soviet peasants, workers, and members of ethnic minorities also were killed. In addition, numerous communists of other nations, particularly German exiles from National Socialism, were murdered by hard-line Party comrades in the antifascist resistance struggle and behind the lines of the Spanish Civil War. ${ }^{11}$

As Stalin shifted to using the idea of antifascism to rally support for his leadership in the fight against Hitler and detract from the mass killings in the Soviet Union, internationalism became an increasingly obsolete and suspect concept. During the first years of National Socialist rule, the Comintern had kept German exiles in check and betrayed to the Party those deemed to be straying from the Communist line. During the Great Purges, however, the Comintern's early leaders were killed, as were I33 of its 492 staff members, and Stalin finally disbanded the organization in $1943 .{ }^{12}$ The same year, Stalin began his concerted attacks on cosmopolitanism to stress Soviet patriotism over any indebtedness to foreign ideas. Stalin borrowed the term rootless cosmopolitanism (byezrodnui cosmopolit) from Russian critic Vissarion Belinsky, who had coined it during the early nineteenth-century struggle against the Westernization of Russian letters to describe those whose aesthetic production was indebted to German models. Rootless cosmopolitanism soon became a code word for Jew and was easily merged with Soviet antifascism, just as the National Socialists had merged Bolshevism with the Jews.

Andrei Zhdanov's I946 appointment as director of Soviet cultural policy led to an increased stress on a pure Soviet culture freed of the degeneration represented by the West. The following year, Soviet writer Vladimir Yermilov denounced rootless cosmopolitanism as nizkopoklonstvo (servility to foreign things), a form of culture inimical to the Soviet aesthetic ideal. ${ }^{13}$ In I948, R. Miller-Budnitskaya claimed that these tendencies were found among German Jewish writers and represented an ancient Jewish trait that dated as far back as 
the writings of first-century Jewish historian Flavius Josephus and that had culminated in Lion Feuchtwanger's "reactionary cosmopolitan idea of a world state [that] meant the Hitlerite "new order in Europe." "14 These bizarre allegations no doubt rested on a deliberate misinterpretation of Feuchtwanger's Josephus trilogy.

In I949, then, a new series of openly antisemitic purges and executions began across the Soviet Union and its satellite countries. Jews were explicitly charged with harboring an international Zionist-cosmopolitanist conspiracy. As early as the I930s, however, a number of Jewish writers had felt a growing unease at Soviet politics and propaganda, which they believed to have antisemitic undercurrents. These concerns clashed with their continuing sympathies with the communist project to liberate the world from social injustice, of which they saw antisemitism as one part. In his I927 essay, The Wandering Jews, for example, Austrian Jewish writer Joseph Roth, who stressed his cosmopolitanist affinities throughout his interwar writings, claimed that the Soviet Russia of his day was "the only country in Europe where anti-Semitism is scorned, though it might not have ceased." 15 While Russian antisemitism might persist on a popular level, the Russian Revolution had swept away the idea of national (here in the sense of ethnic) politics as well as the idea of the Jews' ethnic particularity. This, Roth contended, would make both Zionism and antisemitism - and perhaps even Judaism itself—obsolete, but the greatest achievement of the revolution would be its release of Jews and non-Jews alike as "one people is freed from the stain of suffering and another from the stain of cruelty" (WJ, I I4). In the new afterword to the volume, which appeared in I 937 in the midst of Stalin's Great Purges, Roth conceded

that the position of the Jews in the Soviet Union, as I tried to describe it in the last section of my book, has in all likelihood changed since that time. ... I remain convinced, however, that nothing in the underlying attitude of Soviet Russia towards the Jews has altered. (WJ I I7)

Roth's assertion illustrates the pains that many liberal-minded Jews felt at acknowledging the Communist Party's increasingly problematic politics regarding the Jews in its ranks. Within the German Communist Party, which largely failed to express its solidarity with Hitler's Jewish victims and even deemed Jews a liability and thus excluded them from its resistance cells, the rifts were evidently clear. ${ }^{16}$ For many, however, a systematic ostracism and persecution of Jews in the Soviet Union, the home of the proletarian revolution, remained unthinkable. Nevertheless, in exile from National Socialist Germany, 
the situation of Jewish intellectuals became increasingly untenable, given that they felt themselves caught in the crossfire of the National Socialists' persecutions and the Stalinist purges, both of which had deadly consequences. Hitler's references to a "poison injected by the international and cosmopolitan Jew[s]," who had formed a conspiracy to destroy the Aryan race, were too similar to Stalin's I950s charges that the Jews were "rootless cosmopolitans" and had created an international Zionist conspiracy to destroy the Soviet Union and undermine its sphere of political influence in the postwar Eastern Bloc. ${ }^{17}$ "It now became startlingly clear," German Jewish political scientist Hannah Arendt wrote in her seminal Origins of Totalitarianism (I950), "how deep an impression this mainstay of Nazi ideology must have made on Stalin."18 Arendt finds the first public indications of Stalin's antisemitism, which drew its "propaganda value" from popular antisemitism in Russia and its satellite countries, in the I939 Hitler-Stalin pact (OT, xxxix).

From the late I930s on, exiled leftist Jewish writers led the way in the critical examination of the Stalinist atrocities. Alice Rühle-Gerstel and Arthur Koestler opened the debate, followed by others including Manès Sperber, Peter Weiss, and Stefan Heym. Given the close historical proximity of Stalin's crimes to Hitler's, it seemed almost inevitable that these writers would draw analogies between these atrocities, if perhaps mainly to draw attention to the ongoing Stalinist persecutions. Indeed, these intellectuals' experience of political and racial persecution by the National Socialists significantly brought into focus their budding critique of Stalin's regime, particularly because Hitler's rise to power, their flight into exile, and the beginning of Stalin's Great Purges not only closely coincided but were also intricately linked. As Sperber wrote in the I974 foreword to the new edition of his sociopsychological essay, "Zur Analyse der Tyrannis" (On the Analysis of Tyranny, I937),

We felt the "Il Duce a sempre ragione" and the well-organized hysteria of "Heil Hitler" to be the essence of fascism, whereas the systematically organized glorification of Stalin, then, necessarily and directly contradicted historical materialism and the principles of the Marxist proletarian movement.

But tyranny, Sperber argued, was not merely an external imposition of power; on the contrary, it was "the tyrant as well as those who make him."19 In their quest for personal responsibility and agency, these authors' soul-searching writings differ considerably from the postwar debates regarding totalitarianism and the comparability of the National Socialist crimes, which have usually bolstered Western Cold War ideologies and their aftermath. 
Writing from her exile in the United States, Arendt was the first to theorize in depth the possible points of comparison between Hitlerism and Stalinism. Arendt established her enduring scholarly fame through Origins of Totalitarianism, even though she did not coin the concept of totalitarianism itself, which had been in use since the I930s to compare the Hitler and Stalin regimes. Arendt's work arose from the post-I945 attempts to bring the National Socialist perpetrators to justice for what were newly dubbed "crimes against humanity" and thus to instate what Seyla Benhabib has more recently termed a "cosmopolitan norms of justice" inspired by Kant's call for a universal law in his Perpetual Peace. ${ }^{20}$ As Arendt wrote in the preface to the first edition of Origins,

Antisemitism (not merely the hatred of Jews), imperialism (not merely conquest), totalitarianism (not merely dictatorship)—one after the other, one more brutally than the other, have demonstrated that human dignity needs a new guarantee, which can be found only in a new political principle, in a new law on earth, whose validity at this time must comprehend the whole of humanity while its power must remain strictly limited, rooted in and controlled by newly defined territorial entities. (OT, ix)

Origins gave the concept of totalitarianism broad currency. In Cold War political rhetoric, the term now served to discredit the Eastern Bloc regimes against the supposedly cleansed democracies of the West, including West Germany. ${ }^{21}$ Totalitarianism thus soon became a contested concept. For obvious reasons, Eastern Bloc ideologues rejected any analogies between state socialism and National Socialism, and behind the Iron Curtain, any discussion of the Stalinist crimes and their legacy remained taboo even after Nikita Khrushchev's secret revelations to the I956 Soviet Party Congress. Criticism also came from Western intellectuals who were concerned about the legacy of the National Socialist past in Western Europe, particularly West Germany, where the term totalitarianism threatened to obliterate the barely acknowledged legacy of the National Socialist past.

In At the Mind's Limits, Austrian Jewish writer and Auschwitz survivor Jean Améry thus argued that despite the heinous atrocities committed by Stalin and after 1945 in countries such as Chile, Brazil, and Cambodia, the National Socialist "Evil really is singular and irreducible in its total inner logic and its accursed rationality." Améry debunked any analogies between communism and National Socialism in particular as essentially different. Whereas it was possible to imagine a communism with a humane face, given the process of de-Stalinization in Eastern Europe after 1956, Hitler's policies of extermina- 
tion and enslavement formed the core of National Socialism. Citing a statement by German writer Thomas Mann in exile, Améry concluded that "no matter how terrible Communism may at times appear, it still symbolizes the idea of man, whereas Hitler-Fascism was not an idea at all, but depravity." 22 Améry's assertion that the communist idea as well as the socialist system could not be collapsed with the atrocities committed under Stalin, Mao, or Pol Pot has recently been reiterated by German Holocaust historian Detlev Claussen, who points out in his foreword to the new German edition of Léon Poliakov's From Antizionism to Antisemitism that such discussions now falsely focus on charging Marx with the supposed plans for these killings. ${ }^{23}$

Although historians in the West have gradually abandoned the concept of totalitarianism, the past three decades have seen a growing body of comparative historiography on National Socialism and Stalinism. Yet a nuanced discussion of the possible relationship between the two systems and their politics of terror is yet to emerge. To date, such discussions display their roots in the Cold War rhetoric that sought to minimize the National Socialist atrocities through such analogies and thus absolve the Western allies of their varying histories of collaboration in the annihilation of European Jewry. In the I980s, when such analogies emerged in the field of academic study, they were still met with wide outrage and considered an expression of fringe right-wing attitudes. Such was the response to two now infamous essays by Ernst Nolte, a professor of history at West Berlin's Free University.

In the first of these two pieces, "Die negative Lebendigkeit des Dritten Reiches" (The Negative Vitality of the Third Reich) (I980), Nolte criticized the assumption that the "violent crimes of the Third Reich are singular." Instead, he drew a line of class-based terror from the French Revolution (and its rightwing responses) to Stalinist terror (and the National Socialist genocide as its response). ${ }^{24}$ These events, Nolte contended, had found their preliminary climax in the recently discovered atrocities of Cambodia's Pol Pot regime between I975 and I978. Nolte drew his proof from an indicatively phrased announcement in the East German communist daily Neues Deutschland on 6 December 1978, on the eve of the Vietnamese invasion of Phnom Penh, which effectively ended the Cambodian genocide. According to this announcement, "The reactionary clique of Pol Pot/Ieng Sary . . . exterminated the villages and landscapes, in which our people had lived since millennia" and "incarcerated our fellow citizens in hidden concentration camps." "The events in IndoChina," Nolte concluded, "should now have made apparent what precisely constitutes original and copy with regard to annihilation based on class, ethnicity, and group affiliation." 25 
Nolte reiterated this claim in terming the National Socialist genocide against the Jews an "Asiatic crime" in his 1986 follow-up article, "Vergangenheit, die nicht vergehen will" (The Past That Refuses to Pass), which would spark the landmark German historians' debate ${ }^{26}$ Nolte's and others' subsequent attempts to academically legitimize comparisons between National Socialism and Stalinism became discredited. However, the opening of Soviet archives after 1989 brought new documentation to light, and such comparisons have since resurfaced under partially revised — yet familiar—parameters. In his foreword to German historian Joachim Hoffmann's evocatively titled Stalins Vernichtungskrieg (Stalin's War of Annihilation), Manfred Kehrig conceded that World War II was "a life-and-death battle between two totalitarian systems that used the same means and methods to achieve their political aims.. ${ }^{27}$ When the volume first appeared in 1995, Kehrig was working for the German Military Research Office, and his foreword gave Hoffmann's book such official weight that it was debated in the German parliament.

Hoffmann's borrowings from Nolte are evident in his attempts to compare the "mass murders" committed by the Stalinist regime "based on motives of class struggle" to those of Hitler's regime based on motives of "race struggle" (SV, 325). That Hoffmann really sought to redress the balance between the historical constellations of German Holocaust perpetrators and their Jewish victims becomes apparent in his chapter on the Wehrmacht, which is subtitled "The Anti-German War and Racial Propaganda of Hatred" and focuses extensively on the writings of Soviet Jewish writer Ilya Ehrenburg. ${ }^{28}$ On the other side of the debate stands what Hoffmann, in his foreword to the second edition, considers "the inflammatory traveling exhibit The Wehrmacht War of Annihilation" (SV, I5), which sought to reveal the Wehrmacht's participation in war crimes against civilians behind the Eastern Front. ${ }^{29}$

Yale historian Timothy Snyder's recent probing into the relationship between Stalinism and National Socialism in his Bloodlands (2010) inadvertently raises the question of the comparability of Hitler's genocide against European Jewry with Stalin's atrocities against his own population. In particular, Snyder favors the generic term mass killing over genocide precisely to propose, albeit in a far more complex manner than Nolte, that Stalin's policies ultimately facilitated Hitler's. ${ }^{30}$ While Snyder's observations on the problematic political and discursive history of genocide are undoubtedly insightful, the blanket term mass killings risks losing the discursive and political specificities of the National Socialist crimes, which found their justification in modern racial and broader genetic biology and thus draw their historical basis from German and European antisemitic and colonialist mass violence. Indeed, Snyder's vision of the Holo- 
caust is severely limited by the regional focus of his study on that part of Eastern Europe where the spheres of Hitler's and Stalin's military aggression overlapped. When Snyder rejects the association of "the Holocaust with rapid industrial killing" as "too simple and clean" (BL, xiv), given that as many of its victims were shot as were gassed, his vision of the ideological, political, and practical specificities of Hitler's and Stalin's killings becomes further limited.

This is so because the widespread perception of the National Socialist camps as "Death Mills" (the title of Billy Wilder's famous I945 documentary) referred as much to the technical ingredients of the German camp atrocities, for which the death camps stood synonymous-the gas vans and gas chambers, the mass-capacity furnaces and constantly smoking chimneys-as it did to the nonstop killing process, which followed the paradigm of industrial shift work. Jean-Claude Pressac's Auschwitz: Technique and Operation of the Gas Chambers (I989) conveys the extent of technological engineering that was required for the mass production and destruction of corpses in the death camps. This inversion of the twentieth-century narrative of cultural advance through technological progress sparked the postwar discourse about the Holocaust as an unprecedented rupture in civilization.

This is, of course, not to say that the comparative study of atrocities is in and of itself illegitimate but rather to point out the authors' inherently political agenda. By proposing the Holocaust as a function of modernity, the work of Polish-British sociologist Zygmunt Bauman, for example, has often been misunderstand to suggest an arbitrariness of the Holocaust in relation to other mass atrocities despite Bauman's explicit rejection of classing the Holocaust "as another item (however prominent) in a wide class of that embraces many 'similar' cases of conflict, or prejudice, or aggression." Instead, Bauman sought to undo the focus on "the Germanness of the crime" as "an exercise in exonerating everyone else, and particularly everything else." 31

More recent studies such as Michael Rothberg's Multidirectional Memories have further demonstrated the necessity of a nuanced and contextual study of memories of the Shoah and crimes committed in the European colonial territories. Here, however, a nuanced examination of Stalin's crimes tends to fall by the wayside, such as when Rothberg critiques Arendt's linkage of "disparate phenomena such as imperialism, Nazism, and Stalinism" in Origins. ${ }^{32}$ Such blanket rejections of any comparability of these phenomena disregards, for example, Russia's imperial policies in and orientalist conceptions of Central Asia, which the Soviet Union inherited and pursued under different parameters. ${ }^{33}$ Furthermore, the overlapping experiences and memories of National 
Socialism and Stalinism form part of Europe's multidirectional memories, which have been coming to the fore in German debates since unification.

Indeed, the close connections between the ways in which Stalinism and National Socialism implemented their systems of terror are evident in their overlapping temporality, their drive for total control by the state and organization of its citizenry into politically streamlined mass organizations, and their mass atrocities and competing expansionist power struggles. The sidelining of Stalinism in these comparative studies of the Holocaust is thus itself born of the old Cold War divides, in which such comparisons constituted a Holocaust apologia. But nothing was further from the heart of those German-speaking Jewish writers who sympathized with the communist cause and were caught in the crossfire between the two regimes. Their writings offer a route of investigation into both systems that does not shirk the questions of political responsibility and personal agency on either side of the political divide.

\section{Writing the Stalinist Purges: Alice Rühle-Gerstel, Arthur Koestler, and Manès Sperber}

Although Arthur Koestler's Darkness at Noon, first published in German in I940, provided the famed template for this body of critical writing, it was preceded by Alice Rühle-Gerstel's novel, Der Umbruch; oder, Hanna und die Freiheit (The Break; or, Hanna and Freedom). ${ }^{34}$ Today Rühle-Gerstel, who was born into a middle-class German-speaking Jewish family in Prague in I 894, is largely forgotten, even though her work has recently seen something of a revival on the German literary scene. After completing a doctorate in philosophy in I9I7, when it was unusual for women to earn even undergraduate degrees, she moved to Munich and later Dresden. Rühle-Gerstel developed a public profile as a women's rights activist and proponent of Alfred Adler's individual psychology while strongly sympathizing with the Austrian Social Democratic Party as well as Austro-Marxist educational programs. ${ }^{35}$ During her years in Germany, Rühle-Gerstel published several psychoanalytic, Marxist, feminist, and sexological works, including a book on sexual analysis co-authored with her husband, Otto Rühle. ${ }^{36}$

From I932 to I935, the couple lived in Prague, where Rühle-Gerstel's friendship and rumored lesbian relationship with Czech writer Milena Jesenská-Franz Kafka's onetime lover and recipient of his Letters to Milenabrought Rühle-Gerstel into contact with Czech oppositional communists and 
Trotskyists. ${ }^{37}$ Despite her personal sympathies for Trotsky, especially after his exclusion from the Soviet Communist Party, she remained skeptical of his political theories. ${ }^{38}$ In I936, Rühle-Gerstel followed her husband into Mexican exile, where she wrote The Break at the height of the Stalinist purges. The novel, which critically examines the political cleansings among the German exile community in Czechoslovakia, was not published until I984, more than forty years after her death. In Mexico, Rühle-Gerstel, who firmly saw herself as an internationalist and anti-Stalinist, struck up friendships with Diego Rivera, Frida Kahlo, and Leon Trotsky, who was murdered there at Stalin's command in I940. At the same time, both she and her husband avoided the local German emigrants' organization, Nationalkomitee "Freies Deutschland" (National Committee for a Free Germany), in which writers such as Bodo Uhse, Anna Seghers, and Rühle-Gerstel's childhood friend, Egon Erwin Kisch, were active. According to the Rühles, the committee was run by faithful Stalinists who had caused the couple's removal from their jobs in the Mexican Ministry of Education. This is not implausible, given that the Stalinist-dominated Mexican trade unions of the time would have taken issue with the Rühles' work for the Dewey Commission, whose I938 report had cleared all the defendants in the Moscow trials, including Trotsky, of the charges against them. ${ }^{39}$ As a result, the Rühles lived in bitter poverty, largely cut off from the public sphere. ${ }^{40}$ Deeply disillusioned personally and politically by her dual experience of National Socialism and Stalinism, Rühle-Gerstel committed suicide in I943 by jumping from the window of her flat in Mexico City, just hours after her husband's death.

The Break weaves together the multiple political and personal dimensions that Rühle-Gerstel had addressed in her earlier essays. These dimensions are also reflected in the novel's title, which in German indicates both rupture and the process of newspaper page makeup. Hanna Aschbach, the protagonist, who works for a Prague newspaper, realizes that "Make-up occurs every day" (B, 260), indicating the huge political and personal ruptures of the time, which here variously signify the National Socialists' rise to power, Hanna's emigration from Berlin to Prague, her gradual alienation from the communist-led exile movement, and her liberation from both bourgeois and the Communist Party's conceptions of female subjectivity and sexuality. Rühle-Gerstel's dissent from hard-line Party politics thus lies precisely in her holistic conception of the Marxist personality type, which retains the important features of individuality - marked as "bourgeois" in official Party propaganda-even under the conditions of class struggle and the fight against fascism. Similar constructions reappear in the works of Rühle-Gerstel's friend, Manès Sperber, and 
later in those of Peter Weiss. In all of these novels, the protagonists representing such holistic views of personality remain outsiders to the Communist Party and become its suspects.

In Rühle-Gerstel's work, as in the later writings of Koestler and Weiss, Jewishness remains an implicit or subdued feature, reflecting the high degree of assimilation common among Jewish authors who later joined the communist movement. The revolutionary relegation of Jewishness to a "secondary problem" that would be resolved through class struggle did not pose an inherent problem for these authors' already secularized self-conceptions. But this did not necessarily mean that they rejected their Jewishness. Like Stefan Zweig, Joseph Roth, and Lion Feuchtwanger, who had embraced the cosmopolitanist label as an expression of their Jewish sensitivity during the interwar period, many Jewish communists saw their political engagement as the necessary consequence of the lethal history of European antisemitism since the Middle Ages. Their fight for overall social justice stemmed from the awareness that Jews as an integral part of modern European culture had also been the historical victims par excellence of European ostracism and violence. Given the extraordinary contribution of German-speaking Jews, including Karl Marx, Ferdinand Lassalle, and Rosa Luxemburg, to the communist and socialist movements, Jewish communists could see themselves as part of a specifically Jewish legacy within the political fight for social justice, which, some argued, went back to the Jewish religion's early attempts to establish forms of welfare for the socially disenfranchised, including the stranger and the slave. This secular Jewish awareness rendered these writers sensitive to the early signs of antisemitism in Stalinist politics though it lay dormant in the I930s propaganda against bourgeois intellectuals and internationalists.

Jewish themes and associations in writings by these authors thus serve as a site of disturbance of and resistance against the grip of Stalinism. While The Break, for example, makes only passing reference to Jews alongside other émigrés and among the politicized, Hanna Aschbach, the daughter of a Czech mother and a German father, bears implicit Jewish connotations through her name as well as through her brother's occupation as a banker. Having grown up bilingual and between national affiliations, Hanna faces the predicament of nonbelonging, which echoes the deterritorialized state of Jewish identity in the diaspora. Hanna's sense that because "her father was German [and] her mother was Czech, she belonged neither here nor there" $(B, 34)$ reflects Gregor Samsa's fantastical wanderings across all the planes of his room in Kafka's Metamorphosis, wanderings that have been read to symbolize the shifting ethnic, national, and cultural locations of acculturated Jews in early twentieth-century Prague. ${ }^{41}$ Hanna's predica- 
ment of nonbelonging fuels her work for the Party, since "we are internationalists, words such as strange lands, home country, abroad mean nothing to us, for there are comrades everywhere" $(\mathrm{B}, 66)$.

Hanna's internationalism, however, renders her a singular figure in the text, and her constant perception by other protagonists as an outsider reflects the Jew as perpetual outsider, an ostracized status that Arendt would describe so memorably in The Jew as Pariah (I944) just a few years later. ${ }^{42}$ The text includes numerous moments of alienation, such as when the staff at the German refugee hostel treat Hanna with suspicion as a result of her "face, which seemed so foreign to the workers" (B, 63), as well as of her educated middleclass origins: "The men looked at her quizzically, she spoke differently than them, but one of the women reached out to shake her hand" $(\mathrm{B}, 54)$. Hanna is then interrogated by one of the leaders, who accuses her of having stolen money from her resistance group back in Berlin. This is only the beginning of Hanna's decline, which ends when the Party itself betrays her to the police for having engaged in political work, thus invalidating her refugee status and leading to her extradition from Czechoslovakia.

The novel focalizes this process of disillusionment through Hanna. When she arrives in Prague, Hanna still idolizes the Soviet Union from her I93 I visit, with its spirit of awakening that resulted from its new agricultural program and five-year plan and the Russians' fervent love for their country. Back then, she had still "understood, condoned, optimistically justified . . . the masses' heroic starvation during the first five-year plan," which she had witnessed. Now, however, "the second five-year plan had come around, the masses continued to starve heroically" (B, I20), while the most efficient workers were beginning to enjoy a better lifestyle. Hanna sees the situation as akin to the "worst type of capitalist slave-driving for the piece rate" (B, I2O). By suggesting that the mass starvation of millions of Soviets during the early I930s was not simply a necessary stage in the construction of the new Soviet society but the product of willful negligence at best and cynical calculation at worst, Rühle-Gerstel injects severe doubt into the official communist narrative of Soviet moral and social superiority.

As the novel progresses, comparisons with the National Socialist persecutions become ever more explicit. Hanna thus feels that the Czech Party's attempts to bring its members into line with new Soviet directives are "awfully similar to Hitler's persecutions into the third and fourth generations" (B, I68), and she believes that the Communist daily writes "almost as nationalistically as a fascist paper" $(\mathrm{B}, 348)$. An inkling of the violent nature of the purges shines through the ellipses in the unfinished sentence when Hanna peruses the newspaper's reports “of vast party purges and its threats of an iron broom 
that . . . set in such small print so as to be hard to read" $(\mathrm{B}, 348)$. The Party ultimately stands for the political Right, as the novel has the Trotskyist Luise respond to Hanna's final plans to join the Spanish Interbrigades: things might "get wrecked there too; of course the party will ensure that the lovely Popular Front turns right wing" (B, 402).

Hanna's alienation from Stalinist Party communism runs parallel to her move toward two alternative male figures, Leon Trotsky and Anatol Svoboda, both of whom the novel ultimately treats with hesitation, albeit in different ways. Although Trotsky does not appear in the novel himself, the text sees several of Hanna's friends turn to Trotskyism as a rallying point against hardline Stalinist Party communism. But Rühle-Gerstel does not let Hanna replace Stalin with Trotsky as a new political father figure. Instead, Hanna makes her way to Spain, where the Popular Front is as yet a leftist movement in flux and thus offers itself more readily to Rühle-Gerstel's vision of a fluid Marxist internationalist, gender, and sexual politics beyond Party structures. But the novel ends with Hanna alone in the geographic no-man's-land between Bohemia and Austria, suggesting that this is utopian vision cannot be realized under existing political conditions.

Svoboda, the editor of the Czech newspaper where the Prague Party chapter has placed Hanna, offers her a more tangible alternative. The paper bears his last name, which means "freedom," and both the character and the publication represent the positively configured bourgeois attributes of education, political liberalism, and cosmopolitanism. In its first editorial, the newspaper had thus

praised in measured words libertarianism, patriotism, and cosmopolitanism as its leitmotifs, while cleverly inserting a few classical quotes and a number of bawdy popular sayings. $(\mathrm{B}, 72)$

Of course, the Party quickly denounced the paper as a "capitalist harlot, camouflaged with liberal phrases" (B, 73), but the novel conveys the considerable allure of its values through Hanna's infatuation with the much younger Anatol. The two initially seem quite similar: like Hanna, Anatol is of mixed ethnic origins, and his cosmopolitanism is thus linked to the theme of ethnic hybridity, as was Hanna's internationalist outlook. The son of a Hungarian mother and a Czech father, Anatol, like Hanna, implicitly displays the physical and intellectual attributes of the Jew. At their first encounter, Hanna perceives Anatol with his "glowing . . . dark eyes," "olive-yellow" complexion, and "strange, non-European" appearance as "nervous, nervous, a nervous aesthete" (B, 98, I36). After all, the claims of the Jews' hybrid racial origins, together 
with their alleged special proclivity for neurasthenia and lack of cultural essence, lay central to the mythology of modern racial antisemitism. ${ }^{43}$

With her husband, Karl, a communist resister and sex educator, interned in a National Socialist jail in Germany, Hanna feels herself single and thus free to embark on a relationship with Svoboda, in which she finds herself fully orgasmic for the first time in her life. The conditions of exile and political illegality thus allow Hanna to temporarily suspend the constraints of both bourgeois and communist conceptions of heterosexual relationships, and her liaison with Svoboda ultimately catalyzes her growing disagreement with the Communist Party. This portrayal seems to reiterate and apply to Stalinism German Jewish Marxist psychoanalyst Wilhelm Reich's construction of the sexually repressed personality as the essential predicament of the authoritarian regimes that fascism epitomized. As Reich wrote in his seminal The Mass Psychology of Fascism (I933),

Sexual repression strengthens political reaction and makes the individual in the masses passive and nonpolitical; it creates a secondary force in man's structure - an artificial interest, which actively supports the authoritarian order. When sexuality is prevented from attaining natural gratification, owing to the process of sexual repression, what happens is that it . . is distorted into brutal sadism, which constitutes an essential part of the mass-psychological basis of those imperialistic wars. ${ }^{44}$

Conversely, then, Reich claimed, "the objective loosening of the reactionary shackles placed on sexuality" would effectively disable political reaction, which "would have no answer and no counter-ideology." 45 This process also seems at work in The Break, where the liberation of Hanna's libido develops alongside her dissident status in the Party. Tellingly, the consolidation of Stalinist Party politics materializes toward the novel's end in the announcement of a new and more restrictive sexual politics. This, Hanna ponders, seeks to reinforce precisely those "bourgeois clichés-family life, marital fidelity, the comfortable home" (B, I66) that the Party had previously denounced. At the same time, the novel lets the Party's older, more liberal sexual politics emerge as only seemingly conducive to a sexually awakened and thus truly liberated personality. The Party's previous approach had been governed by pragmatism, whereby sexuality was only a secondary issue given the primacy of political struggle: "Marital fidelity? That's amongst yourselves, says the party, we have transcended bourgeois monogamy as well bourgeois liberti- 
nage, says the party, the choice of arrangement is up to you, but you must be decent, reliable comrades" (B, I 29).

In the past, both Hanna and Karl had defended this view in their work and private lives. But in her encounter with Anatol, Hanna realizes that the Party's view of sex as a "hygienic measure" (B, I65) to safeguard the primacy of political struggle has left her sexually unfulfilled even in her relationship with her beloved Karl. But the novel's ending restates the importance of political struggle over the sexual and the wider personal, albeit under reconfigured parameters, as Hanna leaves behind both Karl and Anatol for an uncertain journey to join the Spanish Interbrigades. In doing so, Hanna symbolically rejects both the Party communism of her adult life (represented by Karl) and the bourgeois cosmopolitanism of her upbringing (represented by Anatol) and instead embraces a truly internationalist stance.

This ending recalls that of Henrik Ibsen's I879 play, A Doll's House, whose protagonist, Nora, became one of the key prototypes of early feminist discourse. Hanna's departure from the male-defined coordinates of her previous life suggests the nomadic rootlessness of the modern woman, which oddly recalls Weininger's notion of women and Jews as signifiers of rootless modernity. ${ }^{46}$ Unlike Weininger, however, Rühle-Gerstel does not present this rootlessness as an essentialized paradigm of the woman and the Jew. Instead, she suggests Hanna's nomadism as the only viable stance for disrupting the ideologies of modernity-National Socialism, Party communism, and bourgeois liberalism and its cosmopolitan configuration - that have led society into a literal dead end.

When Arthur Koestler wrote his seminal novel Darkness at Noon (I940), he obviously did so with far more extensive knowledge of the Great Purges than Rühle-Gerstel had available in I937-38. ${ }^{47}$ The son of a Hungarian Jewish father and an Austrian Jewish mother, Koestler was born in Budapest in I905. In I9I9, his family moved to Vienna, where Koestler joined the Zionist student movement. Between I926 and I929, he worked in Palestine as a correspondent for the Ullstein press. He subsequently moved to Paris and later Berlin, where he joined the Communist Party in I93 I. In I933, just after visiting the Soviet Union, Koestler went into exile in Paris. He joined the French antifascist movement and went to Spain in I936 to report on the Spanish Civil War for the British News Chronicle. He returned to Paris in I938, left the Communist Party, and spent four months interned at the notorious Le Vernet camp. In I940, he found refuge in Britain, where he began to write in English. He died in London in 1983 . 
Darkness at Noon provided the first concerted literary attempt to address the Great Purges. The novel conveys the profound disillusionment and shock that Koestler felt during his I933 visit to the Soviet Union, during which he encountered the regime's betrayal of its own subjects, a betrayal that became the novel's central theme. Koestler located this betrayal in the foundations of Stalinist ideology and politics. While in Baku, Koestler had fallen in love with a Russian woman, who he learned was a suspected counterrevolutionary spy. Koestler reported on her, lost touch with her, and ultimately left her to an uncertain fate, but his betrayal long haunted him. ${ }^{48}$ So profound was Koestler's disillusionment with Soviet communism that Manès Sperber found Koestler completely changed in appearance after his return to Paris. No longer a carefree man but a worried and trembling individual, Koestler's "total impression was quite different." 49

Set in a Soviet jail, the novel explores the Stalinist purges of first-guard revolutionaries between 1936 and I938 through the eyes of the accused former Comintern representative Nicolas Salmanovitch Rubashov. Through Rubashov, Koestler not only places the Jew at the center of the Stalinist narrative and its critical examination but also preempts the post-I945 Stalinist persecution of Jews among the communist guard. As with Rühle-Gerstel's Hanna, Rubashov's Jewishness remains only implicit, a narrative strategy reflecting the subordinate role of Jewishness within both assimilationist and communist identity politics. ${ }^{50}$ Rubashov's Jewish origins are suggested through his middle name, Salmanovitch, which indicates that his father bore the Hebrew first name Salman. In this context, Rubashov's intellectual pretenses, his internationalist convictions, and his extensive travels abroad link him to the image of the Jew as a nomad and thereby add further meaning. While installed as a functionary, Rubashov had delivered "long [and] difficult to understand" (DN, I5) speeches praising the Comintern and the world revolution, suggesting his abstract intellectualism-a mode of thinking that antisemitic discourse ascribed to the Jews. Now, the Party deems him a "querulous intellectual" (DN, 29). This, together with his frequent international missions for the Comintern, renders him a suspect.

As in many other cases, Rubashov's faithful service, first to the revolution and then to the communist state, predestines him for rather then protects him from the purges. Once a dedicated communist, Rubashov has delivered others presumed to be political deviants to the deadly purges. But the purges leave him increasingly disillusioned and his turn ultimately comes. The same is true for another convict in the jail, the former chair of the Comintern. This character is a thinly veiled representation of Grigory Zinoviev, the Jewish former Comintern leader who was executed in the I936 purges. Zinoviev's case illustrates the 
complex relationship between communist perpetrators and their victims, for he had provided the ideological justification for Stalinist mass murder when he declared at a I9I 8 meeting of Bolsheviks that "we must carry along with us 90 out of the IOo million of Soviet Russia's inhabitants. As for the rest, we have nothing to say to them. They must be annihilated." ${ }^{1}$ But by I936, as Stalin was establishing his new Soviet nationalism, close involvement with the Comintern meant a death sentence, no matter how faithful a functionary had been to the early revolutionary cause. As Rubashov's interrogator, Gletkin, states,

The policy of the International had to be subordinated to our national policy. Whoever did not understand this necessity had to be destroyed. Whole sets of our best functionaries in Europe had to be physically liquidated. We did not recoil from crushing our own organizations abroad when the interests of the Bastion required it. (DN, 226)

As Koestler shows, the particular horror of the Stalinist persecutions lay in the victims' extensive collaboration and identification with their persecutors because the victims had previously been the hangmen. In his earlier role as a Comintern functionary, Rubashov had traveled abroad to purge communist resisters in National Socialist Germany who had customized the Party's leaflets to speak more effectively to the masses. This was deemed a deviation from the Party line, even if it occurred in the service of its cause. Most important, however, Stalinism also achieved its lethal effect by compelling its victims to behave according to their own belief systems. Rubashov thus conceives his relationship with his interrogator, Ivanov, as that of twins "nourished by the umbilical cord of a common conviction. . . . They had the same moral standard, the same philosophy, they thought in the same terms. Their positions might just as well have been the other way round" (DN, I Io). Out of sheer Party discipline, the victims performed the part of the traitor because that was what their leaders required. As Rubashov wonders in his cell, "What if, after all No. I were in the right? If here, in blood and dirt and lies, after all and in spite of everything, the grandiose foundations of the future were being laid?" (DN, I26).

Unlike Rühle-Gerstel's The Break, which outlines through Hanna an internal position of dissent from Stalinism within the communist idea, Koestler's novel erodes any internal resistance. Stalinism has consumed the communist idea in its entirety, and having previously been the hangmen, the victims have lost any position of moral authority over their tormentors. This is, of course, yet another moment where the psychological mechanisms at work in Stalin's and Hitler's atrocities seem to overlap. In his final book, The Drowned and the Saved 
(I986), Primo Levi, too, observed an "identification or imitation, or exchange of roles between oppressor and victim" in his study of the Jewish special squads at Auschwitz, who were forced to aid the SS in processing the dead bodies produced in the gas chambers. As Levi wrote in his chapter, "The Gray Zone,"

It is naive, absurd and historically false to believe that an infernal system such as National Socialism sanctifies its victims; on the contrary, it degrades them, it makes them resemble itself, and this all the more when they are available, blank, and lacking a political armature. ${ }^{52}$

Therein, however, also lie the essential differences in the ideological conception of the Soviet and the German atrocities. In the National Socialist camps, the seeming convergence between masters and slaves never suspended the hierarchy of power that marked the biologized difference between the masters and their slaves: all Jews were designated to die, whether or not they had been accessories to murder. Such essentialized differences did not exist between Stalin's henchmen and their victims, and Stalin could thus ideologically contaminate his victims in a way that National Socialism, which viewed its Jewish victims as subhuman outsiders and therefore did not require them to identify with its cause, did not demand.

This is, of course, not to say that Stalin's crimes equaled or outweighed Hitler's but rather to pinpoint the finer nuances by which both ideologies enveloped and utilized their victims in very different ways. Yet in Darkness at Noon, National Socialism and Stalinism still look deceptively similar on the surface. This emerges most clearly in the novel's final scene, when Rubashov, having made a false confession, is convicted and led to his execution. As he is hit by a blow to his head, he dreams of his arrest, wondering which country he is in and whether the portrait of Stalin or Hitler is looking down on him. Was it

he with the ironic smile or he with the glassy gaze? A shapeless figure bent over him, he smelt the fresh leather of the revolver belt; but what insignia did the figure wear on the sleeves and shoulder straps of its uniform — and in whose name did it raise the dark pistol barrel? (DN, 254)

Such analogies, however, do not absolve individual responsibility by pointing a finger at a similar evil. If anything, such comparisons serve as a last call to awaken the human and leftist conscience in particular to disrupt everyday complacency toward such atrocities. As Koestler wrote in his I944 essay "On Disbelieving Atrocities" in the New York Times Magazine, 
A dog run over by a car upsets our emotional balance and digestion; three million Jews killed in Poland cause but a moderate uneasiness. Statistics don't bleed.... Thus we all live in a state of split consciousness. ... We live in a society of the Jekyll and Hyde pattern magnified into gigantic proportions. ${ }^{53}$

At the same time, Koestler's earlier analogies between National Socialism and Stalinism obviously result from the fact that Darkness at Noon was written several years before the National Socialists' Final Solution unfolded. Before the erection of the death camps, it was possible to read Stalin and Hitler as evil twins who utilized seemingly similar mechanisms to manipulate the masses and ensnare their political victims. The knowledge of the mechanized nature of the National Socialist death camps changed that equation. When the bare outlines of that news emerged, despite inaccuracies of detail resulting from the sparse information available, Koestler saw that crime as unmistakably unique:

At present we have the mania of trying to tell you about the killing, by hot steam, mass-electrocution and live burial, of the total Jewish population of Europe. So far three million have died. It is the greatest mass-killing in recorded history; and it goes on daily, hourly, as regularly as the ticking of your watch. ${ }^{54}$

In making the Holocaust the universal paradigm of the human loss resulting from modern mass violence, Manès Sperber's Like a Tear in the Ocean similarly suggests the uniqueness of the National Socialist genocide while simultaneously probing its intersections with Stalinism. ${ }^{55}$ Sperber's trilogy on the communist struggle in times of war, written in German but first published in French between I948 and I952, delivers extensive descriptions of Stalinist atrocities as well as the National Socialists' annihilation of European Jewry, though it does not represent the gas chamber killings themselves. The German original was not published until I96I.

Sperber was born into an Orthodox Jewish family in eastern Galicia in I905, where he received a traditional Jewish upbringing. In I9I6, Sperber's family moved to Vienna, where he joined the socialist-Zionist youth movement Hashomer Hatzair. Like Rühle-Gerstel, with whom he later became friends, Sperber was a follower of Alfred Adler's individual psychology before breaking with him in 1932. In 1927, Sperber moved to Berlin, joining the Communist Party one year later. After the National Socialists' rise to power, he fled via Vienna and Zagreb to Paris, where he worked for the Comintern Institute for the 
Study of Fascism. In I937, Sperber left the Communist Party and joined Koestler as a contributor to Willi Münzenberg's journal, Die Zukunft (The Future). Sperber survived the Holocaust in France and from I942 in Swiss exile. During this time, he was already writing the first book of his trilogy, which he began in I942 and completed in I948. Having returned to Paris, he wrote the second and third volumes between I948 and I95 I against the backdrop of a new wave of Stalinist purges directed explicitly against Jews as "rootless cosmopolitans."

The case of Willi Münzenberg and his associates echoes through the first two volumes of Sperber's trilogy. In I9I8, Münzenberg, a non-Jew from a working-class family, had been a founding member of the German Communist Party. Münzenberg was a leading Comintern member, and he remained a loyal Stalinist until the beginning of the Great Purges in I936. When Münzenberg refused to purge the Communist Party of Germany, his own life became endangered. Walter Ulbricht, the later East German president who was also in Paris exile at the time, working for the Comintern, traveled to Prague to run the German Communist Party's secret operations there. By Stalin's order, Ulbricht attempted to lure Münzenberg to Moscow, where he most certainly would have faced execution, but these plans failed. ${ }^{56}$ After purging "disloyal" communists behind the battle lines of the Spanish Civil War, Ulbricht turned his attentions back to Paris, where he betrayed communists associated with the Comintern and Münzenberg, and within two years, the vast majority had been expelled or killed by the Soviet secret police. In I940, Münzenberg, who had escaped from a French internment camp, was found strangled in a forest in southeastern France, from where he had been trying reach Switzerland. His killers are widely believed to have been Stalin's agents.

Münzenberg is echoed in Sperber's protagonist Herbert Soennecke, once a popular leader of the working class and a friend of Rosa Luxemburg, who is brought to trial in Moscow, accused of being a Trotskyite, and shot. His interrogator, Bärtchen, the German communist who in I934 first reported Soennecke to the political division of the Soviet secret police, evokes the real-life Ulbricht. Like Ulbricht, Bärtchen superficially resembles Lenin through the small beard and glasses that he began to sport while in exile. By the end of the novel, most of Soennecke's associates, just like Münzenberg's, have been killed by the political secret police or delivered by the Party into the National Socialists' hands. "Nowhere else in the world have so many Communists been killed as in Russia" (LTO, I:332), says Albert Gräfe, another protagonist in the novel. The Party delivers Gräfe to the Gestapo, but he survives National Socialist torture, jail, and camp internment, believing that he had been betrayed by Soennecke. The Party leads his common-law wife, Erna, to believe that she is 
responsible for the betrayal and she therefore commits suicide. Later, in Swiss exile, Gräfe survives a violent attack by Party agents, who then betray him to the Swiss police as double agent of the Gestapo and secret police. In the end, he is murdered by fascist Croatians while fleeing through Yugoslavia.

Betrayal of his most faithful comrades lay at the heart of Stalin's power politics. Sperber reveals the anatomy of this system's total moral evisceration of its subjects in the section dealing with the farcical investigation and murder of Soennecke and two of his comrades in Moscow. Following Bärtchen, another and by all appearances more intellectual investigator arrives: "He was clever and obviously experienced in political matters" (LTO, I:349). He explains to Soennecke that the true reason for his conviction is that "You're an old revolutionary, and therefore, ipso facto, an opponent of the present regime" (LTO, I:349). But unless Soennecke falsely confesses to having planned Stalin's assassination, all Parties and their organs, as well as intellectual sympathizers globally, will be instructed to denounce him as a National Socialist agent and counterrevolutionary. This process is necessary, the interrogator states, because the Party has committed many grave mistakes, such as starvation and shortages in agricultural production.

Cleansing the Party's reputation and preserving its existence demands the sacrifice of its individual followers, the interrogator states: "Afterwards the water's dirty, but the Party's clean. Under what epithet a man dies for is utterly unimportant" (LTO, I:35I). As Sperber's account of the interrogation suggests, the merged identities of hangmen and victims safeguards the smooth running of this system. Until this point, despite his nagging doubts, Soennecke has delivered his comrades to their incarceration and death. Therefore, the interrogator argues, Soennecke's refusal to die, bears no scrutiny. Conversely, the hangman's compliance was ensured by giving him a previous taste of the Gulag, "and there's no place in the world where dying's easier" (LTO, I:350), the interrogator states. But Soennecke dies steadfast, despite threats to target his children. Alternating physical deprivation and comforts such as better food, alcohol, showers, and fresh clothes are also used to extract a false confession from Soennecke's fellow inmate, Vasso. In exchange for a confession, Vasso is promised a stay in a sanatorium in the Crimea or the Caucasus, after which he will be ordered abroad to "reorganize" the Party and "take the whole business firmly in hand" (LTO, I:367). But like Soennecke, Vasso refuses to comply and is killed.

As Sperber suggests, Stalinist ideology depended on a supreme degree of its internalization by the individual, to the extreme of total self-sacrifice and self-effacement for the clean reputation of the Party. As Arendt argued in Ori- 
gins, the demand for "total, unrestricted, unconditional, and unalterable loyalty of the individual member" (OT, 323) formed the hallmark of totalitarian movements. This is the "atomized individual" (OT, 338) of modern society, whose lack of social ties forms the essential precondition for its total surrender to the Party or movement. As a consequence of the great upheavals of the Bolshevik Revolution, Arendt argued, the early Soviet Union thus became a laboratory for the workings of totalitarian power. Soviet propaganda specialized in coercing the "isolated mass man" (OT, 353) into fabricated self-confessions of guilt, which were essentially predicated on this individual's great dependency on the Party or movement for his sense of personal truth and belonging. "In a situation where the dividing line between fiction and reality is blurred by the monstrosity and the inner consistency of the accusation," Arendt wrote, it is all the more difficult for this individual "to resist the temptation to yield to the mere abstract possibility of guilt" (OT, 353). It seems plausible, then, that the act of selfconfession-even of entirely fabricated convictions leading to the knowing victim's execution - supplied the individual with at least the solace of having remained loyal to the Party and its abstract belief system, even if doing so was to its own detriment.

Similarly, Soennecke's friend, Josmar, succumbs to his interrogators before reportedly killing himself between the battle lines in Spain. Josmar's final letter to his comrades conveys his personal sense of guilt while reiterating the integrity of his faith to the Party: "I've remained true to the Party and to no one and nothing else" (LTO, I:388). The influence of Arendt's Origins on Sperber is particularly apparent in the second and third volumes of Like a Tear, which repeatedly invoke the concept of the totalitarian by drawing analogies between National Socialism and Stalinism. ${ }^{57}$ Protagonist Doino Faber, who, like Sperber, hailed from the provinces of tsarist Russia and abandoned his traditional Jewish upbringing for communism, represents Arendt's atomized modern individual. As a child, Faber had been taught to wait for the Messiah, who would do away with the tsar's executions of innocent people. Having grown older, he rejected such a passive stance and instead chose, in the words of his friend, Stetten, a different kind of "Messiah, only now he calls him 'world revolution' or perhaps a "classless society", (LTO, I:I46). Faber subsequently became

one of those men of a generation for whom all ceremonial and all symbolic gestures had long lost their value. Such men scarcely knew the meaning even of shame anymore. Yet though they would speak of their desires and disappointments in straightforward, matter-of-fact terms, it 
embarrassed them when they had to express their sufferings. And that, precisely because they had discarded traditional forms as a man might throw away a worn-out fancy dress. (LTO, 2:I8I)

This reduced state becomes even further pronounced under the intersecting conditions of political illegality, exile, and the Stalinist persecutions. The text's unpredictable shifts into a multitude of characters and perspectives whose identities often emerge only after several pages of narration, reflect the isolated condition of Sperber's protagonists, who are struggling for moral integrity and ultimately sheer physical survival. In this situation, leaving the Party or being marked as a traitor by it is tantamount to death because, as Sperber writes elsewhere, both Party members and sympathizers would thrust the apostate into "soundproof isolation." 58 In Like a Tear, the Serb poet, Djoura, is thus ostracized by three other Party members, who like him are awaiting their execution by the Croatian police. The recognition that the Party itself has betrayed the cause is devastating beyond words. Faber tries but fails to describe his state of bereavement and loss beyond repair:

Perhaps it is the anguish of solitude and of being deprived of all future. What is usually called sadness contains within itself the consolations of self-pity. But this particular anguish destroys that pity, it petrifies your heart and immobilizes time itself. (LTO, 2:70)

The story of Petrovitch, a Serb who escaped from a northern Siberian camp, stands out among the repeated expressions of such personal desolation. Petrovitch's report to Faber and Gräfe of the conditions in the gulag suggests the eerie parallels between Stalin's camps and Hitler's, down to invoking the image of the Muselmann, the term for inmates in the National Socialist annihilation camps who had lost all desire to live:

The wave of arrests, the overcrowded communal cells, the solitaries, the convictions without trial or opportunity for defense, the overcrowded railroad cars that transported the prisoners eastward, the hopeless struggle against the real criminals who were with them, thirst, hunger, the endless marching, the chicanery that went on, the first camp, the second camp; he described how men can be humiliated and debased until they are capable of only one feeling, hunger, of only one sensation, exhaustion, permanent exhaustion. (LTO, 2:I5I) 
But although Faber and Gräfe believe Petrovitch's apocalyptic account of the camps, they refuse to follow his pleas to make this truth public. As they reason, Stalin is their only reliable ally-although, as Petrovitch points out, Stalin in fact has killed all of his allies - in the fight against the main enemy, Hitler. Their response reflects Sperber's reaction to the Great Purges, which he described in "On the Analysis of Tyranny": "To remain faithful to [the Party and comrades whom Hitler had incarcerated and murdered], it was imperative to never lose sight of the true enemy and, so long as he existed, to disregard any other evil in the world." 59 Faced with this silence, Petrovitch commits suicide.

The novel lets Faber's Jewishness emerge as a humanizing feature that enables him to take on the role of witness and break through his emotional ossification. Before their execution, both Soennecke and Vasso had outlined the survivor's role in identifying individual responsibility for the Stalinist atrocities and preserving the memory of the crimes. That person's role is to find out "exactly when this development began and what part each of us played in it. He'll have to assess the guilt of each individual one of us exactly" (LTO, I:354). As Vasso demanded, Faber was to study the events of his death without either rejecting communism on the one hand or succumbing to the logic of his murderers on the other. But Doino's flight across Europe, which sees him joining the Yugoslav partisans in their armed struggle against the occupation, has rendered him hardened personally and politically. Unable to devote himself to a lover, Faber has left or lost all the women he loved, and his vow to become "hard, violent" and "observe the murderers with murderers' eyes" (LTO, 3:96) has resulted both in the loss of his comrades' lives for the sake of symbolic resistance, and in the Germans' eradication of the village that has sheltered them.

The trilogy's prologue, which relates a modern version of the biblical story of the burning bush, reflects the centrality of Jewish paradigms for Sperber's vision of the dashed hopes of communism. The fires of the burning bush, from which the hidden Hebrew god speaks to Moses in the Torah, has led humans to live in its light, until one day the branches and even the roots of the bush are consumed to ash. But the new masters kill everyone who expresses their sense of betrayal that the miracle has failed. They are enemies, these masters claim to their new slaves, to whom the light of the bush remains obscured. Yet, secret voices persist, and despite their persecution and annihilation, they claim that one must find or plant another bush. But the stranger telling this story is speaking into a void, for his listeners are tired of starting anew.

This void is reflected at the end of the novel, when only the "principle of hope" remains, to use the memorable title of the German Jewish philosopher Ernst Bloch's wartime magnum opus. ${ }^{60}$ By tracing this principle back to the 
biblical story of Job, Like a Tear identifies the idea as a Jewish inheritance. As Stetten surmises, "Wherever there were rebels, there, too, were the Jews, driven by their belief that they could bring about a happy ending on earth" (LTO, I:225). This hope, the novel suggests, lies in the steadfast rejection of power and the embrace of the victims' stance-the only resistance that does not repeat injustice. At the end of the novel, Faber thus accepts his earlier realization "that power corrupts, and that, therefore, the man who has it inevitably misuses it" (LTO, I:I45) by rejecting political action. Faber's rejection of action runs parallel to his renewed interest in Jewish tradition, if only as an intellectual blueprint. Faber's recovered memory of the Jewish legend of the Lamed Vov, the thirty-six just men who are said to exist in every generation and whose merits ensure the continued existence of the world, thus maintains the imperative of justice, albeit in a reconfigured way.

Faber's course is echoed in the story of the Jews of Wolyna, from which the novel takes its title. Faber's counterpart Edi, a secular Viennese Jew and social democrat, arrives in Wolyna on the eve of its destruction by the Germans. Faced with their imminent annihilation, first the rabbi and then his son refuse to follow Edi's call for armed resistance because doing so this would compromise their faith in God. Furthermore, as he contends, the Jews have never been defeated because they alone have refused to resemble their enemies. In contrast, actionism and its reflection in battle are meaningless:

"Try, just once, to describe a battle," the rabbi's son tells Edi, "and you will find that all those actions taken together are smaller and more shapeless than a tear in the sea" (LTO, 3:I90). The centrality of this statement for the novel-it is even part of the title-is apparent. These teachings, then, chime with the convictions of Faber's Viennese friend and professor of history, Stetten, who represents "the corpse of Austria" (LTO, I:228), with its destroyed liberal legacy. Driven out of Vienna, Stetten dies in exile, but his papers record that "intellectual man must leave action to others and only intervene when it is a question of presenting certain actions or of protesting, and also when a moral or intellectual need threatens to become a general danger" (LTO, 3:252).

\section{The Left and the Stalinist Purges after 1945: Rudolf Leonhard, Peter Weiss, and Stefan Heym}

Sperber wrote the last two volumes of his trilogy against the backdrop of renewed Stalinist purges, in which the persecution of internationalists assumed a clearly antisemitic tone. The I930s purges had occurred on the back of the 
Stalin-Trotsky split. When in I948 Yugoslavia embarked on a more liberal version of communism under Josip Broz Tito, a new series of purges began across the Soviet satellite countries. Albania came first. Next was Romania, where Ana Pauker, born into an orthodox Jewish family and now the de facto leader of the Communist Party, was purged with two comrades. Pauker survived, but one fellow defendant was executed. The show trials heightened in intensity and antisemitic tone as the Noel Field Affair unfolded beginning in I949, recapitulating in new ways the I930s battle between internationalists and those who had remained in the Soviet Union. The hard-line Stalinists, many of whom had been trained in the Soviet Union during the war, now targeted those with Western ties, which were seen as synonymous with Jews and Israel.

The British-born Noel Field and his wife, Herta, both non-Jews, were avowed antifascists with Soviet sympathies. Raised in the United States and educated at Harvard, Noel Field served as a U.S. State Department employee from the late I920s until his appointment with the League of Nations in Geneva. ${ }^{61}$ By this time, he had already been recruited by the Soviet secret police. In I938, he was posted as a League of Nations representative in Spain, where he and his wife aided Franco victims and Republican fighters. In I94I, Field moved to a new post in Marseille, where he and Herta became involved in rescue operations for persecuted Jews, often putting their own lives on the line. Field also established connections for the American wartime intelligence service, the Office of Strategic Services, with Communist resistance fighters. In I949, the Fields moved from Switzerland to Prague. Just a few days after their arrival, Field, his wife, his brother, and his daughter were arrested in various Eastern Bloc countries and accused of having headed a spy network. Field was taken to Hungary to serve as an accessory in the László Rajk trial, which opened a new round of show trials in September I949. Noel Field survived torture and five years of solitary confinement; his wife was imprisoned in the infamous Soviet Lyublyanka prison, where her initial death sentence was commuted to forced labor in Siberia. In I954, all members of the Field family were released. Yet like so many other Soviet sympathizers, Noel and Herta Field identified with their torturers rather than condemning them. As Field wrote during his imprisonment,

My accusers essentially have the same convictions that I do, they hate the same things and the same people I hate-the conscious enemies of socialism, the fascists, the renegades, the traitors. Given their belief in my guilt, I cannot blame them. I cannot but approve their detestation. That is the real horror of it all. ${ }^{62}$ 
The antisemitic tone of the new purges culminated in an infamous November I952 Prague show trial in which Rudolf Slánský, secretary-general of the Czech Communist Party, and thirteen other high-ranking members of the Czech Communist establishment were charged with high treason, espionage, and participation in a Zionist conspiracy for Field's alleged spy network. Eleven of the fourteen defendants were Jews, including Slánský himself. Slánský and ten others were hanged, while the remaining three received life sentences.

At the same time, show trials took in East Germany when Paul Merker, a longtime communist and anti-National Socialist resistance fighter, was arrested on charges of having led the East German operation of yet another supposed spy network uncovered during the Prague trials. In particular, Merker was accused of having been recruited for the French secret service by three of the Jewish defendants executed in the Slánský trials. A non-Jew, Merker was charged with having Zionist sympathies and contacts with "Zionist circles" during his time in Mexico. These charges rested on a 1942 article in which Merker demanded postwar reparations for the National Socialists' Jewish victims. This article is a unique war-time German demonstration of empathy regarding the plight of the Jews:

If all German rivers were ink, and all German forests quills, they would not suffice to describe the innumerable crimes which Hitler fascism has committed against the Jewish population. . . Only those antifascists can acquit themselves from responsibility for the monstrous consequences of antisemitism who have, since Hitler's rise to power, tirelessly risked their freedom and lives to fight against the mighty gulf of darkness and the reactionary forces that reached their bloodied climax in Hitler fascism. . . . It is them who, fuelled by the ideals of their struggle for the progress of humanity, voluntarily accept responsibility for reparation-if that is even possible-for the crimes perpetrated on their Jewish fellow citizens. ${ }^{63}$

After more than two years of detention, Merker was brought to trial in I955 and sentenced to eight years in jail. After serving one year, he was released and secretly cleared of all charges. However, these accusations of Jewish sympathies and coding as a Zionist resonate with the East German Communist Party's position on postwar reparations for the Jews. This position was clear from I946 onward, when the Eastern Zone's reparations committee declared that communists were the only genuine National Socialist victims and treated Jews and all other categories of victims as secondary, awarding them little or no 
material support because unlike the communists, they had supposedly failed to resist the National Socialists. ${ }^{64}$

In the polarized postwar climate, few writers addressed the continuing legacy of the Stalinist crimes. Among the notable exceptions on the Western side of the Iron Curtain are Wolfgang Leonhard's autobiographical Child of the Revolution (1955) and Peter Weiss's literary epic, The Aesthetics of Resistance, and Stefan Heym's works in the East. Weiss's Aesthetics of Resistance, published in three volumes between I975 and I98I, reiterates the central themes of Sperber's Like a Tear but adopts an experimental aesthetic form that reflects the early call for the unconditional openness of revolutionary art, which had become abandoned under Stalin. ${ }^{65}$ Born to a Hungarian Jewish father and a Christian mother in what is now Potsdam-Babelsberg in I9I6, Weiss emigrated to the United Kingdom in I934 and from there via Prague to Sweden four years later. He died in Sweden in I982. The Investigation (I965), a dramatic treatment of the Frankfurt Auschwitz trials that drew inspiration from Kafka's The Trial, became Weiss's most famous work other than the Aesthetics. In both writings, Weiss takes implicit issue with Theodor Adorno's apprehensions against art on atrocity, which Adorno had expressed in response to the Shoah. Opening with a poetic account of the ancient Greek atrocities at Pergamon, the Aesthetics thus staunchly insists on the ability of language and art to account for atrocity. The Aesthetics must be considered the most profound exploration to date of the relationships among the individual, political resistance, and art.

As a result of the novel's monumental extent and stream-of-consciousness style, Walter Jens considers the Aesthetics "the equal of Ulysses." ${ }^{\text {" And in- }}$ deed, Weiss's magnum opus utilizes both formally and thematically the patterns laid by that classic of early twentieth-century world literature, a concept that historically has been closely tied up with the cosmopolitanism ideal. Like James Joyce's epos, the Aesthetics sets out from Greek myth. However, Weiss uses the figure of Heracles, who is said to have been both a protector and benefactor of humanity on the one hand and to have visited terrible violence on those who betrayed him on the other. Weiss's Heracles becomes the perfect symbol for the dichotomous twentieth-century history of communism, which fought fascism in the name of humanity while enacting monstrous violence during its purges. Weiss's autobiographically inspired novel chronicles this history from his first-person protagonist's participation in the antifascist struggle in Germany and the Spanish Interbrigades through his emigration and postwar life in Sweden.

Weiss suggests that proletarian art remains necessarily limited by the conditions of violence dictated first by the proletarian revolution and then by the 
antifascist struggle. Under the current condition of national revolutions rather than the world revolution for which Marx had originally called, artistic abstraction and internationalist-indeed, cosmopolitanist sentiment-thus remained the stuff of bourgeois art:

Modernism, Abstraction had to remain the privilege of people who dealt with artistic problems, no proletarian art could arise from there even if the artists believed they were speaking the true language of a revolutionary nation. ... These ponderings included the opposition between the national and the international guidelines. Had the Revolution spread, then art would likewise have maintained a revolutionary versatility. (AR, 57)

Weiss's novel seeks to recover that lost multiplicity by presenting its discussion of history, politics, and art through a dialogue of interwoven narrative voices. In doing so, the humanist cosmopolitan narrative, with its emphasis on the individual, remains in constant tension with the first-person narrator's exploration of proletarian art and communist internationalism. The narrator thus rejects the "view that a writer must belong to a country, a precisely outlined sphere of existence, a national culture for his writings to sound convincing" (AR, I I7). Instead, he seeks his audiences beyond national borders, and defines internationalism as the sign of his affiliation. These political views and the global network of people leading the same struggle define his sense of belonging.

The Spanish Civil War, then, which drew left-sympathizing volunteers from all vocations and corners of the Western world into the Interbrigades, forms a preliminary highlight in international solidarity as well as leftist coalition politics. Thirty-five thousand volunteers, workers, intellectuals, and artists joined in the "pan-European war against fascism" (AR, 282) between the autumn of I936 and the spring of I939. Lying in the trenches of the Spanish Interbrigades, Weiss's narrator invokes Nikolai Bukharin's speech to the first Soviet All-Union Congress of Writers in I934, which passionately attacked "the freedom of revolutionary art, on the unconditional openness of form . . . , a call for the development of individuality" (AR, 254). By turning time and again to physician and sex educator Max Hodann, a close ally of Magnus Hirschfeld and like him a Communist Party sympathizer, the text reflects on personal development as part of the envisioned new society. Even in the Spanish trenches, faced with his own annihilation by the fascist troops and the communists' deadly purges of political deviants behind the lines, Hodann combines his communist views with the demand for personal happiness and sexual liberation. 
By this time, internationalists are becoming increasingly suspect within the communist ranks. In the Soviet Union, they represent those who spent the prerevolution years in exile and whose views now clash with those who had remained in Russia. With Stalin's turn toward nationalism, the I930s saw a steady decline in Comintern politics, even though it was formally disbanded only in I943.

A former exile, first-rank revolutionary, and later member of the Soviet politburo, Bukharin, too, epitomized the interchangeable roles of hangman and victim under Stalin. Bukharin played in instrumental role in ousting $\mathrm{Zi}$ noviev as Comintern secretary before becoming the organization's head. Political disagreements with Stalin, however, led to Bukharin's purge as a supposed leader of the counterrevolution. Weiss's text reverberates with the shock of Bukharin's rapid confession, conviction, and execution in the early hours of I5 March I938. In Weiss's account, Bukharin's self-denunciation provides the pivotal moment in his demise: "What had induced him, Lenin's closest confidant, to describe himself to the world as the organizer of an antiSoviet bloc and to deny everything he had fought for all his life" (AR, 254). This malaise has spread through the communist movement, and the narrator and his comrades watch unquestioningly and unresistingly as their ranks are decimated by the liquidation: "We accepted everything, we knew how to rationalize everything” (AR, 269). However, Ruth Marcauer, a young Jewish woman and Communist Party member since her youth, offers a point of resistance in this narrative of complacency. She refuses to take on the complicity that Stalin demanded of his victims. She not only loudly refutes suspicions that she may have been a Trotskyite but even discusses in front of comrades Stalin's liquidation of long-term revolutionaries. Weiss's description of her friends' response is chilling:

We tried to keep Marcauer quiet, to shield her from her own words. But whenever we talk about our own war, she said, in the presence of the political commissar, we also have to talk about the other war, which is being waged simultaneously in our ranks against holders of dissident opinions, a war whose weapons I can never approve of. . . . No one could help Marcauer when her arrest was ordered. We wanted to reduce the significance of the interrogations that she could expect. . . . Yet we already knew that we would repress any thought of this woman who came from an uppermiddle-class family in Hamburg. And soon the hour was blurred, the early morning when she was taken away by the military police. (AR, 275) 
The communist atrocities, the novel asserts through Hodann, affected that generation more deeply than the destruction wrought by the National Socialists, because communists staunchly identified with and defended the Soviet Union. Fascism, in contrast, represented a known enemy and therefore constituted a monster they could fight. "Politics and art are of equal importance," Hodann states near the end of the novel, and art, which "stood synonymous for humanity," therefore needed "to compensate for the failures of politics." ${ }^{167} \mathrm{Art}$ "would, one day, be able to describe" (ÄW, I025) the inhumane treatment of the National Socialists' Jewish victims, which the narrator's mother had witnessed while incarcerated and which had rendered her silent. The text offers a detailed description of the gas chamber murders before turning to Stalin's betrayal of revolutionary idealism: "The land of the Revolution, too, had lost its dignity even before entering into the great struggle, in which it might win back its greatness and prepare a change of thought in us, at the cost of millions of dead" (ÄW, I025). Therein, Hodann asserts, lay the schism that would need to be overcome so that the leftist exiles could once again lend meaning to their lives. Weiss attributes a key role to the exiles and their art production in this process when he asserts through Hodann "that they who wanted to take on the classical heritage of German culture would also need to inherit the cultural wreckage upon returning to that deformed country" (ÄW, I I65).

Stefan Heym's novel, Collin (I979), concerned itself with precisely that ideological and moral wreckage. Born in I9I3 into a Jewish textile manufacturer's family in Chemnitz, the "German Manchester," Heym had been a leftist sympathizer since his youth. Immediately after the National Socialists' rise to power in 1933, he fled to Prague and emigrated from there to the United States in I935. During World War II, he served as a sergeant in the U.S. Army's Ritchie Boys, a special unit in charge of psychological warfare. In the course of the U.S. Senator Joseph McCarthy's infamous persecutions of communists, Heym and his American wife, Gertrude, left the United States in 1952 and settled in East Berlin. After the publication of his novel, The King David Report (I972), which offered a thinly veiled treatment of the Stalinist crimes through the biblical story of King David, Heym became East Germany's top dissident and persona non grata. ${ }^{68}$ From that point until I986, his works were published only abroad, a practice that left Heym on the constant brink of legal prosecution.

Collin remains singular in its treatment of the Paul Merker Affair and the complicity of East German intellectuals who had previously fought against National Socialism in the postwar Stalinist persecution of alleged Zionists and 
dissenters in the East German Party ranks. Merker served as the model for Heym's protagonist, Julius Faber, a faithful Party member who spent the years of exile from National Socialism in France and Mexico before joining the East German Party elite after the war. But in 1952, Faber is accused at the Party conference of being an agent of the class enemy-indeed, a member of Noel Field's "imperialist-Zionist world conspiracy." ${ }^{9}$ Faber's emigration to the West turns out to be the crucial moment in his indictment, when his accusers claim that he had enabled the SS to murder his Party comrades, "the survivors of the heroic International Brigades" (C, I26-27), by impeding their attempts to escape while he, "well-nourished and well-preserved, was able to betake himself to Mexico" (C, I27). As Heym's protagonist, writer Hans Collin observes, these accusations closely follow the pattern of Stalinist show trials elsewhere:

How familiar, these charges. The names are interchangeable, the details may vary, but always you hear this talk of treason and conspiracy, in Moscow and Budapest, in Sofia, Bucharest, Prague, not to mention Belgrade where a small clique of contemporary renegades is still holding sway. (C, I27)

Even now, in novel's present-tense setting of the I970s, plainclothes members of East Germany's secret service, the Stasi, hound Faber during an outing to a café, where he is heckled as "Judas" (C, I28), a "traitor to the working class" and "Zionist agent" (C, I 29) for the Americans. Heym exposes the perfidiousness of these accusations through Wilhelm Urack, a reflection of Stasi director Erich Mielke, whose journey in exile had closely resembled Faber's. Each man's destiny in Party politics was, therefore, not simply determined by his Western rather than Soviet exile but by his ability to play the power game. According to Urack, Faber's true crime lay in his innocence and the fact "that he was there, and that he was the person he was. He was just a natural for the lot that fell to him" (C, 2 I 5). Even worse than Trotsky, whose destiny made him "a big-mouthed failure whose skull is bound to be cracked by some assassin's pickaxe," Faber was "a lamb. And therefore was sacrificed like a lamb" (C, 2 I6). Contends Urack,

What predestined one man to lead the plow and the other, to be plowed under, lay deep inside his heart and was something almost irrational. It lay precisely in the difference between Comrade Faber and Comrade Urack. They were, so-to-speak, of different races . . . ; you took one sniff and your instinct told you: this guy is different and therefore dangerous, 
whether he plans something against you or not, he is one you can't work with, he doesn't fit into the group, he is not of my kind. (C, I7I)

But whereas the brute Urack's views on the victims of the Stalinist persecutions may be predictable, the position of the intellectual in the novel emerges as more troubling. For all of the intellectuals in the novel with the notable exception of Jewish critic Theodor Pollock, who can be seen as Heym's alter ego from his King David Report onward, have in their own ways betrayed the accused victims of Communist state persecution. Collin echoes the complacent Heym in his early East German years, remaining silent against the absurd accusations against Faber, who later becomes an accessory in the farcical trial against state official Georg Havelka. At Havelka's trial, too, Collin remains silent.

Heym's portrayal of the Havelka case follows the contours of the real-life prosecution of Walter Janka, a former political inmate in the National Socialist concentration camp at Sachsenhausen who then went on to fight in the Spanish Interbrigades. Janka became a star in the East German publishing industry and by 1956 he was serving as head of Aufbau Verlag, the leading East German publisher. During the Hungarian anticommunist uprising that year, Janka became involved in the attempted rescue of Jewish literary critic Georg Lukács, a communist official and dissenter, from enemies on both sides of the uprising. ${ }^{70}$ Lukács's escape was plotted by high-ranking representatives of East Germany's cultural scene, including poet and minister of culture Johannes R. Becher; Anna Seghers, head of the East German writers' association; and Helene Weigel an actress who served as artistic director of the renowned Berliner Ensemble Theatre after the death of her husband, Bertolt Brecht. Seghers and Becher, who had supported the heinous earlier accusations against Merker, now played a key role in persuading Janka to fetch Lukács from Budapest. Then, however, East German president Walter Ulbricht, whom Becher had informed of the plan, called it off. Nine months later, Janka was arrested and sentenced to five years in jail. Seghers, Becher, and Weigel were present at his trial but remained silent. Merker, who had just been unofficially rehabilitated and was facing threats, played his allocated part as witness for the prosecution. And thus the moral demise of the East German intellectual was complete, long before the scandal involving leading East German writer Christa Wolf's Stasi links surfaced in 1993 .

These events are reflected in Heym's protagonists Curd and Pamela Piddelkoe, the former a poet and minister like Becher, the latter a theater director like Weigel, who also sit silently through Havelka's trial while the pathetic Faber makes his confession. Heym suggests that the leftist cause in the East Ger- 
man republic will not survive their moral failure. Collin's secret recording of these events in his memoirs in the present-day of the novel is bracketed by two heart attacks. The first one sees him hospitalized and inspires him to write; the second one, however, takes place at the end of the novel and is fatal. Urack, who is being treated at the same hospital, lives on, signifying the Stalinists' victory long after Stalin himself has passed. Yet Urack's triumph is only momentary, for Collin's unfinished memoirs are preserved, and Pollock has secretly taken possession of them. As in Feuchtwanger's Josephus, Heym's great model for the writing of Jewish historical fiction, the ancient Jewish writer thus acts as a repository of a counterhistory to the history of twentieth-century state violence.

Collin uncovered the skeletons in the East German cupboard just as the news of communism's most atavistic crime, the 1975-79 Cambodian genocide, became public. In the last volume of Aesthetics of Resistance, published in $198 \mathrm{I}$, Weiss made implicit reference to what would turn out to be the final act in the communist system's moral demise. Weiss recounted the I93os journey of a hard-line communist, Stahlmann, who also appears in Heym's Collin, to the ancient Cambodian cities of Angkor Wat and Angkor Tom. These are sites of death: Angkor Wat is "the image of the monstrous symmetry of a system of domination which, albeit sunken, continued to control the hidden site with its remains" (ÄW, 979). On this "night of all nights" (ÄW, 980), Stahlmann accesses Angkor Tom via the solemn figures of stone warriors who guard a "gate of death," behind which the Buddha's myriad faces beckon at the Bayon Temple, "dominating the world, emerging from the timeless ether, rising above the decay" (ÄW, 98I). Stalin and his emulators, concluding with Pol Pot, are now part of a mythology of atrocity that Weiss traces from the Pergamon altar to these hidden cities in the jungle.

Weiss appropriately closes his mythology of atrocity here. Annihilating first-guard revolutionaries alongside ethnic minorities and intellectuals-that is, the educated middle class, people in command of foreign languages, and people wearing glasses - the Khmer Rouge had attempted to construct a total agrarian society from which all signs of cosmopolitanism would be erased. Unbeknownst to Weiss, Pol Pot's crimes, which destroyed up to two million lives-20 percent of the Cambodian population-in less than four years, represented the sunset of communism. 


\section{Chapter 7}

\section{Russian Jews as the Newest Cosmopolitans}

\section{Rooted German Cosmopolitans?}

If the models of Jewish cosmopolitanism (as well as the more covert ones of Jewish nomadism) truly have national and cultural variations over time, then the mid- to late-twentieth-century diaspora of Russian-speaking Jews should be the best litmus test for the limits of their flexibility. ${ }^{1}$ Are they cosmopolitan, postcolonial, hybrid, transcultural, or merely nomads, refugees, or exiles? $?^{2}$ Indeed how do they understand themselves? As Russians and as Jews, or indeed as Jewish Russians or Russian Jews? What happened to their identity as Soviet Jews, so very politically important in the I970s and I980s? What happens when they become German- or English-speaking and -writing members of a new imagined community where the cosmopolitan is a prized if contested category?

Russian-speaking Jews left for Western Europe, Israel, the United States, and Canada in growing numbers beginning with the refusniks (in Russian otkaznik)—Jews who applied for exit visas to leave the USSR after the I967 Six Days' War in the Middle East. This exodus continued in starts and spurts through the end of the Cold War and sped up following the dissolution of the Soviet Union. During the I970s, only about 7,00o Jews left for political or religious reasons (which were often the same), a number that grew to 250,000 over the following decade. In 1989, although the USSR required departing Jews to declare their intention to immigrate to Israel, only I2, I I 7 of the 7I, O0O who officially left followed through on that declaration. By the time of the Soviet Union's collapse, more than I.I million Russian Jews had emigrated to Israel, and 500,000 had moved to the United States. Germany and Austria received at least $250,000 .{ }^{3}$ Some were religious Jews, some ethnic, some were Jews simply because their Soviet passports listed them as of Jewish (innerSoviet) nationality. Some were transformed by the move into categories of 
Jews that they could not have imagined while living in the USSR or its successor states.

All became cosmopolitan Jews by dint of having left the homogenous identity politics of the Soviet Union and the hegemonic power of a Russian cultural identity. This was the underlying power of an imperial notion of a Russian literary culture grafted on to Homo Sovieticus, the "social type molded by State Socialism over its seventy plus years of ideological indoctrination and meager living conditions. Usually implies such features as social dependency, lack of initiative, and compliance with social control, along with manipulation of the state bureaucracy at all levels ('working the system, bending the rules') as a survival tool." 4 To this one can add the complexity of being Jewish, however defined, under such circumstances. But being Jewish, even in the sense of belonging to a religious minority in such contexts, had a very different ambiance:

Indeed, for the Russian-speaking Jews, socialized into a society that is Eastern Orthodox and once Communist, the idea of communal Jewish life is unfamiliar. Many could not, upon arrival, understand paying for membership in a synagogue, and even wearing a yarmulke was seen by many immigrants as shameful. The Russians would not speak of their religion (religia), as American Jews do, but rather spoke of their faith (vera); to Russophones, religia connotes tiresome rituals, whereas vera refers to individuals contemplating their fate. ${ }^{5}$

Only in the context of attempts at integration are such views. According to social scientist David D. Laitin, this integration into a religious identity begins with the children of the immigrants, who become exposed to and then accept the strictures of an Orthodox Jewish religious education and then move their parents into what is for Americans and Germans a more familiar identification of Judaism as religious belief and religious practice $(\mathrm{L} / \mathrm{D}, 32)$. But such a transformation was rarely the norm.

For many of these Jews, however defined, high culture (kulturni) became the residue that continued to define them during and following their physical move from the USSR. Gogol was also much more central to their understanding of culture than was Sholem Aleichem, their schooling in Russian culture and language more central than their fragmented Yiddish past. In an odd way, the portability of Russian culture as a defining quality of Russian Jews (even with the limitations of the Russian language beyond the USSR) mirrors a central trope of Jewish identity. The written word has a special sense within the Jewish tradition, as Arnold Eisen points out: it became a mobile holy space replacing 
the concrete rooted place of the Temple. ${ }^{6}$ Russian Jews brought Gogol, Tolstoy, and Pushkin rather than Torah, but in the new cosmopolitan diaspora, the written word gave them status and meaning, serving as a secular Torah.

Russian Jews were certainly cultured in the old Soviet sense of the word, "especially considering the discussion of what Jewishness meant in the context of the former Soviet Union, this view of 'others' fit directly into the traditional perception of self as an 'urbanized' and 'cosmopolitan' ethnic group."7 Indeed, these immigrants at least initially showed "a stronger detachment from the home-country on the one hand, and a certain sense of cosmopolitanism and self-perception as a 'European' or even a world citizen on the other hand, as many of the younger respondents commented on considering educational or professional opportunities in other European countries or in the US, or on having already made arrangements for such plans" (I, I89). Being Russian and Jewish thus already defined one as a member of the cultured world, both cosmopolitan and very Russian, as "the Jewish minority in the former Soviet Union could be seen as the most acculturated ethnic group, becoming an active consumer and even producer of Russian culture" (I, 299). Being Jewish thus "came to be defined by a specific set of social and cultural characteristics rather than exclusively by the ones conventionally associated with ethnicity" and was "defined according to a certain life style and social position, while the most prominent attributes of Jewishness in the Soviet and post-Soviet context centered around the notions of being 'able,' 'talented,' or 'cultured'" (I, 299).

The Germans, whether Jewish or Christian, did not share such views. They saw Russian Jews as Russians, and that stereotype of the drunken peasant did not contain any commitment to high culture. ${ }^{8}$ As Italian-born Canadian academic Arianna Dagnino evokes in her diaries from a I985 trip to the USSR, the world from which these Soviet Jews came was a "humid subterranean world of mechanics who read Gogol, of poet-engineers, of incognito intellectuals, of non-declared Jews. Vodka, Marina Tsvetaeva's poems and cigarettes without filters." "9 Are they cosmopolitans traveling the world or merely migr, émigrés, exiles, just like the White Russian exiles in Weimar Germany after I9I9?

What does it mean then to speak of a new Jewish rootedness or cultural cosmopolitanism in light of the movement of a large minority of Russianspeaking Jews not only into a global Jewish diaspora but specifically into a complex Israeli, German, and American Jewish context? Each setting demands that we rethink and redefine the models of the cosmopolitan and how Jews enter into these cosmopolitanisms as self-defined exiles, diaspora Jews, Russians, or new Israelis, Americans, or Germans. Cultural objects enable us to trace the trajectory of the new cosmopolitanisms and their reception, but we 
also must begin to recognize that such notions of nomadism and cosmopolitanism have an absolute link between nomadic experience and aesthetics, as Eva Aldea has noted. ${ }^{10}$ Literary works are the space, a thought experiment, in which the double bind of movement across space as cosmopolitan and/or as exile is worked out.

\section{In Germany, Gogol Is Not Sholem Aleichem}

The mass relocation of Jews from the former Soviet Union to the Federal Republic of Germany provides a unique set of literary examples of cosmopolitan thought experiments about being an Eastern European Jew and a German. ${ }^{11}$ The status of the Eastern European Jew in Germany ran the gamut from being the focus of German Jewish anxiety as the "cause" of German antisemitism, as in the views of Weimar figures such as the Jewish theologian Hans Joachim Schoeps, who as late as the I930s saw Eastern Jews as a grave danger to the social standing of German Jewry to representing a romanticized transcendental Jewry, as in the pre-World War I literary work of Martin Buber, which created the German fantasy of an authentic East European Jewry. Residues of such images remained in the German literary imagination after the Holocaust and even became part of the German Jewish cultural legacy among many Jews whose Eastern European parents and grandparents had remained in the various German "zones" after I945. Hannah Arendt's postwar question about the relationship of exiled German Jews to Germany_or, indeed, the status of any people driven from their homeland and seen as exiles rather than as cosmopolitansremained valid: "To what extent do we remain obligated to the world even when we have been expelled from it or withdrawn from it?"12

In today's Germany, with its official designation of the Jews as one of the four state-sanctioned religious communities, being Jewish is officially defined by the state as a religious status. ${ }^{13}$ It seems to be free of undertones, without any sense of the outsider or the sojourner, the exotic cosmopolitan or the rooted national. Yet it is more than being a "Jewish fellow citizen," to use Konrad Adenauer's clichéd term from the I96os. If anything, these new German Jews, most of whom come from the former Soviet Union, perpetuate an ethnic identity for the Jews (in the older vocabulary a "national" identity as inscribed on their passports) as the internal Other. Such an identity is malleable in that it enables the Jews to focus on transforming themselves into Jews in Germany. Indeed, they believe that they can become Jewish by becoming German. Many of the Russian Jews were not Jewish by Orthodox standards - that is, they nei- 
ther have a Jewish mother (and grandmother) nor have undergone Orthodox conversion. ${ }^{14}$ Even into the twenty-first century, a large number have not joined the official Jewish community, yet they also set themselves apart from other communities of Russian-speaking immigrants.

However, after February I99I, being Jewish was an important qualification for permission to settle in Germany. The category of Kontingentflüchtlinge (quota refugees) had previously encompassed primarily Vietnamese boat people and a few Albanian officials but was expanded to include those whose papers labeled them as of a "Jewish nationality" or as having a least one "Jewish" parent. ${ }^{15}$ Thus, anyone who possessed an internal Soviet passport that used the label "Jewish" as a nationality or who had a parent with such a passport was guaranteed admission to Germany. This label had been disadvantageous in the USSR and its successor states as well as in other communist countries, so many Jews had transformed themselves into Russians (or members of other Soviet nationalities), meaning that if they sought to move to Germany, they had to draw on their parents' national identities. German Jewish authorities consequently were confronted with "Jews" who did not fulfill any religious definition of Jewish identity, much less the official Orthodox definition. This tension that echoes in much of the cosmopolitan literature written by "Russian" Jews, whose collective identity is shaped much more by their shared high Russian culture.

After the economic downturn of 2008, Jews from the former Soviet Union faced new legal barriers to entry into Germany as the federal government turned immigration matters over to the states and to various Jewish communities. Earlier immigrants matured as Germans, taking an increasingly caustic view of their new country, in large part as a result of their sense of uniqueness. In addition, new immigrants had to have at least one "Jewish" parent and could not be active members of any other religion; some of the ethnic Jews from the former USSR had been Russian Orthodox. Moreover, those with Jewish fathers could be admitted as immigrants but would not be defined as Jewish in the official religious community. Because the new regulations also stated that immigrants must be "accepted into a Jewish Community by the Central Welfare Office for Jews in Germany," some would-be immigrants were caught by a built-in contradiction. Moreover, immigrants had to also have a working knowledge of the German language and, and this was vital, had to have a "positive prognosis for integration." That meant that the German government must judge them as fulfilling the cultural and social expectations of being "German" prior to coming to the country. ${ }^{16}$ Thus, post-2008 arrivals were perceived as the best of the new migrants, ripe for integration not only into German culture but also into the German economy. (In contrast to recent claims of many Germans, 
especially those supporting the new Alliance for Germany Party, that asylum seekers from the Middle East and North Africa lacked any desire to integrate into German society.) The older model of the Jews as cosmopolitan agents of capitalism had morphed into the notion of the ability to achieve economic integration as a positive quality of these Jewish migrants.

These shifts in what it means to become German are reflected in the changing debates about cosmopolitanism in the literary products of these new Jewish arrivals. The central question reflected in their work is their integration into a new but not very cosmopolitan Germany. Indeed, the debate about Germany remains the debate about rootedness in geographic as well as cultural senses. Yet all of these narratives center on the cosmopolitan tradition of representing Jews on the move, where the experience of spatial mobility serves as a metaphor for social and cultural cosmopolitanism. ${ }^{17}$

The hottest of the cool mobile cosmopolitan Jewish writers to come out of the newest Russian Jewish diaspora in the new Germany is Wladimir Kaminer. Born in 1967 in Moscow, he was released from the Soviet army in I989. He arrived in the German Democratic Republic with the first wave of young "Jews" invited by the dying East Germany in I990 when officials conceived some type of coming to terms with "world" Jewry and Israel as allies in preserving the "transforming" socialist state. Kaminer noted, "I was youngtwenty-two - so nobody was really calling for me. I had friends there that I had met in Moscow. This was I990; you didn't need a visa, not even a passport. All you needed was an invitation. And it was inexpensive." 18 By the end of the I990s, he had become a cabaret and club performer (as a DJ spinning Russian club music, ska-punk), and he published his first volume, Russendisko (Russian Disco), in 2000. ${ }^{19}$ It was an immediate and hugely popular as well as economic success. It generated six musical recordings between 2003 and 2013 as well as a 2012 film by Oliver Ziegenbalg.

Russendisko questions the notion of being Jewish as a unitary category. Kaminer accounts for the emigration of Jews-who are Russians claiming to be Jews-to East Germany in I990. These "Jews" were the ultimate cosmopolitan conglomeration: "They could be Christians or Muslims or even atheists, blond, red-haired or black, with a retroussé nose or a hook nose. The only unifying factor was that their passports said they were Jewish. It was enough at the [refugee camp] at Marienfelde if one in the family was Jewish or a half or quarter Jew" (K/R, I3). Here, the ironic tone of the postmodern reflects a German sensibility about what it means to be Jewish. A rabbi asks a woman what Jews ate at Easter: “'Pickles and Easter cake.' 'Well,' she said, 'I know what you mean. We Jews eat matzos.' Do you actually know what matzos are, the 
rabbi asked. 'But of course,' the woman answered gleefully, 'they are the cookies that are baked from an ancient recipe out of the blood of small children.' The rabbi fainted dead away" (K/R, I4). Are these Jews without knowledge of being Jewish or Jews who know well what is expected of them and ironically resist their transformation into members of a religion from members of an ethnicity? The Jews in the community take many of the new immigrants to heart but insist, for example, that uncircumcised males undergo the procedure in a gesture that redefines being Jewish in purely ritual terms (K/R, I5). At least one complies.

After this opening chapter, any confrontation with the question of a Jewish identity in Kaminer's first book vanishes. Kaminer seems to become a Russian, similar to the hundreds of thousands of Spätaussiedler (late resettlers) from the former USSR and Central Europe who returned to a virtual German fatherland from which their ancestors emigrated in the seventeenth and eighteenth centuries. Indeed, after reunification, members of both groups were treated identically as immigrants from the former USSR. Coming to Germany defines Kaminer as a Jew because of the German reader's expectation of what it means to fulfill a missing link in the superficially multicultural world of Germany, a Germany "robbed" not so much of its Jews but of its connection with what is imagined to be authentic Jewry - the world of klezmer, the world of the East, the world of Fiddler on the Roof. That this eastern world is totally Russified by the I990s seems lost on the Germans but not on Kaminer, who becomes a Jew only by becoming a German and quickly finds this transformation discomfiting. The volume quickly becomes the tale of a young man adapting to a German multicultural ambiance in which he is part of the new German "multi-kulti" world as a Russian émigré.

Kaminer's biography makes up the stuff of his literary work and therefore offers a window onto the claims of Germany's cosmopolitanism or at least onto its fantasies of the displaced Soviet now as new citizen in a Western cosmopolitan world. Kaminer thinks about being a Jew only when he represents his life in the USSR. Antisemitism is a feature not of Germany but of the USSR. In Militärmusik (Military Music, 200I), being Jewish is seen as a potential disadvantage. ${ }^{20}$ Jewish actors and choreographers such as his employer, Stein, who had worked at the Moscow Jewish Theater, had been persecuted as dissidents (K/M, 40-4I). Indeed, when Kaminer joins Stein in a dissident actionurinating on the stage at the Majakowski Theater-it is denounced officially as a "Zionist conspiracy" (K/M 49). Indeed, many hoary antisemitic myths are recycled, meaning that Jewish scientists and engineers are accused of having poisoned Lake Baikal with a "Jewish cancer" that destroyed it (K/M, 88). 
Kaminer never saw himself as "a real Russian, because the word "Jew" stood in my passport, I was a member of the Komsomol, a bit of a hippy and a passive dissident" (K/M, 54). As an outsider, he moves elegantly to Germany, where all of the things that excluded him now enable him to function on a relatively high cultural level. Already in his next memoir Die Reise nach Trulala (The Trip to Trulala, 2002) the entire residue of things Jewish vanishes from his forced memories of the USSR. ${ }^{21}$ His German audience wants happy memories of the Russian past that are just primitive enough to warrant an exaltation of the Berlin present.

The antisemitism that defined Jewishness for Kaminer in the USSR seems to be missing in his 200I account of the cosmopolitan world of Schönhauser Allee (Schönhauser Avenue), the working-class neighborhood where he lives. ${ }^{22}$ In this volume, which focuses on his life in the Germany, all of the Jewish references vanish. Russians, Vietnamese, Germans show up in various combinations and colors in the apartment blocks that make up this quarter of Berlin. Even after seeing someone on the street who reminds him of Albert Einstein (K/S, 5I), Kaminer does not think about himself or the fictive world he now creates as more than multi-kulti, with Jewishness simply an invisible quality. Indeed, this may be one of the very few mentions of Einstein in a modern literary work that does not evoke his role as the Jewish genius. This is Kaminer's most successful creation of a utopian Berlin cosmopolitan world in which all of the ethnicities and nationalities blur into a Russian-colored world that displaces any negative Jewish identity. In this hybridity, the solvent is vodka. Kaminer finds it necessary to supply a bit of a philosophical afterword, noting that "group interests manifest themselves, human beings create various units, and exchange experiences with one another, attend yoga courses, and at some point can do virtually everything" (K/SI89). Schönhauser Allee comes to be the "real" setting, according to the author, of his newer, safer multicultural Berlin. It is the place in which individual difference exists but is not pernicious, not destructive, not Jewish.

In 2002 Kaminer collaborated with photographer Helmut Höge on Helden des Alltages: Ein lichtbildgestützter Vortrag über die seltsamen Sitten der Nachkriegzeit (Everyday Heroes: A Slide Lecture about the Unusual Habits of the Postwar Period) ${ }^{23}$ The photographs are banal, recording moments in the daily life of Germans and self-consciously presented without any aesthetic pretensions. The volume includes an essay, "People in a Park," in which Kaminer ruminates about the meaning of public art. The protagonist and his children pass a monument with an open book and two hands in the Arnimplatz. They theorize about what the monument could be: a writer who always told the truth 
in his books and who was rewarded by having his hands cut off; merely a pair of gloves and a book left by a child on the way to kindergarten. Kaminer's youngest child has no theory but shakes the hand/glove each day as they pass.

Kaminer knows Germany now and understands that "this monument, as with all of the others in the capital city, actually has to do either with the German reunification or with the expulsion of the Jews" (K/H 27). Such public sculptures are often illegible to those who live in the area. Thus there are Holocaust monuments that seem to have no meaning: "The giant chair that lies tipped over in the Koppenplatz, which should remind one of the expulsion of the Jews, and which the artist has labeled 'the abandoned room"” (K/H 28). No Shoah, no murder of the Jews, only an expulsion: the term is evocative but in no way condemnatory, as his memories of Soviet antisemitism are. These public arenas, according to Kaminer, have lost any sense of the aesthetic message. The parks are full of drunks who appear in the morning and "form a living monument of the newest age" (K/H 28). But this monument is no longer German. "German" monuments are those understood now as reflecting the combination of the "expulsion of the Jews" (not their systematic murder) and the reunification.

Any new monument must reflect Kaminer's world of the new immigration. One of the drinkers has carefully deposited a glass in one of the trees. Earlier, the drunks simply mixed their beer and whiskey in their guts. "Through the merging of international customs the alcoholics have achieved a new quality of life, new perspectives are open to them. It even smells better" (K/H 29). Here, the "Jewish" aspect of the world is subsumed in the rhetoric of German monuments to the past; the new immigrants (Russian Jews included) have added a new layer to the public experience and created their own monument. The glass in the tree is their monument to the cultural hybridity of the new multicultural world, which even smells better.

In light of his construction of a cosmopolitan Germany, Kaminer's weakest book is the most revealing. Mein deutsches Dschungelbuch (My German Jungle Book, 2003) is his account of a lecture tour across the country. ${ }^{24} \mathrm{He}$ leaves the confines of his self constructed Schönhauser Allee and enters the small towns and byways of the Federal Republic. He is announced as "the Russian" or "the German Writer of Russian Descent" or "A Jewish Writer" (K/D I I7). He answers, as he observes, to any and all of these labels. In Fulda he learns of the town myth that a Jew, filled with hate after being driven from the town, was responsible for its bombing during the war: his family's house, seized by the National Socialists, was hit six times (K/D I 27). Kaminer also finds older Germans suffering under the burden of the guilt that they believe that no one will allow them to avoid: "In spite of everything, this fact will al- 
ways be my burden" (K/D I95). In Heidelberg, a Russian band plays antiwar songs, bringing to mind Kaminer's father, who warned that within everyone a soldier is hidden, as well as Kaminer's half-brother in Israel, where he is under attack by Saddam Hussein's Scud missiles (K/D 225). In Germany, unlike in the multikulti fantasy of Berlin, the past is present in ways that pierce the utopian notion of any hybrid or rooted cosmopolitanism. Kaminer claims that while his work seems autobiographical, "I wouldn't say my prose is autobiographical. It isn't about Wladimir Kaminer, it's about others. The narrator is transparent, a cipher. The reader doesn't learn any intimate details about the narrator's life; the focus is on the surrounding world, the past, the future, encounters. Dialogue is hugely important, because communication is." 25 The Jewishness of Kaminer's self-representation in Germany is on the very edges of how he needs to see and sell himself. It is part of the German past, yet he is anxious not to exploit the German philosemitic desire to love all Jews, even the new immigrants, if they are "Jewish" enough.

By 2004 Kaminer had become the "representative Russian" in Germany. His Ich mache mir Sorgen, Mama (I am Concerned, Mama) has only one reference to a Jew-the publisher of Berlin's daily Russian newspaper. ${ }^{26}$ Kaminer's personal life forms the center of this volume, in which his father, unable to attain his professional goals in the USSR because of his Jewish identity, has become a Russian pensioner in Berlin. All references to being Jewish are deleted from Kaminer's family portrait. Most striking is the inclusion of an icon of the Virgin Mary on the "memory shelf" compiled by his wife. The question of a hyphenated identity remains but is transmuted into that of the Russian in Berlin, much like the hero of Montesquieu's Lettres persanes (I72 I) or Samuel Johnson's The History of Rasselas, Prince of Abissinia (1759) - the exotic who comes to Europe and is amazed at the antics of its inhabitants. But these antics no longer contain any reference to antisemitic comments. Indeed, by 2003 , Kaminer had come to believe that "the Soviet Union is my homeland. Berlin is my home. Russian is my mother tongue. German writer is my profession."27 The Jewish Kaminer had vanished completely.

In his 2005 book, Karaoke, Kaminer recapitulates his initial celebrity role as a DJ in Russendisko and provides the reader with an elaborate riff on the role of music in creating his newfound Russian identity. ${ }^{28}$ The role of global popular music and the anxiety of the new German Left about pop culture frames his image of the Germany in which he is a citizen $(\mathrm{K} / \mathrm{K}, 29)$. His position is, of course, contrarian in that he advocates the totality of contemporary music, a perspective that is not only truly cosmopolitan but also oddly conservative. The advocacy of Americanism in music was, of course, oppositional during Ka- 
miner's youth, both in the USSR as well as in East Germany (K/K, 53). His claims that "Russendisko" was the medium by which "Russian punk rock" (and other Russian pop cultural manifestations) were made available for Russians and Germans alike in the new Berlin is not at all tinged with irony. Many contemporary Russian and Chinese artists take a different position, recycling Soviet or Maoist cultural representations in an ironic mode. The seriousness of Kaminer's claims can be found in his evocation of a memory of Jim Morrison's lyrics sung in a mixture of Russian, English, and German in Berlin in 1990 $(\mathrm{K} / \mathrm{K}, 83)$. For Kaminer, the musical "world cultural inheritance" is the "Ramones, Sex Pistols, the Clash" (K/K, IOI). German music is reduced to the band Rammstein, which was initially popular in Russia because Russian skinheads saw it as a "Nazi" band (K/K, I07). Only with a false sense of history, Kaminer implies, can the "German" be elided with the "Nazi." What is striking about Kaminer's use of music as the universal, cosmopolitan language is what is missing: given Berliners' two-decade-long obsession with klezmer, the complete absence of any reference to "Jewish" music (often in Berlin played by non-Jews) is telling. This musical memory chest has no space for anything Jewish but accommodates only the global, the universal, the cosmopolitan.

By 2006, Kaminer joined his wife, Olga, in presenting his Küche totalitär (Socialist Cookbook), a rather rapid tour of the states of the former USSR accompanied by "authentic" recipes. ${ }^{29}$ From Armenia to Tartestan, the memories of youth are tied to the world of food. Like music, food is used based on its universal as well as particular claims to shaping identity. Beginning with the celebration of Kaminer's father's birthday in a Russian restaurant in Berlin (K/O, I 2), the ripples of food and memory spread across the former USSR as a "magic door" to the past (K/O, I6). Evocations of the exotic are matched with the mundane, as Armenians and Georgians, Ukrainians and Siberians in Berlin are sought out as the parallels to Kaminer's need for an authentic cultural experience. And after each confrontation, a set of "authentic" recipes enables readers to at least vicariously taste the reality depicted in Kaminer's diasporic world. As with the search for an authenticity of world music, Kaminer here represses anything and everything Jewish. Alice Nakhimovsky has chronicled the resurgent interest in "Jewish" foods in contemporary Russia even though there is little sense of the religious bounds that defined that cuisine. ${ }^{30}$ This has truly vanished in Kaminer's evocation of the former USSR: it would be too Jewish and not "Russian" enough.

The final transformation of the Russian Jew into the Berlin celebrity Wladimir Kaminer comes in his 2007 Ich bin kein Berliner (I'm Not a Berliner), playing off of John F. Kennedy's oft-quoted I963 declaration, "Ich bin 
ein Berliner." 31 To be a member of the club, to become a German, one has to be beyond the national, beyond the local. That is precisely the claim of German cosmopolitanism as well as the ultimate national and local claim. Following the same format as the cookbook, Kaminer provides snapshots of aspects of Berlin life from dialect to shopping to criminality to weddings, each followed by suggested tourist tips. The volume concludes with a guidebook-like list of addresses and opening times and blurbs for all of the "sights" mentioned. Here the odd chapter out is "Nazis and Other Sights." As with virtually all Kaminer's evocations of the National Socialist past, it is ironic and distanced. He tells the story of a Russian avant-garde artist who shows up on his doorstep wearing an Iron Cross as jewelry and who wants to explore the National Socialist underground. He sends her to a "former" SS bar where her jewelry elicits a sad (but perhaps also threatening) comment that the Führer would not have approved (K/I 72). Kaminer's suggested tourist stops here include the Jewish Museum, but he notes that only the "British and American tourists" with their false consciousness who want to visit “Göring's barber's shop or Hitler's sock knitter's establishment" (K/I 72). Kaminer thus equates those tourists with the Russian skinheads who seek out "neo-Nazi" German bands. The Holocaust is someone else's problem and someone else's interest, even as a tourist. But the Holocaust appears only in an ironic comment on foreign Holocaust tourism-unlike the more serious comments on the "Turkish" sites that Kaminer sprinkles through the volume. The Holocaust is no longer the Germans' problem, especially for Germans such as himself.

Kaminer arrived in East Germany as a young adult with a sense of autonomy that enabled him to believe that he could shape himself as well as the world he comes to inhabit. And in complex ways, given the remarkable success of his work, he is quite right. Yet the question of his "Jewish" perspective in the Federal Republic of Germany remains part of his public persona. For him, Germany is very different than Austria: "An awareness of what took place, and vigilance to ensure it never happens again-I mean, it took so little to unleash that madness - permits the Germans to consider the past with some remove, makes it possible to envision a future. It's totally different in Austria. I heard this joke about Austria recently. There's a documentary on television about concentration camps, and two old ladies on the bus are talking about it. 'What horror!' they're saying. 'You would never have something like this [on TV] under the Fuhrer.' There's absolutely no national remorse, no soul-searching at all."32

Kaminer had by this point become a landmark on the German cultural map, publishing a book each year, with good if not great sales. ${ }^{33}$ And the tensions between the Russian, the now virtually invisible Jew, and the German 
cultural hero remain. In 20 I 2 he returned to his autobiography, rewriting it in a manner appropriate for the times. In Onkel Wanja kommt: Eine Reise durch die Nacht (Uncle Vanya Is Coming: A Journey through the Night), the central conceit is that his grandfather's brother, now ill and aged, wishes to finally visit his great-nephew in Berlin. The narrator is the author or the author's ghost, seeking his work in the train station bookshop between Franz Kafka and Heinz Konsalik, whose bodice-ripping romances of Russia color the Germans' fantasy in Kaminer's world. He sees himself trapped here, yet his works are not on the shelves. In reality, however, cheap paperback copies of Kaminer's works are available in virtually every train station bookshop.

The quest for Russian high culture is captured in the book's title, since Uncle Vanya is of course the title of Anton Chekov's I 897 drama. Ivan Petrovitch Voynitsky, the title character, struggles to preserve the tradition of Russia as he is confronted by crass demands to sell the farm that he has struggled to manage. In the third act, Vanya curses its owner, raging that he should not have wasted his life: had he tried, he could have become another Schopenhauer or Dostoevsky. Kaminer is a sort of reverse Uncle Vanya in this tale. He is perhaps the young writer mocked in the account of how Ivan Turgenev, old and ill in Paris, complained to a young writer about no longer being able to write anything sensible and received the reply, "I am now writing extensively and very well" (K/V, 36). More likely, however, Kaminer is the cosmopolitan Turgenev, who spends much of his life moving among London, Baden-Baden, and Paris, a member of the pantheon of a mobile Russian literary culture. Indeed, the mention of the old Turgenev signals that Kaminer belongs to those with kulturni. That Kaminer desires to be associated with such Russian high culture is evidenced by his 2008-I4 production of radio programs (subtitled "Berichte aus den Tiefen der Russischen Literatur" [Reports from the Depths of Russian Literature]) that became audiobooks on Leo Tolstoy, Mikhail Bulgakov, Anton Chekhov, and Soviet-era satirist Daniil Kharms. Kaminer's newest account of his life recapitulates each moment, telling the tale in reverse, from his presentday life in Berlin back through his time in the army to his childhood.

His uncle was always the odd one out in the family, the lovable but idiosyncratic member hidden when guests came to visit. He is the barely visible one in the forty-four black-and-white family photos, hidden in a corner, only his elbow showing. He is a presence, a ghost who provides the narrator with frozen memories of his Soviet past $(\mathrm{K} / \mathrm{V}, 5,7)$. His uncle is the litmus test for the re-creation of lost memories from the fragments of the past.

His uncle arrives on the night train from St. Petersburg; unable to find a taxicab, he and the author walk across multicultural Berlin. The narrator retells 
his life through his uncle's appearances. They walk while unraveling his life backward. They stop for drinks in a pub with other night visitors from Russiatour agents who had been on the same train on their way to a convention to tout their regional attractions, most of which center on killing and stuffing animals. The drinkers are told that taxis are available across from a kebab stand, where they meet drivers from Syria and Afghanistan-former professionals, doctors, and engineers who drive cabs in the new multicultural Berlin. But although there are drivers, there are no cabs.

They continue their walk and the narrator spins the tale of his life back to Odessa, where he visited his uncle during a summer vacation. This is a Russian narrative, repeatedly stressing the displacement of Russians in a world in transition from the old Soviet Union to Putin's Russia, "where good and evil have merged, socialist braggadocio and capitalist cleverness" (K/V, 5), reinforcing the wisdom of the narrator's flight to East Germany. But the tales told about and by his uncle contain a hidden agenda.

His uncle is the Russian Jewish wanderer, moving from house to house, from room to room across the old Soviet Union, from Moscow to Grodno to Krasnodar, always trying and failing to find the appropriate "home" (K/V, I3I4). Lost in the sense of rootlessness in the geography of the space he is in, he heralds its socialist sense of community. In Berlin, he bemoans the loss of Soviet camaraderie, the "mustard sandwich communism" where at least one could get free bread, mustard, and tea in the poorly functioning restaurants (K/V, 59). In capitalist Berlin, nothing is free and things Russian have been reduced to a bad joke, a comic dressed as Ivan the Terrible (K/V, I). Berlin is a city of tourists, like his uncle, easily tricked into buying bits of the Berlin Wall just as they buy bits of the Great Wall when visiting China (K/V, I I 2). Berlin in this sense is only a simulacrum of a city, contrasting with the real spaces of the socialist past. It is certainly not a "Jewish space" in the sense that Anna Lipphardt and Julia Brauch evoke it, a space where the Jewish diaspora allows multiple inner Jewish comparisons as well as comparison with other diasporas, including this new "Russian" one, which can (but need not) be simultaneously Russian and Jewish. ${ }^{34}$ Yet given Berlin's intense preoccupation with the Holocaust, with multiple moments, museums, and institutes, it is a haunted Jewish space in the present.

As the narrator unravels his past and his present, he recedes into his past, where his Jewish past is hidden in an odd, fossilized manner: "I managed to avoid as a child and as a youth the problem of religion. I had no inkling of a religious education, and I begin to stutter when asked about Judaism or Christianity and any other-ity. My parents weren't even atheists. They were always 
concerned with the daily grind of existence and had no time to concern themselves with the greater questions of conscience. Therefore they simply live without any depression, happily and without worries" (K/V, I29-30). The question of a Jewish identity in the Soviet Union — and in Berlin, with its reinvigorated Jewish community of Russian Jews-has nothing really to do with religion any more than it did in the USSR. The narrator sees the reappearance of religion in Russia a sign of a shift in emphasis but not in an increase in piety. Where the parents of his neighbors in Moscow become Russian Orthodox after the collapse of the USSR, their children become Buddhists (K/V, I3I). Kaminer's grandmother now uses the holy water from the spring behind the local church to treat her ailments without any confession of faith (K/V, I40).

At fourteen, another manifestation of the narrator's identity as a Soviet Jew reappeared - a political and ethic definition that dominated Kaminer's first autobiographical volumes. He casts this manifestation in the conceit of recognizing that the USSR had borders, since he had always lived thousands of miles from any border and could not even imagine that such a thing existed. He spends a summer visiting his uncle in Odessa, pleased because his girlfriend, Ella, is also there (K/V, I 57). She is about to leave the Soviet Union: her parents had "applied for an exit visa and were preparing their emigration" (K/V, I57). She did not want to leave, but "her parents could not succeed in socialism. Both were doctors and as such they were convinced that they would have a much better life in the West. She already was homesick even before she emigrated" (K/V, I57). They are refusniks, waiting for visas to Israel but imagining their future in Europe. She points out that the Turkish border lies just over the horizon, on the other side of the Black Sea. Never before had the narrator been aware of these borders, but they are clear references to his sudden awareness of his identity as the new cosmopolitan, able but yet unwilling to travel. They are startled by the guard walking along the beach. The "halfway friendly soldier" confronts them; though they do not have their papers, he simply tells them "to go home" (K/V, I 59). But where is home for the Jew about to leave the USSR either as a quota refugee or, in Kaminer's case, as a visitor to the East Germany, whose "worthless coins littered the ground" when he first visited the newly reunited Berlin (K/V, 28).

The wanderers through the night arrive at the narrator's apartment, where he takes stock of his memories and the objects that fix them. His grandmother is long dead, her cuckoo clock silent and frozen on his wall. "The silver cross that his father had obtained from a gypsy in trade for a case of beer" is on a shelf. The objects, he observes, "are created not for the moment but for eternity" (K/V, I90). They are frozen memories, "for our planet is a museum. The 
visitors come and go, the objects remain" (K/V, I90). At this moment his uncle is telling him a joke, constantly interrupted by the narrator's memories. "The Orthodox priest says, the flood is coming in three days, let us drink up all our vodka" (K/V, I88). "The imam says to his flock, the flood is coming in three days, let us finally roast a pig" (K/V, I90). And finally, the point of the joke: "The rebbe says: brothers and sisters! We have three days to learn how to live underwater" (K/V, I90). Thus the narrator concludes the volume "with a broken clock, a cracked cup and a joke that is not told to its conclusion, whose laughter is lost in the waves of time" (K/V, I9I). Kaminer's second bite of the autobiographical apple is now nostalgic, in the worst sense of the word. This nostalgia is what Vladimir Nabokov in his study of Gogol mocks as poshlost, "not only the obviously trashy but mainly the falsely important, the falsely beautiful, the falsely clever, the falsely attractive." ${ }^{35}$ Nabokov later extends the idea to include "corny trash, vulgar clichés, Philistinism in all its phases, imitations of imitations, bogus profundities, crude, moronic and dishonest pseudoliterature."36 Kaminer has become the wanderer, the cosmopolitan, truly at home only in memory, not in the night passages of multicultural Berlin; his work, however, leaves a false sense of its own importance.

An alternative set of "Russian" voices is also present in today's German culture. Gender plays a role here, but so does the author's age at his arrival in Germany. As Adrian Wanner notes, “In Germany ... emergent 'Russian' writers such as Lena Gorelik ... stress their difference from Wladimir Kaminer" (W/O I89). Gorelik's first highly autobiographical novel recounts her I992 move from the USSR to Germany and her acclimatization there as a Jew. ${ }^{37}$ Born in Leningrad in I98I, Gorelik creates a protagonist who mirrors of her imaginary image of the new Germany, which she entered at the age of eleven. She spends an early chapter depicting the struggle of her protagonist's somewhat older brother for a Jewish identity in Germany. He is sequentially a Buddhist, a Jew for Jesus, and an Orthodox Jew. All are answers to what Gorelik labels the struggle of Russian Jewish emigrants without any religious identity whatsoever for some type of orientation in the new Germany. "He is an emigrant, seeking a spiritual home" (G, 4I). His Jewish orthodoxy is a phase through which he passes, including keeping the kosher laws and going to Israel to learn Hebrew, the litmus test for a Jewish religious identity in Germany. The Hebrew classes at the Jewish Center in Berlin are offered in Russian. The brother seeks not a secular Jewish identity in Israel but a religious one that transforms his body. When he reappears in Berlin, his grandmother sees his long beard and responds that such a man will never find a bride. But once he develops an interest in a leftwing fellow student who decries religion, his religious fervor lapses. After her 
comes a nice Russian Jewish immigrant, whose only flaw is that she believes in Jesus. Gorelik notes in an aside that this struggle for a religious identity is not a German anomaly: many Russian Jews in the United States become Scientologists $(G, 45)$. Religious identity as a Jew is here truly a performance that is rooted in the struggle for a new Western identity.

"Religious" identity defines the Jew, but the Jew's ability to be understood as part of "German" culture retains an older and still valid association. The Jew must speak German. ${ }^{38}$ In Germany, the role of the non-English writer writing about the diaspora experience in his indigenous language is always suspect. For whom does he write? Why does he not address me, the German- or Englishlanguage reader? The notion of a "German" literature rejects works written in German in America or in English in Germany. (The debate about the status of Spanish-language writing in the United States or Turkish writing in Germany is equally fraught.) Thus, "religious" identity is paired with the ability to function bilingually. The figure of the Russian Jewish writer mediates between two cultures: a real one of the reader's experience and a fictive one, given the claim of authenticity of the world reflected in the writer's representation of his or her experience of the East or of the eastern image of the West.

Language determines what defines a German as German and has remained central in the most recent transformation of eastern Jewish writers into German writers. Survivor-author Jurek Becker, a native Polish-speaker, saw command of the German language as defining him as a "better German" than his classmates (and competitors). He became a German, rooted, rather than a displaced person, the term used for the "wandering Jew" in immediate postwar Europe. Like Becker, Russian Jews in the second decade of the twenty-first century are reinventing themselves in German and in Germany. ${ }^{39}$ Like Becker, they must find their way into a new language and a new culture that many find inferior to Russian culture. For the older generation of Russian Jewish immigrants (as for most immigrants in Germany), language adoption continues to pose a major barrier to social and economic integration. It is little wonder that Germany's Central Jewish Organization strongly suggested that "a good knowledge of German" (and not a more stringent religious definition) serve as a litmus test for limiting further immigration of Jews after 2005 and that this suggestion has become state policy. ${ }^{40}$ For these youngest writers, among them, Gorelik, "speaking Russian" comes to be negatively coded by her German compatriots. It is "speaking too loudly, speaking in a confused manner" (G, 63). That is, as she notes, "simply speaking" (G, 63). Language and audience are vital to these writers, but they see themselves as the conduit for the Russian Jewish experience for their German-language readers. 
By 2013 such an identity as a migrant comes with a rather different quality ascribed to the language of the cosmopolitan. In her screed Sie können aber gut Deutsch! Warum ich nicht mehr dankbar sein will, dass ich hier leben darf, und Toleranz nicht weiterhilft (My, You Speak German Well! Why I Am No Longer Grateful That I Am Allowed to Live Here and Why Tolerance Doesn't Help).$^{41}$ Her sense of being rooted rather than simply a migrant (the term that has replaced displaced person in the discourse of Russian Jewish writers, is contested constantly. The Germans bemoan the high rate of criminality among those "Russian descended, so many problems: they remain among themselves, can't speak good German" (G/W, 9). Yet for her, the reality is quite different. The "migrants" root for German football teams and speak virtually no Russian; they can't, in many cases, even read the Cyrillic alphabet (G/W, 9). Their teachers think of them as "Russians" with a Russian mentality quite different from the German. She imagines a Venn diagram of her own mentality: "White-Russian. Black-German. Gray-Jewish" (G/W, I I). The "Russians" about whom she speaks may well be Russian-speaking Jews from the former USSR, but they could also be the Russian-speaking descendants of the Swabian Germans. She stresses, as do the characters that people her account, that they are Russians, and that that are integrating themselves into the new Germany as Russians. Here she falls very much in line with the St. Petersburg Club's competition for Russian writing in German. A jury headed by Kaminer selected and published twenty texts by Russian Jews and Russian Germans under the title Neuer Hafen: Migrantenerzählungen (New Port: Migrant Tales, 2007)(W/O, 50). These are the new collective Russian migrants in the eyes of the new Germany. They share a lost language and the adaptation of their culture to the dominant Russian cultural model, as Vera Irwin notes: "Both [groups] have almost completely lost their ethnic languages-German and Yiddish - throughout history, and have become speakers of Russian. After migration to Germany, both communities acquired German as a second language" (I, I). In addition, they retain their fantasies of cultural integration.

Religious identity for Gorelik remains a vague and contested concept. Zvi Gitelman has pointed out that for Jews in the Soviet Union who defined themselves as Jewish, "Judaism no longer defines the content or boundary of Jewish identity. This is quite logical: if Jewishness is ethnicity only, then one should be able to practice whatever religion one wishes without affecting one's ethnicity." 42 Yet Gorelik's memory of her process of becoming rooted is colored by her Jewish identity, as when she notes when attending the compulsory religious instruction in school, "I, as a Jewess, sometimes attended the evangelical; sometimes the catholic" (G/W, I7). She begins to be integrated into the school 
only when a teacher of German stops seeing her as a "little, eleven-year-old person from Russia" (G/W, I9) and asks her simply to write a story. But is she a " "person speaking a non-German language,' or a 'person of foreign origin" or a "member of an ethnic minority settled in Germany?"' (G/W, 32). She seeks to integrate herself into Germany but realizes that trying to do so poses a barrier to her integration. In the camp, she changes her hairstyle and buys "German" clothes $(\mathrm{G} / \mathrm{W}, 44)$ yet still feels that she appears different. She continues to feel that she is a "Russian-with the Jewish bonus" (G/W, 65). That makes her life in a Germany now filled with migrants from throughout the world more tolerable. Perhaps, she notes, because "the old Nazi object of hate the 'Jew' has now been replaced by a new object of hate "the Muslim", (G/W, I 55). Thirtytwo times she evokes the debate about integration caused by the popularity of Deutschland schafft sich ab (Germany Does Away with Itself, 20 Io), Thilo Sarrazin's best-selling screed against German multiculturalism. A prominent member of the German Social Democratic Party, minister of finance for the state of Berlin from 2002 until 2009, and at the time of the book's publication a respected member of the executive board of the Deutsche Bundesbank, Sarrazin "showed how in each of us an anxiety resides" about social integration (G/W, I4). Gorelik's critique rests in Sarrazin's claim that "no integration can occur without assimilation" (G/W, 236). The keyword is integration (G/W, 85). She still does not feel herself in any way integrated. She does not mention Sarrazin's claim that unlike present-day Muslims, the Jews were the ideal example of social assimilation before National Socialism. He decries the dilution of twenty-first-century "German" society by the reproductive capacity of a permanent and unassimilable underclass of "Muslim immigrants" in Germany. ${ }^{43}$

Gorelik reads to a women's group a chapter from her first book about how greedy German dentists remove teeth from immigrant children to replace them with expensive bridges, provoking an angry response from her hosts: "You need to think about what you write when you write in our language. A bit of thankfulness would be expected" (G/W, I99). Though she is perfectly at home in German, she never feels at home in Germany. Yet her account is missing the key reference that perhaps made her hosts most uncomfortable: the greedy removal of migrants' teeth in the camps where they have been concentrated (Asylbewerberwohnheim) evokes the removal of gold teeth from Jewish prisoners in the National Socialist death camps. The new camps, with "twelvesquare-meter rooms that housed Russian Jews" and where "they came, they brought us things, that we actually did not need, where they taught us German" (G/W, 206), haunt her memories of Germany and her own transition. She knows that "families such as ours were a present for such helpers. Jews from 
the former Soviet Union" (G/W, 20I6). Here the Germans had a "bonus," as they were helping Jews.

Gorelik's new status as a German-speaking writer means that she is now at least virtually integrated into a society that found such integration difficult to comprehend. Her sense of this is coded in her Jewishness, a factor that is less visible in her account than her Russianness. Jewishness is both foreign and homely, unlike the exoticism of the Russians:

When I recognized that I had not assimilated myself, I always thought of the Jews of the I920s, the so-called Western Jews, who were the opposite of the Eastern Jews. The Eastern Jews were those with their black caftans and their long, gray beards, who among themselves retained their Yiddish, that unusual German, who stood in their synagogues that they called shul and ran there to pray, and who remained what they had always been in the eastern lands, now in this new land. The Western Jews looked down on the Eastern Jews, embarrassed, and distanced themselves from them and were self-conscious and proud to be assimilated. . . . Being assimilated carried with it the promise of a better life, to be seen as better, to become a better human being. (G/W, 235)

Gorelik has become both and is discomfited by that fact. She sees a Germany that has radically changed but that cannot itself recognize the alteration of a fantasy homogenous culture into a cosmopolitan one in which Gorelik feels both comfortable and ill at ease. She remains most comfortable among "Russians," with their food and their friendship. This is the odd feeling of being at home in the fantasy Russia that she presented in her 2008 guidebook to St. Petersburg for Germans, Verliebt in St. Petersburg (In Love in St. Petersburg), where she attempted to introduce the dos and don'ts of her birth city to an ideal but oblivious German audience. She finds this on her return trip to the "motherland," a return to the familiar, to the world of her parents and her childhood. In Russia, "there is always more on the table than one can eat in an evening. . . . I feel happy and find to my amazement how relaxed I am" (G/W, I6o). It is the relaxation of the familiar rather than the staged, of the experienced rather than the performed. Gorelik has moved far from what Wanner called her 'personae of the female 'immigrant overachiever,' [that] fit neatly into the utopian projection of the New Germany as a happy multicultural community" (W/O, I9I). She has become a frustrated cosmopolitan in a Germany never multicultural enough. 


\section{In America, Nabokov Really Is Not Sholem Aleichem}

Cosmopolitanism as depicted in writings by Russian Jews in twenty-first-century Germany can be compared with works by Russian Jews of the same generations who migrated to Brooklyn, New York. Though different sources provide widely varying numbers based on differing definitions of Jewish, by 20I4, the United States was home to as many as 750,000 Russian-speaking Jews. ${ }^{44}$

As in Germany, America's Russian Jews are culturally, ethnically, and religiously mixed. Indeed, the late-twentieth-century Russian Jewish immigrant community was distinctly more secular and less religious than the Central and Eastern European Jews who migrated to New York nearly a century earlier. ${ }^{45}$ Unlike their counterparts in Germany, however, Russian Jews in the United States become more Jewish the longer they write. According to Morris Dickstein, "Once these writers arrived in North America, they all turned more Jewish, as if licensed by the strong Jewish presence in American literary culture, but also by a multicultural environment that equates ethnic identity with personal authenticity." 46 Or as real estate agents say, what is important is location, location, location. Ironically, more than any other feature, location defines modern cosmopolitanism.

As with the confluence of Jewish and non-Jewish Russians in Germany, teasing out the differences is complex. Yet among Russians Jews in the United States, the boundaries were clear. Even those who were neither religiously Jewish nor ethnically Jewish set themselves apart from non-Jewish Russians, who clearly defined themselves as not Jewish. In Germany, this process was more complex, as both groups immigrated at roughly the same time and most of the non-Jewish Russians were of ethnic German descent. In the United States, the staggered arrival made the boundaries sharper but no less contentious. One Russian Jew interviewed by Laitin

rationalized [the divide] by stipulating that the Russians who came to Brighton Beach after I99I were different. These mostly non-Jewish Russophones were poor and came to the United States for financial reasons, she explained, while the earlier wave, mostly Jewish Russophones, was well to do and came for political reasons. The more recent immigrants, therefore, were having more problems assimilating, while the earlier ones had assimilated easily. ... Another third-wave interviewee made the same argument. She did not "blame" the members of the fourth wave for their failure to connect with third-wave immigrants, but she found little in common with them. (L/D, I9) 
Bound together by a common language and putatively by a common cultural heritage, the Russian Jews remained too cosmopolitan in the eyes of their Russian compatriots. Unlike the Russians, Russian Jews quickly became a voice on the American cultural scene.

Kaminer's rise to fame in Germany was very much paralleled by Gary Shteyngart's rise in New York City. Like Kaminer, Shteyngart quickly became a media darling: according to Wanner, "Shteyngart emerged as a sort of iconic Russian-American personality. A full-page photograph in the New York Times Magazine in summer 2002 showed him in a melancholic pose behind a glass of vodka in the Manhattan restaurant Russian Samovar" (W/O, 95). A star as a Russian Jewish writer, Shteyngart's experience was of the Russian child growing up in America.

Shteyngart's family immigrated to New York City in I978, when he was six, yet he turned his "American Jewish" experience into his first novel, The Russian Debutante's Handbook (2002) ${ }^{47}$ His account stresses the impossibility of integration. The protagonist, Russian Jew Vladimir Girshkin, is employed (in a Henry Miller sort of manner) by the Emma Lazarus Immigrant Absorption Society, a position that his middle-class professional parents find well below his potential. (The American Jewish poet Emma Lazarus (I849-87) wrote "The New Colossus," the text that appears at the base of the Statue of Liberty: "Give me your tired, your poor, / Your huddled masses yearning to breathe free, / The wretched refuse of your teeming shore.") Each week is a different "cultural week" at the Emma Lazarus Society: "Chinese Week," with "tea and a stuffed panda. ... Although Vladimir was taught to foster multiculturalism, he looked blankly into the sneering faces of his countrymen, stamping his way through their mountains of documents" ( $\mathrm{S} / \mathrm{R}, 65)$. The Russians (read: Jews) claim that they are kulturni, cultured, unlike the other immigrants: "Vladimir [hoped] his childhood excursions to the Kirov ballet and the Hermitage had made him kulturni enough" (S/R, 70). This defines the new migrants as members of an elite. And this Russian cultural elite is analogous to the fantasy of a German high cultural elite defined by Goethe and Schiller, two writers whose translations into Russian belonged as much to Russian high culture as German and defined German Jewish high culture of the early twentieth century. ${ }^{48}$

While his parents have integrated themselves into suburban American (in their own fantasy), Vladimir never can. America is a multicultural hell called Brooklyn, which according to one Russian character comprises: "A studio apartment. Spanish people everywhere. Oh, the plight of the poor." But though the Russian immigrant in question “... was happy to be reunited with his $p a$ - 
patchka, but he was still a young man. He wanted to bring a girl over, to screw her thoroughly from top to bottom. It wasn't easy on him, believe me. And there was no work around that really took advantage of his natural intelligence. Maybe a few Greeks hired him to blow up their diners for insurance purposes. He was proficient in these matters, so boom boom-" (S/R 20). America, at least Brighton beach, is a place from which to escape-where else but to Eastern Europe, perhaps to "Prava? Vladimir perked up. The Paris of the 9os? The stomping ground of America's artistic elite? The SoHo of Eastern Europe?" (S/R, 20). In Prague he comes across a world of American Jews, exemplified by the "writer Perry Cohen" from Iowa. In Prague, that most Jewish of cities and now the city of Kafka, whose visage has become the logo for Prague tourism, Cohen "discovers" himself. In Prague there is a hotel where "Kafka took an important crap in I92I. . . See the plaque by the door" (S/R 279). But Vladimir is not impressed with Cohen's seemingly tortured acknowledgment of his new Jewish identity: "In the end what determines your fate is the size of your trust fund, the slope of your nose, the quality of your accent. At least his daddy wasn't accusing him of walking like a Jew" (S/R, 207-8). Prague is the "waiting room to the West" (S/R, 267), where mindless violence defines daily life, where identity is one of the objects available for exchange. Indeed Prague became exactly such a space for the American Jewish imaginary in works such as Philip Roth's The Prague Orgy (1985), the epilogue to his trilogy featuring his alter ego, the exemplary American Jewish writer Nathan Zuckerman. Between I972 through 1977, Roth actually travelled to Prague every spring for a week. Valdimir was following in impressive literature footsteps.

Vladimir-nose, walk, and all—eventually realizes that Prague has become the new multicultural city, with Cohen now typical of its inhabitants. One could have "a kale-and-cabbage lunch at the new Hare Krishna joint, or head for the Nouveau where they drank Turkish coffees and became awake and animated, played footsie to the quick time of Dixieland jazz" (S/R, 308). Populated by young Americans from the Midwest, Prague slowly takes on the qualities of a simulacrum of that world.

The protagonist remains too Russian (and therefore too Jewish) for a cosmopolitan America, even a cosmopolitan America transplanted to the East. His mother had noted that unlike American Jews, his difference is written on his body: "Look at how your feet are spread apart. Look how you walk from side to side. Like an old Jew from the shtetl. . . How can a woman love a man who walks like a Jew" (S/R, 44). His mother endeavors to walk like a "normal" American and urges, 
You, too, could walk like a gentile. You had to keep your chin in the air. The spine straight.

Then the feet would follow. $(\mathrm{S} / \mathrm{R}, 46)$

But Vladimir never quite learns this lesson. He is unable to transform himself into a gentile, even in the world of Prague.

Vladimir's autonomy as a Russian Jew separates him from all other groups, each of which is also defined as physically different. His adventures in New York City as well as those in Central Europe, where he becomes the Russian Mafia's "American Jew," illustrate his sense of never really belonging. Prague is the "New, Proved \& Euro-Ready Prava" (S/R, 324). Vladimir remains what he is - an incomplete hybrid, neither Jew nor Russian, nor American gentile. Yet one thing does define him - the Holocaust as a space, a place. He travels to Auschwitz in a convoy of (German) BMWs taking Cohen and his Prague acquaintances to "confront" their virtual past. Vladimir's family had been spared the Holocaust because his grandmother had negotiated a move from the Ukraine to Leningrad before the Germans came. At Auschwitz, the "rootless" Vladimir "if he possessed even the trace of doubt of an agnostic, now would be the time to mumble what he remembered of the Mourner's Kaddish. But with Hebrew school resolving the last enigmas of the empty heaven above, Vladimir could only smile and remember the feisty Grandma he once know as a child" (S/R, 405). Again, the Enlightenment image of Jewish education as destructive is evoked to acknowledge Vladimir's "ethnic" (or in Soviet terms "national") identity as a Jew even at Auschwitz. Only when he attempts to leave the new Russia with his criminal collaborators from the Russian Mafia and is confronted at the airport with the violence of the new world does he moan: “'Oh, my poor people,' said Vladimir suddenly as the violence commenced. Why had he said this? He shook his head. Stupid heritage. Dumb multicultural Jew" (S/R, 446). In the end, the "multicultural" returns to define Vladimir's humanity, a humanity put into question, as in Henry Miller's world, but never quite abandoned. And the name for this compassion is multiculturalism. The novel's last line offers a utopian imagining the America of Vladimir's imagined son, who lives in Cleveland, one of "the most ignominious parts of the earth" (S/R, 45I): “An American in America. That's Vladimir Girshkin's son" (S/R, 452).

The Russian Debutante's Handbook is in many ways the exemplary cosmopolitan novel in its evocation of the impossibility of being rooted in a cosmopolitan America. Yet at the end, biological hybridity marks the goal of the New Jewish writer. To become an American, one must - the theme is one from 
the nineteenth century-physically merge with America. Only in that way can one stop walking like a Jew. Shteyngart's literary antecedents lie more in the Russian tradition of Goncharov's Oblomov than in such North American immigrant novels as Abraham Cahan's The Rise of David Levinsky (19I7) and Mordechai Richler's account of the second generation in The Apprenticeship of Duddy Kravitz (1959). Shteyngart's second novel, Absurdistan (2006), is a self-consciously "literary" novel rather than an autobiographical one wrapped in literary cloth, as he noted in 2009: “The Russian Debutante's Handbook (2003) was a very autobiographical book in many ways, whereas Absurdistan, my second book, obviously, was not. Absurdistan was based on a lot of things — on a lot of literature: Goncharov's Oblomov, or Confederacy of Dunces, or even Candide." 49 The cloth in its essence is that of a reader of Russian high culture or at least someone who aspires to Russian high culture at one generation removed.

Shteyngart felt isolated in his new cosmopolitan America and captured that sense of failure in what became a very successful novel. When Shteyngart (like his protagonist Vladimir) returns to Russia, he seems pleased that his accent is seen not as American but as Jewish: "After I'm in Russia for a while, I lose it. The key is to inflect your voice in a way that makes you sound like you're completely furious and depressed." ${ }^{50}$ His accent-the mark of his hybridity_vanishes, and he becomes neither American nor Jew, just another exiled Russian. Contrast this with the obsession of Russian Jewish writers in German about the claim that no matter how perfect their German they remain permanent outsiders. The brave new frontier of multiculturalism uses Jewish difference but does so in ways that often contrast with those of Jewish writers who feel that they have achieved cultural success as "mainstream" authors rather than marginal voices. Yet doing so of course requires them to be more multicultural than the self-proclaimed multicultural authors. They must fit in everywhere by not fitting in anywhere. This is, then, the transition to their transformation. This "cool” Jewish cosmopolitanism in America certainly has analogies elsewhere.

Shteyngart's identification with twenty-first-century cosmopolitanism, embodied in his fantasy of New York City, is the focus of "The New Two-Way Street," where he claims "today people like myself, Russians by birth and Americans by education, don't need to choose a single, exclusive identity. Equally at home (and equally homeless) in both cultures, we are global citizens of an increasingly borderless world." ${ }^{51}$ Wanner notes that "the concept of being equally at home and homeless in multiple countries may come dangerously close to the old stereotype of the rootless cosmopolitan (interestingly, the word 
"Jew" never comes up in the essay)" (W/O, I26). Being Jewish is simply easier in America. The old Soviet-era split between belief and faith gives way to the notion of American Jewish ethnicity as a quality of the melting pot. Jews are simply in and of New York. According to Shteyngart,

Being Jewish is being Jewish, of course, and being in a diaspora is being in a diaspora. Well, you know, it's different. I think American Jews areand I won't speak for all of them-but I think those that are several generations behind feel certainly more American than anything. Now there are organizations, of course, for every ethnic group that try to keep the spirit going because it's in their own interest to perpetuate. But, American Jewishism isn't religious, and it's really, maybe, a euphemism for feeling out of place. ${ }^{52}$

Indeed the key here is his neologism. For a writer supremely attuned to the nuances of language, the word Jewishism may well summarize his sense of the function of the Jew in the new cosmopolitan world.

Like Kaminer, Shteyngart followed his debut with other very successful books, including not only Absurdistan but Super Sad True Love Story (2010). And also like Kaminer, Shteyngart then returned to the autographical world of his initial success.

Little Failure: A Memoir (20I4), traces the trajectory of the protagonist, Gary Shteyngart, from the USSR to Oberlin to New York City and back to St. Petersburg, through the prism of his long-term psychoanalysis, which is one of the book's touchstones. ${ }^{53}$ The book ends with him "back on my psychoanalyst's coach trying on the words I have taught myself. I am not a bad son" (S/L, 3 I9). And the volume is dedicated to this therapist, in spite of or perhaps because of his father's response to the news that Gary has begun psychoanalysis: the older man is full of the "post-Soviet distrust of the practice-mental hospitals were used by the Soviet state against its dissidents" (S/L, $32 \mathrm{I}$ ). But the father also fears distrust that psychoanalysis may give Gary the ultimate weapon against his father-silence (S/L, $32 \mathrm{I}$ ). The book is ultimately about Oedipus, his unknown father, and their competition not for Shteyngart's mother but for the motherland, for Leningrad, for the Russia of memory, and for his "preimmigrant father . . . bathed in his untrammeled love for me" (S/L, 9). Gary was a disappointment, a "Failurchka, or little failure" (S/L, 4), in the odd neologism of his mother, neither English nor Russia yet both. Constantly ill with asthma as a child, Igor (later transformed into the American Gary) is a sad sack in his own memory. He is terrified of life because, as his mother explains when he is an 
adult, "you were born a Jewish person" (S/L, 25). His memory of his youth is crystalline, "attuned, vibrant, and frighteningly perfect" (S/L, 46).

His father of memory looks Jewish: "the big brows, the near-Sephardic skin tone, the harried expression of someone to whom life had been invariably unkind" (S/L, 8). His father had been a refusnik, "a designation that brought with it a kind of jobless state-sanctioned purgatory" (S/L, I6). His mother is "from a good family and not merely another Jewess you can informally insult" $(\mathrm{S} / \mathrm{L}, 20)$. She "looks half-Jewish, which given the place and time, is too Jewish by half" (S/L, 2 I ). When the family is about to leave Leningrad, she finally works up the nerve to confront the Soviet system in the form of the servers at the gastronom, the local grocery store, who constantly sold her only the fat of the ham. The server "in the stained white smock" shouts at her that "when you move to Israel they'll slice the ham for you without the fat!" And she with "unkosher absurdity" responded, "In Israel I'll have the fatless ham, but all you will ever have is the fat" (S/L, 47).

If such a fantasy of Israel dominates his parents' idea of the golden pavements awaiting them, Shteyngart's image of Russia at the opening of the volume is self-consciously full of "the vulgar nostalgia, the 'poshlost' Nabokov so despised" (S/L, 7). Even as a nineteen-year-old, Gary had been full of "the nostalgia that Nabokov thinks is vulgar poshlost" (S/L, 263) at Oberlin. Vladimir Nabokov-nobleman, exile, and very much not a Jew-is in complex ways the spiritus locus of this memoir. Gary returns to St. Petersburg "to be carried away by a Nabokovian torrent of memory for a country that no longer exists" (S/L, I5). Shteyngart puts himself in "Nabokov's Speak, Memory, in which Vladimir Vladimirovich's nobleman father is being ceremonially tossed in the air by the peasants of his country estate," the same treatment Gary receives from his fellow Oberlin students (S/L, 26I). When interviewed about the novel in the New York Times Shteyngart again evoked the world of the cosmopolitan exile: “I've read Nabokov's Pnin so many times the book no longer has a spine. Has there ever been a better novel written about a fumbling Russian migr [émigré]? I mean, like, why do I even bother?"54 But Gary's father in the novel is not a landed nobleman, not exiled for his politics, not assassinated in error in Berlin in I922; Gary is not the cosmopolitan, trilingual Nabokov (with his own Jewish mother) in Berlin, Boston, Ithaca, and Montreux; he is merely the damaged Jewish son of his damaged Jewish father.

Gary's parents view his decision to become a writer as tinged with a sense of failure in America, and they want him not to "write like a self-hating Jew" (S/L, 29). Gary should neither mention the names of his relatives in his books nor delve into their relationship with him. But Gary, unsure of his identity as 
American, Russian, and Jew, hears only his father's whisper not to write like a self-hating Jew (S/L, 33). Gary eventually acknowledges that "there is nothing as joyful as writing, even when the writing is twisted and full of hate, the selfhate that makes writing not only possible but necessary" (S/L, I48) and comes to hear the pain contained in his father's warning. This pain originated in Russia (S/L, 322).

Shteyngart's ancestry is linguistically Russian, although his grandmother, who comes with them to America, had been raised in the Ukraine and struggled to learn Russian in Leningrad under siege and then in internal exile. In school "her instructor takes pity on her and helps her master the tongue of Pushkin and Dostoyevsky" (S/L, 35). Yet her grandson remembers that she "struggled against the despised Jewish accent," although his father "says emphatically 'Your grandmother never had a Jewish accent"' (S/L, 35). Yet in her confrontation with her husband over their sick child in I979, his mother "retreats into the primordial Yiddish of her late grandmother from the Belorussian shtetl of Dubrovno" (S/L, 52). In America, Gary's parents become masters of the hybrid languages of Brooklyn, while the fourteen-year-old boy "loses his Russian accent" (S/L, I78) and pretends "to be a good East German" (S/L, 277) at the Orthodox day school he attends.

In 20I I, after the success of his first novels, Gary returns with his parents to Russia, to St. Petersburg. His mother had not been back since the death of her mother twenty-four years earlier, and his father had been away for thirtytwo years, since he left as a refusnik. Their American son only hollowly echoes their Russian (S/L, 326). His father is intent to pass by the "two-hundred year old Mariinskaya Hospital," where he offhandedly observes to his son " II spent time here . . . in the nevnoye otdeleniye.' I run the Russian through my mind. . . . The Nervous Department. What exactly is he trying to say?" (S/L, 330). His father reveals that he suffered a seizure at age twenty-three and was diagnosed with "soldering of the vessels of the brain" (S/L, 33 I), resulting in an extended hospital stay during which he was subjected to horrific and unnecessary therapies. When he was finally released, he went into a severe depression and recovered only after a long visit to the countryside. His mother called him a failure, just as Gary's mother had done to him: "You are an exact copy of your father" (S/L, 332), as a friend once told Gary.

Out of this revelation of weakness also comes the suppressed memory of his father's lashing out at him, giving him a bloody nose on the street in Leningrad because "he started to behave rascally" (S/L, 343). Igor would not stop playing with a toy helicopter that they had flown from a neighboring church. The toy helicopter haunts the adult Gary's dreams, and "when I came back to 
Russia as an adult and walked by here I began to feel very scared" (S/L, 343). "I didn't want to beat you," his father relies, "it was by accident. I waved my hand and hit you in the nose" (S/L, 344). "In America," Gary begins, but he cannot complete the thought: you could not, would not do that. Putin's Russia, according to the advertisements, is against violence against children, at least in 20 Io (S/L, 344). Russia has become sensitized to such actions, but it is also the Russia of the antisemites: "The Slavic Realm is for Slavs only," reads another graffito (S/L, 342).

Gary and his parents go to the battlefield memorial to the defenders of Leningrad, a group that includes his father's father. "'Oh, son,' he says to me, 'why didn't me and my mother come here earlier?" "What I notice is that he has stopped calling me 'Little Son.' Now I am just his son” (S/L, 347). There, on the battlefield, his father asks him to say Kaddish for his grandfather: "The words coming out of my mouth are gibberish to me. And they can only be gibberish to my father's ear as well. . . . I chant the gibberish backwards and forwards, tripping over words, mangling them, making them sound more Russian, more American, more holy" (S/L, 349). The novel closes with the final words of the Kaddish - "Let us say, Amen"—-in Hebrew, English, and Russian (S/L, 349).

If Shteyngart is the American parallel to Kaminer, than the youngest Russian Jewish writer in English, Yelena Akhtiorskaya, continues the autobiographical vein of cosmopolitan Jewish narratives furthered by Gorelik. ${ }^{55}$ Akhtiorskaya was born in I985 and moved with her family from Ukraine to Brighton Beach in I992. The novel is set the Brooklyn and Odessa in the I990s; it is the tale of the Nasmertovs and their errant brother and uncle, the poet Pasha, the last remaining family member in the Ukraine. Esther and Robert, professionals in the Ukraine (and before that in the USSR), have transformed themselves in America; their daughter, Marina, too, has become American, at least in the ironic eye of the narrator. Robert, a clinical neurologist in Odessa, has physically collapsed, and Esther has developed breast cancer.

The novel focuses on Pasha and his two trips to Brighton Beach in the early I990s. He had converted to the Russian Orthodox Church to marry his pregnant girlfriend at twenty, leaving "an open wound in the family flesh." His wife is the antithesis of the narrator's fantasy of Jewish femininity. She is the "cold, insane, pasty, pear-shaped, droopy-haired Northern Nadia, who didn't even give off the good-in-bed aura" (A/P, 48). The family sees the conversion as "an elaborate theater of spite," while "the priest practically apologized on God's behalf, as if Pasha's soul had ended up in the Yid pile by accident, in a forgetful or clumsy moment" (A/P, I I-I2). He remains "Jewish" even while wearing a "conspicuous though not a garish silver cross around his neck" (A/P, 
I2). Yet his conversion is a sign of the cosmopolitan Jew, for at its heart, he thought, was "a appropriation of aesthetic symbols and traditions essential to his craft" as a poet (A/P, I 2) - symbols of Russian Orthodoxy, of course, not Judaism. As in all of these novels, being Jewish is seen as a handicap, as when Pasha had attended "the gifted-and-talented high school (unhindered by the four layers of added hurdles, one for each Jewish grandparent" (A/P, 36). In Brooklyn the family is really not Jewish enough to be seen as Jewish: "They wouldn't have hired Marina were she not Jewish, but neither did they consider her Jewish" (A/P, 92). She couldn't even bring her own food in the house "because of their wacko laws! Kosher schmosher!" (A/P, I I6). She is eventually fired after giving the child of the house some pepperoni pizza.

Pasha visits his semi-estranged family in Brighton Beach, where as a Jewish cosmopolitan, his command of language allowed him to fit partially in: "He knew English, but strangers in an existential hurry did not" (A/P, 34). Language, the tool of the poet, is his only currency. In America, "he'd be following in the steps of Conrad and Nabokov and transmuting his literary output to the only language now acknowledged" (A/P, 38). In the old Soviet Union, his poetic gift was acknowledged but was also coupled with the real terror of its implications, as when he burned all of the avant-garde literary magazines in his flat when he "found out that the KGB was on the way," accidentally destroying his mother's jewelry and savings, well hidden in the fireplace (A/P, 43). In his memory, however, the incident involved his mother destroying his work out of spite. In Odessa he is famous, at least according to his friends: he is "the Brodsky-of-our-time, dorogoy drug i vlikiy poet (a dear friend and poet), whose poetry built emotion through a fantastic accrual of detail" (A/P, 269). At home he is "a world-historical figure grappling with Dostoeveskian forces. But outside world squinted and asked, Pasha who?" (A/P, 2I6). Brodsky is of course a reference to Russian Jewish poet Joseph Brodsky ( I940-96), who was officially "encouraged to depart" from the USSR in I972 for the United States and who, in I986 received the Nobel Prize for Literature. There and in the USSR he often read his poetry with a large gold Orthodox cross prominently hung about his neck.

Unlike the cosmopolitan Brodsky, Pasha is stranded in Odessa, a provincial town where he is a star but no cosmopolitan; he is merely "an aging, bearded Russian-Jewish-Christian poet (though it is quite charming when you think about it); that he should've moved to New York or at least Moscow, cosmopolitan cities in which he had friends, readers, supporters . . ., where he could meet more like-minded people. .. . ] [I]n Odessa he had only enemies" (A/P, 269-70). Moscow is the definition of the cosmopolitan. In New York his 
friends are "youngish intellectual types who exhibited in equal measure Odessa humor, Petersburg interests (sans pretensions), Moscow cosmopolitanism (without the coarseness or hard consonants), and New York transit proficiency" (A/P, 2 I 5).

But America is crude and capitalistic and was and is not cosmopolitan in the same way as Odessa. His Jewish best friend from Odessa has made it and lives in Manhattan, where his family has acquired "the full American-dream package, which included a certificate of struggle completion, Park Avenue penthouse, tasteful collection of automobiles, new face for the wife even before the old one went to shit" (A/P, 37-38). In the latter half of the novel, Marina's young-adult daughter, Frida, comes to Odessa for her cousin's 2008 wedding, and Odessa is revealed to be just as parochial as is Pasha's fantasy of New York. By that time, "the entire Jewish population had relocated to Brighton's stinky hub" (A/P, 290). And Odessa seemed bereft. Her uncle seemed even less fixed: "The great Russian poet Pavel Robertovich Nesmertov . . . wasn't really Russian considering he had never lived in Russia proper but only in Ukraine, only don't dare to call him Ukrainian, and furthermore was Jewish, which in Russia qualified as a separate nationality if not species, though he wasn't really Jewish having converted" (A/P, 290). He is surrounded by similar dislocated figures such as a woman "who saw logic in wearing a crucifix, a kabbalah bracelet, and a bindi simultaneously" (A/P, 257). If anything, such mixes do not reveal themselves to be either cosmopolitan or rooted, they are the mix of transitions between national and local identities. Yet they differ little from the complex mix and reestablishment of identities in both the USSR and the United States: when one is everything, one is either nothing or the newest cosmopolitan. Yet these cosmopolitans are in the business of generating complex texts about writers who are complex cosmopolitans. It is their theme as writers across and within cultures. What on the one hand recognizes confusion of identity as a legitimate examination of the past and its echoes in the present in the United States is on the other hand seen as a negation of the integration of the Russian Jewish writer into a complex if ephemeral German multiculturalism. In neither case does authenticity as a Jew trump performance as a cosmopolitan.

The movement of peoples is constant; their response varies. People articulate their sense of the meaning associated with such movement culturally, whether they do so from political or economic motivations and whether they move voluntarily or involuntarily. They experience and narrate such movement in terms of their interiority, not merely the external world. As E. O. Wilson has commented, "Homo sapiens is the only species to suffer psychological ex- 
ile." ${ }^{56}$ Whether this acknowledgment of the presence of the self, of the environment, of decay and death is solely true of our species has and can be debated, but it is clear that we are the only species that documents such psychological exile in our cultural objects. Wilson continues, "The dominating influence that spawned the arts was the need to impose order on the confusion caused by intelligence." ${ }^{57}$ Here, our fictions are the continuation of that imposition of order on our perception of reality, while our sense of displacement, our giving meaning to the displacement of others, has been a continuous part of this process from the Enlightenment to the present. It is indeed the emphasis on movement rather than space stressed by James Clifford, but it is also an analogous processing of the symbolic value of such movement by Jews, creating symbolic movements as thought experiments in a fixed world of high status, the world of fiction. Clifford stresses that "the language of diaspora is increasingly invoked by displaced peoples who feel (maintain, revive, invent) a connection with a prior home," but for Russian Jewish writers in North America and Europe, it is not the actual language itself but the cultural artifacts that mirror it in the new cultural environment of rooted cosmopolitan in Germany and the United States. ${ }^{58}$ Germany and North America become "sacred spaces" in Amir Eschel's sense of the search for the dichotomy between "cosmos" and "makom," between the universal and the concrete notion of space in Jewish writing. ${ }^{59}$ These writers' works become repositories of the memories of the Russian past and its seeming rootedness, as opposed to the nomadic nature the authors see in modern globalization. Cosmopolitans bear witness to this search as they seek their roots in a Russia of their imagination and write for a reading public in their new cosmopolitan world. 


\section{ChAPTER 8}

\section{Walls and Borders: Toward a Conclusion}

Franco-Jewish philosopher Jacques Derrida has provocatively asked, "Where have we received the image of cosmopolitanism from? And what is happening to it?"1 This book draws on the world of images, of literary representations, to answer that complex question in the light of the representations and selfrepresentations of the cosmopolitan Jew. Such images seem to have a life of their own given the ongoing Western preoccupation not merely with cosmopolitanism but with shifting understandings and representations of identity, including Jewish identity. As Rosi Braidotti states, this notion of identity is shaped by "the cultural mutations, which I call 'the cultural cartography." The map of patterns reflects "what is happening to bodies, identities, belongings, in a world that is technologically mediated, ethnically mixed and changing very fast in all sorts of ways." "2 And yet it is also a world that still houses stereotypes of what are understood to be immutable categories of identity.

The more identities shift, the more we desire them to be stable. This study ends with Russian Jews in America, a cosmopolitan identity in a heterogeneous world, both very different than but in reality more and more similar to today's Germany, a nation that more or less acknowledges (for good or for ill) that it is transforming into a multicultural society. It is no surprise that an American poet best summarizes the tension between the affect attendant to cosmopolitanism and rootedness. Robert Frost understood this tension between the erosion of permanence and its necessary illusion: "Something there is that doesn't love a wall." Each winter "the frozen-ground-swell under it, / And spills the upper boulders in the sun." The walls are necessary and seemingly permanent, yet they collapse with the forces of nature. The poet asks why the walls are necessary:

Before I built a wall I'd ask to know

What I was walling in or walling out, And to whom I was like to give offence. 
Yet in the end his neighbor rebuilds the walls each year, in keeping with tradition:

He will not go behind his father's saying, And he likes having thought of it so well

He says again, "Good fences make good neighbors."3

Frost's sense of his New England neighbor's necessary yet unfathomable sense of permanence lies at the core of the debates about the cosmopolitan and the nomadic in modernity.

Cosmopolitanism is both a challenge and a goal in the twenty-first century. For Jews in the post-Enlightenment German-speaking world, cosmopolitanism not only played both those roles but also provided one of the means by which Jews defined themselves and were defined. Given the multiplicity of identities that Jews had and have in the modern world, cosmopolitanism also constructed models of what being Jewish should or should not be. Whether a Hofjude or a banker, whether an urban merchant or a rural seller of horses, whether a member of the intelligentsia or a manual laborer, the rootless, nomadic, cosmopolitan defined the Jew in European consciousness among nonJews and Jews alike and shaped Jewish identity politics.

There seem to have been only two periods of concerted cosmopolitanism among non-Jewish German/European writers as well as their Jewish counterparts, who saw themselves as both embedded in and transcending national literary cultures. The first moment ran from the late Enlightenment through the end of the Napoleonic era, when parts of Europe were consolidated under one jurisdiction and therefore had some shared code of law and ethics. Derrida stresses that such notions of a secular cosmopolitanism are closely bound to our evolving understanding of urban spaces and the evolving idea of the city as refuge within the nation-state since the Enlightenment. Indeed the more urban the idea of the cosmopolitan becomes after the Enlightenment, the more it is paired with (and then separated from) the nomad, that ultimate antiurban entity. As the separation of the urban from the rural fades in the West with the primacy of the city as that space defining the nation (think Paris and France, Berlin and Germany, London and England), the nomad, too, begins to fade from the preoccupation with Jewish difference.

Thus the idea that European Jewry in the twenty-first century forms or will form an autonomous "third pole" to Jews in the United States and Israel is fundamentally flawed. That idea requires a rooted national collective rather than the mobile and often uncomfortable global cosmopolitanism that defines groups today, including American, European, and Israeli Jews. The specter of 
Israeli Jews in Berlin, of Russian Jews in Brooklyn, of American Jews in Hong Kong draws Diana Pinto's anticosmopolitan thesis of three poles into question. While she sees that "national Jewish traditions have been put on the back burner in the creation of a vast Jewish global village," she believes that this village is not truly cosmopolitan, a word that she does not use. ${ }^{4}$ Some members of this global village will certainly become settled in new national identities; some will for multiple reasons return to their land of origin, as Saskia Sassen has shown happens with all emigrations; some will move across other borders and will retain or reshape their identities. ${ }^{5}$ Thus, the tales that they tell and the books and films that they make are accessible indicators of the complex meanings they attach to their cosmopolitan state.

Cosmopolitanism, in any of its forms and in all of its objects, is not a freefloating notion. The shared notion of a specific governmentality centered on a dynamic encounter between what the French poststructuralist Michel Foucault termed biopower and biopolitics lies at the core of the shaping of the idea of the Jew (and thus the internal self-awareness of individual Jews, for good or for ill). ${ }^{6}$ Foucault focused on the often invisible and shifting approaches, withdrawals, claims, and enforcement that shadow multiple institutions and forms of knowledge in human society, linking them in complex ways. Capital in all its forms is a form of biopower. Cosmopolitanism, too, is a form of state-sanctioned (or -denied) identity. Without the modern state, no notion of cosmopolitanism can exist, even if it evokes a classical Greek model. Foucault's notion of diffuse, "nonegalitarian and mobile" processes of confrontation that shapes the individual's relationship to the state also shapes the idea of the cosmopolitan. ${ }^{7}$

This is as true of the evocation of classical definitions of cosmopolitanism in the German Enlightenment as it is in the denunciation of the cosmopolitan in totalitarian systems in the twentieth century and in its reappearance as a claim of universal human rights in the twenty-first. Our present fascination with the cosmopolitan contains a built-in utopianism. Ulrich Beck rejects the post-Kantian idea of a local or the emancipatory understanding of a global cosmopolitanism. Today, he argues, "the human condition itself has become cosmopolitan," requiring "a reconfiguration of our modes of perception." The cosmopolitan in the twenty-first century is a "global sense, a sense of boundarylessness. An everyday, historically alert, reflexive awareness of ambivalences in a milieu of blurring differentiations and cultural contradictions. It reveals not just the 'anguish' but also the possibility of shaping one's life and social relations under conditions of cultural mixture. It is simultaneously a skeptical, disillusioned, self-critical outlook." 8 Yet constraints exist, and they are those of the individual bound by the realities of power in lived experience. 
For Foucault, biopower became "a political technology that brought life and its mechanism into the realm of explicit calculations and made knowledge/ power an agent of transformation of human life," but it also had a history. ${ }^{9}$ Such notions of control and its various forms shape and define cosmopolitanism, and they have a history, as Foucault notes:

History has no "meaning," though this is not to say that it is absurd or incoherent. On the contrary, it is intelligible and should be susceptible of analysis down to the smallest detail-but this in accordance with the intelligibility of struggles, of strategies and tactics. Neither the dialectic, as logic of communication, nor semiotics, as the structure of communication, can account for the intrinsic intelligibility of conflicts. "Dialectic" is a way of evading the always open and hazardous reality of conflict by reducing it to a Hegelian skeleton, and "semiology" is a way of avoiding its violent, bloody and lethal character by reducing it to the calm Platonic form of language and dialogue. ${ }^{10}$

This expansion of scientific and philosophic governmentality has also produced new accounts of cosmopolitanism, some of which employ social scientific research and arguments, while a host of others simply employ the language of the social sciences and the humanities.

With the Enlightenment and the rise of the modern nation-state, Jewish emancipation comes to mark the political instantiation of the cosmopolitan. But for the Enlightenment, the Jew is both a social and a racial category since it is defined by the mental status ascribed to a collective Jewish mind or character. At the core of this stereotype is the immediate association between the Jewish character and the nature of capitalism, still in the Enlightenment a dubious social presence, even for Adam Smith in his 1776 book, An Inquiry into the Nature and Causes of the Wealth of Nations and his awareness of the market's "invisible hand." When conceived of as pernicious, that hand was often seen as Jewish. Indeed, even Smith praises the Portuguese Jews for introducing modern capitalism to the first ragtag settlers of Brazil. ${ }^{11}$ Sephardic Jewish/Turkish/ American political philosopher Seyla Benhabib has argued that cosmopolitanism is primarily about universal rights and that the Jews are its true litmus test. $^{12}$ If the Jews can be cosmopolitan in a positive manner, then they share human rights; if cosmopolitanism turns out to defy national or racial identities, then they are beyond the pale. Thus the eighteenth- and nineteenth-century debates center on whether being rooted or mobile, being a socially defined or a biologically defined entity, lies at the core of notions of difference. 
The second period of concerted cosmopolitanism occurred between World War I and World War II, after and before rampant nationalism was revealed as radically destructive. During the imperial period in the nineteenth century, with a new Germany and an Austro-Hungarian Empire consolidating its power, Jews, the touchstone of the cosmopolitan (with all of its contradictions) in Enlightenment Europe, came to be seen as nomads rather than cosmopolitans. In this moment, the Jews formed the fantasy structure of an economic underground that spread with them across the world. Jewish nationalism, whether in the form of local identification with the national state (Prussia, Germany) or Zionism, made only a form of rooted cosmopolitanism acceptable. This revitalization of the charges of nomadism picks up an older image that sees Jewish mobility as inherently dangerous to rooted populations. It is no surprise, then, that both political and racial antisemitism picked up this thread as a defining quality of the Jew.

During the interwar period, the self-professed cosmopolitan Jewish writers attempted to rewrite the image of the Jewish nomad into a productive prototype of the cosmopolitan. The fantasy was that World War I had proven the fruitlessness of models of national identity for Jews while providing a wide range of alternatives for other groups as well as Jews. While this claim seems tautological, the notion of the cosmopolitan and ideas of rootedness was redefined by various groups of self-identified Jews during the late nineteenth century. Zionists (who come in many shades) and German nationalists (who also come in many shades) took one stance; Jews who saw themselves are cosmopolitan took many other paths, from a national cosmopolitanism to a global one. The association with capital became less and less overt yet was never completely abandoned by either the Zionists, who saw this as a core failing of European Jewry, or the German nationalists, who stressed the economic integration of the Jews into European society. Even those Jewish-identified writers who in the I920s advocated most strongly for a new cosmopolitanism and wrote for a global elite were rooted in strong cultural traditions. If there is an irony here, it is that political persecution and exile—which for Jewish writers in Central Europe was not voluntary, as it was for most political exiles, among them Thomas Mann and Stefan George-became a living embodiment of earlier claims about cosmopolitanism. The global elite to which they fantasized about belonging turned out to have as much hesitation about their presence as it did for all other Jewish refugees.

Only after the Holocaust did Jewish writers again become seen as European writers promoting some sort of universality across the Iron Curtain. Many of these cosmopolitans became inherently uncomfortable with their mobility, 
seeing rootedness as having greater value in the twenty-first century than it did in the nineteenth. Soviet Jews, whose national identity in the USSR was as Jews, became Americans, Germans, or Austrians of Russian (Jewish) descent, often with nostalgia not for the USSR but for an ill-defined, ahistorical "Russia." All the while, they wrote about the problems of their economic as well as cultural integration in the world of capitalism. The irony, of course, is that while this becomes a leitmotif of their writing, the critical as well as economic success of their work rested on their exposition of their struggle with their new rootlessness. Jews come to test and define the new cosmopolitanism.

Jewish mobility was and is both a sign of modern cosmopolitanism and its contradiction. Nationalism was and is not inherently seen as oppositional to cosmopolitanism - unless, of course, nationalism was seen as cosmopolitanism's contradiction. This tension marked and marks the status of Jews, alien cosmopolitans or Jewish nomads. Following the 2015 attacks on Jewish institutions in Europe, the Israeli prime minister stated, "To Jews, to our brothers and sisters, Israel is your home. We are preparing and calling for the absorption of mass immigration from Europe."13 $\mathrm{He}$ does not conceive of his call as aimed at the ever-growing Israeli population of Jewish cosmopolitans (?) or nomads (?) in Europe. These contradictions still have their power.

One example from a very different context concludes our examination of Jews and cosmopolitanism. On May 25, 1948, the former U.S. soldier Garry Davis turned in his passport at the American embassy in Paris and declared himself a "citizen of the world." He then created his own passport, rarely recognized at national borders, and found that the more nation-states harassed him about his status as a true cosmopolitan, the more publicity his One World Movement received. Six months after renouncing his citizenship, he stormed a session of the United Nations General Assembly in Paris: "We, the people, want the peace which only a world government can give," he proclaimed. "The sovereign states you represent divide us and lead us to the abyss of total war."14 Davis re-created himself in public as the good cosmopolitan in large part because of nationalism's impact in the world. The viewing of the cosmopolitan, the world citizen, the citizen without borders, as corrosive had been a pillar of the National Socialist ideology against which Davis fought. ${ }^{15}$ He was of Jewish descent, and his call for the elimination of borders rejected what he defined as the fascist idea that borders and peoples were uniform and static.

The cosmopolitan is simply another way of speaking about the potential for movement-across borders, class boundaries, and cultural norms. All of recorded human history speaks of such movement all over the world, from ancient Greek city-states to the expansion of the Han into what is now consid- 
ered China during the same period. But must one oppose the nation-state if one sees oneself, as Davis did, as a citizen of the world? Being cosmopolitan does not cancel being national or regional or ethnic in the twenty-first century as it did for Davis after World War II. Being cosmopolitan simply means that one has the potential for movement, for transformation, for change-not that it must take place. We often think of cosmopolitanism as a form of multiculturalism. But there is a model that sees the nation-state as groups of peoples from throughout the world who live, function, compete, and collaborate with one another. These groups may shift, they may transform, they may come to speak the language of the nation-state (and then in the third generation rediscover and learn the language spoken by their grandparents). What cosmopolitanism promises us today is the potential for change, for movement-not to spite the claims of the nation-state but to ever renew them, to make them flexible. Garry Davis died in the summer of 2013, still a citizen of the world. But he died in Burlington, Vermont, not terribly far from his birthplace in Bar Harbor, Maine, a citizen of the world but still very much a Jewish New Englander. ${ }^{16}$ It was a world that, as Frost commented, favored the building of walls over their transcendence. Yet Davis's life exemplified Frost's questioning the placement of walls where they were not needed:

There where it is we do not need the wall:

He is all pine and I am apple orchard.

My apple trees will never get across

And eat the cones under his pines, I tell him.

He only says, "Good fences make good neighbors."17

As one commentator notes, the figures in the poem "share an activity that divides them; maintaining the division requires their shared activity. . . W Walls are acknowledged as dividers, but are also imagined as seams." ${ }^{18}$ Perhaps this remains the central dilemma about Jewish cosmopolitans in our world? 



\section{Notes}

\section{CHAPTER 1}

I. See, for example, Beck and Sznaider, "Unpacking Cosmopolitanism." On the taxonomies of cosmopolitanisms see Scheffler, "Conceptions of Cosmopolitanism."

2. Shaw, John Bull's Other Island, I 7.

3. The focus of this book is on German-speaking Jews as well as their representations within German-speaking cultures. While we have some comparative examples to frame this material, we recognize that there are alternative models for Jewish identity beyond those employed in this study (Enlightenment, emancipation, urbanization). See Hundert, Jews in Poland-Lithuania, which presents a case study of what he argues is the "positive evaluation of Jewishness" (3) in a very different modern context.

4. "Theresa May's Conference Speech."

5. Geschiere, Perils of Belonging, I I6.

6. Ibid., I.

7. Certainly the best recent engagement with this discussion is the chapter on "Diaspora and Postethnicity" in Cheyette, Diasporas of the Mind, 244-64.

8. Kane, Constructing Irish National Identity, 74.

9. Tibi, Europa ohne Identität?

Io. Sassen, "Global City," 39.

I I. Beck, Cosmopolitan Vision, 2.

I2. Ibid., 3 .

I3. Ibid., I3-I4.

I4. Neusner, Self-Fulfilling Prophecy.

I5. Davies, Territorial Dimension.

I6. Alcalay, After Jews and Arabs, 64.

I7. Bowman, "Jewish Diaspora," I92, reflects one current usage of the two terms, where galut refers to an involuntary-usually negative-exile, whereas diaspora (tfutsot) has a more positive, voluntary connotation.

I8. The superb work of Gruen, Rethinking the Other, on Jews in antiquity reveals that a complicated sense of home (and place in general) extends much further back than is often assumed.

I9. Wolfe, At Home in Exile, I7 (hereafter cited in the text as W).

20. Sznaider, Jewish Memory, 6I (hereafter cited in the text as Sz).

2 I. Benedict Anderson, Imagined Communities, 6-7. 
22. Veer, Imperial Encounters, I38.

23. Asad, Formations of the Secular.

24. Robbins, Perpetual War, I34.

25. Berger, Sacred Canopy, and Taylor, Secular Age, have respectively framed and contested this basic debate within cosmopolitanist theory from the mid-twentieth century.

26. Slezkine, Jewish Century, 24.

27. Diogenes Laertius, Lives of Eminent Philosophers, 2:64-65. See Baldry, The Unity of Mankind, I02-IO.

28. Dee, General and Rare Memorials, 54.

29. "Mitteilungen," I3.

30. Hall, "Cultural Identity and Diaspora," 234: "Diaspora does not refer to us to those scattered tribes whose identity can only be secured in relation to some sacred homeland to which they must at all costs return, even if it means pushing other people into the sea. This is the old, the imperializing, the hegemonizing, form of 'ethnicity.' We have seen the fate of the people of Palestine at the hands of this backward-looking conception of diaspora" (244).

3I. This "shall be Limited to Conditions of Universal Hospitality. . . . [I]t is not a question of philanthropy but of right" (Kant, "To Perpetual Peace," I I 8). This text remains a touchstone for much of the contemporary debates, pro and con, about cosmopolitanism. See Muthu, "Kant's Anti-Imperialism."

32. See Benhabib and Eddon, "From Antisemitism"; Benhabib, Another Cosmopolitanism.

33. Kleingeld, “Approaching Perpetual Peace.” See also Cavallar, Imperfect Cosmopolis, 64-84.

34. Appiah, Cosmopolitanism, 63 (hereafter cited in the text as A).

35. Brennan, At Home in the World.

36 Hollinger, Postethnic America, 92-93. Hollinger's volume is part of an ongoing discussion about the nature of cultural and ethnic identity in America begun by Glazer and Moynihan, Beyond the Melting Pot.

37. Lallement, Choix de rapports, 23 I (translation by the authors).

38. Berkovitz, Rites and Passages, I52.

39. Actually he wrote "Die Religionen Müsen alle Tolleriret werden und Mus der fiscal nuhr das auge darauf haben, das keine der andern abruch Tuhe, den hier mus ein jeder nach Seiner Fasson Selich werden!” (cited by Raab, Kirche und Staat, I94). See also Kleingeld, "Six Varieties of Cosmopolitanism."

40. Wieland, Private History, 2:32. On the status of the Jews in Enlightenment cosmopolitan argument see Schlereth, The Cosmopolitan Ideal, I47-200.

4I. Alfred Rosenberg, "Bolshewismus als Aktion," IO-I I.

42. Penslar, Shylock's Children. See also Muller, Capitalism and the Jews.

43. Bauman, Liquid Modernity, 206; Derrida, Jewish Identity and Liquid Times.

44. Wolin, "Modernity," 742. Compare Feldt, Transnationalism and the Jews.

45. Benedict Anderson, Imagined Communities, I9-22.

46. Ibid., 209.

47. Soyer, Persecution of the Jews and Muslims. 
48. Gilman, Multiculturalism and the Jews.

49. Vieten, Gender and Cosmopolitanism, 7.

50. Freidank, "Nordische Ekstase," 4.

5I. Deleuze and Guattari, Thousand Plateaus, 32 I-22.

52. Judaken, Jean-Paul Sartre and "the Jewish Question."

53. See, for example, Noyes, "Nomadism, Nomadology, Postcolonialism." See also Bignall and Patton, Deleuze and the Post-Colonial.

54. Patton, "Marxism and Beyond."

55. Braidotti, Nomadic Subjects (hereafter cited in the text as B).

56. Adorno, Minima Moralia, 87.

57. Said, "Reflections on Exile," 365.

58. Tentzel, Monatliche Unterredungen, 833.

59. Wagenseil, Benachrichtigung, 473-88.

6o. Schudt, Jüdische Merckwürdigkeiten, 470-5I2 (hereafter cited in the text as $\mathrm{Sc})$.

6I. Noyes, "Goethe on Cosmopolitanism and Colonialism," 45I.

62. Kant, "Conjectural Beginning."

63. For an elaboration of the idea of difference in the Enlightenment see Mack, "The Other."

64. Marx, Capital, I:I82-83.

65. Ezrahi, "Considering the Apocalypse," I38-39.

66. Simmel, Philosophy of Money, 353.

67. Pinsker, Auto-Emancipation, 5.

68. Ibid., 2.

69. Kohler, Deutschland und die Juden, 8.

70. "Kosmopolitismus der jüdischen Race," 40 I.

7I. Nietzsche, Anti-Christ, I4.

72. Goldziher, Mythos bei den Hebraern; translation by the authors (hereafter cited in the text as G).

73. Dühring, Judenfrage, 70.

74. Sombart, Jews and Modern Capitalism, 325.

75. See Radkau, Max Weber, 44I.

76. Weber, Ancient Judaism (hereafter cited in the text as W).

77. "The stranger that is within thee shall get up above thee very high; and thou shalt come down very low. He shall lend to thee, and thou shalt not lend to him: he shall be the head, and thou shalt be the tail."

78. Tawney, Religion and the Rise of Capitalism (hereafter cited in the text as T).

79. Hittite scholar Archibald H. Sayce was indeed philosemitic. In his I 903 Gifford Lectures, he declared, "It is usually the fashion to ascribe this concentration of religion upon the present world, with its repellent views of Hades and limitation of divine rewards and punishments to this life, to the inherent peculiarities of the Semitic mind. But for this there is no justification. There is nothing in the Semitic mind, which would necessitate such a theological system. It is true that the sun-god was the central object of the Semitic Babylonian faith, and that to the nomads of Arabia the satisfaction of their daily wants was the practical end of existence. But it is not among the nomads of Arabia 
that we find anything corresponding with the Babylonian idea of Hades and the conceptions associated with it. The idea was, in fact, of Babylonian origin. If the Hebrew Sheol resembles the Hades of Babylonia, or the Hebrew conception of rewards and punishments is like that of the Assyrians and Babylonians, it is because the Hebrew beliefs were derived from the civilisation of the Euphrates" (Sayce, Religions of Ancient Egypt and Babylonia, 295).

8o. Chamberlain, Foundations, 369.

8I. Wahrmund, Gesetz des Nomadentums, 9I; translation by the authors.

82. Gildemeister, Judas Werdegang, I5.

83. See, for example, Meiners, "Kurze Geschichte der Hirtenvölker."

84. Ratzel, History of Mankind, 83-84 (hereafter cited in the text as R).

85. Brod, "Erfahrung in ostjüdischen Schulwerk," 35: "Man soll uns nicht eine Zentifugalkraft einimpfen und hintenach wundern, 'Nomadentum" und 'kritische Zersetzung' an unserm Leichnam konstatiren!"

86. Hitler, Mein Kampf, 300-3 I I, 324-27.

87. Jung, Interviews and Encounters, 193.

88. Bloom, Personal Identity, 52.

89. Ibid., 74.

90. "Cosmopolitain, ou Cosmopolite," in Encyclopédie ou Dictionnaire, 4:297.

9I. Jaucourt, "Jew"; originally published in ibid., 9:24-25.

92. Ibid.

93. Benedict Anderson, Imagined Communities, 6.

\section{CHAPTER 2}

I. Berghahn, "Comedy without Laughter"; Goetschel, "Lessing's 'Jewish' Questions"; Blass, "Vorurteile als Kunstfehler des Verstehens"; Och, "Lessings Lustspiel 'Die Juden.'" See also Helfer, Word Unheard, 3-22.

2. Knigge, Über den Umgang mit Menschen; unless otherwise noted, the translations are from Knigge, Practical Philosophy of Social Life (I796) (hereafter cited in the text as $\mathrm{K})$.

3. Jütte, Zeitalter des Geheimnisses.

4. Lessing, Jews. See also Robertson, “'Dies hohe Lied der Duldung'?; Mecklenburg, "Lessing Lustspiel 'Die Juden."”

5. Knigge, Practical Philosophy of Social Life (I805), 3 I7. See also Riechers, " "Vis à vis de soi-même'”; Fenner, "Lessing wäre auch ein Mann für uns."

6. See Israel, European Jewry; Penslar, Shylock's Children; Karp, Politics of Jewish Commerce.

7. All references are to the on-line translation, Lessing, The Jews.

8. Schneiders, Aufklärung und Vorurteilskritik, 203-62.

9. See Albrecht, Kosmopolitismus, 22-37.

Io. Joll, Nineteen-Fourteen.

I I. Jonathan M. Hess, Germans, Jews, and the Claims of Modernity, 87.

I 2. Rentschler, Ministry of Illusion, I5762.; Etlin, Art, Culture, and Media; Ascheid, Hitler's Heroines; Saul Friedländer, Years of Extermination, I00-I03. 
I3. Berend, Case Studies, I4.

I4. Gottlieb, Faith and Freedom, ix.

I5. Rorty and Schmidt, Kant's "Idea," 89.

I6. Sorkin, "Mendelssohn Myth."

I7. Berghahn, "I769 Lavater's Attempt."

I8. Paul Meyer, "Judaism as a Vehicle."

I9. Habermas, Structural Transformation, 72.

20. Sorkin, Moses Mendelssohn, I I I-I 2.

2 I. Herder, Outlines, 658 (hereafter cited in the text as H).

22. Quoted by Michael N. Forster in his introduction to Herder, Philosophical Writings, xxxii.

23. Berlin, "Herder and the Enlightenment."

24. Wirtz, Patriotismus und Weltbürgertum.

25. Fichte, Johann Gottlieb Fichtes sämmtliche Werke, I49.

26. Michael Mack, German Idealism and the Jew, 5.

27. Nussbaum, "Kant and Cosmopolitanism."

28. Kant, "Idea for a Universal History." (hereafter cited in the text as UH).

29. Kant, "'Toward Perpetual Peace' in Practical Philosophy," 329 (hereafter cited in the text as PP). See also Heater, World Citizenship and Government, 83-84.

30. Garrett Wallace Brown, Grounding Cosmopolitanism.

3I. Roth, Wandering Jews, I25.

32. Kleingeld, Kant and Cosmopolitanism, I22.

33. Kant, Anthropology, 77.

34. Michael A. Meyer and Michael Brenner, German-Jewish History, I: I 29-30.

35. Mendelssohn, "Über die Frage?," I I 7.

36. Mendelssohn, Jerusalem, 72-73.

37. Mendelssohn, "Über die beste Staatsverfassung," I 46.

38. Slezkine, Jewish Century, 9-I I.

39. Grattenauer, Über die physische und moralische Verfassung, 3 (hereafter cited in the text as G).

40. Coignard, "Gibt es ein Kulturmuster Kosmopolitismus?"

4I. Curthoys, "Diasporic Reading." Curthoys refers to the drama as revealing "a cosmopolitan sensitivity to world-historical time . . . a a genealogical sensibility that reads the play as an enthusiastic commentary on the pluralistic and polyglot societies of the Levant and Moorish Spain, in which a convivencia, a sometimes fragile but productive coexistence of Muslim, Jew, and Christian, was capable of provoking and edifying Christian Europe" (70-7I).

42. Goozé, "Wilhelm von Humboldt."

43. Humboldt's ambiguity may well have rested on his acknowledgment that whether Jews were socially acceptable or not should not limit their access to civil society. See Hertz, Jewish High Society, 256.

44. August Wilhelm Schlegel, Vorlesungen über schöne Litteratur und Kunst, 2 I. See also Thielking, Weltbürgertum, 44-47.

45. Novalis, Christianity in Europe.

46. Behm, Moses Mendelssohn, I 50.

47. Miller and Ury, "Dangerous Liaisons," 553. 
48. David Friedländer, "Freimüthige Gedanken," 576. See also Lowenstein, "Jewishness of David Friedländer."

49. This discussion of Kuh is based on the biography by Moses Hirschel that prefaces the two-volume edition of Kuh's poetry, Hinterlassene Gedichte (hereafter cited in the text as Kuh), as well as the later biography by Kayserling, Der Dichter Ephriam Kuh. See also Seitz, "Verschwiegene Texte."

50. Kranz, Über den Missbrauch, I4.

5I. Schiller, Early Dramas, 49.

52. Schiller, Werke, 22.

53. On Schiller and the Jews, see Oellers, "Goethe und Schiller."

54. Schiller, Early Dramas, I 2. For a more detailed analysis of the nationalist argument, see Misch, "Spiegelberg und sein Judenstaatsprojekt."

55. Michael A. Meyer and Michael Brenner, German-Jewish History, 2:202.

56. Humboldt, "Über den Entwurf," 96.

57. Beachy, "Recasting Cosmopolitanism"; Hart, "Schiller's 'An die Freude"”; Hofmann, "Wege der Humanität."

58. Text and translation taken from Potkay, Story of Joy, I67-7 I.

59. Helfer, Word Unheard, 23-56.

6o. Schiller, "Die Sendung Moses," in Werke und Briefe, 468; translations from Helfer, Word Unheard (hereafter cited in the text as $\mathrm{S} / \mathrm{H}$ ).

6r. Auerbach, Dichter und Kaufmann, I (hereafter cited in the text as A). See Ferstenberg, "German-Jewish Creative Identity."

62. Briefe II, 6 October I 872, I23, cited in De Maio, "Berthold Auerbach's 'Dichter und Kaufmann,", 283.

63. Robertson, "Jewish Question,” 89.

64. Skolnik, "Writing Jewish History," I07.

65. Michael A. Meyer, Origins of the Modern Jew, 8

66. Presner, Mobile Modernity, I75-77.

67. Burkhardt, Goethes Unterhaltungen, Ioo .

68. Fritz Strich, Goethe and World Literature, 35. A similar model emerged in emerged in Friedrich Schlegel's lectures on the History of European Literature ("Geschichte der europäischen Literature").

69. All references are from Noyes, "Goethe on Cosmopolitanism and Colonialism."

70. Goethe, Goethes Werke, I, 37, I75-90.

7I. Goethe, Faust, 377.

72. Körte, Uneinholbarkeit des Verfolgten, I34.

73. All quotations from Heine, Germany.

74. Jahn, Deutsches Volksthum, I4-I5. Grimms' Deutsches Wörterbuch (28: I 57I) gives this citation for weltflüchtig with the translation "durch die welt fliehend, nomadisierend, unstet."

75. Translation from David J. Rosenberg, "Towards a Cosmopolitanism," 5.

76. All references are to the on-line translation, Heine, Germany: A Winter's Tale.

77. Translation from Kohut, Standard Book, 7I 2-I3.

78. Courtemanche, "Marx, Heine, and German Cosmopolitanism," I I.

79. Adorno, "Der Wunde Heine," 96. 
8o. Kolb, Ambiguity of Taste.

8I. Prawer, Heine; Kortländer, "During the Day"; Presner, "Jews on Ships"; Peters, "“Jeder Reiche ist ein Judas Ischariot"”; Schonfield, "Satire and Laughter."

82. For much of this interpretation we are indebted to Courtemanche, "Marx, Heine, and German Cosmopolitanism" (hereafter cited in the text as Co).

83. Blumenberg, "Eduard Müller-Tellering."

84. Moses Hess, Rome and Jerusalem, 64.

85. Lars Fischer, Socialist Response, 56-I02, chronicles how Marx's essay became a lightning rod for the Left's understanding of Jews and Jewish internationalism.

86. Feuerbach, Essence of Christianity, I I4.

87. Jonathan Sperber, Karl Marx, I28-29.

88. Marx, "On the Jewish Question," in Karl Marx, 66 (hereafter cited in the text as M).

89. Perkins, Christendom and European Identity, 223.

90. Vital, People Apart, I76-77. Bismarck becomes one of the central authorities on the ambiguity of Jewish cosmopolitanism. A classic antisemitic work, Theodor Fritsch's Handbook of the Jewish Question (I 893), cited Bismarck's table talk that "the Jews have no true home (Heimat). They have something generally Europeancosmopolitan about them; they are nomads. Their fatherland is Zion, Jerusalem" (Fritsch, Handbuch, 28I). This quote reappears through the early twentieth-century debate about Jewish cosmopolitanism: for example, it was included in a December 20, I907, compilation of "Statements of Famous People on the Jews and Their Relationship to Other Peoples and Races" submitted by the Austro-Hungarian House of Deputies to the minister of justice.

9I. Raymond Williams, Keywords, 89.

92. Brunner, Conze, and Koselleck, Geschichtliche Grundbegriffe.

93. Herder, "Spirit of Hebrew Poetry" (hereafter cited in the text as SHP).

94. Herder, "Letters Concerning the Study of Theology," 2 I 3.

95. See Efron, German Jewry, I93.

96. Sachs, Religiöse Poesie, I42, 342, I8 I, I 82.

97. Zunz, Zur Geschichte und Literatur, 2; translation from Karpeles, Jewish Literature, I I.

98. Zunz, Zur Geschichte und Literatur, 6; translation by the authors.

99. Geiger, Judaism and Its History, 60 (hereafter cited in the text as JH).

I00. Geiger, Judenthum und seine Geschichte (hereafter cited in the text as JG); translation by the authors.

IO I. Steinschneider, "Ueber die Volkslitteratur der Juden," 4; translation by the authors.

I02. Ibid., 9.

I03. Karpeles, Geschichte der jüdischen Literatur, I:4; translation by the authors (hereafter cited in the text as GJL).

I04. Gosche, "Idyll und Dorfgeschichte," I 74.

I05. Cited by Rossman, Russian Intellectual Antisemitism, 8 .

Io6. Renan, "Judaism as Race and Religion," 73-74, 77 (hereafter cited in the text as JRL). Widely translated, the original was "Le Judaïsme comme race et comme religion" 
(paper presented at the Conférence Faite au Cercle Saint-Simon, Paris, 27 January I 883).

I07. Renan, History, I:42-43, I2 (hereafter cited in the text as HPI).

I08. Delitzsch, Babel and Bible, 75-76.

I09. Contrast this with Henry James's views on cosmopolitanism and Jewish capitalism in The Golden Bowl (I904): Oster, "Shop of Curiosities."

I Io. Raabe, Hungerpastor, I:2 I0. Against this argument, see Denkler, "Das "wirckliche Juda."”; for support, see Holub, "Raabe's Impartiality."

I I I. Mosse, "Image of the Jew," 226.

I I2. Cited by Shills, Constitution of Society, 36.

I I3. Freud, Standard Edition, I 8: Ioo.

\section{CHAPTER 3}

I. See, for example, the case within Germany presented in Hochstadt, Mobility and Modernity, and the case for German Jewry in Jonathan M. Hess, Germans, Jews, and the Claims of Modernity, I9-2 I. Feiner, "Pseudo-Enlightenment," further distinguishes between Central European Jewish modernism and its later Eastern European forms.

2. See, for example, Thielking, Weltbürgertum, 79-80, which devotes only a short section to Jews in pre-World War I cosmopolitanist thought. While Thielking argues that Jews more generally embraced cosmopolitanist ideas as a defense against their increasing external perception as outsiders to the German nation, she collapses the Jewish Renaissance, with its "national Jewish mission," with Zionism, to which she attributes a flat-out rejection of cosmopolitanism.

3. Quoted from Hans Mommsen, "Habsburgische Nationalitätenfrage," I I 2; translation by the authors. As Mommsen points out, the right to practice one's national particularity was thus largely defined in terms of cultural activity, which was to remain separate from the umbrella of Austrian state politics. The latter was, of course, dominated by the German and Hungarian social elites of the dual monarchy. For an exploration of ethnic and national politics in the Habsburg Empire, see also Robertson and Timms, Habsburg Legacy.

4. Michael A. Meyer and Michael Brenner, German-Jewish History, 3:I68.

5. Beller, Vienna and the Jews, I58-60.

6. Schulze and Wolf, "Economic Nationalism."

7. Burger, "Jüdischsein."

8. Timms, "Musil's Vienna and Kafka's Prague."

9. Michael A. Meyer and Michael Brenner, German-Jewish History, 3:3 I I-I 2.

Io. Quoted in Bein, Theodor Herzl, I73.

I I. Stanislawski, Zionism and the Fin de Siècle, I6-I8.

I2. Herzl, Jewish State, I 53 (hereafter cited in the text as JS). See also Wisse, Jews and Power, I04ff.

I3. Fichte, Johann Gottlieb Fichtes sämmtliche Werke, 239; translation by the authors.

I4. Robertson, German-Jewish Dialogue, I50. 
I5. Oppenheimer, "Zionismus und Kosmopolitismus"; translation by the authors.

I6. Morgan, "Nietzsche and National Identity," 472.

I7. Sternhell, Founding Myths of Israel, 47.

I8. Arendt, "Herzl and Lazare," 338-39.

I9. See Stanislawski, Zionism and the Fin de Siècle, 90-95; Burgers, "Max Nordau, Madison Grant, and Racialized Theories."

20. Nordau, Degeneration, 38-58. See Schivelbusch, Railway Journey. See also Presner, Mobile Modernity.

2I. Nordau and Gottheil, Zionism and Antisemitism, 45.

22. Baron, Justifying the Obligation, 89 .

23. Ibid.

24. Nordau, Jewish Return, 6.

25. Arthur D. Lewis, Cosmopolitanism and Zionism, 4, 7.

26. Freud, Complete Letters, 285.

27. Slezkine, Jewish Century, 63.

28. For details on this point, see Gilman, Freud, Race, and Gender.

29. Kaplan, Jewish Radical Right.

30. Freud, Standard Edition, 20:274 (hereafter cited in the text as SE).

3I. Reik, Jewish Wit, I2.

32. Tauber, "Freud's Dream of Reason."

33. Pitt-Rivers, Clash of Culture, 82.

34. Saundby, "Diabetes Mellitus."

35. Hitler, Mein Kampf, 5I-52.

36. Wes Anderson, Grand Budapest Hotel.

37. Zweig, Beware of Pity; Zweig, Post Office Girl.

38. Prochnik, "'I Stole from Stefan Zweig."”

39. Zweig, Burning Secret; Thomas Mann, Death in Venice.

40. Zweig, "Zutrauen zur Zukunft," I67; translation by the authors.

4I. Zweig, Confusion.

42. See Mittelmann, "Fragmentation," I72.

43. In contrast, Gelber, Stefan Zweig, Judentum und Zionismus, has recently argued for a "Jewish sensitivity" at the core of Zweig's writings.

44. Zweig, World of Yesterday (hereafter cited in the text as WY).

45. Zweig, "Land ohne Patriotismus," 8; translation by the authors.

46. Zweig, "Heimfahrt nach Österreich," 25, 27; translation by the authors.

47. Zweig, "Wort von Deutschland," 30-3 I; translation by the authors.

48. Zweig, "Vom 'österreichischen' Dichter," 5I; translation by the authors.

49. Zweig, Brazil.

50. See Gelber, Melancholy Pride, I 2.

5I. Ibid.

52. Ibid.

53. Zweig, "Im Schnee"; translation by the authors (hereafter cited in the text as IS). Gelber, has similarly noted Zweig's shifting expressions of Jewish affinity, which ranged from a more distanced stance toward Judaism to his embrace of certain aspects of early Jewish nationalism (Stefan Zweig, Judentum, und Zionismus, I6, I7).

54. Zweig, Briefe, I897-I9I4, I9; translation by the authors. 
55. Gelber, Stefan Zweig, Judentum und Zionismus, I88, argues that Zweig's ultimate acceptance of this publication venue demonstrates that the writer had at least some affinity with the Zionist movement.

56. For this stereotype and its literary saliency, see Gilman, "Salome, Syphilis." See also Krobb, Schöne Jüdin.

57. Zweig, Briefe, I9I4-I9I9, I30.

58. Le Rider (“Stefan Zweig," 208) similarly contends that Zweig's cosmopolitanism grew from a new sense of homelessness that was catalyzed by the dissolution of the Habsburg Empire at the outbreak of World War I as well as rising antisemitism.

59. Zweig, "Wanderung"; translation by the authors.

6o. Weininger, Sex and Character.

6I. Renan, "Judaism as Race and Religion."

62. Zweig, "Wunder des Lebens"; translation by the authors.

63. Michael A. Meyer and Michael Brenner, German-Jewish History, 3:3 I3-24.

64. Reifowitz, Imagining an Austrian Nation, I.

65. Kafka, "Great Wall of China," 244. (Hereafter cited from Glatzer, The Complete Stories in the text as TCS.) See also Zilcosky, Kafka's Travels; Engel, "Entwürfe symbolischer Weltordnungen"; Benno Wanger, "Lightning No Longer Flashes."

66. Regine Rosenthal, "Reinscribing the Other," I27-53; Konzett, "Difficult Rebirth"; Caygill, "Fate of the Pariah."

67. Bruce, Kafka and Cultural Zionism.

68. "Tschechischer Juden," 3-4.

69. Wahrmund, Gesetz des Nomadentums, 9I.

70. Sznaider, Jewish Memory, 34.

7I. Momigliano, "Note."

72. Arendt, "Franz Kafka."

73. Kafka, Kritische Kafka-Ausgabe, 62 I. See also Rumold, "Kafka's Nomad Images."

74. Kafka, Man Who Disappeared, I96.

75. Zangwill, Works, 2:49-I98 (hereafter cited in the text as Z/W). On Zangwill's politics, see Vital, "Zangwill." On The Melting Pot, see Slobin, "Some Intersections"; Biale, "Melting Pot and Beyond"; Nahshon, "From the Ghetto to the Melting Pot."

76. Kraus, "How the Melting Pot Stirred America"; Szuberla, "Zangwill's The Melting Pot Plays Chicago," 20.

77. Abu-Laban and Lamont, "Crossing Borders."

78. Quoted by Heinze, Jews and the American Soul, 27.

79. Zangwill, "Zionism and Territorialism."

8o. "Territorialism and Zionism," 663.

8I. Ibid., 665.

82. Verein Jüdischer Hochschüler Bar Kochba, Vom Judentum; translation by the authors.

83. Mendes-Flohr, Divided Passions, 84-85

84. Efron, German Jewry, I4-I5.

85. Margarete Susman, "Spinoza und das jüdische Weltgefühl," in Verein Jüdischer Hochschüler Bar Kochba, Vom Judentum,5I. 
86. Moritz Goldstein, "Wir und Europa," in ibid., I97.

87. Ibid., I 95 .

88. Ibid., 209.

89. Scholem and Benjamin, Story of a Friendship, I28.

90. Friesel, "German-Jewish Encounter."

9I. Scholem and Benjamin, Story of a Friendship, I28.

92. Robert Weltsch, "Theodor Herzl und wir," in Verein Jüdischer Hochschüler Bar Kochba, Vom Judentum, I 58.

93. Ibid., I64.

94. Kennan, Fateful Alliance, I64.

95. Hamann, Hitler's Vienna, 90.

96. Winkler, "Nationalismus, Nationalstaat, und nationale Frage," I3. See also Thielking, Weltbürgertum, 77.

97. Michael A. Meyer and Michael Brenner, German-Jewish History, 3:3 I3.

98. Gelber, Stefan Zweig, Judentum und Zionismus, I7-54.

99. Cornicelius, Politik, I:I. See also Thielking, Weltbürgertum, Io (hereafter cited in the text as T); translation by the authors.

Ioo. Levy, Antisemitism in the Modern World, 69-73.

I0I. Raabe, Novels, I6o. See also Krobb, Erkundungen im Überseeischen.

I02. Meinecke, Cosmopolitanism, 2 I-22 (hereafter cited in the text as M).

I03. Dawidowicz, Holocaust and the Historians, 59.

I04. Du Bois, "Present Condition," I75.

I05. Barkin, "W. E. B. Du Bois' Love Affair," 286.

Io6. Bornstein, "W. E. B. Du Bois and the Jews."

I07. Appiah, Lines of Descent.

I08. Du Bois, "Present Condition," I75.

I08. Ibid., I7I.

I08. Ibid., I75.

I I I. Du Bois, "Socialism," I92.

I I2. David Levering Lewis, W. E. B. Du Bois, I43.

I I3. Simmel, Philosophy of Money, 334.

I I4. An analogous position is held in Vienna by Karl Popper, a convert to Protestantism whose ethnic identification with the Jews rejected crass nationalism in favor of a radical Jewish cosmopolitanism in the wake of his rereading of Kant. See Naraniecki, "Karl Popper."

I I 5. Simmel, "Stranger," I45. We are here indebted to Morris-Reich, "Three Paradigms"; Morris-Reich, "Circumventions and Confrontations."

I I6. Simmel, Rembrandt, I40.

I I7. Gilroy, Black Atlantic, 208.

I I 8. Rahden, Jews and Other Germans, 5.

I I9. See Sznaider, Jewish Memory, I I-I4.

I 20. Rathenau, "Höre Israel"; German text reprinted in Schutte and Sprengel, Berliner Moderne, I72-77 (hereafter cited in the text as R). See also Volkov, Walter Rathenau, 47-49.

I 2 I. Wahrmund, Gesetz des Nomadentums, 9I 
I 22. Hirsch, "Nomadenthum und Judenherrschaft," 722.

I23. Volkov, Walther Rathenau, I Io.

I24. Kauders, "False Consciousness?"

I25. Schulin, "Walther Rathenau."

I26. Walther Rathenau, Das Tagebuch, I7 January I920, in Hauptwerke und Gespräche, 2: I I I-45.

I27. Kessler, Walter Rathenau, 3 I4.

I28. Thomas Mann to Arthur Hubscher, 27 June I928, in Thomas Mann, Briefe, 345.

I29. Zweig, "Walther Rathenaus Persönlichkeit."

I30. Berkowitz, Zionist Culture.

I3I. Thielking argues that the Jews remained largely excluded from the "political nationalism tied to the nation-state," which became an "integrative ideology" (Weltbürgertum, 79) in the Wilhelmenian empire. This German model was diametrically opposed to the enshrined supranationalism of the Austro-Hungarian Empire, with profound implications for the formation of cosmopolitanist ideas before World War I.

I32. Cornicelius, Politik, I:344-45.

I33. See Heizer, Jewish-German Identity, 27-29; Horch, "“Verbrannt wird auf alle Fälle ..."”

I34. Wassermann, Literat oder Mythos und Persönlichkeit, 78.

I35. Jacob Wassermann, "Der Jude als Orientale," in Verein Jüdischer Hochschüler Bar Kochba, Vom Judentum, 5-8.

I36. Ratzel, History of Mankind, 83-85.

I37. Wassermann, My Life, I56.

I38. Ibid., I I 8-I9.

I39. Ibid., 98.

I40. Kaznelson, "Um jüdisches Volkstum."

I4I. Albanis, "Jakob Wassermann's Memorial," I8.

\section{CHAPTER 4}

I. For the impact of World War I on Zweig's and Roth's works more broadly, see, for example, Steinman, "Stefan Zweig"; Kimmich, "Über den Schmerz."

2. We borrow the term sensitivity from Gelber, Stefan Zweig, Judentum, und Zionismus, which argues that a Jewish sensitivity lay at the core of Zweig's writings more generally.

3. Thielking (Weltbürgertum), Sznaider (Gedächtnisraum Europa), and Benhabib (Another Cosmopolitanism) touch on the question of Jewish intellectuals within cosmopolitanist discourse but do not fully explore the contribution made by Jewish literary writers to this body of thought.

4. For the nineteenth-century precursors of this engagement, see Wirtz, Patriotismus und Weltbürgertum.

5. Michael A. Meyer and Michael Brenner, German-Jewish History, 4:7-9, 33346.

6. For an extended discussion of the contemporaneous streams in cosmopolitanist thought, see Thielking, Weltbürgertum, 84 n. 3, 84-87. 
7. Kontje, Thomas Mann's World. See also Beck, Cosmopolitan Vision, I I.

8. Thomas Mann, "Kosmopolitismus," I9I; translation by the authors.

9. Zweig, "Opportunismus," I34 (hereafter cited in the text as SW); translation by the authors.

I0. Zweig, "Internationalismus oder Kosmopolitismus," 74-75. See also Thielking, Weltbürgertum, I20 n. 279.

I I. Jolas, Man from Babel, 58-60.

I2. Fisher, Romain Rolland, 58-59.

I3. Woodrow Wilson, "The Second Inaugural Address, March 5, I9I7," 4I: 335.

I4. Cooper, Woodrow Wilson, 494.

I 5. See Gelber, Stefan Zweig, Judentum und Zionismus.

I6. See Michael A. Meyer and Michael Brenner, German-Jewish History, 3: Io.

I7. See Thielking, Weltbürgertum, I36.

I8. Spengler, Decline of the West (hereafter cited in the text as DW).

I9. Here, we are paraphrasing Evans, Coming of the Third Reich, I 2 I.

20. Bein, Jewish Question, 332-33.

2 I. Hitler, Mein Kampf, 53 (hereafter cited in the text as MK).

22. Theodor Mommsen, Römische Geschichte, 2 I6, quoted in Hitler, Hitler's Second Book, $\mathrm{I} 52$.

23. Zweig, World of Yesterday (hereafter cited in the text as WY).

24. See Gelber and Ludewig, Stefan Zweig und Europa, 8-Io. See also Müller, "Aspekte des europäischen Erbes."

25. Wistrich, "Stefan Zweig and the 'World of Yesterday,", 60.

26. See Thielking, Weltbürgertum. See also the interview with Sigrid Thielking and Ulrich Beck in Rents, "Ist Kosmopolitismus nur eine Intellektuellen-Idee?"

27. Mosse, German Jews, 44-45.

28. This idea seemed nowhere more apparent than in James Joyce's Ulysses (I922), that great work of European modernism whose main protagonist, Leopold Bloom, invokes both Homer's Odysseus and the Christian legend of the Wandering Jew as prototypes of the rootless man in modernity. See Davison, James Joyce, I25; Reizbaum, James Joyce's Judaic Other, 68, I 58.

29. Gelber, Stefan Zweig, Judentum und Zionismus.

30. Beck, Cosmopolitan Vision, $32 \mathrm{I}$.

3I. Mephisto's claim that blood is a very special fluid in Goethe's Faust I (Faust signs his bargain with the Devil in blood) is transmuted into a code for race in the nineteenth century. Blood is in German culture retains its mystical implications even in the age of racial antisemitism. Quoting Mephistopheles, theosophist Rudolf Steiner thus argued in 1906 for the drive toward racial identity when he wrote, "We understand race only as far as we understand the meaning of blood." Blood is understood as the innate but mystical force that defines the racial difference. See, Rudolf Steiner, Blut ist ein ganz besonderer Saft, 30. See also Steinwachs, Rudolf Steiner, 6I-62; Biale, Blood and Belief, I23-62.

32. Zweig, "Turm zu Babel," 73 (translation by the authors).

33. Zweig, "Europäische Gedanke in seiner Entwicklung," I 88. As Armin A. Wallas and Hanni Mittelmann have observed, Zweig's treatment of Jewish themes remained largely subdued to his universalist engagement. However, the writings explored in this 
section suggest that the Jew remained in the palimpsest of the cosmopolitan, much in the vein of what Gelber considers Zweig's "Jewish sensitivity" more generally. See Wallas, "Mythen der Übernationalität"; Mittelmann, "Fragmentation"; Gelber, Stefan Zweig, Judentum und Zionismus.

34. The I927 publication contained only five stories; subsequent editions expanded to twelve and then fourteen stories. The English edition, Zweig, Tide of Fortune, contains all fourteen stories.

35. Zweig, Tide of Fortune, 5 (hereafter cited in the text as ToF).

36. Zweig, "Old-Book Peddler" (hereafter cited in the text as OBP).

37. See Gilman, Jewish Self-Hatred.

38. Richard Wagner, "Judaism in Music." For an examination of the trajectory of this image from Wagner to the post-Holocaust era, see Gilman, Jewish Self-Hatred.

39. Weininger, Sex and Character.

40. See, for example, Zohn, "Stefan Zweig, the European and the Jew." See also Mittelmann, "Fragmentation."

4I. For Zweig's sense of himself as an "impotent humanist," see Thielking, Weltbürgertum, I63.

42. Weigel, "Kaffeehaus als Wille und Vorstellung."

43. Zweig's original text, which here reads "Gastlichkeit" (hospitality) rather than "asylum," no doubt consciously invokes Kant's "Weltbürgerrecht der Hospitalität"i.e., the "cosmopolitan right to hospitality"-in his "Toward Perpetual Peace."

44. Zweig, "Herz Europas," 74.

45. Established in I93 I, Birobidzhan remains an autonomous Jewish province of Russia.

46. Lazaroms, Grace of Misery.

47. Ibid., 2.

48. See Wallas, "Mythen der Übernationalität," I 79.

49. For an exploration of the emergence of the supranationalist ideal, see Reifowitz, Imagining an Austrian Nation. See Brinkmann, "From Immigrants to Supranational Transmigrants," 56 .

50. See Grande, "Cosmopolitan Political Science."

5I. For a discussion of Zweig's and Roth's references to the Jews as a "supranation," see Brinkmann, "From Immigrants to Supranational Transmigrants," 48, 56.

52. Hacohen, "Kosmopoliten in einer ethnonationalen Zeit?," 282, 285.

53. Hugo von Hoffmannsthal had expressed the idea of Austria as a miniature Europe ("ein Europa im Kleinen") in "Krieg und Kultur" (Thielking, Weltbürgertum, 92).

54. Lazaroms, Grace of Misery.

55. Roth, Hotel Savoy (hereafter cited in the text as HS).

56. Lazaroms, Grace of Misery, xiv.

57. See Metzler, Tales of Three Cities, 285-86.

58. Ibid., xvi.

52. Fontane, "Deutsche Gasthof" (hereafter cited in the text as G); translation by the authors.

6o. Kracauer, "Hotel Lobby" (hereafter cited in the text as HL).

6I. Zweig, "Bei den Sorglosen" (hereafter cited in the text as S). 
62. Joseph Roth, "Arrival in the Hotel," in Hotel Years, I55, I57 (hereafter cited in the text as HY).

63. Roth, Wandering Jews (hereafter cited in the text as WJ).

64. Roth, Radetzky March (hereafter cited in the text as RM); Roth, Emperor's Tomb.

65. For a study of Roth's literary gauging of antisemitic stereotypes, see Ochse, Joseph Roths Auseinandersetzung.

66. The German word Orient in the original is somewhat diffusively translated as "the East" in the English edition.

67. The German original here reads "Abkömmlich eines slowenischen Invaliden und des merkwürdigen Helden von Solferino" (Roth, Radetzkymarsch, 50). To convey the protagonist's Otherness that this passage suggests, a better translation is "descendant of a Slovenian invalid and the strange hero of Solferino" (translation by the authors).

68. Volkov, "Dynamics of Dissimilation."

69. See Wallas, "Mythen der Übernationalität," I 78.

70. Volume I has been translated into English as Feuchtwanger, Josephus (hereafter cited in the text as $\mathbf{J}$ ).

7I. Sznaider, Jewish Memory, I I.

72. Beck, Cosmopolitan Vision, I3.

73. Graf, "Burn Me!," 454.

74. For a discussion of the relationship between the different versions of Jud Süss, see Kugelmann and Backhaus, Jüdische Figuren in Film und Karikatur.

75. Karl Mannheim, Ideologie and Utopie (I929), cited in Köpke, "Lion Feuchtwangers Josephus," I 40.

76. Feuchtwanger, "Was ist Wahrheit?," I; translation by the authors.

77. Zweig, "Europäische Gedanke," 25.

78. Spengler, Decline of the West, I:I9.

79. Kahler, Israel unter den Völkern. See also Thielking, Weltbürgertum, I 54-60.

\section{CHAPTER 5}

I. Goebbels, Sinn der nationalsozialistischen Revolution.

2. See Kushner, "Negotiating and Narrating Homelessness"; Jordan, Leff, and Schlör, Jewish Migration.

3. Bos, German-Jewish Literature, 66-67.

4. Palmier, Weimar in Exile.

5. Tengler, "Historical Novel."

6. Klaus Mann, Turning Point, 270.

7. Benjamin, "Vom Weltbürgertum zum Großbürger."

8. See the debate about philosemitism in Small, "Case of Thomas Mann's 'Joseph und seine Brüder"'; Schöll, Joseph im Exil.

9. Quoting McDonald, Thomas Mann's Joseph and His Brothers, I3. References are to Thomas Mann, Reflections, I8 (hereafter cited in the text as O). Con- 
cerning Mann's cosmopolitanism and the act of writing, see also Schmeling, "Artiste cosmopolite."

I0. Feder, "Manifest zur Brechung," I4-I5: "In our mammonistic delusion we have forgotten how to see that the theory of the sacredness of interest is a monstrous selfdeception, that the gospel of salvation by interest has entangled our entire thinking in the golden nets of the international plutocracy. Therefore, emancipation from the bondage of interest is the clear solution for the world revolution, for the emancipation of productive labor from the fetters of the international money powers."

I I. Fine, "Kant's Theory," 6r6: "The ostensible reconciliation Kant finds in the republican order between the 'particular' and the 'universal'-i.e. between the maximal individual liberty compatible with the liberty of others and the "collective, universal and powerful Will that can provide the guarantees required' - conflates the actual identity of individual liberty with conformity to the state."

I2. Barth, "Konfirmandenunterricht I909/I0," 28.

I3. Heinrich Mann, "Europa," 577: "neue Kampfform staatserhaltender Gesinning."

I4. Lars Fischer, Socialist Response, 200.

I 5. In Thomas Mann's untitled contribution to Moses, Lösung der Judenfrage, 24248 (hereafter cited in the text as L). We cite from the original edition as it presents the text in its original context. Reprinted in Thomas Mann, "Zur jüdischen Frage"; all translations are ours.

I6. Kontje, Thomas Mann's World, I9-24; on Joseph and "ancient cosmopolitanism," see I I 8-52.

I7. Robert Weltsch, "Tragt ihn mit Stolz, den gelben Fleck," in Jüdische Rundschau, April I933, translation from Dawidowicz, Holocaust Reader, I47-50 (hereafter cited in the text as W/JR). The star marked Jewish businesses against which the I933 National Socialist boycott was directed.

I8. "Theodor Herzl und wir," in Verein Jüdischer Hochschüler Bar Kochba, Vom Judentum, I55-68.

I9. All English references are to Thomas Mann, Joseph and His Brothers (hereafter cited in the text as JB). The German citations are to Thomas Mann, Gesammelte Werke (hereafter cited in the text as GW). While the new translation is a brilliant attempt to capture the original, there are enough nuanced differences that we cite the German original where we wish to evoke Mann's language.

20. On 4 February I925, Mann wrote to Nietzsche scholar Ernst Bertram, "In this way I will be en route for about four weeks. . . . For me, not wanting to tread too near to the classical spots, it is primarily to do with Egypt. I will take a look at the desert, the pyramids, the Sphinx" (quoted in Bürgin and Mayer, Thomas Mann, 77-78). See also Michael A. Rosenthal, "Art and the Politics of the Desert."

2 I. Marquardt, "Difference and Demeanor," 228. For a counterview, see Levenson, "Christian Author, Jewish Book?"

22. Thomas Mann, Selbstkommentare, 309.

23. Thomas Mann, Thomas Mann's Addresses, I I. See also Mark Anderson, "Jewish Mimesis?"

24. Kontje, Thomas Mann's World, 8 n. 5 I. 
25. Lewisohn, "Joseph and His Brothers."

26. Thomas Mann, Thomas Mann's Addresses, I 2.

27. Josipovici, Book of God, 293.

28. Kontje, Thomas Mann's World, 222.

29. Weigall, Life and Times, 69.

30. Ibid., 4I.

3I. Thomas Mann, Magic Mountain, 542 (hereafter cited in the text as MM). For a discussion of the ramifications of this figure, see Jamison, " SSaaltochter in Schwarz und Weiß.",

32. See Picart, Thomas Mann and Friedrich Nietzsche.

33. On Mann and Jewish physicality, see Elsaghe, "Judennase.",

34. Neues Wiener Journal, 30 May I9I 8, 8.

35. Schlaffer, Kurze Geschichte, I38-40; translation by the authors.

36. Kinder, Geldströme.

37. Simmel, Philosophy of Money, 353, 254.

38. Weber, Essays in Sociology, I4. See Goldman, Max Weber and Thomas Mann.

39. Frisby and Featherstone, Simmel on Culture, r6o.

40. This point has been hotly debated since Momigliano, "Note."

4I. Simmel, Sociology, 407-IO.

42. Simmel, "Stranger," I45.

43. Coser, Masters of Sociological Thought, I82-83.

44. Simmel, Rembrandt, I04. See Morris-Reich, "Circumventions and Confrontations," 200.

45. Yamamuro, "Ironie und Demokratie."

46. Schmitt, Concept of the Political, 27. On Schmitt's status in contemporary historiography, see Caldwell, "Controversies."

47. Schmitt, "Nationalsozialistisches Rechtsdenken," 227.

48. Heinrich Himmel on the "Gypsy Plague" (I2 December I938) reproduced in Döring, Zigeuner im nationalsozialistischen Staat, I97.

49. Klüger, "Thomas Manns Jüdische Gestalten."

50. Freud, Letters, 95.

5I. McDonald, Thomas Mann's Joseph and His Brothers, 3: "Young Siegmund [sic], in a rough approximation to Joseph, was himself a younger brother born late to Jacob Freud's third, 'true' wife. Both left their homes for foreign lands, cosmopolitan career, and fame."

52. Freud, Standard Edition, I 5:230 (hereafter cited in the text as SE).

53. Assmann, Thomas Mann und Ägypten, I90-94.

54. Sigmund Freud to Martha Bernays, 23 July I882, in Fichtner et al, Brautbriefe, I:2 I 4 .

55. Thomas Mann, Pro and Contra Wagner, I49-5I.

56. Heidegger, Being and Time, 84.

57. George Steiner, Martin Heidegger, I 22.

58. Martin Heidegger, "Über Wesen und Begriff von Natur, Geschichte, und Staat," Übung aus dem Wintersemester 1933-34, in Denker and Zaborowski, Heidegger und der Nationalsozialismus, 4:82. 
59. Heidegger, "Überlegungen XIV, I 2 I." We are indebted to Trawny, Heidegger.

6o. Heidegger, Gesamt-Ausgabe, 95:97 (Überlegungen VIII), 5.

6r. Huber, "Antisemitismus der NSDAP," 9I.

62. Jäckel and Kuhn, Hitler, 88-90.

63. Goebbels, "Communism with the Mask Off," 5.

64. Baumböck, Juden machen Weltpolitik, 29.

65. Heidegger, Gesamt-Ausgabe, 96:26I-62 (Überlegungen XV). September? I94I.

66. Gründel, Jahre der Überwindung, 93-94.

67. Zweig, Erasmus (hereafter cited in the text as E).

68. For Zweig's image of Britain, see Görner and Renoldner, Zweigs England.

69. Roth, Hotel Savoy.

70. See, for example, Spengler, "Die weisse Weltrevolution," I4I-43. On the question of Luther and antisemitism in the Third Reich (and in the National Socialist movement from the I920s), see Heschel, Aryan Jesus.

7I. Schmollinger, "Intra muros et extra," I I6. See also Riordan, "Depictions of the State."

72. Markish, Erasmus and the Jews, 97.

73. Zweig, "Old-Book Peddler."

74. Görner, "Erasmisches Bewusstsein," I3.

75. Ibid., I 8.

76. Améry, At the Mind's Limits; Levi, Drowned and the Saved.

77. Zweig, "Wanderung."

78. Zweig, "Buried Candelabrum," I4I. See also Le Rider, "Stefan Zweig,” 2 I4I5.

79. Zweig, World of Yesterday (hereafter cited in the text as WY); Roth, Radetzky March.

80. Roth, Emperor's Tomb (hereafter cited in the text as ET). For Roth's stay with the Zweigs, see Friderike Zweig, Spiegelungen des Lebens, I67.

8I. Klaus Mann, Turning Point, 240.

82. See, for example, Duong, "Schwinden vertrauter Welten."

83. Roth, Wandering Jews, 48-49.

84. See also Wistrich, "Stefan Zweig and the "World of Yesterday," 6o, which argues that The World of Yesterday idealizes the Austro-Hungarian Empire for its presumed political and social stability while largely eliding its internal contradictions. Against the frequent reading of The World of Yesterday as a historical source text, Gelber, Stefan Zweig, Judentum und Zionismus, argues that World constitutes an exile novel.

85. Zweig, Triumph und Tragik, 25.

86. Zweig, Conqueror of the Seas.

87. Pooth, Blick auf das Fremde, 2.

88. See, for example, Gobineau, Inequality of Human Races; Chamberlain, Foundations. For a critical study, see Young, Colonial Desire.

89. Kontje, Thomas Mann's World, 3-5.

90. Pfanner, "Döblin." 
9I. Bell, Jews in the Early Modern World, 65.

92. Zweig, Brazil, I89 (hereafter cited in the text as ZB).

93. This phrase appears only in the German original. See Zweig, Brasilien, I56; translation by the authors.

94. Zweig's mention of the "sin against the blood" here refers to Artur Dinter's widely read novel by that title, which in the vein of racial theory links racial hybridity to mental and physical degeneracy. See Dinter, Sünde wider das Blut. Thomas Mann had replied to this in I92 I (GW I7:662).

95. This argument found its precursor in the arch-Zionist Max Nordau's drama Dr. Cohen (I 898). See also Gilman, "Max Nordau and Sigmund Freud." For a discussion of Zweig's Brazil as a response to the racial ideology of National Socialism, see also Eckl, "Stefan Zweig's Concept of Brazil."

96. See also Young, Colonial Desire.

97. Tannenbaum, Slave and Citizen, 97.

98. Assis, Machado de Assis, I36.

99. Massa, Jeunesse de Machado de Assis, 47.

Ioo. Nunes, Cannibal Democracy, 73.

IO I. As Gobineau (Inequality of Human Races, 3I), for example, argues, race mixing would degenerate the superior race but improve the lower one, creating a new race "less powerful certainly than the better of its ancestors but still of considerable strength." For a critical study, see Gubar, Racechanges.

I02. The insertion in brackets is our translation of the German words "zu Tierheit," which were omitted from the English translation. Existence would be a better word than living in the first sentence, with connotations of the physical, spiritual, and moral associations of Zweig's portrayal of the native condition in the German original: "Gerade weil die Urbevölkerung auf dem Tiefstand lebt" (Zweig, Brasilien, 40).

I03. See also Bunzel, "Josephus-Trilogie."

I04. Feuchtwanger, Jew of Rome, 362 (hereafter cited in the text as JR). The German original uses the term kosmopolitische Sendung (cosmopolitan mission) here (Feuchtwanger, Söhne, 304).

I05. Feuchtwanger, Day Will Come, 3: I6 (hereafter cited in the text as DWC).

I06. The German original here uses the term Vernichtung (annihilation or destruction) (Feuchtwanger, Söhne, 268), which invokes the National Socialists' Vernichtungskrieg (war of annihilation).

I07. Given that Feuchtwanger's German original uses the term Weltbürgertum (Söhne, 384), universalism would here better be translated as cosmopolitanism.

\section{CHAPTER 6}

I. Muller, Capitalism and the Jews, 6; Berkowitz, Western Jewry, I02.

2. Scholem, From Berlin to Jerusalem, 42-43. See also Miriam Zadoff, Der rote Hiob.

3. Huber, "Antisemitismus der NSDAP."

4. Marx, "On the Jewish Question," in Marx-Engels Reader, 27. 
5. See Philip Spencer, "Marxism, Cosmopolitanism and 'the' Jews", which reads Marx's critique of Bruno Bauer as an expression of Kantian cosmopolitanism because of Marx's insistence that Jews and Judaism should have the same political rights as all other individuals. See also Fine, "Rereading Marx."

6. Grüner, Patrioten und Kosmopoliten, 42.

7. See Claussen, "Versuch über den Antizionismus," I3. See also Grüner, Patrioten und Kosmopoliten, 4.

8. See Philip Spencer, "Marxism, Cosmopolitanism and 'the' Jews"; emphasis in original.

9. Hunt, Guide to Communist Jargon, I29.

Io. See Claussen, "Versuch über den Antizionismus," I5.

I I. Grüner, Patrioten und Kosmopoliten, I36, I47; Snyder, Bloodlands, 67; Frank, Walter Ulbricht, I39.

I2. Courtois et al., Black Book of Communism, 298-30 I.

I3. Leder, My Life, 288

I4. Pinkus, Soviet Government and the Jews, I54, I83, I8 I-86.

I5. Roth, Wandering Jews, Io6 (hereafter cited in the text as WJ).

I6. Beginning in I936, the German Communist Party ordered Jews to either emigrate or form separate resistance groups. In I938, the Austrian Communist Party similarly instructed its Jewish members "to emigrate, so as not to endanger other comrades and the illegal work of the party" (Kwiet and Eschwege, Selbstbehauptung und Widerstand, I I3-I5).

I7. Hitler, Mein Kampf, 459.

I8. Arendt, Origins of Totalitarianism, xxxix (hereafter cited in the text as OT).

19. Manès Sperber, Zur Analyse, I0, 34; translation by the authors.

20. Benhabib, Another Cosmopolitanism, I5-I7. Like Benhabib, Sznaider (Gedächtnisraum Europa, I27-32. links Arendt's cosmopolitanist thought mainly to her later book, Eichmann in Jerusalem.

2 I. See Fine, Political Investigations, 107.

22. Améry, At the Mind's Limits, viii, 3I.

23. Claussen, "Versuch über den Antizionismus," Io.

24. Nolte, "Zwischen Geschichtslegende und Revisionismus?," I5.

25. See "Erklärung des 'Zentralkomitee der Nationalen Einheitsfront Kampucheas für Nationale Rettung,'” Neues Deutschland, 6 December I978, 6, quoted in ibid., 2526,32 ; translation by the authors.

26. Nolte, "Vergangenheit," 45; translation by the authors.

27. Manfred Kehrig, "Zum Geleit," in Hoffmann, Stalins Vernichtungskrieg, I I (hereafter cited in the text as SV); translation by the authors.

28. Several recent studies have examined the postwar German tendency to absolve Germans of their guilt by reimagining them as the Allies' or Jews' victims. See, for example, Niven, Germans as Victims; Schmitz and Seidel-Arpaci, Narratives of Trauma.

29. The Hamburg Institut für Sozialforschung presented this exhibit between I 995 and I999. When newly found documents revealed that a number of the depicted war atrocities had been perpetrated by Soviet rather than German forces, it was revised and 
exhibited again between 200I and 2004. For the catalog, see Stiftung Hamburger Institut für Sozialforschung, Verbrechen.

30. Snyder, Bloodlands (hereafter cited in the text as BL). Coined by Polish Jewish lawyer Rafael Lemkin in I943, genocide has been invoked by the United Nations since I 948 for atrocities based on national, ethnic, racial, or religious affiliation. According to Snyder, this usage of the term carries its own political history, given that the Soviets ensured that "contrary to Lemkin's intentions, the term excluded political and economic groups" (BL, 4I3), no doubt to focus its application on Nazi atrocities rather than Stalinist crimes.

3I. Bauman, Modernity and the Holocaust, 2, xii.

32. Rothberg, Multidirectional Memory, 43.

33. See Tolz, Russia's Own Orient.

34. Rühle-Gerstel, Umbruch oder Hanna (hereafter cited in the text as B); translation by the authors.

35. Biographical information from Marta Marková, "Alice Rühle-Gerstel, eine deutsch-jüdische Intellektuelle aus Prag," in ibid., 4I7-4I.

36. Rühle and Rühle, Sexual-Analyse.

37. Kafka, Letters to Milena.

38. See Rühle-Gerstel, Kein Gedicht für Trotzki, I I.

39. Commission of Inquiry, Not Guilty.

40. See the introduction by Stephen S. Kalmar, who befriended the Rühles in Mexico, in Rühle-Gerstel, Kein Gedicht für Trotzki, 6-7.

4I. Robertson, Kafka. Judaism, Politics, and Literature.

42. Arendt, Jew as Pariah.

43. See Gilman, Difference and Pathology.

44. Reich, Mass Psychology of Fascism, 66.

45. Ibid., 224.

46. Weininger, Sex and Character.

47. Koestler, Darkness at Noon (hereafter cited in the text as DN).

48. See Cesarani, Arthur Koestler, 93.

49. Ibid., 98 .

50. This subdued importance of Jewishness also marked Koestler's attitudes toward his own Jewishness. According to Cesarani, "The 'real' Koestler was always somewhere, someone else; a person with many other beliefs, habits and attributes that were only hinted at or entirely repressed. Among these was his Jewishness" (ibid., 398).

5I. Pipes, Russian Revolution, 820.

52. Levi, Drowned and the Saved, 48, 40.

53. Koestler, "On Disbelieving Atrocities," 92.

54. Ibid., 90.

55. Manès Sperber, Like a Tear (hereafter cited in the text as LTO).

56. Ulbricht was, in effect, removing any competitors for the German Party leadership, for which he had campaigned after the National Socialists arrested Ernst Thälmann. See Podewin, Walter Ulbricht; Frank, Walter Ulbricht. Thälmann died in Buchenwald in 1944.

57. Sperber further invoked Arendt when he characterized the mechanics of the 
Moscow trials, which ushered in the Great Purges, with the false confessions, conviction, and execution of first-guard revolutionaries including Grigory Zinoviev and Nikolai Bukharin, as "manifestations of an extreme alienation from oneself" that resulted from threats of a "psychologically atomizing" nature. See his foreword to Sperber, Tyranny, I5.

58. Sperber, Like a Tear, 9. This was, in fact, the case with Sperber's essay on tyranny, which communists and their sympathizers refused to read. The Party's verdict of silence even led the mainstream emigrants' papers to refuse to publish a paid announcement for the book. The Gestapo finally destroyed the entire edition. See foreword to Sperber, Tyranny, I8.

59. Sperber, Tyranny, I I.

6o. Bloch, Principle of Hope.

6r. See Hermann Field and Field, Trapped in the Cold War.

62. Noel Field, "Hitching Our Wagon to a Star."

63. Merker, "Hitlers Antisemitismus und wir," 9.

64. Groehler and Groehler, Zweierlei Bewältigung, 43.

65. As Fredric Jameson argues in his foreword to the English edition, "The Aesthetics of Resistance is not so much a contribution to aesthetic theory as rather the working out of an aesthetic pedagogy" (Weiss, Aesthetics of Resistance, $\mathrm{x}$ [hereafter cited in the text as AR]).

66. Scherpe, "Reading the Aesthetics of Resistance," 97.

67. Weiss, Ästhetik des Widerstandes, I025, I024 (hereafter cited in the text as ÄW); translations from vol. 3, which has not been translated into English, by the authors.

68. See Hutchinson and Zachau, Stefan Heym.

69. Heym, Collin, I26 (hereafter cited in the text as C).

70. See Janka, Schwierigkeiten mit der Wahrheit.

\section{CHAPTER 7}

I. See the complex theoretical account by Weingrod and Levy, "Paradoxes of Homecoming."

2. Smola, "Postkolonial, hybrid, transkulturell." See also Shneer, "The Third Way."

3. Wanner, Out of Russia (hereafter cited in the text as W/O); Yelenevskaya, "Cultural Diaspora in the Making"; Honsza and Szurkowski, Deutsch-jüdische Identität.

4. Remennick, Russian Jews on Three Continents, 384.

5. Laitin, "De-Cosmopolitanization of the Russian Diaspora," 22 (hereafter cited in the text as L/D).

6. Eisen, Galut, 50.

7. Irwin, "More Than Just Ethnic," Io6 (hereafter cited in the text as I).

8. See, for example, the analogous problem in Goska, "Bieganski," I38-40.

9. Dagnino, Transcultural Writers and Novels, 34.

Io. Aldea, "Nomadism," 753.

II. Lubrich, "Zwischen den Sprachen"; Lubrich, "Are Russian Jews Post- 
Colonial?"; Darieva, Russkij Berlin; Fischer-Kania, "Berlin, von Moskau"; Wanner, "Wladimir Kaminer"; Hector, "Top of Form Humor”; Molnár, “Bessere Welt war immer anderswo""; Meurer, "Ihr seid anders und wir auch"”; Gargano, "Die Berliner Romane"; Baker, "Smiling Bonds and Laughter Frees." On the complexity of such constructions, see Postoutenko, "Imaginary Ethnicity."

I2. Arendt, Men in Dark Times, 22.

I3. The four "official religions" are supported by a tax on their declared membership: Roman Catholicism, the Evangelical (Protestant) Church, Jehovah's Witnesses, and the state acknowledged Jewish Community. Islam (however defined) is not an official religion.

I4. The official Jewish community defines Jewish identity solely in terms of Orthodox religious practice.

I 5. "Integration jüdischer Kontingentflüchtlinge."

I6. Leventhal, "Community, Memory, and Shifting Jewish Identities," 37.

I7. Bottà, "Interculturalism and New Russians."

I 8. Fishman, "Interview with Wladimir Kaminer."

I9. Kaminer, Russendisko (hereafter cited in the text as K/R; translation by the authors); published in English as Russian Disco. See also Fischer-Kania, "Berlin, von Moskau."

20. Kaminer, Militärmusik, 23 (hereafter cited in the text as K/M; translation by the authors). See also Karelina, "Identitätskonstruktion als Imagemaking."

2 I. Kaminer, Reise nach Trulala.

22. Kaminer, Schönhauser Allee (hereafter cited in the text as K/S; translation by the authors).

23. Kaminer and Höge, Helden des Alltages (hereafter cited in the text as $\mathrm{K} / \mathrm{H}$; translation by the authors).

24. Kaminer, Mein deutsches Dschungelbuch (hereafter cited in the text as K/D; translation by the authors). See also Kathleen Condray, "Colonization of Germany."

25. Fishman, "Interview with Wladimir Kaminer."

26. Kaminer, Ich mache mir Sorgen, Mama.

27. "Leser wie Tanzpartner bewegen," 69.

28. Kaminer, Karaoke (hereafter cited in the text as $\mathrm{K} / \mathrm{K}$; translation by the authors).

29. Kaminer, Küche totalitär (hereafter cited in the text as $\mathrm{K} / \mathrm{O}$; translation by the authors).

30. Nakhimovsky, "You Are What They Ate."

3I. Kaminer, Ich bin kein Berliner (hereafter cited in the text as K/I; translation by the authors).

32. Fishman, "Interview with Wladimir Kaminer." See also Lubrich, "Are Russian Jews Post-Colonial?," 35-53.

33. See Kaminer, Mein Leben im Schrebergarten; Kaminer, Salve Papa!; Kaminer, Es gab keinen Sex im Sozialismus; Kaminer, Meine russischen Nachbarn; Kaminer, Leben ist kein Joghurt; Kaminer, Meine kaukasische Schwiegermutter; Kaminer, Liebesgrüße aus Deutschland; Kaminer, Onkel Wanja kommt; Kaminer, Diesseits von Eden (hereafter cited in the text as K/V).

34. Lipphardt and Brauch, "Gelebte Räume-Neue Perspektiven." 
35. Nabokov, Gogol, 70.

36. Nabokov, Strong Opinions, Ioo.

37. Gorelik, Meine weißen Nächte (hereafter cited in the text as G; translation by authors). On the fictionality of her text, see Münchener Merkur, 7 November 2004: "I am not a hundred percent Anja, but I believe, that each writer is - at least, if she writes in the first person-that one can not avoid one's own experience. Certainly Anja is sometimes me, or I am sometimes Anja. Perhaps Anja is a bit more exaggerated but sometimes is also understated." Gorelik's other works include Meine weißen Nächte, Hochzeit in Jerusalem, Verliebt in Sankt Petersburg, Lieber Mischa, Diese eine Frage. See also Lena Muchina, "Lenas Tagebuch"; Smola, "Postkolonial, hybrid, transkulturell."

38. Lubrich, "Zwischen den Sprachen."

39. Gilman, Jurek Becker.

40. Berlin Morgenpost, I3 January 2005, 2.

4I. Gorelik, Sie können aber gut Deutsch! (hereafter cited in the text as G/W).

42. Gittelman, "Becoming Jewish," 5 I.

43. Sarrazin, Deutschland schafft sich ab, 95. See Gilman, "Thilo Sarrazin."

44. Cohen, Ukeles, and Miller, Jewish Community Study, 225.

45. Ritterband, "Jewish Identity," 327.

46. Dickstein, "Questions of Identity," I 29.

47. Shteyngart, Russian Debutante's Handbook (hereafter cited in the text as S/R). See also Friedman, "Nostalgia, Nationhood, and the New Immigrant Narrative"; Taugis, "There and Back."

48. See, for example, Barner, "Jüdische Goethe-Verehrung," I27-5I; Boden, "Goethes Faust." As a case study, see also Walker, "Nabokov's Lolita."

49. Sara Brown, "I Am the World, I'll Eat the World," 30.

50. Daniel Zalewski, "From Russia with Tsoris," 54.

5I. Shteyngart, "New Two-Way Street," 285-86.

52. Sara Brown, "I Am the World, I'll Eat the World," 30.

53. Shteyngart, Little Failure (hereafter cited in the text as S/L).

54. "By the Book: Gary Shteyngart," $7(\mathrm{~L})$.

55. Akhtiorskaya, Panic in a Suitcase (hereafter cited in the text as A/P). See also John Williams, "Emigrate?," C7.

56. E. O. Wilson, Consilience, 245.

56. Ibid.

58. Clifford, "Diasporas," 255.

59. Eschel, "Cosmopolitanism and Searching."

\section{CHAPTER 8}

I. Derrida, On Cosmopolitanism and Forgiveness, 3.

2. "Interview with Rosi Braidotti."

3. Frost, "Mending Wall," 33. First published just before World War I in his North of Boston. 
4. Pinto, New Jewish Identity.

5. Sassen, Guests and Aliens.

6. Foucault, "Confession of the Flesh."

7. Foucault, History of Sexuality, I:92.

8. Beck, Cosmopolitan Vision, I-4.

9. Foucault, History of Sexuality, I:I34.

IO. Foucault, "Truth and Power," I I 4-I 5.

I I. Smith, Inquiry, 477; on Portuguese Jews, see I02.

I2. Benhabib, Another Cosmopolitanism; Benhabib, Rights of Others.

I3. Reuters, "Israel Eyes European Jewish Immigration."

I4. World Service Authority, "What Is the World Government?"

I5. See his autobiography, Davis, World Is My Country, 29.

I6. Fox, "Obituary: "Garry Davis."

I7. Frost, "Mending Wall," 34.

I8. Trachtenberg, "Good Neighbors," I 22. 



\section{Works Cited}

Abu-Laban, Yasmeen, and Victoria Lamont. "Crossing Borders: Interdisciplinarity, Immigration, and the Melting Pot in the American Cultural Imaginary." Canadian Review of American Studies 27 (I997): 23-43.

Adelson, Leslie A. Making Bodies, Making History: Feminism and German Identity. Lincoln: University of Nebraska Press, I 993.

Adorno, Theodor. Minima Moralia: Reflections from Damaged Life. London: New Left, I95I.

Adorno, Theodor. "Der Wunde Heine.” In Gesammelte Schriften, edited by Rolf Tiedemann. I I: 95-I00. Frankfurt am Main: Suhrkamp, I970.

Akhtiorskaya, Yelena. Panic in a Suitcase. New York: Riverhead, 20 I4.

Albanis, Elisabeth. "Jakob Wassermann's Memorial to Walther Rathenau in 'Etzel Andergast."” German Life and Letters 50 (I997): I8-34.

Albrecht, Andrea. Kosmopolitismus: Weltbürgerdiskurse in Literatur, Philosophie, und Publizistik um I80o. Berlin: de Gruyter, 2005.

Alcalay, Ammiel. After Jews and Arabs: Remaking Levantine Culture. Minneapolis: University of Minnesota Press, I992.

Aldea, Eva. "Nomadism." In The Encyclopedia of Literary and Cultural Theory, edited by Michael Ryan, 753. Oxford: Wiley Blackwell, 20 I I.

Améry, Jean. At the Mind's Limits: Contemplations by a Survivor on Auschwitz and Its Realities, translated by Sidney Rosenfeld and Stella P. Rosenfeld. Bloomington: Indiana University Press, I980.

Anderson, Benedict. Imagined Communities: Reflections on the Origin and Spread of Nationalism. London: Verso, I983.

Anderson, Mark. "Jewish Mimesis?: Imitation and Assimilation in Thomas Mann's 'Wälsungenblut' and Ludwig Jacobowski's 'Werther, der Jude.'” German Life and Letters 49 (1996): 193-204.

Anderson, Wes. The Grand Budapest Hotel. 2014.

Appiah, Kwame Anthony. Cosmopolitanism: Ethics in a World of Strangers. New York: Norton, 2007.

Appiah, Kwame Anthony. Lines of Descent: W. E. B. Du Bois and the Emergence of Identity. Cambridge: Harvard University Press, 2014.

Arendt, Hannah. Eichmann in Jerusalem: A Report on the Banality of Evil. London: Penguin, 2006. 
Arendt, Hannah. "Franz Kafka, Appreciated Anew." In Reflections on Literature and Culture, 94-I09. Stanford: Stanford University Press, 2007.

Arendt, Hannah. "The Jew as Pariah: A Hidden Tradition.” In Reflections on Literature and Culture, 69-90. Stanford: Stanford University Press, 2007.

Arendt, Hannah. The Jew as Pariah: Jewish Identity and Politics in the Modern Age. New York: Grove, I978.

Arendt, Hannah. "Herzl and Lazare" (I942). In Hannah Arendt, The Jewish Writings, edited by Jerome Kohn and Ron H. Feldman, 338-42. New York: Schocken, 2007.

Arendt, Hannah. Men in Dark Times. New York: Harcourt Brace, I 968.

Arendt, Hannah. The Origins of Totalitarianism. Orlando: Harcourt, 1985.

Asad, Talal. Formations of the Secular: Christianity, Islam, Modernity. Stanford: Stanford University Press, 2003.

Ascheid, Antje. Hitler's Heroines: Stardom and Womanhood in Nazi Cinema. Philadelphia: Temple University Press, 2003.

Assis, Machado de. Machado de Assis afro-descendente: Escritos de caramujo, edited by Eduardo de Assis Duarte. Rio de Janeiro: Pallas, 2007.

Assmann, Jan. Thomas Mann und Ägypten: Mythos und Monotheismus in den Josephsromanen. Munich: Beck, 2006.

Auerbach, Bertold. Dichter und Kaufmann. Stuttgart: Cotta, I860.

Baker, Julia K. "Smiling Bonds and Laughter Frees: Marginal Humor and Modern Strangers in the Works of Hung Gurst and Wladimir Kaminer." In Finding the Foreign, edited by Robert Schechtman and Suin Roberts, 46-57. Newcastle upon Tyne, England: Cambridge Scholars, 2007.

Baldry, H. C. The Unity of Mankind in Greek Thought. Cambridge: Cambridge University Press, I965.

Barkin, Kenneth. "W. E. B. Du Bois' Love Affair with Imperial Germany." German Studies Review 28 (May 2005): 285-302.

Barner, Wilfried. "Jüdische Goethe-Verehrung vor I933." In Juden in der deutschen Literatur: Ein deutsch-israelisches Symposion, edited by Stéphane Mosès and Albrecht Schöne, I27-5I. Frankfurt am Main: Suhrkamp, I986.

Baron, Ilan Zvi. Justifying the Obligation to Die: War, Ethics, and Political Obligation with Illustrations from Zionism. Lanham, MD: Lexington, 2009.

Barth, Karl. "Konfirmandenunterricht I909/ıo." In Gesamtausgabe: I: I8 Konfirmandenunterricht 1909-192I, edited by Jürgen Fangmeier, 28. Zurich: Theologischer Verlag Zürich, I987.

Bauman, Zygmunt. Liquid Modernity. London: Polity, 2000.

Bauman, Zygmunt. Modernity and the Holocaust. Ithaca: Cornell University Press, I996.

Baumböck, Karl. Juden machen Weltpolitik. Berlin: Propaganda-Verlag Paul Hochmuth, I942.

Beachy, Robert. "Recasting Cosmopolitanism: German Freemasonry and Regional Identity in the Early Nineteenth Century." Eighteenth-Century Studies 33 (2000): 266-74.

Beck, Ulrich. The Cosmopolitan Vision. Cambridge: Polity, 2006.

Beck, Ulrich, and Natan Sznaider. "A Literature on Cosmopolitanism: An Overview." British Journal of Sociology 57 (2006): I53-64.

Beck, Ulrich, and Natan Sznaider. "Unpacking Cosmopolitanism for the Social Sciences: A Research Agenda." British Journal of Sociology 57 (2006): I-23. 
Behm, Britta L. Moses Mendelssohn und die Transformation der jüdischen Erziehung in Berlin: Eine bildungsgeschichtliche Analyse zur jüdischen Aufklärung im I8. Jahrhundert. Münster: Waxmann, 2002.

Bein, Alex. The Jewish Question: Biography of a World Problem, translated by Harry Zohn. Rutherford, NJ: Fairleigh Dickinson University Press, I990.

Bein, Alex. Theodor Herzl. Vienna: Selbstverlag Der Österreichisch-Israelischen Gesellschaft, I974.

Bell, Dean Philip. Jews in the Early Modern World. Lanham, MD: Rowman and Littlefield, 2008.

Beller, Steven. Vienna and the Jews, I867-1938: A Cultural History. Cambridge: Cambridge University Press, I99I.

Benhabib, Seyla. Another Cosmopolitanism. Oxford: Oxford University Press, 2008.

Benhabib, Seyla. The Rights of Others. Cambridge: Cambridge University Press, 2004.

Benhabib, Seyla, and Raluca Eddon. "From Antisemitism to 'the Right to Have Rights': The Jewish Roots of Hannah Arendt's Cosmopolitanism." In Antisemitism and Philosemitism in the Twentieth and Twenty-First Centuries: Representing Jews, Jewishness, and Modern Culture, edited by Phyllis Lassner and Lara Trubowitz, 63-80. Newark: University of Delaware Press, 2008.

Benjamin, Walter. "Vom Weltbürgertum zum Großbürger." In Gesammelte Schriften: Kleine Prosa, edited by Rolf Tiedemann and Hermann Schweppenhäuser, 4: 8I 562. Frankfurt am Main: Suhrkamp, I99I.

Berend, Tibor Iván. Case Studies on Modern European Economy: Entrepreneurs, Inventions, Institutions. New York: Routledge, 2013.

Berger, Peter L. The Sacred Canopy: Elements of a Sociological Theory of Religion. New York: Anchor, 1967.

Berghahn, Klaus L. "I 769 Lavater's Attempt to Compel the Conversion of Moses Mendelssohn Abuses the Friendship Cult Surrounding Jewish and Christian Intellectuals." In Yale Companion to Jewish Writing and Thought in German Culture, Iog61996, edited by Sander L. Gilman and Jack Zipes, 6I-67. New Haven: Yale University Press, I997.

Berghahn, Klaus L. "Comedy without Laughter: Jewish Characters in Comedies from Shylock to Nathan." In Laughter Unlimited: Essays on Humor, Satire, and the Comic, edited by Reinhold Grimm and Jost Hermand, 3-26. Madison: University of Wisconsin Press, I99I.

Berkovitz, Jay R. Rites and Passages: The Beginnings of Modern Jewish Culture in France, I650-I860. Philadelphia: University of Pennsylvania Press, 2004.

Berkowitz, Michael. Western Jewry and the Zionist Project, I9I4-I933. Cambridge: Cambridge University Press, I997.

Berkowitz, Michael. Zionist Culture and West European Jewry before the First World War. New York: Cambridge University Press, I993.

Berlin, Isaiah. "Herder and the Enlightenment." In Three Critics of the Enlightenment: Vico, Hamann, Herder, edited by Henry Hardy, I68-242. Princeton: Princeton University Press, 2000.

Biale, David. Blood and Belief: The Circulation of a Symbol between Jews and Christians. Berkeley: University of California Press, 2007.

Biale, David. "The Melting Pot and Beyond: Jews and the Politics of American Identity." In Insider/Outsider: American Jews and Multiculturalism, edited by David 
Biale, Michael Galchinsky, and Susannah Heschel, I7-33. Berkeley: University of California Press, I998.

Bignall, Simone, and Paul Patton, eds. Deleuze and the Post-Colonial. Edinburgh: Edinburgh University Press, 20 Io.

Blass, Regine. "Vorurteile als Kunstfehler des Verstehens: Betrug und Ehrlichkeit in Lessings frühem Drama Die Juden.” Jahrbuch der Deutschen Schillergesellschaft: Internationales Organ für Neuere Deutsche Literatur 47 (2003): 4I-69.

Bloch, Ernst. The Principle of Hope, translated by Neville Plaice, Stephen Plaice, and Paul Knight. Cambridge: MIT Press 1995.

Bloom, William. Personal Identity, National Identity, and International Relations. Cambridge: Cambridge University Press, I990.

Blumenberg, Werner. "Eduard Müller-Tellering: Verfasser des ersten antisemitischen Pamphlets gegen Marx." Bulletin of the International Institute of Social History 6 (I95I): I78-99.

Boden, Dieter. "Goethes Faust und das Deutschlandbild in russischer und sowjetischer Literatur." In Faust-Rezeption in Russland und in der Sowjetunion, edited by Günther Mahal, I3-I7. Knittlingen: Faust-Museum, I983.

Bornstein, George. "W. E. B. Du Bois and the Jews: Ethics, Editing, and The Souls of Black Folk." Textual Cultures I (2006): 64-74.

Bos, Pascale R. German-Jewish Literature in the Wake of the Holocaust: Grete Weil, Ruth Klüger, and the Politics of Address. Basingstoke: Palgrave Macmillan, 2005.

Bottà, Giacomo. "Interculturalism and New Russians in Berlin." In Perspectives on Identity, Migration, and Displacement, edited by Steven Tötösy de Zepetnek, IChun Wang, and Hsiao-Yu Sun, I63-8I. Kaohsiung, Taiwan: National Sun Yat-Sen University, 20 Io.

Bowman, Steven. "Jewish Diaspora in the Greek World." In Encyclopedia of Diasporas: Immigrant and Refugee Cultures around the World, edited by Melvin Ember, Carol R. Ember, and Ian Skoggard, I 92-20 I. New York: Springer, 2005.

Braidotti, Rosi. Nomadic Subjects: Embodiment and Sexual Difference in Contemporary Feminist Theory. New York: Columbia University Press, I 994.

Breckenridge, Carol A., ed. Cosmopolitanism. Durham, NC: Duke University Press, 2002.

Brennan, Tim. At Home in the World: Cosmopolitanism Today. Cambridge: Harvard University Press, 1997.

Brinkmann, Tobias. "From Immigrants to Supranational Transmigrants and Refugees: Jewish Migrants in New York and Berlin before and after the Great War." Comparative Studies of South Asia, Africa, and the Middle East 30 (2010): 47-57.

Brod, Max. "Der Erfahrung in ostjüdischen Schulwerk." Der Jude I (I9I6-I7): 32-36.

Brown, Garrett Wallace. Grounding Cosmopolitanism: From Kant to the Idea of a Cosmopolitan Constitution. Edinburgh: Edinburgh University Press, 2009.

Brown, Sara. "I Am the World, I'll Eat the World: A Conversation with Gary Shteyngart." World Literature Today 83 (2009): 29-32.

Bruce, Iris. Kafka and Cultural Zionism: Dates in Palestine. Madison: University of Wisconsin Press, 2007.

Brunner, Otto, Werner Conze, and Reinhart Koselleck, eds. Geschichtliche Grundbegriffe: Historisches Lexikon zur politisch-sozialen Sprache in Deutschland 2. Stuttgart: Klett-Cotta, I975. 
Bunzel, Andrea. "Die Josephus-Trilogie im Zeichen des Exils." In Lion Feuchtwanger und die deutschsprachigen Emigranten in Frankreich von 1933 bis I94I, edited by Daniel Azuélos, 235-44. Bern: Lang, 2006.

Burger, Hannelore. "Jüdischsein in der Epoche des Ausgleichs und der Staatsgrundgesetze (I867-I9I 8)." Austriaca 73 (20 I I): 22 I-36.

Burgers, Johannes Hendrikus. "Max Nordau, Madison Grant, and Racialized Theories of Ideology." Journal of the History of Ideas 72 (20I I): I I9-40.

Bürgin, Hans, and Hans-Otto Mayer. Thomas Mann: Eine Chronik seines Lebens. Frankfurt am Main: Fischer, I980.

Burkhardt, C. A. H., ed. Goethes Unterhaltungen mit dem Kanzler Friedrich von Müller. Stuttgart: Cotta, I 898 .

"By the Book: Gary Shteyngart." New York Times Book Review, February 2, 20I4, $7(\mathrm{~L})$.

Caldwell, Peter C. "Controversies over Carl Schmitt: A Review of Recent Literature." Journal of Modern History 77 (June 2005): 357-87.

Cavallar, Georg. Imperfect Cosmopolis: Studies in the History of International Legal Theory and Cosmopolitan Ideas. Aberystwyth: University of Wales Press, 20 I I.

Caygill, Howard. "The Fate of the Pariah: Arendt and Kafka's 'Nature Theatre of Oklahama." College Literature 38 (20 I I): I-I4.

Cesarani, David. Arthur Koestler. New York: Free Press, I 998.

Chamberlain, Houston Stewart. The Foundations of the Nineteenth Century. London: Lane, Bodley Head, I9I 2.

Cheyette, Bryan. Diasporas of the Mind: Jewish and Postcolonial Writing and the Nightmare of History. New Haven: Yale University Press, 2014.

Claussen, Detlev. "Versuch über den Antizionismus." In Léon Poliakov, Vom Antizionismus zum Antisemitismus, translated by Franziska Sick, Elfriede Müller, and Michael T. Koltan, 7-20. Freiburg: Ça ira, 2013.

Clifford, James. "Diasporas." In Routes: Travel and Translation in the Late Twentieth Century, 244-79. Cambridge: Cambridge University Press, I997.

Cohen, Steven M., Jacob B. Ukeles, and Ron Miller. Jewish Community Study of New York: 2OI I. New York: UJA-Federation of New York, 2012.

Coignard, Tristan. "Gibt es ein Kulturmuster Kosmopolitismus?: Beispiele einer weltbürgerlichen 'posture' in der Publizistik um I80o.' Das achtzehnte Jahrhundert 35 (20I I): 204-I9.

Commission of Inquiry into the Charges Made against Leon Trotsky in the Moscow Trials, New York, I937. Not Guilty: Report of the Commission of Enquiry into the Charges made against Leon Trotsky in the Moscow Trials. New York: Harper, 1938.

Condray, Kathleen. "The Colonization of Germany: Migrant and German Identity in Wladimir Kaminer's 'Mein deutsches Dschungelbuch.'” Seminar: A Journal of Germanic Studies 42 (2006): 32 I-36.

Cooper, John Milton. Woodrow Wilson: A Biography. New York: Knopf, 2009.

Cornicelius, Max, ed. Politik: Vorlesungen, gehalten, an der Universität zu Berlin von Heinrich von Treitschke. 2 vols. Leipzig: S. Hirzel, I 897-98.

Coser, Lewis A. Masters of Sociological Thought: Ideas in Historical and Social Context. New York: Harcourt Brace Jovanovich, I977.

Courtemanche, Eleanor. "Marx, Heine, and German Cosmopolitanism: The I844 'Deutsch-Französische Jahrbücher.'” Telos I59 (20 I 2): 49-63. 
Courtois, Stéphane, Nicolas Werth, Jean-Louis Panné, Andrzej Paczkowski, Karel Bartosek, and Jean-Louis Margolin. The Black Book of Communism: Crimes, Terror, Repression, translated by Jonathan Murphy and Mark Kramer. Cambridge: Harvard University Press, I999.

Curthoys, Ned. "A Diasporic Reading of Nathan the Wise." Comparative Literature Studies 47 (2010): 70-95.

Dagnino, Arianna. Transcultural Writers and Novels in the Age of Global Mobility. West Lafayette, IN: Purdue University Press, 2015.

Darieva, Tsypylma. Russkij Berlin: Migranten und Medien in Berlin und London. Münster: Lit, 2004.

Davies, W. D. The Territorial Dimension in Judaism. Minneapolis: Fortress, I99I.

Davis, Garry. The World Is My Country. London: Macdonald, I962.

Davison, Neil R. James Joyce, Ulysses, and the Construction of Jewish Identity: Culture, Biography, and 'the Jew' in Modernist Europe Culture. Cambridge: Cambridge University Press, 1996.

Dawidowicz, Lucy S. The Holocaust and the Historians. Cambridge: Harvard University Press, I98I.

Dawidowicz, Lucy S., ed. A Holocaust Reader. West Orange, NJ: Behrman, 1976.

Dee, John. General and Rare Memorials Pertayning to the Perfect Arte of Navigation. London: Daye, I577.

Deleuze, Gilles, and Félix Guattari. A Thousand Plateaus, translated by Brian Massumi. Minneapolis: University of Minnesota Press, 1987.

Delitzsch, Friedrich. Babel and Bible: Two Lectures Delivered before the Members of the Deutsche Orient-Gesellschaft in the Presence of the German Emperor, translated by C. H. W. Johns. New York: Putnam's, I903.

Denker, Alfred, and Holger Zaborowski, eds. Heidegger und der Nationalsozialismus: Dokumente. Freiburg: Alber, 2009.

Denkler, Horst. 'Das 'wirckliche Juda' und der 'Renegat': Moses Freudenstein als Kronzeuge für Wilhelm Raabes Verhältnis zu Juden und Judentum.” German Quarterly 60 (I987): 5-I8.

Derrida, Jacques. Jewish Identity and Liquid Times: Living in an Age of Uncertainty. London: Polity, 2007.

Derrida, Jacques. On Cosmopolitanism and Forgiveness, translated by Mark Dooley and Michael Hughes. London: Routledge, 200I.

Dickstein, Morris. "Questions of Identity: The New World of the Immigrant Writer." In The Writer Uprooted: Contemporary Jewish Exile Literature, edited by Alvin H. Rosenfeld, I IO-32. Bloomington: Indiana University Press, 2008.

Dinter, Artur. Sünde wider das Blut. Leipzig: Matthes und Thost, I9I7.

Diogenes Laertius. Lives of Eminent Philosophers. 2 vols. Loeb Classical Library I 8485. Cambridge: Harvard University Press, I925.

Döring, Hans Joachim. Die Zigeuner im nationalsozialistischen Staat. Hamburg: Kriminalistik, I967.

Du Bois, W. E. B. "The Present Condition of German Politics (I893)." Central European History 3I (1998): I70-87.

Du Bois, W. E. B. "The Socialism of German Socialists." Central European History 3 I (I998): I89-96. 
Dühring, Eugen. Die Judenfrage als Frage der Racenschädlichkeit für Existenz, Sitte, und Cultur der Völker. 4th ed. Berlin: Reuther, I 892.

Duong, Phuong. "Das Schwinden vertrauter Welten." In Joseph Roth: Zur Modernität des melancholischen Blicks, edited by Wiebke Amthor and Hans Richard Brittnacher, 69-79. Berlin: de Gruyter, 2012.

Eckl, Marlen. "Stefan Zweig's Concept of Brazil in the Context of German-Jewish Emigration." In Stefan Zweig and World Literature: Twenty-First-Century Perspectives, edited by Birger Vanwesenbeeck and Mark H. Gelber, I9I-2 I 2. Rochester, NY: Camden House, 2014.

Efron, John. German Jewry and the Allure of the Sephardic. Princeton: Princeton University Press, 2015.

Eisen, Arnold M. Galut: Modern Jewish Reflections on Homelessness and Homecoming. Bloomington: Indiana University Press, I986.

Elsaghe, Yahya. “Die 'Judennase' in Thomas Manns' Erzählwerk.” Journal of English and Germanic Philology I02 (2003): 88-I04.

Encyclopédie ou Dictionnaire raisonné des sciences, des arts, et des métiers. Paris: n.p., I754-.

Engel, Manfred. "Entwürfe symbolischer Weltordnungen: China und China Revisited: Zum China-Komplex in Kafkas Werk I917-1920." In Kafka, Prag und der Erste Weltkrieg, edited by Manfred Engel and Ritchie Robertson, 22 I-36. Würzburg: Königshausen und Neumann, 2012.

Eschel, Amir. "Cosmopolitanism and Searching for Sacred Space in Jewish Literature." Jewish Social Studies 9 (2003): I 2 I-38.

Etlin, Richard A. Art, Culture, and Media under the Third Reich. Chicago: University of Chicago Press, 2002.

Evans, Richard. The Coming of the Third Reich. London: Penguin, 2003.

Ezrahi, Sidra DeKoven. "Considering the Apocalypse: Is the Writing on the Wall Only Grafitti?" In Writing and the Holocaust, edited by Berel Lang, I37-59. New York: Holmes and Meier, I988.

Feder, Gottfried. "Das Manifest zur Brechung der Zinsknechtschaft des Geldes." Kritische Rundschau 2 (I9I9): I4-I5.

Feiner, Shmuel. "The Pseudo-Enlightenment and the Question of Jewish Modernization." Jewish Social Studies, n.s. 3 (I996): 62-88.

Feldt, Jakob Egholm. Transnationalism and the Jews: Culture, History and Prophecy. London: Rowman and Littlefield International, 2016.

Fenner, Wolfgang. "Lessing wäre auch ein Mann für uns: Neuigkeiten über Knigge und Lessing." Euphorion: Zeitschrift für Literaturgeschichte 88 (I 994): 478-83.

Ferstenberg, Helen. "German-Jewish Creative Identity in the Age of Lessing and Beyond: Berthold Auerbach's 'Dichter und Kaufmann.”' Focus on Literatur 5 (I998): I-I I.

Feuchtwanger, Lion. The Day Will Come, translated by Caroline Oram. 3 vols. London: Hutchinson, I968.

Feuchtwanger, Lion. The Jew of Rome: A Historical Romance, translated by Willa Muir and Edwin Muir. London: Hutchinson, I935.

Feuchtwanger, Lion. Jew Süss, translated by Willa Muir and Edwin Muir. London: Pordes, I977. 
Feuchtwanger, Lion. Josephus: A Historical Romance, translated by Willa and Edwin Muir. London: Secker, I932.

Feuchtwanger, Lion. Die Söhne. Berlin: Aufbau, I 997.

Feuchtwanger, Lion. "Was ist Wahrheit?" Unterhaltungsblatt der Vossischen Zeitung, 2 I October I932.

Feuerbach, Ludwig. Essence of Christianity, translated by George Eliot. New York: Harper, 1957.

Fichte, I. H., ed. Johann Gottlieb Fichtes sämmtliche Werke. Berlin: Veit und comp., I $845-46$.

Fichtner, Gerhard, et al., eds. Sigmund Freud, Martha Freud, Die Brautbriefe: I882-I886. Frankfurt am Main: Fischer, 20 I I.

Field, Hermann, and Kate Field. Trapped in the Cold War: The Ordeal of an American Family. Stanford: Stanford University Press, I999.

Field, Noel. "Hitching Our Wagon to a Star." Mainstream I4 (I96I): 3-I7.

Fine, Robert. "Kant's Theory of Cosmopolitanism and Hegel's Critique." Philosophy and Social Criticism 29 (2003): 609-30.

Fine, Robert. Political Investigations: Hegel, Marx, Arendt. London: Routledge, 200 I.

Fine, Robert. "Rereading Marx on the 'Jewish Question': Marx as a Critic of Antisemitism?" In Antisemitism and the Constitution of Sociology, edited by Marcel Stoetzler, I37-59. Lincoln: University of Nebraska Press, 20 I4.

Fischer, Eugen. Die Rehobother Bastards und das Bastardierungsproblem beim Menschen. Jena: Fischer, I9I3.

Fischer, Lars. The Socialist Response to Antisemitism in Imperial Germany. New York: Cambridge University Press, 2007.

Fischer-Kania, Sabine. "Berlin, von Moskau, und anderswo aus betrachtet: Stadtwahrnehmungen in Wladimir Kaminer's 'Russendisko' und 'Schönhauser Allee." In "Weltfabrik Berlin": Eine Metropole als Sujet der Literatur: Studien zu Literatur und Landeskunde, edited by Matthias Harder and Almut Hille, 257-72. Würzburg,: Königshausen und Neumann, 2006.

Fisher, David James. Romain Rolland and the Politics of Intellectual Engagement. Berkeley: University of California Press, 1988.

Fishman, Boris. "An Interview with Wladimir Kaminer." Words without Borders: The Online Magazine for International Literature.http://www.wordswithoutborders.org/ article/an-interview-with-wladimir-kaminer

Fontane, Theodor. "Der deutsche Gasthof, das kosmopolitische Hotel und die Engländer.” In Sämtliche Werke, I 8:37 I-77. Munich: Nymphenburger, I 972.

Foucault, Michel. "The Confession of the Flesh.” In Power/Knowledge: Selected Interviews and Other Writings, 1972-1977, edited by Colin Gordon, I94-228. New York: Vintage, I980.

Foucault, Michel. The History of Sexuality: An Introduction. New York: Vintage, I990. Foucault, Michel. "Truth and Power." In Power/Knowledge: Selected Interviews and Other Writings, 1972-1977, edited by Colin Gordon, I09-33. New York: Vintage, I980.

Fox, Margalit. "Obituary: Garry Davis, Man of No Nation Who Saw a World of No War." New York Times, July 28, 2013.

Frank, Mario. Walter Ulbricht: Eine deutsche Biographie. Berlin: Siedler, 200 I.

Freidank, Eberhard. "Nordische Ekstase." Reichswart 5 (26 February I933): 4.

Freud, Sigmund. The Complete Letters of Sigmund Freud to Wilhelm Fliess, I887- 
1904, edited by Jeffrey M. Masson. Cambridge: Belknap Press of Harvard University Press, 1985.

Freud, Sigmund. The Letters of Sigmund Freud and Arnold Zweig, edited by Ernst L. Freud. New York: New York University Press, I987.

Freud, Sigmund. Standard Edition of the Complete Psychological Works of Sigmund Freud, edited by J. Strachey, A. Freud, A. Strachey, and A. Tyson. 24 vols. London: Hogarth, 1955-74.

Friedländer, David. "Freimüthige Gedanken eines Juden über den Vorschlag an die Juden, das Purimfest abzuschaffen." Berlinische Monatschrift (I979): 563-77.

Friedländer, Saul. The Years of Extermination: Nazi Germany and the Jews, I939-1945. New York: HarperCollins, 2008.

Friedman, Natalie. "Nostalgia, Nationhood, and the New Immigrant Narrative: Gary Shteyngart's 'The Russian Debutante's Handbook' and the Post-Soviet Experience." Iowa Journal of Cultural Studies 5 (2004): 77-87.

Friesel, Evyatar. "The German-Jewish Encounter as a Historical Problem: A Reconsideration." Leo Baeck Institute Yearbook 4I (I996): 263-74.

Frisby, David, and Mike Featherstone, eds. Simmel on Culture: Selected Writings. London: Sage, I997.

Fritsch, Theodor. Handbuch der Judenfrage. Leipzig: Hammer, I944.

Frost, Robert. Collected Poems of Robert Frost, ed. Edward Connery Latham. New York: Holt, I969.

Frost, Robert. "Mending Wall." In North of Boston. I I-I3. London: Nutt, I9I4.

Gargano, Antonella. "Die Berliner Romane von Wladimir Kaminer." In Gedächtnis und Identität: Die deutsche Literatur nach der Vereinigung, edited by Fabrizio Cambi, 85-97. Würzburg: Königshausen und Neumann, 2008.

Geiger, Abraham. Judaism and Its History, translated by Maurice Mayer. Vol. I. New York: Thalmessinger and Cahn, I866.

Geiger, Abraham. Das Judenthum und seine Geschichte von dem Anfange des dreizehnten bis zum Ende des sechzehnten Jahrhunderts. Breslau: Skutsch, I87I.

Gelber, Mark H. Melancholy Pride: Nation, Race, and Gender in the German Literature of Cultural Zionism. Tübingen: Niemeyer, 2000.

Gelber, Mark H. Stefan Zweig, Judentum und Zionismus. Innsbruck: Studienverlag, 2014.

Gelber, Mark H. Stefan Zweig Reconsidered: New Perspectives on His Literary and Biographical Writings. Tübingen: Niemeyer, 2007.

Gelber, Mark H., and Dorothea Ludewig, eds. Stefan Zweig und Europa. Hildesheim: Olms, 20 I I.

Geschiere, Peter. The Perils of Belonging: Autochthony, Citizenship, and Exclusion in Africa and Europe. Chicago: University of Chicago Press, 2009.

Gildemeister, Otto. Judas Werdegang: In vier Jahrtausenden. Leipzig: Weicher, I92 I.

Gilman, Sander L. Difference and Pathology: Stereotypes of Sexuality, Race, and Madness. Ithaca: Cornell University Press, I985.

Gilman, Sander L. Freud, Race, and Gender. Princeton: Princeton University Press, I993.

Gilman, Sander L. Jewish Self-Hatred: Anti-Semitism and the Hidden Language of the Jews. Baltimore: Johns Hopkins University Press, 1986.

Gilman, Sander L. Jurek Becker: A Life in Five Worlds. Chicago: University of Chicago Press, 2003. 
Gilman, Sander L. "Max Nordau and Sigmund Freud: The Politics of Conversion." Southern Humanities Review 27 (I993): I-25.

Gilman, Sander L. Multiculturalism and the Jews. New York: Routledge, 2006.

Gilman, Sander L. "Salome, Syphilis, Sara Bernhardt, and the Modern Jewess." German Quarterly 66 (I993): I 95-2 I I.

Gilman, Sander L. "Thilo Sarrazin and the Politics of Race in the Twenty-First Century." New German Critique I I7 (2012): 47-60.

Gilroy, Paul. The Black Atlantic: Modernity and Double Consciousness. Cambridge: Harvard University Press, I 993.

Gittelman, Zvi. "Becoming Jewish in Russia and Ukraine." In New Jewish Identities: Contemporary Europe and Beyond, edited by Zvi Gitelman, Barry Kosmin, and Andras Kovács, 75-I04. Budapest: Central European University Press, 2003.

Glazer, Nathan, and Daniel P. Moynihan. Beyond the Melting Pot: The Negroes, Puerto Ricans, Jews, Italians, and Irish of New York City. Cambridge: MIT Press, I963.

Gobineau, Arthur Comte de. The Inequality of Human Races. New York: Fertig, I967.

Goebbels, Joseph. Communism with the Mask Off. Delivered on I3 September 1935. Berlin: Müller, I935.

Goebbels, Joseph. Der Sinn der nationalsozialistischen Revolution. Wolfenbüttel: Heckners, I933.

Goethe, Johann Wolfgang. Faust, Egmont, the Sorrows of Young Werther, edited by Charles William Eliot. Cambridge: Harvard Classics, I909.

Goethe, Johann Wolfgang. Goethes Werke-im Auftrag der Großherzogin Sophie von Sachsen. Weimar: Böhlaus, I887-I919.

Goetschel, Willi. “Lessing's 'Jewish' Questions.” In Literature Criticism from I 400 to I80o, edited by Thomas J. Schoenberg and Lawrence J. Trudeau, I43: 6I-68. Farmington Hills, MI: Gale, 2008.

Goldman, Harvey. Max Weber and Thomas Mann: Calling and Shaping the Self. Berkeley: University of California Press, I99I.

Goldziher, Ignaz. Der Mythos bei den Hebraern: Und Seine Geschichtliche Entwickelung. Leipzig: Brockhaus, I 876.

Goozé, Marjanne E. "Wilhelm von Humboldt und die Judenemanzipation: Leistungen und Widersprüche.” Seminar: Journal of German Studies 48 (2012): 3 I 7-32.

Gorelik, Lena. Diese eine Frage. Hamburg: Probsthayn, 2013.

Gorelik, Lena. Hochzeit in Jerusalem. Munich: SchirmerGraf, 2007.

Gorelik, Lena. Lieber Mischa . . . Du bist ein Jude. Munich: Graf, 20 I I.

Gorelik, Lena. Die Listensammlerin. Berlin: Rowohlt, 2013.

Gorelik, Lena. Meine weißen Nächte. Munich: SchirmerGraf, 2004.

Gorelik, Lena. Sie können aber gut Deutsch!: Warum ich nicht mehr dankbar sein will, dass ich hier leben darf, und Tolerenz nicht weiterhilft. Munich: Pantheon, 2012.

Gorelik, Lena. Verliebt in Sankt Petersburg: Meine russische Reise. Munich: SchirmerGraf, 2008.

Görner, Rüdiger. "Erasmisches Bewusstsein: Über einen Empfindungs- und Denkmodus bei Stefan Zweig." In Stefan Zweig und Europa, edited by Mark H. Gelber and Anna-Dorothea Ludewig, I I-29. Hildesheim: Olms, 20 I I.

Görner, Rüdiger, and Klemens Renoldner, eds. Zweigs England. Würzburg: Könighausen und Neumann, 2014. 
Gosche, Richard. "Idyll und Dorfgeschichte im Alterthum und Mittelalter." In Archiv für Litteraturgeschichte, edited by Richard Gosche, I69-227. Leipzig: Teubner, I870.

Goska, Danusha V. "Bieganski: The Brute Polak Stereotype and Its Application in Polish-Jewish Relations and American Popular Culture.” Ph.D. diss., Indiana University, 2002.

Gottlieb, Michah. Faith and Freedom: Moses Mendelssohn's Theological-Political Thought. New York: Oxford University Press, 20 I I.

Graf, Oskar Maria. "Burn Me!" In The Third Reich Sourcebook, edited by Anson Rabinbach and Sander L. Gilman, 454-56. Berkeley: University of California Press, 2013 .

Grande, Edgar. "Cosmopolitan Political Science.” British Journal of Sociology 57 (2006): 87-I I I.

Grattenauer, Karl Wilhelm Friedrich. Über die physische und moralische Verfassung der Juden. Leipzig: Voß, I79I.

Groehler, Ulrich Herbert, and Olaf Groehler. Zweierlei Bewältigung: Vier Beiträge über den Umgang mit der NS-Vergangenheit in den beiden deutschen Staaten. Hamburg: Ergebnisse, I992.

Gruen, Erich S. Rethinking the Other in Antiquity. Princeton: Princeton University Press, $201 \mathrm{I}$.

Gründel, E. Günther. Jahre der Überwindung. Breslau: Korn, I934.

Grüner, Frank. Patrioten und Kosmopoliten: Juden im Sowjetstaat, I94I-I953. Cologne: Böhlau, 2008.

Gubar, Susan. Racechanges: White Skin, Black Face. New York: Oxford University Press, 1997.

Habermas, Jürgen. The Structural Transformation of the Public Sphere: An Inquiry into a Category of Bourgeois Society, translated by Thomas Burger. Cambridge: MIT Press, I994.

Hacohen, Malachi Haim. "Kosmopoliten in einer ethnonationalen Zeit?: Juden und Österreicher in der Ersten Republik." In Das Werden der Ersten Republik, edited by Helmut Konrad and Wolfgang Maderthaner, 28 I-3 I6. Vienna: Gerold's, 2008.

Hall, Stuart. "Cultural Identity and Diaspora." In Theorizing Diaspora: A Reader, edited by Jana Evans Braziel and Anita Mannur, 223-47. Malden, MA: Blackwell, 2003.

Hamann, Brigitte. Hitler's Vienna: A Portrait of the Tyrant as a Young Man. London: Tauris Parke, 20I0.

Hart, Gail K. "Schiller's 'An die Freude' and the Question of Freedom.” German Studies Review 32 (2009): 479-93.

Heater, Derek. World Citizenship and Government: Cosmopolitan Ideas in the History of Western Political Thought. New York: St. Martin's, I996.

Hector, Anne. "Top of Form Humor as Socioliterary Camouflage in Postwall Germany: Jakob Hein's Antrag auf ständige Ausreise (2007) and Wladimir Kaminer's Es gab keinen Sex im Sozialismus (2009)." In Strategies of Humor in Post-Unification German Literature, Film, and Other Media, edited by Jill E. Twark, 78-I00. Newcastle upon Tyne, England: Cambridge Scholars, 20I3.

Heidegger, Martin. Being and Time, translated by J. Macquarrie and E. Robinson. Vol. I2, Oxford: Blackwell, I962. 
Heidegger, Martin. "Überlegungen XIV, I2 I." In Überlegungen XII-XV: GesamtAusgabe, edited by Peter Trawny, 96: 243. Frankfurt am Main: Klostermann, 2014.

Heine, Heinrich. Germany: A Winter's Tale, translated by Joseph Massaad. N.d. http:// www.heinrich-heine.net/winter/winteregoodb.htm

Heinze, Andrew R. Jews and the American Soul: Human Nature in the Twentieth Century. Princeton: Princeton University Press, 2004.

Heizer, Donna K. Jewish-German Identity in the Orientalist Literature of Else LaskerSchüler, Friedrich Wolf, and Franz Werfel. Columbia, SC: Camden House, I 996.

Helfer, Martha B. The Word Unheard: Legacies of Antisemitism in German Literature and Culture. Evanston, IL: Northwestern University Press, 20 I I.

Herder, Johann Gottfried. "Letters Concerning the Study of Theology." In Against Pure Reason: Writings on Religion, Language, and History, 2 I 8-53. Minneapolis: Fortress.

Herder, Johann Gottfried. Outlines of a Philosophy of the History of Man, translated by T. Churchill. London: Johnson, I800.

Herder, Johann Gottfried. Philosophical Writings, translated and edited by Michael N. Forster. Cambridge: Cambridge University Press, 2002.

Herder, Johann Gottfried. "The Spirit of Hebrew Poetry," translated by Marcia Bunge. In Against Pure Reason: Writings on Religion, Language, and History, I58-75. Minneapolis: Fortress, I993.

Hertz, Deborah. Jewish High Society in Old Regime Berlin. Syracuse, NY: Syracuse University Press, 2005.

Herzl, Theodor. The Jewish State (Der Judenstaat), translated by Sylvie d'Avigdor. New York: American Zionist Emergency Council, I949.

Heschel, Susannah. The Aryan Jesus: Christian Theologians and the Bible in Nazi Germany. Princeton: Princeton University Press, 20 Io.

Hess, Jonathan M. Germans, Jews, and the Claims of Modernity. New Haven: Yale University Press, 2002.

Hess, Moses. Rome and Jerusalem: A Study in Jewish Nationalism, translated by Meyer Waxman. New York: Bloch, I9I8.

Heym, Stefan. Collin. London: Hodder and Stoughton, I980.

Hirsch, Isaac. "Nomadenthum und Judenherrschaft." Jeschurunein: Monatsblatt zur Förderung jüdischen Geistes und jüdischen Lebens in Haus, Gemeinde und Schule I9 (I 8 November I886): 72 I-22.

Hitler, Adolf. Hitler's Second Book: The Unpublished Sequel to Mein Kampf, edited by Gerhard L. Weinberg. New York: Enigma, 2003.

Hitler, Adolf. Mein Kampf, translated by Ralph Manheim. Boston: Houghton Mifflin, I943.

Hochstadt, Steve. Mobility and Modernity: Migration in Germany, I820-1989. Ann Arbor: University of Michigan Press, I999.

Hoffmann, Joachim. Stalins Vernichtungskrieg, I94I-1945: Planung, Ausführung, und Dokumentation. Munich: Herbig, 2000.

Hofmann, Michael. "Die Wege der Humanität: Krise und Erneuerung des HumanitätsParadigmas im Werk Goethes und Schillers." In "Verteufelt human"?: Zum Humanitätsideal der Weimarer Klassik, edited by Volker C. Dörr and Michael Hofmann. I4I-59. Berlin: Schmidt, 2008.

Hollinger, David A. Postethnic America: Beyond Multiculturalism. New York: Basic Books, I996. 
Holub, Robert C. "Raabe's Impartiality: A Reply to Horst Denkler." German Quarterly 6o (I987): 6I7-22.

Honsza, Norbert, and Przemyslaw Szurkowski, eds. Deutsch-jüdische Identität: Mythos und Wirklichkeit: Ein neuer Diskurs. Frankfurt am Main: Lang, 20 I3.

Horch, Hans Otto. “'Verbrannt wird auf alle Fälle . . .': Juden und Judentum im Werk Jakob Wassermanns.” In Im Zeichen Hiobs: Jüdische Schriftsteller und deutsche Literatur im 20. Jahrhundert, edited by Gunter E. Grimm, Hans-Peter Bayerdörfer, and Konrad Kwiet, I24-46. Königstein/Ts.: Athenäum, I985.

Huber, Engelbert. "Der Antisemitismus der NSDAP.” In Das ist Nationalsozialismus: Organisation und Weltanschauung der NSDAP, 90-96. Stuttgart: Union Deutsche, I933.

Humboldt, Wilhelm von. “Über den Entwurf zu einer Konstitution für die Juden.” In Werke in fünf Bänden, ed. Albert Leitzmann, 4:95-I I2. Stuttgart: Wissenschaftliche, I 964.

Hundert, Gershon David. Jews in Poland-Lithuania in the Eighteenth Century: A Genealogy of Modernity. Berkeley: University of California Press, 2004.

Hunt, R. N. Carew. A Guide to Communist Jargon. London: Bles, I957.

Hutchinson, Peter, and Reinhard K. Zachau, eds. Stefan Heym: Socialist-DissenterJew / Stefan Heym: Sozialist—Dissident—Jude. Oxford: Lang, 2003.

"Integration jüdischer Kontingentflüchtlinge: Realität oder Utopie?," FH-Potsdam Werkstatt, http://forge.fh-potsdam.de/ Sozwes/werkstatt/adf/integration/integrationkontingent.html

"Interview with Rosi Braidotti," http://www.euroalter.com/2010/on-nomadism-interview-with-rosi-braidotti/

Irwin, Vera V. "More Than Just Ethnic: Negotiation of Ethnicity through Language among Russian German Re-Settlers and Jewish Refugees from the Former Soviet Union in Germany.” Ph.D. diss., University of Michigan, 2009.

Israel, Jonathan I. European Jewry in the Age of Mercantilism, I550-I750. Oxford: Oxford University Press, I99I.

Jäckel, Eberhard, and Axel Kuhn, eds. Hitler: Sämtliche Aufzeichnungen 1905-1924. Stuttgart: Deutsche Verlags-Anstalt, I980.

Jahn, Friedrich. Deutsches Volksthum. Lübeck: Niemann, I 8 Io.

Jamison, Robert L. “'Eine Saaltochter in Schwarz und Weiß': The Dwarf Waitress Emerentia in Thomas Mann's 'Der Zauberberg.'” Colloquia Germanica: Internationale Zeitschrift für Germanistik 38 (2005): 223-42.

Janka, Walter. Schwierigkeiten mit der Wahrheit. Reinbek bei Hamburg: rororo, I989.

Jaucourt, Louis, Chevalier de. "Jew." In The Encyclopedia of Diderot and d'Alembert: Collaborative Translation Project. Ann Arbor: MPublishing, University of Michigan Library, 2002. http://hdl.handle.net/2027/spo.did2222.0000.022

Jolas, Eugéne. Man from Babel. New Haven: Yale University Press, I998.

Joll, James. Nineteen-Fourteen: The Unspoken Assumptions: An Inaugural Lecture Delivered 25 April 1968. London: London School of Economics and Political Science; Weidenfeld and Nicolson, I968.

Jordan, James, Lisa Leff, and Joachim Schlör, eds. Jewish Migration and the Archive. New York: Routledge, 20I6.

Josipovici, Gabriel. The Book of God. New Haven: Yale University Press, I988.

Judaken, Jonathan. Jean-Paul Sartre and "the Jewish Question": Anti-Antisemitism and the Politics of the French Intellectual. Lincoln: University of Nebraska Press, 2006. 
Jung, C. G. Interviews and Encounters. Princeton: Princeton University Press, I977.

Jütte, Daniel. Das Zeitalter des Geheimnisses: Juden, Christen und die Ökonomie des Geheimen, I40O-I80O. Göttingen: Vandenhoeck und Ruprecht, 2012.

Kafka, Franz. The Complete Stories, edited by Nahum N. Glatzer, 235-49. New York: Schocken, I97I.

Kafka, Franz. Kritische Kafka-Ausgabe: Tagebücher, edited by Hans-Gerd Koch, Michael Müller, and Malcolm Pasley. Frankfurt am Main: Fischer, I990.

Kafka, Franz. Letters to Milena, translated by Philip Boehm. New York: Schocken, I990.

Kafka, Franz. The Man Who Disappeared, translated by Ritchie Robertson. Oxford: Oxford University Press, 2012.

Kahler, Erich. Israel unter den Völkern. Munich: Delphin-Verlag, I933.

Kaminer, Wladimir. Diesseits von Eden: Neues aus dem Garten. Munich: Goldmann, 2013.

Kaminer, Wladimir. Es gab keinen Sex im Sozialismus: Legenden und Missverständnisse des vorigen Jahrhunderts. Munich: Goldmann, 2009.

Kaminer, Wladimir. Ich bin kein Berliner: Ein Reiseführer für faule Touristen. Munich: Manhattan, 2007.

Kaminer, Wladimir. Ich mache mir Sorgen, Mama. Munich: Manhattan, 2004.

Kaminer, Wladimir. Karaoke. Munich: Manhattan, 2005.

Kaminer, Wladimir. Küche totalitär: Das Kochbuch des Sozialismus von Wladimir und Olga Kaminer. Munich: Manhattan, 2006.

Kaminer, Wladimir. Das Leben ist kein Joghurt: Wladimir Kaminer und Kitty Kahane erzählen eine Geschichte von Adam und Eva. Frankfurt am Main: Edition Chrismon im Hansischen, 20 Io.

Kaminer, Wladimir. Liebesgrüße aus Deutschland. Munich: Goldmann, 20 I I.

Kaminer, Wladimir. Mein deutsches Dschungelbuch. Munich: Manhattan, 2003.

Kaminer, Wladimir. Mein Leben im Schrebergarten. Munich: Goldmann, 2007.

Kaminer, Wladimir. Meine kaukasische Schwiegermutter. Munich: Goldmann, 20 Io.

Kaminer, Wladimir. Meine russischen Nachbarn. Munich: Goldmann, 2009.

Kaminer, Wladimir. Militärmusik. Munich: Manhattan, $200 \mathrm{I}$.

Kaminer, Wladimir. Onkel Wanja kommt: Eine Reise durch die Nacht. Munich: Goldmann, 2OI2.

Kaminer, Wladimir. Die Reise nach Trulala. Munich: Manhattan, 2002.

Kaminer, Wladimir. Russendisko. Munich: Manhattan, 2000.

Kaminer, Wladimir. Russian Disco, translated by Michael Hulse. London: Ebury, 2002.

Kaminer, Wladimir. Salve Papa! Munich: Goldmann, 2008.

Kaminer, Wladimir. Schönhauser Allee. Munich: Manhattan, 200 I.

Kaminer, Wladimir, and Helmut Höge. Helden des Alltages: Ein lichtbildgestützter Vortrag über die seltsamen Sitten der Nachkriegzeit. Munich: Manhattan, 2002.

Kane, Anne. Constructing Irish National Identity: Discourse and Ritual during the Land War, I879-I882. New York: Palgrave Macmillan, 2012.

Kant, Immanuel. Anthropology from a Pragmatic Point of View, translated by Mary J. Gregor. The Hague: Nijhoff, I974.

Kant, Immanuel. "Conjectural Beginning of Human History." In Toward Perpetual Peace and Other Writings on Politics, Peace, and History, ed. Pauline Kleingeld, 24-37. New Haven: Yale University Press, 2006. 
Kant, Immanuel. "Idea for a Universal History with a Cosmopolitan Aim ( I784)," translated by Allen Wood. In The Cambridge Edition of the Works of Immanuel Kant: Anthropology, History, and Education, edited by Günter Zöller and Robert B. Louden, I07-20. Cambridge: Cambridge University Press, 2007.

Kant, Immanuel. "Religion within the Boundaries of Mere Reason, from Religion and Rational Theology," translated by Allen W. Wood and George di Giovanni. In The Cambridge Edition of the Works of Immanuel Kant: Religion and Rational Theology, 55-2 I 5. Cambridge: Cambridge University Press, 200 I.

Kant, Immanuel. "To Perpetual Peace: A Philosophical Sketch," translated by Ted Humphrey. In Perpetual Peace and Other Essays on Politics, History, and Morals, I06-43. Indianapolis, IN: Hackett, I983.

Kant, Immanuel. "“Toward Perpetual Peace' in Practical Philosophy,” translated by M. J. Gregor. In Cambridge Edition of the Works of Immanuel Kant: Practical Philosophy, 3I3-56. Cambridge: Cambridge University Press, I999.

Kaplan, Eran. The Jewish Radical Right: Revisionist Zionism and Its Ideological Legacy. Madison: University of Wisconsin Press, 2005.

Karelina, Ekaterina. "Identitätskonstruktion als Imagemaking: Wladimir Kaminer's 'Militärmusik."' In Autobiographisches Schreiben in der deutschsprachigen Gegenwartsliteratur, vol. I, Grenzen der Identität und der Fiktionalität, edited by Ulrich Breuer and Beatrice Sandberg, I02-I I. Munich: Iudicium, 2006.

Karp, Jonathan. The Politics of Jewish Commerce: Economic Thought and Emancipation in Europe, I638-1848. New York: Cambridge University Press, 2008.

Karpeles, Gustav. Geschichte der jüdischen Literatur. 2 vols. Berlin: Poppelauer, I9202 I.

Karpeles, Gustav. Jewish Literature, and Other Essays. Philadelphia: Jewish Publication Society of America, I 895.

Kauders, Anthony D. "False Consciousness?: 'German-Jewish Identity' after Emancipation." Tel Aviver Jahrbuch für deutsche Geschichte 28 ( I999): 459-75.

Kayserling, Meyer. Der Dichter Ephraim Kuh: Ein Beitrag zur Geschichte der deutschen Literatur. Berlin: Springer, I 864.

Kaznelson, Siegmund. "Um jüdisches Volkstum." Der Jude 6 (I92 I-22): 49-52.

Kennan, George F. The Fateful Alliance: France, Russia, and the Coming of the First World War. Manchester: Manchester University Press, I984.

Kessler, Harry Graf. Walter Rathenau: Sein Leben, sein Werke. Frankfurt am Main: Fischer, I988.

Kilcher, Andreas B., ed. Metzler Lexikon der deutsch-jüdischen Literatur: Jüdische Autorinnen und Autoren deutscher Sprache von der Aufklärung bis zur Gegenwart. Stuttgart: Metzler, 2012.

Kimmich, Dorothee. "Über den Schmerz: Weltkriegstrauma in der Literatur." Cahiers d'Études Germaniques 66 (20I4): 5I-I66.

Kinder, Anna. Geldströme: Ökonomie im Romanwerk Thomas Manns. Berlin: de Gruyter, 2013.

Kleingeld, Pauline. "Six Varieties of Cosmopolitanism in Late Eighteenth-Century Germany." Journal of the History of Ideas 6o (I999): 505-24.

Kleingeld, Pauline. "Approaching Perpetual Peace: Kant's Defence of a League of States and His Ideal of a World Federation." European Journal of Philosophy I 2 (2004): 304-25. 
Kleingeld, Pauline. Kant and Cosmopolitanism: The Philosophical Ideal of World Citizenship. Cambridge: Cambridge University Press, 20 I I.

Klüger, Ruth. "Thomas Manns jüdische Gestalten.” In Katastrophen: Über deutsche Literatur, 39-58. Göttingen: Wallstein, I994.

Knigge, Adolf Freiherr von. Practical Philosophy of Social Life, translated by Peter Will. 2 vols. London: Cadell, I796.

Knigge, Adolf Freiherr von. Practical Philosophy of Social Life; or, The Art of Conversing with Men, translated by Peter Will. Lansingburgh, NY: Penniman and Bliss, I805.

Knigge, Adolf Freiherr von. Über den Umgang mit Menschen. 3 vols. Frankfurt: n.p., I794.

Koestler, Arthur. Darkness at Noon, translated by Daphne Hardy. London: Hutchinson, I973.

Koestler, Arthur. "On Disbelieving Atrocities." In The Yogi and the Commissar, and Other Essays, 8 I-93. London: Hutchinson, I965.

Kohler, K. Deutschland und die Juden: Der jüdische Cosmopolitismus. New York: Steiger, I88I.

Kohut, George Alexander, ed. The Standard Book of Jewish Verse. New York: Dodd, Mead, I9I7.

Kolb, Jocelyn. The Ambiguity of Taste: Freedom and Food in European Romanticism. Ann Arbor: University of Michigan Press, I995.

Kontje, Todd. Thomas Mann's World: Empire, Race, and the Jewish Question. Ann Arbor: University of Michigan Press, 20 I I.

Konzett, Matthias. "The Difficult Rebirth of Cosmopolitanism: Schnitzler and Contemporary Austrian Literature.” In A Companion to the Works of Arthur Schnitzler, edited by Dagmar C. G. Lorenz, 349-69. Rochester, NY: Camden House, 2003.

Köpke, Wulf. "Lion Feuchtwangers Josephus: Ost und West." In Lion Feuchtwanger: Materialien zu Leben und Werk, edited by Wilhelm von Sternburg, I34-50. Frankfurt am Mein: Fischer, I989.

Körte, Mona. Die Uneinholbarkeit des Verfolgten: der Ewige Jude in der literarischen Phantastik. Frankfurt am Main: Campus, 2000.

Kortländer, Bernd. "During the Day a Big Accounting Office and at Night a Huge Bordello: Heine and Hamburg." In Patriotism, Cosmopolitanism, and National Culture: Public Culture in Hamburg, I700-1933, edited by Peter Uwe Hohendahl, I67-79. Amsterdam: Rodopi, 2003.

"Der Kosmopolitismus der jüdischen Race." Monatsschrift für Geschichte und Wissenschaft des Judentums 9 ( I 860): 40 I-6.

Kracauer, Siegfried. “The Hotel Lobby.” In The Mass Ornament, I73-85. Cambridge: Harvard University Press, I995.

Kranz, J. Über den Missbrauch der geistlichen Macht und die weltlichen Herrschaft in Glaubensachen. Berlin: n.p., I782.

Kraus, Joe. "How the Melting Pot Stirred America: The Reception of Zangwill's Play and Theater's Role in the American Assimilation Experience." MELUS 24 (1999): 3-I9.

Krobb, Florian. Erkundungen im Überseeischen: Wilhelm Raabe und die Füllung der Welt. Würzburg: Königshausen und Neumann, 2009.

Krobb, Florian. Die schöne Jüdin: Jüdische Frauengestalten in der deutschsprachigen 
Erzählliteratur vom I7. Jahrhundert bis zum Ersten Weltkrieg. Tübingen: Niemeyer, I993.

Kugelmann, Cilly, and Fritz Backhaus. Jüdische Figuren in Film und Karikatur: Die Rothschilds und Joseph Sïß Oppenheimer. Sigmaringen: Thorbeke, I996.

Kuh, Ephraim Moses. Hinterlassene Gedichte. Zurich: Orell, Gessner, Flissli, I792.

Kushner, Tony. "Negotiating and Narrating Homelessness: Refugees from the I930s." In Exiles, Émigrés, and Intermediaries, edited by Barbara Schaff, 255-67. Amsterdam: Rodopi, 20 Io.

Kwiet, Konrad, and Helmut Eschwege. Selbstbehauptung und Widerstand: Deutsche Juden im Kampf um Existenz, und Menschenwürde, I933-1945. Hamburg: Christians, I 984 .

Laitin, David D. "The De-Cosmopolitanization of the Russian Diaspora: A View from Brooklyn in the 'Far Abroad." Diaspora I3 (2004): 5-35.

Lallement, Guillaume N. Choix de rapports, opinions et discours prononcés à la tribune nationale depuis I789 jusqu'à ce jour I5 (I82 I): 23 I.

Lazaroms, Ilse Josepha. The Grace of Misery: Joseph Roth and the Politics of Exile, I9I9-1939. Leiden: Brill, 2013.

Leder, Mary M. My Life in Stalinist Russia. Bloomington: Indiana University Press, $200 \mathrm{I}$.

"Leser wie Tanzpartner bewegen.” Der Spiegel, I October 2003, 69.

Lessing, Gotthold Ephraim. The Jews: A Comedy in One Act Completed in the Year I749, translated by Coby Lubliner. I 999. http://www.ce.berkeley.edu/ coby/jews. htm

Levenson, Alan. "Christian Author, Jewish Book?: Methods and Sources in Thomas Mann's Joseph.” German Quarterly 7I (I998): I66-78.

Leventhal, Robert. "Community, Memory, and Shifting Jewish Identities in Germany since I989: The Case of Munich." Journal of Jewish Identities 4 (20I I): I3-42.

Levi, Primo. The Drowned and the Saved, translated by Raymond Rosenthal. New York: Vintage, I989.

Levine, Donald, ed. Georg Simmel: On Individuality and Social Forms. Chicago: University of Chicago Press, I97I.

Levy, Richard S., ed. Antisemitism in the Modern World: An Anthology of Texts. Lexington, MA: Heath, I99I.

Lewis, Arthur D. Cosmopolitanism and Zionism. London: English Zionist Federation, I9I9.

Lewis, David Levering. W. E. B. Du Bois, I868-I9I9: Biography of a Race. New York: Holt, I993.

Lewisohn, Ludwig. "Joseph and his Brothers." New Palestine 34 (I5 September I944): 5I9-20.

Lipphardt, Anna, and Julia Brauch. "Gelebte Räume-Neue Perspektiven auf jüdische Topographien." In Jewish Space: Die Katagorie "Raum” im Kontext kultureller Identitäten, edited by Petra Ernst and Gerald Lamprecht, I3-32. Innsbruck: Studienverlag, 20 IO.

Lowenstein, Steven M. The Jewishness of David Friedländer and the Crisis of Berlin Jewry. Braun Lectures in the History of the Jews in Prussia. Ramat Gan: Bar-Ilan University Press, I994. 
Lubrich, Oliver. "Are Russian Jews Post-Colonial?: Wladimir Kaminer and Identity Politics." East European Jewish Affairs 33 (2003): 35-53.

Lubrich, Oliver. "Zwischen den Sprachen-zwischen den Kulturen: Jüdische Einwanderer in Deutschland." In Sprachraum ohne Grenzen: Spracherwerb in Europa, edited by Claudia Hummel and Andreas Krüger, 57-69. Berlin: Gesellschaft zur Förderung des Internationalen Informationsaustausches, 2002.

Mack, Michael. German Idealism and the Jew: The Inner Antisemitism of Philosophy and German Jewish Responses. Chicago: University of Chicago Press, 2003.

Mack, Michael. "The Other." In The Oxford Handbook of German Philosophy in the Nineteenth Century, edited by Michael N. Forster and Kristin Gjesdal, 736-50. Oxford: Oxford University Press, 2015.

Maio, Irene De. "Berthold Auerbach's 'Dichter und Kaufmann': Enlightenment Thought and Jewish Identity." Lessing Yearbook I9 (I987): 267-85.

Mann, Heinrich. "Europa: Reich über den Reichen." Die neue Rundschau 35 (I923): 577-602.

Mann, Klaus. The Turning Point: Thirty-Five Years in this Century. London: Gollancz, I944.

Mann, Thomas. Briefe, I889-1936, edited by Erika Mann. Frankfurt am Main: Fischer, I96I.

Mann, Thomas. Death in Venice, translated by H. T. Lowe-Porter. Harmondsworth: Penguin, 1957.

Mann, Thomas. Gesammelte Werke in I3 Bänden. Frankfurt am Main: Fischer, I974.

Mann, Thomas. Joseph and His Brothers, translated by John E. Woods. New York: Knopf, 2005.

Mann, Thomas. "Kosmopolitismus.” In Gesammelte Werke, I0:I84-9I. Frankfurt am Main: Fischer, I960.

Mann, Thomas. The Magic Mountain, translated by John E. Woods. New York: Vintage, I996.

Mann, Thomas. Pro and Contra Wagner, translated by Alan Blunden. Chicago: University of Chicago Press, I985.

Mann, Thomas. Reflections of a Nonpolitical Man, translated by Walter D. Morris. New York: Ungar, I983.

Mann, Thomas. Selbstkommentare: Joseph und seine Brüder, edited by Hans Wysling. Frankfurt am Main: Fischer, I999.

Mann, Thomas. Thomas Mann's Addresses Delivered at the Library of Congress, 19421949. Rockville, MD: Wildside, 2008.

Mann, Thomas. "Zur jüdischen Frage.” In Gesammelte Werke, 8:466-75. Frankfurt am Main: Fischer, I974.

Markish, Shimon. Erasmus and the Jews, translated by Anthony Olcott. Chicago: University of Chicago Press, I986.

Marquardt, Franka. "Difference and Demeanor: Literary Anti-Semitism in Thomas Mann's Joseph Novels." Germanic Review 8o (2005): 228-53.

Marx, Karl. Capital. Harmondsworth: Penguin, 1976.

Marx, Karl. "On the Jewish Question." In Karl Marx: Selected Writings, edited and translated by David McLellan, 46-70. Oxford: Oxford University Press, 2000.

Marx, Karl. “On the Jewish Question.” In The Marx-Engels Reader, edited by Robert Tucker, 26-46. New York: Norton, 1978. 
Massa, Jean-Michel. La jeunesse de Machado de Assis (I839-I870): Essai de biographie intéllectuelle. Vol. I. Aix-en-Provence: Rennes, I969.

McDonald, William E. Thomas Mann's Joseph and His Brothers: Writing, Performance, and the Politics of Loyalty. Rochester: Camden House, I999.

Mecklenburg, Norbert. 'Lessing Lustspiel 'Die Juden' im Kontext seiner Kritik des christlichen Antisemitismus." Zeitschrift für Deutsche Philologie I33 (20 I4): 48 I-503.

Meinecke, Friedrich. Cosmopolitanism and the National State, translated by Robert B. Kimber. Princeton: Princeton University Press, I970.

Meiners, Christoph. "Kurze Geschichte der Hirtenvölker in den verschiedenen Theilen der Erde." Neues Göttingisches historisches Magazin 2 (I793): 654-85.

Mendelssohn, Moses. Jerusalem; or, On Religious Power and Judaism, translated by Alan Arkush. Hanover, NH: University Press of New England, I983.

Mendelssohn, Moses. "Über die beste Staatsverfassung." In Gesammelte Schriften: Jubiläumsausgabe, vol. 6, I, Kleinere Schriften I, edited by Alexander Altmann, I4348. Stuttgart: Frommann, I98I.

Mendelssohn, Moses. “Über die Frage: Was heißt aufklären?” In Gesammelte Schriften: Jubiläumsausgabe, vol. 6, I, Kleinere Schriften I, edited by Alexander Altmann, I I3-2 I. Stuttgart: Frommann, I98I.

Mendes-Flohr, Paul. Divided Passions: Jewish Intellectuals and the Experience of Modernity. Detroit: Wayne State University Press, I99I.

Merker, Paul. "Hitlers Antisemitismus und wir." Freies Deutschland I (October I942): 9-II.

Metzler, Tobias. Tales of Three Cities: Urban Jewish Cultures in London, Berlin, and Paris (c. I880-1940). Wiesbaden: Harrassowitz, 2014.

Meurer, Christoph. "'Ihr seid anders und wir auch': Inter- und transkulturelle Russlandbilder bei Wladimir Kaminer." In Von der nationalen zur internationalen Literatur: Transkulturelle deutschsprachige Literatur und Kultur im Zeitalter globaler Migration, edited by Helmut Schmitz, 227-4I. Amsterdam: Rodopi, 2009.

Meyer, Michael A. The Origins of the Modern Jew: Jewish Identity and European Culture in Germany, I749-I824. Detroit: Wayne State University Press, I979.

Meyer, Michael A., and Michael Brenner, eds. Deutsch-jüdische Geschichte in der Neuzeit. 4 vols. Munich: Beck, 2000.

Meyer, Michael A., and Michael Brenner, eds. German-Jewish History in Modern Times. 4 vols. New York: Columbia University Press, I996-98.

Meyer, Paul. "Judaism as a Vehicle for the Enlightenment: The Contribution of Moses Mendelssohn." Studies on Voltaire and the Eighteenth Century 263 (I989): 57 I-74.

Miller, Michael L., and Scott Ury. "Dangerous Liaisons: Jews and Cosmopolitanism in Modern Times." In Routledge International Handbook of Cosmopolitan Studies, edited by Gerard Delanty, 550-62. Abingdon: Routledge, 20 I 2.

Misch, Manfred. "Spiegelberg und sein Judenstaatsprojekt." In "In Spuren gehen . . .": Festschrift Helmuth Koopmann, edited by Andrea Bartl, I27-38. Tübingen: Niemeyer, I998.

“Mitteilungen: Weltbürger." Neuphilologische Mitteilungen 27 (I926): I3.

Mittelmann, Hanni. "Fragmentation and the Quest for Unity: Stefan Zweig's Novellas as Tales of the Assimilationist Jewish Predicament." In Stefan Zweig Reconsidered, edited by Mark H. Gelber, I63-74. Tübingen: Niemeyer, 2007.

Molnár, Katrin. “'Die bessere Welt war immer anderswo': Literarische Heimatkon- 
struktionen bei Jakob Hessing, Chaim Noll, Wladimir Kaminer und Vladimir Vertlib im Kontext von Alija, jüdischer Diaspora und säkularer Migration.” In Von der nationalen zur internationalen Literatur: Transkulturelle deutschsprachige Literatur und Kultur im Zeitalter globaler Migration, edited by Helmut Schmitz, 3 I I-36. Amsterdam: Rodopi, 2009.

Momigliano, Arnaldo. "A Note on Max Weber's Definition of Judaism as a PariahReligion." History and Theory I9 (I980): 313-I8.

Mommsen, Hans. "Die habsburgische Nationalitätenfrage und ihre Lösungsversuche im Licht der Gegenwart." In Nationalismus-Nationalitäten-Supranationalität, edited by Heinrich August Winkler and Hartmut Kaelble, I08-22. Stuttgart: KlettCotta.

Mommsen, Theodor. Römische Geschichte, vol. 5, Die Begründung der Militärmonarchie, section 2, Der letzte Kampf der römischen Republik. Munich: dtv, I976.

Morgan, Diane. "Nietzsche and National Identity." In A Companion to Nietzsche, edited by Keith Ansell-Pearson, 455-74. Malden, MA: Blackwell, 2006.

Morris-Reich, Amos. "Circumventions and Confrontations: Responses to AntiSemitism in Georg Simmel, Franz Boas, and Arthur Ruppin.” Patterns of Prejudice 44 (20I0): I95-2I5.

Morris-Reich, Amos. “Three Paradigms of 'The Negative Jew': Identity from Simmel to Zizek." Jewish Social Studies Io (2004): I79-2 I4.

Moses, Julius, ed. Die Lösung der Judenfrage: Eine Rundfrage. Berlin: Wigand, I907.

Mosse, George L. German Jews beyond Judaism. Bloomington: Indiana University Press, 1985.

Mosse, George L. "The Image of the Jew in German Popular Culture: Felix Dahn and Gustav Freytag." Leo Baeck Institute Yearbook 2 ( I 957): 2 I 8-27.

Mosse, George L. Toward the Final Solution: A History of European Racism. Madison: University of Wisconsin Press, I985.

Muchina, Lena. “Lenas Tagebuch”: Leningrad, I94I-1942, translated by Lena Gorelik and Gero Fedtke. Munich: Graf, 2013.

Müller, Karl. "Aspekte des europäischen Erbes und die 'Vereinigten Staaten Europas.'” In Stefan Zweig und Europa, eds., Mark H. Gelber and Anna-Dorothea Ludewig. Hildesheim: Georg Olms, 20 I I, 30-54.

Muller, Jerry Z. Capitalism and the Jews. Princeton: Princeton University Press, 2010.

Muthu, Sankar. "Kant's Anti-Imperialism: Cultural Agency and Cosmopolitan Right." In Enlightenment against Empire, I72-209. Princeton: Princeton University Press, 2003.

Nabokov, Vladimir. Gogol. New York: New Directions, 1944.

Nabokov, Vladimir. Strong Opinions. New York: McGraw-Hill, I973.

Nahshon, Edna. "From the Ghetto to the Melting Pot: Israel Zangwill's Jewish Drama." Jewish Quarterly 46 (I999): 53-60.

Nakhimovsky, Alice. "You Are What They Ate: Russian Jews Reclaim Their Foodways." Shofar 25 (2006): 63-78.

Naraniecki, Alexander. "Karl Popper on Jewish Nationalism and Cosmopolitanism." The European Legacy: Toward New Paradigms I7 (2012): 623-37.

Neusner, Jacob. Self-Fulfilling Prophecy: Exile and Return in the History of Judaism. I987. Atlanta: Scholars, I990. 
Nietzsche, Friedrich Wilhelm. The Anti-Christ, Ecce Homo, Twilight of the Idols, and Other Writings, edited by Aaron Ridley and Judith Norman. Cambridge: Cambridge University Press, 2005.

Niven, Bill. Germans as Victims: Remembering the Past in Contemporary Germany. London: Palgrave Macmillan, 2006.

Nolte, Ernst. "Vergangenheit, die nicht vergehen will: Eine Rede, die geschrieben, aber nicht gehalten werden konnte." In Historikerstreit: Die Dokumentation der Kontroverse um die Einzigartigkeit der nationalsozialistischen Judenvernichtung, 39-47. Munich: Piper, I987.

Nolte, Ernst. "Zwischen Geschichtslegende und Revisionismus?: Das Dritte Reich im Blickwinkel des Jahres I980.” In Historikerstreit: Die Dokumentation der Kontroverse um die Einzigartigkeit des nationalsozialistischen Judenvernichtung, I3-35. Munich: Piper, I987.

Nordau, Max. Degeneration. London: Heinemann, I9I3.

Nordau, Max. The Jewish Return to Palestine. London: English Zionist Federation, I920.

Nordau, Max, and Gustav Gottheil. Zionism and Antisemitism. New York: Fox, Duffield, I905.

Novalis, Friedrich. Christianity in Europe, translated by John R. C. Dalton. London: Chapman, I844.

Noyes, John K. "Goethe on Cosmopolitanism and Colonialism: Bildung and the Dialectic of Critical Mobility." Eighteenth-Century Studies 39 (2006): 443-62.

Noyes, John K. "Nomadism, Nomadology, Postcolonialism." Interventions 6 (2004): I59-68.

Nunes, Zita. Cannibal Democracy: Race and Representation in the Literature of the Americas. Minneapolis: University of Minnesota Press, 2008.

Nussbaum, Martha. "Kant and Cosmopolitanism." In Perpetual Peace: Essays on Kant's Cosmopolitan Ideal, edited by James Bohman and Matthias Lutz-Bachmann, 25-58. Cambridge: MIT Press, 1997.

Och, Gunnar. 'Lessings Lustspiel 'Die Juden’ im I 8 Jahrhundert: Rezeption und Reproduktion." In Theatralia Judaica: Emanzipation und Antisemitismus als Momente der Theatergeschichte: Von der Lessing-Zeit bis zur Shoah, edited by Hans-Peter Bayerdörfer, 42-63. Tübingen: Niemeyer, I992.

Ochse, Katharina. Joseph Roths Auseinandersetzung mit dem Antisemitismus. Würzburg: Königshausen und Neumann, I999.

Oellers, Norbert. "Goethe und Schiller in ihrem Verhältnis zum Judentum.” In Conditio Judaica: Judentum, Antisemitismus, und deutschsprachgige Literatur vom I8. Jahrhundert bis zum ersten Weltkrieg, edited by Hans Otto Horch and Horst Denkler, I08-30. Tübingen: Niemeyer, I988.

Oppenheimer, Franz. “Zionismus und Kosmopolitismus.” Die Welt, I 8 December I903, I-5.

Oster, Sharon B. 'The Shop of Curiosities: Henry James, 'The Jew,' and the Production of Value." ELH 75 (2008): 963-92.

Palmier, Jean-Michel. Weimar in Exile: The Antifascist Emigration in Europe and America, translated by David Fernbach. London: Verso, 2006.

Patton, Paul. "Marxism and Beyond: Strategies of Reterritorialization." In Marxism and the Interpretation of Culture, edited by Cary Nelson and Lawrence Grossberg, I2338. London: Macmillan, I988. 
Penslar, Derek. Shylock's Children: Economics and Jewish Identity in Modern Europe. Berkeley: University of California Press, 200 I.

Perkins, Mary Anne. Christendom and European Identity: The Legacy of a Grand Narrative since I789. Berlin: de Gruyter, 2004.

Peters, George F. "'Jeder Reiche ist ein Judas Ischariot': Heinrich Heine and the Emancipation of the Jews." Monatshefte I04 (20I2): 209-3 I.

Pfanner, Helmut F. "Döblin, the Critic of Western Civilization: The Amazon Trilogy." In A Companion to the Works of Alfred Döblin, edited by Roland Dollinger, Wulf Koepke, and Heidi Thomann Tewarson, I93-2 I4. Rochester, NY: Camden House, 2003.

Picart, Caroline Joan S. Thomas Mann and Friedrich Nietzsche: Eroticism, Death, Music, and Laughter. Amsterdam: Rodopi, I999.

Pinkus, Benjamin. The Soviet Government and the Jews, 1948-1967: A Documentary History. Cambridge: Cambridge University Press, I984.

Pinsker, Leon. Auto-Emancipation, translated by D. S. Blondheim. New York: Maccabean, I906.

Pinto, Diana. A New Jewish Identity for Post-I989 Europe. I996. http://www.bjpa.org/ Publications/details.cfm?PublicationID $=4333$

Pipes, Richard. The Russian Revolution, I899-1919. London: Fontana, I990.

Pitt-Rivers, George Henry Lane Fox. The Clash of Culture and the Contact of Races. London: Routledge, I927.

Podewin, Norbert. Walter Ulbricht: Eine neue Biography. Berlin: Dietz, I995.

Poliakov, Léon. Geschichte des Antisemitismus. 8 vols. Worms: G. Heintz, I977-89.

Poliakov, Léon. Vom Antizionismus zum Antisemitismus, translated by Franziska Sick, Elfriede Müller, and Michael T. Koltan. Freiburg: Ça ira, 2013.

Pollock, Griselda, and Max Silverman, eds. Concentrationary Imaginaries: Tracing Totalitarian Violence in Popular Culture. London: Tauris, 2015.

Pooth, Xenia. Der Blick auf das Fremde: Stefan Zweigs Brasilien, ein Land der Zukunft Marburg: Tectrum, 2005.

Postoutenko, K. "Imaginary Ethnicity: Jews and Russians in Russian Economical Mythology." American Behavioral Scientist 45 (200I): 282-95.

Potkay, Adam. The Story of Joy: From the Bible to Late Romanticism. Cambridge: Cambridge University Press, 2007.

Prawer, S. S. Heine, the Tragic Satirist: A Study of the Later Poetry, I827-I856. Cambridge: Cambridge University Press, I96I.

Presner, Todd Samuel. "Jews on Ships; or, How Heine's 'Reisebilder' Deconstruct Hegel's Philosophy of World History." PMLA I I 8 (2003): 52 I-38.

Presner, Todd Samuel. Mobile Modernity: Germans, Jews, Trains. New York: Columbia University Press, 2007.

Prochnik, George. "II Stole from Stefan Zweig': Wes Anderson on the Author Who Inspired His Latest Movie." Telegraph, 8 March 20I4. http://www.telegraph.co.uk/ culture/film/10684250/I-stole-from-Stefan-Zweig-Wes-Anderson-on-the-authorwho-inspired-his-latest-movie.html

Raab, Heribert, ed. Kirche und Staat: Von der Mitte des 15. Jahrhunderts bis zur Gegenwart. Munich: Deutscher Taschenbuch, I 966.

Raabe, Wilhelm. Der Hungerpastor. Berlin: Janke, I 864.

Raabe, Wilhelm. Novels, edited by Volkmar Sander. New York: Continuum, I 983.

Radkau, Joachim. Max Weber: A Biography. Cambridge: Polity, 2009. 
Rahden, Till van. Jews and Other Germans: Civil Society, Religious Diversity, and Urban Politics in Breslau, I860-1925, translated by Marcus Brainard. Madison: University of Wisconsin Press, 2008.

Rathenau, Walther. Hauptwerke und Gespräche, edited by Ernst Schulin. Munich: Müller, I977.

Rathenau, Walther. "Höre Israel.” Die Zukunft 5 (6 March I 897): 454-62.

Ratzel, Friedrich. The History of Mankind. London: Macmillan, I 896.

Reich, Wilhelm. The Mass Psychology of Fascism, translated by Vincent R. Carfagno. London: Penguin, I970.

Reifowitz, Ian. Imagining an Austrian Nation: Joseph Samuel Bloch and the Search for a Multiethnic Austrian Identity, I846-I9I9. Boulder, CO: East European Monographs, 2003.

Reik, Theodor. Jewish Wit. New York: Gamut, I962.

Reizbaum, Marilyn. James Joyce's Judaic Other. Stanford: Stanford University. Press, I999.

Remennick, Larissa. Russian Jews on Three Continents: Identity, Integration, and Conflict. New Brunswick, NJ: Transaction, 2007.

Renan, Ernest. History of the People of Israel. 3 vols. London: Chapman and Hall, I 888-9I.

Renan, Ernest. “Judaism as Race and Religion.” Translated by David Fernbach. In On the Nation and the "Jewish People," edited by Shlomo Sand, 69-I0o. London: Verso, 20I0.

Rents, Edo. "Ist Kosmopolitismus nur eine Intellektuellen-Idee? [Is Cosmopolitanism Just an Intellectual Idea?]," in Frankfurter Allgemeine, I7 January 20I4. http://www. faz.net/aktuell/feuilleton/debatten/der-kosmopolitische-blick/serie-der-kosmopolitische-blick-ist-kosmopolitismus-nur-eine-intellektuellen-idee-12755351.html

Rentschler, Eric. The Ministry of Illusion: Nazi Cinema and Its Afterlife. Cambridge: Harvard University Press, 1996.

Repington, Charles. The First World War: I9I4-1919: The Personal Experiences of Lieut.Col. C. à Court Repington. London: Constable, I920.

Reuters. "Israel Eyes European Jewish Immigration after Denmark Attack." I 5 February 20I5. http://www.reuters.com/article/2015/02/15/us-denmark-shooting-israelidUSKBNOLJOH620150215

Rider, Jacques Le. "Stefan Zweig-Darstellungen des Judentums in den Erzählungen der dreißiger und vierziger Jahre." In Stefan Zweig: Exil und Suche nach dem Weltfrieden, edited by Mark H. Gelber and Klaus Zelewitz, 206-24. Riverside, CA: Ariadne, I992.

Riechers, Hans-Christian. "“Vis à vis de soi-même': Knigges Über den Umgang mit Menschen." Achtzehnte Jahrhundert 37 (2013): 74-82.

Riordan, Colin. "Depictions of the State in Works of the Inner Emigration." In Flight of Fantasy: New Perspectives on Inner Emigration in German Literature, 1933-1945, edited by Neil H. Donahue and Doris Kirchner, I 52-67. New York: Berghahn, 2003.

Ritterband, Paul. "Jewish Identity among Russian Immigrants in the US." In Russian Jews on Three Continents: Migration and Resettlement, edited by N. Lewin-Epstein, R. I. Yaacov and P. Ritterband, 325-44. London: Cass, 1997.

Robbins, Bruce. Perpetual War: Cosmopolitanism from the Viewpoint of Violence. Durham, NC: Duke University Press, 2012. 
Robertson, Ritchie, ed. The German-Jewish Dialogue: An Anthology of Literary Texts, I749-I993. Oxford: Oxford University Press, I999.

Robertson, Ritchie. "'Dies hohe Lied der Duldung'? The Ambiguities of Toleration in Lessing's 'Die Juden and Nathan der Weise.'” Modern Language Review 93 (I998): I05-20.

Robertson, Ritchie. The "Jewish Question" in German Literature, I749-1939: Emancipation and Its Discontents. New York: Oxford University Press, I999.

Robertson, Ritchie. Kafka: Judaism, Politics, and Literature. Oxford: Oxford University Press, 1985.

Robertson, Ritchie, and Edward Timms, eds. The Habsburg Legacy: National Identity in Historical Perspective. Edinburgh: Edinburgh University Press, I994.

Rorty, Amélie, and James Schmidt, eds. Kant's "Idea for a Universal History with a Cosmopolitan Aim": A Critical Guide. Cambridge: Cambridge University Press, 2009.

Rosenberg, Alfred. "Der Bolshewismus als Aktion einer fremden Rasse." In Europa und sein Todfeind, 3-48. Munich: Nachfolger, I935.

Rosenberg, David J. "Towards a Cosmopolitanism of Self-Difference: Heinrich Heine and Madame de Stael between France and Germany." Ph.D. diss., University of California, Santa Barbara, 2007.

Rosenthal, Michael A. "Art and the Politics of the Desert: German Exiles in California and the Biblical 'Bilderverbot."' New German Critique 40 (20I3): 43-64.

Rosenthal, Regine. "Reinscribing the Other: Transformations of the Wandering Jew in Heym, Kafka, and Werfel.” Carleton Germanic Papers 24 (I996): I27-53.

Rossman, Vadim Joseph. Russian Intellectual Antisemitism in the Post-Communist Era. Lincoln: University of Nebraska Press for the Vidal Sassoon International Center for the Study of Antisemitism, Hebrew University of Jerusalem, 2002.

Roth, Joseph. The Emperor's Tomb, translated by Michael Hofmann. London: Granta, 2013.

Roth, Joseph. Hotel Savoy, translated by John Hoare. London: Granta, I 986.

Roth, Joseph. The Hotel Years, translated by Michael Hofmann. New York: New Directions, 2015.

Roth, Joseph. The Radetzky March, translated by Michael Hofman. London: Granta, 2002.

Roth, Joseph. Radetzkymarsch. Cologne: Kiepenheuer und Witsch, I932.

Roth, Joseph. The Wandering Jews, translated by Michael Hofman. London: Granta, 200 I.

Rothberg, Michael. Multidirectional Memory: Remembering the Holocaust in the Age of Decolonization. Stanford: Stanford University Press, 2009.

Rühle, Otto, and Alice Rühle. Sexual-Analyse: Psychologie des Liebes- und Ehelebens. Rudolstadt i.Th.: Greifenverlag, I929.

Rühle-Gerstel, Alice. Kein Gedicht für Trotzki: Tagebuchaufzeichnungen aus Mexiko. Frankfurt am Main: Neue Kritik, I979.

Rühle-Gerstel, Alice. Der Umbruch oder Hanna und die Freiheit. Berlin: Aviva, 2007.

Rumold, Rainer. "Kafka's Nomad Images: From Multilingual Borderland to Global Experience." Journal of the Kafka Society of America: New International Series 27 (2003): $65-78$. 
Rushbrook, Dereka. "Cities, Queer Space, and the Cosmopolitan Tourist." GLQ: A Journal of Lesbian and Gay Studies 8 (2002): 183-206.

Sachs, Michael. Die religiöse Poesie der Juden in Spanien. Berlin: Veit, I845.

Said, Edward. "Reflections on Exile." In Out There: Marginalization and Contemporary Cultures, edited by R. Fergusson, M. Gever, T. M. Trinth, and C. West, 357-66. Cambridge: MIT Press, I990.

Sarrazin, Thilo. Deutschland schafft sich ab: Wie wir unser Land aufs Spiel setzen. Munich: Deutsche Verlags-Anstalt, 20 Io.

Sassen, Saskia. "The Global City: Introducing a Concept." Brown Journal of World Affairs 9 (2005): 27-43.

Sassen, Saskia. Guests and Aliens. New York: New Press, I999.

Saundby, Robert. "Diabetes Mellitus." In A System of Medicine, edited by Thomas Clifford Allbutt, I97-99. London: Macmillan, I897.

Sayce, Archibald H. The Religions of Ancient Egypt and Babylonia. Edinburgh: Clark, I903.

Scheffler, Samuel. "Conceptions of Cosmopolitanism," Utilitas I I (I 999): 255-76.

Scherpe, Klaus R. "Reading the Aesthetics of Resistance: Ten Working Theses." New German Critique 30 (1983): 97-I05.

Schiller, Friedrich. Early Dramas, translated by Charles J. Hempel. Vol. 2. London: Bell, i90i.

Schiller, Friedrich. "Die Sendung Moses." In Friedrich Schiller Werke, NationalAusgabe I7, edited by Karl-Heinz Hahn, 377-4I3. Weimar: Böhlau, I970.

Schiller, Friedrich. Werke. Vol. 3. Weimar: Nachfolger, I943.

Schiller, Friedrich. Werke und Briefe in zwölf Bänden, edited by Otto Dann. Vol. 6. Frankfurt am Main: Deutsche Klassiker, 2000.

Schivelbusch, Wolfgang. The Railway Journey: The Industrialization of Time and Space in the Nineteenth Century. Berkeley: University of California Press, I 986.

Schlaffer, Heinz. Die kurze Geschichte der deutschen Literatur. Munich: Hanser, 2002.

Schlegel, August Wilhelm. Vorlesungen über schöne Litteratur und Kunst: Dritter Teil (I803-I804): Geschichte der romantischen Litteratur. Heilbronn: Henninger, I 884.

Schlegel, Friedrich. "Geschichte der europäischen Literatur." I803-4. In Friedrich Schlegel, Kritisch Ausgabe, ed. Ernst Behler. Paderborn: Schöningh, I958, I I: II 85

Schlereth, Thomas J. The Cosmopolitan Ideal in Enlightenment Thought: Its Form and Function in the Ideas of Franklin, Hume, and Voltaire, I694-I790. Notre Dame: University of Notre Dame Press, I977.

Schmeling, Manfred. "L'Artiste cosmopolite: Conception théorique et pratique littéraire chez Thomas Mann." In ICLA '9I Tokyo: The Force of Vision, vol. 2, Visions in History: Visions of the Other, edited by Earl Miner, 506-I2. Tokyo: International Comparative Literature Association, I995.

Schmitt, Carl. The Concept of the Political, translated by George Schwab. Chicago: University of Chicago Press, 2004.

Schmitt, Carl. "Nationalsozialistisches Rechtsdenken." Deutsches Recht: Zentralorgan des Bundes Nationalsozialistischer Deutscher Juristen, 25 May I934, 225-29.

Schmitz, Helmut, and Annette Seidel-Arpaci, eds. Narratives of Trauma: Discourses of German Wartime Suffering in National and International Perspective. Amsterdam: Rodopi, 20 I I. 
Schmollinger, Annette. "Intra muros et extra": Deutsche Literatur im Exil und in der inneren Emigration: Ein exemplarischer Vergleich. Heidelberg: Winter, I 999.

Schneiders, Werner. Aufklärung und Vorurteilskritik: Studien zur Geschichte der Vorurteilstheorie. Stuttgart: Fromann-Holzboog, I983.

Scholem, Gershom. From Berlin to Jerusalem: Memories of My Youth, translated by Harry Zohn. New York: Schocken, I980.

Scholem, Gershom, and Walter Benjamin. The Story of a Friendship, translated by Harry Zohn. Philadelphia: Jewish Publication Society, I98 I.

Schöll, Julia. Joseph im Exil: Zur Identitätskonstruktion in Thomas Manns ExilTagebüchern und -Briefen sowie im Roman Joseph und seine Brüder. Würzburg: Königshausen und Neumann, 2004.

Schonfield, Ernest. "Satire and Laughter in Heine's Deutschland: Ein Wintermärchen." Oxford German Studies 4I (2012): I8 I-96.

Schudt, Johann Jakob. Jüdische Merckwürdigkeiten: Vorstellende was sich curieuses und denckwürdiges in den neuern Zeiten bey einigen Jahrhunderten mit denen in alle IV. Theile der Welt, sonderlich durch Teutschland, zerstreuten Juden zugetragen. Frankfurt: n.p., I7I4.

Schulin, Ernst. "Walther Rathenau und sein Integrationsversuch als 'Deutscher jüdischer Stammes.” In Jüdische Integration und Identität in Deutschland und Österreich, I848-19I8: Internationales Symposium, April I983, edited by Walter Grab, I3-40. Tel Aviv: University of Tel Aviv, I984.

Schulze, Max-Stephan, and Nikolaus Wolf. "Economic Nationalism and Economic Integration: The Austro-Hungarian Empire in the Late Nineteenth Century." Economic History Review 65 (2012): 652-73.

Schutte, Jürgen, and Peter Sprengel, eds. Die Berliner Moderne, I885-I9I4. Stuttgart: Reclam, I987.

Seitz, Regina Maria. "Verschwiegene Texte: Kritik an der Aufklärung bei Mendelssohn, Behr, Maimon und Kuh.” Ph.D. diss., University of Virginia, I997.

Shaw, George Bernard. John Bull's Other Island and Major Barbara: Also How He Lied to Her Husband. New York: Brentano's, I907.

Shills, Edward. The Constitution of Society. Chicago: University of Chicago Press, I982.

Shneer, David. "The Third Way: German-Russian-European Jewish Identity in a Global Jewish World." European Review of History I8 (20 I I): I I I-2 I.

Shteyngart, Gary. Little Failure: A Memoir. New York: Random House, 2004.

Shteyngart, Gary. "The New Two-Way Street.” In Reinventing the Melting Pot: The New Immigrants and What It Means to Be American, edited by Tamar Jacoby, 285-92. New York: Basic Books, 2004.

Shteyngart, Gary. The Russian Debutante's Handbook. New York: Riverhead, 2002.

Simmel, Georg. Philosophy of Money, translated by Tom Bottomore and David Frisby. London: Routledge and Kegan Paul, I978.

Simmel, Georg. Rembrandt: Ein kunstphilosophischer Versuch. Leipzig: Wolff, I9 6.

Simmel, Georg. The Sociology of Georg Simmel, translated by Kurt H. Wolff. New York: Macmillan, I950.

Simmel, Georg. "The Stranger." In Georg Simmel: On Individuality and Social Forms, edited by Donald Levine, I45-50. Chicago: University of Chicago Press, I97I. 
Skolnik, Jonathan. "Writing Jewish History between Gutzkow and Goethe: Auerbach's Spinoza and the Birth of Modern Jewish Historical Fiction." Prooftexts I9 (I999): IOI-25.

Slezkine, Yuri. The Jewish Century. Princeton: Princeton University Press, 2004.

Slobin, Mark. "Some Intersections of Jews, Music, and Theater." In From Hester Street to Hollywood: The Jewish-American Stage and Screen, edited by Sarah Blacher Cohen, 29-43. Bloomington: Indiana University Press, I983.

Small, Lauren Cohen. "The Case of Thomas Mann's 'Joseph und seine Brüder': An Essay in German-Jewish Cultural Assimilation.” Ph.D. diss., Johns Hopkins, I986.

Smith, Adam. An Inquiry into the Nature and Causes of the Wealth of Nations, edited by Edward Cannan. Chicago: University of Chicago Press, I977.

Smola, Klavdia. "Postkolonial, hybrid, transkulturell: Moderne Schreibweisen in der zeitgenössischen russisch-jüdischen Literatur." Zeitschrift für Slavische Philologie 69 (2012-I3): I07-50.

Snyder, Timothy. Bloodlands: Europe between Hitler and Stalin. London: Bodley Head, 201 I.

Sombart, Werner. The Jews and Modern Capitalism, translated by Mortimer Epstein. New York: Dutton, I9I3.

Sorkin, David. "The Mendelssohn Myth and Its Method." New German Critique 77 (I999): 7-28.

Sorkin, David. Moses Mendelssohn and the Religious Enlightenment. Berkeley: University of California Press, I996.

Soyer, François. The Persecution of the Jews and Muslims of Portugal: King Manuel I and the End of Religious Tolerance (I496-7). Leiden: Brill, 2007.

Spencer, Philip. "Marxism, Cosmopolitanism and 'the' Jews." Jews on the Move: Particularist Universality in Modern Cosmopolitanist Thought, special double issue of the European Review of History, ed. Cathy S. Gelbin and Sander L. Gilman. Vol. 23 Numbers 5-6 2016, 828-46.

Spengler, Oswald. The Decline of the West, translated by Charles Francis Atkinson. 2 vols. London: Allen and Unwin, I932.

Sperber, Jonathan. Karl Marx: A Nineteenth-Century Life. New York: Liveright, 2014.

Sperber, Manès. Like a Tear in the Ocean, translated by Constantine Fitzgibbon. 3 vols. New York: Holmes and Meyer, 1988.

Sperber, Manès. Zur Analyse der Tyrannis. Graz: Leykam, 2006.

Stanislawski, Michael. Zionism and the Fin de Siècle: Cosmopolitanism and Nationalism from Nordau to Jabotinsky. Berkeley: University of California Press, 200 I.

Steiner, George. Martin Heidegger. Chicago: University of Chicago Press, I99I.

Steiner, Rudolf. Blut ist ein ganz besonderer Saft: Eine esoterische Betrachtung. Berlin: Theosophische Gesellschaft, I907.

Steinman, Lionel B. "Stefan Zweig: The Legacy of World War I and the Tasks of Exile." In Stefan Zweig und die Suche nach dem Weltfrieden, edited by Mark H. Gelber and Klaus Zelewitz, 73-87. Riverside, CA: Ariadne, I995.

Steinschneider, Moritz. "Ueber die Volkslitteratur der Juden." In Archiv für Litteraturgeschichte, edited by Richard Gosche. I-2 I. Leipzig: Teubner, I872. 
Steinwachs, Frank. Rudolf Steiner, der Gral, und der völkische Nationalismus. Berlin: Berliner Wissenschafts-Verlag, 20 I4.

Sternhell, Zeev. The Founding Myths of Israel: Nationalism, Socialism, and the Making of the Jewish State, translated by David Maisel. Princeton: Princeton University Press, I998.

Stiftung Hamburger Institut für Sozialforschung. Verbrechen der Wehrmacht: Dimensionen des Vernichtungskrieges, I94I-I944. Hamburg: Hamburger Edition, 200 I.

Strich, Fritz. Goethe and World Literature. London: Routledge, I949.

Sznaider, Natan. Gedächtnisraum Europa. Bielefeld: Transcript, 2008.

Sznaider, Natan. Jewish Memory and the Cosmopolitan Order. Cambridge: Polity, 201 I.

Szuberla, Guy. "Zangwill's The Melting Pot Plays Chicago." MELUS 20 (I995): 3-20.

Tannenbaum, Frank. Slave and Citizen: The Classic Comparative Study of Race Relations in the Americas. I946. Boston: Beacon, I992.

Tauber, Alfred I. "Freud's Dream of Reason: The Kantian Structure of Psychoanalysis." History of the Human Sciences 22 (2009): I-29.

Taugis, Michaël. "There and Back: Cross-Cultural Journeys and Interweavings in Gary Shteyngart's 'The Russian Debutante's Handbook."' In Hybridity: Forms and Figures in Literature and the Visual Arts, edited by Vanessa Guignery, Catherine PessoMiquel, and François Specq, I90-200. Newcastle upon Tyne: Cambridge Scholars, 2OII.

Tawney, Richard Henry. Religion and the Rise of Capitalism: Holland Memorial Lectures, I922. London: Murray, I926.

Taylor, Charles. A Secular Age. Cambridge: Belknap Press of Harvard University Press, 2007.

Tengler, Heinz Frieder. "The Historical Novel in German Exile Literature ( I 933-I945): Central Characters as Counter-Figures and Analogues to Fascist (and Other) Dictators.” Ph.D., University of California, San Diego, I982.

Tentzel, W. E. Monatliche Unterredungen Einiger Guten Freunde von Allerhand Büchern und andern annehmlichen Geschichten: allen Liebhabern Der Curiositäten Zur Ergetzligkeit und Nachsinnen heraus gegeben I ( I689): 833.

"Territorialism and Zionism." The Menorah (Jewish Chautauqua Society) 38-39 (I905): 204-I7.

“Theresa May’s Conference Speech in Full,” Financial Times. 5 October 2016. https:// www.ft.com/content/ffb25e84-8af2-11e6-8aa5-f79f5696c731

Thielking, Sigrid. Weltbürgertum: Kosmopolitische Ideen in Literatur und politischer Publizistik seit dem achtzehnten Jahrhundert. Munich: Fink, 2000.

Tibi, Bassam. Europa ohne Identität?: Leitkultur oder Wertebeliebigkeit. Munich: Siedler, 2004.

Timms, Edward. "Musil's Vienna and Kafka's Prague: The Quest for a Spiritual City." In Urban Experience in Modern European Literature and Art, edited by Edward Timms and David Kelley, 247-63. New York: St. Martin's, I985.

Tolz, Vera. Russia's Own Orient: The Politics of Identity and Oriental Studies in the Late Imperial and Early Soviet Periods. Oxford: Oxford University Press, 20 II.

Trachtenberg, Zev. “Good Neighbors Make Good Fences: Frost's 'Mending Wall.”' Philosophy and Literature 2 I (I997): I I4-22. 
Trawny, Peter. Heidegger und der Mythos der jüdischen Weltverschwörung. Frankfurt am Main: Klostermann, 20 I4.

"Tschechische Juden.” Der Bauernbündler, I November I9 I 8, 3-4.

Twark, Jill E., ed. Strategies of Humor in Post-Unification German Literature, Film, and Other Media. Newcastle upon Tyne: Cambridge Scholars, 20I3.

Veer, Peter van der. Imperial Encounters: Religion, Nation, and Empire. Princeton: Princeton University Press, 200I.

Verein Jüdischer Hochschüler Bar Kochba. Vom Judentum: Ein Sammelbuch. Leipzig: Wolff, I9I3.

Vieten, Ulrike M. Gender and Cosmopolitanism in Europe: A Feminist Perspective. Farnham: Ashgate, 2012.

Vital, David. A People Apart: The Jews in Europe, I789-1939. New York: Oxford University Press, I999.

Vital, David. "Zangwill and Modern Jewish Nationalism." Modern Judaism 4 (I984): 243-53.

Volkov, Shulamith. "The Dynamics of Dissimilation: Ostjuden and German Jews." In The Jewish Response to German Culture: From the Enlightenment to the Second World War, edited by Jehuda Reinharz and Walter Schatzberg, I95-2 I I. Hanover, NH: University Press of New England, I985.

Volkov, Shulamith. Walther Rathenau, Weimar's Fallen Statesman. New Haven: Yale University Press, 2012.

Wagenseil, Johann Christof. Benachrichtigung wegen einiger die gemeine Jüdischheit betreffenden wichtigen Sachen. Leipzig: Johann Heinichen Witwe, I705.

Wagner, Benno. “'Lightning No Longer Flashes': Kafka's Chinese Voice and the Thunder of the Great War." In Franz Kafka: Narration, Rhetoric, and Reading, edited by Jakob Lothe, Beatrice Sandberg, and Ronald Speirs, 58-80. Columbus: Ohio State University Press, 20 I I.

Wagner, Richard. "Judaism in Music." Translated by William Ashton Ellis. In Richard Wagner's Prose Works, 79-I00. London: Kegan Paul Trench, Trubner, I894.

Wahrmund, Adolf. Das Gesetz des Nomadentums und die heutige Judenherrschaft. Karlsruhe: Reuther, I887.

Walker, Steven F. "Nabokov's Lolita and Goethe's Faust: The Ghost in the Novel." Comparative Literature Studies 46 (2009): 5I 2-35.

Wallas, Armin A. "Mythen der Übernationalität und revolutionäre Gegenmodelle: Österreich-Konzeptionen jüdischer Schriftsteller zwischen Monarchie und Exile: Mythen der Übernationalität: Stefan Zweig und Joseph Roth.” In ÖsterreichKonzeptionen und jüdisches Selbstverständnis, edited by Hanni Mittelmann and Armin A. Wallas, I7 I-93. Tübingen: Niemeyer, 200I.

Wanner, Adrian. Out of Russia: Fictions of a New Trilingual Diaspora. Evanston, IL: Northwestern University Press, 20 I I.

Wanner, Adrian. "Wladimir Kaminer: A Russian Picaro Conquers Germany." Russian Review 64 (2005): 590-604.

Wassermann, Jacob. My Life as German and Jew. London: Allen and Unwin, I933.

Wassermann, Jakob. Der Literat oder Mythos und Persönlichkeit. Leipzig: Insel, I909. Weber, Max. Ancient Judaism, translated by Hans H. Gerth and Don Albert Martindale. New York: Free Press, I967. 
Weber, Max. Essays in Sociology. New York: Oxford University Press, I946.

Weigall, Arthur. The Life and Times of Akhnaton, Pharaoh of Egypt. Edinburgh: Blackwood, I9I0.

Weigel, Hans. "Das Kaffeehaus als Wille und Vorstellung." In Das Wiener Kaffeehaus, edited by Christian Brandstätter and Werner J. Schweiger. Vienna: Molden, I978.

Weingrod, Alex, and André Levy. "Paradoxes of Homecoming: The Jews and their Diasporas." Anthropological Quarterly 79 (2006): 69I-7I6.

Weininger, Otto. Sex and Character. London: Heinemann, I906.

Weiss, Peter. The Aesthetics of Resistance, translated by Joachim Neugroschel. Durham, NC: Duke University Press, 2005.

Weiss, Peter. Die Ästhetik des Widerstandes. 3 vols. Frankfurt am Main: Suhrkamp.

Wieland, C. M. Private History of Peregrinus Proteus the Philosopher. London: Johnson, 1796.

Williams, John. "Emigrate? And Give Up the Odessa Apartment?" New York Times, 6 August 20 I4, C7.

Williams, Raymond. Keywords: A Vocabulary of Culture and Society. New York: Oxford University Press, I985.

Wilson, E. O. Consilience: The Unity of Knowledge. New York: Knopf, I998.

Wilson, Woodrow. "The Second Inaugural Address, March 5, I9I7," In The Papers of Woodrow Wilson: January 24-April 6, I9I7, edited by Arthur S. Link, 4I: 332-36. Princeton: Princeton University Press, 1983).

Winkler, Heinrich August. "Nationalismus, Nationalstaat, und nationale Frage in Deutschland seit I945." In Nationalismus-Nationalitäten-Supranationalität, edited by Heinrich August Winkler and Helmut Kaelble, I 2-24. Stuttgart: Klett/Cotta, I993.

Wirtz, Michaela. Patriotismus und Weltbürgertum: Eine begriffsgeschichtliche Studie zur deutsch-jüdischen Literatur, I750-I850. Tübingen: Niemeyer, 2006.

Wisse, Ruth. Jews and Power. New York: Schocken, 2007.

Wistrich, Robert S. "Stefan Zweig and the 'World of Yesterday." In Stefan Zweig Reconsidered: New Perspectives on His Literary and Biographical Writings, edited by Mark H. Gelber, 59-77. Tübingen: Niemeyer, 2007.

Wolfe, Alan. At Home in Exile: Why Diaspora Is Good for the Jews. Boston: Beacon, 2014.

Wolin, Richard. "Modernity: The Peregrinations of a Contested Historiographical Concept." American Historical Review I I6 (20 I I): 74 I-5I.

World Service Authority. "What Is the World Government of World Citizens?" http:// www.worldservice.org/gov.html

Yamamuro, Nobutaka. "Ironie und Demokratie: Thomas Manns Ironie im Kontext der zeitgenössischen Ideengeschichte." Hitotsubashi Journal of Arts and Sciences 49 (2008): I I-24.

Yelenevskaya, Maria. "A Cultural Diaspora in the Making: Former Soviets in Israel and in Germany." Jews and Slavs I 5 (2005): 265-79.

Young, Robert J. C. Colonial Desire: Hybridity in Theory, Culture, and Race. London: Routledge, I995.

Zalewski, Daniel. "From Russia with Tsoris." New York Times Magazine, 2 June 2002, 54-57. 
Zadoff, Miriam. Der rote Hiob: Das Leben des Werner Scholem. Munich: Carl Hanser, 2004.

Zangwill, Israel. Works. I4 vols. London: Globe, I925.

Zangwill, Israel. "Zionism and Territorialism.” Living Age, i I June I9Io, 663-67.

Zilcosky, John. Kafka's Travels: Exoticism, Colonialism, and the Traffic of Writing. New York: Palgrave Macmillan, 2004.

Zohn, Harry. "Stefan Zweig, the European, and the Jew." Leo Baeck Institute Yearbook 27 (I982): 323-36.

Zunz, Leopold. Zur Geschichte und Literatur. Berlin: Veit, I845.

Zweig, Friderike. Spiegelungen des Lebens. Frankfurt am Main: Fischer, 1985.

Zweig, Stefan. "Bei den Sorglosen.” [1918] In Die schlaflose Welt: Aufsätze und Vorträge aus den Jahren I909-I94I, ed., Knut Beck. I04-II. Frankfurt am Main: Suhrkamp, I983.

Zweig, Stefan. Beware of Pity, translated by Phyllis Blewitt and Trevor Blewitt. London: Pushkin, 2003.

Zweig, Stefan. Brasilien: Ein Land der Zukunft. Berlin: Insel, 20 I3.

Zweig, Stefan. Brazil: Land of the Future, translated by Andrew St. James. London: Lowe and Brydone, I942.

Zweig, Stefan. Briefe, I897-I9I4. Frankfurt am Main: Fischer, I 995.

Zweig, Stefan. Briefe, I9I4-I9I9. Frankfurt am Main: Fischer, I 998.

Zweig, Stefan. Buchmendel: Erzählungen. Frankfurt am Main: Fischer, I 994.

Zweig, Stefan. "The Buried Candelabrum." Translated by Eden Paul and Cedar Paul. In Jewish Legends, 3-I4I. New York: Wiener, I987.

Zweig, Stefan. Burning Secret. London: Pushkin, 2008.

Zweig, Stefan. Confusion: The Private Papers of Privy Councillor R. von D. London: Pushkin, 2002.

Zweig, Stefan. Conqueror of the Seas: The Story of Magellan. New York: Literary Guild of America, I938.

Zweig, Stefan. Erasmus: The Right to Heresy, translated by Eden Paul and Cedar Paul. London: Souvenir, I979.

Zweig, Stefan. "Der europäische Gedanke in seiner Entwicklung." In Die schlaflose Welt, I85-2 I0. Frankfurt am Main: Fischer, I990.

Zweig, Stefan. "Heimfahrt nach Österreich.” In Die schlaflose Welt, 25-29. Frankfurt am Main: Fischer, I990.

Zweig, Stefan. “Das Herz Europas.” In Die schlaflose Welt, 74-89. Frankfurt am Main: Fischer, I990.

Zweig, Stefan. "Im Schnee." In Buchmendel, 96-I Io. Frankfurt am Main: Fischer, I994.

Zweig, Stefan. "Internationalismus oder Kosmopolitismus" (Internationalism or Cosmopolitanism). In Zweig, Stefan. Zeit und Welt. 72-77. Frankfurt am Main: Fischer, I982.

Zweig, Stefan. "Das Land ohne Patriotismus.” In Die schlaflose Welt, 7-I6. Frankfurt am Main: Fischer, I990.

Zweig, Stefan. "The Old-Book Peddler: A Viennese Tale for Bibliophiles." In The OldBook Peddler and Other Tales for Bibliophiles, I9-73. Evanston, IL: Charles Deering Library, Northwestern University, 1937. 
Zweig, Stefan. "Opportunismus, der Weltfeind.” In Die schlaflose Welt, I32-35. Frankfurt am Main: Fischer, I990.

Zweig, Stefan. The Post Office Girl, translated by Joel Rotenberg. London: Sort of Books, 2009.

Zweig, Stefan. Die schlaflose Welt: Aufsätze und Vorträge aus den Jahren I909-I94I. Frankfurt am Main: Fischer, I990.

Zweig, Stefan. The Tide of Fortune. London: Cassell, 1942.

Zweig, Stefan. Triumph und Tragik des Erasmus von Rotterdam. Frankfurt am Main: Fischer, 2009.

Zweig, Stefan. "Der Turm zu Babel.” In Die schlaflose Welt, 68-73. Frankfurt am Main: Fischer, I990.

Zweig, Stefan. "Vom ‘österreichischen’ Dichter.” In Die schlaflose Welt, 48-5 I. Frankfurt am Main: Fischer, I990.

Zweig, Stefan. "Walther Rathenaus Persönlichkeit: Zum Jahrestag seiner Ermordung, 24. Juni I922." Beilage zum Berliner Börsen-Courier, 24 June I 923.

Zweig, Stefan. "Die Wanderung." In Buchmendel, 7-I4. Frankfurt am Main: Fischer, I994.

Zweig, Stefan. The World of Yesterday. London: Cassell, I944.

Zweig, Stefan. "Ein Wort von Deutschland." In Die schlaflose Welt, 30-33. Frankfurt am Main: Fischer, I990.

Zweig, Stefan. "Die Wunder des Lebens.” In Buchmendel, I5-95. Frankfurt am Main: Fischer, I994.

Zweig, Stefan. "Zutrauen zur Zukunft.” In Die schlaflose Welt, I66-74. Frankfurt am Main: Fischer, I990. 


\section{Index}

Abbt, Thomas, 32

Abraham, 23-24, 25, 26

Absurdistan (Shteyngart), 247, 248

Adenauer, Konrad, 226

Adler, Alfred, I97, 207

Adorno, Theodor, I9, 55, 216

Aesthetics of Resistance, The (Weiss), 2 I6I 9, 222, 284n65

Against the Jews (Grattenauer), 4I

Ahad Ha'am, 86, 99, I I6

Ahasverus (Cartaphilus), 20

Akhtiorskaya, Yelena, 25I-53

Alcalay, Ammiel, 5

Aldea, Eva, 226

Alexandria (Egypt), I40, I42

Also a History of Mankind (Herder), 37

Altenberg, Peter, I73

Amazonas trilogy (Döblin), I75-76

Améry, Jean, I70, I93-94

Amundsen, Roald, I22

Ancient Judaism (Weber), 25

Andersch, Alfred, I9

Anderson, Benedict, 7, I6, 30

Anderson, Wes, 83-84

Andorra (Frisch), I9

Anthropology (Kant), 39-40

Antichrist, The (Nietzsche), 23

antifascism, I48, I90, 203, 2I 4, 2I 5, 2I6-I 7

antisemitism: Arendt on, I93; attacks on

Jewish institutions of $2 \mathrm{I05}, 260$; in

Austro-Hungarian Empire, I73; Berlin

debate of I 878, IoI; communist condemnation of, I 89; on Czech Jews, 92; Eastern European Jews seen as cause of German, 226; Freud on, I6o, I6I; of German Protestants, I6I; of German romantics, I09; Heidegger and, I63; Herzl on, 77; of
Hitler, I I 9; Jewish cosmopolitanism seen as doomed to fail under conditions of, I38; Jewish economic success in, I87; on Jewish intellect, I23, 204; on Jewish nomadism, 68, 259; on Jews and capital, I, I04; Jews see communism as antidote for, I 88, I99; in Jud Süss film, 34-35, I 38, I 58 ; in Kaminer's works, 229, 230; leftist-liberal Jews writers rewrite antisemitic image of Asiatic Jew, I20; of Lueger, 73; of Luther, I67; Mann and, I49, I58, I6 I; National Socialist, I44; Nordau on, 79; pogroms, 77, 96; political, I00, 259; postwar rise in, 78, II 3, I20, I42, I89; in Prague and Vienna compared, 9I; racial, 4I, I63, 259, 275n3I; in Rathenau assassination, I38; Rembrandt and, I05; resurgent local prejudice, I4; Roth and, I34, I35; in Soviet Union, I9o, I9I-92, 229, 230; of Stalin, I92; in United States, I49; in Vienna, 9I, I74; Zweig and, 90, I 68

Appiah, Kwame Anthony, I2-I 5, I8, 29, IO3

Apprenticeship of Duddy Kravitz, The (Richler), 247

Arendt, Hannah: on antisemitism, 77; on exiled German Jews, 226; on Hitlerism and Stalinism, I92, I93, I96; The Jew as Pariah, 200; on Jews as perpetual outsiders, 200; on Kafka's cosmopolitanism, 93; Origins of Totalitarianism, I92, I93, I96, 209-IO; on right to have rights, I2; on Soviet Union as laboratory for totalitarianism, 2 I0; Sperber influenced by, 2 Io, $283 n 57$

"Arrival in the Hotel" (Roth), I3I-32 
Aryans: as agricultural, I07; cosmopolitanism seen as foreign to, I7; Goldziher contrasts Jews with, 24; Greeks as, 27; Hitler on Jewish conspiracy against, I92; Jung contrasts Jews with, 28; National Socialist depiction of, I68; as rooted, I65; Schmitt on their repugnance for Semites, 68

Asad, Talal, 7-8

assimilation: becomes dominant paradigm, 68; of Eastern European Jews, I35; in Feuchtwanger's Der jüdische Krieg, I39; in Freytag's Debit and Credit, 67; Gorelik on, 242; Herder on Jewish emancipation and, 37; of Jewish authors who became communists, I99, 204; Jews as ideal example of social, 24I; Jews assimilated to different nations, 65; Jews embrace, 69; Mann on, I47; National Socialism and, I44; Nordau on Zionism and, 78; Rathenau on, I06, I07; as response to social exclusion, 93; rooted cosmopolitanism compared with, I I5; in Roth's Radetzky March, I36; Wassermann on cosmopolitanism and, I09; Zionism questions, 99IOO; Zweig and, 84, I I6, I 2 I, I 24

asylum seekers, I-2, 3, 30

At the Mind's Limits (Améry), I93-94

Auerbach, Bertold, 50-5I

Aufnordung (Nordification), I8 I

August II of Saxony, 45

Auschwitz: Technique and Operation of the Gas Chambers (Pressac), I96

Aus Dodos Kindheit (Mann-Bruhns), I75

Austria: cosmopolitanism in, 70, 84; dual monarchy creates conflicting allegiances in, 85; Freud's relationship with, I6I; German speakers in, 234; Jews in, 72, 83, I73; Kaminer contrasts Germany and, 234; nationalism in, 85; Russian Jews emigrate to, 223; unification with National Socialist Germany, I70, I73; Zionism arises in, I35; Zweig's cosmopolitanism and "old," I20. See also Vienna

Austro-Hungarian Empire: conflicting alliances in, 85; cosmopolitanism of, I 7 I-72, I73-74; Franz Joseph I, 7 I, 85, 9I-92, IOO, I35; hotels and coffeehouses in, I I7, I 20; humanism of, I36, I73; on Jewish nomadism, 259; Jews of, 7I-72; language wars in, 72; as miniature Europe, I 28 ; mo- bility in, 7I, 77; nostalgic image of, I73; Roth on, I20, I27, I28-29, I34-35, I7073; successor states to, I I I; supranational character of, 70, 72, 77, 85, 9I, I09, I28; Treitschke on, IOI; Zionism in, 73, I08, I35, I73; in Zweig's The World of Yesterday, 84, 88, I20, I24-25, I70, I73-74, 280n84. See also Vienna

Auto-Emancipation (Pinsker), 2 I

Babel und Bibel (Delitzsch), 66

Bahr, Hermann, I73

bankers, 25, 35, I99, 256

Baron, Ilan Zvi, 78

Barrow, George, I 57

Barth, Karl, I47

Barthels, Adolf, 67

Bauer, Bruno, 58, 59, 60, 6I, I88, 282n5

Baum, Vicki, I 17

Bauman, Zygmunt, I 5, I96

Baumböck, Karl, I64

Becher, Johannes R., 22 I

Beck, Ulrich, 4, 257

Becker, Jurek, 239

Bedouins, 2 I, 24, 26, 4I

Beer-Hofmann, Richard, I73

"Bei den Sorglosen" ("Visiting the Careless") (Zweig), I3 I

Being and Time (Sein und Zeit) (Heidegger), I 62

Belinsky, Vissarion, I90

Benhabib, Seyla, I93, 258

Benjamin, Walter, 93, 99, I07, I42, I45-46

Benn, Gottfried, I65

Berens-Totenohl, Josefa, 67

Bergengruen, Werner, I67-68

Berkowitz, Michael, I08, I87

Berlin, IOO-I I2; antisemitism debate of I878, IO I; as center of German-speaking world, 69, I I I ; centripetal cosmopolitanism of, 70; as city of tourists, 236; cosmopolitanism in, 70, $\mathrm{IO}_{3}, 230$; in defining Germany, 256; the Holocaust as preoccupation in, 236; Jewish Center in, 238; in Kaminer's Ich bin kein Berliner, 233-34; klezmer as obsession in, 233; multiculturalism in, 232, 236; Rome compared with, I39-40; Viennese-style coffeehouse in, I 25

Berlin, Isaiah, 37 
Bernstein, Eduard, I 47

Betrachtungen eines Unpolitischen (Observations of a Non-Political Man) (Mann), I I4, I46

Beware of Pity (Zweig), 83-84

Beyond Good and Evil (Nietzsche), 23

biopower, 257, 258

Bismarck, Otto von, 22, 6I, IOO, IO I, $269 n 90$

Black Notebooks (Heidegger), I62

Bloch, Ernst, 2 I 2

Bloch, Joseph Samuel, 9I

Bloodlands (Snyder), I95

"Blood of the Walsung" (Mann), I I I, I 58

Bloom, William, 28-29

Blue Tiger, The (Döblin), 176

Bolshevism, I64, I87, I90

Bonnet, Charles, 36

Bowman, Steven, 263n I 7

Braidotti, Rosi, I9, 255

Brauch, Julia, 236

Brazil (Zweig), 86, I24, I74-82

"Bridge and Door" (Simmel), I55

British Gypsy Lore Society, I57

Brod, Max, 27, 9I , 99, 266n85

Brodsky, Joseph, 252

Bruhns, Júlia da Silva, I75, I8o

Bryce, James, 176

Buber, Martin: cultural Zionism and, 86; The Jew (Der Jude) periodical, 27, I I I on Palestine as authentic location of Jewish culture, 87; Roth influenced by, I I6; in Vom Judentum volume, 98, I09, I I I; Zweig on, 89

"Buchmendel" ("The Old-Book Peddler") (Zweig), I23-27, I68

Budapest: becomes economic center, 73; as center of German-speaking world, 69; as peripheral, 70

Buddenbrooks (Mann), I45, I75

Bukharin, Nikolai, 2I 7, 2 I8

"Buried Candelabrum, The" (Zweig), I70

Burning Secret (Zweig), 84

cafés (coffeehouses), I I7, I20, I25, I29, I36, I7I, I 72

Cahan, Abraham, 247

Calvin, John, 25

cannibalism, I78-79

capital: cosmopolitanism associated with, 23, 60-6I, I07; Enlightenment on capitalism,
258; as form of biopower, 257; global, 3 , 4; Jews associated with, I, I5, I 8, 2I, 2426, 30, 36, 39-40, 6I, 62, 76-77, I04, I48, I63-64, 228, 258, 259, 260; knows no boundaries, I07; Marxism on antisemitism and capitalism, I 88; mobility of, I04; rootlessness of, I64; Rothschilds as avatars of capitalism, 5I; ruthlessness of international capitalism, I30; Simmel on capitalism and nomadism, I 55; social mobility and, I05; Weber on capitalism, I 55

Central Jewish Organization (Germany), 239

Centralverein deutscher Staatsbürger jüdischen Glaubens (Central Association of German Citizens of Jewish Faith), I I6, I 87

Chamberlain, Houston Stewart, 25-26, 27, I8I

Chekhov, Anton, 235

Child of the Revolution (Leonhard), 2 I 6

Christianity: Catholic Church's concordat with National Socialism, I6I; cosmopolitanism of, 23, I6I, I85; Feuchtwanger on pacifism of, I 84; fulfillment narratives in, I50; Jesuits, I76, I78, I79, I8 I-82; Jewish literature aligned with, 63; in Mann's Joseph and His Brothers, I54; Marx on, 6I; native Brazilians convert to, I79; rational, 43, 49; Reformation, I67; seen as universal mouthpiece of Jewish teachings, 62; Tolstoy's primitive, I37; universalism of, 65, I6I, I84-85; Zweig on, 89-90

Christianity in Europe (Novalis), 42 circumcision, I58, I60, 229 class, I03, I32, I33, I 95

Claussen, Detlev, I94

Clifford, James, 254

coffeehouses (cafés), I17, I20, I25, I29, I36, I7I, I72

Collin (Heym), 2 I9-22

colonialism: cosmopolitanism and, I74, I76; mass violence of, I95; in Raabe's Stopfkuchen, IOI-2; in Zweig's Brazil, I76, I 78 , I $80-8 \mathrm{I}$

Comintern (Communist International; Third International), I89, I90, 205, 2 I 8 communism: antisemitism condemned by, I89; Bolshevism, I64, I87, I90; communist internationalism, I89-90, 2I4, 2I 7I 8; cosmopolitanism and, I 88-92; 
communism (continued)

German Communist Party, I9I, 208, 282ni6, 283n56; Jews attracted to, I87, I88; in Koestler's Darkness at Noon, 2037; McCarthy's persecution of communists, 2 I9; "mustard sandwich," 236; RühleGerstel's association with Czech, I97-98; in Rühle-Gerstel's Der Umbruch (The Break), I98-203; sexual politics of, 2023; in Sperber's Like a Tear in the Ocean, 207-I3; as universalist, I89

Communist International (Comintern; Third International), I89, I90, 205, 2 I 8

Concept of the Political, The (Schmitt), 67, I 56

Concerning the Amelioration of the Civil Status of the Jews (Dohm), 36, 4I

Confusion (Zweig), 84

Conjectural Beginning of Human History (Kant), 2 I

Conrad, Joseph, IOI-2, 252

Contribution to Correcting Judgments about the French Revolution, A (Fichte), 37

cosmopolitanism: American, 245; of ancient Egypt, I49, I50-5I; ancient Greek concept of, 9, I I, 29; ancient Judaism seen as forerunner of, 40; anti-Jewish uses of, 3; of Austro-Hungarian Empire, I7I-72, I73-74; in Berlin, 70, I03, 230; bourgeois, I66, 203; bourgeois nationalism and, I8990; capital associated with, 23, 60-6I, I07; center-periphery dichotomy and, 70$7 \mathrm{I}$; as challenge and goal in twenty-first century, 256; Christian, 23, I6I, I85; civic, 39; colonialism and, I74, I76; communism and, I88-92; composite, I37; cosmopolitan nationalism, 96; cultural, I48, I66, 225, 228; debates over, I, 3, 9-I2; as defense against nationalism, 4 ; as defining feature of era of reflexive modernity, 4; Derrida on, 255; diversity and, 3, I I; economic, 57, 58, 8I, I48; European, 54, 6I, I37, 269n9o; in European etymologies, Io; German, 42, IOO, IO I, I I I, I I 5, I44, I 5 I, I 58, 223-26, 229, 234, 242; global, 48, 256, 257-58; in Goldziher's portrayal of Abraham, 23-24; historical constitution of term, 9; Hitler on, I I 9; Holocaust and notion of, Io; Humboldt's, I02; hybrid, 232 ; intellectual, I I4, I84; internal, 6r; in- troducing the problem of, I-9; of Jesuits, I 76; the Jew in theories of, 5, I I, I 2-I 7; Jews associated with, 8-9, I4-I5; Kant and, I I-I 2, 38-39, 40, 98, 99, I I4, I I6, I39, I47, 264n3 I Lewis on, 78-79; liberal, I86; location defines modern, 243; of Mann, I I4-I 5, I46-47; mobility as sign of, 34-35, I I 7; multiculturalism and, 3, 9, 26I; music as cosmopolitan language, 233; of Nabokov, 249; national, 28, I I4, I I 5, I 28, 259; nation-state seen as undermined by, 3, 26I; new, 4, I5-I6, I8, 30, 5I, 76, 95, I48, 225, 237, 259, 260; nomadic, I I3-I4, I I6, I I7, 256; nomadism as sister concept to, I; Nordau on degeneration and, 78; One World Movement, 260; patriotism and, I I, 74, 97, I I6; poetic, 48; political, 36 , I66; as potential for movement, 260-6I; Raabe on colonialism and, IOI-2; range of cosmopolitanisms, IO; regional, I7; rehabilitation of concept of, I I; in Roman Empire, I39; romantic, 42, 98; rooted, 7, I4, 6I, 66, 98, I07, I I4, I I 5, 232, 259; rootedness versus, 68, 255-56, 259; rootless, 2, 9, I0, 76, 77, I I5, I909I, I92, 203, 208; roots in the nation-state, 42; Soviet concern about, I88, I 89-90; Spengler on, I I7-I 8; spiritual, I09; as state-sanctioned (or -denied) identity, 257; supranationalism linked with, I27-28; tension with nationalism, I07, I47, I83, I85, 260; for thinking about globalization, I-2; of Turgenev, 235; twenty-first-century, 257-58; two periods of concerted, 256-59; universal, I4, 38, 4I-42, 43, 233; universalism of, IO, I I, I2, I3, I6, 38, 40-4I, I I4, I 24; as urban, 256; in Vienna, 70, 84, I73; of Wilson, I I 5; of World War I, IOOIO I; Zweig and, I65-70, I75-76, I79-8I, I86. See also Enlightenment cosmopolitanism; Jewish cosmopolitanism

Cosmopolitanism and the National State

(Meinecke), I02, I47

Coughlin, Father Charles, I49

Country Doctor, The (Kafka), 94-95

Courtemanche, Eleanor, 57

Court Jews (Hoffaktoren), 35, 6o, 256

crimes against humanity, I I, I93

"Critique of Hegel's Philosophy of Law"

(Marx), 57 
Critique of the Times (Rathenau), I07

"Cultural Identity and Diaspora" (Hall), I I

Curthoys, Ned, 267n4I

"Customs Official in E. and the Traveling Jew, The" (Kuh), 44-45

Dagnino, Arianna, 225

Darkness at Noon (Koestler), I97, 203-7

David (King of Israel and Judah), I 54

Davies, W. D., 5

Davis, Garry, 260, 26I

death camps, I96, 207, 24I

Death in Venice (Mann), 84, I46

"Death Mills" (Wilder), I96

Debit and Credit (Soll und Haben) (Freytag), 67

"Decisive Hour at Waterloo, The" ("Die Weltminute von Waterloo") (Zweig), I22

Decline of the West (Spengler), I I7-I 8

Dee, John, Io

Degeneration (Nordau), 78

Deleuze, Gilles, I7-I8, I9

Delitzsch, Friedrich, 66

"De Profundis" (Rathenau), I07

Derrida, Jacques, 255, 256

Deutsche Dichtung (journal), 87

"deutsche Gasthof, das kosmopolitische Hotel, und die Engländer, Der" (The German Inn, the Cosmopolitan Hotel, and the English") (Fontane), I30-3 I

Deutschland schafft sich ab (Sarrazin), 24I

"Development of European Idea, The" (Zweig), I39, I43

Dewey Commission (Officially, the Commission of Inquiry into the Charges Made against Leon Trotsky in the Moscow Trials), 198

diabetes, $8 \mathrm{I}$

diaspora: Christian, 63; cosmopolitanism as the new, 2; cosmopolitanism contrasted with, 3, 9; cultural Zionism and, 87, 9I; diversity and, 3 ; ghetto mentality of, 88 ; globalized cities as diasporic, 4; Hall on Jews on, I I, 264n3o; Holocaust and notion of, IO; of Israelis, I I, 257; Israel on, IOI I; in Jewish cosmopolitanism, 22; literal meaning of, 4; Otherness and, 9, I I; questioning of, 3; shilat ha' golah, 6; Zweig on, 89. See also Jewish diaspora

Dickstein, Morris, 243
Dinter, Artur, 28 In94

Diogenes of Sinope (the Cynic), 9

displaced persons, I, 239, 240, 254

dissimilation, I36

Dithmarchers, The (Barthels), 67

diversity, 3, I I

Döblin, Alfred, I75-76

Dr. Cohen (Nordau), 28In95

Dr. Faustus (Mann), I70

Dohm, Christian Wilhelm von, 36, 4I, 49

Doll's House, A (Ibsen), 203

double consciousness, $\mathrm{IO}_{3}$

Dreyfus Affair, 73, 77, I65

Drowned and the Saved, The (Levi), 205-6

Du Bois, W. E. B., I03-4, I05

Dühring, Eugen, 24

Eastern European Jews: assimilated, I35; Buber on, 98; cultural Zionism on, 87; Freud on, 79, 8I-82; in Germany, 226; Gorelik on, 242; immigration to Berlin, I40; League of Nationalist German Jews on, I I4; Mann on, I47, I 53; in New York City, 243; on the Paris hotel, I29; Rosenzweig's encounter with, IOI; Roth on, I27, I32-33; universal lessons drawn from diaspora by, 6; world of, 82, 229; on Zionism, 89; in Zweig's works, 83, I23, I24, I25. See also Russian Jews

Ehrenburg, Ilya, I95

Eisen, Arnold, 224-25

Eisner, Kurt, I I 4

emancipation, Jewish. See Jewish emancipation

Emperor's Tomb, The (Roth), I34, I70-73

Encyclopédie (Diderot), 29-30, 40

Engels, Friedrich, 57

Enlightenment: on assimilation, Ioo; break with religion in, 8; on capitalism, 258; on cosmopolitan Jews, IO, I7, 28, 3I-42, 82; on education of Jews, 246; German, Io, I $3,25,36,38,4 \mathrm{I}, 43,44,46,53$, I08, 257; Haskalah, 40, 43; on Jews, 25-26, 49, 50; on mega-metropolis, $5 \mathrm{I}$; Mendelssohn on, 36; mobility as concern of, 35 ; nationstate and, 7, 30, 258; on nomads, 20-2 I, 26,62 ; as period of concerted cosmopolitanism, 256; universalism of, 6I, 74; unspoken assumptions of, 33-34. See also Enlightenment cosmopolitanism 
Enlightenment cosmopolitanism: classical roots of, 9, 29; Goldstein on cosmopolitanism as Enlightenment writ large, 98; Jewish cosmopolitans in literature and, I I I; Jewish writers write Jews back into, 74; Jews excluded from, 8, I I; Meinecke on transition to German state from, I02; particularist universality of, I7; as rooted, I4, $6 \mathrm{I}$; tension between universalism and localism in, 9-IO, I3, 70, 96

Erasmus, IO

Erasmus (Zweig), I65-70, I74, I82, I86

Eschel, Amir, 254

ethnocentrism, I6

Etzel Andergast (Wassermann), I I I

"europäische Gedanke in seiner Entwicklung, Der" (Zweig), I2 I-22

European Union, I 20

European unity, 42, I I 5, I2 I, I 22, I38, I43

Ewen, David, I 2 I

exclusivity, 68

exile: of Mann, I46, 259; nomadism and, I, I9-20; non-Jewish exiles from National Socialism, I62; Said on, I9-20. See also Jewish exile

Faust (Goethe), I22, 275n3 I

Feiwel, Berthold, 86

Femhof, Der (Berens-Totenohl), 67

Fénelon, François de Salignac de la Mothe, I3, 37

Feuchtwanger, Lion, I37-42; on borderlands, I39; cosmopolitanism of, I I6, I9I, I99; on diaspora Jew as model for future European citizenship, I I6; exile of, I82-83; internment by National Socialists, I 83; interwar writings of, I I 5 ; Jewish sensitivity of, I I3, I I5, I99; on Jews and fringes of Austro-Hungarian Empire, I I 7; Josephus trilogy, I37, I43, I82-86, I9I; Der jüdische Krieg (The Jewish War), I37, I384I; Jud Süss, I37-38; on Rome as homogenizing force, 66; Spengler opposed by, I4I; Der Tag wird kommen, I 85; "Was ist Wahrheit?," I38; Zionist sympathies of, I 6 , I 82, I 83

Feuerbach, Ludwig, 8, 58, 59

Fichte, Johann Gottlieb, 8, 37, 49, 53, 74

Field, Noel, 2 I 4

"Final Solution of the Jewish Problem" ("Die
Lösung der Judenfrage”) (Mann), I47-48, I 52, I $58,278 \mathrm{nI} 5$

Fontane, Theodor, I30-3I

food, 233

Ford, Henry, I49

Förster, Bernard, IO I

Foucault, Michel, 257, 258

Foundations of the Nineteenth Century (Chamberlain), 25-26

Frank, Julius J., 97

Frank, Leo, I 49

Franz Joseph I (emperor), 7I, 85, 9I-92, I I0, I35

Franzos, Karl Emil, 87

Freidank, Eberhard, I7

Freud, Sigmund, 79-83; on difference and conflict, 67-68; exile of, I6I; "Group Psychology and the Analysis of the Ego," 6768, I56; The Interpretation of Dreams, 8o-8I ; on Jewish cosmopolitanism, 8083 ; on the Jewish problem, $82-83$; on Joseph in Egypt, I59-62; Moses and Monotheism, I59; moves from periphery to center of Empire, 72; on sons of firstgeneration of Jewish liberals, 79; as younger son, 279n5 I

Freytag, Gustav, 67

Friedländer, David, 43

Friedrich II (Frederick the Great) (king of Prussia), I3, 35, 36, 43, 46, 264n39

Frisch, Max, 19

Fritsch, Theodor, $269 n 90$

From Antizionism to Antisemitism (Poliakov), I94

Frost, Robert, 255-56, 26I

Future, The (periodical), I05

galut (golah), 5-6, 263nI 7

Geiger, Abraham, 63-64

Gelber, Mark, IOo, I 20, I 2 I, 27 In53, 272n55, 274n2

genocide, I64, I74, I75, I94-95, 222, $283 n 30$

George, Stefan, 98, I44-45, 259

German-French Yearbook (DeutschFranzösische Jahrbücher), 57-58

German Jews: in Auerbach's Poet and Merchant, 50; Buber on, 98; Central Jewish Organization, 239; convergence between German and Jewish culture, 42; Eastern 
European Jews seen as threat to, 226; high culture of, 244; humanistic values of, I 20 ; increasingly become seen as outsiders, 6970; language in defining, 239; nomadic cosmopolitanism constructed by, I I3-I4; in Prague, 9I; Rathenau on, I07; rooted, 50, 72; on Russian Jews, 225; as statesanctioned religious community, 226, 285nI3; Wassermann on, I09; writers and the Stalinist Purges, I97-2 I3

German Museum, The (periodical), 43

German nationalism: cosmopolitanism and, I I, 259; Du Bois on, I04; on economic integration of Jews, 259; Heine on, 53; Kohler on, 22-23; Meinecke on, I02; Raabe on scramble for Africa and, IOI; among Weimar Jews, I I4; Zionism associated with, I09. See also National Socialism

Germany: Bismarck, 22, 6I, IoO, IOI, 269n9o; centers of German-speaking world, 69; convergence between German and Jewish culture, 42; cosmopolitanism in, 42, IOO, IOI, I I I, I I 5, I44, I 5 I, I 58 , 223-26, 229, 234, 242; Enlightenment in, Io, I3, 25, 36, 38, 4I, 43, 44, 46, 53, Io8, 257; Friedrich II (Frederick the Great), I3, 35, 36, 43, 46, 264n39; German Communist Party, I9I, 208, 282ni6, 283n56; German identity, 70, 72, I07; Germans lack nation-state, 62; Germans seen as nomads, I07; Israeli diaspora in, I I, 257; on Jewish nomadism during imperial period, 259; Kulturkampf, Ioo; Mann on German culture, I46-47; migrants in, 24I; multiculturalism in, 229, 24I, 242, 253, 255; Muslims in, 24I; philo-Semitism in, 232; racial science in, I76; reunification of, 229; romanticism in, I09, I 57; rootedness of Germans, I6I, I62, 228; Russian Jews in, 226-42; Schlaffer on German culture, I 53; seen as cosmopolitan nation per se, 42 ; socialist revolutions of I9I8-I9, I I4; Spengler on, I I 8; Zionism in, I08. See also Berlin; German Jews; German nationalism; Weimar

Germany: A Winter's Tale (Heine), 53-57, 58-59

Geschichte der jüdischen Literatur (Karpeles), 64
Geschiere, Peter, 2, 8

Gilbert, Felix, I02

Gildemeister, Otto, 26

Gilroy, Paul, I05

Gitelman, Zvi, 240

globalization: Appiah on bridging local and global, I 2; cosmopolitanism as internal, 4; cosmopolitanism as surrogate for thinking about, I-2; global capital, 3, 4; globalized cities, 3-4; romanticized notion of nomadism in discourse on, I7; universal claim of, I 2

Gobineau, Arthur, Comte de, 28 In Io I

Goebbels, Joseph, 20, I44, I64, I68

Goethe, Johann Wolfgang von: on America, 6o; Faust, I 22, 275n3 I; Heine on, 53; Hermann und Dorothea, 52; on intermarriage, 5I, 6I; on Jews, 52-53, I 20; on modern city, 5I; on murder of Moses, I6I; on the nomad, 20-2 I, I57; Russian high culture influenced by, 244; "Two Important yet Unasked Biblical Questions," 52; universalism of, 5I-52, I20-2 I, I 22; Wilhelm Meister, 20-2 I, 52-53, I 22, I 52; on world literature, 62

Gogol, Nikolay, 224, 225, 238

Goldberg, David J., 6

Goldstein, Moritz, 98-99

Goldziher, Ignaz, 23-24

Goncharov, Ivan, 247

Gordon, Aaron David, 77

Gorelik, Lena, 238-42; Akhtiorskaya compared with, 25I; Meine weißen Nächte, 238, 286n37; Sie können aber gut Deutsch!, 240; Verliebt in St. Petersburg (In Love in St. Petersburg), 242; works of, 286n37

Gosche, Richard, 65

Graf, Oskar Maria, I37

Grand Budapest Hotel, The (Anderson), 8384 , I I 7

Grattenauer, Carl Wilhelm Friedrich, 4I, 42

Great Purges (Soviet Union): Dewey Commission clears victims of, I98; German Jewish writers and, I97-2 I3; Hitler's rise to power and, I92; Jewish culture destroyed by, I90; in Koestler's Darkness at Noon, 203-7; in Sperber's Like a Tear in the Ocean, 208, 2 I2; Zweig's Erasmus and, I66 
Grégoire, Abbé, I3, 30, 37

Grimm, Friedrich Melchior, Baron von, 54

Großtyrann und das Gericht, Der (Bergengruen), I 67-68

"Group Psychology and the Analysis of the Ego" (Freud), 67-68, I56

Gruen, Erich S., 263nI 8

Guattari, Félix, I7-I8, I9

Guenon, René, 65

Gypsies (Sinti and Roma), 3, 9, 20, 4I, 53, I $57-58$

Haas, Willi, I42, I45-46

Habermas, Jürgen, 39

Hacohen, Malachi Haim, I 28

Hall, Stuart, I I, 264n3o

Hamilton, Thomas, 60

Handbook of the Jewish Question (Fritsch), $269 n 90$

Harden, Maximilian, I05

Harlan, Veit, 34-35, I 58

Haskalah (Jewish Enlightenment), 40, 43

"Hear O Israel" (Rathenau), I05

Heart of Darkness (Conrad), IO I-2

"Heart of Europe, The" ("Das Herz Europas") (Zweig), I 26

Hebrew language, 62, 86

Heidegger, Martin, I44, I62-65

"Heimfahrt nach Österreich" (Zweig), 85-86

Heine, Heinrich: Freud compared with, 8I;

Germany: A Winter's Tale, 53-57, 58-59; ironic cosmopolitanism of, 57; as model for European cosmopolitan, 54; "Das neue israelitische Hospital zu Hamburg" (Heine), 54; The Romantic School, 53; Wassermann on, I I I

"Heine's Wound" (Adorno), 55

Helden des Alltages (Kaminer), 230-3 I

Helfer, Martha, 49

Herder, Johann Gottfried von: Also a History of Mankind, 37; Heine on, 53; Ideas for a Philosophy of the History of Mankind, $36-$ $38,6 \mathrm{I}-62$; on Jewish adaptability, 22; on Jewish emancipation, 37; on Jewish migration, 37-38; on Jewish nomadism, 5I, 6I62; Kant's response to, 38 ; Letters Concerning the Study of Theology, 62; on the nation-state, 36-37, 5I; The Spirit of Hebrew Poetry, 62; Theological Letters, 37; Zangwill compared with, 97
Hermann und Dorothea (Goethe), 52

"Herz Europas, Das" ("The Heart of Europe") (Zweig), I26

Herzl, Theodor, 73; on authentic Jew, 98; cosmopolitanism of, 76-77; Darwinism of, 74; on diaspora, 6; encounter with Zweig, 88-89; high-culture idea of progress of, 75-76; on Jewish adaptability, 74, Io6; on Jewish cosmopolitanism, 73-74; Judenstaat (The Jewish State), 74, 75; The New Ghetto, 82; Weltsch on, I48; Zangwill and, 96; Zionism of, 70, 74-77, 86, 98, 99, IOI, I09; Zweig influenced by, 83

Hess, Moses, 58

Heym, Stefan, 2 I9; Collin, 219-22; The King David Report, 2 I9, 22 I; Stalinist atrocities criticized by, I92, 2 I6, 2 I9-22

Himmler, Heinrich, I $57-58$

Hintschmann, Eduard, 80

Hirsch, Isaac, I07

Hirschel, Moses, 43

Hirschfeld, Magnus, 2 I 7

Historikerstreit (historian's debate), I95

History of Mankind (Ratzel), 26-27

History of Rasselas, The, Prince of Abissinia (Johnson), 232

History of the People of Israel (Renan), 65

Hitler, Adolf: on Austro-Hungarian Empire, Ioo; comes to power, I44; Feuchtwanger compares Emperor Domitian with, I84; on Jewish cosmopolitanism, IO, I I 8-20, I92; on Jewish nomadism, 27-28, I I9; on Jews and money, I63-64; on Jews as invisible, 83, I I9; on Jews' responsibility for the coming war, I64; Mein Kampf, 27-28, 83, I I 8, I I9, I63; new order in Europe of, I9I; Stalin compared with, I92-97, 2067; Zweig's Erasmus and, I66, I67, I68

"Hitlers Antisemitismus und wir" (Merker), $215,284 n 63$

Hodann, Max, 2I 7, 2 I9

Hofer, Johannes, 53

Hoffaktoren (Court Jews), 35, 60, 256

Hoffmann, Joachim, I95

Höge, Helmut, 230

Holbach, Baron d', 32

Holocaust, the: Adorno on art and, 2 I6; Berlin's preoccupation with, 236; death camps, I96, 207, 24I; Feuchtwanger's Der jüdische Krieg and, I42; monuments to, 
23I; notions of diaspora and cosmopolitanism affected by, Io; seen as unprecedented rupture in civilization, I96; in Shteyngart's The Russian Debutante's Handbook, 246; Stalinist crimes compared with, I 94-97; tourism, 234; as universal paradigm of modern mass violence, 207

homesickness, 53-54, 57

l'homme, 29

hospitality, 38-39, I I 5, I 26

"Hotel Lobby, The" (Kracauer), I3 I

hotels, I I7, I20, I29, I30-3I, I36, I7 I

Hotel Savoy (Roth), I29-34, I66

Huber, Engelbert, I 88

Huizinga, Johan, 30

humanism: of Austro-Hungarian Empire, I36, I73; of Erasmus, I68, I82; European, I 27; global reach of, I74; of Jesuits, I8I82; Renaissance, I66; universal, I22, I7I; as verbal rather than action, I69; Zweig on, I67

human rights, 4, I 2, I26, 257, 258

Humboldt, Wilhelm von, 42, 48, IO2, IO3, 267n43

Hungary: modernization in, 72; new radical nationalism in, 3; resurgent anti-Jewish prejudice in, I4. See also AustroHungarian Empire; Budapest

Hunger Pastor, The (Raabe), 66-67, 102 hybridity: Braidotti on global, I9; cultural, 23 I; hybrid cosmopolitanism, 232; of Jews, I8I, 20I-2, 223, 230, 23I; of languages in Brooklyn, 250; racial hybrids, I75, I79-80, I8I, I82, 20 I-2; Shaw on, I; in Shteyngart's The Russian Debutante's Handbook, 246, 247; in Zangwill's The Melting Pot, I 2

Ibsen, Henrik, 203

Ich bin kein Berliner (Kaminer), 233-34

Ich mache mir Sorgen, Mama (Kaminer), 232

Idea of a Universal History with Cosmopolitan Intent (Kant), I 2, 38

Ideas for a Philosophy of the History of Mankind (Herder), 36-38, 6I-62

identity: collective, I07; cosmopolitanism as state-sanctioned (or -denied), 257; ethnic, 8I, 9I , I27, 226, 243; food in shaping, 233; German, 70, 72, I07; hyphenated,
232; individual, 37; Irish, 2-3; Jung on, 28; performance of, I07; political, 2, 6, 36; racial, I02, I 2 I; religious, 2-3, 7, 36, 239, 240; shifting, 255. See also Jewish identity; national identity

Iden-Zeller, Oskar, 95

Idyll and Village Tales in Antiquity and the Middle Ages (Gosche), 65

Imagined Communities (Anderson), I6 immigrants: to Brazil, I77, I8 I; European Jews to Israel, 258; in globalized cities, 3; Jews to America, 50; Jews to Palestine, I35; large-scale immigration, 3; Muslim, 24I; Russian Jews, 243; undocumented, 2, 30

Im Schnee (In the Snow) (Zweig), 87-88 individualism, 98, I09, I89

intellectuals: antisemites on Jewish, 204; free-floating intelligentsia, I38; incognito Russian Jewish, 225; liberal bourgeois, I89; National Socialism on, I65; in Zweig's Erasmus, I68-70

intermarriage (mixed marriage), 5I, 6I, I58, I 75

International Brigades (Interbrigades), 20 I, 203, 2 I 6, 2 I 7, 22 I

internationalism: communist, I 89-90, 2 I4, 2 I7-I 8; Hitler on Bolshevik, I I9; in Koestler's Darkness at Noon, 204; Mann on, I46-47, I5 I, I58; proletarian, I89; Rühle-Gerstel and, I98, 200, 20 I, 203; Soviet concern about, I 88; Stalin on, I89; of Zionism, I9I, I92; Zweig on, I I5

"Internationalismus oder Kosmopolitismus" (Zweig), I I 5

"International Situation and the Defense of the USSR, The" (Stalin), I 89

Interpretation of Dreams, The (Freud), 80-8 I In the Snow (Im Schnee) (Zweig), 87-88

Investigation, The (Weiss), 2 I 6

Irish identity, 2-3

Irwin, Vera, 240

Israel: cosmopolitanism in, 70; on the diaspora, IO-I I ; European Jews emigrate to, 258; multiculturalism in, I4; as pole of world Jewry, 256; Russian Jews emigrate to, 237; in Shteyngart's Little Failure: A Memoir, 249

Israel unter den Völkern (Kahler), I42-43

Itzig, Daniel, 35 
Jahn, Friedrich “Turnvater," 53

Jameson, Fredric, 284n65

Janka, Walter, 22 I

Jaucourt, Louis, Chevalier du, 29-30

Jean Paul, (pseudo. Jean Paul Friedrich Richter) 53

Jens, Walter, 2 I 6

Jeremias (Zweig), I86

Jerusalem (Mendelssohn), 40

Jesenskà, Milena, 197

Jesuits, I76, I78, I79, I8I-82

Jew, The (Der Jude) (periodical), 27, I I I

Jew as Pariah, The (Arendt), 200

Jewish cosmopolitanism: in Akhtiorskaya's

Panic in a Suitcase, 25I-53; as antithesis of nationalism, 62; Appiah on, I4-I5; assimilation preferred to, 68; Auerbach on wandering Jew and, 50; Bismarck on, 269n9o; capitalism and, I, 23, 24, 25, 6I; center-periphery dichotomy and, 70-7I; communist affinities with, I 89 ; contradictions in imperial worlds of Austria and Germany, 69-I I 2; cosmopolitans uncomfortable with their mobility, 259-6o; diaspora in, 22, 62-63; diasporic, 6, 97, I0 I, I 38 , I 82 ; as doomed to fail under conditions of antisemitism, I38; Du Bois on, I03-4; Enlightenment on, IO, I7, 28, 3I42, 82; and the European idea, I9I8-I933, I I3-43; Feuchtwanger and, I I6, I37-42, I82-86, I9I, I99; Freud on, 80-83; Goebbels on Bolshevism and, I64; Goethe on, 53; Goldstein on, 98-99; in Heine's Germany: A Winter's Tale, 54-56; Herzl and, 73-74, 76-77; Hess on, 58; Hitler on, I I 8-20, I92; humanizing mission of, I 82; images of, 255; interwar writers on, I2042; Jesuit cosmopolitanism compared with, I76; Jewish national identity versus, 73; Jewish nationalism and, 24; Jews writing their own, 6I-68; of Josephus, I38, I40; Kafka on, 94, 95-96; Kohler on, 22, 23; Lindbergh on, I49; as litmus test, I, 8, IO, I48, 258; in Mann's Joseph and His Brothers, I5I; Marx on, 58, 60; mobility and, 69, 72-73; modern nervousness seen as problem of, 77; national and cultural variations of, 223; under National Socialism and in exile, I44-86; as new cosmopolitanism, 30, 5I; nomadism and, 24,
259; non-Jewish German constructions of, I50; Nordau on, 77-78; Raabe on, IO2; racial identity in, 23; Rathenau and, I05-8, I38; remains Jewish at its core, I 53, I 5859; rooted in ethnic identity, 8I; Rosenberg on, I5; Roth and, I I6, I28-29, I35, I73, I82, I9I, I99; in Roth's Hotel Savoy, I29-34; Russian Jews as newest cosmopolitans, 223-54; in Schiller's The Robbers, 47-48; in Shteyngart's The Russian Debutante's Handbook, 246-47; Simmel on, I05; as third force between national citizenship and nomadism, 68; Treitschke on, IOI; two periods of concerted, 256-59; Verein jüdischer Hochschüler Bar-

Kochba's Vom Judentum on, 97-I00; Wassermann on, I08-I I; Weimar, I08, I38, I39; after World War I, I I 3-20; in Zangwill's The Melting Pot, 96-97; Zionism and, 6, 27, 70, 79, 97, 99, I9I, 259; of Zweig, 83, 84, 86, I20, I28-29, I67, I82, I86, I99; Zweig on, 83-9I, I20-27

Jewish diaspora: Berlin and, 236; Buber on, 89; cosmopolitan culture emerges from, 62-63; diasporic cosmopolitanism, 6, 97, IOI, I38, I82; of European Jews fleeing National Socialism, I9; even in Palestine, 99; exile and, 5-6; Feuchtwanger on cosmopolitanism and, I38; Freud on Joseph's exile and, I6I; invocations of language of, 254; Jews made into cosmopolitans by, 22; language and German Jewish writing on, 239; as model for future European citizenship, I I6; muscle Jew versus ghetto mentality of, 88; Roth's diasporic sensibility, I 27; of Russian-speaking Jews, 223; Shteyngart's The Russian Debutante's Handbook on, 248; as site of Jewish creativity, 87; Spanish Jewish culture in, 64; Wassermann on, I08-9; Zionism seeks to remasculate, I4I; in Zweig's early Jewish novellas, 86

Jewish emancipation: cosmopolitanist discourse influenced by, II; Dohm on, 36, 4I; Franz Joseph on, 7I; of French Jews, I3; Goethe on, 6I; Herder on, 37; marks political instantiation of the cosmopolitan, 258; Marx on, 6o; Meinecke on, I03, I08; politicization of theology in debate over, 59 
Jewish Encyclopedia, 35

Jewish exile: of Feuchtwanger, I 82-83; of Freud, I6I; galut experienced as, 5-6; of German Jews, 226; Jewish cosmopolitanism during, I44-86; Jewish nomadism and, I, I44; Jewish writers claiming to be the real German culture, I53; Roth and, I27, I29, I70; Rühle-Gerstel and, I98, 202; of Sperber, 208; Steinschneider on Jews' compensations for, 64; of Zweig, I45, I65, I66, I68, I77, I79; Zweig's exile novels, $83-84$

Jewish identity: Arendt on Kafka's pariah status and, 93; in Berlin, 237; centerperiphery dichotomy and, 70-7I; cultural Zionism on, 9I; defining, 8; Enlightenment's alleged effect on, $5 \mathrm{I}$; factors in shaping, 256; French citizenship versus, I3; Heine on fragmented nature of, 57; Jewish cosmopolitanism and, 6-7, 79, 8I; Kafka seen as symbol of European, 92-93; in Kaminer's works, 229, 230; modeled on German nationalism by Jewish nationalists, I I I m multiplicity of, 256; national identity and, II, 22-23, 58, 70, 73, 74, 259; overlapping elements of, 2-3; Penslar on Shylock's curse and, I5; performance of, I07; in Raabe's The Hunger Pastor, 67; race and, 23; railroad and the trauma of confronting, 79; religious identity defines, 239; Roth on, I27, I32; in Schiller's The Robbers, 47; seen as in crisis, I27; in Shteyngart's The Russian Debutante's Handbook, 245; Slezkine on, 8-9; Verein jüdischer Hochschüler Bar-Kochba's Vom Judentum on, 97-98; Wassermann on, I Io, I I I; Weimar and, I08; Weltsch on, I48; written word in, 224-25; Zionist model for, 163

Jewish Memory and the Cosmopolitan Order (Sznaider), 7

Jewish nationalism: in Feuchtwanger's Josephus trilogy, I83; of Flavius Josephus, I38, I39, I42; Freud on, 80; Goldstein on, 98-99; Herzl on, 99; Jewish identity modeled on German nationalism by, I I I; on Jewish nomadism, 27; Pinsker on, 22-23; recuperation of, 68; on rooted cosmopolitanism, 259. See also Zionism

Jewish nomadism: antisemites on, 68, 259;
Arendt on, 93; assimilation preferred to, 68; Bismarck on, 269n9o; contemporary theories of, I7; Czech Jews and, 92; economic aspect of, 20, 30; in Egypt, I54; Enlightenment cosmopolitanism contrasted with, 6I; Enlightenment view of, $2 \mathrm{I}-28$; in Harlan's Jud Süss, 34; Heidegger on, I62; Herder on, 5I, 6I-62; Hitler on, 27-28, I I9; Imperial Austro-Hungarian Jews deny, 72; intellectual nomads, I7; Jahn and, 53; Jewish cosmopolitanism and, $5 \mathrm{I}$, I I 3,259 ; in Jewish identity politics, 256; Jewish mobility and, 69; Jews as service nomads, 8, 4I; Kafka on, 94-95, I 53; in Mann's Joseph and His Brothers, I5O, I5I, I 52, I 58; Mendelssohn on, 4I; national and cultural variations of, 223; Neusner on dialect between agriculture and, 5; Rathenau on, I05-7; Roth on, I29, I30, I32-33; in Schiller's work, 47, 48, 49-50, 54; Schmitt on, I 56-57; seen as impeding cultural development, 64-65; Zweig becomes lifelong nomad, I68

Jewish particularism: Bauer on, 58, 59; Enlightenment rejection of, I4, I7;

Feuchtwanger on, I38, I39, I 83-86; Freud on, 80, I6o; Goldstein on, 98-99; Herzl on, 74; Marx on, 58; as particularist universality, I I3, I24, I83; Renan on, 65; Roth on, I28, I9I; Slezkine's model of Jewish identity and, 9; Soviet view of, I 89; Zweig on, 89, 90, I25, I28, I 86

Jewish Renaissance, 70, 73, 86, I00, 270 2 Jewish rootlessness: economic factor as reflex of, 77; Enlightenment cosmopolitanism and, 8, 6I; in Freytag's Debit and Credit (Soll und Haben), 67; galut and, 5; Heidegger on, I62-65; Herder's notion of the state and, 5I; Hitler on, I I 9; Israeli Jews in Berlin resuscitate charge of, I I ; in Jewish identity politics, 256; National Socialism on, 9; nomadic cosmopolitanism and, I I3-I4; persecution based on accusations of, IO; Roth on, I32; seen as innate, I07; Spengler and, I I7; Zweig's Erasmus and, I 68

Jewish State, The (Judenstaat) (Herzl), 74, 75 Jewish universalism: Feuchtwanger on, I I6, I38, I43; Goldstein on, 98; Herzl on, 74; Jews seen at core of universal human 
Jewish universalism (continued) narrative, I I4; in Josephus, I40; Kohler on Jewish cosmopolitanism and, 23; as particularist universality, I I3, I 24, I 83, I 83; Renan on, 65-66; Roth on, I I6, I38; Zweig on, I I6, I 22, I25, I38, I43

Jews: American, I49, 224, 245, 246, 248, 257; in Austria, 72, 83, I73; bankers, 25, 35; la belle juif, 88; in Berlin, IOO-I I2; Bolshevism and, I64, I90; in Brazil, I76, I80, I82; capital associated with, I, I5, I 8, 2 I, 24-26, 30, 36, 39-40, 6I, 62, 7677, I04, I48, I63-64, 228, 258, 259, 260; as chosen people, I59-60; circumcision by, I 58 , I6o; communism as attraction for, I87, I88; conflicting definitions of, 36 ; in contemporary theories of cosmopolitanism, I 2-I 7; cosmopolitanism associated with, 8-9, I4-I 5; diabetes associated with, $8 \mathrm{I}$; early attempts to establish forms of welfare, I99; in early cosmopolitanist theory, II; as economic factor, I5, 20, 24, 27, 29, 38, 59, I03-4, I06, I48, I 53-54, I87, 259; Encyclopédie on, 29-30, 40; Enlightenment on, 25-26, 49, 50; as ethnic identity, 2, 8, 9, 8I, 86, 9I, 97, I05, I I6, I27, 225, 226, 229, 240, 248; ghetto, 34, 87, 88, I I I, I47, I48, I56; Goethe on, 52-53, I 20; during Golden Age of Spain, I4, I6, 63, 64, 98; Greek influence on, 63; Habsburg emperor and, 7I-72; Haskalah, 40, 43; hybridity of, I I, 20 I-2, 223, 230, 23 I; Imperial Austro-Hungarian, 7I-72; intellect of, I23; Judaism as universal religion, 7, 65, 90; Kant on, 2 I, 38, 39-40, 58; in Koestler's Darkness at Noon, 204; in Mann's Joseph and His Brothers, I49; marginality, 93; Meinecke on, IO2-3; mimicry by, 35; mobility of, I I, 39, 40, 42-6I, 69, I06-7, I32, 228, 259-60; "muscle Jews," 88; mystical Jewry, 98-99; National Socialism on, I 5, I 8, I 58 ; and the nation-state, 28-30, 62; overlapping histories with Roma and Sinti, 20; "overrepresentation" of, 73; as pariahs, 93; peddlers, 22; as people without borders, II ; in Prague, 9I-IOO; as a "race," 8, I 5, 23, 69, I34, I64, 20I-2, 258; radicalism associated with, 58; rootedness of, 5, 22, 93, I06, I08, I36, 259, 260; as rootless cos- mopolitans, 9, I0, 77, I62, I90-9I, I92, 203, 208, 247; in Rühle-Gerstel's work, I99; in Schiller's "The Legation of Moses," 49-50; secularized Jewish fathers, 79 ; seen as antithesis of universalism, I I ; self-hating, I48, 249-50; "Semitic" features, I 52; soldiers' loyalty during World War I, 78; Spengler on, I I 8; stiffneckedness of, I60; as supranation, I28; three poles of, 256-57; usury by, 25, 29, 40, 53, I63; in Vienna, 72, 73-9I, I73-74; wandering, 50, 60, I33, I 52, 239, 275n28; Westernized, I28. See also antisemitism; Eastern European Jews; German Jews; Holocaust, the; Jewish cosmopolitanism; Jewish diaspora; Jewish emancipation; Jewish exile; Jewish identity; Jewish nationalism; Jewish nomadism; Jewish particularism; Jewish rootlessness; Jewish universalism; Russian Jews; Zionism

Jews, The (Lessing), 3 I-34, 35, 44

Jews and Modern Capitalism, The (Sombart), 24-25

Jew Süss (film), I38

Johnson, Samuel, 232

Joll, James, 34

Joseph and His Brothers (Mann), I48-59, I66, I69, I70, I83, 222

Josephus, Flavius, I37, I38-39, I83-86, I9 I

Josephus trilogy (Feuchtwanger), I37, I43, I 82-86, I9I

Josipovici, Gabriel, I50

Joyce, James, 275n28

Judaism and Its History (Geiger), 63-64

"Judaism as Race and Religion" (Renan), 65, 90, 269n Io6

Judaism in Music (Wagner), I 23

Judenstaat (The Jewish State) (Herzl), 74, 75

jüdische Krieg, Der (The Jewish War)

(Feuchtwanger), I37, I38-4I

Jüdische Monatsschrift (periodical), 23

Jüdische Rundschau (Jewish Review), I48

Jud Süss (Feuchtwanger), I37-38

Jud Süss (film), 34-35, I38, I58

Jung, Carl G., 28

Kafka, Franz, I8; antimystical stance of, 99; on building a Great Wall, 93-94, 96; The Country Doctor, 94-95; cultural Zionism of, 87, 9I; on the emperor, 9I-92; family's 
geographic and linguistic mobility, 72, 92; on Jewish cosmopolitanism, 94, 95-96; on Jewish nomadism, 94-95, I 53; Letters to Milena, I97; Metamorphosis, I99; "An Old Manuscript," 94-95; Prague becomes city of, 245; secularized father of, 79; seen as symbol of European Jewish identity, 92-93; The Trial, 2 I6; Zangwill compared with, 97

Kahler, Erich von, 98, I42-43

Kallen, Horace, I 2

Kaminer, Wladimir, 228-38; in competition for Russian writing in German, 240; $\mathrm{Hel}$ den des Alltages, 230-3 I; Ich bin kein Berliner, 233-34; Ich mache mir Sorgen, Mama, 232; Karaoke, 232-33; Küche totalitär, 233; Mein deutsches Dschungelbuch, 23 I-32; Onkel Wanja kommt, 23538; "People in a Park," 230-3 I; radio programs of, 235; Die Reise nach Trulala, 230; Russendisko (Russian Disco), 22829, 232; Schönhauser Allee, 230, 23 I; Shteyngart compared with, 244, 248, $25 \mathrm{I}$

"Kampf in den Südpol, Der" ("Quest of the South Pole") (Zweig), I 22

Kane, Anne, 2-3

Kant, Immanuel: Anthropology, 39-40; categorical imperative of, 39; Conjectural Beginning of Human History, $2 \mathrm{I}$; on cosmopolitanism, 38-39, 40, 98, 99, I I4, I I6, I39, I47; cosmopolitanist dialectic of particularist universality, 9, 278n I ; on human inclination to association, 4I; Idea of a Universal History with Cosmopolitan Intent, I 2, 38; on Jews, 2 I, 38, 39-40, 58; on nomads, 2 I; Perpetual Peace, I I, 38, I93; on religion, 39, 40; on universal hospitality, 38, I I 5, I 26; on universal law, I 2, I93; on world citizenship, I I-I 2, 264n3 I

Karaoke (Kaminer), 232-33

Karpeles, Gustav, 64

Kaznelson, Siegmund, I I I

Kehrig, Manfred, I95

Khrushchev, Nikita, I93

King David Report, The (Heym), 2 I9, 22 I

Kisch, Egon Erwin, I98

Kishinev Pogrom, 96

Kleingeld, Pauline, 39

klezmer, 229, 233
Klüger, Ruth, I 58

Knigge, Adolf, Freiherr von, 3I, 32-33

Koestler, Arthur: Darkness at Noon, I97, 203-7; on the Holocaust, 207; Jewishness in work of, I99; Jewishness of, 204; "On Disbelieving Atrocities," 206-7; Stalinist atrocities criticized by, I92, 203-7; writes for Münzenberg's Die Zukunft, 208

Kohler, Kaufmann, 22-23

Kolb, Annette, I I 5

Kontingentflüchtlinge, 227

Köpke, Wulf, I38

"Kosmopolit, Der" (Schlosser), 37

"Kosmopolitismus" (Mann), I I4

Kracauer, Siegfried, I3 I

Küche totalitär (Kaminer), 233

Kuh, Ephraim Moses, 43-46, 50-5 I

Kulturkampf, Ioo

Laitin, David D., 224, 243

Lamed Vov, 2 I3

Lamprecht, Jakob Friedrich, Io

Landauer, Gustav, 98

"Land ohne Patriotismus, Das" (Zweig), 8485

Lassalle, Ferdinand, I99

Lavater, Johann Kaspar, 36, 50

Lazare, Bernard, 77, 93

Lazaroms, Ilse, I27, I29

Lazarus, Emma, 244

League of Nationalist German Jews, I I4

Lectures on Belles Lettres and Art (Schlegel), 42

Left, the: and the Stalinist purges after I945, 2 I3-22; in World War II and thereafter, I87-88. See also communism; socialism

"Legation of Moses, The" (Schiller), 49-50

Leitkultur, 3, 6

Lemkin, Rafael, 283n3o

Lenin, I 57, 208, 2 I 8

Leo X (pope), I67, I69

Leonhard, Wolfgang, 2 I6

Le Rider, Jacques, 272n58

Lessing, Gotthold Ephraim: on cosmopolitan Jews, 33-34, 82; cosmopolitan used by, Io; Heine on, 53; The Jews, 3I-34, 35, 44; Kuh and, 43, 50; Mendelssohn and, 35, 36, 42; Nathan the Wise, 42, 47, 48, I6o, 267n4I; on pan-German cosmopolitanism, I0o; "Parable of the Three Rings," I6o 
Letters Concerning the Study of Theology

(Herder), 62

Letters to Milena (Kafka), I97

Lettres persanes (Montesquieu), 232

Levi, Primo, I70; The Drowned and the Saved, 205-6

Lewis, Arthur D., 78-79

Lewisohn, Ludwig, I49

Li, Tania Murray, 2

Like a Tear in the Ocean (Sperber), 207-I3, 2 I 6

Lindbergh, Charles, I49

Lipphardt, Anna, 236

List, Friedrich, 57

Little Failure: A Memoir (Shteyngart), 248$5 \mathrm{I}$

"Lösung der Judenfrage, Die" ("Final Solution of the Jewish Problem") (Mann), I4748, I 52, I 58, 278nI5

Ludendorff, Erich, I65

Ludewig, Anna-Dorothea, I 20

Ludwig, Emil, I46

Lueger, Karl, 73, 80, I74

Lukács, György (Georg), 79, 22 I

Luther, Martin, I67, I68, I69

Luxemburg, Rosa, I I4, I99, 208

Maccabees, 88

Machado de Assis, Joaquim Maria, I80

Magellan, I74-75

Magic Mountain, The (Mann), I46, I5I-52

Maimon, Salomon, 50

Mann, Heinrich, I I 5, I44

Mann, Klaus, I70-7I

Mann, Thomas, I45-59; on antisemitism, I6 I; "Blood of the Walsung," I I I, I 58; Buddenbrooks, I45, I75; on communism and National Socialism, I94; cosmopolitanism of, I I4-I 5, I46-47; Death in Venice, 84, I46; Dr. Faustus, I70; exile of, I46, 259; on hybrid colonial South America, I75; Joseph and His Brothers, I4859, I66, I69, I70, I83, 222; "Kosmopolitismus," I I4; lectures on Freud, I 59; "Die Lösung der Judenfrage" ("Final Solution of the Jewish Problem"), I47-48, I52, I58, 278n I5; The Magic Mountain, I46, I 5I-52; metaphor of two souls divided against themselves, I75; mother of, I75, I80; National Socialism opposed by, I46;
National Socialist dismissal of, I62; Observations of a Non-Political Man (Betrachtungen eines Unpolitischen), I I4, I46; on Rathenau's assassination, I08; on supranationalism, I28; "Tonio Kröger," I75; Tristan, I46; Wassermann compared with, I08; Zweig's Burning Secret and, 84 Mannheim, Karl, I38

Marcauer, Ruth, 2 I 8

"Marienbader Elegie" (Zweig), I22

Marx, Karl: antisemitic rhetoric and, I63; in communist leadership, I87, I99; "Critique of Hegel's Philosophy of Law," 57; internationalism of economic vision of, 57; on Jewish cosmopolitanism, 58, 60; on Jews and modernity, 59; on New World as model for mobility, 60; on nomads, $2 \mathrm{I}$; "On the Jewish Question," 57, 58-6I, I88, 282n5; on religion, 6I; sees himself as antithesis of image of the Jew, 59; on sons of first-generation of Jewish liberals, 79; on world not national revolution, 2 I 7

Marxism: on cosmopolitanism, I5; Jewishness as contested question for, I88. See also communism

Mass Psychology of Fascism, The (Reich), 202

May, Theresa, 2

McCarthy, Joseph, 2 I 9

Meier, Georg Friedrich, 32

Mein deutsches Dschungelbuch (Kaminer), 23I-32

Meinecke, Friedrich, IO2-3, I47

Meine weißen Nächte (Gorelik), 238, 286n37

Mein Kampf (Hitler), 27-28, 83, I I8, I I9, I63

Melting Pot, The (Zangwill), I 2, 96-97

Men and Manners in America (Hamilton), 60

Mendelssohn, Moses: elected to Prussian Academy of Sciences, 46; Hess on cosmopolitan Judaism and, 58; Jerusalem, 40; Kuh and, 43, 50; Lessing and, 35, 36, 42; moves to Berlin, 35-36; on religion and citizenship, 40, 42, 43

Mendes, Lothar, I38

"Mending Wall" (Frost), 255-56, 26 I, 286n3

Menschen im Hotel (Baum), I 17

Merker, Paul, 2 I 5, 2 I9-20, 22 I

Metamorphosis (Kafka), I99

"Metropolis and Mental Life, The" (Simmel), I 55 
Meyer, Michael A., 5I, 53

Meyerbeer, Giacomo, 57

Michaelis, Johann David, 34

Mielke, Erich, 220

migrants: in Germany, 24I; Gorelik as, 240; nomadism and cosmopolitanism and, 2, 3o. See also immigrants

Miller-Budnitskaya, R., I90-9I

Minima Moralia (Adorno), I9

Miracles of Life, The (Die Wunder des Lebens) (Zweig), 90

miscegenation (race mixing), I75, I80, I8I, 28 InIoI

Mittelmann, Hanni, 275n33

mixed marriage (intermarriage), 5I, 6I, I58, I 75

mixed-race individuals, 26, 65, I80, I8 I

mobility: anxiety generated by, 69, 7I, 72; in Austro-Hungarian Empire, 7I, 77, I00; of capital, I04; cosmopolitanism as potential for movement, 260-6I; as defining characteristic of modernity, 69; economic, 72; eighteenth-century view of, 36 ; Enlightenment on, 33, 35; in Herder's The Jews, 33; Jewish cosmopolitanism and, 72-73; of Jews, I I, 39, 40, 42-6I, 69, I 06-7, I32, 228, 259-6o; of Kafka, 72, 92; Marx on New World as model for, 6o; National Socialism on cosmopolitanism and, 34-35; responses to human movement, 253-54; of Russian literary culture, 235; as sign of cosmopolitanism, 34-35, I I 7; Simmel on, I 55; social, I, 35, 39, 46, 47, 69, 7I, 72, I04, I05; universal cosmopolitanism implied by, 43; of urban elite, I I7. See also nomadism

modernity: atomized individual of, 2 Io; Heidegger's critique of technological, I62; Holocaust seen as function of, I96; Jewish success in, I04; liquid, I5; Marx on Jews and, 59; mobility as defining characteristic of, 69; modernization turns the nomad into the cosmopolitan, 5I; nervousness attributed to, 77, 79; Nordau on degeneration and, 78; Rathenau on, Io6; reflexive, 4; rootlessness of modern society, I3 I, 203; Simmel on, I 55; Spengler on, I I 7, I I 8; Wolin on new cosmopolitanism and, I5I6

Mommsen, Theodor, I I9, 270n2 monotheism, 2 I, 27, I 24, I 5 I, I6o

Montesquieu, Charles-Louis de Secondat,

Baron de, 4I, 232

Moses, I60-6I

Moses and Monotheism (Freud), I59

Mosse, George, 67

Müller, Friedrich von, 5 I

Muller, Jerry, I 87

Müller, Karl, I 20

Müller-Tellering, Eduard, 58

multiculturalism: in Austro-Hungarian Empire, 72; in Berlin, 232, 236; in Brooklyn, 244-45; cosmopolitanism as the new, 2; cosmopolitanism contrasted with, 3, 9, 26I; diaspora contrasted with, 4; diversity and, 3; in Germany, 229, 24I, 242, 253, 255; in Israel, I4; Jews in analysis of, I7; Otherness and, 9, I I; in post-I989 Europe, I20; in Prague, 245; questioning of, 3 ; in Shteyngart's The Russian Debutante's Handbook, 244, 246, 247

Multidirectional Memories (Rothberg), I96

Münzenberg, Willi, 208

Münzer, Thomas, I69

"muscle Jews," 88

music, 232-33

Muslims, 24 I

My Life as a German and a Jew (Wassermann), I IO

Nabokov, Vladimir, 238, 249, 252

Nabuco, Joaquim, I8o

Nakhimovsky, Alice, 233

Nathan the Wise (Lessing), 42, 47, 48, I60, $267 \mathrm{n} 4 \mathrm{I}$

national identity: Enlightenment on religion and, 6r; and geographic affiliation, I I6; German mystical notion of, I I I; Heine and, 55, 56; imperial, 72; Jahn on nomads and, 53; for Jews, I I, 22-23, 58, 70, 73, 74, 259; Jews' symbolic function in defining, 28; of Mendelssohn, 36; new, 257; nomadism and corrosion of Europeans', 2 I; Raabe on, I02; religion as surrogate for, 3; of Russian Jews in Germany, 226, 227; separate from religion, 7; Shteyngart's The Russian Debutante's Handbook on, 246. See also Jewish identity 
nationalism: in Berlin, I02; bourgeois, I8990; cosmopolitan, 96; cosmopolitanism and the new, 2; cosmopolitanism as defense against, 4; cosmopolitanism gives way to, 98 ; Feuchtwanger on resistance to violence of, I84; Graf on National Socialism's barbaric, I37; Herder coins term, 62; intensifying in late nineteenth century, 69, 72 , I20; Jewish cosmopolitanism as antithesis of, 62; methodological, I9; movement from emancipatory to integral, Ioo; on national identity and geographic affiliation, I I 6; national literary cultures, 256; new, 2, 5I, 68, 72, 74, I02; One World Movement's opposition to, 260; political, 8I, 274nI3 I; postwar growth in, 78, I I3, 259; in quest for South Pole, I22; radical, 3, I73, I84, I88-89, 259; regional nationalisms, 72; rooted, 257; in rump state of Austria, I I I Russian Revolution sweeps away idea of, I9I; Schiller and, 48-49; Serb, I73; Soviet, 205; Stalin's turn to, 2 I 8; tension with cosmopolitanism, I07, I47, I83, I85, 260; of Weltsch, I48; World War I and, I I 5, I I6, I34; Zionism as, 6, 70; Zweig and, 85, I65, I67, I68, I76. See also German nationalism; Jewish nationalism; national identity; supranationalism

Nationalkomitee "Freies Deutschland," I98

Nationalökonomie, 57

National Socialism: on annihilation of Jews, 9; on Aryan vitality and strength, I68; on Aufnordung (Nordification), I8I; book destruction by, I42; Catholic Church's concordat with, I6I; clash with Stalinism, I67; Feuchtwanger defends cosmopolitanism against, I37; Graf's response to, I37; Harlan's Jud Süss, 34-35; Heidegger's support for, I62; on intellectuals, I65; Jewish cosmopolitanism under, I44-86; on Jews, I5, I8, I58, I64; on Jews and capitalism, I48; on Jews and communism, I88; Jews see communism as antidote for, I88; in Kaminer's works, 233, 234; on land and ethnic type, I7I; Luther and antisemitism of, I67; Mann dismissed by, I62; Mann's opposition to, I46; nationalism and rise of, 4; on nomads, I7, I 57-58; Nuremberg Laws, I75; One World Movement's opposition to, 260; on race, I75,
I76, I79, I8I, I95; radical nationalism in emergence of, I89; the revolution of I933, I44-45; in Rühle-Gerstel's Der Umbruch (The Break), I98; Schmitt on, I56; Stalinist Soviet Union compared with, I92-97, 200, 206-7; tendency to absolve Germans of their guilt, I95, 282n28; unification of Austria and Germany, I70, I72, I73. See also Hitler, Adolf; Holocaust, the

nation-state: conflict between states, 67; consolidation of European, 256; cosmopolitanism seen as undermining, 3, 26r ; cosmopolitanism's roots in, 42; dynastic state replaced by, I6; Enlightenment and, 7, 30, 258; globalized cities rooted in, 3-4; Herder on, 36-37, 5I; Humboldt on, IO2; Jahn on, 53; Jewish cosmopolitans and, 79; Jews and, 28-30, 62; origin of concept of, 7; renewing, 26I; rooted cosmopolitanism based on, I4; rootedness required for, 67; roots in nomadic world before capital, 23; Treitschke on, IOI, IO2

Naumann, Max, I I4

Nazism. See National Socialism

"negative Lebendigkeit des Dritten Reiches, Die" (Nolte), I94

"neue israelitische Hospital zu Hamburg, Das" (Heine), 54

Neuer Hafen: Migrantenerzählungen (anthology), 240

Neusner, Jacob, 5, 6

"New Colossus, The" (Lazarus), 244

New Ghetto, The (Herzl), 82

"New Two-Way Street, The" (Shteyngart), 247-48

Nietzsche, Friedrich, 23, 76, IO I, I 50

Nolte, Ernst, I94-95

Nomadic Subjects (Braidotti), I9

nomadism: aesthetics linked to, 226; Bedouins, 2I, 24, 26, 4I; contemporary theories of, I7-20; cosmopolitanism as sister concept to, I; Enlightenment view of, 20-2 I, 26, 62; exile and, I, I9-20; Germans seen as nomads, I07; Goethe on, 20-2 I, 52-53, I 57; Jesuits as nomads, I78; Lenin's policies on, I57; Mann comes to terms with, I46; National Socialism on, I7, I 57-58; nation-state's roots in, 24; nomadic cosmopolitanism, I I3-I4, I I6, I I 7, 256; romanticized view of, I 57; rooted, I7I; root- 
lessness contrasted with, I64; rootless nomads, 8; in Rühle-Gerstel's Der Umbruch (The Break), 203; in Schiller's The Robbers, 47, 48; service nomads, 8-9, 4I; Simmel on, I 54-56; Spengler on modernity and, I I 8; as ultimate antiurban, 256. See also Jewish nomadism

Nordau, Max, 72, 77-78, 79, 28In95

Novalis, 42, 98

Nunes, Zita, I80

Nuremberg Laws, I75

Nussbaum, Martha, 38

Oblomov (Goncharov), 247

Observations of a Non-Political Man (Betrachtungen eines Unpolitischen) (Mann), I I 4 , I 46

"Old-Book Peddler, The" ("Buchmendel"), I 23-27, I 68

“Old Manuscript, An” (Kafka), 94-95

"On Disbelieving Atrocities" (Koestler), 206-7

One World Movement, 260

"On Joy" ("An die Freude") (Schiller), 48

Onkel Wanja kommt (Kaminer), 235-38

"On the Analysis of Tyranny" (Sperber), 2 I 2 , $284 \mathrm{n} 58$

On the Jewish Question (Bauer), 58, 59

"On the Jewish Question" (Marx), 57, 58-6I, I 88, 282n 5

Oppenheimer, Franz, 76

Oppenheimer, Joseph Süss, 34, 35, I38

"Opportunismus, der Weltfeind" (Zweig), I I4

Origins of Totalitarianism (Arendt), I92, I93, I96, 209-IO

Panic in a Suitcase (Akhtiorskaya), 25 I-53, 286n55

"Parable of the Three Rings" (Lessing), I6o

Paris: in defining France, 256; Eastern European Jews on hotels of, I 29; Freud on, 8I; German radicals in, 57; Heine and, 53, 54, 57, 67; Herzl in, 73, 75; Jewish exiles from National Socialism in, I44; Jews and French cosmopolitanism, I3; in Jud Süss, 34; Marx in, 57, 58; as mega-metropolis, 5I; Nordau in, 72, 77; Roth and, I33, I45, I70; as social and intellectual center of Europe, 77; Spengler on symbolism of, I4I particularism: of Austro-Hungarian Empire's subjects, I36; cosmopolitanism contrasted with, 6; of food, 233; of German lands, I I; in Goldziher's portrayal of Abraham, 2324; Jewish nationalism as universal particularist, 23; of Josephus, I40; new Jews for confronting, I6; particularist universality, 9, I 7, 74, 86, I I3, I24, I30, I32, I39, I83; of religious affiliation, I4; tension between universalism and, 6, 8; and universalism in Zweig's early writing, 84; Zionism and, 70. See also Jewish particularism patriotism: Bernstein on Jewish, I47; cosmopolitanism and, I I, 74, 97, I I6; German, I48; Goethe on art and, 52; Meinecke on, I02; in Roth's works, I29, I32; Stalin emphasizes Soviet, I90; Tolstoy's national, I37; Zweig on Austrian, 84-85

Patton, Paul, I8-I9

Pauker, Ana, 2 I 4

Paul, St., 23

Penslar, Derek, I5

"People in a Park" (Kaminer), 230-3 I

Perpetual Peace (Kant), I I, 38, I93

Perpetual War: Cosmopolitanism from the Viewpoint of Violence (Robbins), 8

Philadelphia Negro, The (Du Bois), IO4

Philosophy of Money (Simmel), 2 I, I04, I 54-55

Pillersdorf Constitution, 7I

Pinsker, Leon, 2 I-23, 99

Pinto, Diana, 257

Pitt-Rivers, George, 8 I

pluralism: cultural, I2, 39; ethnic, I28; religious, 7; of systems of law, 36

Poet and Merchant (Auerbach), 50-5 I

pogroms, 77, 96

Poliakov, Léon, I94

"Polish Jew, Who Became a Christian, The" (Kuh), 45-46

Pol Pot, I94, 222

Popper, Karl, 273nI I4

poshlost, 238, 249

Post Office Girl, The (Zweig), 83-84

Practical Philosophy of Social Life (Über den Umgang mit Menschen) (Knigge), 3 I

Prague, 9I-IOO; as center of Germanspeaking world, 69; multiculturalism in, 245; as peripheral, 70; represents Old Central Europe, 7I; in Rühle-Gerstel's Der Umbruch (The Break), 200; in Shteyn- 
gart's The Russian Debutante's Handbook, 245-46; train line to Vienna, 7 I, 92

Prague Orgy, The (Roth), 245

prejudice, 32

Pressac, Jean-Claude, I96

Principle of Hope, The (Bloch), 2 I 2

Private History of Pereginus Proteus (Wieland), I3-I4

Protestant Ethic and the Spirit of Capitalism, The (Weber), 24

"Psalm of the Citizen of the World" (Josephus), I40

psychoanalysis, 73, 80, I 59, 248

"Quest of the South Pole" ("Der Kampf in den Südpol”) (Zweig), I 22

Raabe, William, 66-67, IOI-2, I75 race: class and, I03; Herder on, 37; hybrids, I75, I79-80, I 8 I, I 82, 20I-2; Jews defined as, 8, I5, 23, 69, I34, I64, 20I-2, 258; mixing, I75, I80, I8 I, 28 InIor; National Socialism on, I75, I76, I79, I8I, I95; racial antisemitism, 4I, I63, 259, 275n3I; racial identity, I02, I 2 I; racial ideologies, I77; racialized psychopathologies, 80; racial politics, I76; racial purity, I79, I8I; racial science, I76; Ratzel on, I09; Simmel on racial inferiority of Jews, I05; in Zweig's writings, 84, 86, I68, I80. See also racism

racism: Du Bois on German, I03, I04;

Zweig's Brazil and, I76, I77, I78

Radetzky March (Roth), I34-37, I38, I70, I7 I, I72, I73

radicalism: cosmopolitan, 57; German radicals in Paris, 57; Jews associated with, 58; radical nationalism, 3, I73, I84, I88-89, 259

Rahden, Till van, I05

railroads (trains), 69, 7I, 77, 79, 8I-82, 92

Rainier, Karl Wilhelm, 43

Rajk, László, 2 I4

Rathenau, Walter, I05-8, I I I, I I3, I38

Ratzel, Friedrich, 26-27, I09-IO, I62-63

"Reflections on Exile" (Said), I9

Reformation, I67

refugees: as cosmopolitans, 3; German

Kontingentflüchtlinge policy, 227; Jews in New Amsterdam as, I 76; from National Socialism, I29, I44, I45; as nomads, I refusniks, 223, 237, 249

Reich, Wilhelm, 202

Reik, Theodor, 80

Reise nach Trulala, Die (Kaminer), 230

religion: Abrahamic, 48; boundary between the state and, 40; Marx on, 6r; monotheism, 2 I, 27, I24, I5I, I60; natural, 43; particularism of religious affiliation, I4; in quest for belonging, 2; rational, 39, 40, 43, 49; religious identities, 2, 7, 36, 239, 240; Roman tolerance for, I39; in Russia, 237; secularization, 8, 79; universal, 7, 65, 90. See also Christianity; Jews

Renaissance, I66-67, I68

Renan, Ernst, 65-66, 67, 90, 269nio6

Richler, Mordechai, 247

Rilke, Rainer Maria, 92

Rise of David Levinsky, The (Cahan), 247

Road into the Open, The (Schnitzler), I I I

Robbers, The (Schiller), 46-49

Robbins, Bruce, 8

Robertson, Ritchie, 50-5I

Rolland, Romain, I I4, I I 5

Roman Empire, 89, I I9, I38-39, I4I-42, I43, I67, I83-86

Romantic School, The (Heine), 53

Rome and Jerusalem: The Last National Question (Hess), 58

Roosevelt, Theodore, 96

rootedness: of Aryans, I65; of Becker, 239; center-periphery dichotomy and, 70-7I; cosmopolitanism versus, 68, 255-56, 259; of German Jews, 50; German nostalgia for, 54; of Germans, I6I, I62, 228; global cities as rooted in nation-states, 3; Goethe on, 52; of Gorelik, 240; Herder on Jews' emancipation and, 37; Jewish, 5, 22, 93, I06, I08, I36, 259, 260; national identity in, 7 ; nation-state predicated on, 67 ; rooted cosmopolitanism, 7, I4, 6I, 66, 98, I07, I I4, I I 5, I I6, 232, 259; rooted nationalism, 257; rooted nomadism, I7 I; Russian Jews and, 225; of the Temple, 225

rootlessness: of capital, I64; of cosmopolitanisms, 2, 9, I0, 76, 77, I I 5, I90-9I, I92, 203, 208; of intellectuals, I65; of international capitalism, I30; in Kaminer's Onkel Wanja kommt, 235-38; of Mendelssohn, 36; of modern society, I3 I, 203; nomadism contrasted with, I64; of nomads, 
8; Ratzel on, I09; of Roth, I27; in Shteyngart's The Russian Debutante's Handbook, 246; Spengler on world cities as rootless, I I 7 Wandering Jew as prototype of rootless modern man, 275n28. See also Jewish rootlessness

Rosenberg, Alfred, I 5, I68

Rosenzweig, Franz, I0o-Io I, I I6

Roth, Joseph, I27-37; "Arrival in the Hotel," I3 I-32; on Austro-Hungarian Empire, I 20, I 27, I28-29, I34-35, I70-73; borderlands in works of, I28-29, I34; cosmopolitanism of, I I6, I28-29, I73, I82, I9I, I99; cultural Zionism's influence on, I I6, I 27; death of, I45, I70; on diaspora Jew as model for future European citizenship, I I6; diasporic sensibility of, I27; The Emperor's Tomb, I34, I70-73; exile of, I70; Feuchtwanger compared with, I38, I39, I40; hotels and coffeehouses in works of, I 29; Hotel Savoy, I 29-34, I66; interwar writings of, I I5, I9I; on Jewish identity in crisis, I27; Jewish sensitivity of, I I3, I I5, I99; on Jews and fringes of AustroHungarian Empire, I I7; Radetzky March, I34-37, I38, I70, I7I, I72, I73; as uprooted, I27; The Wandering Jews, I32-33, I35, I7I, I9I; on Zionism, I35; Zweig compared with, I 27-28, I39

Roth, Philip, 245

Rothberg, Michael, I96

Rothschild, Meyer Amschel, 35

Rothschild, Nathan Mayer, I 22, I 23

Rothschilds, 5 I

Ruge, Arnold, 58

Rühle, Otto, I97

Rühle-Gerstel, Alice, I97-98; Jewishness in work of, I99; Sperber as friend of, 207; Stalinist atrocities criticized by, I92, I97203; suicide of, I98; Der Umbruch; oder, Hanna und die Freiheit (The Break), I97, I 98-203, 204, 205

Russendisko (Russian Disco) (Kaminer), 228-29, 232

Russia: mobility of literary culture of, 235; nationalism in, 3; religion in, 237; Russian Revolution, I33, I69, I9I, 2 Io. See also Russian Jews; Soviet Union

Russian Debutante's Handbook, The (Shteyngart), 244-47
Russian Jews: camps for, 24I ; criminality of, 240; as cultured, 224-25, 227; diaspora of, 223; in Germany, 226-42; as newest cosmopolitans, 223-54; as not Jewish by Orthodox standards, 226-27; refusniks, 223, 237, 249; Soviet, 223-25, 227, 232, 237, 260; Soviet concern about, I88, I89; speaking Russian in Germany, 239; as ultimate cosmopolitan conglomeration, 228; in the United States, 243-54, 255, 257

Russian Revolution, I33, I69, I9I, 2 I0

Sachs, Michael, 62

Said, Edward, I9-20

Sarrazin, Thilo, 24I

Sartre, Jean-Paul, I 8

Sassen, Saskia, 3, 257

Sayce, Archibald H., 26, 265n79

Schickele, René, I I4, I I 5

Schiller, Friedrich: Freud compared with, 8I; Heine on, 53; "The Legation of Moses," 49-50; on Moses, I6 I; "On Joy" ("An die Freude"), 48; The Robbers, 46-49; Russian high culture influenced by, 244

Schlaffer, Heinz, I 53

Schlegel, August Wilhelm, 42, 98

Schlegel, Friedrich, 268n68

Schlosser, Johann Georg, 37

Schmitt, Carl, 67, I56-57

Schnitzler, Arthur, I I I, I 73

Schoeps, Hans Joachim, 226

Scholem, Erich, I87

Scholem, Gershom, 99, IOI, I 87

Scholem, Reinhold, I 87-88

Scholem, Werner, I 87

Schönhauser Allee (Kaminer), 230, 23 I

Schrötter, Leopold, Freiherr von, 42

Schudt, Johann Jakob, 20

Scott, Robert Falcon, I22

Second International, I 89

"Secret of Cosmopolitan Order, The"

(Wieland), I3

secularization, 8, 79

Seghers, Anna, I98, 22 I

Selbstwehr, Die (journal), 92

Seligmann, Joseph, I49

Selina (Paul), 53

Sex and Character (Weininger), 89, I I 7, I 24

Shaw, George Bernard, I, 2, I 2

shilat ha' golah, 6 
Shoah, the. See Holocaust, the

Sholem Aleichem, 224

Shteyngart, Gary, 244-5I; Absurdistan, 247, 248; Kaminer compared with, 244, 248, 25I; literary antecedents of, 247; Little Failure: A Memoir, 248-5I; "The New Two-Way Street," 247-48; The Russian Debutante's Handbook, 244-47; Super Sad True Love Story, 248

Sie können aber gut Deutsch! (Gorelik), 240 Simmel, Georg, 2 I, I04-5, I 54-56

Singapore, 3-4

Sinti and Roma (Gypsies), 3, 9, 20, 4I, 53, I $57-58$

Skolnik, Jonathan, 5 I

Slánský, Rudolf, 2 I 5

slavery, I74, I75, I77-78, I79, I80-8I, I82

Slezkine, Yuri, 8-9, 4I, 79

Sloterdijk, Peter, I69

Smith, Adam, 258

Snyder, Timothy, I 95-96, 283n3o

socialism: bourgeois cosmopolitanism versus revolutionary, I66; Du Bois on Jews and, I04; German revolutions of I9I 8-I9, I I4; Graf on socialist provincialism, I37; National Socialism compared with state, I93; sense of community in, 236; among Weimar Jews, I I4. See also communism; National Socialism

Sociology (Simmel), I 55-56

Socrates, IO

Sombart, Werner, 24-25

Song of Songs, 65

Souls of Black Folks, The (Du Bois), I03

Soviet Union: antisemitism in, I90, I9I-92, 229, 230; borders of, 237; cosmopolitanism as concern in, I88, I89-90; forced collectivization of agriculture, I90; Homo Sovieticus, 224; identity politics of, 224; Jews in, 223-25, 227, 232, 237, 260; Kaminer's tour of, 233; Koestler's visit to, 204; as laboratory for totalitarianism, 2 IO; Lenin, I 57, 208, 2 I8; mass starvation in, 200, 209; nationalism in, 205; National Socialism compared with Stalinist, I9297, 200, 206-7; in Rühle-Gerstel's Der Umbruch (The Break), 200; supranationalism of, I28. See also Great Purges; Stalin Spanish Civil War, I90, 20I, 203, 208, 2 I4, 2I 6, 2I 7, 22 I
Speak, Memory (Nabokov), 249

Spencer, Herbert, 74

Spencer, Philip, I89

Spengler, Oswald, I I7-I 8, I4 I

Sperber, Jonathan, 59

Sperber, Manès, 207-8; Arendt as influence on, 2 Io, 283n57; common constructions with Rühle-Gerstel, I98; on Koestler on his return from Soviet Union, 204; Like a Tear in the Ocean, 207-I3, 2 I6; "On the Analysis of Tyranny," 2 I 2, 284n58; Stalinist atrocities criticized by, I92, 207-I3

Spinoza, Baruch, I4

Spirit of Hebrew Poetry, The (Herder), 62

Stalin: antisemitism of, I92; betrays his most faithful comrades, 209; on cosmopolitanism, I 89; Hitler compared with, I92-97, 206-7; on internationalism, I 89; Jewish communists criticize crimes of, I88; on Jews as rootless cosmopolitans, 9, I0; Khrushchev reveals crimes of, I93; in Koestler's Darkness at Noon, 203-7; the Left and the purges after I945, 2 I3-22; nationalist turn of, 2 I 8; National Socialism's clash with Stalinism, I67; in RühleGerstel's Der Umbruch (The Break), I98203; Sperber's Like a Tear in the Ocean on crimes of, 207-I3. See also Great Purges (Soviet Union)

Stalins Vernichtungskrieg (Hoffmann), I95

Steiner, George, I62

Steinschneider, Moritz, 64

Sternstunden der Menschheit (The Tide of Fortune) (Zweig), I22-23

Stopfkuchen: A Sea and Murder Mystery (Raabe), IOI-2, I75

stranger, the, 38, I05, I 55-56, I99

Stuyvesant, Peter, I76

subjectivities: deterritorialized, I72; diasporic, I0; liminal, I I6, I I 7, I30, I34, I35, I72; modern, I25; nomadic, I9 Sulzer, Johann, Georg, 46

Sünde wider das Blut (Dinter), 28 In94 Super Sad True Love Story (Shteyngart), 248 supranationalism: of Austro-Hungarian Empire, 70, 72, 77, 85, 9I, I09, I 28; cosmopolitanism linked with, I27-28; Zweig on Luther and, I67

Susman, Margarete, 98, 99

Sznaider, Natan, 7, I37 
Tag wird kommen, Der (Feuchtwanger), I 85

Tawney, R. H., 25

Tentzel, W. E., 20

Thalia (periodical), 48, 49

Theological Letters (Herder), 37

Thielking, Sigrid, I I 7, 270n2, 274nI3 I

Thousand Plateaus, A (Deleuze and Guattari), I 8

Thus Spoke Zarathustra (Nietzsche), I50

Tide of Fortune, The (Sternstunden der Menschheit) (Zweig), I22-23

Tito, Josip Broz, 2 I 4

Toller, Ernst, I 29, I 45

Tolstoy, Leo, I37, 235

“Tonio Kröger" (Mann), I 75

totalitarianism, I93, I94, I95, 2 I0, 257

trains (railroads), 69, 7I, 77, 79, 8I-82, 92

train stations, 7I, 92, I 7 I

Treitschke, Heinrich von, IOI, I03, I08, I I I

Trial, The (Kafka), 2 I 6

Tristan (Mann), I46

Trotsky, Leon, I90, I98, 20I, 2 I4, 220

Tucholsky, Kurt, I45

Turgenev, Ivan, 235

"Turm zu Babel, Der" (Zweig), I 2 I

"Two Important yet Unasked Biblical Questions" (Goethe), 52

Ueber die Volkslitteratur der Juden (Steinschneider), 64

Uhse, Bodo, 198

Ulbricht, Walter, 208, 22 I, 283n56

Ulrich von Hutten, I69

Ulysses (Joyce), 275n28

Umbruch, Der; oder, Hanna und die Freiheit (The Break) (Rühle-Gerstel), I97, I98203, 204, 205

Uncle Vanya (Chekhov), 235

universalism: Austro-Hungarian Empire's universalizing mission, I36; Christian, 65, I6I, I84-85; of communism, I89; cosmopolitan, IO, I I, I2, I3, I6, 38, 40-4I, I I4, I 24; of Enlightenment, 6I, 74; food as universal, 233; globalization's claim of, I 2; of Goethe, 5I-52, I2O-2 I, I 22; in Goldziher's portrayal of Abraham, 23-24; of human rights, I 26, 257, 258; Jewish nationalism as universal particularist, 23; Jewish writers promote universality across Iron Curtain, 259-60; Jews on Europe as universal idea, 90; Jews seen as antithesis of, I I; of Josephus, I40; Kant on universal law, I2, I93; music as universal, 233; new discourses in late nineteenth century, 72; and particularism in Zweig's early writing, 84; particularist universality, 9, I7, 74, 86, I I3, I24, I30, I32, I39, I83; psychoanalysis on universal human psychology, 80; of rooted cosmopolitanism, I4; rooted universality, 8; Roth on Russian Revolution and, I33; Schiller and, 48-49; tension between particularism and, 6, 8; universal cosmopolitanism, I4, 38, 4I-42, 43, 233; universal culture, I27; universal hospitality, 38-39, I I 5, I 26; universal humanism, I 22, I7I; universalized human subject, 9; universal religion, 7, 65, 90; Zionism and, 70. See also Jewish universalism

USSR. See Soviet Union

usury, 25, 29, 40, 53, I63

Veer, Peter van der, 7

Verein jüdischer Hochschüler Bar-Kochba, 97-IOO

"Vergangenheit, die nicht vergehen will" (Nolte), I95

Veríssimo, José, I 80

Verliebt in St. Petersburg (In Love in St. Petersburg) (Gorelik), 242

Vienna, 73-9I; antisemitism in, 9I, I74; as capital of rump state of Austria, I I I; as center of Austro-Hungarian Empire, 7I, 73; as center of German-speaking world, 69; centrifugal cosmopolitanism of, 70; coffeehouses in, I25; cosmopolitan spirit at, 70, 84, I73; cultural Zionism emanates from, 86; Hitler encounters Jews in, I I9; Jews in, 72, 73-9I, I73-74; Lueger elected mayor of, 73, 80, I74; as megametropolis, 5I ; in Roth's Radetzky March, I36; train line to Prague, 7I, 92; in Zweig's The World of Yesterday, I76

Vieten, Ulrike, I 7

"Visiting the Carefree" ("Bei den Sorglosen") (Zweig), I3 I

Volkov, Shulamith, I07, I36

Voltaire, 24

Vom Judentum (On Jewry) (Verein jüdischer Hochschüler Bar-Kochba), 97-IO0, I09

"Vom ‘österreichischen' Dichter" (Zweig), 86 
"Vom Weltbürger zum Großbürger" ("From World Citizen to Upper-Class Citizen")

(Benjamin and Haas), I42, I45-46

Vorwärts! (periodical), 57

Wagenseil, Johann Christoph, 20

Wagner, Richard, 28, 75, I23, I46

Wahrmund, Adolf, 26, 92, I06-7

Wallas, Armin A., I 27, I 28, 275n 33

wandering Jew, 50, 60, I33, I 52, 239, $275 \mathrm{n} 28$

Wandering Jews, The (Roth), I32-33, I35, I7I, I9I

"Wanderung, Die" (Zweig), 89-90, I70

Wanner, Adrian, 238, 242, 244, 247

"Was ist Wahrheit?" (Feuchtwanger), I 38

Wassermann, Jakob, 98, I08-I I, I48

Weber, Max, 24, 25, 93, I 55

Weerth, Georg, 57

Wehrmacht War of Annihilation, The (exhibition), I95, 282n29

Weigall, Arthur, I50-5I

Weigel, Helene, 22 I

Weimar: acculturated Jews in, I40; antisemitism in, I42; Eastern European Jews as threat to German Jews in, 226; far-left Jews in, I I4, I87; Jewish cosmopolitanism in, I08, I39; particularist Jews in, I38;

Rome compared with, I39

Weininger, Otto, 89, 90, I I 7, I 24, 203

Weiss, Peter, 2 I6; The Aesthetics of Resistance, 2 I6-I9, 222, 284n65; common constructions with Rühle-Gerstel, I99; The Investigation, 2 I6; Jewishness in work of, I99; on proletarian art, 2 I6-I7; Stalinist atrocities criticized by, I92, 2 I6-I 9

Welt, Die (weekly), 87

Weltbürger, Der (periodical), Io

"Weltminute von Waterloo, Die" ("The Decisive Hour at Waterloo") (Zweig), I22

Weltsch, Felix, 9I, 99

Weltsch, Robert, 99, I48

"What Is a Nation?" (Renan), 67

Wieland, Christoph Martin, I3-I4

Wilder, Billy, I96

Wilhelm II (emperor), 9I

Wilhelm Meister (Goethe), 20-2 I, 52-53, I 22, I 52

Wilson, E. O., 253-54

Wilson, Woodrow, I I 5
Winkler, Heinrich August, Ioo

Wissenschaft des Judentums, 64

Wistrich, Robert, I20, $280 n 84$

Wohlskehl, Karl, 98

Wolf, Christa, 22 I

Wolf, Elcan Isaac, 50

Wolfe, Alan, 6

Wolin, Richard, I5-I6

women: la belle juif, 88; in globalized cities, 3; nomadic rootlessness of modern, 203; in Rühle-Gerstel's Der Umbruch (The

Break), I98; Zweig's depiction of, 84 World of Yesterday, The (Zweig), 84, 88, I20, I 24-25, I27, I70, I73-74, I76, 280n84

Wunder des Lebens, Die (The Miracles of Life) (Zweig), 90

xenia, 26, 38, 39

Yermilov, Vladimir, I90

Yiddish language, 87, 92, I 58, 224, 240, $25^{\circ}$

Zangwill, Israel, I 2, 96-97, 99

Zanzibar; or The Last Reason (Andersch), I9

Zinoviev, Grigory, 204-5, 2 I 8

Zionism: on ancient warrior Jew, I4I; assimilation questioned by, 99-I00; Austro-

Hungarian context of, 73, I08, I35, I73; cosmopolitanism and, 6, 27, 70, 79, 97, 99, I9I, 259; cultural, 70, 86-87, 9I, 9798, 99, I I6, I27; as emanation of Jewish Renaissance, 70; European dimension of, 98; Feuchtwanger and, I I6, I38-39, I 82, I83; First Zionist Congress, 99; Freud on, 80; German versus Austro-Hungarian, Io8; of Herzl, 70, 74-77, 86, 98, 99, I0I, I09; in Heym's Collin, 220; internationalism of, I9I, I92; Jewish attraction to communism and, I 87; Jewish nationalism recuperated by, 68; on Jews and capital, 259; Mann on, I47; Merker accused of, 2 I 5 ; model for Jewish identity of, I63; mystical, 99; nationalism and, 6, 70; on nomadism, 27; political, 70, 79, 86, 88, 9I, 97, 98, IOI; on rooted cosmopolitanism, 259; Roth on, I35; of Scholem, 99, I87; as supranational ideal, Ioo; Die Welt weekly, 87; Zangwill on, 96-97; Zweig on, 88-89 Zionist Federation, I48

Zukunft, Die (journal), 208 
Zunz, Leopold, 63

"Zur Analyse der Tyrannis" (Sperber), 192

Zur Geschichte und Literatur (Zunz), 63

Zweig, Arnold, I59

Zweig, Stefan, I20-27; alignment of cosmopolitanism with European idea, I2 I; assimilation and, 84, I I6, I2 I, I24; as Austrian Jew, 83; Austro-Hungarian Empire in interwar writings of, I 20; "Bei den Sorglosen" ("Visiting the Carefree"), I3 I; Beware of Pity, 83-84; Brazil, 86, I24, I7482; "Buchmendel" ("The Old-Book

Peddler"), I23-27, I68; "The Buried Candelabrum" (Zweig), I70; Burning Secret, 84; on Christian pacifism, I84; Confusion, 84; cosmopolitanism of, 83, 84, 86, I 20, I 28-29, I67, I 82, I 86, I99; cultural Zionism of, 87; "The Development of European Idea," I39, I43; on diaspora Jew as model for future European citizenship, I I 6; early Jewish novellas of, 86-89; encounter with Herzl, 88-89; Erasmus, I6570, I74, I 82, I 86; "Der europäische Gedanke in seiner Entwicklung" (Zweig), I 2 I-22; on European art, 90; exile novels of, 83-84; exile of, I45, I65, I66, I68, I77, I79; Feuchtwanger compared with, I38, I39, I40; German patriotism of, 8586; "Heimfahrt nach Österreich," 85-86; "Das Herz Europas" ("The Heart of Europe"), I26; Im Schnee (In the Snow), 87-
88; "Internationalismus oder Kosmopolitismus," I I5; interwar writings of, I I5, I23; Jeremias, I86; Jewish characters of, I23; on Jewish cosmopolitanism, 83-9I, I20-27; on Jewish identity in crisis, I27; on Jewish particularity, I86; Jewish sensitivity of, II3, II 5, I2 I, I23, I99; on Jews and fringes of Austro-Hungarian Empire, I I7; "Der Kampf in den Südpol" ("Quest of the South Pole") (Zweig), I22; "Das Land ohne Patriotismus," 84-85; later Jewish novellas, 89-90; on Mann's cosmopolitanism, I I 4-I 5; "Marienbader Elegie," I22; as model European, I2O-27; nomadic cosmopolitanism of, I I6; "Opportunismus, der Weltfeind," I I4; The Post Office Girl, 83-84; on Rathenau, I08; on Rome, 66, I43; Roth compared with, I27-28, I39; suicide of, I24, I45, I86; "Der Turm zu Babel," I2 I; on the Viennese coffeehouse, I25; "Vom 'österreichischen' Dichter," 86; "Die Wanderung," 89-90, I70; "Die Weltminute von Waterloo" ("The Decisive Hour at Waterloo"), I22; women as depicted by, 84; The World of Yesterday, 84, 88, I20, I24-25, I27, I70, I73-74, I76, 28on84; on World War I, 84; Die Wunder des Lebens (The Miracles of Life), 90; on Zionism, 88-89

Zweistromland (Land of Two Rivers) (Rosenzweig), I 6 
